\title{
Etnografía Antigua General del Estado de Oaxaca
}

\author{
Mtro. Luis Rodrigo Álvarez
}




\title{
Etnografía Antigua General del Estado de Oaxaca
}

\author{
Copyright ${ }^{\circledR} 2018$ \\ Universidad Autónoma "Benito Juárez" de Oaxaca \\ Av. Universidad S/N Col. Cinco Señores C.P. 68120, \\ Oaxaca de Juárez, Oax. \\ http://www.uabjo.mx
}

Todos los derechos reservados. Este libro está protegido por los derechos de autor. Ninguna parte de esta publicación puede ser reproducida, almacenada en un sistema de recuperación o transmitida en forma alguna y por ningún medio electrónico o mecánico, incluyendo fotocopias, sin autorización previa del editor.

Primera edición, 2018

ISBN 978-607-9061-57-9

El contenido del libro es responsabilidad exclusiva del autor. El editor no se responsabiliza de ninguno de los conceptos transcritos por el autor y su aplicación queda a criterio de los lectores.

Edición e impresión: Corporativo Intermédica, S.A de C.V.

Miembro de la Cámara Nacional de la Industria Editorial Mexicana

Registro No. 2860

Impreso en México / Printed in Mexico 


\title{
Etnografía Antigua General del Estado de Oaxaca
}

\author{
Mtro. Luis Rodrigo Álvarez
}





\section{AGRADECIMIENTOS}

A mi compañera, la Dra. Delia Enriquez Habib, quien me ha sostenido con un amor y apoyo invaluable.

A mis hijas Delia y Corinna, que siempre me cuidan.

A mi yerno, Héctor, que hace lo mismo.

A mi tío materno, el Lic. José Rogelio Álvarez Encarnación, porque con la Enciclopedia de México matuvo abierta la puerta para la divulgación real de lo que es México, sus pueblos originarios, su potencial y sus gentes valiosas.

Al Dr. Jose Antonio León Ruiz, amigo fraterno.

Discutir y crear un libro sobre Oaxaca con él es toda una experiencia.

A la Mtra. Arcelia Yañiz Rosas, ayer desaparecida (1918-2014), por su cariñosa amistad, su sólido apoyo y el gran cariño que le tuvo a mi madre, la Profra. Esperanza Álvarez Encarnación de Rodrigo. ¡Cómo se evaluaron!. ¡Cómo se entendieron!.

A nuestros pueblos originarios y a mi bisabuela materna, Doña Donaciana, india nahua de occidente, que hablando su idioma y el español, vivió, creó y luchó en las sierras de Mascota y San Sebastián, Jalisco, en pleno porfiriato $\mathrm{y}$ en plena fase armada. 



\section{ÍNDICE}

Agradecimientos 5

Las Voces Del Pasado 9

Introducción 11

Consideraciones Iniciales $\quad 13$

Mapas 23

Negros, Afromestizos, Afromexicanos 25

Zapotecos $\quad 43$

Chatinos $\quad 81$

Mixtecos $\quad 97$

Tacuates 129

Mazatecos 141

$\begin{array}{ll}\text { Cuicatecos } & 159\end{array}$

Chinantecos 175

Triquis 191

Amuzgos 205

$\begin{array}{lr}\text { Popolocas } & 219\end{array}$

Chochos 233

Ixcatecos 249

Mixes 265

Huaves 281

Zoques 295

Chontales 311

Nahuas $\quad 327$

Bibliografía General $\quad 339$ 



\title{
LAS VOCES DEL PASADO
}

\author{
"América ha de salvarse con sus indios"
}

Nuestra América. JOSE MARTÍ

"Solo con los indios se podrá hacer algo en México. Se parecen a los árabes. Es lo que hay de mejor, de más interesante. Esa población dedicada a duras labores, iy pensar que no participa del fruto de su trabajo!”.

General de División. Víctor Auguste Margueritte. (1823-1870). Comandante de sus "Cazadores de África”. Guerra de Intervención Francesa. Carta a su esposa (Mayo de 1863).

"Los Indios no son el problema. ¡Son la solución! Hermann Bellinhausen.

Artículo publicado en "La Jornada”. 2007, "Deseo saldar una deuda que tengo como oaxaqueño. Consiste en devolverle a mi tierra parte de las riquezas que me ha dado a través de la música, de la cultura y que procuré sintetizar en el disco OAXACA PROFUNDA.

El componente más destacado de la cultura oaxaqueña es el indígena, lo que nos da la dignidad, que nos ofrece la belleza de los textiles, de las artesanías, la sabiduría de la literatura, de la comida, los sonidos de la flauta de carrizo...

Ing. René Villanueva Arce. Folklorista de cepa. En las notas al disco "Oaxaca Profunda”, terminado en 1999. 



\section{INTRODUCCIÓN}

Este es un trabajo de divulgación. Es el producto de mucho tiempo de recopilación de datos, período que se inició en 1985, cuando locutores de la entonces Dirección de Radio Televisión Oaxaca, a cargo del periodista Virgilio Dante Caballero Pedraza, amigo y compañero de tertulias cafeteras juveniles, me visitaron para solicitarme les preparase guiones etnográficos sobre la población originaria estatal, con miras a realizar una serie de dieciséis programas televisivos, dedicados, uno a cada grupo.

No obstante existir muy importantes libros y artículos sobre los respectivos temas, publicados por el ya desaparecido Instituto Nacional Indigenista (LA POBLACION INDIGENA DE MEXICO), por la Universidad Nacional Autónoma de México (ETNOGRAFIA DE MEXICO), por el Manual de Indios Mesoamericanos (HANDBOOK OF MESOAMERICAN INDIANS), por el Instituto José María Luis Mora (OAXACA, TEXTOS DE SU HISTORIA), por el Instituto Nacional de Antropología e historia (LOS PUEBLOS INDIGENAS DE OAXACA, ATLAS ETNOGRAFICO) y por el actual Consejo para el Desarrollo de los Pueblos Indígenas, y anterior y posteriormente, según los momentos, por los investigadores Frederick Starr, Nicolás León, Carlos Basauri, Bronislaw Malinovsky, Roberto Weitlaner, Carlo Antonio Castro, Julio de la Fuente, Lucio Mendieta y Núñez, Guillermo Bonfil Batalla, Mercedes Olivera de Vázquez, Margarita Nolasco Armas, Leonardo Manrique Castañeda, Laura Nader, Salomón Nahmad Sitton, Alicia Mabel Barabas, Miguel Bartolomé, Lilian Scheffler, Jorge Hernández Díaz. Benjamín Maldonado Alvarado, María Luisa Acevedo Conde, Enrique Marroquín Zaleta y las fotógrafas y fotógrafos Tina Modotti, Cora Von Schilling, Berenice Kolko, Leonora Carrington, Raúl Estrada Discúa, Carlos Sáenz y Alfonso Muñoz, considero de absoluta actualidad poner al alcance de los estudiantes universitarios y la población en general, relacionados con sus respectivas etnias, esta información concentrada que les señale cómo fueron, como vivian y que han hecho sus ancestros, así como orientarles respecto a la historia, principalmente la antigua, de sus respectivos pueblos, tema que, siendo de tanto interés, no ha recibido la divulgación deseada, máxime que prácticamente los libros mencionados no son actualmente asequibles.

Incluyo un material gráfico muy importante, en parte tomado por mí y por amigos en diferentes lugares, así como poblaciones y en parte obtenido de archivos antiguos, tanto los del Instituto de Investigaciones Sociales de la UNAM, como varios del Instituto Nacional de Antropología e Historia (INAH), en fotografías tomadas en expediciones de mis maestros y de otros investigadores, del cual hago cumplido reconocimiento dando los 
créditos. La bibliografía es la indispensable para poder fundamentar lo aquí expuesto, y además me sustento en un corpus de observaciones y registros de campo obtenidos desde el año de 1973, en que vine encantado a la ciudad de Oaxaca como uno de los fundadores del Centro Regional del Instituto Nacional de Antropología e Historia.

Va, pues este trabajo, que reconoce la importancia de los pueblos auténticos y originarios como soportes de nuestras tradiciones e identidad, como una aportación a la información y el conocimiento de los jóvenes indígenas y no indígenas oaxaqueños. La cultura y la gente de la que todos los mexicanos debemos sentirnos orgullosos. José Martí, el Gral. Víctor Auguste Margueritte, Herman Bellinhausen y René Villanueva Arce no han estado equivocados.

MTRO. LUIS RODRIGO ALVAREZ. 


\section{CONSIDERACIONES INICIALES SOBRE EL DESARROLLO HISTORICO DE LOS GRUPOS ORIGINARIOS 0 INDIGENAS DEL ESTADO}

En la actualidad, el Estado de Oaxaca está poblado por un mosaico cultural de pueblos indígenas, originarios o etnias, sumamente variado. ¿Desde cuando ha sido así? Para saberlo tenemos que hurgar en los datos que nos aportan la Historia y las Ciencias Antropológicas, interrelacionándolas. Para empezar, sabemos que esas etnias hablan y han hablado lenguajes muy antiguos que, desde el punto de vista lingüístico, han quedado clasificados en tres grandes grupos. Propiamente, y debido a la imposibilidad de explorar arqueológicamente todo el territorio del estado, aún desconocemos la mayor parte de los procesos históricos que tuvieron lugar, el origen de su diversidad y los porqués de su posición geográfica actual.

La mayor parte de las lenguas habladas en la entidad corresponden al grupo Otomangue y se dividen en cinco familias, a saber: Zapoteca, Mixteca, Chocho-Popoloca, Mazateca y Chinanteca. Además, los otros grupos son: El Nahua-Cuitlateco, que está representado en el estado por la familia Náhuatl; y el Maya-Totonaco, que en la entidad está representado por la familia Mixe-Zoque-Popoluca.

Estos datos llevan a una serie de consideraciones. Es obvio que debió existir en tiempos muy remotos un tronco común de lenguas del cual se debieron diferenciar estos grupos, por lo que nos deberemos retrotraer a períodos prehistóricos, actualmente muy lejanos (más de 9000 años atrás) para intentar detectar las primeras diferencias entre los grupos humanos que entonces poblaron el estado.

Desde el punto de vista de la arqueología prehistórica solamente algunas regiones estatales pueden ser, actualmente, comenzadas a interpretar. Entre ellas se encuentran los Valles Centrales, un pequeño sector de La Cañada, otro de la Costa, uno más del Istmo de Tehuantepec y porciones de la Mixteca, particularmente los Valles de Nochixtlán y Huajuapan, comenzándose a conocer otros.

El inicio, como en todo el continente y el mundo, es una etapa de caza y recolección. Podemos fecharla con cierta exactitud entre 13000 y 6000 años atrás. De esta etapa solamente tenemos hallazgos aislados y los resultados de las exploraciones en unas cuantas cuevas y abrigos; además de varas aguzadas y el fuego, la tecnología era muy sencilla, pero de talla complicada. Unas cuantas puntas de proyectil, quizá usadas en venablos, 
átlatls o pequeñas lanzas, y un utillaje específico para el destace, el guardado, la molienda y el procesamiento de lo recolectado. Del tipo físico nada sabemos. Aunque en los suelos, que por su alcalinidad, generalmente permiten la conservación, no se han localizado huesos humanos correspondientes a la etapa, lo encontrado en los relativamente próximos valles de Tehuacán y Oaxaca permite imaginar provisionalmente cómo pudieron haber sido aquellas gentes. Su organización social ha sido tentativamente asignada a un carácter de microbandas, debido a que en esas condiciones sólo un reducido número de personas pueden subsistir de los recursos de un ecosistema limitado dado, y esto con carácter cíclico, es decir, volviendo en cada época del año a los lugares en que un determinado tipo de árboles o de vegetales produce una semilla o comida determinadas, o donde se puede dar una concentración de algún tipo de fauna de relativamente fácil captura.

Bastantes siglos después, aproximadamente hacia el año 3000 a C. podemos localizar en el territorio del estado grupos más o menos establecidos, con poblaciones de mayor envergadura y dedicadas a un tipo de caza y recolección más especializado, debido a los cambios en los ecosistemas generados por las sucesivas fluctuaciones climáticas. Su utillaje es mucho más especializado, y en varios lugares se sembró maíz, un maíz primitivo, sin dejar de aprovechar el teocintle, $y$, masticadas estando tiernas, las partes superiores de las cañas del tripsacum, dos parientes muy próximos de éste.

Hacia el 2500 a C, como en casi todo el territorio mesoamericano, se observa ya un sedentarismo y un principio de actividades agrícolas en una etapa absolutamente protoagrícola. Casi simultáneamente, a consecuencia de una sedentarización mayor, surgieron las pequeñas aldeas y, curiosamente, en las regiones situadas en valles de la mixteca, el sur de Puebla, y las cañadas de los ríos oaxaqueños que vierten a la Cuenca del Papaloapan, se continuaron sembrando gramíneas del tipo del maíz o el teocintle, varios tipos de calabaza, varios tipos de frijol, chile y el amaranto, éste, que había crecido silvestre en casi toda el área. Este conjunto de plantas cultivables dio el apoyo decisivo para el desarrollo de las culturas posteriores. Hacia el año de 1500 a C, los grupos pobladores del estado de Oaxaca comenzaron a tener una fuerte interrelación con otros conjuntos humanos que, como los Pre-olmecas, simultáneamente, ya estaban asentados en lo que hoy son los territorios de los estados de Tabasco y Veracruz.

La arqueología mexicana designa a estos grupos como los Olmecas Arqueológicos. Su influencia se dejó sentir en Oaxaca con amplia profundidad y sin embargo, no sabemos, por falta de un corpus amplio de exploraciones, hasta que punto influyeron en el surgimiento de los grupos mayoritarios, zapotecos y mixtecos, aunque muchos datos lo hacen suponer en alto grado.

En ese momento se generaron en todo el extremo oriental de la entidad, grupos indígenas que quedan inscritos en el grupo Maya-Totonaco, entre ellos los mixes, los zoques y los popolucas (éstos, hoy confinados al sur del macizo de Los Tuxtlas, en Veracruz). Recientes trabajos arqueológicos realizados en el Istmo señalan una antigua presencia mixe-zoque, y la permanencia zoque se mantuvo muchísimos años, hasta la actualidad, sobre todo en la zona de los Chimalapas y, por ende, en el altiplano occidental de Chiapas. 
Durante el primer milenio anterior a Cristo, la situación cultural de los grupos en el estado ya está más diferenciada. En algunas regiones la influencia olmeca fue decisiva. En otras se comienza a observar rasgos procedentes del altiplano. Hacia el final del milenio, es decir, en la época de Cristo, está francamente definida una etapa urbana en la que se construyen ciudades o poblaciones diseñadas con divisiones de tres tipos, tanto urbanas como por clases y por especialización en el trabajo, es decir, ya hay agricultores de diferentes alcances y potencialidades y hay también un estrato sacerdotal que incuestionablemente se consolida al principio del milenio siguiente, y que se va a desarrollar conformando un estamento social que dominará a la población logrando una mística hacia determinadas deidades, y cuya acción se extiende durante el primer milenio después de Cristo, es decir, sus primeros novecientos años. Esquemáticamente hablando, este estrato social teocrático regirá los destinos de todos los grupos y poblaciones del estado. Los contactos con el mundo teotihuacano son, también, incuestionables, ya que por el territorio debieron pasar comerciantes, dignatarios y conceptos cuya acción puede verse, además de Monte Albán y otros sitios, en otras zonas tan lejanas como la ciudad de Kaminaljuyú, en el altiplano guatemalteco y Tikal, en el Petén. Con lo maya sucedió algo similar. Aparentemente siempre hubo comercio.

De esta etapa viene la marginación a la que algunas etnias se vieron impelidas como consecuencia de la acción invasora y los poderes tecnológicos, económicos y poblacionales de otras.

Desconocemos las circunstancias exactas en que grupos tales como los chochos, ixcatecos, triquis y amuzgos fueron enviados a los lomeríos, las montañas o los valles altos que ocupan actualmente, pero en el caso de Chochos e Ixcatecos, entre los factores que casi seguramente los impulsaron a esas áreas debieron estar los entonces incipientes principalatos mixtecos que surgieron en zonas con mayores recursos (bosques, vegetación, fauna, buena tierra a orillas de ríos, etc.) y, por ende, con mayor población y necesidades de expansión.

En el caso de los triquis y amuzgos, su historia está muy relacionada con las de la Mixteca Baja y la Costa, Durante esos novecientos años la región quedó pulverizada en pequeños principalatos que se combatieron entre sí, y que en ocasiones se unificaron entre sí también, lo que quedó históricamente registrado con la existencia del Principal 8 Venado "Garra de Jaguar". De este modo se observa que el proceso militarista surgió en Oaxaca ya indudablemente durante la segunda mitad del primer milenio después de Cristo. Sabemos muy poco de la organización social y militar de estos grupos porque nuestros documentos gráficos y códices sólo nos hablan de indumentaria, reuniones y conquistas, y sólo de los dignatarios, Principales y Sacerdotes, así como de algunas deidades, por lo que contienen pocos datos al respecto. Algo más sabemos por las crónicas y algunos códices y lienzos posteriores de la época azteca, pero sobre todo sabemos poco de la estructura de apoyo que cada principalato se pudo dar para contar con los elementos para desarrollar sus campañas militares. Esta etapa, a la cual damos el nombre de Militarista o de las Ciudades-Estado, marca el máximo momento de las grandes diferencias entre los grupos zapoteco, mixteco y 
varios otros. Durante esas guerras varias veces poblaciones situadas en los Valles Centrales de Oaxaca y otras áreas cambiaron de manos. Para ese momento, el concepto y modelo constructivo de ciudad, ejemplificado en el complejo Monte-Albán, El Gallo, Atzompa y Monte Albán chico, había sido modificado, y ya se edificaron ciudades tales como Yagul, apoyadas con fortificaciones elevadas. Muy próxima a Mitla puede observarse, y visitarse, una extraordinaria fortificación de ese tipo. En el Istmo un sólido caso de área fortificada es Guiengola.

También en esta etapa, y existen ciertas crónicas que hablan de ello, hay una organización política diferente, basada no sólo en el apropiamento del territorio, sino también en la tributación. Para el momento de la conquista azteca o mexica del territorio hoy oaxaqueño, ocurrida en el cuarto siglo del segundo milenio, la tributación entre los diferentes principalatos estaba muy difundida, hasta el punto de que para los aztecas fue muy fácil controlar, tanto las rutas como los productos, gracias a su brillante grupo de comerciantes, los Pochtecas, y a su extraordinaria red de espías militares, observadores "pochtecas" especializados, que permitieron las intervenciones exactas en momentos precisos, utilizando unidades militares convenientemente abastecidas y perfectamente organizadas. Asimismo, los aztecas encontraron grupos diferenciados, pero también grandes afinidades culturales, con la gente de los territorios guerrerense, poblano, veracruzano y chiapaneco.

A partir del año de 1519 se produjo en mesoamérica la conquista española. Después del proceso de desarrollo de este impactante acontecimiento en el centro y la costa oriente del país, a partir de 1520 varios grupos indígenas oaxaqueños entraron en contacto directo con las tropas de Hernán Cortés y de sus capitanes. De este impacto nos hablan varios documentos, tales como el Lienzo de Chicomexúchitl, población de la Sierra Juárez, que muestra un combate y el aperreamiento de indígenas (perros mastines que los muerden y despedazan), con lo que la población indígena comenzó a ser sistemáticamente perdedora y explotada.
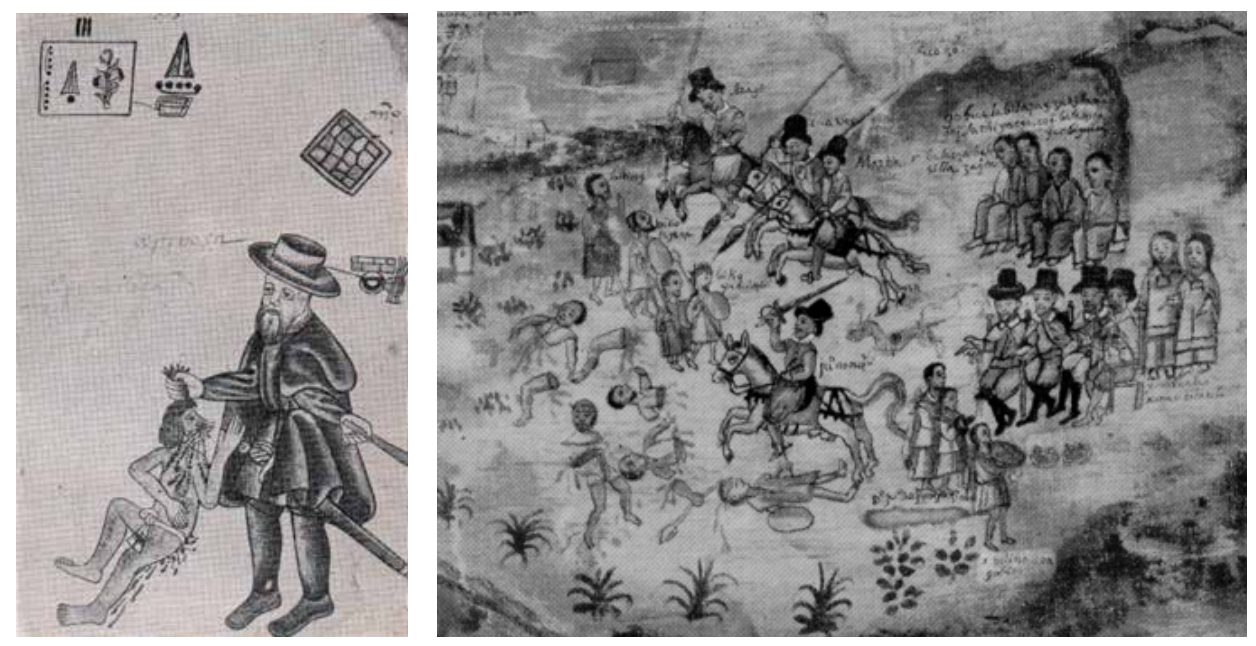

Barbarie de un conquistador-encomendero y asesinato de indígenas. Codice de Tepetlaoztloc, Estado de México y Lienzo de Chicomezúchitl, Oax. (Fotos: Wikipedia y Revista Acervos). 
La Conquista de Oaxaca fue muy cruenta. Hubo regiones en que la ambición española ocasionó verdaderas matanzas que tuvieron lugar siempre relacionadas con la sujeción económica. Posteriormente las habría en el nombre de la sujeción religiosa. Las instituciones españolas, trasplantadas a esta parte del país, hicieron perder sus tierras y recursos, en beneficio de españoles, a la mayor parte de las comunidades y a la casi totalidad de las personas que detentaban el poder político hasta ese momento. Hubo muchos grupos que fueron totalmente despojados, con la muerte violenta de quienes se opusieron. En cambio, surgió el Marquesado del Valle, los Fundos Legales de las poblaciones, y las grandes extensiones de tierras, aparentemente sin dueños, donde se establecerían, primero las Estancias de Ganado Mayor y Menor, y después las Haciendas, muchas y algunas muy importantes de ellas, como las que constituyeron propiedades eclesiásticas.

En Oaxaca se practicó la encomienda; en todas las ocasiones impuesta y realizada en el nombre de la predicación (evangelización) del catolicismo y la posterior cristianización de la población sujeta. También tuvieron parte importante en la despoblación indígena las sucesivas epidemias de enfermedades tales como la viruela, el tifo y el cólera, para las que la población nativa no tuvo defensas. Durante la segunda mitad de la época colonial se había acentuado la marginación de muchos grupos, que habían sido víctimas de las concentraciones, y la casi totalidad de los indígenas desempeñaba labores estrictamente circunscritas a la obtención de materias primas para el desarrollo económico español; entre ellas los productos agrícolas, la grana-cochinilla, obtenida de un insecto (Caccus cactli), y el oro y la plata, obtenidos de minas, y el primero, de gran cantidad de placeres que luego derivaron en socavones y tiros.

$\mathrm{Al}$ producirse el movimiento independentista, los decretos que Hidalgo y Morelos emitieron no fueron aplicados en el territorio oaxaqueño, salvo en el pequeño período en que los insurgentes de Morelos ocuparon la ciudad de Oaxaca entre fines de 1812 y el principio de 1813. Por tanto, la estructura colonial se mantuvo hasta la consumación de la Independencia.

Durante la vida independiente del país los indígenas oaxaqueños han desempeñado una parte particularmente brillante, sobre todo como soporte social, económico y físico a las sucesivas integraciones que han tenido, tanto la sociedad, (¿cuantas indígenas, en cuantos pueblos y ciudades, han sido "nanas" cuidando a los hijos en familias mestizas y de españoles?) como las fuerzas armadas nacionales. Indígenas y afromestizos oaxaqueños, muchas veces agarrados de leva, formaron parte, tanto de fuerzas realistas como de insurgentes en la Guerra de Independencia. Posteriormente, combatieron y murieron junto con el General Antonio de León y el Coronel Gregorio Gelati en 1847 en la Guerra de Intervención Norteamericana. Asimismo, las fuerzas jefaturadas por los Generales Porfirio Díaz e Ignacio Mejía en la Guerra de Reforma estuvieron compuestas por miembros de etnias. También indígenas zapotecos, mixtecos y mazatecos fueron víctimas de la explosión de la Colecturía de Rentas de San Andrés Chalchicomula (Puebla) al principio de la Guerra de Intervención Francesa (1862) y poco después varios batallones que los reemplazaron y que participaron en las siguientes y sucesivas batallas (5 de Mayo de 1862 en Puebla y Sitio 
de Puebla (1863) también eran de zapotecos, mixtecos, chatinos y mazatecos. Todas las fuerzas de Díaz a partir de ese momento, y que estuvieron presentes en Taxco, Miahuatlán, La Carbonera, Oaxaca, el Asalto a Puebla del 2 de abril de 1867, San Lorenzo y el Sitio a México de 1867 también estuvieron compuestas por indígenas y mestizos zapotecos de valles, serranos e istmeños y mixtecos de varios distritos, así como pequeños contingentes de chatinos, chochos, popolocas, mazatecos y cuicatecos.

Indígenas oaxaqueños formaron parte de las fuerzas porfiristas en la Batalla de Tecoac, y muchos de ellos, posteriormente, fueron esclavos en las plantaciones de Valle Nacional o fueron enviados con el mismo carácter a los campos de las haciendas henequeneras yucatecas.

Durante la Revolución Mexicana, indígenas de casi todos los grupos de Oaxaca, formaron parte de fuerzas constitucionalistas, y también los hubo en las villistas; así como también muchos pertenecieron al Ejército Federal. Varias unidades compuestas por oaxaqueños combatieron como soberanistas asimilados circunstancialmente al zapatismo y cuando el enfrentamiento entre constitucionalista-carrancistas y villistas, muchos zapotecos, mixtecos, chatinos, mazatecos, huaves y zoques formaban parte de batallones obregonistas. Poco después, en la Rebelión Delahuertista, zapotecos ístmicos y huaves, subordinados a los Grales Joaquín Amaro y Heliodoro Charis Castro dieron el triunfo, después de un cruento y sangriento combate, al General Álvaro Obregón con el cruce del Río Lerma en Ocotlán, Jalisco, al derrotar a las tropas del General Enrique Estrada.

Como puede verse, la cuota de sangre aportada por los indígenas oaxaqueños ha sido muy alta.

Como contrapartida, muchos maestros rurales diseminados en la república mexicana desde antes de la época de Dn. Benito Juárez García han sido indígenas o mestizos oaxaqueños; así como también lo han sido algunos de los técnicos y especialistas que hicieron posibles las actuales máximas instituciones económicas y de salud del país. Asimismo, entre los profesionistas, investigadores y artistas que en México laboran asiduamente, figuran muchos de origen indígena procedentes de los grupos oaxaqueños, como lo fueron Rodolfo Morales, Erasto Cortés Zurita y lo es, por ejemplo, Héctor Hernández Martínez, el pintor y diseñador gráfico que, contratado por la NASA, adquirió fama por haber diseñado el logotipo de la Cápsula Espacial del Proyecto norteamericano Apolo 11. Además, se puede agregar que, en su casi totalidad, el ejército mexicano actual está constituido por indígenas y mestizos de nuestras etnias, cosa que ellos mismos parecen querer olvidar.

A mayor abundamiento, creo necesario señalar que, para las comunidades indígenas, no sólo de Oaxaca, sino de todo el país, las condiciones de desarrollo no están siendo de ninguna manera favorables, y que, por tanto, la estructura política y social nacional tiene obligaciones con ellas; que los mestizos nacionales se están olvidando, lamentablemente, de que su origen es mayoritariamente indigena o afromestizo, que es imperativo hacer realidad los acuerdos de San Andrés Larrainzar (Chiapas), y que al observar su ancestral cultura puede verse que mucho de lo que somos en México, y gran parte de la idiosincrasia del mexicano procede de su tradición cultural, complementada por muchos de los factores 
que dieron origen a nuestro mestizaje. No es correcto que población fundamental en el devenir y el desarrollo del país esté siendo víctima de depauperación y discriminación aún dentro de su territorio, todo el territorio nacional y menos que se esté legislando en beneficio de quienes necesitan la desaparición de la población originaria y de los mestizos para poder explotar hasta el total agotamiento los recursos humanos, reinstalar un semi-esclavismo ien pleno Siglo XXI! y agotar los recursos naturales, orgánicos e inorgánicos.

Finalmente, por la importancia y actualidad que presenta, considero indispensable transcribir la parte postrera del libro "El Sur de México. El Istmo de Tehuantepec”, de 1946, del maravilloso mexicano que fue el artista y antropólogo Miguel Covarrubias. Un gran ciudadano y un gran experto en nuestros pueblos originarios. Éste es su texto:

"Los conquistadores españoles llegaron a México ávidos de fortuna, resueltos a enriquecerse con el oro que allí había, destruyendo, saqueando y quemando a los pueblos que oponían resistencia. Su profundo desprecio por la cultura indigena y sus ideales fanáticos los llevaron a quemar manuscritos, a destrozar estatuas y a arrasar ciudades y monumentos. De no haber sido por la curiosidad de unos cuantos frailes españoles bien intencionados, esencialmente etnólogos aficionados e historiadores como Sahagún, Torquemada, Burgoa, Motolinia y Las Casas, todo conocimiento de lo que hubo en México antes de la llegada de los españoles, habría quedado irremediablemente en el olvido.

La inquisición, cuya fuerza se perpetuó por cientos de años y la incesante persecución de "idólatras" destruyeron todo vestigio del eminente arte y cultura indígenas. Nada de ello quedó, a excepción de las notas de los misioneros, enterradas en las bibliotecas de los monasterios y conventos. Nada escapó de la ira de los españoles, de no ser aquello que se encontraba fuera de su alcance, bajo tierra y aquellos objetos y manuscritos enviados a España como prueba de sus conquistas.

Pocas veces se ha visto a una gran cultura quedar completamente aniquilada. Todo quedó destruido, hasta los mismos manuscritos que daban fe de la ciencia de un pueblo que había inventado y usado un calendario basado exclusivamente en observaciones astronómicas, más exacto aún que el calendario juliano empleado en Europa en aquel entonces. Nada prevaleció, ni el arte de una raza de artistas que tallaba el jade con tal exquisitez, que creó ornatos tan delicados de oro y que lució ricas vestimentas de algodón tejido y mosaicos de plumas diminutas de colibrí, ni la iniciativa ni el talento arquitectónico de los creadores de aquellas grandes ciudades de piedra. Después de cuatro siglos de esclavitud, de explotación y de degradación, los descendientes de esa gran civilización no tienen ni una vaga noción de su pasado tan glorioso. Apenas y logran relacionar aquellos jades, aquella cerámica pintada y aquellas esculturas de piedra, descubiertos accidentalmente por una pala, o extraídos de los montes por las lluvias, con aquel pueblo de antaño, su pueblo, quien les dio vida. Para ellos no son más que curiosidades capaces de divertir a los niños, o amuletos no más importantes que una herradura oxidada de caballo o un guijarro ordinario.

No es difícil imaginar el grado de cultura que dicha civilización, la más avanzada entre las culturas americanas antiguas, habría logrado alcanzar, de haberse respetado sus tradiciones, arte y filosofía, es muy probable que en américa, hubiese surgido una civilización 
semejante a la china. Sin embargo, los indígenas fueron aniquilados, obligados a servir a los conquistadores a costa de su arte, de sus tierras y de su libertad. Se les despojó de todo, a excepción del odio y de la desconfianza ante sus esclavizadores. Eran impotentes ante la avaricia de sus colonizadores, antiguos o contemporáneos, abandonados en una miseria absoluta, encadenados a una economía feudal sin precedente que jamás les permitió llevar una vida holgada, sino que siempre se les obligó a vivir como bestias.

Los indígenas no tardaron en perder todo rastro de unión étnica, de no ser en aquellos casos en que optaron por penetrar en las montañas inaccesibles para vivir en tribus que, aunque no dejaba de ser una vida miserable, les permitía gozar de una mayor libertad. Hubo indígenas que se mezclaron con toda nueva raza que llegó a México y que perdieron su identidad. Los peones mestizos e indígenas formaron una clase distinta a las demás; se les consideraba como indígenas, término empleado al referirse a los nativos de la región, a los campesinos, obreros y sirvientes. Eran sirvientes ignorantes de las gentes de razón, de los terratenientes, políticos y burócratas. Pese a las buenas intenciones de la Guerra de Independencia, en donde México se liberó del yugo español, de las leyes liberales de Reforma, de la derrota de los imperialistas de Maximiliano y el advenimiento de la República, nada logró modificar el modo de vida de los indígenas. Surgió una nueva clase dominante de mexicanos de raza blanca, amos feudales que poseían grandes extensiones de tierra y que desperdiciaban en Europa el producto de la árdua labor de los indígenas.

La mano de hierro de Porfirio Díaz puso fin a la sangrienta guerra civil, la cual duró setenta largos años y ello hizo que el capital extranjero pusiera interés en México. La situación de los indígenas y de los campesinos se hizo cada vez más inhóspita. México abrió sus puertas a la inversión extranjera, se construyeron vías de ferrocarril, se explotó el petróleo, las propiedades crecieron y las fábricas comenzaron a producir. Represión y tiranía crecieron simultáneamente en fuerza y rigor. El descontento culminó al fin con la Revolución de 1910 y lo que se creía que sería un complot para derrocar al dictador empedernido, llegó a convertirse en un movimiento popular que exigía tierra, justicia social y la restitución de los derechos humanos que le correspondían. Revoluciones y contra-revoluciones asolaron al país durante diez años y un pueblo combatiente comenzó a darse cuenta, mediante el derramamiento de sangre y la experiencia, que si realmente estaban ávidos de una democracia, jamás encontrarían respuesta en el corazón y en las manos de sus explotadores.

El país atravesó por un período de transición: se crearon nuevas constituciones con cláusulas que imponían nuevas condiciones de vida. Se hizo un ligero esfuerzo por ponerlas en práctica. Empero, los tiranos de antaño, actuando bajo nombres ficticios, haciéndose pasar por líderes cívicos y revolucionarios, anularon dicho esfuerzo, dedicándose a enriquecerse y a adquirir poder político. En aquel entonces había un gobierno (el cardenista) que fungía como mediador para contrarrestar estos abusos, mas fue calificado como peligroso por ser excesivamente radical y se le fue presionando poco a poco hasta perder todo poder político. Mucho se logró para impedir las degradaciones económicas, morales y políticas de las clases mexicanas de bajo estrato social a través de la educación, de la 
legislación social y de la redistribución de la riqueza, pero la batalla continuó y los enemigos de la verdadera democracia, bajo los cuales el pueblo no podía prosperar, prepararon constantes ataques para interferir con los objetivos de las clases oprimidas.

La Segunda Guerra Mundial tendría repercusiones sociales y económicas decisivas en el Istmo de Tehuantepec, así como en el futuro del resto de América Latina. Muchos consideran el triunfo arrollador del mundo democrático ante el fascismo como el fin de una enorme pesadilla, como el fin definitivo a uno de los períodos más funestos en la historia de la humanidad. Empero, existe la tendencia peligrosa de considerar al fascismo como un fenómeno meramente europeo al que puede descartársele una vez que se haya aniquilado a aquellos que pretendieron, en un momento, convertirse en conquistadores del universo.

Desafortunadamente el fascismo ni es nuevo ni ha muerto tampoco, aún cuando se haya logrado destruir a sus elementos más perniciosos. En su sentido mas profundo, el fascismo es la versión moderna del siglo XX del feudalismo de la Edad Media, tratando, a toda costa, de implantar el sistema feudal de la sociedad a la era de la tecnología avanzada. De hecho, tiende incesantemente a hacer uso discordante y simultáneo de los medios ultramodernos y de las estrategias de guerra más avanzadas, así como de la propaganda y la represión, con conceptos tan obsoletos como la discriminación racial, el nivel inferior de la mujer y la división de clases. Pretende ocultar su imperialismo bajo un tamiz de nacionalismo "glorioso", arrasando con toda educación y ciencia progresistas que se oponen a su ideología.

El fascismo en Europa ha sido derrotado y destrozado, pero éste prevalece aún en el Nuevo Mundo. Sus estrategias de expansión han sido modestas por ahora. No puede permitirse a sí mismo el incurrir en una conquista territorial y, con frecuencia, se muestra renuente a llamar la atención en forma negativa, pero sus métodos e ideología son brutales e injustos, más sadistas aún que los de los nazis. Su ideal de sociedad se ha reflejado aún en su afán de mantener a una clase inferior, dócil y servil de campesinos, campesinas, obreros y obreras piadosos, ignorantes y conformistas, sometida a las órdenes de un triunvirato privilegiado: la iglesia, el ejército y los hacendados, o su imagen moderna, el empresario conservador tanto nacional como extranjero. Dichos medios expansionistas han sido y son en toda la historia de América Latina, el eslabón que ha obligado a millones de indígenas, negros y mestizos a someterse a un estado de servilismo semicolonial. Se han doblegado ante un sinnúmero de fuhrers nacionales, desde los dictadores pintorescos y ávidos del derramamiento de sangre, incluyendo a los Díaz, Gómez, Machado y Trujillo, hasta los "hombres poderosos" más discretos y los caciques más déspotas del país, quienes gobiernan para el beneficio exclusivo de sus amistades y socios comerciales.

La práctica de los verdaderos principios democráticos, el apoyo a los auténticos líderes demócratas y una educación adecuada, seguirán siendo siempre las armas más poderosas para combatir a estos opositores perniciosos. Los descendientes de las antiguas generaciones mexicanas, víctimas, en su gran mayoría, de los vicios de épocas en las que predominaron la injusticia social, el aislamiento y una depravación moral sin precedente, están ofreciendo oportunidades hoy en día para vivir mejor, para alimentarse mejor, para 
instruirse y, más importante aún, para tener la fuerza, la confianza y la habilidad para crear. En una ocasión, visitando una antigua iglesia convertida en la Biblioteca y Museo del Estado de Veracruz, vimos una exposición de cartelones creados por los alumnos de una escuela. Nos llamó poderosamente la atención un cartelón rudimentario, pintado en colores comunes, sobre un pliego de cartulina. El cartelón ratificaba aún este nuevo ímpetu: mostraba a tres hombres desnudos, de tez obscura, levantando una enorme lápida sepulcral, en torno a unas flores rojas gigantes, con la siguiente inscripción: "UNIDOS COMO UN SOLO HOMBRE, SALGAMOS DE LA SEPULTURA, DONDE EL MUNDO SERÁ UN JARDIN".

Ahora que los retos se están incrementando, si los mexicanos, mayoritariamente de origen y fenotipo indígena, ahora inmersos en un choque de civilizaciones con quienes pretenden desaparecerlos y expoliar los recursos del país, y con la inapreciable y combativa co-dirección de los pensantes de nuestro pueblo y nuestros pueblos originarios, nos unimos para lograr salir de la sepultura, el país será un jardín. Tiene todo para serlo, y por supuesto, incluidos sus maravillosos indígenas.

Mtro. Luis Rodrigo Álvarez. 


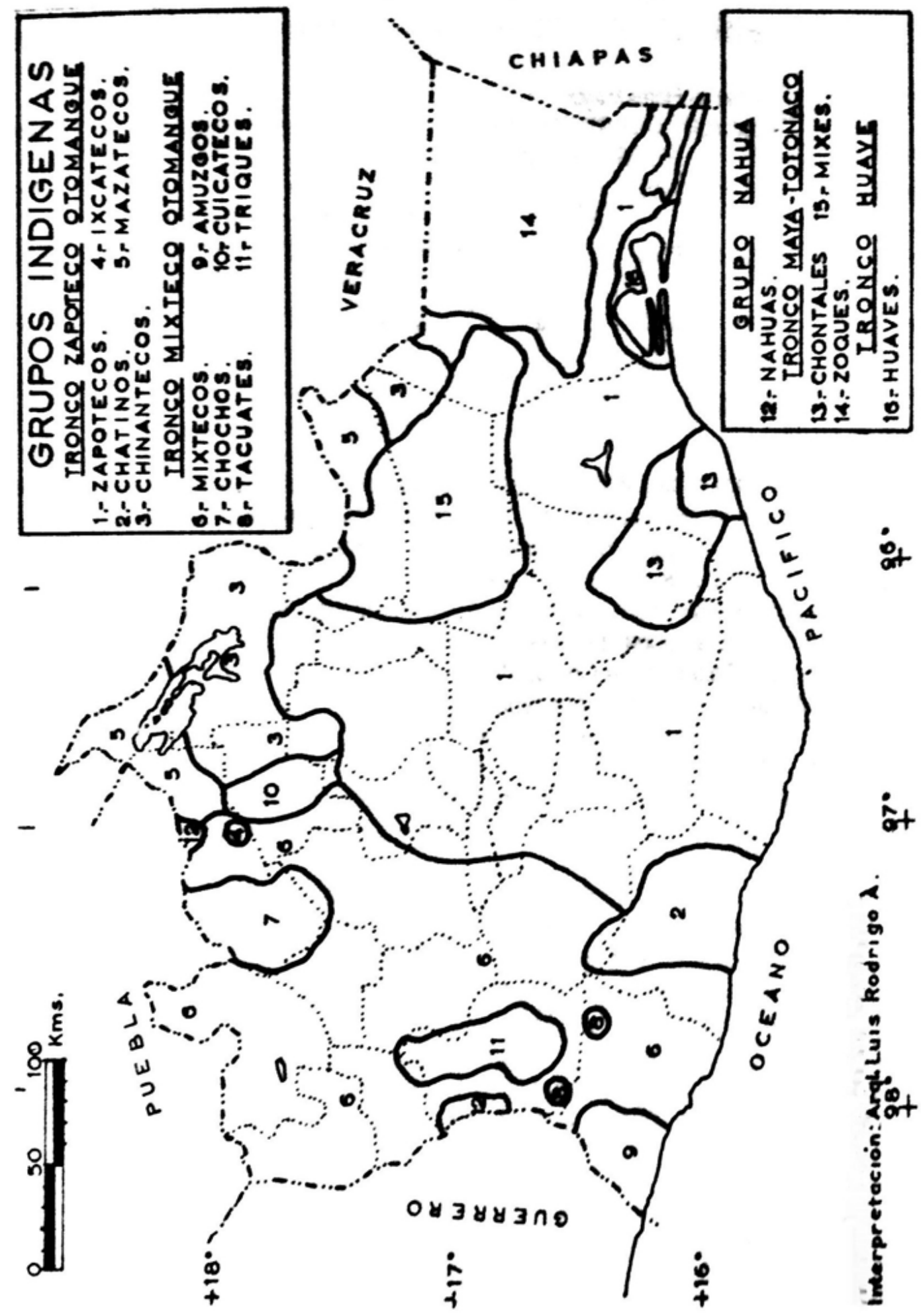




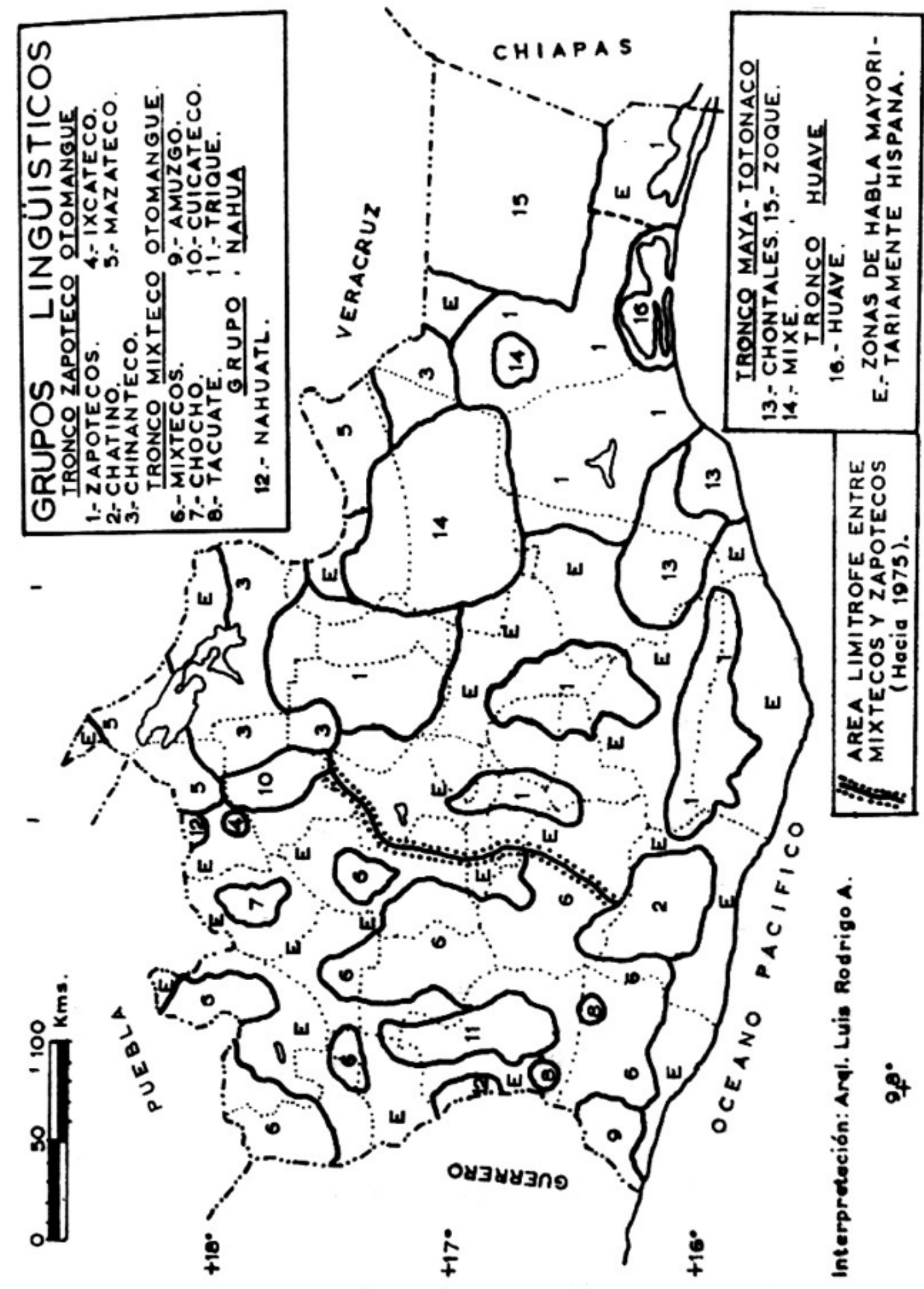




\section{NEGROS, AFROMEXICANOS, AFROMESTIZOS, AFROMIXTECOS O AFROAMUZGOS}

Autodenominación: Negros. Afromexicanos.

Sinónimo en su lengua: ca’a nda'i, afromestizo, negro.

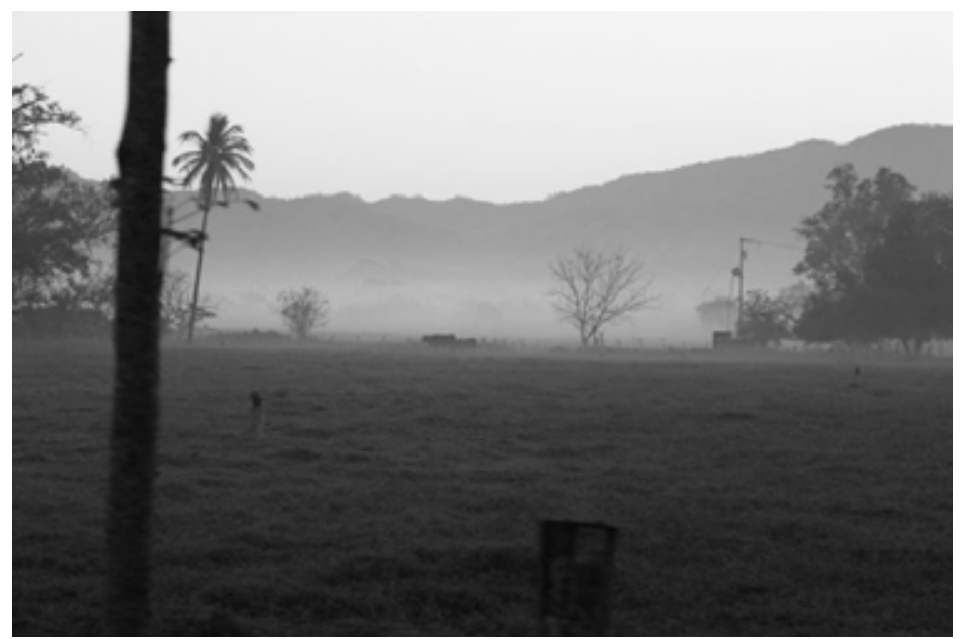

Amanecer en José María Morelos, Jamiltepec, Oax. (Foto: Israel Galán Baños).

UBICACIÓN GEOGRÁFICA. Aunque distribuida individualmente por todo el estado, y particularmente en la Costa y el Istmo de Tehuantepec. la población negra o afromestiza se concentra en un área situada en los Distritos de Jamiltepec y Juquila, más o menos 140 kilómetros alrededor de la intersección del paralelo 16³0' con el meridiano 97 30', excepto en la zona de contacto continental con el mar, donde la distancia es menor. Esa población se concentra mayormente en los municipios de Pinotepa Nacional, San José Estancia Grande, Santo Domingo Armenta, San Juan Bautista Lo de Soto, Santa María Cortijos, Santiago Tapextla, y en la Agencia Municipal de Collantes, y de manera más diluida en Mártires de Tacubaya y Santiago Llano Grande. Además, hay población afromestiza muy presente en el resto del Distrito de Jamiltepec y en los distritos de Cuicatlán, Juquila, Pochutla, Tehuantepec y Juchitán, así como en los Valles Centrales. Geográficamente, el área de mayoritaria ocupación afromestiza, tuvo originalmente una selva media caducifolia y subcaducifolia, ocupante de lomeríos y pequeños planes a la orilla de los ríos Cortijos y de la Arena, así como manglares de tres especies, próximos a dunas con cubierta de plantas rastreras, en el borde de las lagunas litorales. 


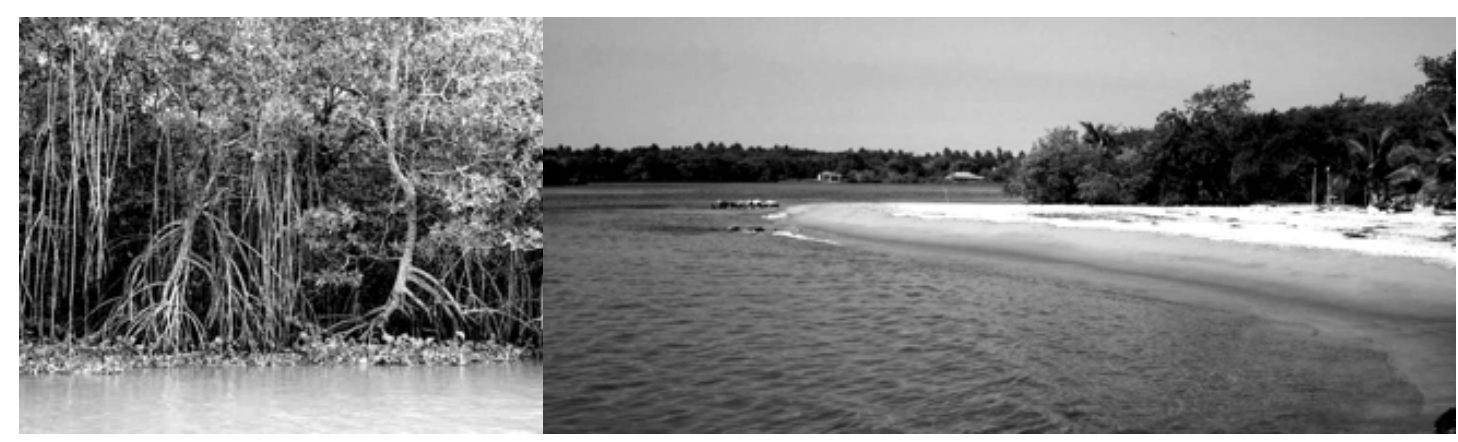

Manglar y Laguna de Chacahua. (Fotos: Notimex y Dirección de turismo estatal).

Los suelos son básicos, relativamente calcáreos y con poco grosor, y sin embargo bastante fértiles. La precipitación pluvial anual está un poco arriba de los 1400 milímetros y los vientos veraniegos soplan del sur, aportando un buen coeficiente de nubosidad. Gran parte del territorio es cálido, con temperaturas que en verano suelen ser ligeramente superiores a los $40^{\circ}$.

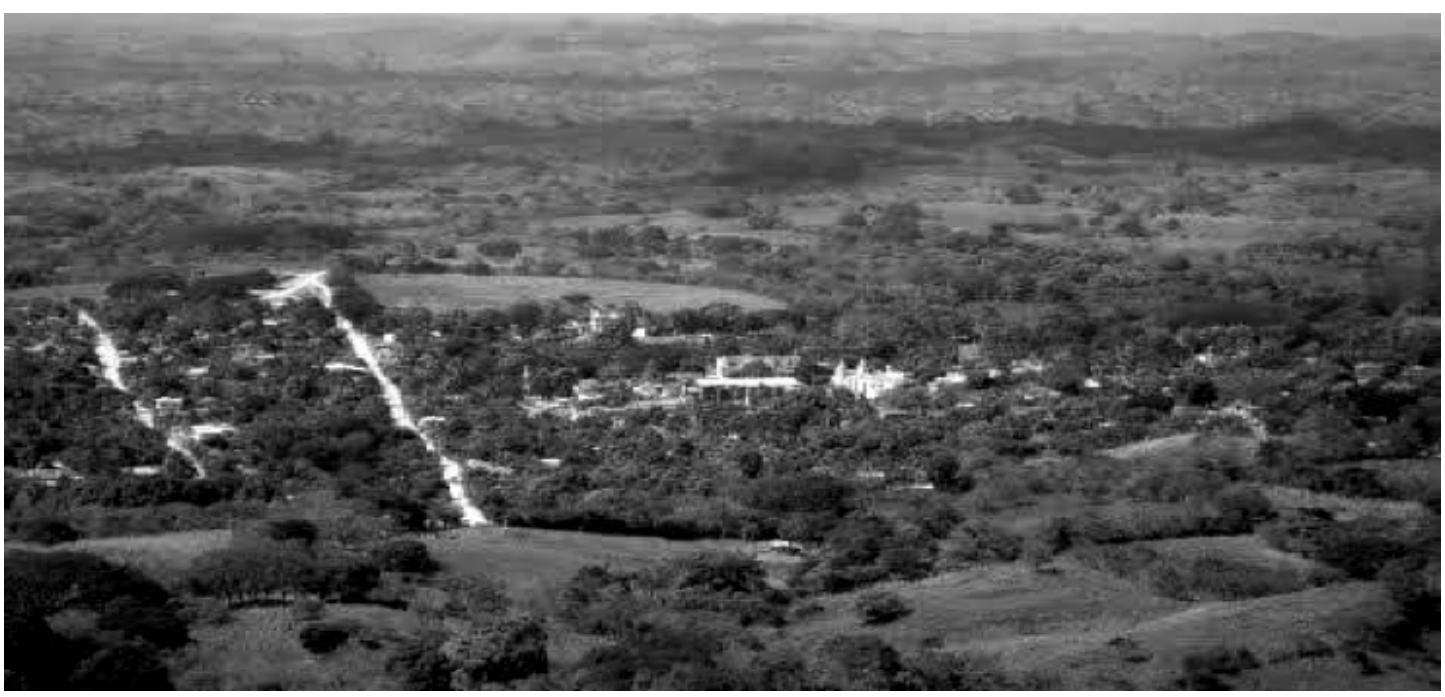

Panorámica de San Miguel Tlacamama. (Foto: Rolando Domínguez Flores).

IDIOMA. Las lenguas originales, de las familias Yoruba y Bantú se perdieron hace mucho tiempo, conservándose algunas palabras que existen incorporadas al mestizaje. Prácticamente la totalidad habla español. Y un alto porcentaje de los negros o afromestizos del distrito de Jamiltepec hablan mixteco, habiendo también, en los territorios respectivos, hablantes de amuzgo y chatino. En otras partes del estado hay también pocos hablantes de zapoteco.

ANTECEDENTES ARQUEOLÓGICOS E HISTÓRICOS . La población afromestiza o negra de México no es autóctona, pese a que en las culturas precolombinas del país se presentan rasgos físicos que durante mucho tiempo hicieron suponer tal situación. Las cabezas co- 
losales olmecas y multitud de figurillas de muchos sitios arqueológicos de varios estados, han sido interpretadas por algunos autores como negroides como una simple apreciación. No se ha tomado en cuenta que en muchos cientos de generaciones sucesivas, desarrolladas y actuantes durante los últimos 60000 años, hay rasgos físicos que llegan a manifestarse como recesivos, creando la consiguiente confusión, porque siempre habrá un hombre o mujer de piel un poco más obscura, con cara redonda, labios gruesos y cabello lacio o crespo, y esa persona puede llegar a tener una posición preponderante en su grupo, por lo cual puede ser representada. Los datos en firme arrancan de los primeros años del período colonial, cuando, hacia 1523, los primeros conquistadores y encomenderos trajeron de las islas de Cuba y Santo Domingo los primeros esclavos, seguidos poco después por las víctimas de las capturas que los negreros portugueses, españoles y árabes norafricanos realizaron en la costa occidental de áfrica y en la orilla de los ríos Niger y Congo, en el interior de ese continente. De este modo los negros traídos a México procedieron de grupos de muy posible origen bantú occidental, mandinga o yoruba, que fueron capturados en Burkina Fasso, Nigeria, Togo, Benin (antes Dahomey) y Camerún, aunque poco después también fueron traídos del Congo, "convertidos" al catolicismo y concentrados en las islas de Cabo Verde antes de hacerles cruzar el atlántico en la sentina de los barcos negreros.

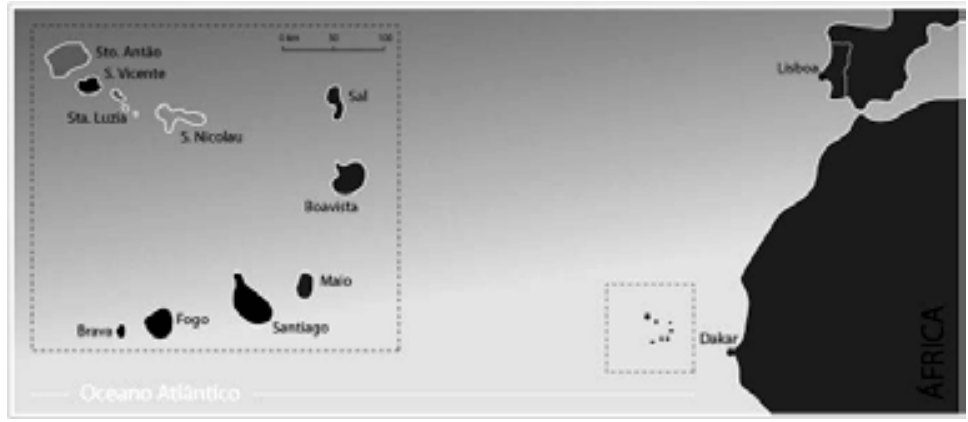

Ubicación de las islas de Cabo Verde. Costa occidental de Africa. (Foto: Departamento de turismo de Cabo Verde).

Con mucha probabilidad, muchos de los inicialmente llegados a territorio oaxaqueño y guerrerense procedieron, huidos (cimarrones), de las primeras plantaciones y de áreas de cultivo regenteadas por el entonces Obispado de Puebla, principalmente de los cañaverales de las regiones veracruzana y de Atlixco. Además, tan temprano como en el año 1530, hubo también esclavos negros traídos por encargo de los primeros encomenderos de la zona, Mateo de Mauleón, Francisco Alavés, Miguel Alavés y Fernán Gómez de la Cueva, ello como consecuencia de la necesidad de trabajadores ante las primeras despoblaciones indígenas causadas por enfermedades (viruela, sarampión, tifo exantemático y peste bubónica).

El mestizaje a través de los tiempos y en todos los continentes, con genes dominantes, a veces recesivos y en todos los seres humanos. (Fotos: Internet).

Además, en el resto de los siglos coloniales y en el XIX llegaron también negroides asiáticos procedentes de las islas del Estrecho de la Sonda, ya que la tradición oral del po- 

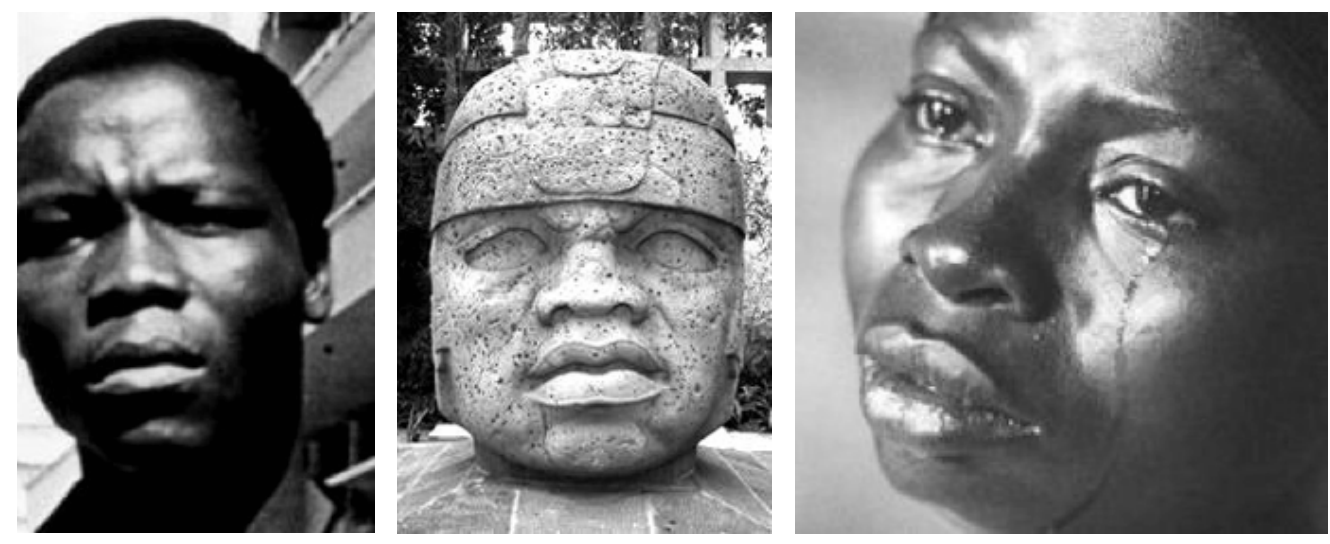

Ubicación de las islas de Cabo Verde. Costa occidental de África. (Foto: Departamento de turismo de Cabo Verde.)

blado de José María Morelos, habla de por lo menos un naufragio ocurrido cerca de Puerto Minizo y muy rápidamente se entremezclaron con los afromestizos ya residentes, así como con los indígenas mixtecos, con el resultado de, posteriormente, presentarse rasgos físicos muy afinados, inclusive el pelo lacio. Durante la colonia, al establecerse los ranchos y comenzar a reproducirse el ganado vacuno, varios afromestizos, que ya conocían el manejo de varios tipos de ganado, por ser su área de origen uno de los primeros focos de domesticación, fueron vaqueros y aún capataces. Con el tiempo algunos fueron propietarios. En ocasiones esto ocasionó roces con indígenas que no quisieron ser así mandados. También, hay indicios de que varios ocupantes españoles iniciales, uno de ellos conocido en esa región como "El Mariscal”, ordenaron a sus esclavos negros la búsqueda y el exterminio de los indígenas en sus territorios dominados. De ello habló Don Manuel Martínez Gracida como el origen de la población de Cortijos y además se observa que durante los siglos XIX y XX, los afromestizos han presentado gran movilidad a lo largo de la costa. Lo revela su presencia en las regiones de Tehuantepec y Juchitán, existiendo antecedentes de un poblamiento del área de Pochutla en el Siglo XVIII.

Aunque teóricamente los esclavos negros llegaron a Nueva España siendo católicos, la catequización en el grupo se produjo casi simultáneamente con los demás pobladores de la región, siendo los frailes dominicos quienes la realizaron, Así, hay poca información y ninguna obra catequística regional que haya trascendido, pero una gran parte de las iglesias regionales fueron edificadas en la segunda mitad del Siglo XVII, en las décadas subsecuentes, o en la primera del XIX, lo que quiere decir que, indudablemente, durante un siglo y cuarto hubo alguna resistencia.

Durante el Siglo XVII, en 1769, se inició en la región de Tuxtepec una congregación que reviste especial importancia en la historia del estado, la de Nuestra Señora de Guadalupe de los Morenos de Amapa, a la que se le dio libertad plena, y que originalmente estuvo constituida por cimarrones que en algún momento delinquieron como asaltantes en la zona de Teutila. Esa población, poco mas adelante, apoyó al gobierno virreinal ante los amagos de los piratas ingleses en la costa veracruzana, y de ese modo obtuvo el asentamiento actual, que hoy es una Agencia Municipal de Tuxtepec. Prácticamente, y de ma- 
nera simultánea y en varias épocas, muchos ya afromexicanos ocuparon rincones costeros donde se convirtieron en pescadores, recibiendo con suma frecuencia a los que llegaban después de huir de otras partes del país.

Durante la Guerra de Independencia hubo afromestizos participando, tanto en las fuerzas realistas, habitualmente agarrados de leva o enviados por hacendados españoles, como en las independentistas de Dn. Antonio Valdés y Miguel Bravo, así como en las de Dn. Vicente Guerrero. Se recuerda que en un combate librado cerca de Ometepec, Gro, las fuerzas independentistas de Dn. Miguel Bravo fueron derrotadas por las realistas de Dn. Francisco Paris. Allí cayó prisionero, para poco después ser fusilado, Dn. José Perfecto García, uno de los primeros oficiales oaxaqueños muertos en la Guerra de Independencia, veterano del Sitio de Cuautla y hoy inmortalizado en siete calles de la ciudad de Oaxaca. Después de 1845 también hubo afromestizos en las fuerzas liberal-republicanas del Gral. Juan Nepomuceno Álvarez. Posteriormente también los hubo en las fuerzas republicanas del Gral. Faustino López Aldana, y con él combatieron, bajo las órdenes del Gral. Porfirio Díaz Mori, en la Batalla de la Carbonera, en el Sitio de Puebla, terminado el 2 de abril de 1867, en el combate de San Lorenzo y en el asedio de la Ciudad de México, comenzado pocos días después.

En el período de la Revolución Mexicana destacó un batallón de afromestizos que, al mando del Mayor. Alberto Arreola, combatió encuadrado como pié veterano en la Brigada constitucionalista "Plan de Guadalupe" del Gral. Juan José Baños, contra los soberanistas oaxaqueños, en San Pedro el Alto, Miahuatlán (donde Arreola cayó muerto) y Ocotlán. Algunos afromixtecos, por su parte, integraron la tropa del Gral. Fidel Baños, enfrentando a los constitucionalistas y muchos miembros de la etnia, reclutados por los mestizos propietarios de su región, participaron en combates contra zapatista-soberanistas, para que ambos grupos, poco después, se encontraran sujetos a cacicazgos. Asimismo, en la década de los 30s, varios sostuvieron las reivindicaciones agrarias, y para ello ocuparon tierras costeñas. Hoy en la zona existen más de treinta ejidos, y sólo Lo de Soto tiene tierras comunales. Se documenta que el grupo ha tenido muy recientemente mayores problemas con caciques, ya que la depauperación es evidente y hay exigencias de reivindicación. En la actualidad existe actividad política partidaria, siendo el PRI y el PRD los partidos de mayor presencia. Ahora la población está consciente de su identidad y lucha por preservarla sin permitir que se le vea con criterio clientelar. Periódicamente, tanto en poblaciones guerrerenses como oaxaqueñas, hay reuniones de miembros de vanguardia de la etnia, donde se plantea, generalmente, la necesidad de la unificación. Los tiempos son difíciles. Y no cabe duda que el grupo ha hecho una substancial aportación a la cultura del país y a la sociedad mexicana, por lo que es necesaria mayor lucha contra la discriminación que ha padecido y sigue padeciendo.

DEMOGRAFIA. No ha habido nunca un censo confiable de la población afromestiza. Primero porque nunca han sido considerados como población independiente y en segundo lugar porque en todas partes están entremezclados, habiendo población de origen afromes- 
tizo-indígena completamente afincada en la zona del Istmo de Tehuantepec y en la Región de Cuicatlán. En el Censo General de Población y Vivienda del Estado de Oaxaca del año 2000 sumaron aproximadamente 300000 personas (incluyendo población itinerante situada en el Estado de Guerrero) y en el Censo del 2010 son mas o menos 240 000, pero se observa que mucha es población flotante que constantemente se desplaza, y la razón es la muy extrema marginalidad.

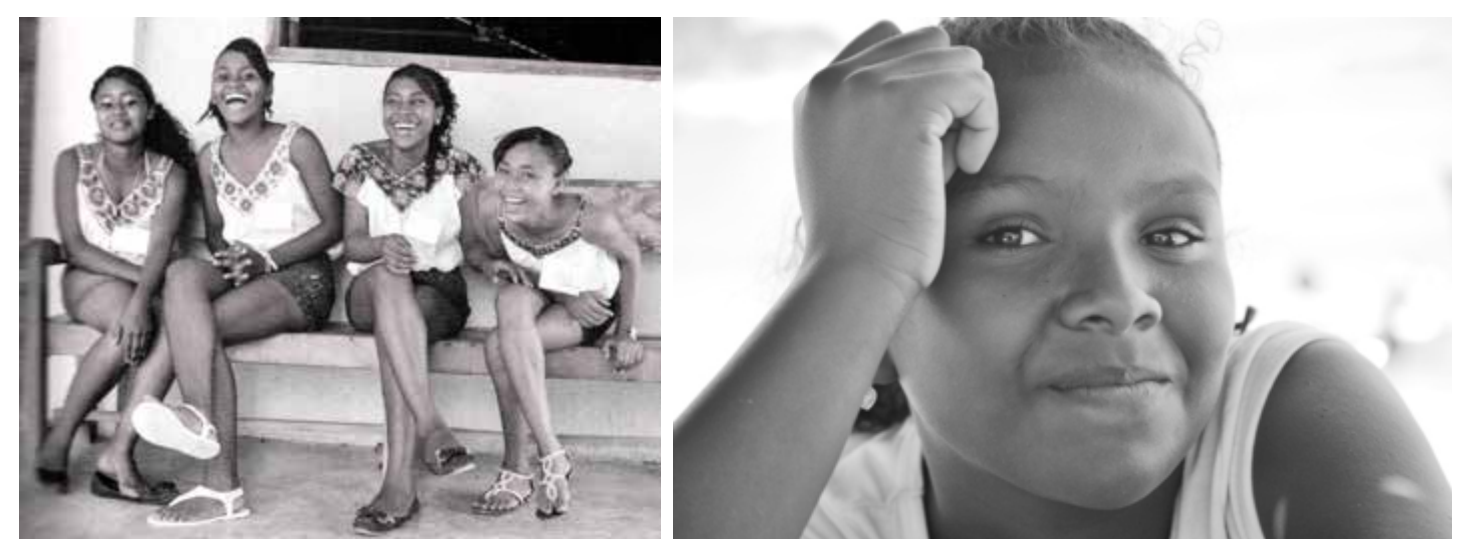

Jóvenes afromestizas. (Fotos: José Luis Martínez Maldonado y Alejandro Linares García).

ACCESOS. Dos son las principales carreteras que cortan en cruz la zona ocupada por la principal concentración del grupo. La costera o federal № 200 y la federal $n^{\circ} 125$, que se unen muy cerca de la población de Pinotepa Nacional. El resto de los poblados ya cuentan con caminos pavimentados secundarios, o bien de terracería revestida. Muchas de esas obras no existían hace 40 años, cuando todo eran brechas madereras, o bien, veredas. Una de ellas tuvo importancia histórica al unir Pinotepa Nocional con Puerto Minizo.

VIVIENDA. Como una característica grupal, quizá derivada de la memoria de la casa tradicional del áfrica occidental, reforzada por un antiguo diseño mixteco, los afromestizos conservaron hasta hace unos treinta años la forma circular en un tipo de casa, autorizada por el dueño latifundista de los terrenos, construida con horcones de madera terminados en horqueta, vigas de amarre laterales y hacia la punta del techo y morillos para su apoyo.

El techo era de pasto o de palapas de palmera, con frecuencia palma real, y las paredes de bajareque juntando ramas o carrizos rectos, con un enjarre de lodo compactado en la parte basal para evitar la entrada del agua. Además, hay un fogón constituido por tres piedras o una cavidad de lodo, a semejanza de un pequeño horno. Esa casa ha virtualmente desaparecido y sobrevive un tipo cuadrangular, y más recientemente, la actual casa de material (concreto de cemento, cal, agua y arena) ampliamente difundida En la población guerrerense casi fronteriza de Cuajinicuilapa, en el Museo de la Negritud, Museo de la Tercera Raíz, o Museo Regional de las Culturas Afromestizas, se conservan aquellas casas tradicionales como un bello recuerdo. Ante la virtual ausencia de servicios sanitarios, hasta hace muy poco tiempo la defecación se hacía en los solares. 


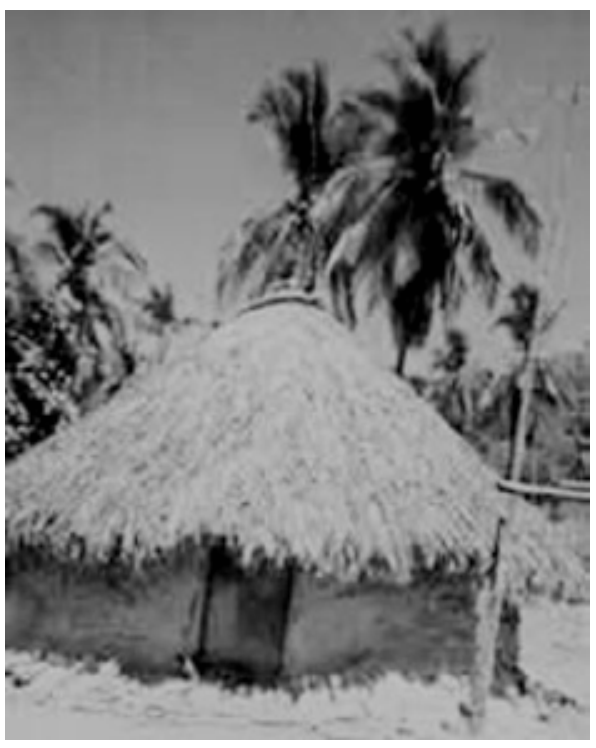

Casa afromestiza. Museo. Cuajinicuilapa, Gro. (Foto: Dirección de Turismo de Guerrero).

INDUMENTARIA. En razón de la elevada temperatura ambiente, la población ha requerido poca ropa de abrigo. La ropa usual fue de algodón; blusa, huipil, refajo de manta y calzón para las mujeres y calzón-pantalón de manta, camisa y sombrero de palma o lana para los hombres; pero en la época colonial y el Siglo XIX, por la presión inquisitorial, se manejó mucho que la desnudez del torso hacía pecaminosa a la población femenina, criterio que también siguieron algunos funcionarios del Instituto Nacional Indigenista. Hubo siempre pocos huaraches y gran parte de la población se desplazaba descalza. Posteriormente, desde hace unos treinta años, el huarache se extendió. Entre las mujeres, muchas son o han sido costureras, y ahora impera mayoritariamente el calzado o las sandalias de plástico, en parte por su costo inferior.

ECONOMÍA. Debido a ser un área considerada marginada, en la que el pueblo afromestizo ocupa uno de los estratos socioeconómicos más bajos, dicha población, aunque genera mucha riqueza, permanece sujeta a los procesos desiguales de producción-comercialización. Por tanto, en los mercados del área pueden verse estos problemas en forma de bajos precios y altos costos para dicho grupo, que entonces tiene que vender a bajo precio los excedentes que genera para poder cubrir los faltantes en sus necesidades. Como un remanente de lo que fue la diferenciación en castas, existe una situación tal que, aunque son posibles los matrimonios entre indígena o mestizo mixteco, amuzgo y negra, no lo son tanto entre negro y mujer mestiza y son pocas las excepciones. En la colonia los productos de tales uniones, con sus variantes, fueron llamados zambos, zambos prietos, salta atrás, chinos, cambujos, lobos, albarazados o barcinos, según fuese la combinación y el "porcentaje" afromestizo o indígena que tuvieran.

Los principales productos sembrados son el maíz y el frijol, con abundancia de otros elementos (ajonjolí, calabaza, chile, camote, caña de azúcar, limón, jamaica y coco, este último ahora ámpliamente extendido). 


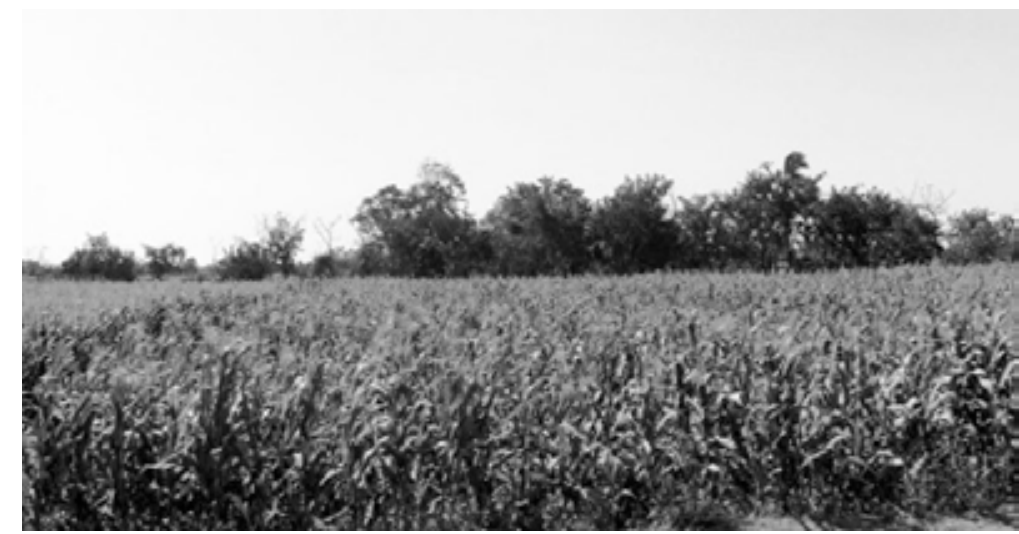

Sembrado de maíz. José María Morelos. (Foto: UNAM).

Hace años sembraron también algodón, cultivo con mucha historia regional. Con el jugo de caña fermentado se hace y ha hecho la chicha, bebida embriagante frecuente en rancherías y pequeñas poblaciones.

CAZA Y PESCA. Como zona subtropical baja que es, el área ocupada por los afromestizos de Jamiltepec y Juquila contiene una amplia variedad de especies de caza, de las que hacen uso cuando se presenta la ocasión. En el área hay, en poca cantidad, o casi al borde de la desaparición, mono araña, ocelote, tigrillo, zorra, oso hormiguero, venado cola blanca, pecarí de collar, conejo rabo de algodón, tejón solitario, tejón de manada, martucha, puerco espín, varios otros mamíferos y gran número de especies de aves y reptiles, y entre ellas tortugas, cocodrilos e iguanas. Muchos miembros del grupo se dedican a la pesca en las lagunas y albuferas litorales, donde los excedentes se salan para su conservación. En los lugares comunicados se seleccionan los productos pescados o capturados, realizándose el congelamiento y envío a los mercados de Pinotepa Nacional, Acapulco y la Ciudad de México de los mejores ejemplares. La Laguna de Chacahua, en razón de ser Parque Nacional, posee actualmente y desde hace algún tiempo, un área de repoblación de cocodrilos, hoy amenazada por ambiciosos y por bocabarras que se tapan, y, junto con las demás lagunas litorales, es un importante santuario de aves de ribera, acuáticas y migratorias.

Hasta la introducción de la lancha de fibra de vidrio con motor fuera de borda, fue tradicional que las canoas se hicieran de troncos ahuecados de ceiba o parota, y en ocasiones de guanacaxtle, caracterizadas por su longitud, determinada por el tamaño lineal del tronco del árbol utilizado. Ese fue el elemento básico para pescar o para navegar en ríos y lagunas litorales y en alguna época debieron tener estabilizador, porque ese rasgo existió en Mesoamérica. 

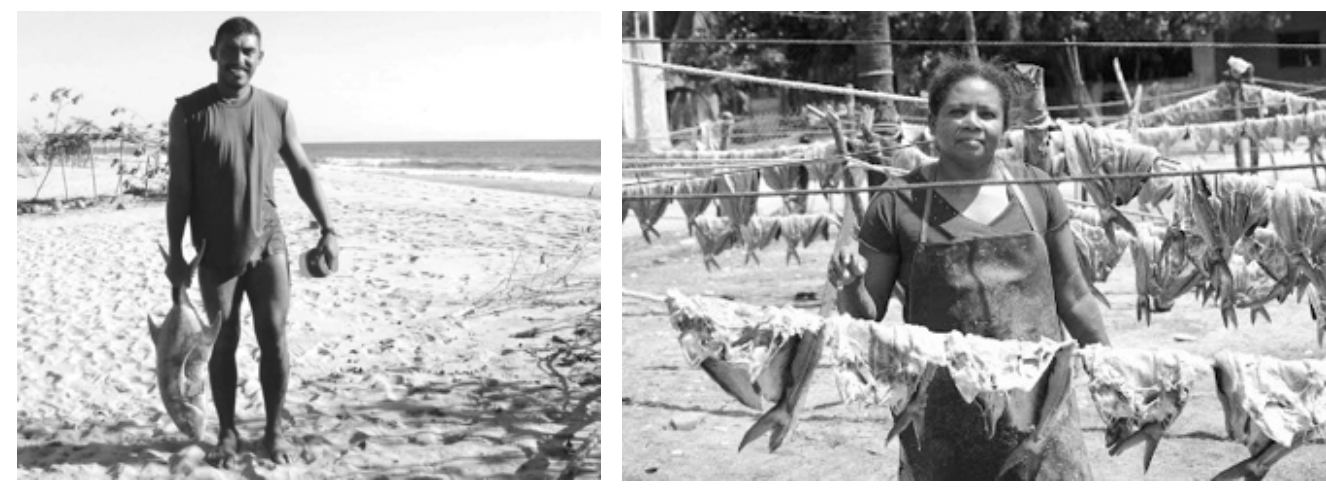

Pescador afromestizo con jurel y secadero y secadora de pescado

(Fotos: Africa A.C.)

MERCADOS. En las varias poblaciones donde el grupo tiene presencia es habitual ver mujeres dedicadas a la comercialización de pescados y mariscos. Esa es una escena frecuente en Pinotepa Nacional. Parte del pescado salado es comercializado hacia la mixteca alta. En todas las poblaciones se compran y venden verduras y frutas, de las que la región es pródiga. Desde mucho tiempo atrás, a los miembros del grupo se les reconoce como honestos, honrados y cumplidores en los casos en que se les otorgan créditos.

ARTESANIAS. Pocas artesanías presenta el grupo afromestizo. En ellas descuella la preparación de artesas, de máscaras de madera y la elaboración de pequeñas guitarras del tipo de los tresillos. En los Siglos XVIII, XIX y en la primera mitad del XX, algunas mujeres usaron el telar de cintura, logrando huipiles, refajos y bandas.

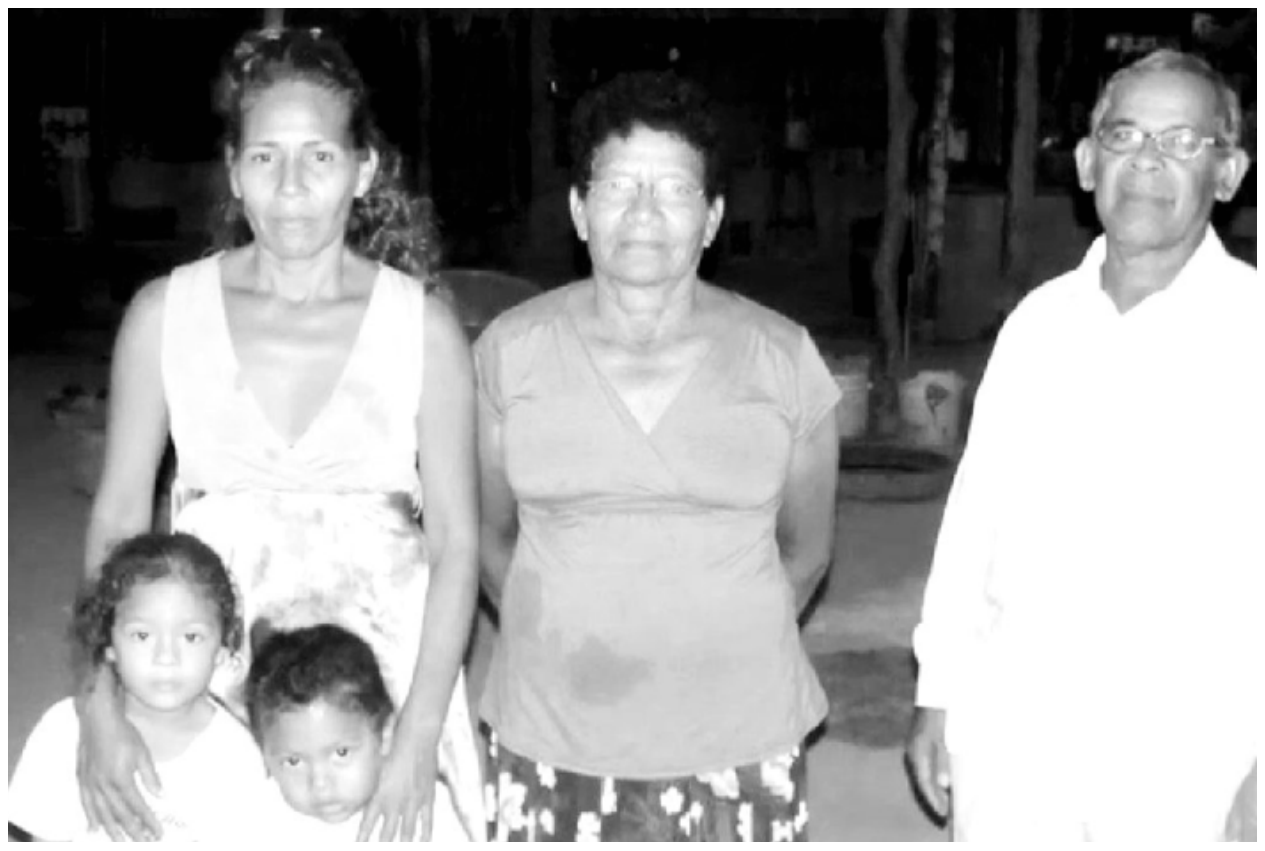

Familia afromestiza. (Foto: Africa A.C.) 
ORGANIZACIÓN SOCIAL. En el grupo rige la patrilocalidad, y cuando falta el padre lleva su representación la madre, primero, y el hermano mayor, a continuación. Hay en el matrimonio una relativa igualdad, lograda por las mujeres, muy fieles y exigentes, ante la relativa necesidad de salir a vender sus productos. Habiendo casi desaparecido las costumbres del Siglo XVIII, lo esencial de los rituales deriva de las prácticas del catolicismo, por lo que existen las Mayordomías y los compadrazgos. Fue habitual que el matrimonio se efectuase cuando los contrayentes tenían aproximadamente 18 el joven y 14 a 16 años la muchacha, respectivamente, y ahora se efectúa a una edad mayor, existiendo una fiesta posterior en la que se come, bebe y se baila.
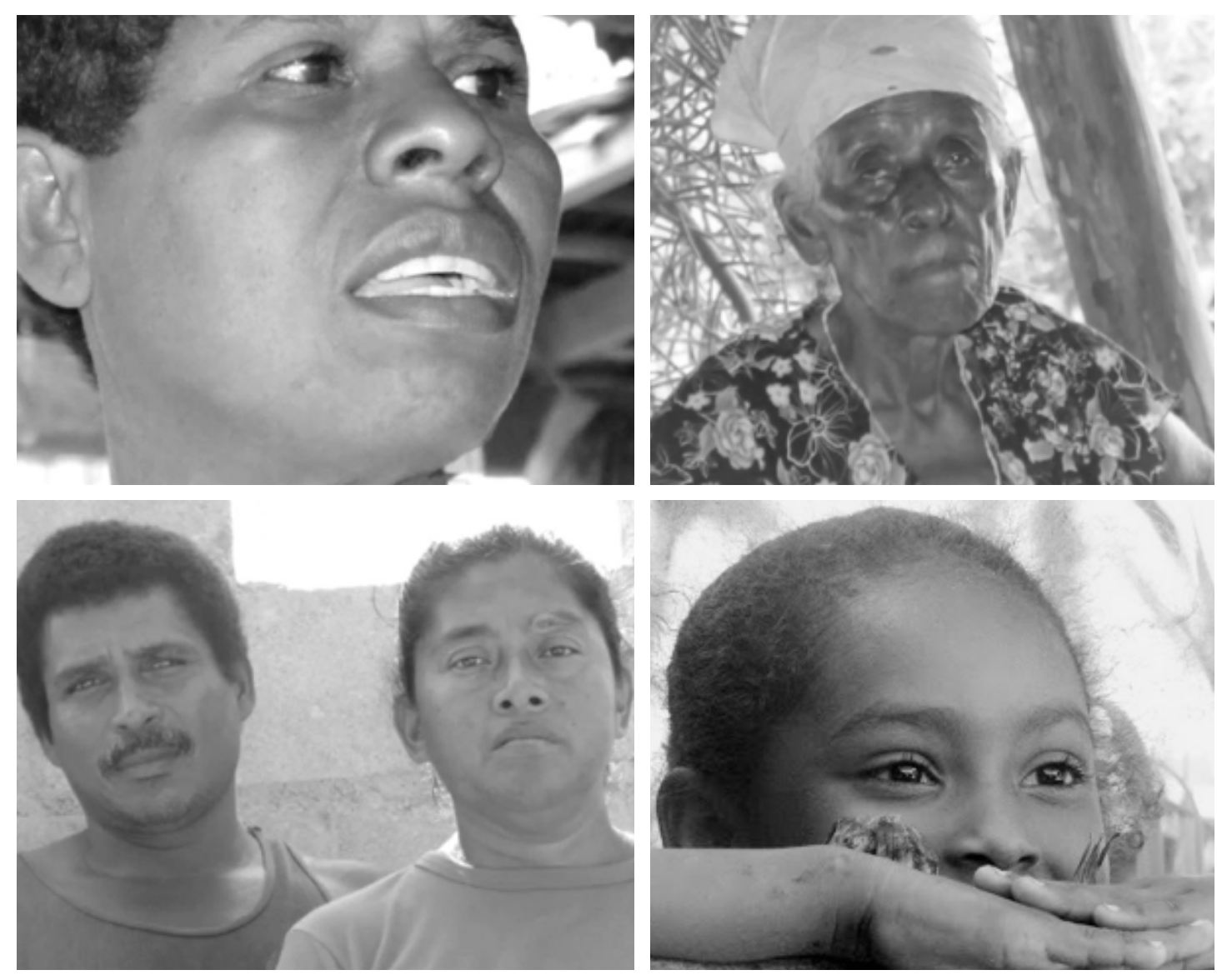

Población afromestiza. (Fotos: Africa A.C.).

Fue habitual el pedimiento de la muchacha, realizado por el padre del pretenso y un Huehue o Huehuete, viejo conocedor y persuasivo, así como que, al regresar de la iglesia, los recién casados recibieran la bendición de los ancianos principales de la comunidad y además sus consejos para una vida productiva, yendo en seguida a habitar su nueva casa, entonces ya conyugal. En la época en que Dn. Manuel Martínez Gracida hizo trabajos sobre ellos (1908), prácticamente no existía la prostitución. Ya hacia 1933, según reporte del Mtro. Carlos Basauri, tal rasgo de encontraba en práctica en viudas y algunas solteras. 


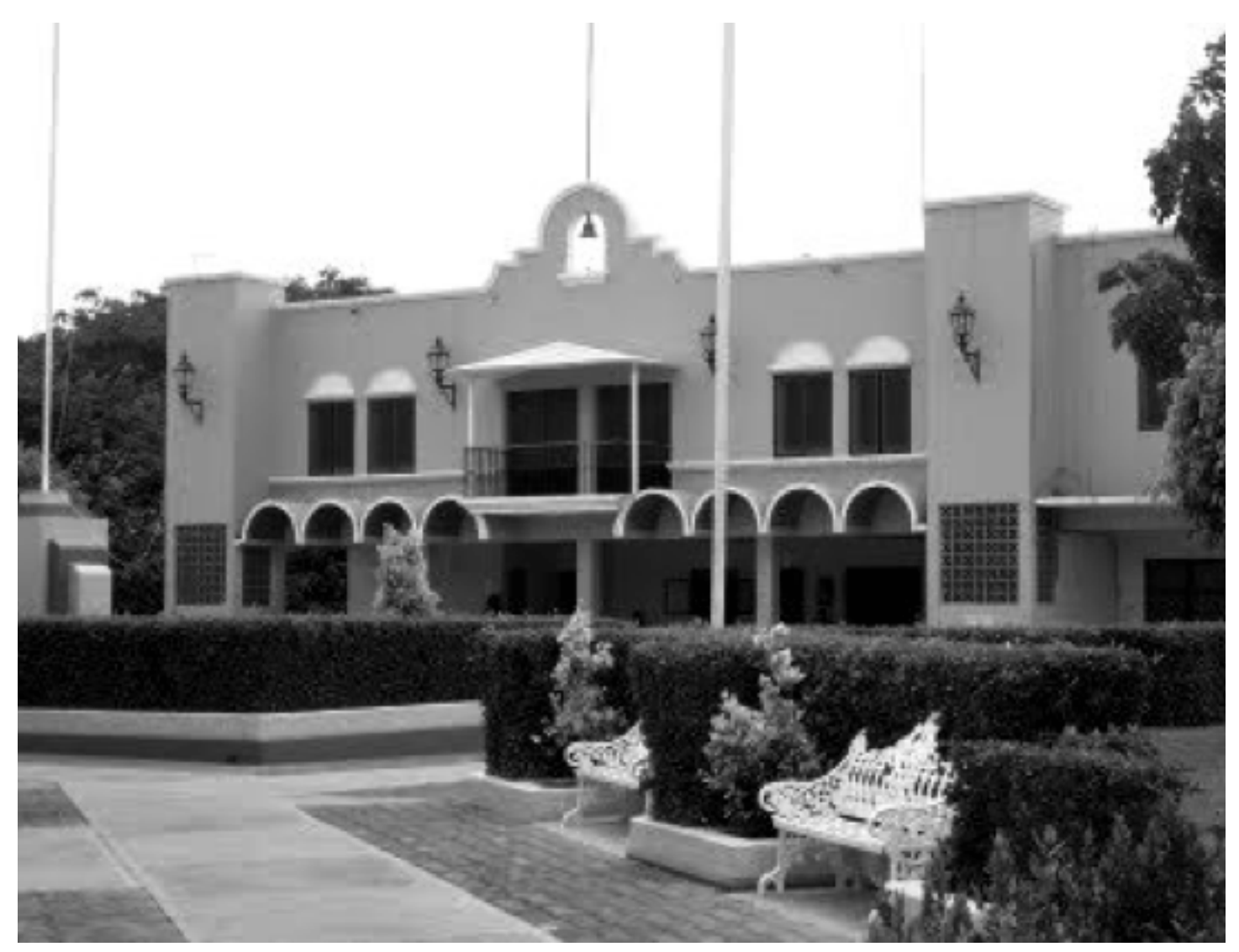

Palacio Municipal de San Miguel Tlacamama. (Dirección de turismo estatal).

GOBIERNO. Independientemente de los sistemas de gobierno que emanan de las autoridades federales y estatales, en la zona se practican otros, similares a los existentes entre los mixtecos y amuzgos, existiendo el consejo de ancianos, los “mandones". En la región la cuestión agraria ha dado lugar, desde el Siglo XIX a cacicazgos que han provocado fuerte disidencia, surgiendo como consecuencia movimientos de oposición, que ahora se engloban en grupos políticos que promueven partidos, el Revolucionario Institucional, el de Acción Nacional y el de la Revolución Democrática. Todos los municipios, aún los de muy alta marginación, como Santiago Tapextla, se rigen bajo el régimen de partidos políticos, con enconadas diferencias entre quienes aspiran a los cargos, debido a que entre otras cosas, ahora conviene ser Presidente Municipal, porque se administran recursos estatales y se percibe un sueldo o se tiene acceso a una cantidad en metálico.

FESTIVIDADES. En los municipios con fuerte presencia afromestiza se realizan un importante número de festividades, descollando las de los santos tutelares de las respectivas poblaciones y las de los fieles difuntos o día de muertos. Esta es una celebración de especial relevancia, en la que participa casi toda la población realizando las diferentes actividades, desde el ir antes del día 31 de octubre al monte a traer las varas y bejucos con los que se hace el altar, y preparar las conservas que se colocarán en él. 


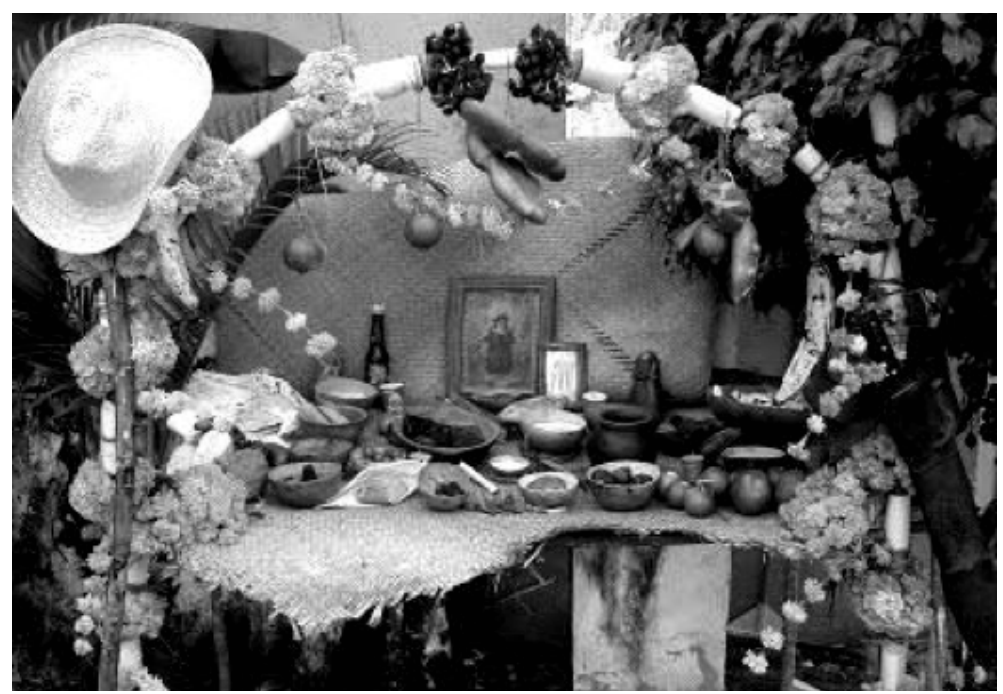

Altar de Muertos de la Costa Chica. (Foto: Dirección de Turismo de Oaxaca).

El altar se adorna con flores amarillas de itacuán y borla y en él se coloca la comida y bebida que más gustaba al desaparecido. A los muertos pequeños se les pone pan chico de muertos, dulces de varios tipos, atole, agua y refrescos. A los grandes, pan de muerto grande, tabaco, cigarros, aguardiente o sotol, atole, frutas, tamales, mole, chocolate y carnes.

Se acostumbra colocar la indumentaria que el fallecido o fallecidos usaron en vida. Así, colocan sombreros, morral, huaraches o sandalias, camisas, blusas, jorongos, machetes, aretes, etc. En el centro del altar se colocan las fotografías, y también imágenes religiosas. Las velas se colocan en un tallo de mata de plátano agujereado. Las veladoras se colocan sobre el altar. Se riegan pétalos de itacuán desde la entrada simulando un sendero por el cual los muertos puedan llegar. El último día por la noche se acostumbra poner velas por todo el camino al camposanto para que cuando se vayan los muertos se lleven sus luces. Se reparte la ofrenda al grito de iofrendai, ¡ofrendai. Entonces, grupos de niños recorren todas las casas del poblado y uno de ellos se va a tocar las campanas, mientras los demás gritan ¡ofrenda para el campaneroj. El día 3, por la tarde, todos llevan al panteón las flores usadas en los altares.
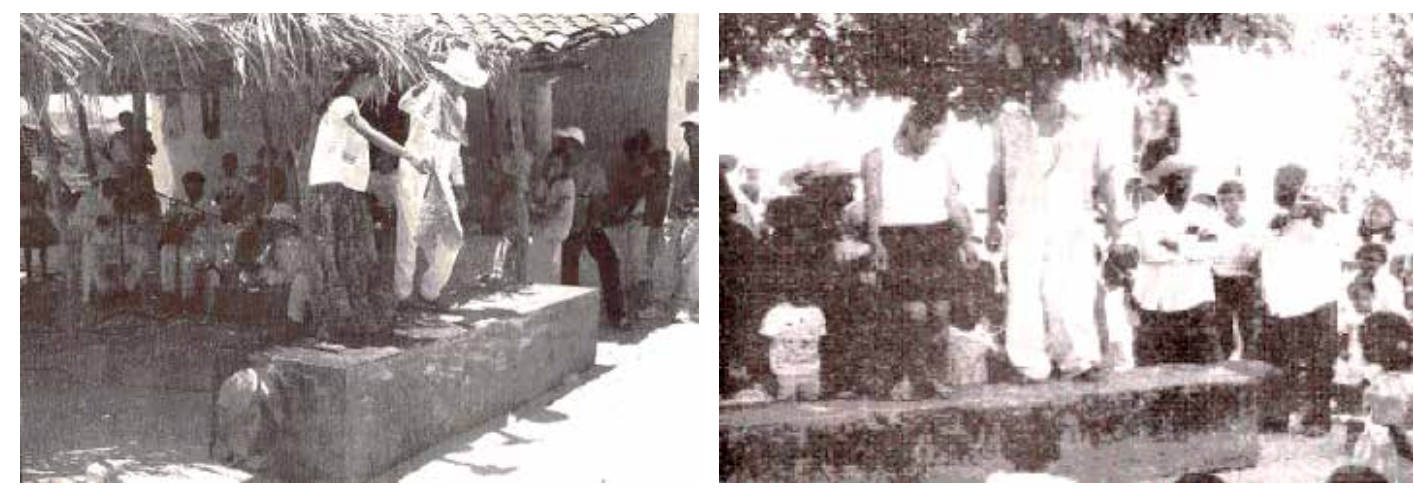

Fandango de la Artesa. (Fotos: Yanet Enedina Betancourt Zarco). 
En las festividades, se ejecutan una serie de danzas, de movimientos libres, y de las que la de los "Diablos", es la más frecuente, ejecutada con máscaras de demonios cornudos que aproximan a lo que encontraremos en el más allá, pero también se bailan las del "Torito de Petate", "La Artesa" (bailada sobre una tarima bien rebajada de tronco de ceiba o parota, con cabeza y cola de caballo y acompañamiento de cajones, varitas y un violín) , "La Tortuga”, "La Conquista” (con su correspondientes Cortés, Moctezuma y Cuauhtémoc) y "Los Doce Pares de Francia" (con su Carlomagno y unos Caballeros Turcos). En la “Danza de los Diablos”, cuyos personajes principales son El Pancho y La Minga, interviene un tambor, una mandíbula de burro llamada charrasca que produce un sonido friccionado como de sonaja, una arcuza y una armónica. Además máscaras y látigos, con los que se finge azotar, o se azota realmente, a los asistentes. Los "Diablos" comienzan su baile frente a la iglesia, continúan por las calles, donde reciben bebidas, ofrendas o dinero, y al atardecer terminan danzando en el camposanto, en una actividad que dura varias horas. Además se bailan chilenas y toda suerte de demás ritmos, pues se trata de gente que quiere y sabe moverse bien. Generalmente los instrumentos usados, excepto la armónica, son del origen del grupo.
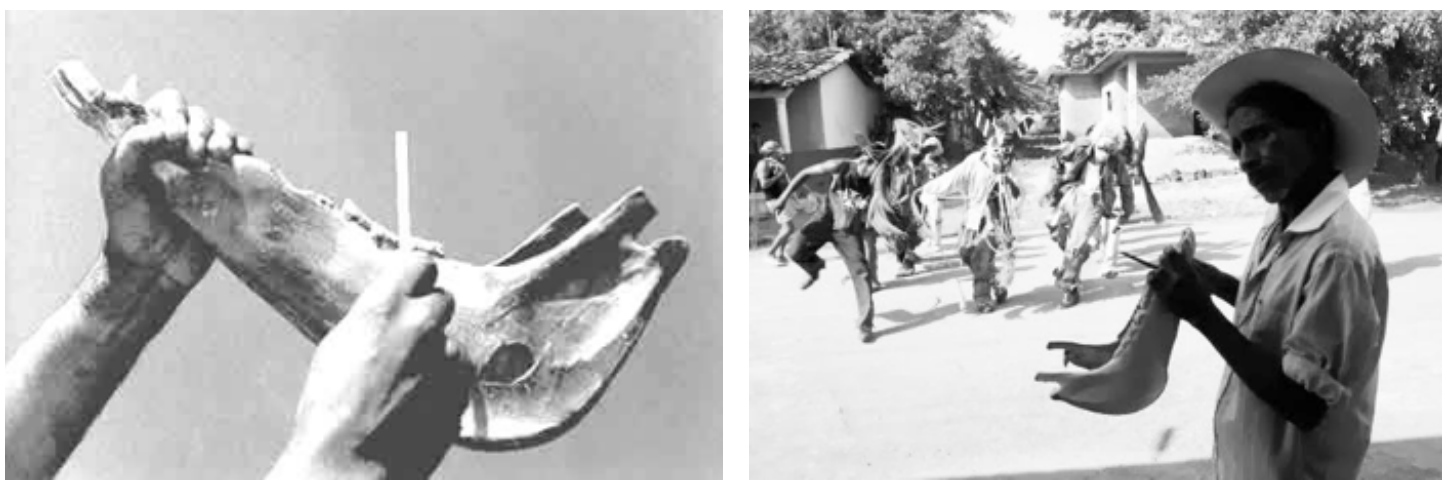

Charrasca. (Fotos: Nicomedes Santa Cruz y Jorge Antonio Díaz Miranda).

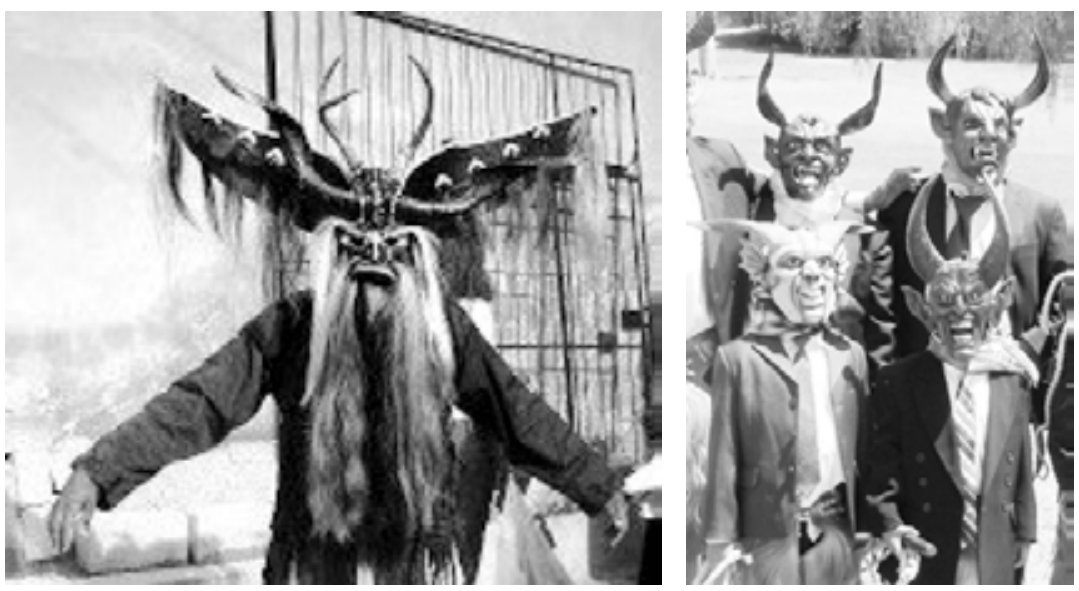

Danza de los Diablos. (Fotos: Jaime López Jiménez). 


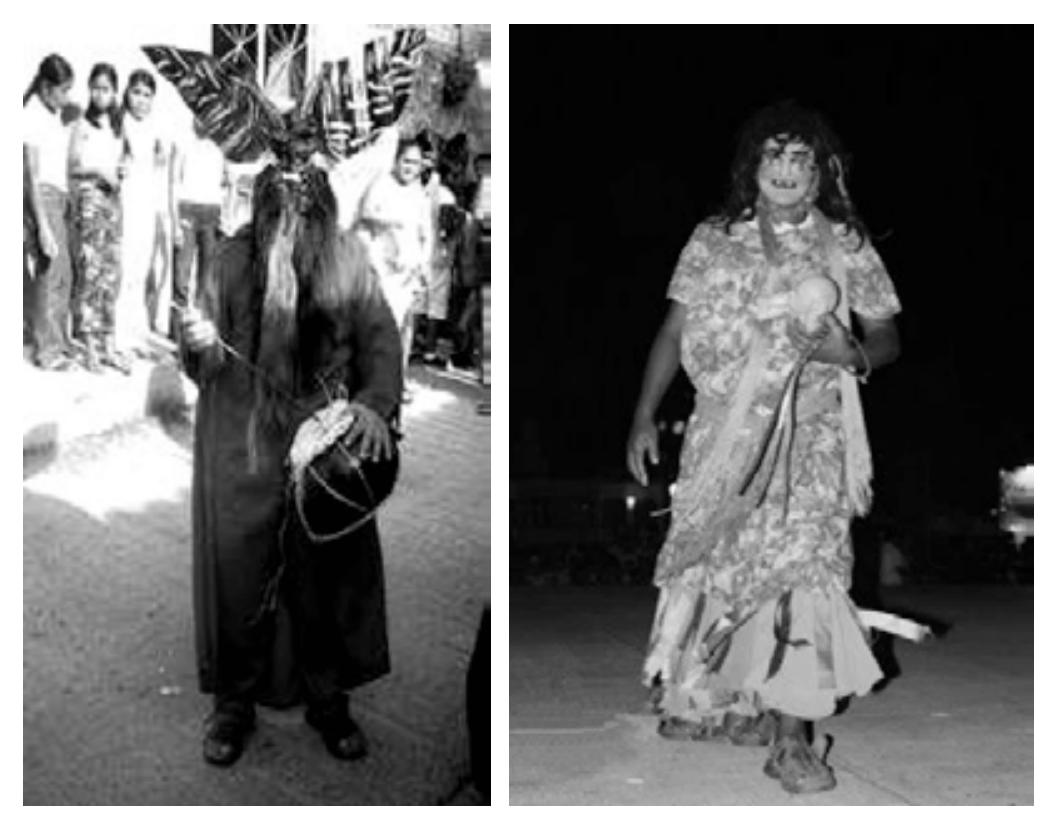

El Pancho y la Minga. (Fotos: AFRICA A.C.)

Hace más de 50 años, hubo sones que se tocaban con violín, guitarra de cinco y un cántaro o botija vacía para el tamboreo. Una versión local de La Malagueña, el Gusto y La Lángora Rumbera son los ejemplos.

Se documenta también que en la primera mitad del Siglo XX hubo grupos de mujeres que, partícipes de barrios diferentes, o secciones de poblaciones, se ponían a competir haciendo versos, y al calor de la competencia se llegaron a pelear, incluso con machetes. Asimismo se sabe, también, que los afromestizos fueron los introductores de la marimba en Oaxaca. Un tipo de marimba con cajas de resonancia más cortas, lengüetas más estrechas y un tamaño menor, marimbas que ya casi no existen. El autor ha visto una conservada en un hotel de Puerto Escondido.

Dn. Manuel Martínez Gracida, en 1906, consignó versos que no han perdido actualidad. Ellos son:

Tengo versos que cantar

Como mil cincuenta y cuatro.

Mi amor ha sido leal,

El tuyo ha sido el ingrato;

Con esto voy a empezar

Para divertirme un rato.

Dame licencia, Señora,

Para que en tu casa cante,

Este corazón amante;

Dicen que por tí no llora, 
Y sí llora a cada instante.

En verso te vengo hablando

Porque a solas no he podido.

Ganas de llorar me dan

De ver que no te he conseguido.

Cuando a la mujer le nace

Del hombre el amor primero.

Luego que se satisface

Quisiera ser maromera

Para deshacer lo que hace.

El que enamora y no da

No tiene conocimiento,

Pues no es posible parar

Una casa sin cimiento.

El enamorar sin dar

Es enamorar queriendo,

Pues ¿cuando había de pensar?

Que usted se andaba vendiendo,

¡Y yo la habría de comprar!.

ORGANIZACIÓN RELIGIOSA. La mayoría de la población profesa de manera oficial la religión católica, aunque ya hay grupos de protestantes y de testigos de jehová que alcanzan cerca del 15\% de la misma. Las iglesias están a cargo de sacristanes y existen comités para su administración, los que se esmeran para el lucimiento de las fiestas. Por otra parte, existe la santería y también comienza a haber devotos de la Santa Muerte.

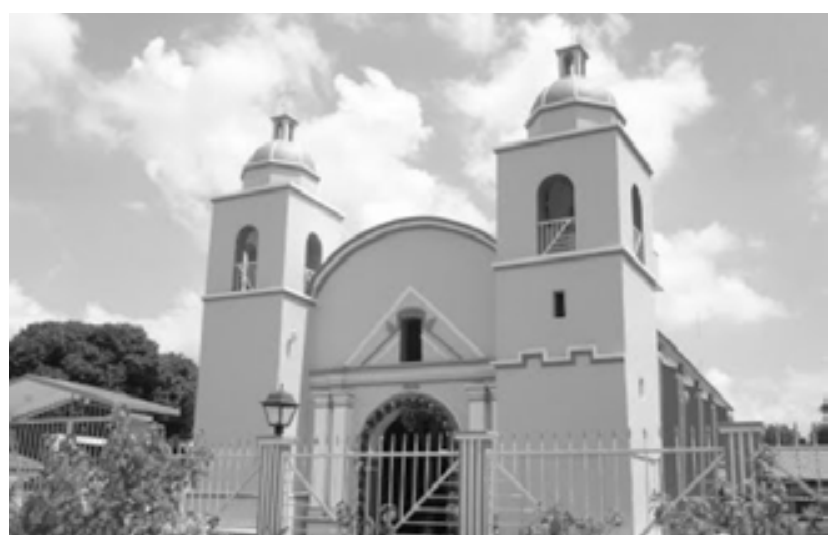

Iglesia de Tlacamama. (Foto: Rolando Domínguez Flores). 
MEDICINA Y MAGIA. En el grupo subsisten prácticas médicas tradicionales. Como la región es rica en vegetales, se conocen y aplican multitud de hierbas, de las cuales echan mano curanderos y parteras empíricas. En gran parte esto ha sido posible porque ha existido el mestizaje con mixtecos, chatinos y amuzgos, quienes han transmitido esos conocimientos, además de los propios del grupo, habiendo sido tradicional que los nacimientos fueran atendidos por curanderos y parteras empíricas. Como en casi todo el país, desde hace unos cuarenta años se comenzaron a instalar en las principales poblaciones Centros de Salud atendidos por pasantes de medicina y enfermería, los cuales han resuelto problemas de primer nivel, con cada vez menos recursos. Sólo en Pinotepa Nacional existe un hospital de zona, que en caso necesario se auxilia con el de Pochutla. Recientemente, se crearon dos pequeños hospitales más. Uno en Lo de Soto y otro en Jamiltepec.

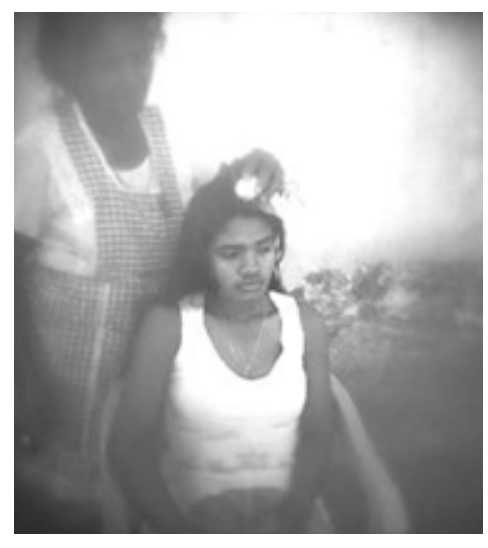

Curandera Afromestiza. (Foto: Wendy Phillips).

EDUCACIÓN. El área está atendida por una red de escuelas pre-primarias, primarias y secundarias. Hay además tres Colegios de Bachilleres en Pinotepa Nacional, Lo de Soto y Pinotepa de Don Luis, Se está instalando en Pinotepa Nacional una Universidad del Sistema Estatal, y otra en Collantes y se trabaja en esos sentidos. Es de desear que en las escuelas de esa región y de todo el país se combata fírmemente la discriminación y el racismo. Como ya se dijo, los negros o afromestizos oaxaqueños representan una riqueza pensante, laboral, económica, social y cultural que nuestro país no puede, ni debe, desperdiciar.

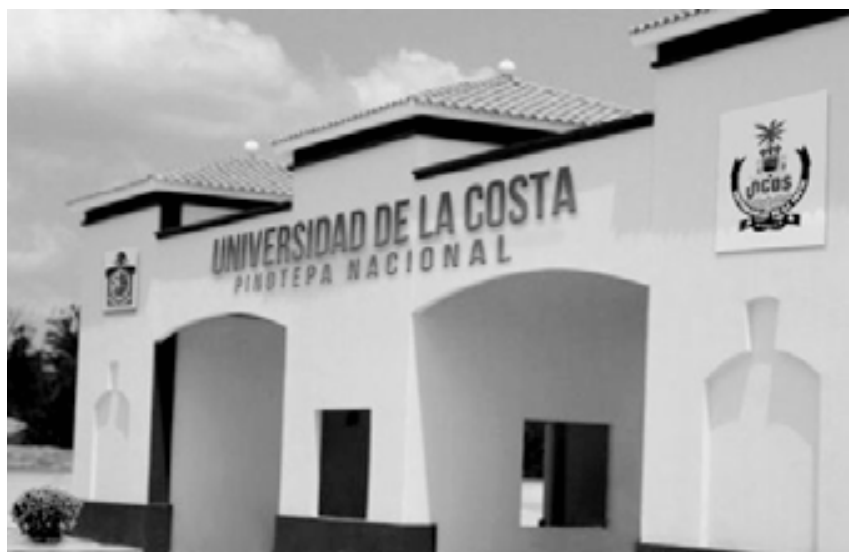

Universidad Estatal en Pinotepa Nacional. (Foto: Sistema de Universidades Estatales) 


\section{BIBLIOGRAFÍA}

Acevedo Conde. María Luisa. 2008 "Los Negros en Oaxaca”. En: Revista. ACONTRAGOLPE. Nos 24 y 25. Carteles Editores. Oaxaca, Oax. 2008.

Alfaro, Mara. Escalona, Inti. 2002 "El Proceso de Colonización, poblamiento y formación de localidades". En: REFLEJOS DE UN PARQUE. Coord: Mara Alfaro. CONANP, PNUD, CIESAS. Plaza y Valdés, Ed. México, 2002.

Basauri, Carlos. 1940 "Población Negra".

Reed. 1990 En: LA POBLACION NEGRA DE MEXICO. Tomo III. Instituto Nacional Indigenista, SEP. México, D F. 1990.

Campos, Luis. 1999 "Negros y Morenos. La Población Afroamericana de la Costa Chica de Oaxaca”. En: CONFIGURACIONES ÉTNICAS EN OAXACA. PERSPECTIVAS ETNOGRAFICAS PARA LAS AUTONOMIAS. Coords: Miguel Bartolomé y Alicia Mabel Barabas. INI, CONACULTA, INAH. México 1999.

2007 LOS NEGROS DE OAXACA, TRASFONDO DE UNA CONSTRUCCION IDENTITARIA. Etnografías Mínimas. Editor: Daniel Quiroz Larrea. Buenos Aires. República Argentina. 2007.

Demol, Celine y Tanat, Oscar. 2012 "Afromexicanos: Por la Visibilidad, el Reconocimiento y el Desarrollo". Revista El Jolgorio Cultural. No 45. Oaxaca, Oax. Enero 2012.

Instituto Nacional Indigenista. 2002 PUEBLOS AFROMESTIZOS. INI. México, D F. 2002

Krickeberg, Walter. 1962 ETNOGRAFÍA DE AMÉRICA. Fondo de Cultura Económica. México, D F. 1964.

Le Riverend Brusone, Julio. 1963 "Afroamérica” En: CUADERNOS AMERICANOS. Vol. Marzo- Abril de 1965. México, D F. 1965. Ngoumbe, Nicolás. 1994 EL AFRICA BANTU EN LA COLONIZACION DE MEXICO. Agencia Española de Cooperación Científica del CSIC. (Consejo Superior de Investigaciones Científicas). Madrid. España. 1994.

Portillo, Andrés. 1910 OAXACA EN EL CENTENARIO DE LA INDEPENDENCIA NACIONAL. 2a Edición. Carteles Editores, Oaxaca, Oax. México. 1910-1992.

Traffano, Daniela. 2012 "Historias e Imágenes del Siglo XX: El Estado de Oaxaca desde sus regiones”. En: CUADERNOS DEL SUR NN 33. Revista de Ciencias Sociales. IISUABJO, CIESAS Carteles Editores. Oaxaca, Oax.

Velázquez Gutiérrez, María Elisa. 2013 La Raíz Africana en México”. En: REVISTA, RELATOS E HISTORIAS EN MÉXICO. Año VI. No 61. Editorial Raíces. México, D F. 2013. 



\section{ZAPOTECOS}

Autodenominación: ben'zaa, binni zaa, didya tizaa.

Sinónimo en su lengua: didxaza, diidzaj, diatza'e.

Significado : Gente de las Nubes. Gente que proviene de las nubes.

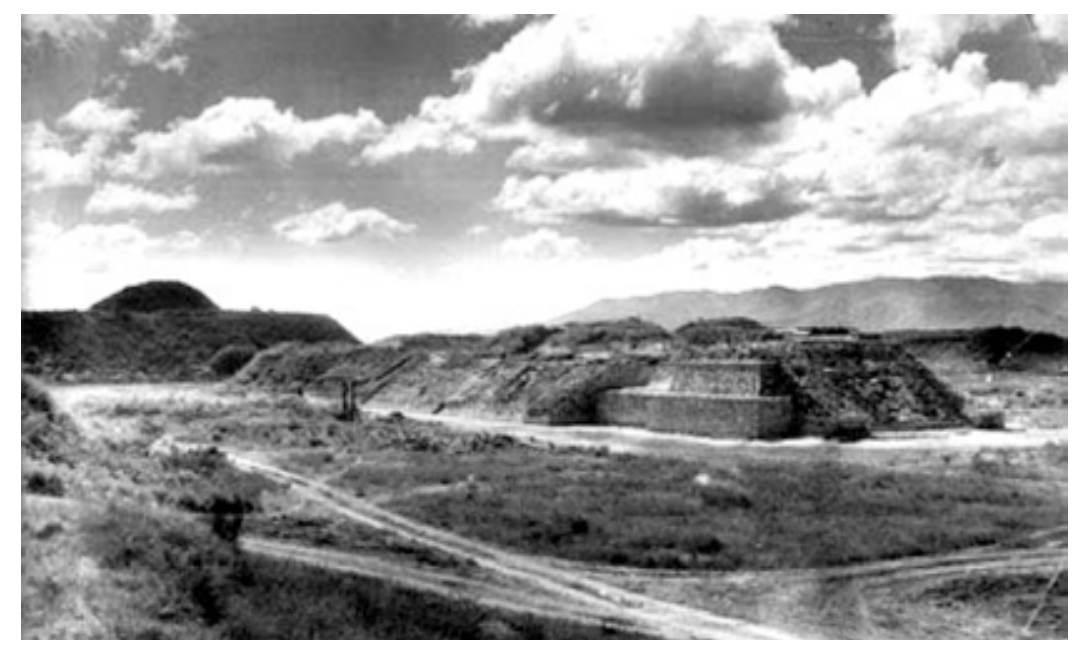

Monte Albán en 1940. (Foto: Arql. Alfonso Caso Andrade)

\section{GRUPO ZAPOTECO}

UBICACIÓN GEOGRÁFICA. Extendido en la región central, norcentral, y oriental del estado de Oaxaca, el grupo Zapoteco se encuentra distribuido en los Distritos del Centro, Etla, Ocotlán, Tlacolula, Ejutla, Miahuatlán, Yautepec, Zaachila, Zimatlán, Choapan, Tehuantepec, Pochutla, Juchitán, Villa Alta y Sola de Vega. Tal conjunto de distritos queda inscrito dentro de un cuadro delimitado por los $15^{\circ} 40^{\prime} 20^{\prime}$ y los $17^{\circ} 47^{\prime}$ de latitud norte y los $93^{\circ}$ $40^{\prime}$ y $96^{\circ} 30^{\prime}$ de longitud occidental: Dentro de este territorio y colindando con los zapotecos, vive también más de la mitad de los grupos indígenas del Estado. Sin embargo, cabe señalar que, desde hace algún tiempo, el grupo se extendió fuera de los límites del mismo, habiendo existido enclaves en territorios mixtecos y nahuas. Debido a que el grupo ocupa un área muy superior a los 40,000 kilómetros cuadrados, el mosaico fisiográfico y climático que ese territorio incluye es muy grande y muy variado. Las alturas sobre el nivel del mar fluctúan entre 0 y 3160 metros, y por esa razón los climas y la precipitación pluvial 
varian de manera muy sensible. La Sierra Norte presenta una vegetación, en su parte alta, compuesta de bosques de coníferas, algunas de cuyas áreas han sido objeto de procesos irracionales de explotación y sobreexplotación.

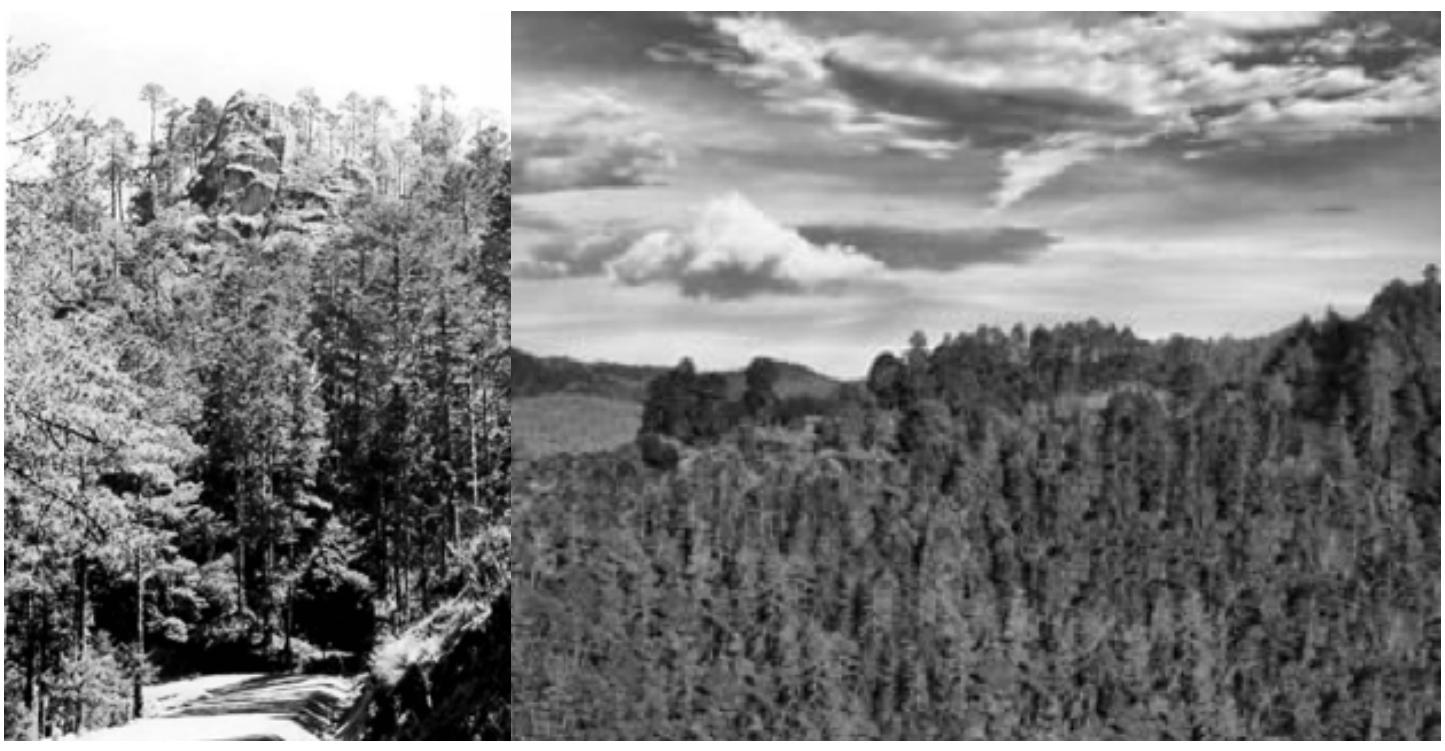

Bosque de Oyamel en Cuajimoloyas y Cresta de Nevería. (Fotos del autor).

Tanto en niveles más bajos, como en la vertiente oriental, prospera una selva media perennifolia muy rica en fauna y variedades vegetales, la cual se extiende hasta las zonas de media altura de la Cuenca del Papaloapan, donde ya ha sido talada con fines de producción forestal, agrícola y ganadera. Los suelos de esta área son ricos en materia orgánica, que generalmente, presentan la forma de migajones negros en las partes altas y la de limos rojizos en las bajas, aunque es frecuente encontrar, también otras texturas arcillosas con cierto grado de intemperización y oxidación. Los climas varían dentro de la gama de los tropicales húmedos y subhúmedos con lluvias todo el año y en verano, con precipitaciones pluviales anuales que fluctúan entre los 800 los 2500 milimetros. En la Sierra Norte, una parte de la cual es la Sierra de Ixtlán o Sierra Juárez, como consecuencia de densa y frecuente nubosidad, se mantiene un índice anual muy elevado de humedad. La región se encuentra totalmente dentro de la cuenca del Río Papaloapan, siendo sus principales corrientes: el Río Grande o de Ixtlán , los Ríos Truchas y de Valle Nacional, así como parte de la cuenca baja del Río Santo Domingo. En la región que se describe, los vientos dominantes soplan del norte a gran altura impulsados por los índices de humedad y calor que se presentan sobre las montañas y en verano los vientos sur ocasionan una permanente condensación.

En la zona Zapoteca del Istmo, que comprende los distritos de Tehuantepec, Juchitán y parte de San Carlos Yautepec, prospera en sus partes altas una vegetación de coníferas, tanto en las crestas de Sierra Atravesada como en las estribaciones en la Sierra Mixe, (región de Guevea de Humboldt), ambas ya sujetas a explotación forestal, En zonas de media 
altura de la misma Sierra Atravesada, prospera la selva media caducifolia, a la que sigue un monte bajo de chaparral en la región costera y llana del Istmo de Tehuantepec, mientras que el manglar se encuentra en los bordes de las lagunas costeras. Aparte, como ya se mencionó, los suelos en las partes altas se encuentran conformados de migajones negros, producto de descomposición de materia orgánica, mientras que los de las partes bajas llanas y costeras son suelos arcillosos fuertemente intemperizados con gran contenido de sílice y micas. Aparte, por su naturaleza, los climas caen dentro de los tropicales subhúmedos con lluvias en verano, registrándose una precipitación anual que fluctúa entre los 600 y los 1400 milímetros. En esta vertiente de la sierra existe un índice de nubosidad mayor debido a la presencia de masas de aire húmedo que se presentan sobre la Sierra Mixe, pero al descender hacia la llanura costera de la vertiente del Pacífico, las zonas alternantes de alta y baja presión establecen un régimen convectivo de vientos que corren principalmente de norte a sur y que, al desarrollar altas velocidades generan una sequedad de elevados índices. Aparte, la región está regada por varias corrientes, la mayor parte de las cuales vierte sus aguas a los ríos Tehuantepec y De los Perros, mientras que los ríos Santo Domingo, Niltepec, Cazadero. Zanatepec-Zuluapa y Novillero, lo hacen a la zona oriental.

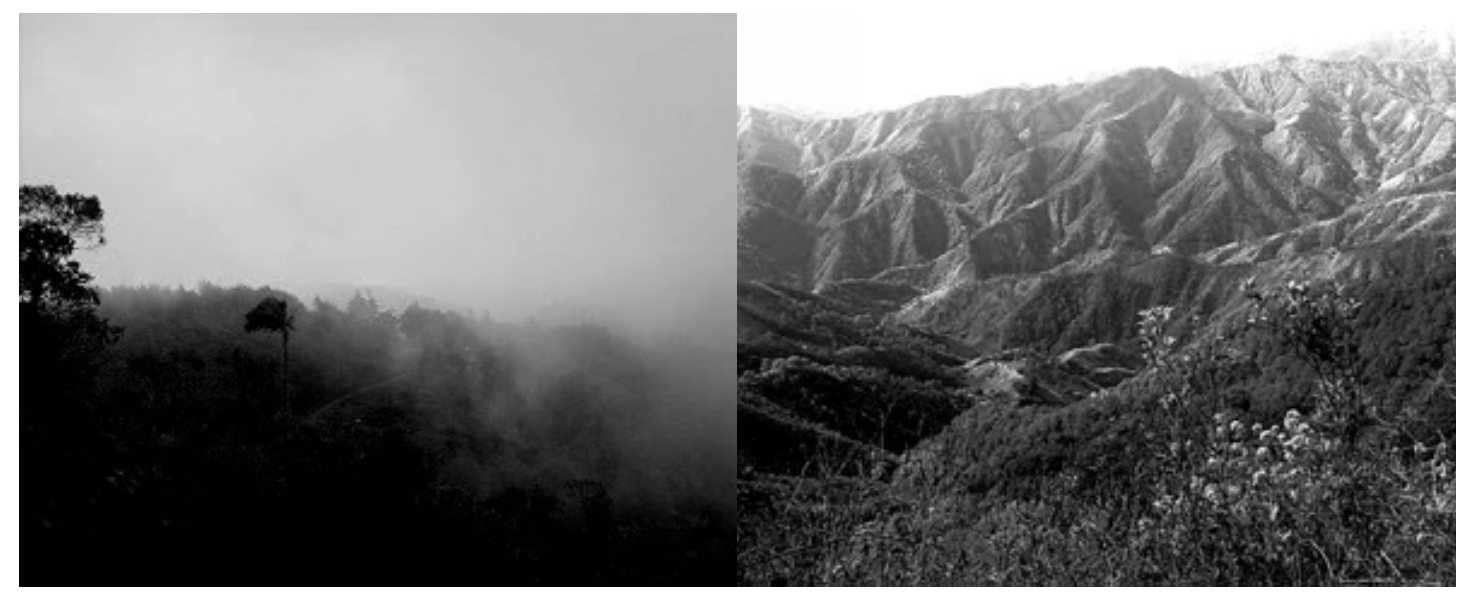

Bosque de Oyamel en Cuajimoloyas y Cresta de Nevería. (Fotos del autor).

La región de la Sierra Sur presenta en las montañas un ya no tan denso arbolado de coníferas ya también sometido a sobreexplotación. En las zonas de media altura de la vertiente del

pacífico puede observarse una faja de monte perennifolio donde, desde el Siglo XIX se ha implantado una zona cafetícola. En las zonas costeras existe una selva media caducifolia casi absolutamente inexplotada y muy rica en maderas tropicales poco valoradas, plantas medicinales y otros muchos recursos mínimamente aprovechados. Los suelos de las partes altas son arcillosos, muy intemperizados y con alto contenido de sílice y micas, habiendo capas humíferas en las zonas de mayor arbolado. En las partes medias y bajas se alternan suelos arcillosos de color negro con algunos de color rojizo o amarillo, sumamente micáceos y siempre expuestos a intemperización. Los climas regionales quedan 
totalmente inscritos dentro de los tropicales subhúmedos con más del 80\% de la precipitación anual en los meses de verano, cuya caída fluctúa entre los 800 y los 1500 milímetros. Mientras tanto, en las vertientes occidental y sur de la sierra, el índice de nubosidad es elevado, principalmente en las cuencas altas de los ríos Ozolotepec, Cozoaltepec, Tonameca y Copalita. Los índices de humedad más elevados ocurren en verano, cuando los vientos soplan de sur a norte.

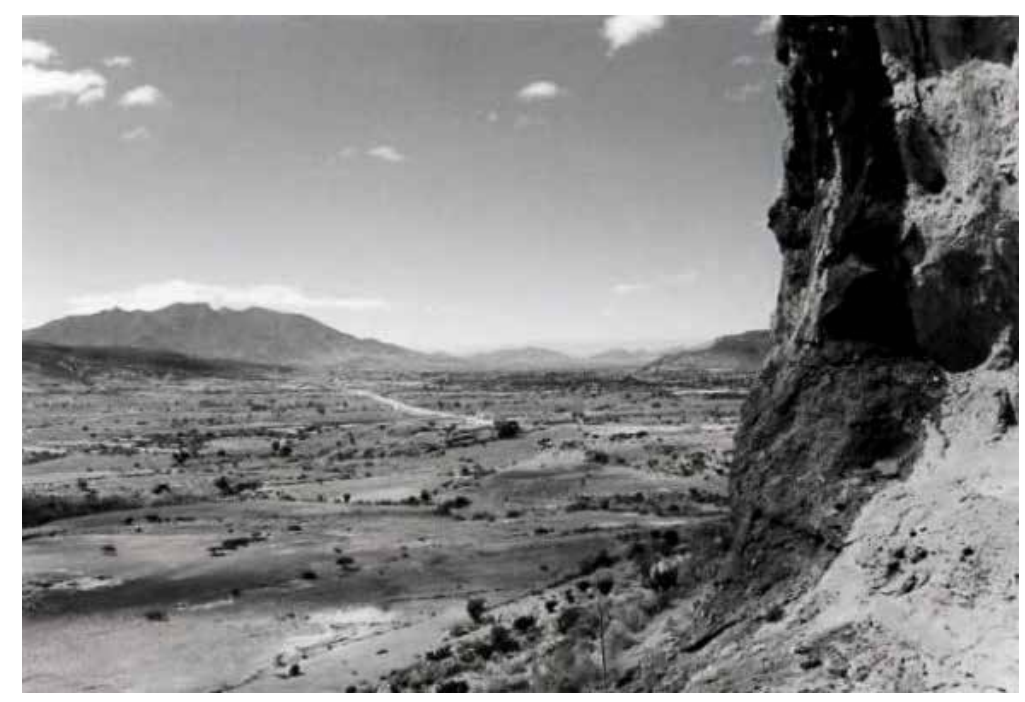

El valle de Tlacolula desde los abrigos de Xaagá. (Foto del autor).

Los Valles Centrales configuran una Y griega cuyos brazos están definidos por los Valles de Etla y Tlacolula, mientras que su base la configura el complejo de Valles de Zimatlán-Ocotlán, a los que vierten las corrientes que provienen de Ejutla y parte de Miahuatlán. Las alturas sobre el nivel del mar fluctúan entre los 3160 metros para el cerro de San Felipe del Agua y los 1200 metros para la entrada al Cañón de Ayoquezco. Las áreas que rodean los valles, y particularmente las laderas de su cuenca, conservan un bosque de coníferas (pino-encino) muy depredado y en constante peligro de desaparición, que en otro tiempo fue bastante denso. A mediana altura, la ladera presenta actualmente un chaparral bajo de encinos y guajes asociado frecuentemente con vegetación xerofítica, mientras que tanto en sus áreas bajas, como en las de los fondos, se practican diferentes tipos de agricultura, principalmente de temporal, con solo un pequeño porcentaje de riego, subsistiendo un contado número de localidades donde el riego con cántaro puede verse aún, sobre todo en poblaciones del occidente del Valle de Etla y en los alrededores de Zaachila, ahora muy agredido por el desplome de los mantos freáticos. Los suelos de la región son arcillosos, de colores gris, rojizo y negro, producto de desintegración de rocas volcánicas y también de rocas paleozoicas y cenozoicas destruidas por la intemperización. Los climas son tropicales subhúmedos con lluvias en verano, con una precipitación anual que fluctúa entre los $600 \mathrm{y}$ los 860 milímetros. El índice de nubosidad es bajo, si bien aumenta en los meses de verano cuando los vientos dominantes soplan del sur. 
La actividad geológica efectuada durante las eras mesozoica y cenozoica dio origen a una serie de factores tectónicos y físicos, configurando la orogenia y una falla, mientras que la labor excavadora de dos ríos, el Atoyac y el Salado, dio a los Valles Centrales su actual configuración. Existe la creencia de que en los valles centrales hubo un gran lago. Me permito observar que se trata de una cuenca exorreica donde el agua recorre ochenta kilómetros con un desnivel que comienza a los 2300 metros sobre el nivel del mar (en Las Sedas) y descarga a los 1200 (en el Cañón de Ayoquezco). Con ese desnivel nunca pudo haber un embalse, porque la inclinación hace correr el agua, aunque hubo, y hay, zonas bajas de nivel freático muy alto que hizo aflorar agua (en el sector de Roaló, en San Juan Teiticpac y en La Ciénega de Zimatlán), pero esa agua siempre estuvo en un movimiento muy lento, casi imperceptible..

IDIOMA. La lengua zapoteca pertenece al grupo Otomangue, Tronco Savizaa. Familia Zapoteca. Es una lengua que ha sufrido profundas modificaciones a través del tiempo, las cuales han sido detectadas por investigaciones efectuadas desde el siglo XIX, hasta nuestros días. Por ellas se sabe que hasta el año de 1970 existieron seis variantes ininteligibles entre sí en diferentes regiones del Estado. En la Sierra Norte por lo menos había cuatro: la Serrana, la Villalteca, la de Nexicho y la de la zona de los Cajonos. En el Istmo de Tehuantepec, el Tehuano y el Juchiteco. En la Sierra Sur el Miahuatleco y además las variantes de Valles Centrales. Tanto las variantes de Sierra Norte como el Miahuatleco de la Sierra Sur presentan sub-variantes dialectales, y en el Istmo existen diferencias en el habla entre Tehuantepec y Juchitán, y aún entre Juchitán e Ixtaltepec.

En la actualidad se considera que son por lo menos cuatro las variantes básicas de la lengua Zapoteca: Sierra Norte, Sierra Sur, Valles Centrales e Istmo, habladas en total por alrededor de trescientas setenta y ocho mil (378 000) personas distribuidas en el territorio. La lengua se distingue por su riqueza, por su estructura gramatical y por el hecho de existir copiosa literatura tanto en prosa como en verso escrita durante más de 400 años, es decir, desde la época colonial y principalmente en las regiones aledañas a la Ciudad de Oaxaca, así como en el Istmo de Tehuantepec. Datos posteriores indican que las variantes dialectales de la lengua superan las 16 .

DEMOGRAFÍA. La etnia cuenta en el Estado con un poco más de 550000 personas, como ya se aludió en el apartado anterior. No obstante, dentro del grupo se ha venido dando un fuerte mestizaje, sobre todo en las regiones donde se cuenta con recursos naturales o con mejores vías de comunicación. Cabe mencionar que existen variantes físicas entre los cuatro grupos zapotecas tanto en su complexión como en su estatura; tales variantes se han debido en parte a que las posibilidades de nutrición que desde tiempo atrás no han sido las mismas en las diferentes regiones, y menos en la época actual, en que hay poblaciones absolutamente marginadas. Por otra parte también han incidido en este aspecto la estructura familiar, las tradiciones religiosas y las costumbres sociales y cívicas, que en algunas comunidades han tenido que ser cambiadas. A esto debe agregarse la influencia 
de una televisión comercial que promueve la pérdida de identidad a través de estereotipos económico-culturales muy ajenos a lo indígena, lo que también se está observando en términos de salud deteriorada y obesidad.

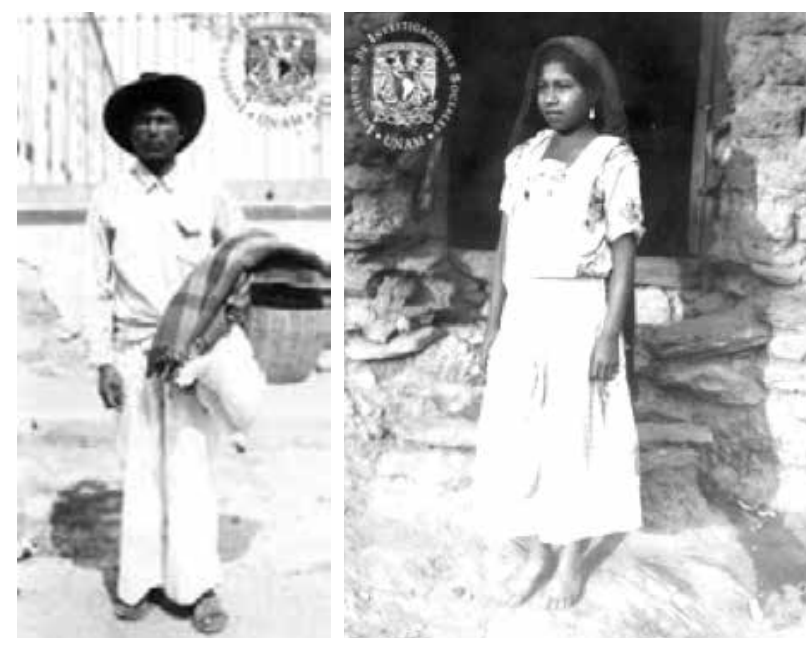

Hombre y mujer zapotecos. (Fotos: IIS-UNAM).

ANTECEDENTES ARQUEOLÓGICOS E HISTÓRICOS. En la actualidad, es virtualmente imposible señalar con exactitud la trayectoria histórica completa del grupo zapoteca dentro del territorio del Estado de Oaxaca. Ello obedece a que una de las razones que impiden tener ese conocimiento es la ausencia casi total de exploraciones arqueológicas en algunas de las áreas que este grupo ocupó y que sigue ocupando, a lo que hay que agregar que en varias de esas zonas también han existido y existen asentamientos de gentes de otras filiaciones culturales (p. ej. mixtecos, cuicatecos y chinantecos) y, en algunos casos, una sucesión de superposiciones culturales con otros grupos (inicialmente olmecas arqueológicos, mixes, zoques, chontales y ahora huaves). El enorme territorio contiene una cantidad muy grande de vestigios arqueológicos, a los que sólo de manera zonal se ha podido dar ubicación en el tiempo y en el espacio, si bien apoyándose en algunos rasgos y estilos culturales es posible dar una colocación tentativa.

En Valles Centrales, la cuenca baja del Río Verde y el Istmo de Tehuantepec ya hay una información mayor. En los primeros, debido a los estudios de los arqueólogos y arqueólogas Leopoldo Batres, Alfonso Caso Andrade, Ignacio Bernal y García Pimentel, Lorenzo Gamio, Jorge Ruffier Acosta, Kent V. Flannery, Joyce Marcus, Richard Blanton, Richard Drennan, Anne Kirkby, Marcus Winter, Nelly Robles y Stephen E.

Kowalewsky. En el segundo, por las exploraciones y reconocimientos superficiales realizados por un equipo de especialistas encabezados por el Arql. Marcus Winter, y en el tercero, por los reconocimientos y pequeñas excavaciones efectuados en el Valle de Tequisistlán, zonas de Tehuantepec y Juchitán, área Huave, Laguna Zope, y los Valles de los ríos Zanatepec y Novillero, realizados por los arqueólogos: Matthew Wallrath, George 
W. Forster, Agustín Delgado, Enrique Méndez Martínez, Luis Rodrigo Álvarez y Roberto Zárate Morán.

Muy recientemente ha habido un incremento en la información como resultado de los reconocimientos efectuados por el Arql. Winter y otro equipo de especialistas distintos de los mencionados, efectuó a lo largo del trazo de lo que será la supercarretera Istmo-Oaxaca. Allí aparecieron ocupaciones de la Etapa de las Aldeas Inferior, y aún datos un poco más antiguos, con algunas cuevas y abrigos ocupados transitoriamente en fases precerámicas de caza y recolección, datos que enriquecen considerablemente los que se obtuvieron años atrás en las exploraciones de las Cuevas Blanca y Guila Naquitz, situadas cerca de Mitla. Todo lo cual dio sustento a que muy recientemente se lograse inscribir esa zona de cuevas y abrigos con yacimientos precerámicos y prehistóricos como Zona de Patrimonio Cultural de la Humanidad.
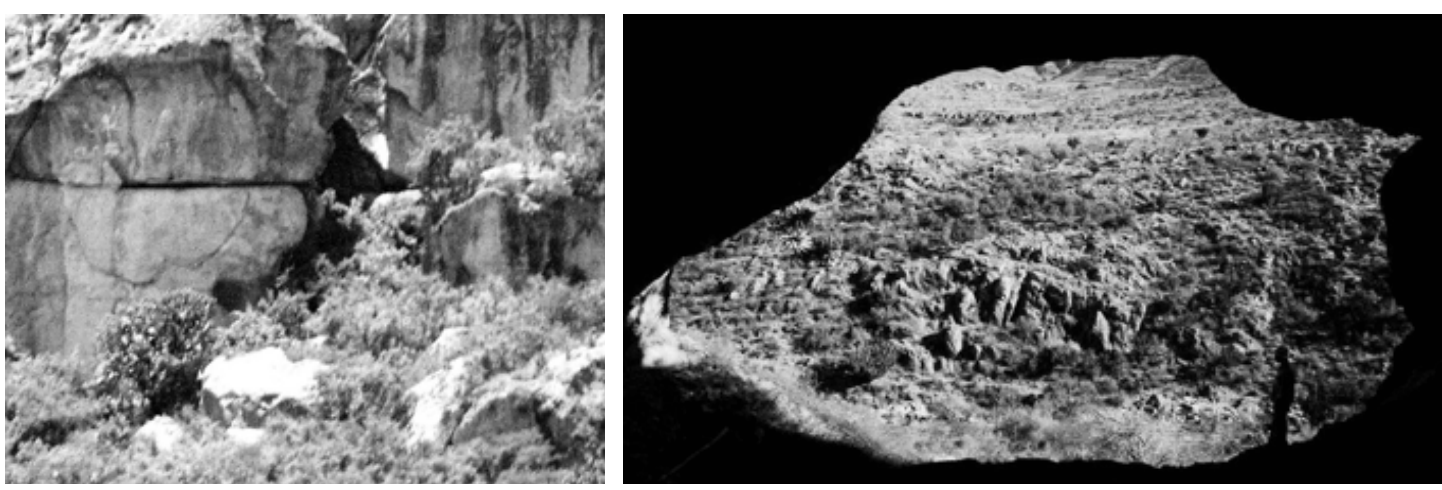

Entrada a la Cueva de Guila Naquitz y el Valle desde una cueva cercana a Mitla. (Fotos UNESCO).

Puede considerarse que en alto grado el grupo zapoteco en los Valles Centrales fue el resultado del encuentro cultural de los pobladores que habían ocupado ese territorio durante los varios miles de años precedentes, con influencias que se integraron a los mismos al finalizar el primer tercio del primer milenio antes de Cristo. Estas influencias pertenecían al complejo cultural olmeca-arqueológico. De esta fusión surgieron una serie de estilos, conceptos calendáricos y cosmogónicos, comienzo de escritura glífıca, concepciones artísticas y modos de vida que dieron origen a la civilización zapoteca tal como ahora la conocemos, resultando de enorme interés que el grupo desde etapas muy tempranas comenzó a terracear las lomas en que vivía, creando así un verdadero soporte para la producción agrícola, que así se vió incrementada con el agregado de la conservación de los suelos y la futura diseminación de los bosques. La arqueología de Oaxaca expone en forma de columna cronológica los por lo menos cinco períodos evolutivos de este grupo, el primero de los cuales se inicia hacia el año 1400 antes de la Era Cristiana, época en la que las muy pequeñas aldeas ubicadas en lomas bajas cerca de los ríos y poseedoras de la práctica de cultivos tales como el maíz, el frijol, el chile, el aguacate y varias frutas más, eran las unidades principales de asentamiento. 
Posteriormente, hacia el año 300 ac., se daría la gestación, introducción y aplicación de conceptos más elaborados, -entre otros el uso del calendario-, las que impulsarían la creación de los primeros centros ceremoniales, entre los cuales se contaron San José Mogote, Monte Albán y San Baltasar Chichicapan, los que ya estarán plenamente establecidos alrededor de la época de Cristo.
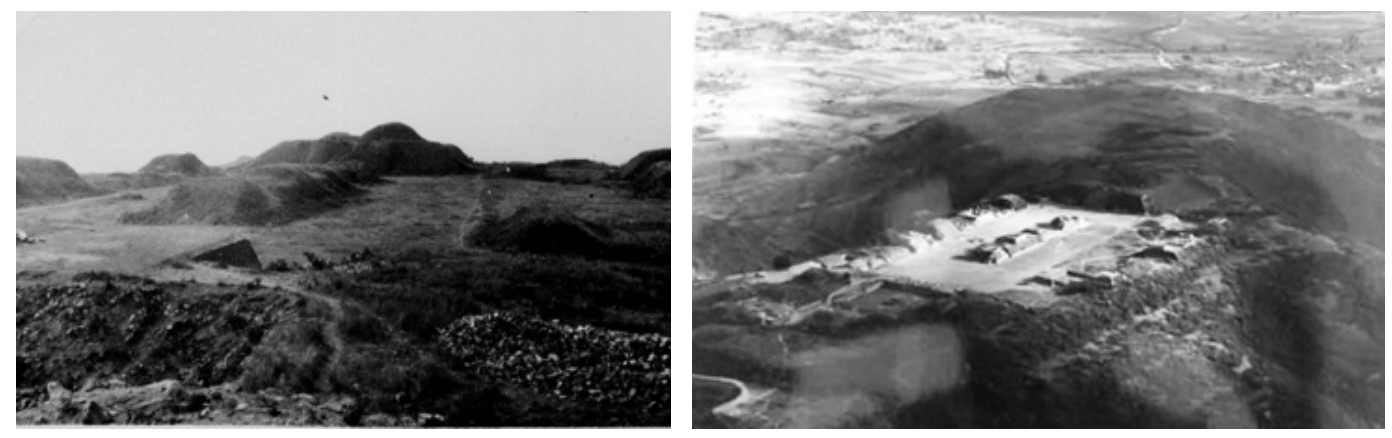

Monte Albán en 1938 y Foto aérea en 1960. (Fotos: Arql. Lorenzo Gamio).

En esta etapa se observa el interactuar de los grupos de la etnia en base a una expansión que se ve en los glifos del edificio J de Monte Albán, donde se habla de localidades situadas en la Cañada y la Sierra Sur, donde también (zona de Sola de Vega) hay una glífica muy relacionada. Después de un período transicional, en que los contactos se diversificaron, y que puede observarse en los estilos cerámicos, un poco antes de la época de Cristo se inició un tercer período que contempla la consolidación de las sociedades teocráticas y la construcción de grandes centros ceremoniales, de los que Monte Albán, El Gallo, Atzompa, Santa Inés Yatzeche, San Baltasar Chichicapan, Reyes Etla, Ayoquezco (El Choco), la primera etapa constructiva en Mitla y Dainzú son ejemplos bastante ilustrativos, en los que la arquitectura y el arte general alcanzaron alturas insospechadas, cuyo motor era el arraigado espíritu místico que exigía el culto a un importante panteón de numerosas deidades, entre las que se encuentran las del fuego, las de la lluvia y las de la fertilidad. Esta etapa terminó al finalizar la primera mitad del primer milenio después de Cristo. Al iniciarse el cuarto período, se observan síntomas de decadencia estilística que llegó a su máximo momento hacia el año 800 de la Era Cristiana, con el abandono de ciertos centros ceremoniales, principalmente de Monte Albán y la redistribución de la población hacia zonas de mayor seguridad y mejores fuentes de abastecimiento de leña y agua, es decir, zonas de ladera y fondos de los valles. Sin embargo, en este período el grupo zapoteco mantuvo su independencia cultural y lingüística frente a la importante presencia nahua que en el centro del país controló zonas geográficas extensas, tales como las de Tula, la Cuenca de México y Cholula.

Las crónicas escritas, la tradición oral y la información arqueológica obtenida principalmente en Valles Centrales, documentan un quinto período que se inicia entre los años 900 y 1000 de la era cristiana, en el cual los centros políticos en los valles se desplazaron sucesivamente a partir de Monte Albán a Zaachila primero y a Mitla después, quedando 
esta última ciudad, ya con edificios espectaculares, como santuario y sede sacerdotal de primera importancia. En este período, como ocurrió en varias partes de Mesoamérica, el grupo conoció y practicó la agricultura de campos elevados, similar a la de chinampas, principalmente en San Juan Teitipac (Tetlicpac) y en La Ciénega, con lo que contó con áreas húmedas de enorme productividad, que alcanzó las tres cosechas de maíz y otras plantas al año. En ese momento, también, los contactos del grupo zapoteco con el mixteco se acrecentaron, ya sea para actuar conjuntamente o para librar guerras, muy posiblemente surgidas en diferencias político-dinásticas. Ante la expansión mixteca el grupo fue perdiendo parte de sus territorios y sólo sería hasta la invasión azteca, emprendida durante el reino de Ahuizotl, que la mayor parte de los territorios zapotecas entraron en la esfera tributaria de Tenochtitlán. Debido a las tensiones que en esa época dieron entre los grupos que entonces poblaban el territorio de lo que hoy es el Estado de Oaxaca, y a efecto de lograr un mayor dominio, los mexicas establecieron una guarnición en la zona de Peña de Armas, elevación montañosa próxima a San Juan Sosola, capturada a los mixtecos después de cruenta batalla, pues desde allí controlarían el tránsito de los comerciantes que desde los Valles Centrales se dirigían hacia la Mixteca Alta y el altiplano, el Anáhuac Ayotlan. En esa misma época tuvo lugar también un importante desarrollo del grupo en el Istmo de Tehuantepec. En esa región, desde la etapa de los primeros asentamientos pre-urbanos, había tenido lugar un proceso cultural desarrollado por grupos de origen proto-mayense (zoques) que habían ocupado la región desde antes de la mitad del primer milenio antes de Cristo. Ya desde los primeros años de la era cristiana habían existido contactos entre grupos zapotecos y los de aquella región. De estos contactos quedan evidencias en Tlacotepec y Laguna Zope: Posteriormente, la expansión zapoteca ejerció fuerte influencia en ese territorio hasta que el grupo lo logró ocupar físicamente en algún momento del primer milenio de la Era Cristiana. Ya para principios del siguiente milenio, en una época estrictamente militarista y en ambos territorios, los principales del grupo zapoteco contaban con centros ceremoniales y fortificaciones importantes.. Yagul y la Fortaleza de Mitla en los Valles y Tehuantepec y Guiengola en el Istmo. La zona Chontal presenció diferendos y guerras entre los zapotecos y sus pobladores. De la evolución del grupo zapoteco en las Sierra Norte y Sur sabemos muy poco. En ambos territorios existen numerosas localidades con vestigios arqueológicos, y lo mas notable es que en muchas de ellas se han encontrado estelas que muestran una escritura glífica muy desarrollada, siendo frecuentes las que contienen registros calendáricos de enorme importancia para los estudios del área.

No es desacertado suponer que durante la primera mitad del segundo milenio d. C. hayan existido frecuentes y estrechos contactos entre los principalatos zapotecos de los valles y los de las localidades de la sierra. La tradición oral habla de una serie de principales que enseñorearon esos territorios, los denominados Zaachila I, II y III, sin que hasta el momento tengamos muchos datos sobre ellos pero que hicieron sentir su presencia, existiendo ya estudios que abordan este tema. Recapitulando, para el momento de la Conquista Española, en sucesión, el grupo zapoteco había recibido aportaciones culturales de los 01mecas Arqueológicos, de los Olmecas-Históricos o Xicalancas, de otros grupos mayenses, 
del grupo Teotihuacano y de toda la tradición Culhua-Tolteca que le siguió en Cholula y en la Cuenca de México, la cual tuvo su momento máximo en la expansión mexica.

La Conquista se caracterizó, además de por el encuentro desproporcionado de fuerzas desiguales, por la saña mostrada en la destrucción cultural del grupo zapoteco. Fueron varios los lugartenientes de Cortés que participaron en la conquista del territorio. El primero fue Gonzalo de Umbría, quién, como la primera cuña, recorrió la zona mixteca de Teposcolula, y poco después, entre ellos se encontraron Pedro de Alvarado, Francisco de Orozco y Francisco Maldonado "El Ancho", de tal manera que hacia 1530 ya se encontraba en proceso la cristianización, proceso respaldado siempre por la Encomienda, el despojo de tierras, y la consiguiente explotación de la población, sobre todo en las actividades mineras, escudada en los conceptos de la cristianización y la castellanización.

En algunas zonas, los zapotecos opusieron resistencia al proceso de evangelización, mientras que en otras la penetración de los misioneros fue más sencilla: En los Valles Centrales y el Istmo el proceso de cristianización se aceleró, mientras que la Sierra Sur permaneció más refractaria por bastantes decenas de años, al grado de que, por ejemplo, en Sola de Vega, un fraile, Gonzalo de Barsalobre, se quejó en el Siglo XVII de que se siguiesen adorando deidades prehispánicas mediante el artilugio de introducir figurillas en los cristos y en las representaciones de santos. En cuanto a la Sierra Norte, existe un documento suscrito por una comisión de ancianos, que testimonia el hecho de que antes de 1530 los pobladores de la región del Rincón y Villa Alta enviaron una embajada ante Cortés solicitándole se cristianizase su región. Esos representantes volvieron de la Ciudad de México bautizados y acompañados por Fray Bartolomé de Olmedo, quien así resultó ser el primer fraile*1 que penetró al territorio del estado para proceder a la cristianización.

Durante los siglos XVI y XVII varios importantes misioneros recorrieron los Valles. La Sierra Norte y el Istmo procediendo a la catequización. Entre ellos se contaron inicialmente Fray Tomás de San Juan, Fray Jordán de Santa Catarina, Fray Bernardino de Minaya y Fray Bernardo de Albuquerque; posteriormente continuaron esta labor varios otros, entre los que se contó Fray Francisco de Burgoa, quien sería el principal fraile-cronista del territorio oaxaqueño, autor de la "Geográfica Descripción del Polo Ártico...” y la "Palestra Historial de Virtudes Apostólicas...”, que años después terminaría de integrar en los conventos de Yanhuitlán, Achiutla y Cuilapan, y aunque en la cristianización intervinieron también frailes franciscanos, agustinos y mercedarios, los de la orden dominica los superaron en esta empresa. De los primeros tres siglos de ocupación colonial se conservan lienzos, mapas y pictografías, entre ellas las de San Juan Tabaa, San Lucas Yatao, Vischer II, Huilotepec y Lienzo de Guevea (siglo XVI), Genealogía de los Señores de Etla (Siglo XVII) y Lienzos de Yatuni y Lachiyoo (Siglo XVIII). También se consigna que en el Siglo XVIII las órdenes religiosas, particularmente los dominicos, poseyeron haciendas de enorme extensión, que ocuparon varias decenas de kilómetros lineales.

1 No olvidar que "Fray” Juan Díaz era solamente seglar, y los seglares ocupan en la jerarquía católica una posición inferior a la de los frailes. 
Durante todo el período colonial los indigenas zapotecos mantuvieron una actitud de subordinación al régimen virreinal, y tal subordinación no siempre fue pacífica, puesto que hubo rebeliones sangrientas que abarcaron un amplio territorio. Como era habitual, a los indígenas les estaba vedada la participación en la vida militar y civil del virreinato, y esto ocasionó, aunado a desproporcionadas elevaciones impositivas, rebeliones tales como, por ejemplo, la de Tehuantepec de 1660 y la de San Francisco Cajonos en 1700, esta última muy recordada porque los indigenas que hicieron la delación, Juan Bautista y Jacinto de los Ángeles, matados por sus compañeros, ahora están beatificados. No fue sino hasta el período de la Guerra de Independencia, que algunos miembros de la etnia formaron parte, tanto de las fuerzas virreinales del Brigadier José María Régules, como de las fuerzas independentistas de Dn. José María Morelos, Don Ramón López Rayón, Don. José Antonio Sesma, los hermanos Mier y Terán y Dn. Antonio de León, ya que las ideas independentistas gustaron en muchas comunidades. Indígenas zapotecos participaron en la última batalla que, en las cercanías de la población de Etla, libraron las fuerzas independentistas del General Antonio de León contra una columna virreinal, comandada por el Gral. Manuel Obeso, que fue obligada a retirarse. En los siguientes movimientos que presenta la historia del país la participación de las etnias zapotecas ha sido particularmente importante.

En el Estado de Oaxaca se estableció y conservó uno de los más importantes bastiones del liberalismo mexicano, una fecunda célula formativa que permitió el surgimiento de la figura señera de un zapoteca emblemático, Don Benito Pablo Juárez García, quien sería un importante factor en el proceso que permitió al país consolidar su emancipación política y poner en vigor y aplicar las Leyes de Reforma. Además, dar a todos los mexicanos su identidad nacional.

Ciertamente, Juárez no pudo evitar que algunos de los notarios que escrituraron aviesamente aplicando esas leyes, perjudicaran a las comunidades indigenas robando sus Títulos Primordiales, quitándoles sus tierras mediante el subterfugio de declararlas baldías y permitiendo la formación de latifundios. Por ello al comenzar el Siglo XX los indígenas zapotecos sólo eran peones de haciendas y ranchos, con muy pocas posibilidades de mejoramiento, en lo que también eran obstaculizados por mestizos aculturados y aún por españoles y sus hijos, con el consiguiente descontento.

Así pues, puede afirmarse que los zapotecos pagaron una elevada cuota de sangre en las Guerras de Reforma y de Intervención Francesa formando parte de las unidades que mandaron los Generales y Coroneles Porfirio y Félix Díaz Mori, José María Díaz Ordaz, José María Ballesteros, Francisco Loaeza, Luis Pérez Figueroa, Manuel González e Ignacio Mejía; participaron en batallas tales como la del 5 de Mayo de 1862, estuvieron presentes en el Sitio de Puebla de 1863, el Sitio de Oaxaca de 1865, batallas de Miahuatlán y la Carbonera de 1866, así como en la toma de Puebla y la Batalla de San Lorenzo, de Abril de 1867, sin contar que veinte años antes también soldados zapotecas participaron en las batallas de Padierna y Molino del Rey contra el ejército estadounidense y posteriormente en todas las campañas que los hermanos Díaz efectuaron durante la Guerra de Reforma. Menciono también que en esta etapa, un importante contingente de miembros de la etnia, 
principalmente tehuanos pertenecientes a $\operatorname{los} 1^{\circ} \mathrm{y} 2^{\circ}$ Batallones de Oaxaca, murió en la explosión de La Colecturía de Rentas de San Andrés Chalchicomula, actualmente Ciudad Serdán, en el Estado de Puebla, en los primeros días de la Guerra de Intervención Francesa en 1862. Esa verdadera tragedia se generó al caer sobre pólvora mal almacenada algún tizón de las fogatas con que las soldaderas preparaban la cena después de un importante desplazamiento.

Durante el porfiriato, la etnia estuvo sometida a una fuerte represión. Muchos de sus miembros participaron como soldados de leva en el Ejército Federal y muchos de ellos también fueron esclavos y murieron de diarrea, extenuación y hambre en las plantaciones del Valle Nacional, víctimas del esclavismo sádico que se implementó en aquella región.

Después de 1910, y durante la Revolución Mexicana, los zapotecos engrosaron, tanto los contingentes de tropas carrancistas, como las de sus adversarios, ya sea federales o posteriormente villistas. Muchos otros participaron en batallas tales como la segunda de Celaya, la de León, la de Trinidad y la de Aguascalientes, formando parte de las fuerzas carrancistas de caballería de los Generales Cesáreo Castro y Fortunato Maycotte, así como también muchos integraron, inscritos en todos los bandos, parte de las tropas de los Grales. Guillermo Meixueiro Delgado, Isaac M. Ibarra, Onésimo Jiménez, Manuel García Vígil, Joaquín Amaro y mayoritariamente de las de un importante subordinado de éste último

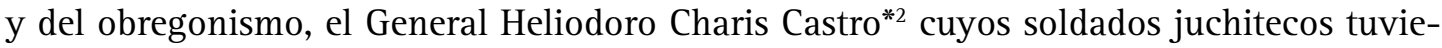
ron una destacada participación, a fines de 1923, en la sangrienta batalla de Ocotlán, Jal, durante la Rebelión Delahuertista, donde, con un enorme costo en vidas, forzaron el paso del Río Lerma, capturando un puente, y desalojando y derrotando a las tropas del Gral. Enrique Estrada. Los muchos cientos de muertos de ese combate tuvieron que ser envueltos en petates, y ello dio lugar a que desde entonces a esa forma de amortajar se le designe como "los tamalitos".

Durante el resto del Siglo XX, el grupo presenció y participó en la degradación de gran parte de su territorio ocupacional. Ha recibido los programas de desarrollo que los gobiernos federal y estatal han implementado y ha situado algunos de sus miembros en muchas de las actividades de la vida estatal y nacional, y, asimismo, según los mayores o menores recursos de sus regiones, ha tenido que enfrentarse a graves problemas con mayores o menores carencias.

En el Istmo ha sido el grupo más perjudicado por los problemas político-administrativos que ha generado la existencia de la presa "Benito Juárez", la que aún no eleva suficientemente la productividad regional y cuyo manejo incrementó los conflictos por la tierra. Ahora, al comenzar el Siglo XXI, vuelve a tenerlos al surgir el interés transnacional en la explotación del potencial eólico regional, potencial que desde hace muchos años, debió ser aprovechado por la Comisión Federal de Electricidad de acuerdo con los campesinos regionales.

2 En uno de sus escritos, el libro 8000 Kilómetros en Campaña, el Gral. Álvaro Obregón, dejó constancia de que, por entonces, prácticamente no existía entonces un cementerio en la República Mexicana que no contuviese los restos de, al menos, un soldado indígena zapoteco o mixteco muerto como parte de fuerzas revolucionarias. 
ACCESOS. La carretera Panamericana (Federal 190) es el eje troncal que divide en dos la región ocupada por esta etnia. A partir de ella, varias carreteras de carácter semi-troncal intercomunican también al resto de las regiones. Entre estos caminos, casi todos ellos pavimentados, se encuentran las carreteras Oaxaca-Tuxtepec, Mitla-Choapan, Oaxaca-Puerto Ángel y la carretera Costera del Pacífico en parte de su tramo Salina Cruz-Santiago Astata-Santa Cruz Huatulco. A partir de 1994 la nueva supercarretera Cuacnopalan-0axaca, también ha partido en dos el territorio de la etnia, sobre todo en la región de Valles Centrales. La futura supercarretera al Istmo lo hará también, en la zona de San Pedro Quiatoni, Distrito de Tlacolula.

A una inmensa mayoría de las poblaciones puede llegarse mediante caminos de terracería revestidos, algunos de ellos transitables todo el año, mientras que por las brechas sólo puede transitarse en la temporada de secas. La mayor parte de ellos entroncan con las rutas pavimentadas.

En varios poblados, principalmente en las Sierras y en el Istmo existen pistas de aterrizaje para comunicación aérea, la cual se realiza con pequeñas avionetas. En Valles Centrales, además del Aeropuerto Federal de Oaxaca y el pequeño Aeropuerto de Mitla, se cuenta también con pequeñas pistas de aterrizaje en algunas comunidades. En el Istmo, existe también el Aeropuerto de Salina Cruz y la Base Aérea Militar, ya que a fines del Siglo XX el Aeropuerto Civil que existía en Ciudad Ixtepec fue fraccionado para hacer colonias, lo cual, a juicio de quien esto escribe, ha sido un monumental error.

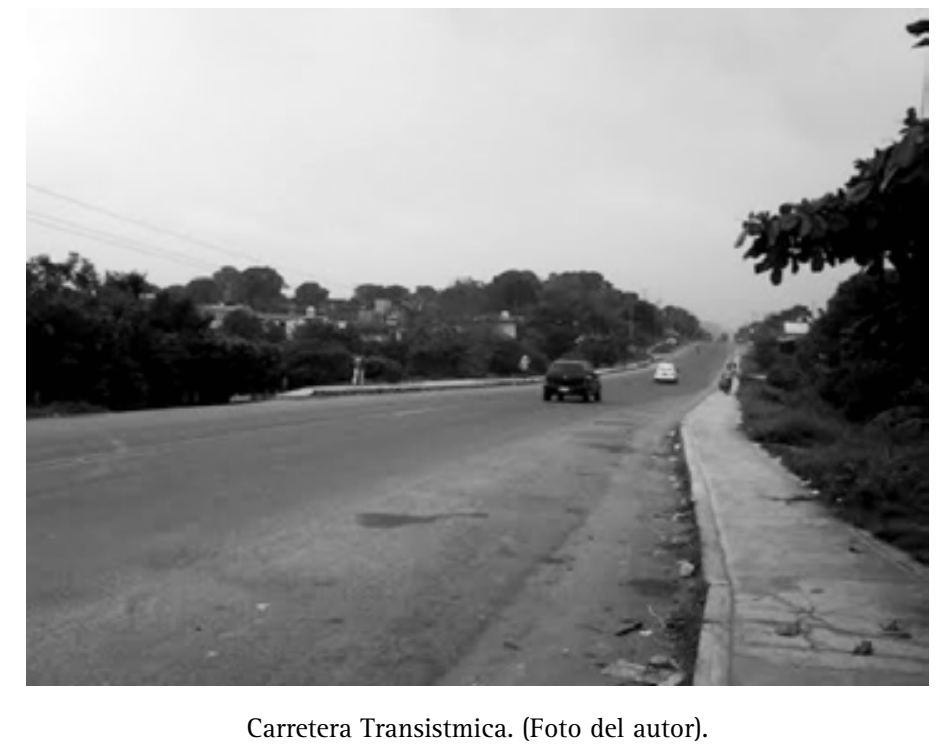

VIVIENDA. La diversidad climática del área ocupada por los zapotecos, ha condicionado desde siempre el tipo de materiales empleados en la construcción de las casas, así como su número, pero raramente en cuanto a la forma. Esta última consistía en una planta rectangular, hecha de horcones o de pilares de mampostería o ladrillo, con una estructura de madera amarrada y clavada, inicialmente con estacas de madera, soporte de la techumbre, 
con un techo de pasto, o bien de teja o tejamanil. Las paredes solían ser de bajareque, carrizo o adobe, en una de las cuales, ya fuera la frontal o la lateral, se abría una puerta, pero ninguna ventana, siendo el piso generalmente de tierra apisonada y raramente de ladrillo o cemento. Era muy frecuente que la habitación fuera colectiva, lo que hacía que la familia durmiese y desarrollase sus actividades en ese solo cuarto. En ocasiones, muy próximo se hizo un temazcal.

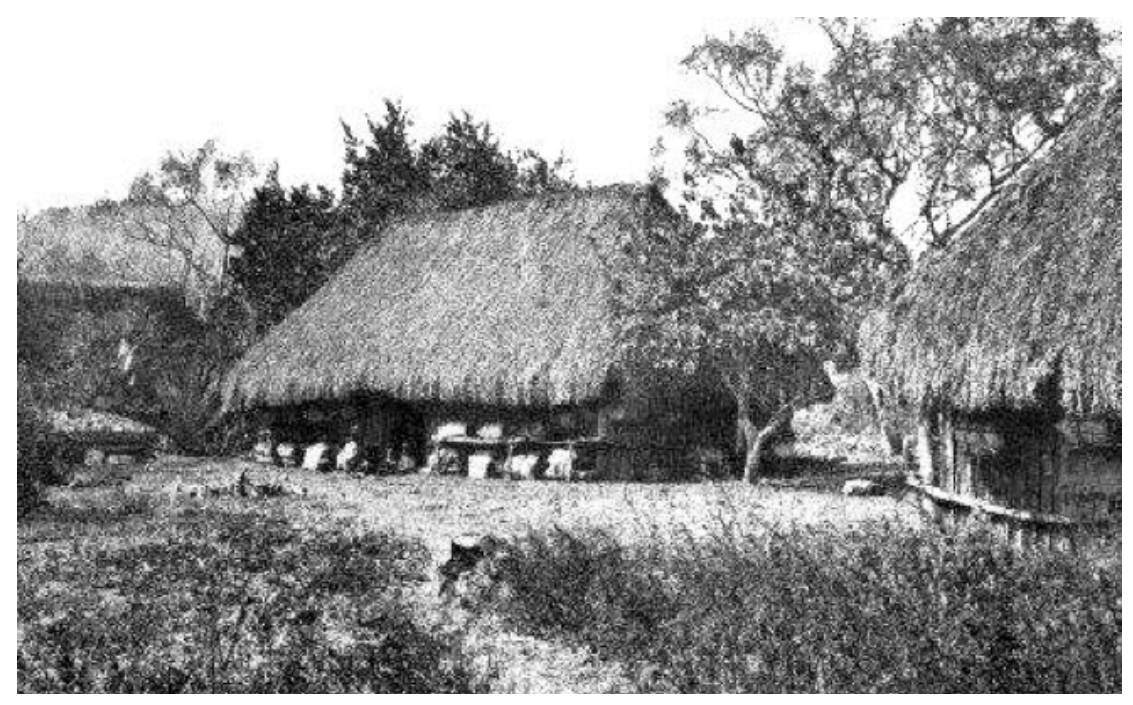

Casa zapoteca en 1906. (Foto: Frederick Starr).

Variando con los diferentes subclimas, las paredes solían ser de bajareque, carrizo o adobe. En el Valle y en la Sierra los agrupamientos de casas han sido compactos, si bien cada casa tiene su pequeño terreno llamado solar, del que se echó mano cuando las necesidades de la familia hicieron indispensable una ampliación, y la segunda casa solía colocarse en ángulo recto con respecto a la primera. Después, si fuera necesario, se construirían una o dos más. En las Sierras Norte y Sur los asentamientos, sin dejar de ser concentraciones de casas, suelen ser más dispersos en razón a las características topográficas de los terrenos en que se encuentran las poblaciones. En el Istmo se alternan ambos tipos debido a que muchos indígenas prefieren vivir en sus parcelas de cultivo. Este rasgo es característico del grupo en estudio, puesto que se presenta en mayor o menor grado en todas las áreas. El principal asentamiento de todas las regiones zapotecas es la población de Tehuantepec, que ejemplifica con sus aparentes trece barrios la organización de un asentamiento urbano prehispánico, no trazado a cordel, ya que las actuales trece iglesias están substituyendo a los antiguos edificios de culto, y su número tiene connotación calendárica. La vida económica de la población gira en torno al mercado, el cual se encuentra en la sección central del área poblacional. Junto a él se levanta el Palacio Municipal, sede de las actividades cívico-políticas, así como la iglesia principal. Donde el terreno lo ha permitido, los asentamientos han sido congregados, con veredas limitrofes que, posteriormente, en muchos casos se han convertido en calles o callejuelas. 

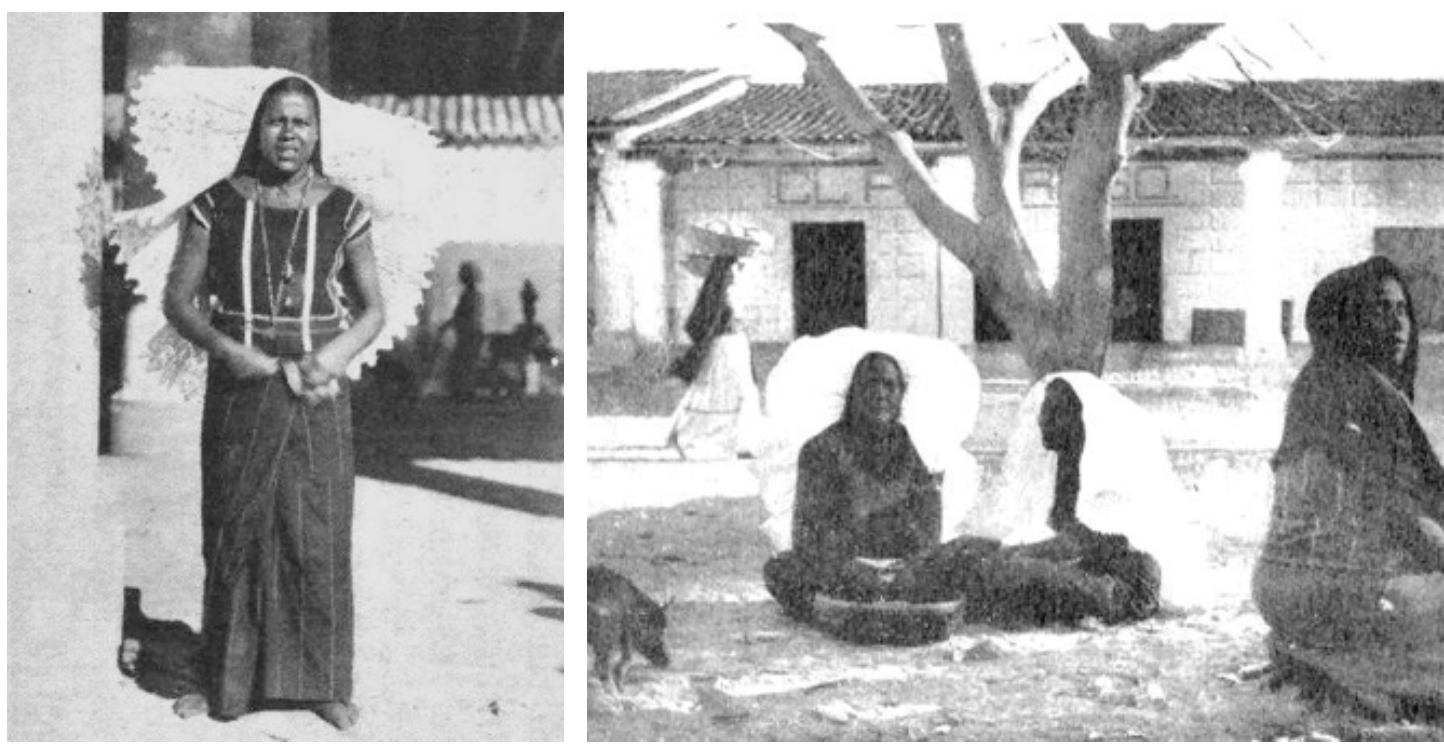

Mujeres zapotecas de Tehuantepec y San Blas Atempa en 1906. (Fotos: Frederick Starr).

INDUMENTARIA. Aunque las tradiciones zapotecas del vestido se han mantenido activas, el proceso de aculturación en las regiones de esta etnia ha hecho que se hayan perdido en gran parte los trajes tradicionales, y en algunos lugares ya no se use el Telar de Cintura, sobre todo en los Valles Centrales y en la Sierra Sur.
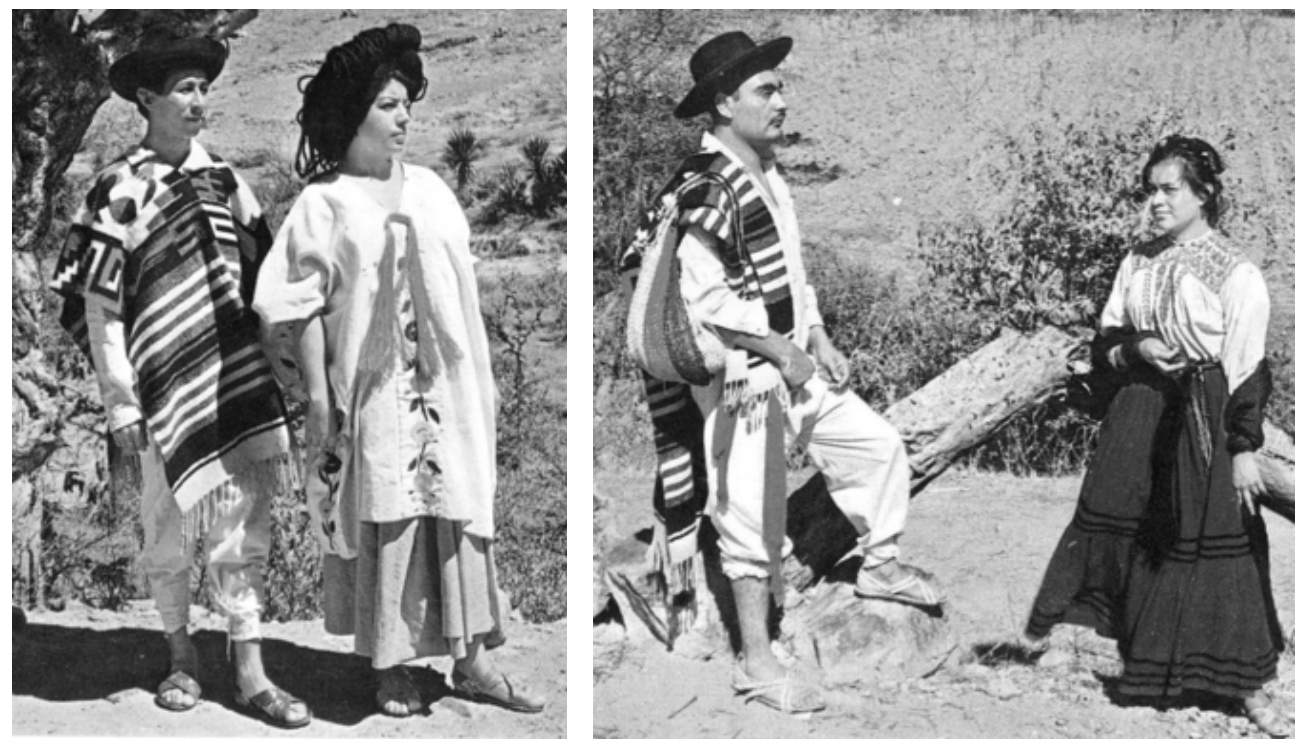

Indumentaria de Zapotecos Yalaltecos y de Coatlán. (Fotos: Colección de la Sra.María Luisa Audiffred).

Las antiguas investigaciones del Maestro Roberto Weitlaner documentaron el uso de indumentaria tradicional masculina en Yalalag. Esta consistía en camisa y pantalón de algodón o de manta, en ocasiones cubierta, en caso de hacer frío, por sarapes o jorongos de lana. Cuando llovía se usaba el capisayo, que consiste en una capa tejida hecha de tallos 
de pasto. Con el paso de los años se fue imponiendo el uso de los pantalones, tanto de dril como de mezclilla y la camisa comercial de algodón o de fibras sintéticas. En el Istmo de Tehuantepec se conservó hasta la década de los sesentas la camisa y el pantalón de manta y los huaraches, así como también el uso del capisayo.
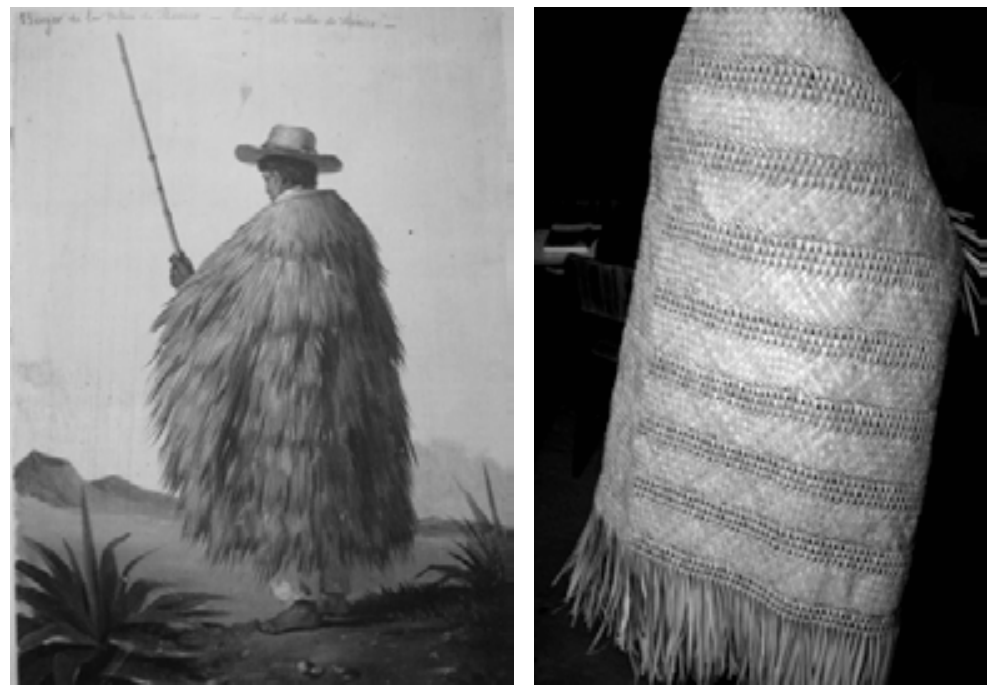

Capisayo y su reverso. (Litografía de Edouard Pringet y foto del Dr. José Antonio. León Ruiz).
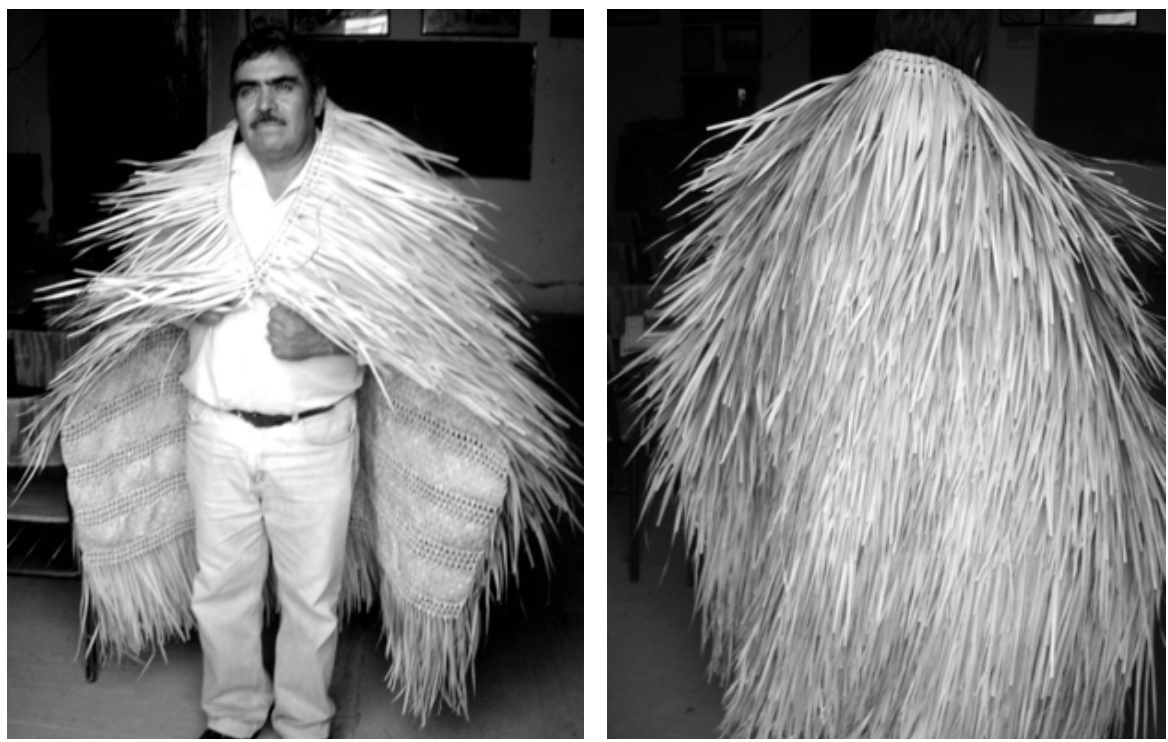

Vista anterior y posterior de un último capisayo. (Fotos: del Dr. José Antonio León Ruiz).

En la actualidad, sólo contadas localidades de las cuatro regiones conservan la indumentaria tradicional masculina, mayoritariamente hecha de manta, usándola sólo en las fiestas y en las ceremonias importantes. 

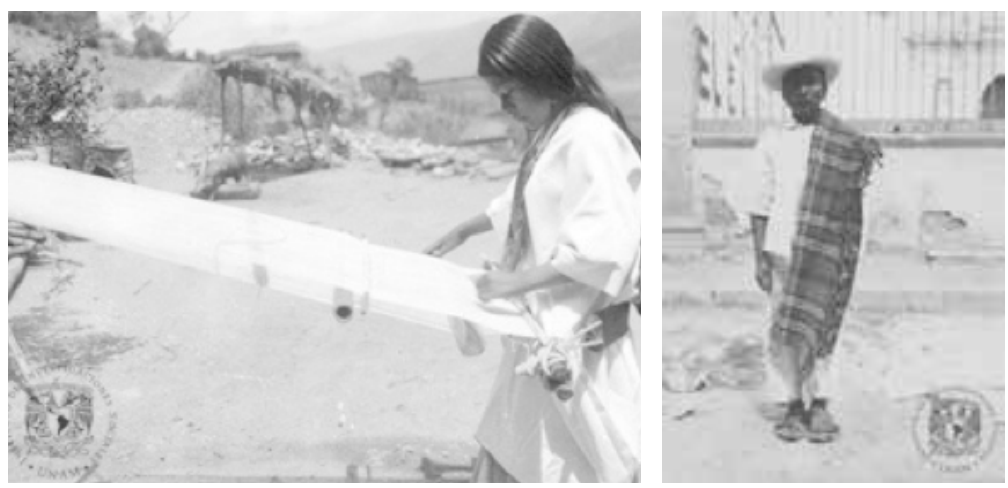

Tejedora y hombre zapotecos. (Fotos: IIS-UNAM).

Por su parte, la indumentaria tradicional femenina, en cambio, por su belleza y sobrio estilo, ha tenido más permanencia. Las prendas tradicionales son el huipil, el refajo, la faja y el sollate. El huipil es de algodón con un mazo de hilos de seda, frecuentemente unidos mediante bordados, para evitar desgarrones en la abertura central y para que cuelguen como adornos, conservándose la tradición de cultivo de la seda en los rebozos de San Pedro Cajonos, pueblo con larga tradición en ese sentido. El enredo es de tela de algodón, siendo tradicional que su manufactura haya sido local en telar de cintura, elaborándose de colores blanco o café. Esta prenda se sostiene con el sollate, el cual es un cinturón de palma ancho y grueso, al que se cose una faja procedente de los Valles. El huipil de lujo es bordado, con frecuencia multicolor, y suele tener un acolchonado fino en los hombros. En San Juan Yaee y Tanetze la falda se hizo de lana blanca, pero el huipil desapareció antes de 1980.

En San Pedro Cajonos hasta hace poco se usó la falda de enredo, y actualmente, como ya señalé, se hacen rebozos de seda.

Según algunos autores, el tipo de huipil denotaba la diferencia entre la muchacha soltera y la joven recién casada. Ambos sexos usaban huaraches y sandalias. Hacia 1960, y sólo en ceremonias, raramente alguno que otro anciano usaba huaraches tejidos antiguos de un tipo bastante más elaborado.

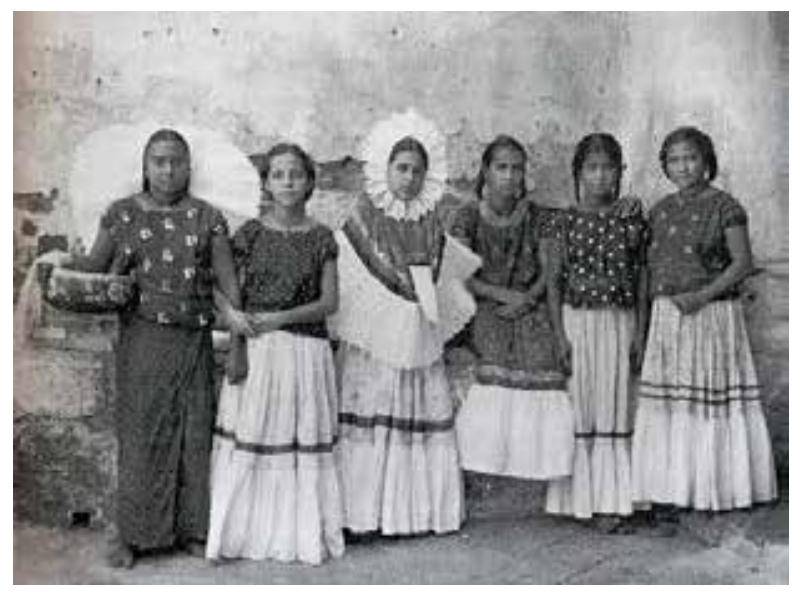

Istmo. Antiguas tehuanas en 1906 (Foto: Frederick Starr). 
Por otro lado, el peinado jugó un importantísimo papel en el atuendo de la mujer serrana, particularmente en la de Yalalag. Los tocados elaborados, en los que se incluyeron cordones de lana de color negro, fueron privativos de la mujer casada, mientras que las solteras llevaron el pelo suelto o bien un tocado diferente. Ha sido tradicional que los aretes fueran usados sólo por niñas y muchachas solteras y dejados de usar por las recién casadas al día siguiente de la boda. No obstante, esta tradición se está perdiendo como consecuencia del proceso de aculturación.
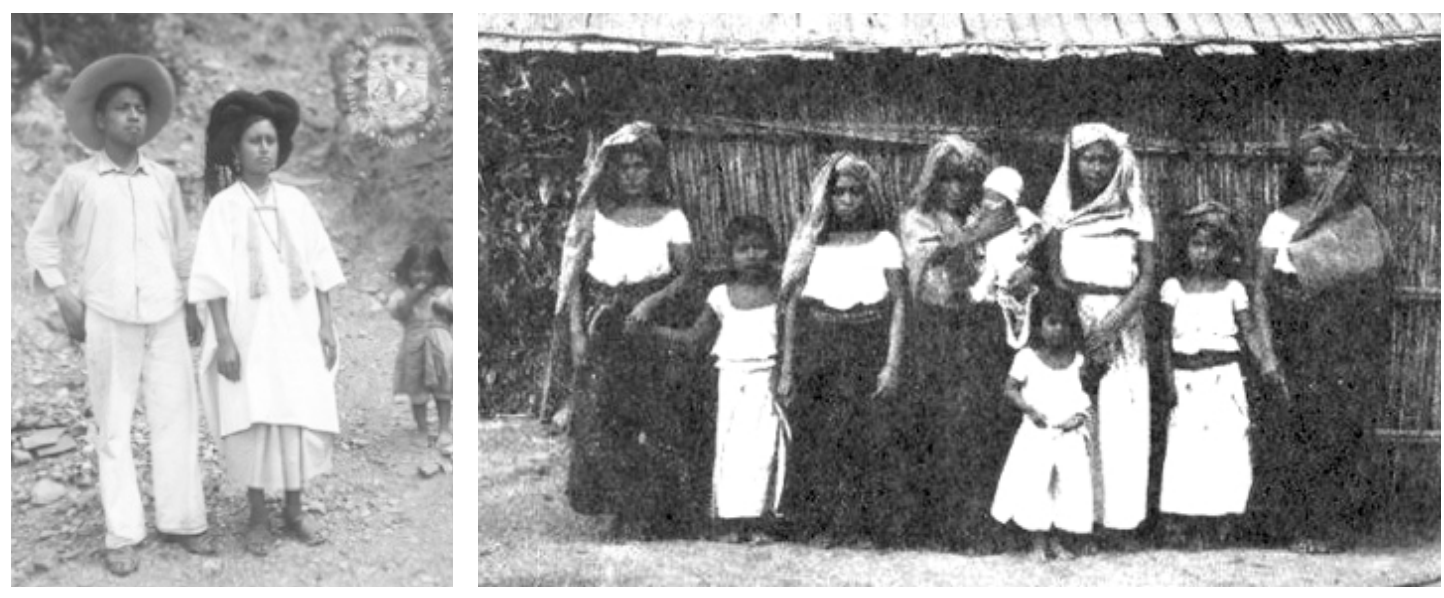

Atuendos de Yalalag y Valles centrales (1906). (Fotos: IIS-UNAM y Frederick Starr).

ECONOMÍA. La economía en las cuatro áreas ocupadas por el grupo zapoteco revisten diferentes niveles de importancia en función de los recursos zonales. Esta economía, como todas las de las zonas indígenas del país no se debe analizar en los términos en que se analizan aquellas en las que intervienen factores de la producción de características más elaboradas. Excepto en una pequeña sección de Valles Centrales o en las zonas húmedas o irrigadas de los Distritos de Juchitán y Tehuantepec, la economía de las áreas zapotecas ha sido de subsistencia, basada en los cultivos de temporal de maíz, fríjol, chile y calabaza, con rendimientos muy bajos, debido al agotamiento de los suelos, a lo delgado, calcáreo o micáceo de los mismos y a la poca fertilización natural, aspecto en el que se ha fracasado al aplicar, desde la década de los 60s, fertilizantes artificiales fosforados. No obstante esto, el grupo Zapoteco manifiesta en alto grado su organización, de tal manera que le caracteriza una amplia división de trabajo tanto por sexos como por edades, lo que en ocasiones le ha permitido superar situaciones adversas.

En las actividades económicas de los zapotecas, independientemente de la región en que se encuentren, se observa el reflejo de formas de vida propias, el uso de una lengua que presenta por lo menos dieciséis variantes dialectales, y un conjunto de valores, costumbres y tradiciones. Con las excepciones mencionadas antes, (quienes se sostienen en tierras de regadío), la sobreexplotación del medio ambiente en su hábitat está llevando a los indígenas de esta etnia a un empobrecimiento cada día más acentuado, ya que, al pretender tomar del medio ambiente los elementos para su subsistencia biológica y social, y 
al no obtenerlos completos, se ven obligados a destinar parte de su producción, y rara vez el excedente de la misma, para adquirir otros bienes que no se producen en la comunidad, situación que hace factible los desiguales sistemas de comercialización. Es muy frecuente que tanto la población masculina como la femenina se vea obligada a abandonar su respectiva región en busca de trabajo. En el año del 2013, más de 100000 miembros de la etnia, monolingües o bilingües, se encuentran en otras regiones del país y del continente, abundando concentraciones como las del estado norteamericano de California. En algunas zonas dentro del grupo existen ocupaciones estacionales. Estas consisten en el desarrollo de varios tipos de cultivos, principalmente maíz, hortalizas, chile, café y cacahuate. Con frecuencia la tenencia de la tierra es comunal y esa ha sido la forma históricamente documentada del grupo; sin embargo, durante el último siglo y medio se ha desarrollado ampliamente la propiedad privada y, a partir de la Revolución Mexicana, la forma ejidal. En todas las regiones se ha practicado y en ocasiones conservado el "tequio" como forma comunal de trabajo colectivo, manteniéndose institucionalizado. Otros cultivos que revisten importancia económica especial son los de maguey mezcalero y los de tabaco obscuro: el primero producido en el valle y distrito de Tlacolula y zonas aledañas del distrito de Yautepec, y el segundo obtenido en la porción sur del Valle de Zimatlán* ${ }^{*}$. Prácticamente en toda el área ocupada por los zapotecas existen colmenas y se mantiene una producción permanente de miel. Aunque la región contiene y ha contenido importantes áreas boscosas, la explotación de ese recurso, salvo casos muy específicos, se ha realizado sin que beneficie a las comunidades indígenas, las cuales sólo han recibido pequeñas aportaciones, o algunos edificios de oficinas, principalmente ayuntamientos y alguna vez pequeños kioscos a cambio de permitir la tala.
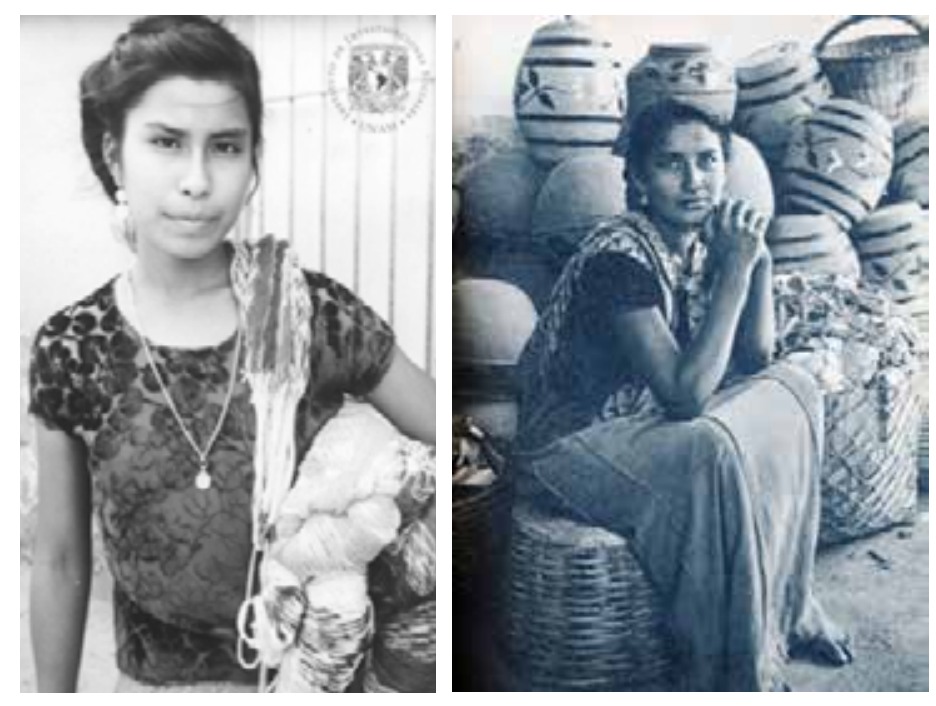

Vendedoras zapotecas de hamacas y de canastos. (Fotos: IIS-UNAM y Berenice Kolko).

\footnotetext{
3 Las inadecuadas y destructivas políticas que el Gobierno Mexicano de tendencias neoliberales ha aplicado al campo del país han terminado con áreas productivas. Desde el año de 1990 ya no se cultiva tabaco en Zimatlán. Esa es una de las inmediatas consecuencias de aquello que se anuncia como "Adelgazamiento del Estado" y que en realidad debe entenderse como empobrecimiento generalizado ante un Estado que incumple sus funciones...
} 
ARTESANIAS. Poseedores de habilidades muy variadas y gran sensibilidad, los zapotecas desarrollaron una amplia gama de habilidades artesanales, que han dejado plasmadas en textiles (muchos de los cuales aún se elaboran con telar de cintura), los bordados, la cerámica, las figuras talladas y labradas de madera, la elaboración de máscaras de madera, la fabricación de cohetes o pirotecnia, la hojalatería, la jarciería, la albañilería, la herrería; también son muy diestros en la elaboración de jabón, de velas de sebo, de aceites de ricino y parlama (caguama), así como varios oficios más, entre los cuales se encuentra el de mezcalero y el de trapichero o elaborador de panela a partir del jugo de caña.

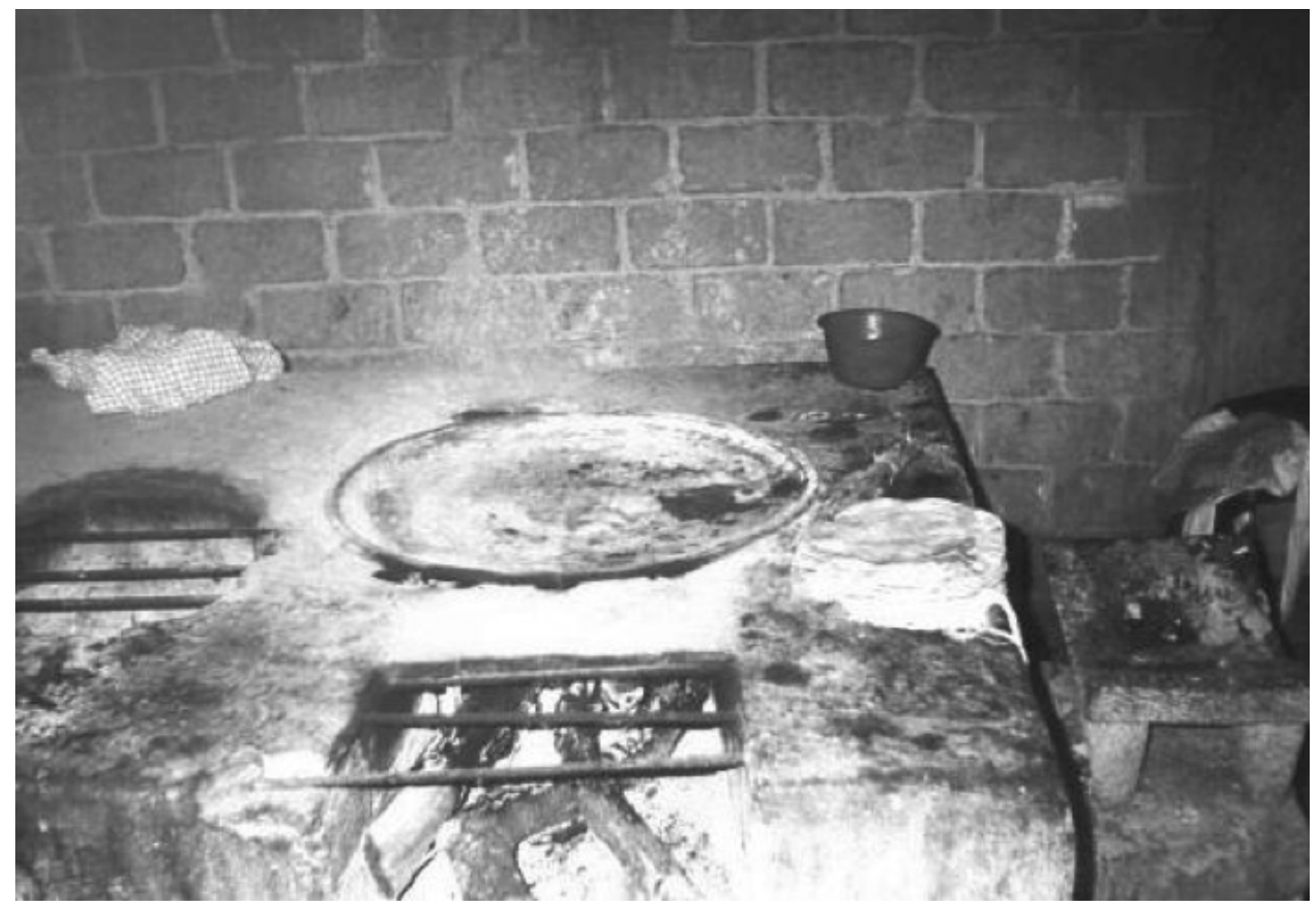

Fogón en casa zapoteca (1984). (Foto del autor)
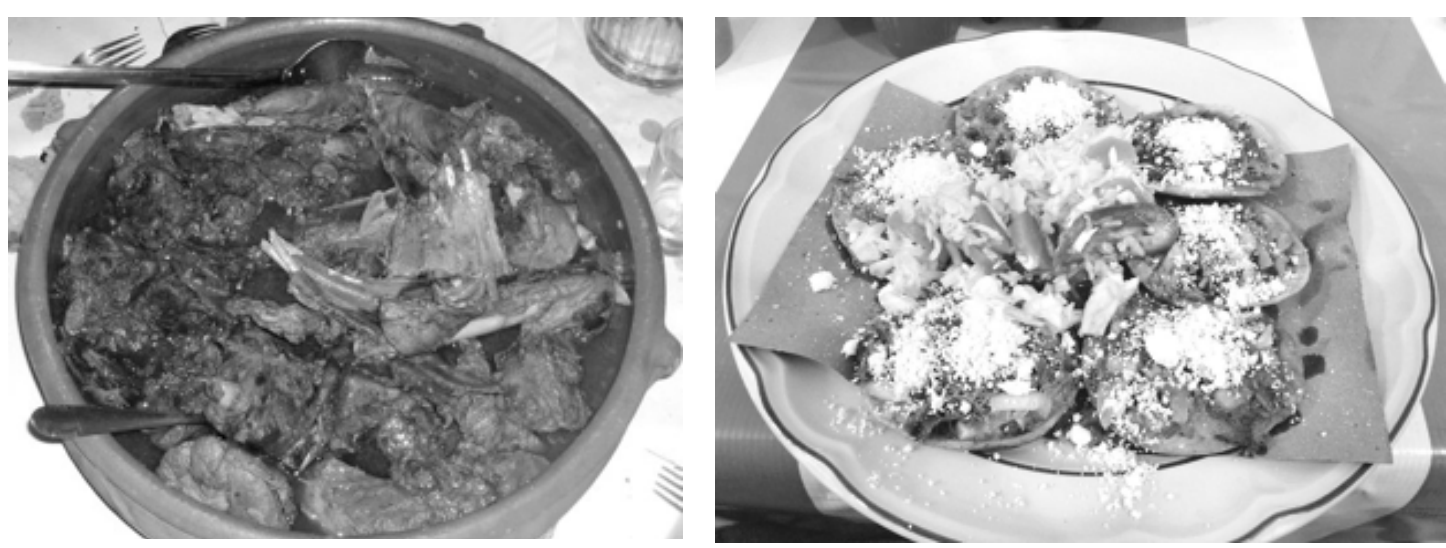

Guisado de iguana y Garnachas ístmicas. (Fotos del autor). 


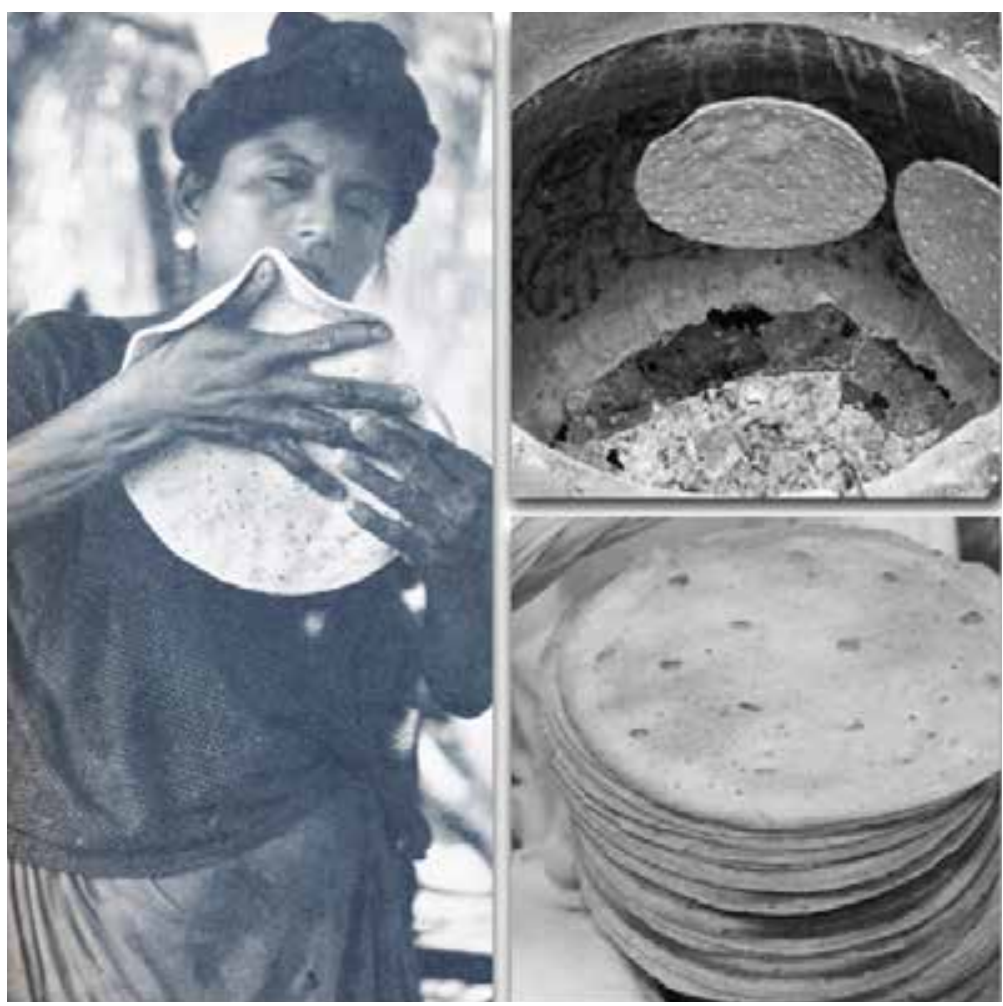

Elaboración de totopo. (Fotos: Berenice Kolko).

La cocina zapoteca es una de las más ricas, sabrosas y variadas de todo el estado, conservando parte de ella reminiscencias prehispánicas y coloniales, ya que en su elaboración se emplean ingredientes de añeja tradición, tales como el guaje, la hoja de aguacate y los chiles chilhuacle, ancho y morita, que le confieren esos sabores excepcionales. También hay bebidas dignas de mención, tales como el tejate de Valles Centrales y los curados del Istmo de Tehuantepec.
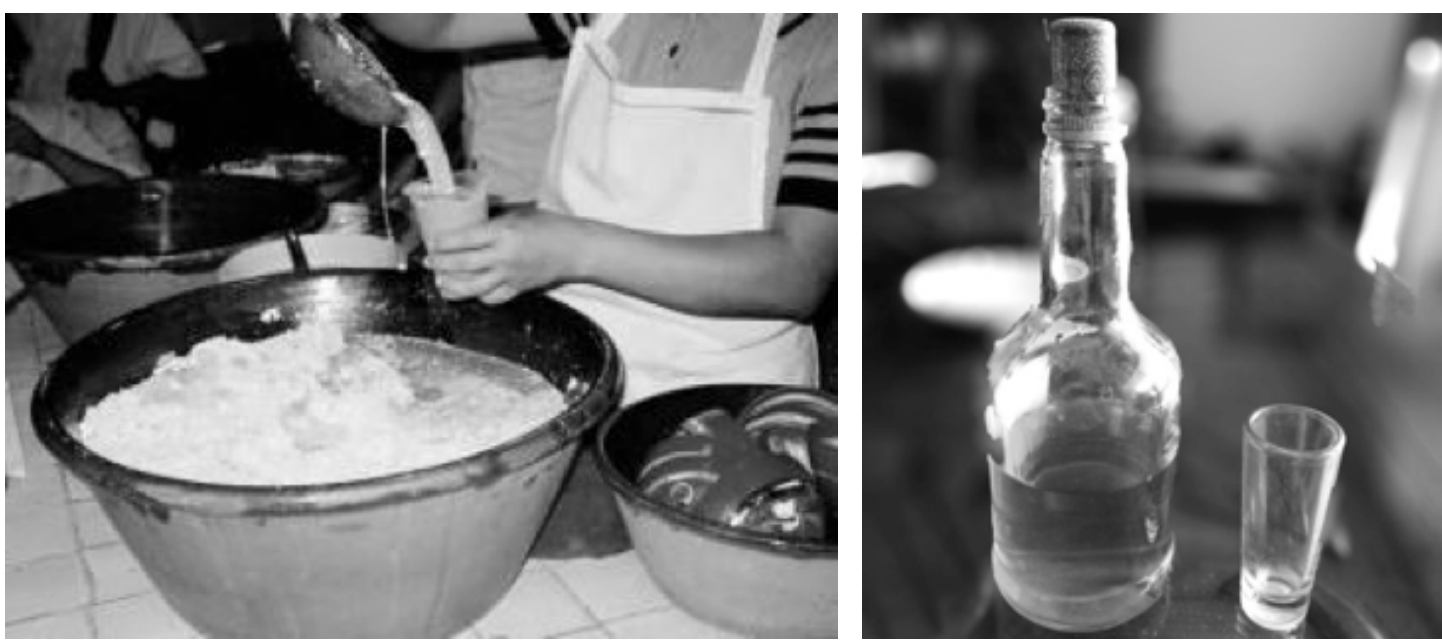

Téjate y curado del istmo. (Fotos del autor). 
La cerámica merece capítulo especial. Poseedora de una tradición documentada de más de 4500 años, que debe arrancar del bule, calabazo o cuscomate, se caracterizó siempre por una enorme diversidad de formas y por la utilización de varios tipos de barro seleccionado, con diferentes colores y con combinaciones de ellos. Con esa materia prima se fabricó cerámica utilitaria y ceremonial, la primera con gran diversidad de formas y diseños, y la segunda utilizada como una forma de representar en todos los sentidos a las divinidades, o bien los personajes del momento. Fue la cerámica prehispánica, con diversidad de ollas, cajetes, vasijas antropo-zoo y fitomorfas, urnas, cajas, sellos, lápidas y sus tipos de barro, de acabados, terminados, pulidos y grosores, la que permitió fijar cinco de los períodos culturales del grupo.
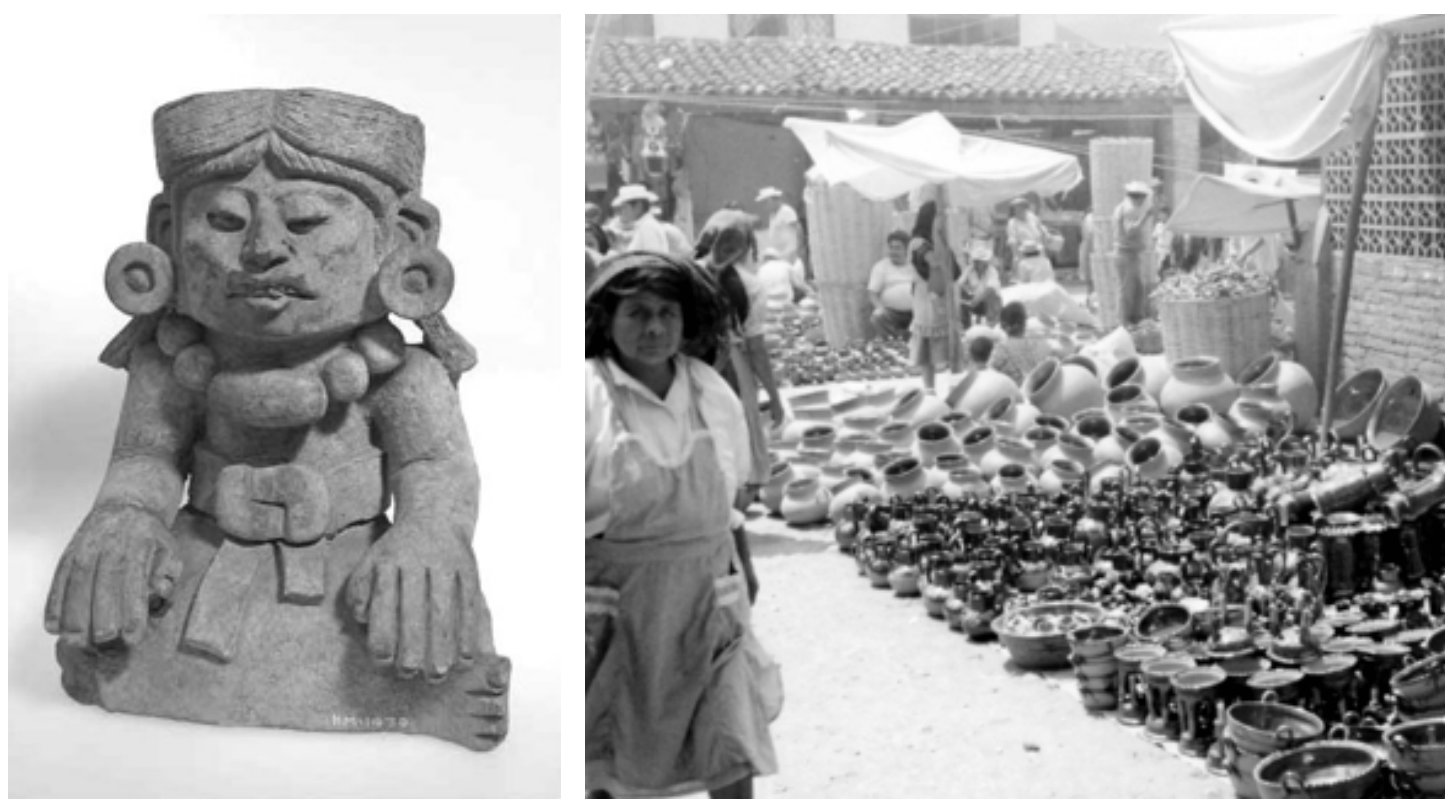

Vasija Efigie prehispánica y Cerámica Zapoteca Mercado de Tlacolula. (Fotos: FAMSI y del autor).

La tradición alfarera se mantuvo durante la época colonial y los últimos dos siglos; y en la actualidad, tanto en los Valles como en la Sierra y el Istmo, se fabrica cerámica utilitaria consistente en ollas globulares de cuellos rectos y curvos, estilos frecuentemente derivados de formas prehispánicas. También se fabrican platos, charolas y macetas, éstas de variadas formas, incluyendo las fito y zoomorfas. Varios pueblos mestizos, entre ellos Santa María Atzompa y San Marcos Tlapazola, así como algunos de Sierra Norte, se caracterizan por la factura de una cerámica de barro rojo cocida en hornos sencillos. En Santa María Atzompa los alfareros, (y no se puede aquí olvidar a $\mathrm{D}^{a}$ Teodora Blanco con sus animalitos músicos), han creado formas más variadas y las piezas se terminan mediante la aplicación de greda, la cual durante la cocción se reparte sobre ellas dándoles un vidriado de color verde oscuro. En San Bartolo Coyotepec se trabaja el barro negro, logrado por oxidación, en una variedad de formas solo limitada por la falta de imaginación del artesano productor (por ejemplo; a lo largo de la segunda mitad del siglo XX hubo quienes 
hicieron una amplia gama de ranas y patos de barro negro extraordinarios y Doña Rosa descolló por la calidad de sus productos y porque moldeaba frente a los visitantes). En la Sierra Norte existen alfareros en Cajonos; en el Istmo se les encuentra en Juchitán, Tlacotepec y Asunción Ixtaltepec, poblaciones en las que se fabrica cerámica de barro negro y rojo, sobre todo de este último color, y siempre en una gran variedad de formas. El maestro Roberto Weitlaner consignó que en San Jerónimo Ixtepec se producía hace ochenta años una cerámica de barro rosado que al ser percutida sonaba como campana. En Tehuantepec tienen mucha importancia unos pequeños juguetes de barro cuya cara con frecuencia está hecha en molde y que pueden consistir, según el sexo del niño a quien están destinados, ya sea en un personaje montado en un caballo y que porta un sombrero de tipo ranchero colonial, o bien una muñequita con atuendo de tehuana, generalmente decorados a mano libre con colores brillantes, o en ocasiones vidriados. Dichos juguetes, que reciben el nombre de "Tanguyus", son obsequiados a los niños en el día de su nacimiento o en ocasiones especiales y tienen que ver con la proyección anímica que sus padres y la comunidad les asignan. Con frecuencia los tanguyús portan vestidos de tela además de los de barro.

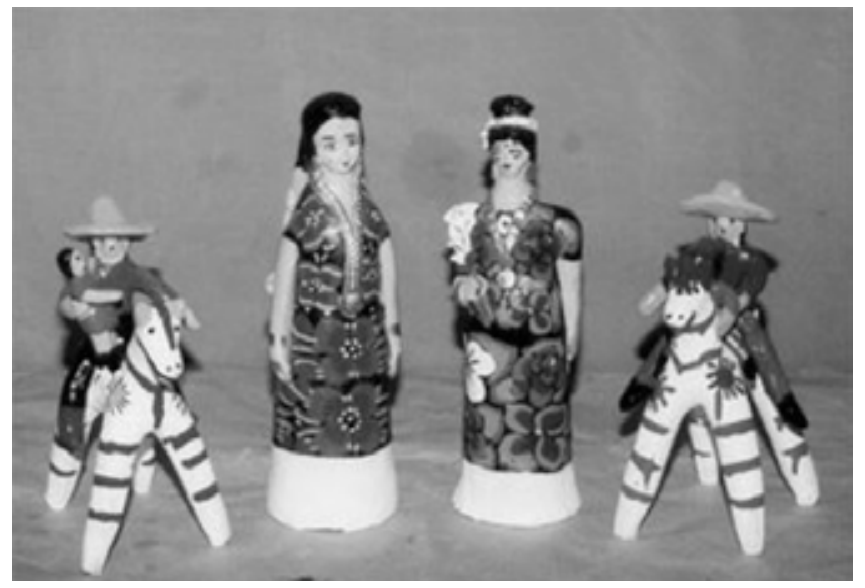

Tanguyus. (Foto: Dir. De Turismo Estatal).

GANADERÍA. Vista desde una perspectiva global, la cría de ganado entre los zapotecos da mayor énfasis a la ovicapricultura y la porcicultura. Esto responde a que las condiciones topográficas y climáticas del territorio, son las cabras y borregos, así como los cerdos, realmente los animales de mayor poder de adaptación. No obstante, prácticamente en todas las localidades y en todas las casas se engordan cerdos y existen bovinos virtualmente en todas las poblaciones, principalmente yuntas de bueyes, que desde la época colonial son la fuerza tractiva principal para las actividades de labranza, habiendo pocas vacas de cría, cuya leche no es suficiente para todos los consumos. La ganadería bovina se práctica de manera extensiva y las calidades de ganado son muy bajas debido a que casi no existen programas de mejoramiento genético. Sólo en Valles Centrales, y en algunas comunidades bajo el control del Instituto Nacional Indigenista, se practicó la inseminación artificial, la cual logró elevar la calidad del ganado zonal para luego ser desaparecida durante la 
década de los 90s, quedando en limitadas manos privadas, con lo que nuevamente la productividad se ha desplomado. Recientemente, al disminuir el ganado criollo, se optó por introducir ganado cebuino como sustento del trabajo agrícola de yunta. y, por supuesto, la producción de leche es aún más insuficiente, ya que tal ganado, con la única excepción de la raza Gyr, no extendida, no se caracteriza por ser de alta producción lechera.
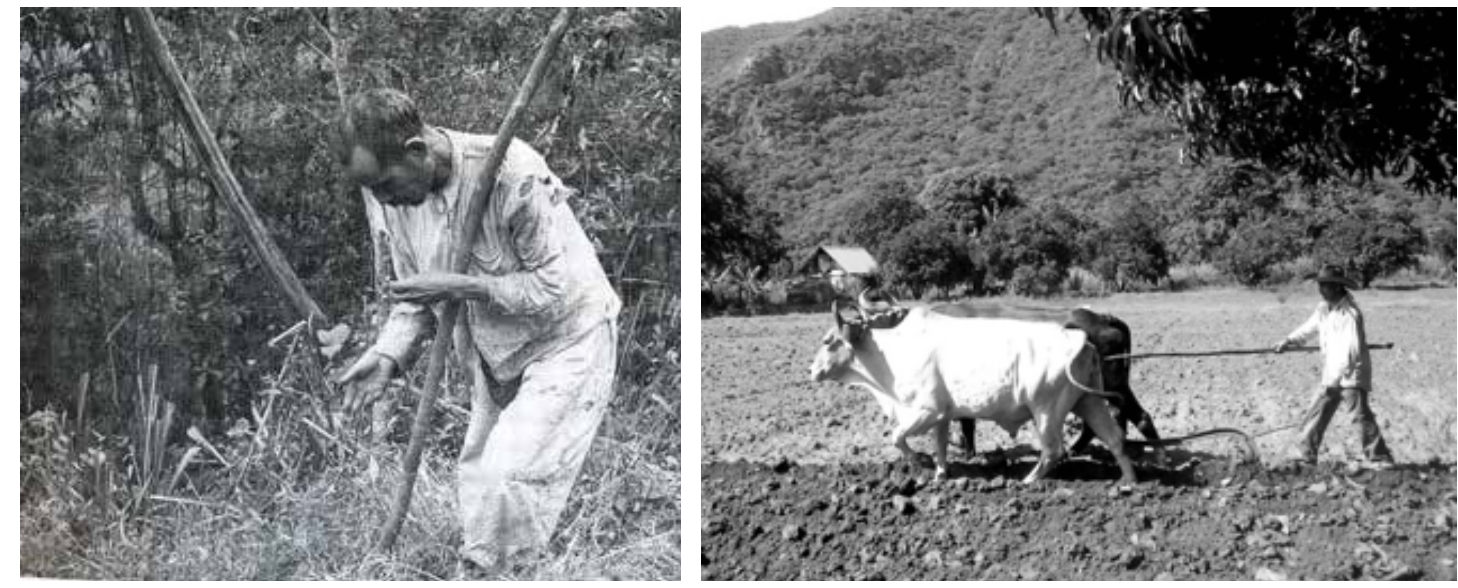

Sembrando con coa y Arando con yunta. (Fotos: Frederick Starr y del autor)

En prácticamente en todas las regiones Zapotecas existe una cría limitada de caballos, burros y mulas, siendo el burro el animal con mayor dispersión. La integración de la red de caminos ha incidido en una radical disminución de la cría de mulas. La mula, por su parte, dejó de ser la espina dorsal de una actividad que fue de capital importancia, la Arriería. No obstante, este animal sigue siendo de particular utilidad en las zonas de topografía agreste o más escabrosa.
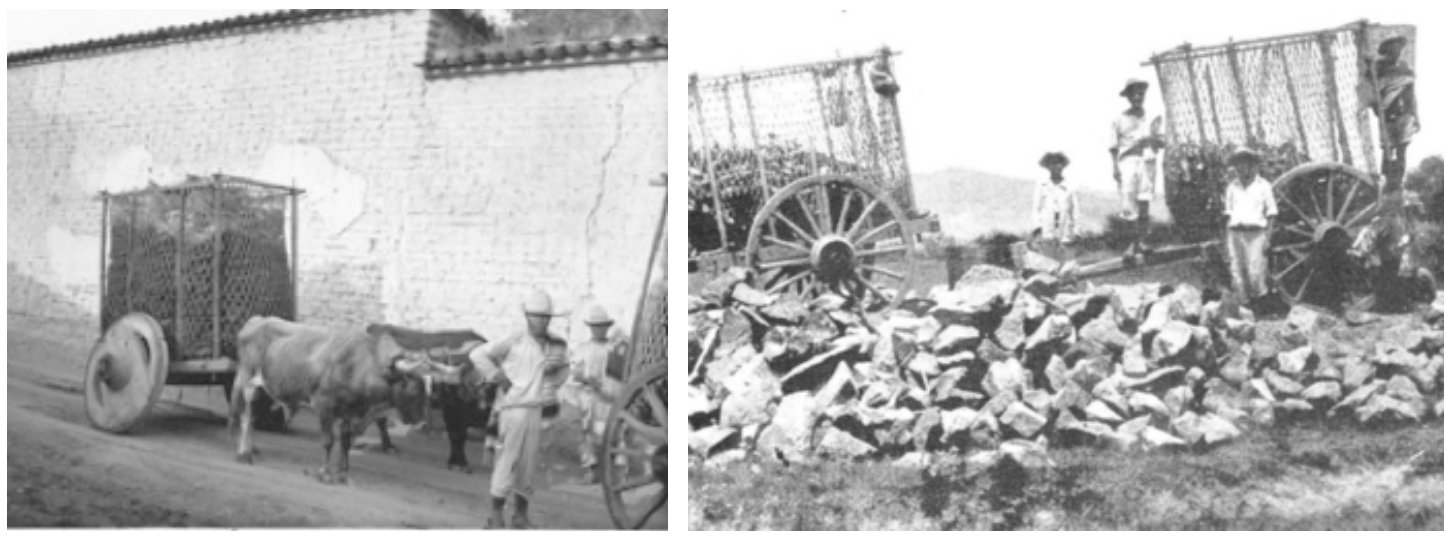

Antgua carreta zapoteca en Valles y carretas recientes. (Fotos: IIS-UNAM).

CAZA Y PESCA. Como consecuencia de sus factores climáticos, meteorológicos y edafológicos, las áreas ocupadas por los zapotecos se constituyeron como uno de los más grandes 
criaderos de fauna silvestre en el país. Son áreas que tienen hábitats muy distintos entre si, por lo que coexisten especies características y, algunas, endémicas. Siempre la fauna silvestre ha consistido en un recurso complementario en la alimentación y los ritos de la etnia, la cual siempre practicó la caza de una manera ocasional y hasta hace aproximadamente 45 años realizando las correspondientes ceremonias propiciatorias, solicitando la "pieza" al "Amo de los Animales". A causa de la desforestación y de la consiguiente destrucción de casi todos los ecosistemas, muchas especies han sufrido mermas considerables, algunas se encuentren en grave peligro de extinción y otras se hayan virtualmente extinguido (algunas especies de aves), particularmente, en el caso de la Sierra Sur, después del paso del huracán Paulina. De otras se están conservando sólo unos pocos ejemplares. Como un ejemplo, podemos señalar que en Valles Centrales la liebre de panza blanca se encuentra en un precario equilibrio debido a que su hábitat (chaparral con ligero pastizal, alternado con áreas de cultivo y pequeños manchones de vegetación xerofítica), ha sido substituido por áreas de cultivo no permanentes que han dejado al descubierto y a merced de predadores los pequeños encames en que se refugia la especie, la que, como es sabido, no se puede ocultar bajo tierra, tal como lo hace el conejo.

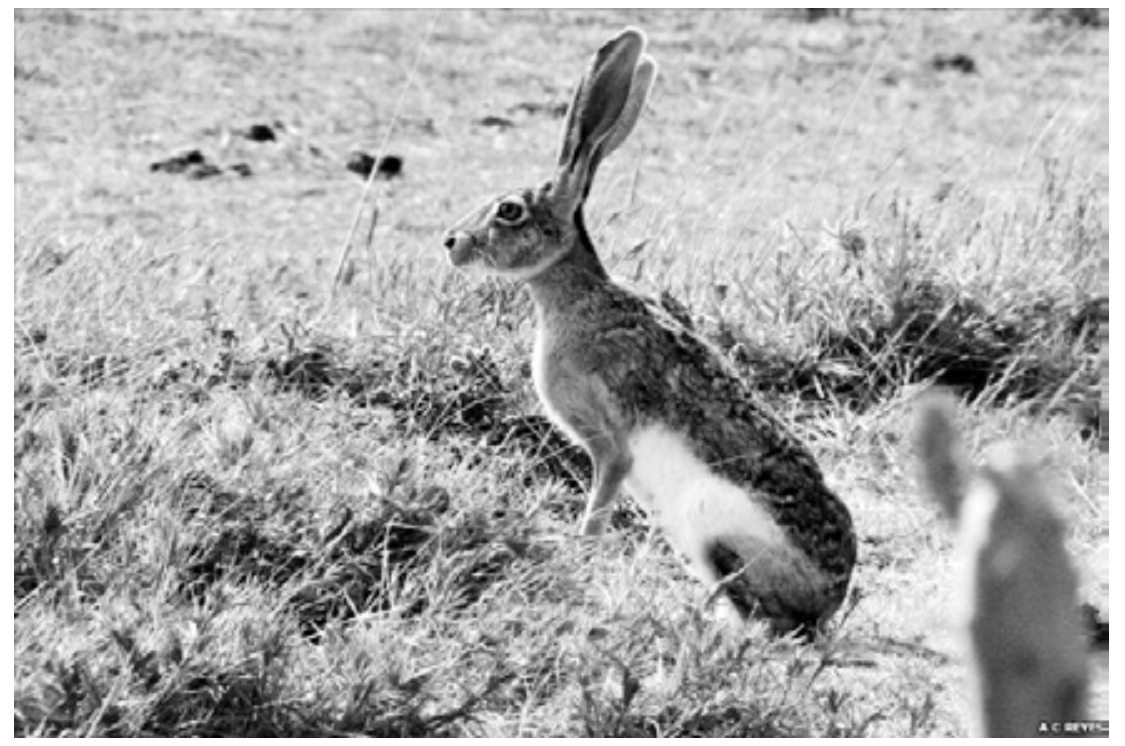

Liebre torda o de panza blanca (Lepus flavigularis). (Foto: UNAM)

Las investigaciones realizadas en la primera mitad de este siglo nos hacen ver que el tlalcoyote (una variedad de tejón de piel listada en blanco y negro, que ocupaba este territorio como el extremo sur de su área continental de dispersión), se extinguió en Valles Centrales y la Mixteca como consecuencia de una feroz persecución combinada fatalmente con una enfermedad epidémica. Como ha sucedido con otras especies, este animal fue muy perseguido porque algunos peleteros pusieron atención en su llamativa piel, que se usó asociada a bases de sillas de montar. Colateralmente, también la región de confluencia de las Sierras Madre de Oaxaca y del Sur, fue el extremo meridional de dispersión del lobo 
mexicano, ahora ya extinto en el estado. En el año de 1958 todavía fueron vistos cinco (5) animales en una serranía del Istmo, casualmente el extremo sur de su área nacional de dispersión. En Pueblos Mancomunados de la Sierra Norte opera un sistema de conservación que ya ha logrado la visualización constante, entre otros, del pájaro bandera (Trogón mexicanus), del lince (Lynx rufus) y del venado cola blanca. Recientemente se han visto linces en terrenos de Dainzú, en valles centrales, lo que da idea del éxito.

Aunque a través del área ocupacional del grupo corren varios ríos y arroyos y en tales corrientes existe una amplia variedad de peces, y entre ellas las platijas, las mojarras blancas, las anguilas y los bagres, la pesca casi no se ha practicado en el grupo, señalándose sólo capturas con tarraya en el Istmo de Tehuantepec, principalmente en los ríos de Tequisistlán y Ostuta y en la presa "Benito Juárez" en Jalapa del Marqués, donde, desde hace aproximadamente treinta años la captura de mojarra tilapia ha sido una importante actividad económica, al grado de haber llevado a la especie al límite de su capacidad reproductiva, capturándose mayoritariamente animales juveniles que, aunque pueden reproducirse, ya no alcanzan el tamaño comercial, y se está a punto de capturarlos de tamaño tal que la reproducción ya no será posible. En esa presa hay, además, bagres de muy apreciable tamaño. En los Valles Centrales, excepto en arroyos altos, o los situados en las cañadas de mayor altura, ya no pueden encontrarse peces debido a la contaminación.

MERCADOS. El sistema de mercados entre los Zapotecas de Valles Centrales es rotativo en diferentes días de la semana, siendo Etla, Zaachila, Ocotlán, Oaxaca y Tlacolula las poblaciones más importantes. En la Sierra Norte las poblaciones de Ixtlán; Capulalpan de Méndez, Villa Hidalgo o Yalalag y San Pedro y San Francisco Cajonos tienen también ese carácter. En la Sierra Sur, Miahuatlán y Pochutla; y en el Istmo, Tehuantepec, Juchitán, Ixtepec, Ixhuatán, Chihuitán y Laollaga.
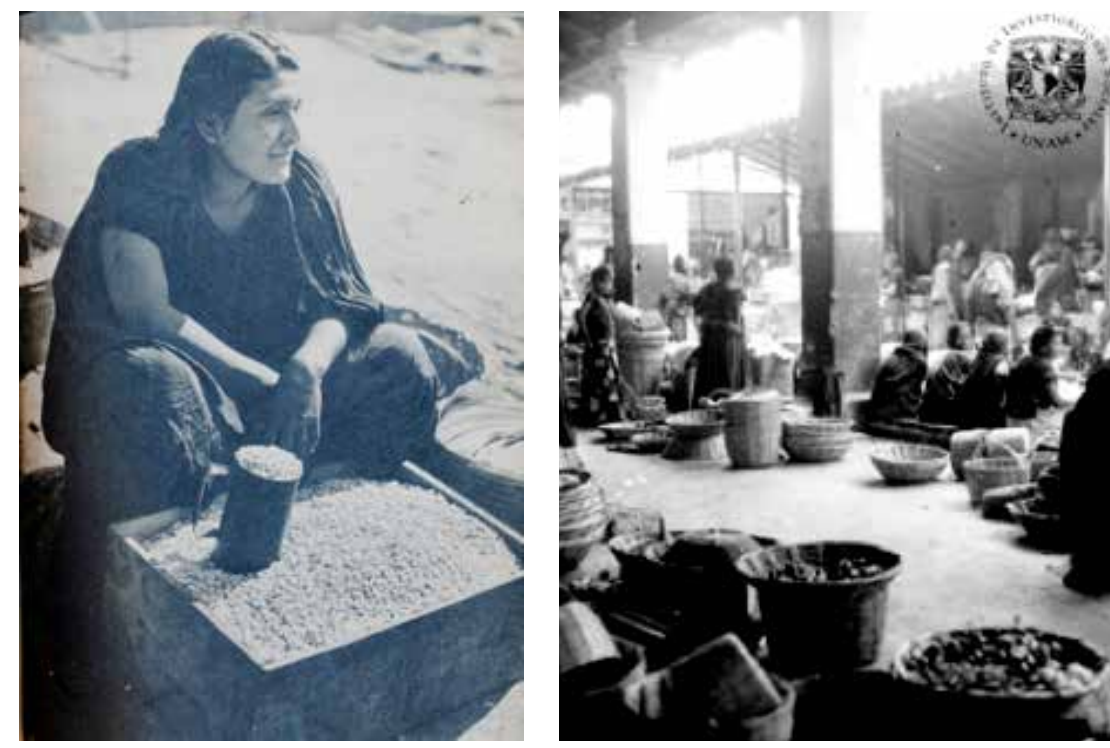

Vendedora de maiz zapoteca del Istmo y mercado de Tehuantepec. (Fotos: Berenice Kolkos e IIS-UNAM)). 
Hasta hace relativamente poco tiempo, en varios mercados se practicó el intercambio de productos o trueque, aunque la mayor parte de las transacciones se han realizado en dinero. Es habitual que en los procesos de intercambio y compra-venta, los indígenas lleven la peor parte. Históricamente, hacia 1946 el antropólogo Bronislav Malinowsky registró un regateo psicológico realizado en un puesto de sarapes del mercado de Tlacolula, el cual contiene una de las dosis de humor y agudas expresiones, de lectura más que recomendable, digno de figurar en las antologías de los libros de antropología.
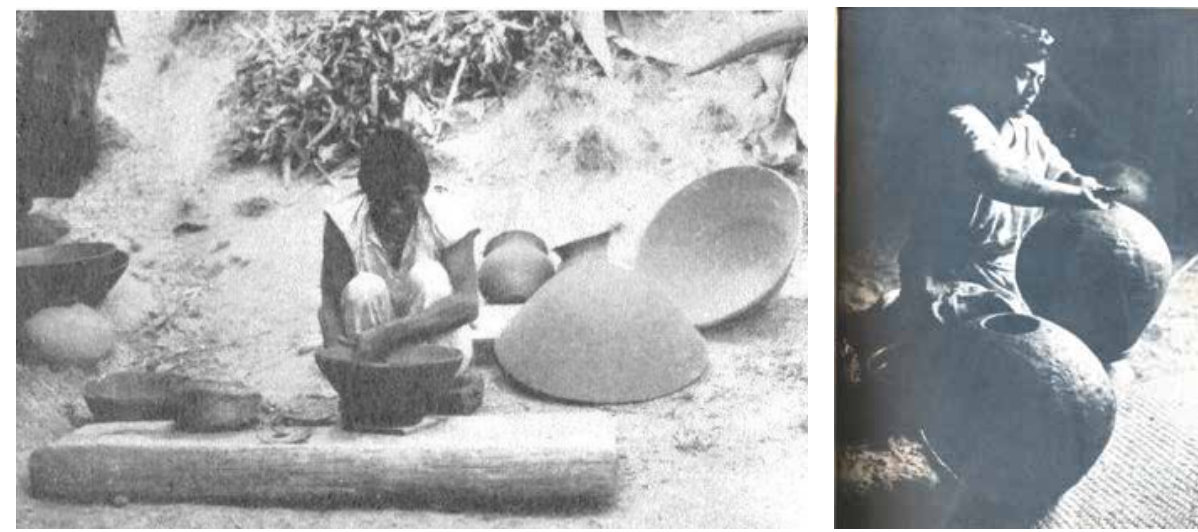

Ceramistas de San Jerónimo, Ixtepec en 1906 y de San Bartolo Coyotepec en 1952 (Fotos:

Frederick Starr y Berenice Kolko))

ORGANIZACIÓN SOCIAL. La sociedad zapoteca está organizada sobre bases de patrilocalidad, patrilinealidad, monogámicas y exogámicas. La célula principal es la familia nuclear, constituida por el padre, la madre y los hijos solteros. En tiempos no muy remotos los matrimonios tenían lugar cuando la edad de la pareja fluctuaba entre los 8 y los 20 años en el caso de las muchachas, y entre los 12 y los 22 en el caso de los varones. La novia era pedida por los padres del muchacho, apegándose rigurosamente a un ritual que era diferente en cada región. En cambio, en el Istmo de Tehuantepec se propagó durante años la "captura" o "robo" de la novia mediante un rapto en el que casi siempre, y de manera secreta, los muchachos ya están, o estaban, de acuerdo. Con mucha frecuencia la decisión de casarse o no hacerlo está en función de los bienes que cada miembro de la pareja puede aportar al matrimonio.

Otra modalidad se observó en la Sierra Norte, Allí los padrinos del varón participaban en el pedimento de la muchacha. Sea de un modo u otro, en todas las regiones la cantidad de artículos que se utilizan y utilizaron para formalizar el compromiso es considerable, $\mathrm{y}$ en las bodas se come y bebe en volumen y con gran calidad, y parece que así ha sido siempre. Entre los zapotecos existe el concepto de tona, el animal protector de cada niño o niña desde su nacimiento.

$\mathrm{Al}$ fallecimiento de un miembro de la etnia se pone en movimiento un importante ceremonial que sólo varía en detalles según las regiones. Si el que muere es un niño o infante, es considerado automáticamente como "angelito", variando su forma de enterramiento 

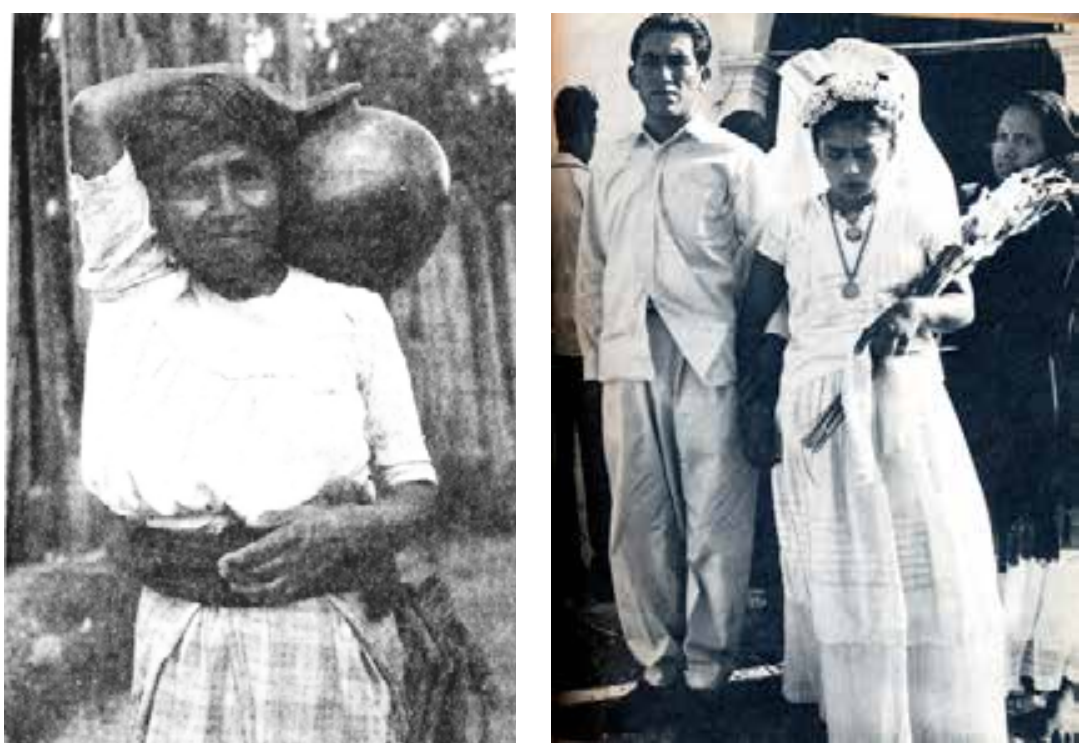

Mujer zapoteca de 1906, y Boda en el Istmo 1952 (Fotos: Frederick Starr y Berenice Kolko)).
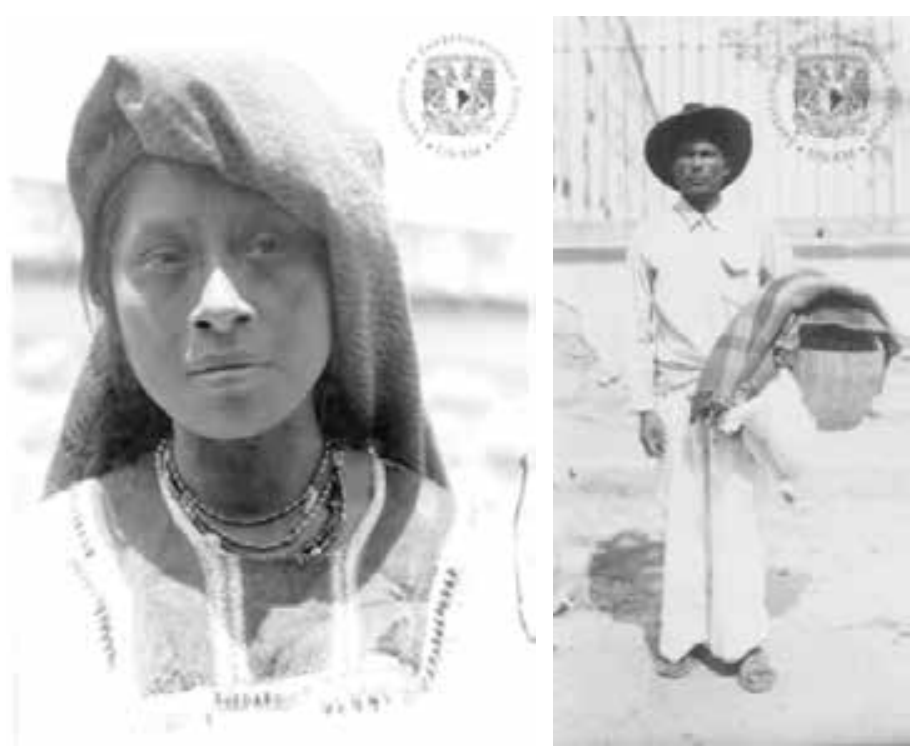

Mujer y hombre zapotecos. (Fotos: IIS-UNAM)

si alcanzó o no a ser bautizado. Si la persona fallecida era un adulto soltero o viudo, varía y varió su forma de enterramiento con respecto a si se casó alguna vez. Ahora bien, en todos los enterramientos, sin excepción, la música y las bebidas son imprescindibles; la primera está a cargo de una banda acompañante que debe ejecutar algunas de las melodías que más gustaban al fallecido en vida. Las segundas casi siempre han consistido en cerveza y un aguardiente de caña o un mezcal de buena calidad, frecuentemente aportado por amigos y algún pariente. Para su inhumación, el cuerpo es colocado en una caja y se le acompaña con una pequeña ofrenda de alimentos, agua y una muda de ropa, todo esto con el fin de hacer mas confortable su viaje al más allá. Por lo dicho anteriormente, y por lo que se expondrá a continuación, se colige que todas las formas zapotecas de enterramiento conservan muy claras e importantes reminiscencias prehispánicas de varios tipos. 
Una costumbre muy conmovedora se observa en la población de Tlacotepec en el Istmo, la cual consiste en que inmediatamente después de cerrar la tumba, los familiares más próximos siembran maíz sobre la misma y lo riegan durante el transcurso de todo el novenario. $\mathrm{Al}$ brotar la milpita consideran que el espíritu del fallecido se mantiene presente. En otras localidades se piensa que dicho espíritu va a permanecer al lado de los familiares durante los siguientes tres o cuatro días posteriores a aquel en que ocurrió la defunción.

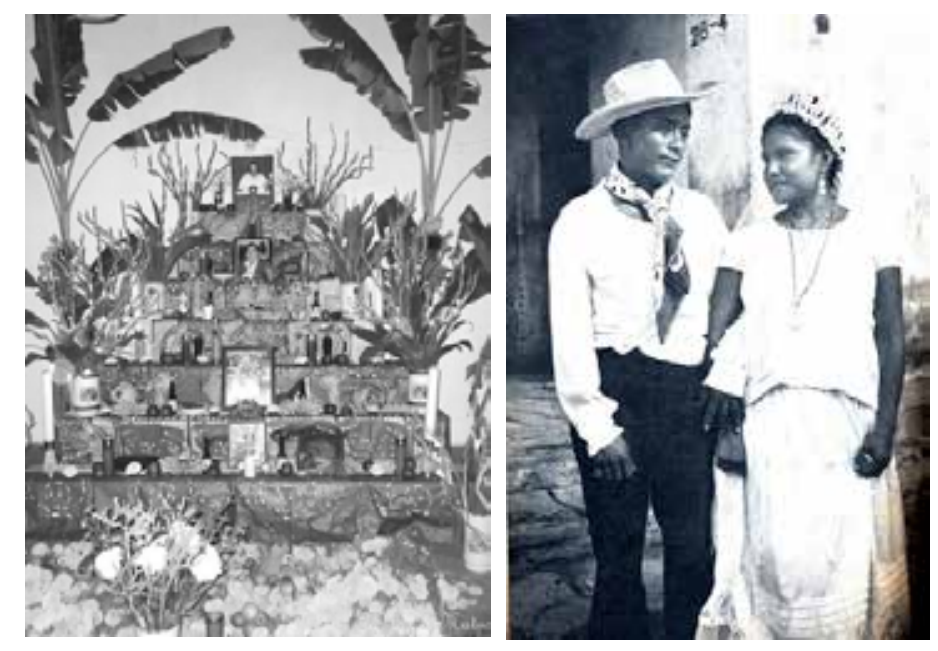

Ofrenda de muertos y recién casados. (Fotos: Macario Matus y Berenice Kolko).

La etnia zapoteca, en todas las regiones, pone especial énfasis en las celebraciones del 1 y 2 de Noviembre, días de difuntos. En algunas localidades de Valles Centrales se colocan en la noche del día primero y la madrugada del día dos, cuatro velas, una en cada esquina de la tumba, con lo cual el espectáculo de los cementerios reviste particular interés y sobrecogimiento, tanto por su peculiar iluminación, como por las ofrendas de flores aromáticas de zempoalxúchitl y de la borla. Otra costumbre prehispánica que han conservado los zapotecas de todas las regiones es la colocación del cadáver, al ser enterrado, con la cabeza hacia el occidente.

GOBIERNO. En las diferentes regiones ocupadas por el grupo subsisten formas propias de Gobierno Indígena de carácter tradicional y costumbrista, que no socava el acatamiento a las decisiones políticas que adopta el gobierno del estado. Sin embargo, entre los zapotecas se está desarrollando un fuerte sentido crítico que se está manifestando en forma de una creciente actividad partidaria, que en el 2011 ha creado fuertes divisiones internas, sobre todo en el Istmo de Tehuantepec, donde ya se alternan en el poder miembros de diferentes partidos políticos, En varias regiones subsisten grupos de mando organizados por jerarquías, a los que los miembros de la etnia solo pueden acceder de acuerdo a la edad y la experiencia adquiridas. En muchas de las cabeceras municipales subsiste la ceremonia de transmisión de mando mediante la entrega del bastón ceremonial, llegando a extenderse tal costumbre hasta algunas cabeceras distritales. 


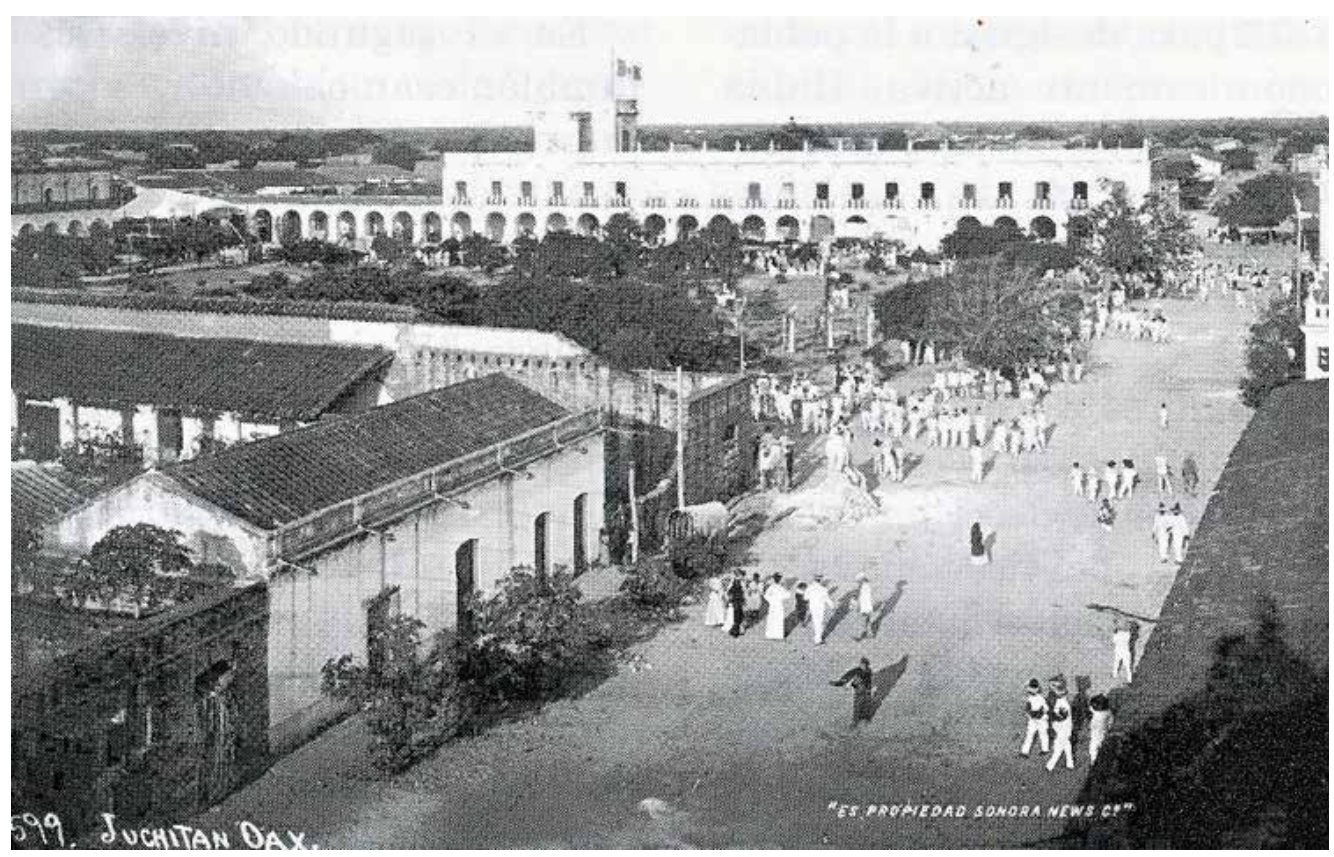

Foto del centro de Juchitán, Oax. (Foto: Archivo Gráfico de la Nación).

FESTIVIDADES: En la época prehispánica el grupo zapoteca debió realizar una serie continua, en sus fechas respectivas, de festividades relacionadas con los calendarios agrícola, astronómico- ritual y con la organización social y política de sus poblaciones. Ahora bien, puesto que fue uno de los grupos creadores del calendario ritual y uno de los primeros que aplicó el calendario agrícola, tales fiestas fueron seguramente muy solemnes y la celebración de ellas debió tener mucha importancia, ya que algunos de sus centros ceremoniales, principalmente Monte Albán, revelan una relación entre el número y la orientación de sus edificios y las zonas habitacionales subsidiarias que los rodean. Esto ha hecho pensar en la existencia de un ritual plenamente establecido, y por consiguiente en un calendario de fiestas. De hecho, los zapotecos observan el año ceremonial de 260 días.

$\mathrm{Al}$ sobrevenir la conquista española, los dos calendarios prehispánicos fueron desplazados para imponer, en su lugar, el calendario ritual de la religión católica con sus fechas móviles de festividades y conmemoraciones, así como las de carácter fijo que revisten importancia en el culto. En varias de las regiones ocupadas por el grupo tienen enorme importancia las festividades religiosas móviles (como la Semana Santa, por ejemplo), y también las fijas de los Santos Patronos de las diferentes poblaciones. En la Sierra Sur la festividad más importante es la del Segundo Viernes de Cuaresma. En esta fiesta, que se realiza en San Agustín Loxicha y algunas poblaciones próximas, se hace una procesión, en la que no puede faltar el acompañamiento de la banda de música y de las campanas de las iglesias echadas a vuelo. En dicha procesión se pasea la imagen de San Agustín, seguida por la de Cristo con la Cruz al hombro, la que es cargada por muchachas jóvenes. En las cuatro regiones, las diferentes festividades del Santo Patrón son difíciles de reseñar aquí debido a su extensión, pero se puede decir que en ellas las bandas respectivas encabezan 
procesiones y se ejecuta una variable cantidad de danzas, siendo el Istmo la región con mayor cantidad documentada de esta clase de manifestaciones.
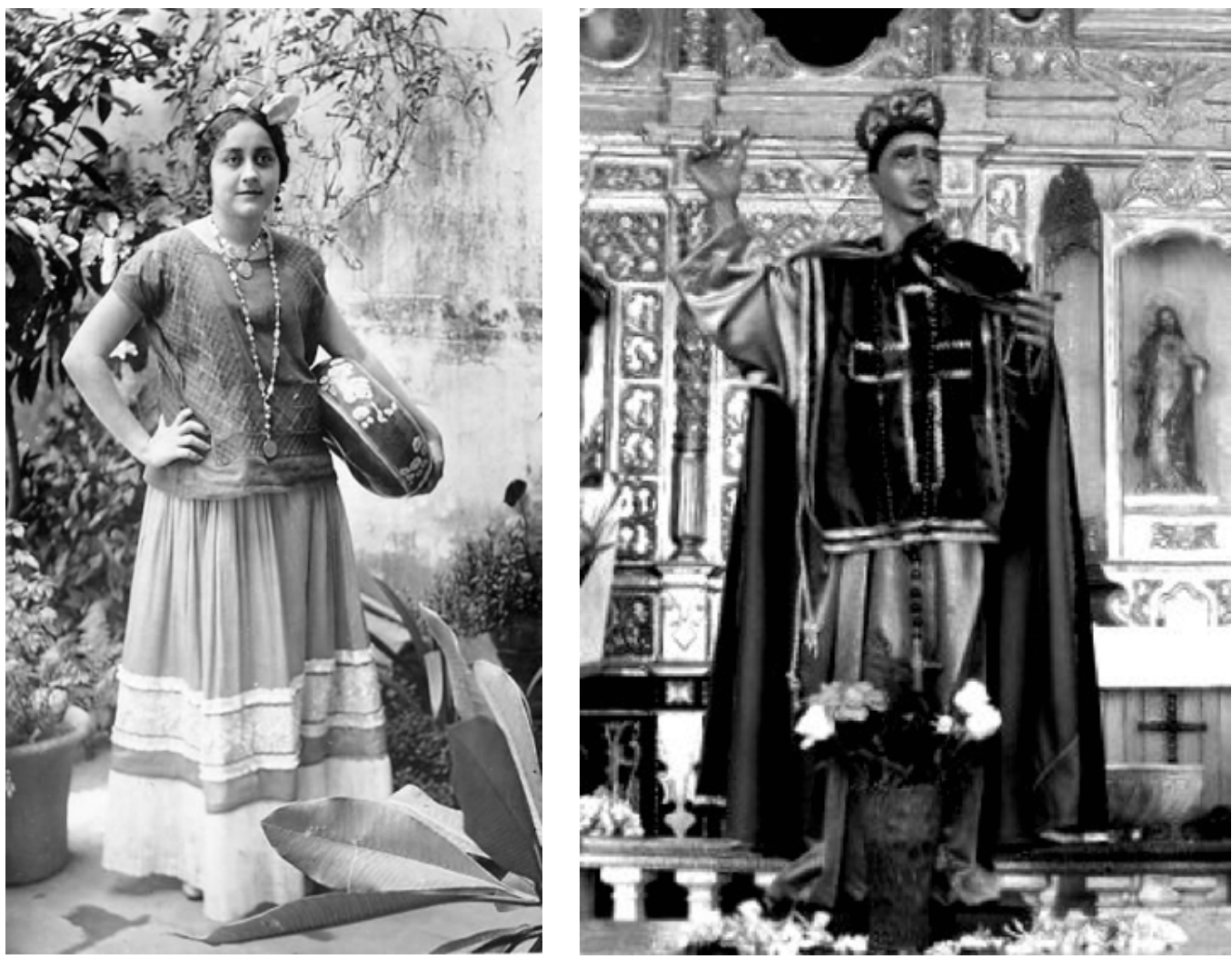

Tehuana con xicapextle en 1912 e imagen de San Vicente Ferrer en Juchitán (Fotos: IIS-UNAM y del autor ).

En esta última región se realizan constantemente las llamadas Velas, con frecuencia desarrolladas durante varios días sucesivos próximos a una festividad fija. En dichas fiestas la abundante y variada comida y la bebida son proverbiales. En Tehuantepec y Juchitán la fiesta de cada barrio se prolonga cerca de una semana y comienza cuando los Mayordomos, por lo general un matrimonio, comienzan a preparar las primeras comidas, invitando a algunas mujeres a moler masa y recibiendo los presentes de la población, dando a cambio chocolate y pan. A partir de ese momento la festividad se centra en la casa del mayordomo, donde primero tres principales de barrios vecinos son atendidos y a continuación los son las tres mujeres que fungen como madrinas. Por la tarde sale una procesión que lleva una banda de música y que visita las iglesias. Al día siguiente hay una nueva procesión y por la noche un baile en el que las muchachas lucen sus mejores adornos y atuendos. La fiesta termina con la "Regada de Frutas", la cual consiste en arrojar desde lo alto de la iglesia, por parte de las muchachas del barrio (a las que se denomina “capitanas"), fruta y jícaras de plástico sobre la gente que está situada debajo. El último día de la festividad es el "lavado de ollas", en el que se festeja ampliamente a los Mayordomos, a las cocineras y se pone en orden todo lo usado en la misma. 

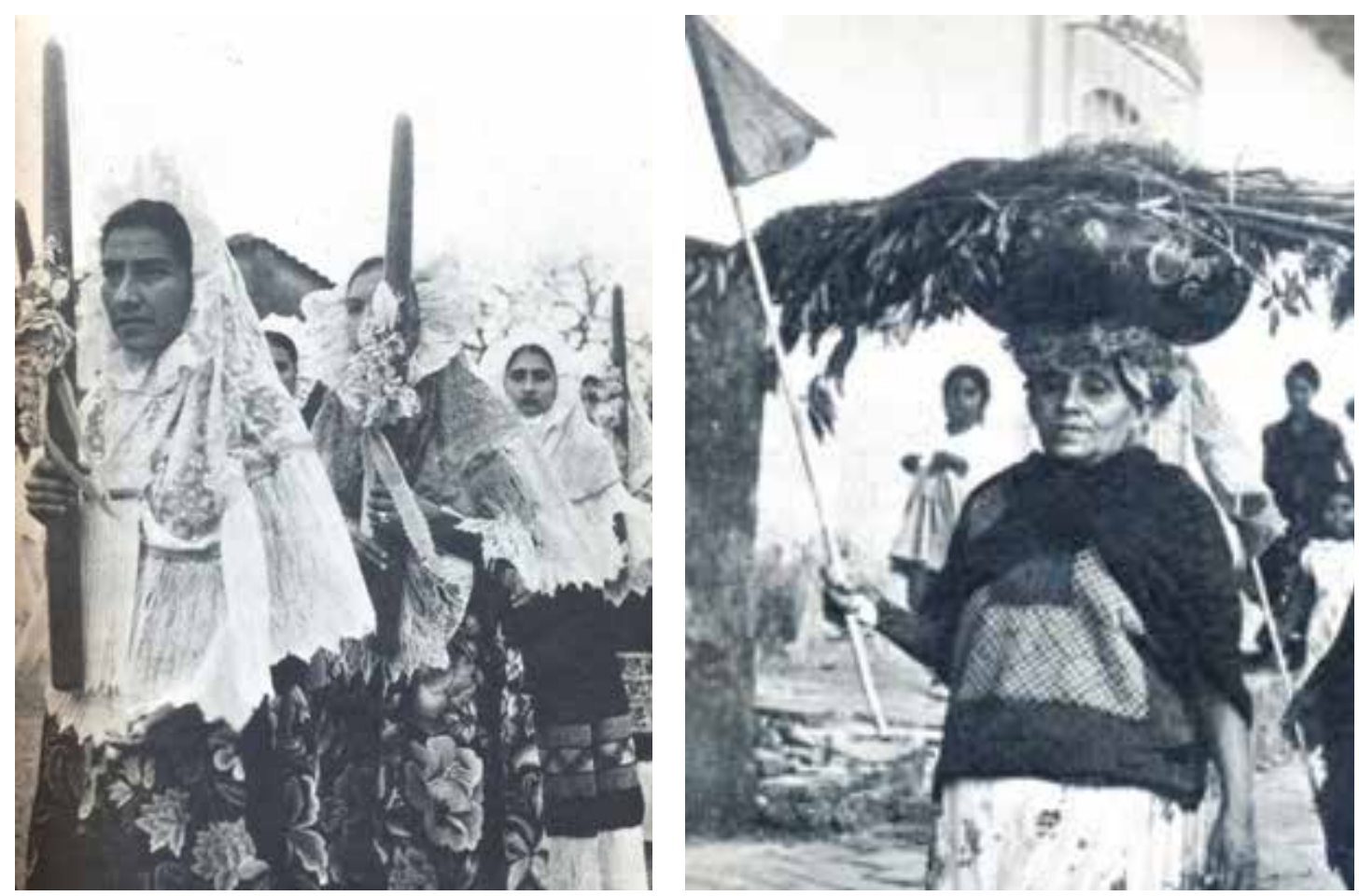

Mayordomía. Procesiones. (Fotos: Berenice Kolko).

Conocidas son las Danzas de Pluma en Valles Centrales (Cuilapan, Zaachila y Teotitlán del Valle principalmente), la Zandunga, la Tortuga, el Mediu Xiga (que se baila en las bodas) y varias más en el Istmo y el Tigre en varias poblaciones.

ORGANIZACIÓN RELIGIOSA. Entre los Zapotecas permanece fuertemente conservada la institución socio-religiosa de la Mayordomía. Prácticamente en todas las iglesias del área existe un sacristán, y casi siempre un comité, quienes son los encargados de cuidar el templo y sincronizar con el mayordomo todo lo relativo a las festividades. También se observa la costumbre de la "Guelaguetza", aportación en especie de carácter recíproco como ayuda al Mayordomo. Sin embargo, la mayor parte de los gastos corren por su cuenta, por lo cual es frecuente que un mayordomo quede arruinado después de la festividad. Como contrapartida, el cargo del mayordomo da tal prestigio entre la comunidad, que siempre hay personas dispuestas a asumirlo.

Por otra parte, en el grupo también se conservan fuertemente arraigados muchos conceptos religiosos prehispánicos: se practican ceremonias de fertilidad y rezos invocando a Dios, San Pablo y a la Cruz. Los lugares preferidos para estas prácticas son aquellos donde existen ruinas arqueológicas, porque se considera que ahí están enterrados los antepasados, lo cual es perfectamente cierto. Cabe señalar que para la realización de algunas ceremonias religiosas ciertas personas modelan imágenes de los bienes que se desean obtener, hechas en barro, para después depositarlas en las cercanías de los santuarios, (práctica frecuente entre los peregrinos que acuden a los de Matatlán y Juquila), en la ladera de 
cerros donde se han instalado cruces, en el interior de las iglesias o en los nichos de sus fachadas, en algunas cuevas (donde se realizan ritos de fertilidad) y ocasionalmente en algunas zonas arqueológicas aisladas. Es importante hacer notar que la trecena, número muy importante en el calendario ritual, suele estar presente en muchas de las ceremonias religiosas y aún en las funerarias. Es muy frecuente que sean trece objetos de la misma clase los que son ofrendados (por ejemplo; las 13 semillas de maíz, 13 tortillas o 13 vainas de guaje que suelen depositarse para acompañar un cadáver al ser inhumado).

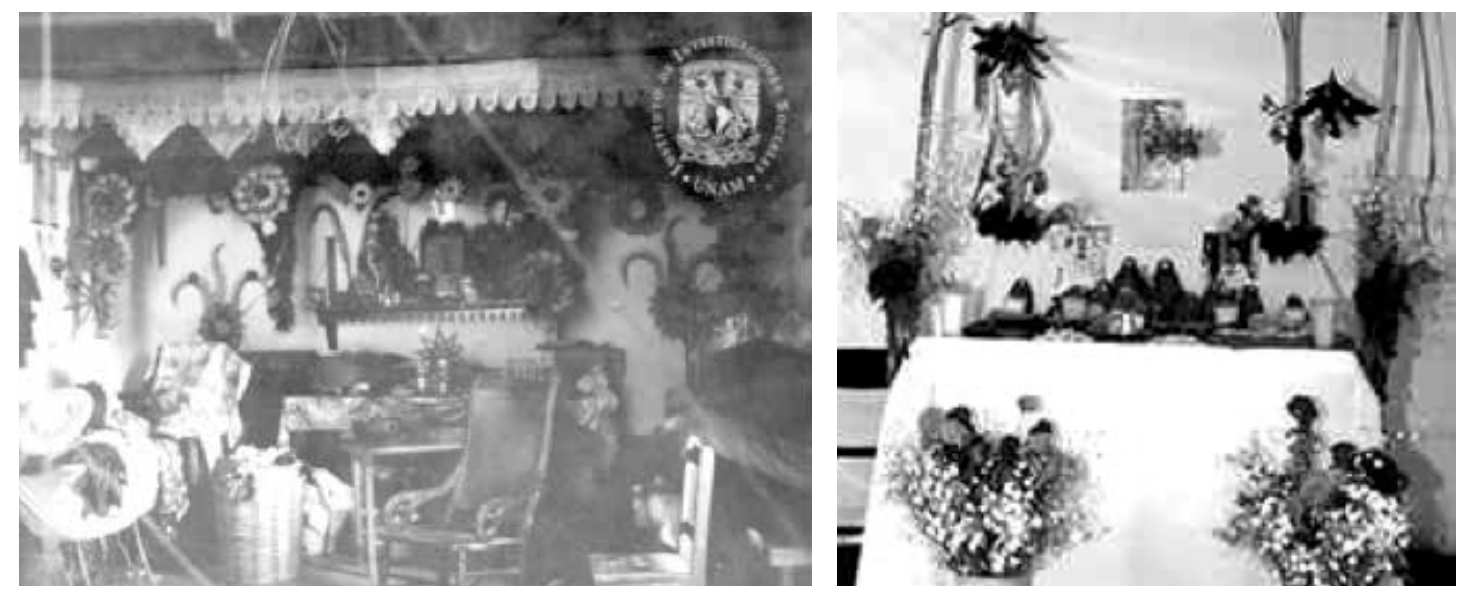

Altares domésticos ístmico y yalalteco.(Fotos: IIS-UNAM y Giselle Muñoz Ramírez)

Durante los últimos 50 años en muchas comunidades han proliferado grupos religiosos adictos al protestantismo en sus diferentes sectas. Parte importante de estas acciones han sido promovidas por miembros del Instituto Lingüístico de Verano, quienes aprovechando su estancia para investigar, han dividido de esa manera a las comunidades generando problemas de interrelación, y de falta de la misma, que han llegado a revestir extrema gravedad. Las comunidades divididas son así fácil presa de la introducción de nuevos y distintos conceptos culturales y de mercadotecnia consumista, por lo cual el proceso de su destrucción física y cultural se ha acelerado. La organización de los grupos protestantes creados dentro de la etnia es en la actualidad exactamente la misma que la de cualquier grupo de la misma religión en cualquier ciudad de los Estados Unidos de los que dicha organización está copiada. Similar situación organizativa puede observarse en el caso de los Testigos de Jehová.

MEDICINA Y MAGIA. En las comunidades zapotecas subsisten aún muchos individuos que practican, con ligeras variantes regionales, actos de hechicería, magia y curanderismo. En las cuatro regiones ocupadas por el grupo la herbolaria es una práctica ampliamente difundida, debido a que en ellas existe un gran número de plantas con propiedades medicinales a las que recurre la población. Como reminiscencia de los conceptos calendáricos prehispánicos, subsiste una cosmogonía que considera que el universo está gobernado por deidades relacionadas entre sí, y que ese universo es una gigantesca isla rodeada de gran- 
des masas de agua, todo lo cual se sostiene en el espacio debido al poder de esos dioses. Esta cosmogonía considera que existen tres grupos de dioses, uno que representa los fenómenos naturales (rayo, lluvia, etc.), otro que rige las actividades agrícolas y productivas y un tercero que tiene funciones estrictamente sociales y principalmente la de la creación del mundo.

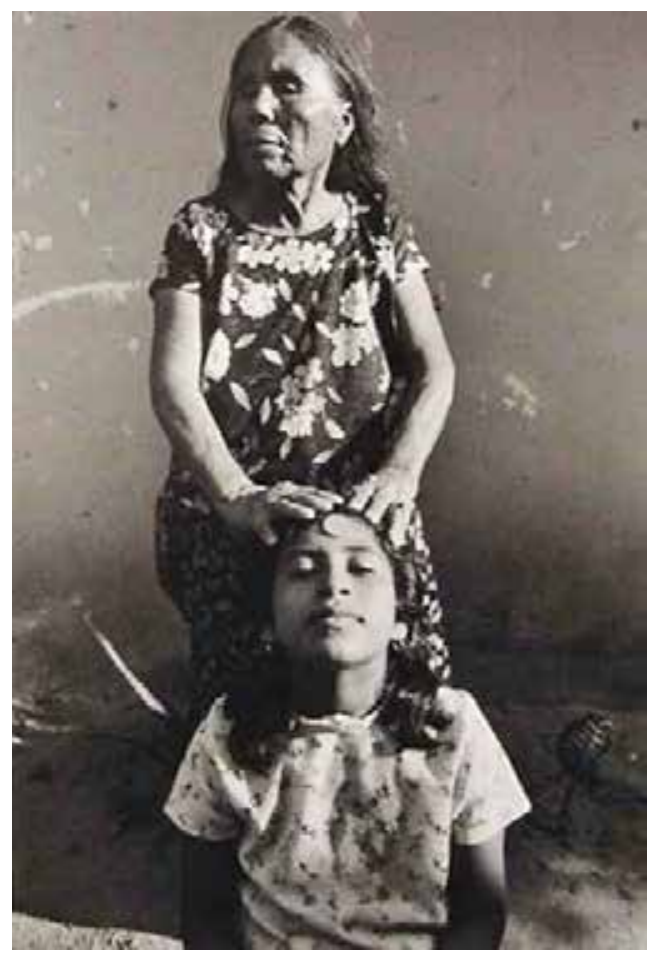

Curandera o shamana zapoteca. (Foto: Graciela Iturbide)

Aún hoy, muchos miembros de la etnia creen en ciertos espíritus tales como la Matlacihua, personaje más o menos equivalente a la Xtabay de Tabasco, que consiste en una mujer muy atractiva e irresistible, siempre portante de un huipil blanco, que atrae a los hombres a los breñales, concentraciones de cactos, huizaches, precipicios, ríos crecidos y lagunas con el objeto de lograr su perdición y su muerte, abundante en las tradiciones de Zaachila y el resto de Valles Centrales y la que en las regiónes de Yalalag en la Sierra Norte, y varios otros pueblos, cuenta con el agregado de poseer una pata de cabra y una de zopilote, o bien una de mula y otra de guajolote. Se cree, además, en una especie de espíritus infantiles, asexuados, extraordinariamente bromistas, traviesos y juguetones, aunque a veces malévolos, a los que se denomina Chaneques, que se la pasan desordenando y escondiendo objetos y haciéndole bromas o creándole enfermedades a la gente. Dentro del grupo persisten dos creencias más: La del Nahualismo y la de la Tona. Ambas están relacionadas con un animal protector, pero la segunda es usada para relacionar a un niño recién nacido con el primer animal que deje huella, con frecuencia en una banda de ceniza o de tierra muy 
fina, colocada frente y alrededor de la casa en que se produjo el nacimiento, el cual le dará su nombre y su protección. En ocasiones subsisten las creencias en los espantos, la pérdida del alma, la envidia, el mal de aire y el mal de ojo, así como la mala combinación de alimentos, a los que se considera "fríos" o "calientes". También existen localidades donde persiste la adivinación con granos de maíz.

En las regiones zapotecas la medicina preventiva está entendida como una sucesión de actos de magia, tanto por simpatía como por contacto. Esta costumbre, observada desde tiempos remotos, está bastante arraigada y consta de dos aspectos: La aplicación de amuletos, fajas, escapularios o cruces, y el aprovechamiento anímico-colectivo de fenómenos naturales tales como los eclipses, etc. Para impedir el aborto, el vientre de la mujer es rociado con un licor dulce y se le pasa en varias ocasiones un huevo. En algunas comunidades de la Sierra Norte se usa como protección nocturna contra el mal de ojo una determinada cantidad de marihuana martajada, a la que previamente se dejó reposando dentro de una vasija durante ocho noches, en compañía de un cuerno de vaca. Prácticamente en todas las regiones los curanderos se distinguen por sus especialidades y en ocasiones la gente se desplaza regulares distancias para poderlos consultar. Como consecuencia de los recientes programas de sanidad implementados por el gobierno federal han llegado pasantes de medicina a realizar su Servicio Social a muchas localidades relativamente aisladas. La eficacia de este servicio se ve obstaculizada por el hecho de que no a todos los dispensarios llegan cantidades suficientes de medicinas y, por consiguiente, muchas personas no reciben una atención completa y efectiva. En el caso de los partos, la inmensa mayoría de los miembros de la etnia han nacido con la ayuda de parteras empíricas, y en muchas localidades, cuando la mujer se encuentra acuclillada. Sólo en las ciudades de Oaxaca, Salina Cruz, Tehuantepec, Juchitán, Pochutla, Miahuatlán y Tuxtepec existen instalaciones hospitalarias dando servicio.

EDUCACIÓN. Por su posición geográfica, el grupo es uno de los mejor atendidos por los programas educativos. En las cuatro regiones existe un considerable número de escuelas primarias y muchas secundarias. En algunas cabeceras distritales se encuentran planteles de enseñanza media y superior que permiten la terminación de ciertas carreras de niveles técnicos y profesionales, tanto en la rama administrativa, como en la agropecuaria y en la de la salud. No obstante esta situación, y debido a los problemas existentes de insuficiencia de recursos, muchos miembros de la etnia no han podido rebasar los niveles inferiores de escolaridad. Sin embargo, durante los últimos 40 años, el gobierno estatal ha creado instituciones de enseñanza media y media superior en varios municipios. Hoy ya se cuenta con Secundarias, Telesecundarias, Colegios de Bachilleres, CECYTES e instituciones de nivel bachillerato en varias poblaciones (Ixtlán, Tehuantepec, Salina Cruz, San Blas Atempa, Espinal, Ixtepec, Juchitán, Matías Romero, Unión Hidalgo, Niltepec, Reforma de Pineda, Chahuites, Santa María Huatulco, Puerto Escondido, Candelaria Loxicha, Pochutla, Puerto Angel, San Pablo Huixtepec, Miahuatlán, San Juan Guichicovi, San Pablo Guilá, Telixtlahuaca, Villa de Etla, Xoxocotlán, Cuilapan de Guerrero, El Tule, San Antonino Castillo 
Velasco, Tlacolula de Matamoros y Mitla y, por supuesto, con universidades en los Distritos del Centro, Ocotlán, Ixtlán, Pochutla, y Miahuatlán, las Universidades del Sistema Estatal, que ofrecen en total 28 licenciaturas, 8 maestrías y un doctorado, pero por la pobreza imperante, la población indígena de esas instituciones sigue siendo muy baja. En general muchos jóvenes con algún grado de instrucción, que estudiaron becados, están recurriendo a la emigración.

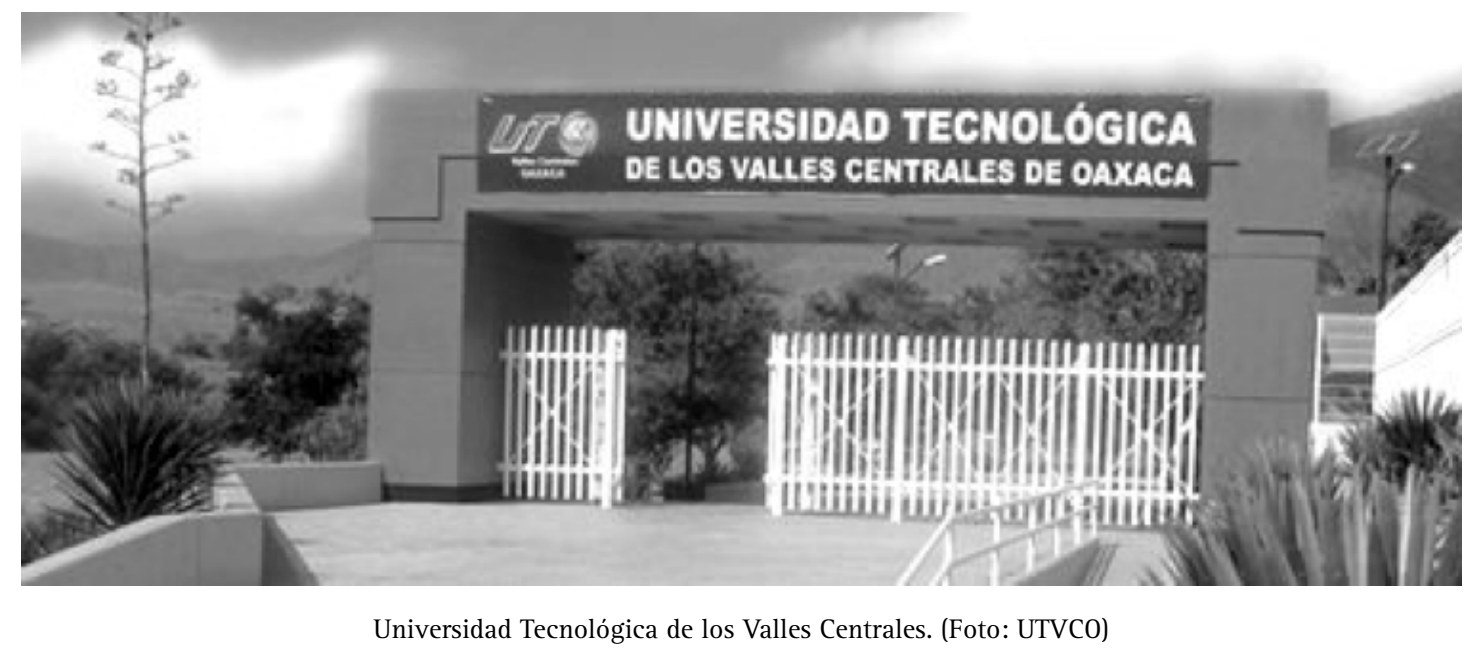

BIBLIOGRAFÍA

Acevedo Conde, María Luisa. 2007 “Los Zapotecos”. En: Revistas A CONTRAGOLPE. Nos 21, 22 y 23. Editorial Carteles . Oaxaca, Oax. 2007.

Acosta Márquez, Eliana. 2005 MIGRACION ZAPOTECA A LA ZONA PETROLERA DEL SUR DE VERACRUZ. Ensayo preliminar para el Proyecto de Etnografía de las Regiones Indígenas de México. INAH. México, D F. 2005. 2008 ZAPOTECOS DEL ISTMO. Comisión para el Desarrollo de los Pueblos Indígenas. México. D F. 1988.

Basauri, Carlos. 1940 “Los Zapotecos”. Reed 1990 En: LA POBLACION INDIGENA DE MEXICO. Secretaría de Educación Pública. México. D F. 1990.

Barabas, Alicia Mabel. Bartolomé, Miguel. 1999 CONFIGURACIONES ETNICAS EN OAXACA. PERSPECTIVAS ETNOGRAFICAS PARA LAS AUTONOMIAS. Instituto Nacional Indigenista, Consejo Nacional para la Cultura y las Artes, Instituto Nacional de Antropología e Historia. México, D F. 1999.

Brasseur de Boubourg, Charles Etienne. 1981 VIAJE POR EL ISTMO DE TEHUANTEPEC. Fondo de Cultura Económica. México, D F. 1981. Chassen, Frances. 1996 "El Desarr llo Económico de Oaxaca a fines del Porfiriato". En: REVISTA MEXICANA DE SOCIOLOGIA. Año XIV, No 1. Enero-Marzo. UNAM. México, D F. 1996.

Cook, Scott y Binford, Leigh. 1995 LA NECESIDAD OBLIGA. LA PEQUEÑA INDUSTRIA RURAL EN EL CAPITALISMO MEXICANO. CONACULTA. México, D F. 1995. 
Coronado Malagón, Marcela Rosa María. 2004 PROCESOS DE ETNICIDAD DE LOS ZAPOTECOS DEL ISTMO DE TEHUANTEPEC, UNA RELACION TRIADICA ENTRE RESISTENCIA Y DOMINACION. Tesis Doctoral en Antropología. ENAH. México, D F, 2004.

Coronel Ortiz, Dolores. 2008 ZAPOTECOS DE LOS VALLES. Comisión para el Desarrollo de los Pueblos Indígenas. México, D F. 1988.

Covarrubias, Miguel. 1946 EL SUR DE MEXICO. (El Istmo deTehuantepec). INI. Clásicos de la Antropología. No 9. México. D F. 1946. Reed 1980.

Cruz, Wilfrido C. 1982 OAXACA RECONDITA. Edición conmemorativa del 450 aniversario de la expedición de la Cédula Real que dio a Oaxaca categoría de Ciudad. Gobierno del Estado. Oaxaca, Oax. 1982.

De La Fuente, Julio. 1977 YALALAG. UNA VILLA ZAPOTECA SERRANA. Instituto Nacional Indigenista (Colección Clásicos de la Antropología Mexicana. No 2). México, D F. 1977. ENCICLOPEDIA DE MEXICO. Tomo 14. 1988 “Los Zapotecas”. p 8253 Editorial Enciclopedia de México. México, D F. 1988.

González, Álvaro. 1995 "Los Zapotecos de los Valles Centrales de Oaxaca”. En: ETNOGRAFIA CONTEMPORANEA DE LOS PUEBLOS INDIGENAS DE MEXICO. REGION VALLES CENTRALES Y NORTE DE OAXACA. INI. Secretaria de Desarrollo Social del Gobierno del Estado de Oaxaca. México, D F. 1995.

Islas, Luz. 1912 "El Hogar del Indio Zapoteca”. BOLETIN DEL MUSEO NACIONAL. México, D F. 1912.

Nader, Laura. 1969 "The Zapotec of Oaxaca”. EN: HANDBOOK OF MIDDLE AMERICAN INDIANS. Vol. 7. University of Texas Press. Austin \&t London. 1969.

Martínez Gracida, Manuel. 1883 HISTORIA ZAPOTECA. Edición del Autor. Oaxaca, Oax. 1883.

Matus, Manuel. 1997 PUEBLOS INDIGENAS DE MEXICO. ZAPOTECOS DEL ISTMO DE TEHUANTEPEC. INI. México, D F. 1997.

Reina, Leticia. 1994 ECONOMÍA CONTRA SOCIEDAD, EL ISTMO DE TEHUANTEPEC 19071986. Ed. Nueva Imagen, México, D F. 1994. 2004 CAMINOS DE LUZ Y SOMBRA. HISTORIA INDIGENA EN OAXACA EN EL SIGLO XIX. CIESAS. Centro Nacional para el desarrollo de los Pueblos Indígenas. México, D F. 2004.

Rodrigo Álvarez, Luis. 2004 GEOGRAFIA GENERAL DEL ESTADO DE OAXACA. Carteles Editores. Oaxaca, Oax. 2004. Romero Frizzi, Ma de los Ángeles. 1996 EL SOL Y LA CRUZ. LOS PUEBLOS INDIOS DE OAXACA COLONIAL. CIESAS. INI. México, D F. 1996.

Ruiz González, María Teresa. 1990 "Los Zapotecos del Valle de Oaxaca". En: OAXACA, TEXTOS DE SU HISTORIA. Tomo I. Instituto “José María Luis Mora”. México, D F. 1990.

Scheffler, Lilian. 1986 “Zapotecos”. Panorama Editorial. Litográfica Ingramex. S A México, D F. 1986.

Stephen, Lynn. 1998 MUJERES ZAPOTECAS. Instituto Oaxaqueño de las Culturas. FONCA. México, D F. 1998.

Varese, Stefano. 1990 "Apuntes para una Historia de la Etnia Zapoteca”. En: OAXACA, TEXTOS DE SU HISTORIA. Tomo I. 
Instituto de Investigaciones “José María Luis Mora”. México, D F. 19902000 “Migrantes Indígenas Mexicanos en los Estados Unidos. Nuevos derechos contra viejos abusos".En: CUADERNOS AGRARIOS. Nueva Época. № 19-20. (Coord: Beatriz Canabal). México, D F. 2000.

Warman, Arturo. 1973 LOS CAMPESINOS, HIJOS PREDILECTOS DEL REGIMEN. Ed: Nuestro Tiempo, México, D F. 1973.

Whitecotton, Joseph. 2004 LOS ZAPOTECOS. PRINCIPES, SACERDOTES Y CAMPESINOS. Fondo de Cultura Económica. México, D F. 2004.

Winter, Marcus C. 1988 “Período Prehispánico”. En: HISTORIA DE LA CUESTION AGRARIA MEXICANA. Coord. Leticia Reyna. Gobierno del Estado de Oaxaca. UABJO. Imprenta Juan Pablos. México, D F. 1988. 


\section{CHATINOS}

Autodenominación: kitse chátnio, chaj naa.

Sinónimo en su lengua: tsa’jñan.

Significado: Los que hablan palabras elaboradas.

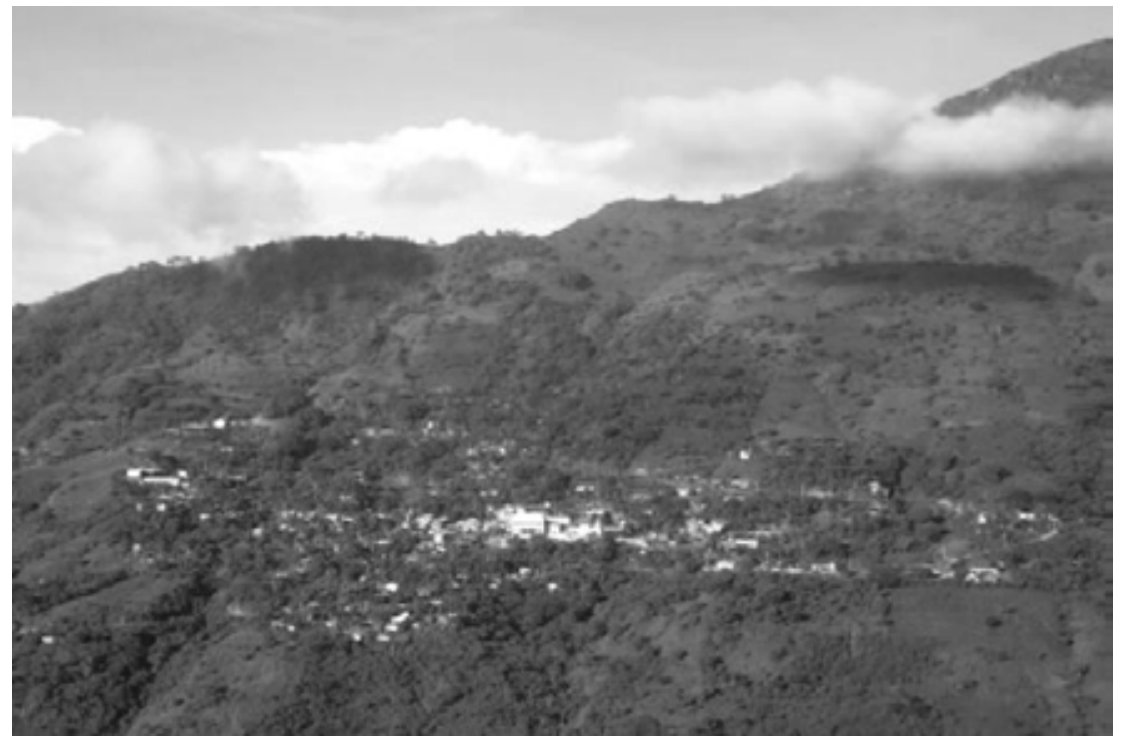

Paisaje de Sta.Cruz Zenzontepec (Foto: Ayuntamiento de Zenzontepec)

\section{GRUPO CHATINO}

UBICACION GEOGRAFICA. Este grupo se encuentra localizado en los Distritos de Juquila y Sola de Vega en la porción suroccidental del estado, ocupando la región central de la Sierra Madre del Sur y en ella los municipios de Santa Catarina Juquila, San Juan Quiahijé, Santiago Amoltepec, Santa Cruz Zenzontepec, San Lorenzo Texmelucan, Santos Reyes Nopala, Tataltepec de Valdez y Santiago Yaitepec. El área queda inscrita entre los paralelos $16^{\circ}$ y $16^{\circ} 50^{\prime}$ de Longitud Norte y entre los meridianos $96^{\circ} 20^{\prime}$ y $97^{\circ} 15^{\prime}$ de Longitud Occidental. El relieve regional es sumamente accidentado y la región ocupada presenta dos cadenas montañosas con una altura máxima sobre el nivel del mar de 2,840 mts., de las que parten varias cuencas que vierten, una al Río Verde, y otras a la costa del Pacífico formando los ríos San Francisco y Grande. 

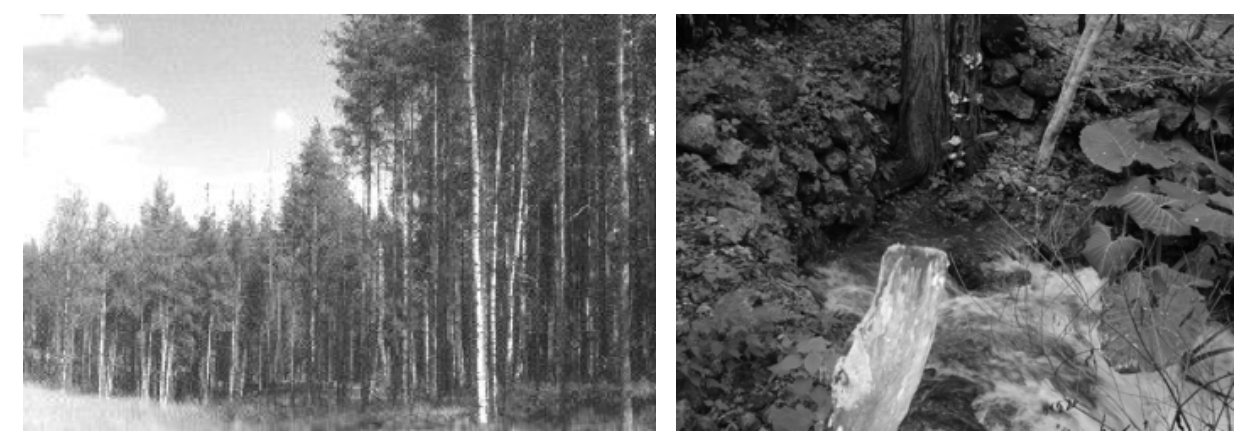

Bosque de coníferas y manantial en zona chatina. Sierra Sur. (Fotos: Ayuntamiento de Zenzontepec.).

La parte alta de la región presenta bosques de coníferas, en proceso de sobreexplotación, y en la porción costera subsiste en manchones la selva baja caducifolia que en algunas localidades fue siendo destruida para abrir campo al cultivo del algodón o a la explotación ganadera. Los climas regionales pueden inscribirse en su casi totalidad dentro de los tropicales subhúmedos con lluvias en verano y los suelos son humíferos en las zonas boscosas, y arenoarcillosos, muy intemperizados, en la región costera.

Debido a que la región presenta vertientes a dos cuencas principales, la precipitación pluvial es variable en razón de que los vientos presentan regímenes diferentes según la época del año. En la cuenca del Río Verde y en la parte alta de las montañas es ligeramente mayor. En la vertiente del Pacífico disminuye considerablemente.

IDIOMA La lengua Chatina pertenece al Grupo Otomangue. Tronco Savizaa, Familia Zapoteca y es la lengua más emparentada con la zapoteca de sus vecinos occidentales. En la actualidad (2014) es hablada aproximadamente por cuarenta mil $(42,000)$ personas, existiendo en apariencia tres variantes, pero en la región subsiste, en tres municipios y conservada por un pequeño puñado de personas, una lengua también emparentada, el Papabuco, ya en innegable peligro de extinción.

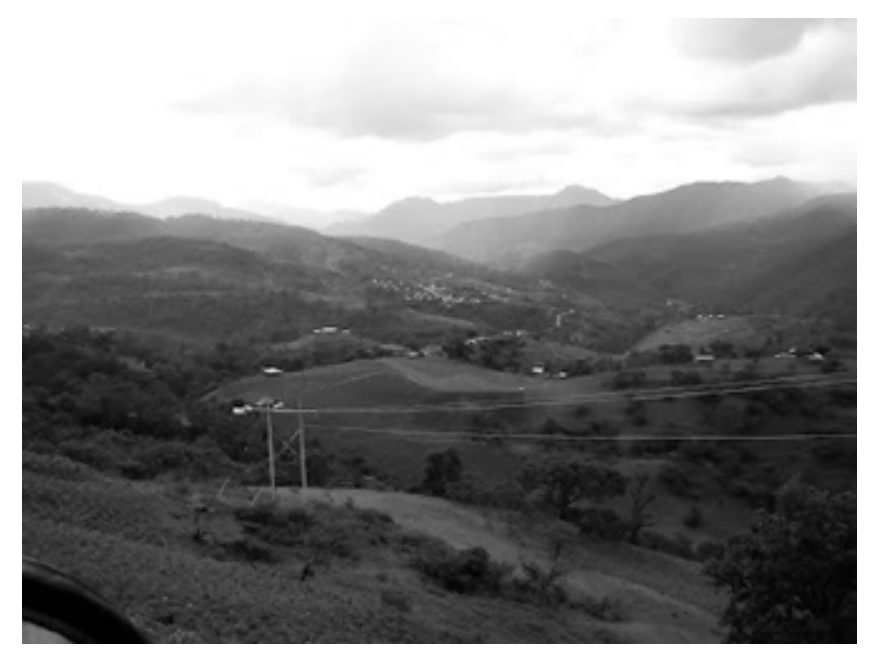

Las montañas donde se habló el Papabuco. Zona chatina, (Foto: Ayuntamiento de San Juan Elotepec). 
ANTECEDENTES ARQUEOLÓGICOS E HISTORICOS. La región Chatina tiene y conserva una muy importante cantidad de sitios arqueológicos, varios de los cuales revelan gran extensión ocupacional, habiendo también varios sitios con monumentos con representaciones glíficas. La casi absoluta falta de investigaciones controladas, fuera de las realizadas en la cuenca inferior del Río Verde, hace casi imposible asignarlas a los grupos que hayan motivado su construcción. En la zona de la cuenca inferior del Rio Verde la ocupación se remonta a la etapa media de las aldeas, hacia el 600 a C. En algún momento posterior entraron en conflicto con los zapotecos, que para entonces ya estaban instalados en la zona de Sola de Vega.

Debido a su relación integral con los Zapotecos, y a su vecindad con los Mixtecos Altos y Bajos, los Chatinos debieron ser, en ciertos momentos históricos, importantes elementos en el desarrollo cultural regional, cosa a la que apunta el hallazgo de varios monolitos grabados con representaciones de personajes en los sitios arqueológicos de Cerro de la Iglesia, de Río Viejo y algunos próximos, y eventual contención y soporte de los principalatos mixtecos, bajo cuyo poder cayeron a partir de la segunda mitad del Siglo XI. La población de Juquila recibía el nombre de Nuu sii Taoo, lo que, traducido al español significa "Lugar de la Nobleza Hereditaria". En los códices existe información de que en el Siglo XI (aparentemente en el año 1031 d C) hubo allí una boda de un hijo del Principal mixteco $\widehat{\jmath} 8$ Venado "Garra de Jaguar", đิ 6 Casa "Que baja del Cielo", con una Principal chatina, $q 9$ Movimiento "Corazón de Jade”.

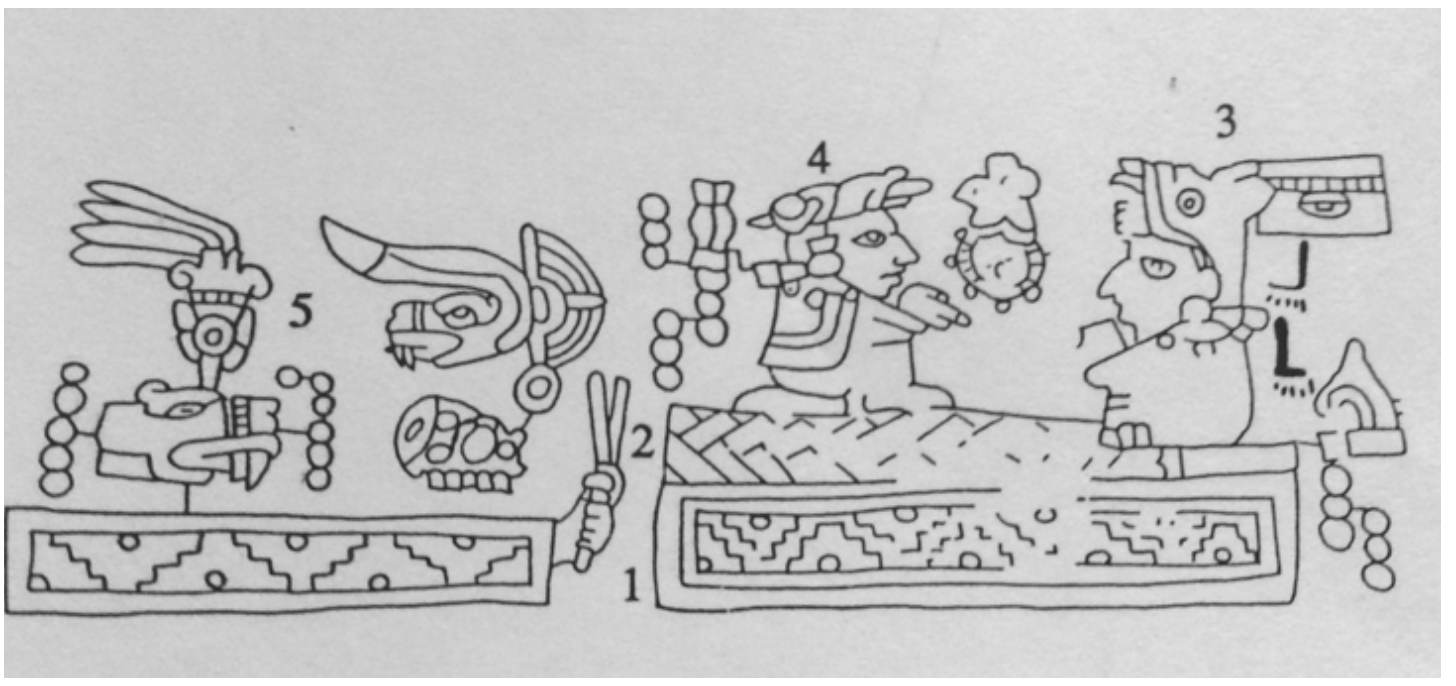

Boda chatina de principales. 3.- 6 Casa (Que bajó del cielo). 4.- 9 Movimiento (Corazón de jade). 5.- El glifo de Juquila con la representación de los nombres de los padres de la novia: 1 Muerte (Serpiente solar) y 11 Serpiente (Flor emplumada). (Códice Selden o Sicuañe).

Las referencias en crónicas y los monumentos arqueológicos ubicados en el territorio, revelan tener una gran importancia histórica. Se consigna que en Teojomulco, Zenzontepec y Juquila durante varios siglos existieron principalatos de importancia. En Teojomulco y Zenzontepec se han hallado restos arqueológicos, principalmente tumbas, que desde el 
siglo XIX quedaron consignadas por primera vez en las obras de Dn. Manuel Martínez Gracida. En Santos Reyes Nopala se conservan varias estelas bajadas de la zona arqueológica de Cerro de la Iglesia y casi todas representan personajes con tocados elaborados, acompañados de numerales y glifos aún no descifrados, casi seguramente representaciones de algunos de los antiguos gobernantes, fechables al fin del clásico mesoamericano, hacia los años 600 a $900 \mathrm{~d}$ C.

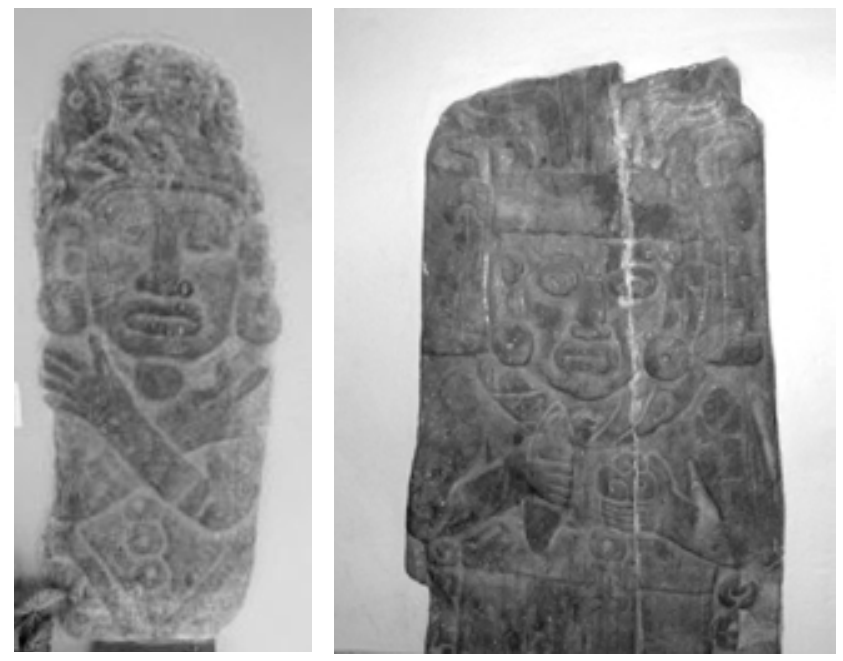

Estelas de Santos Reyes Nopala. (Fotos: Arql. Lorenzo Gamio).

Durante el período postclásico los mixtecos fueron adueñándose poco a poco de la región chatina, y hacia el 1300 d C, el principalato que enseñoreaba la región era Tututepec. A esa población los chatinos entregaban ropa, mantas, maíz, plumas y jícaras conteniendo oro como tributo, y aunque conservaron cierta autonomía, un poco mayor en el caso de Zenzontepec, muy probablemente dada por el idioma y las costumbres, pasaron al vasallaje. Al sobrevenir la conquista, el personaje dominante era $\widehat{\jmath}$ Usia andoo (7 caña), el principal en Tututepec, vejado y conquistado por el español Pedro de Alvarado y sus hombres.

Un poco antes, en el Siglo XIV, la región fue conquistada por los ejércitos aztecas. Poseedora de recursos que los tenochcas necesitaban, y entre ellos las plumas, el oro, las mantas, una arena abrasiva muy especial para labrar la piedra y una piedra especial para pulir, avanzaron sobre ella cuando el Señor de Tenochtitlan era Moctezuma I Ilhuicamina, logrando dominarla hacia el año 1460. No obstante, los deseos de independencia chatina se mantuvieron latentes, volviéndose a manifestar cuando, en 1502 hubo una rebelión, ahora reprimida por los hombres de Moctezuma II Xocoyotzin. La siguiente invasión ya sería española.

Existen bastantes datos que otorgan liderazgo a la región Chatina desde el punto de vista religioso. En el área la evangelización comenzó hacia 1525 con la acción de Fray Gonzalo Lucero, quién fue adoctrinando sucesivamente a los pobladores de Mixtepec, Zenzontepec y Juquila, a lo cual seguirían las demás. En ésta última población, existe un importante santuario religioso desde la época colonial. En esa iglesia fue depositada una 
figurilla de la Virgen de la Concepción o Virgen de Juquila (de magnífica factura hispano-filipina), que había sido donada en el Siglo XVI por Fray Jordán de Santa Catarina a un joven del poblado de Amialtepec, y que había quedado incólume después de encontrarse en el centro de un incendio. Una vez instalada en la iglesia de Juquila, y dada su alta eficiencia para hacer milagros, se pierde en el tiempo la relación de peregrinaciones que todos los días 8 de diciembre de año con año, llegan desde lugares situados en el norte, centro, sur y sureste de México. Guatemala y Honduras, en su visita anual. El sentir popular y los peregrinos no dudan de la eficiencia de la imagen, ya coronada y Juquila, en la actualidad, es una de las parroquias que más recursos aporta a la estructura de la iglesia católica estatal.

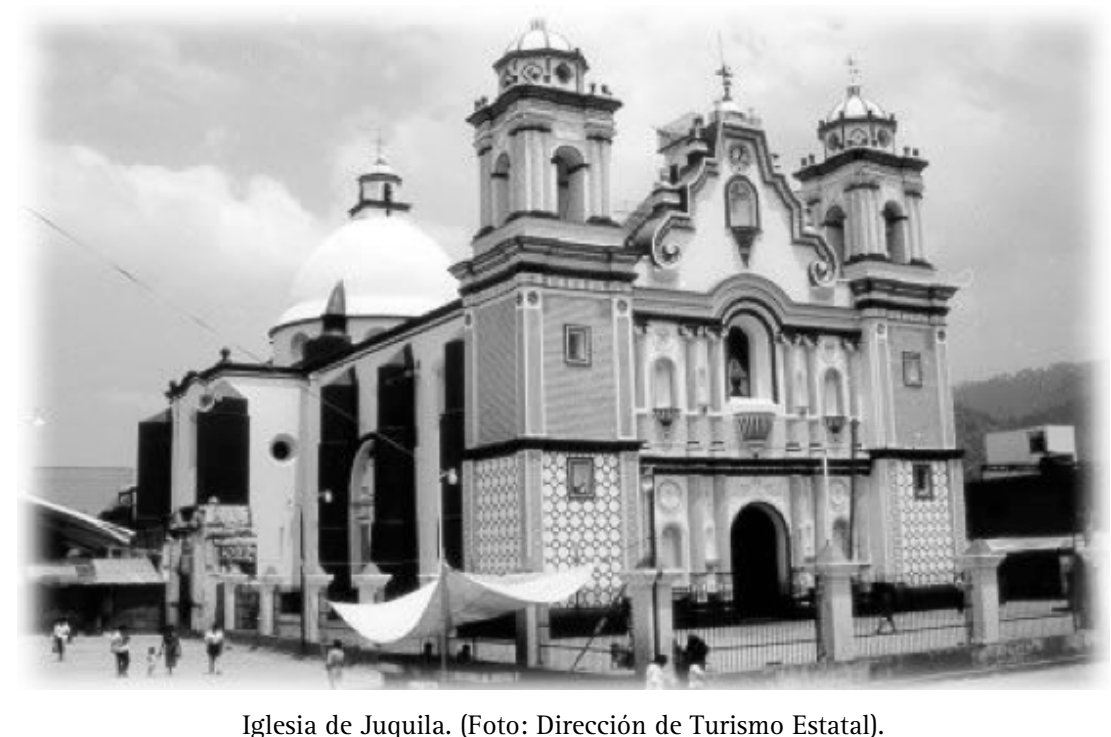

Durante los dos últimos siglos de la historia nacional, la etnia chatina fue perdiendo terrenos usufructuados por mestizos. Aportó hombres como combatientes en la Guerra de Independencia; Inicialmente el contingente de Dn. Antonio Valdés, quién sostuvo combates contra las realistas del comandante Francisco Paris en la región de Chacahua, y más tarde a algunas otras fuerzas, también insurgentes, que se incorporaron a las del General Vicente Guerrero. También se registra su participación en la Guerra de Reforma en enfrentamientos zonales entre liberales y conservadores, jefaturados éstos por José Eustaquio Manzano. Poco después hubo chatinos en las fuerzas oaxaqueñas que combatieron la Intervención Francesa, particularmente en las secciones que, al mando del Gral. Faustino Vázquez Aldana, participaron en la Batalla de La Carbonera, en el Asalto a Puebla del 2 de abril de 1867 y en el Sitio de México. Posteriormente, en varias ocasiones se han rebelado contra injusticias del Gobierno Federal, sobre todo porque como consecuencia de las Leyes de Reforma de 1859, y con manifiesta mala fe por parte de algunos jefes políticos y notarios, muchas de sus tierras comunales pudieron ser escrituradas para la creación de importantes fincas cafeteras, algunas de más de 2000 hectáreas. Ya en el Siglo XX, hubo 
pequeños contingentes chatinos en las fuerzas soberanistas del Gral. Juan Rodríguez, y en 1935 - 37, indígenas de esta etnia participaron en las acciones de los dos bandos que se enfrentaron con el resultado de hacer abortar uno de los últimos movimientos cristeros realizados en el país, el que jefaturó el Prof. David Rodríguez, quién en 1935 terminó traicionado y muerto. El grupo, aunque en ocasiones conservó o tuvo acceso a tierras, continúa siendo víctima de marginación y enfrentamientos intermunicipales, presentándose actividad política partidaria, la que surgió entre miembros de la Confederación Nacional Campesina. Actualmente tienen presencia los partidos Revolucionario Institucional (PRI) y el de la Revolución Democrática (PRD).

DEMOGRAFÍA. A principios de 1983 existían aproximadamente 55,000 personas de este grupo en el Estado. Algunos de ellos ya fuertemente mestizados con los zapotecos del sur. La actual población (censo del 2010) alcanza más de 80 000, no obstante que ha habido una fortísima emigración, tanto a los Valles Centrales del Estado, como al norte del país, a los EE UU y Canadá.

ACCESOS. En algunas comunidades existen pequeñas pistas de aterrizaje. Un reciente programa en vías de realización esta dotando a la zona de una buena red de caminos de terracería de acceso. La principal ruta troncal de esta región consistió en la carretera de terracería, ahora ya pavimentada, que une Sola de Vega con Puerto Escondido. De ella, en el punto elevado denominado "El Vidrio" se aparta una desviación transitable todo el año, y ahora ya con pavimento, que da acceso a Santa María Juquila, la cabecera distrital. En el resto del área existen bastantes brechas, generadas por la explotación de madera. Y varias de ellas se trazaron sobre las veredas que se han usado desde la época prehispánica, tal como es el caso de los caminos que, partiendo de Sola de Vega, cubren el ámbito de Teojomulco. También, y siguiendo un antiguo camino prehispánico, se ha tendido una carretera entre Juquila y Jamiltepec.

VIVIENDA. Habitualmente la vivienda Chatina era una casa rectangular con techo de pasto o teja, generalmente de dos aguas, sustentada en horcones y con muros de ramas rectas, bajareque o carrizo, con enlucido en las partes altas. En ocasiones la parte inferior de los muros era reforzada con adobe y la puerta era lateral. Solía no haber ventanas. El piso siempre fue de tierra y el terreno en que se asentó la construcción se limpió completamente. El menaje consistió, habitualmente, de petates, hamacas, una mesa, sillas, bancas y ollas y cazuelas de barro. Ocasionalmente hubo una cama de ramas recubierta con un petate.

Hoy son mayoría las casas de material. 

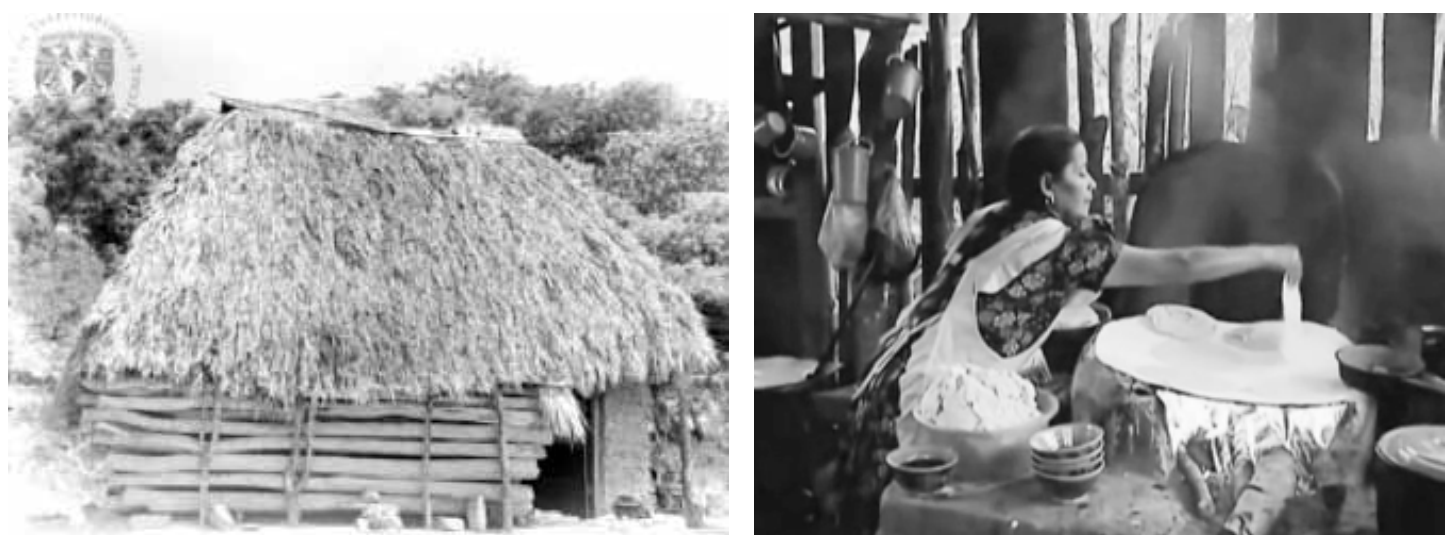

Casa y cocina chatinas. (Foto: IIS-UNAM y CELCI).

Hasta la actualidad, y también de manera habitual cada familia posee una casa en su área de siembra, a la que se traslada en las temporadas de cultivo y de cosecha. Como los campos de cultivo se encuentran a determinada distancia de la población, el ajuar de esa casa se completa en razón directa a la distancia que se encuentra del poblado. Las más completas son las más distantes. Las familias suelen vivir en promiscuidad, incluso con animales domésticos.

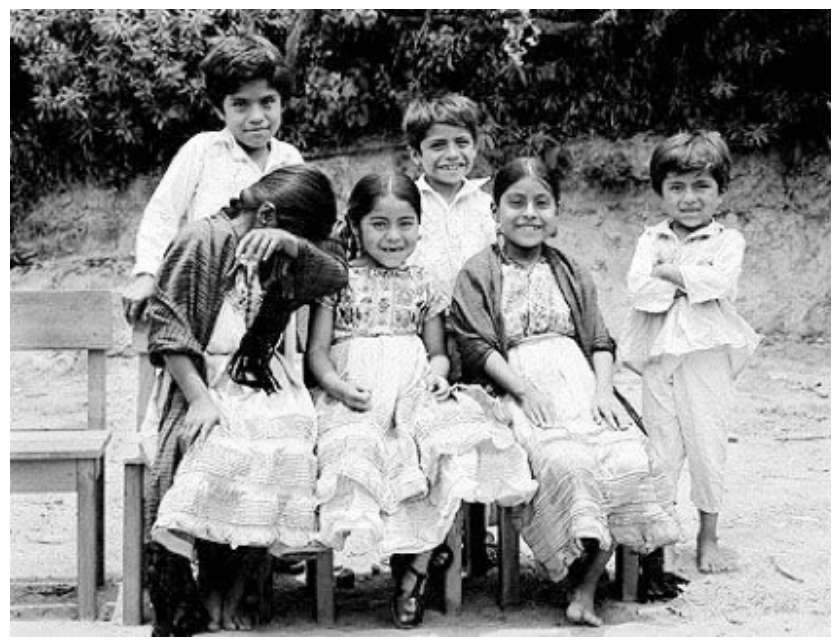

Niños y ancianos chatinos. (Fotos: IIS-UNAM).

INDUMENTARIA. La camisa y el calzón de manta fueron por excelencia la ropa masculina, ahora ya modificada por los patrones de conducta exteriores que han impuesto la camisa de algodón o de fibras sintéticas y el pantalón de mezclilla o de dril. Se siguen usando los huaraches. La indumentaria femenina consistió en una falda de algodón ligero estampado y una blusa bordada con hilo alrededor del cuello y de las mangas, rebozo de colores obscuros, principalmente el negro, y delantales con adornos en las orillas. Los rebozos solían ser utilizados ya sea como enredos en la cabeza o para proteger los hombros, o bien como soportes para proteger a los hijos. 

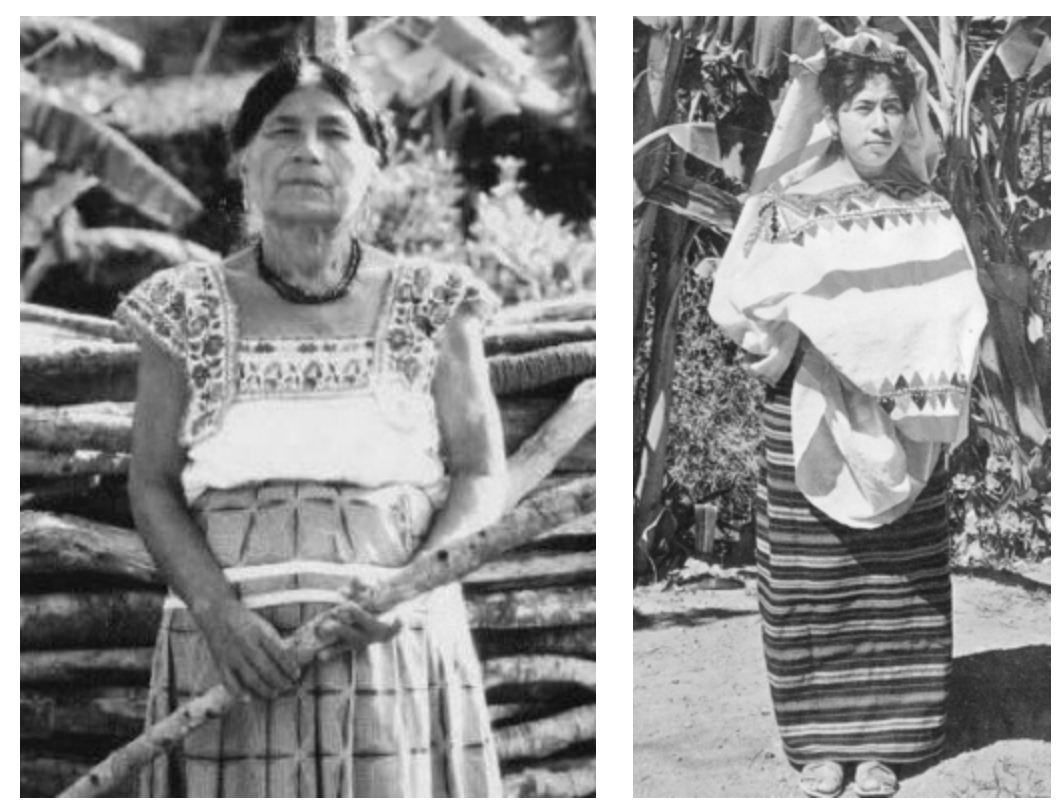

Blusa, falda y enredo chatinos. (Fotos: Turismo del Edo. y Colección Sra. Maria Luisa Audiffred).

La indumentaria femenina ha estado cambiando y desde hace varios años ya se encuentran entre las jóvenes las blusas, faldas y vestidos comerciales. Tradicionalmente las mujeres chatinas se elaboraron su ropa, para lo cual contaron con sus propios telares de cintura y sus propias técnicas de costura. En la primera mitad del siglo XX se ha introducido y utilizado la máquina de coser de pedal.

ECONOMÍA. La economía chatina está fundamentada en cultivos de subsistencia basados en la agricultura de roza. Los principales productos obtenidos son maíz, frijol, calabaza y chile, los cuales se logran en el ciclo agrícola de temporal en zonas donde la profundidad de los suelos lo permite. La tecnología de cultivo es la de roza clásica, en la que se tira el monte con hacha y machete y se siembra el maíz con la coa o palo plantador. Entre el derribe y la siembra se dejan transcurrir dos meses, de tal manera que las plantitas de maíz se desarrollen con las lluvias de junio, y la mazorca se coseche al finalizar la temporada de lluvias. Otro cultivo es el café y antiguamente se plantó algodón en laderas muy bajas, con cierta humedad.

Como puede observarse, la economía chatina está sujeta al coeficiente anual de precipitación pluvial y a las condiciones en que se encuentre el suelo sembrado. En algunas zonas de la región el cultivo de complemento es el café. Aunque las plantaciones de café regionales casi no pertenecen a indígenas, son éstos los que participan activamente en la cosecha, mediante un pago monetario.

Puesto que la mayor parte de la etnia no puede producir todo lo que consume, y necesita artículos de otras procedencias, se generan relaciones comerciales injustas para la parte indígena, que es la que siempre tiene menor poder adquisitivo y de decisión. Para 
algunos indígenas la emigración a trabajos eventuales de carácter agrícola, que se realizan en las zonas agrícolas del país, y fuera de él, ha sido una manera de intentar reforzar el presupuesto familiar. Ahora la emigración es cosa corriente.

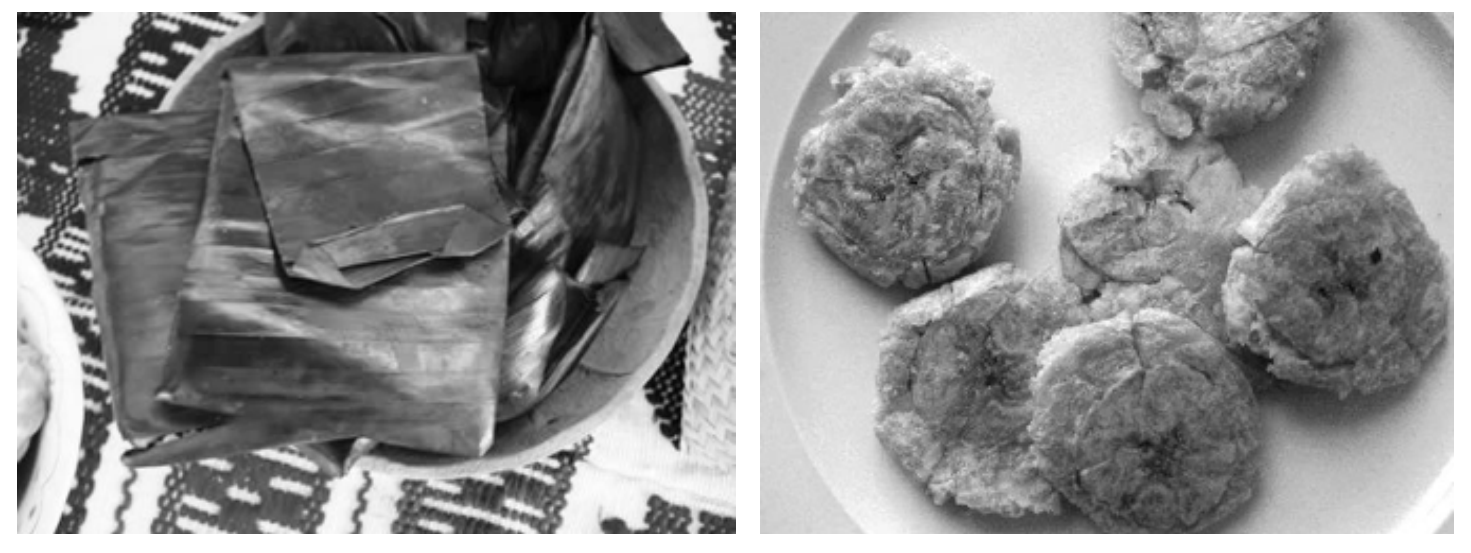

Comida chatina: Tamales y plátanos. (Fotos del autor).

CAZA Y PESCA. La cubierta vegetal regional, hasta hace pocos años intocada, permitió siempre la existencia de una fauna silvestre equilibrada y con un adecuado desarrollo. La desforestación indiscriminada ha destruido parte importante de los ecosistemas de la región, con lo cual muchas especies de animales, como por ejemplo los tinámidos (gallinas de monte), han visto drásticamente reducido su número. Ese problema se agudizó después del paso del huracán Paulina. La población indígena siempre vio a la fauna silvestre como un recurso limitado pero permanente de complementación alimenticia. La "pieza” era pedida al "Amo de los animales".

Entre las especies en peligro en el área se encuentran el jaguar, el puma, el ocelote, el tigrillo, el pecarí, el venado cola blanca y varios tipos de aves, incluyendo los tinámidos y algunas especies de aguilillas y gavilanes, así como un tipo de loro (el de cabeza amarilla) y varios de pericos y cotorras, además de aquellas que dependen de las áreas boscosas para su supervivencia, tales como las codornices, trepadorcitos y cuclillos, Debido a que son pocas las corrientes permanentes de la región, existen algunas especies de peces a las que se pesca de manera muy limitada, entre ellas la platija y el bagre. Hay además muchas variedades de invertebrados, y entre ellos crustáceos endémicos, ya estudiados por el Dr. Fernando Álvarez Noguera, biólogo investigador de la UNAM, que se han capturado con la mano o con pequeñas redes hechas ex profeso.

MERCADOS. Existen mercados en Juquila, Nopala y Panixtlahuaca, pero se registra que el principal fue el de San Juan Tututepec. En las relaciones comerciales ha subsistido el trueque, pero ya la mayor parte de las transacciones se realizan con dinero. En las relaciones de compra-venta, los comerciantes zapotecos y mestizos han dominado la situación en detrimento de la capacidad adquisitiva de la población indígena. 

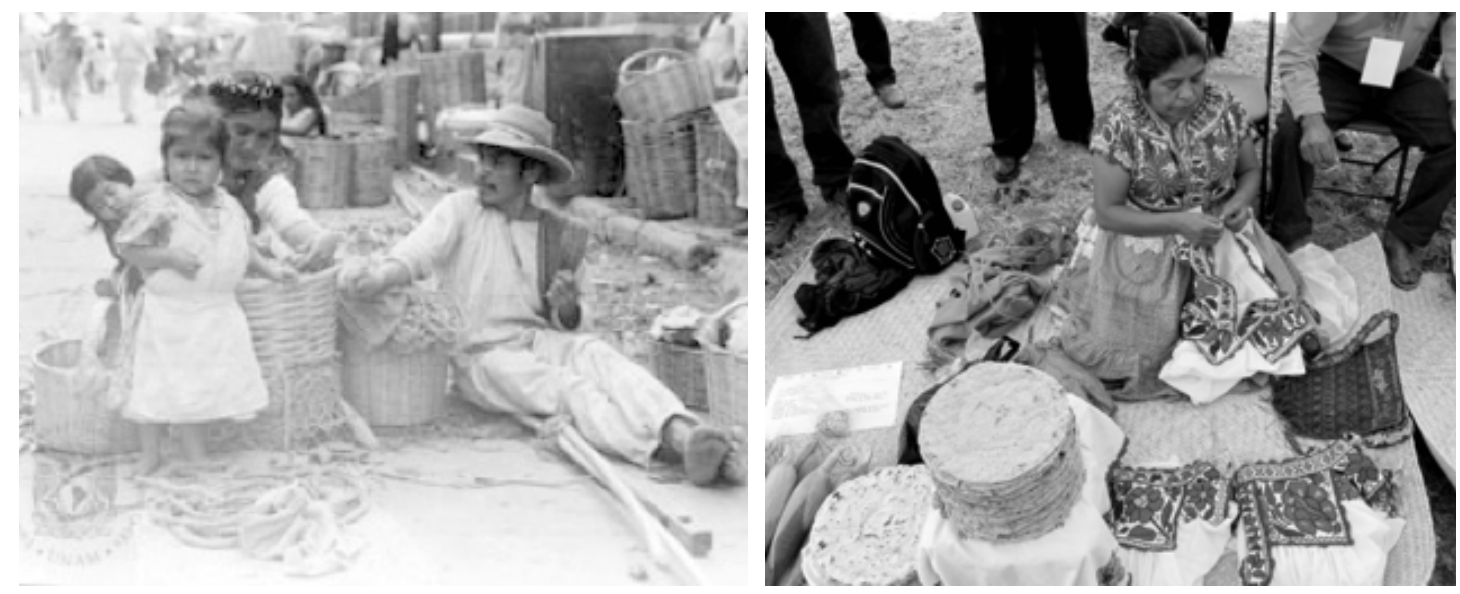

Familia y vendedora en mercado chatino. (Foto: IIS-UNAM y Dir. Turismo, Gbno. Del Estado)

GANADERÍA La ganadería en la región Chatina es extensiva y muy raquítica, fundamentada en ganado vacuno criollo y unos cuantos hatos de ganado ovicaprino. Las yuntas están bajo la advocación de San Isidro Labrador. Se están iniciando programas para introducir ejemplares ovicaprinos mejorados y especies menores. Las condiciones climáticas de la región pueden permitir establecer a bajo costo criaderos de especies menores (conejo, codorniz, paloma y gallinas y de algunas especies de fauna silvestre (pecarí, venado cola blanca, zorra gris y martucha), cuya carne y pieles pueden tener demanda.
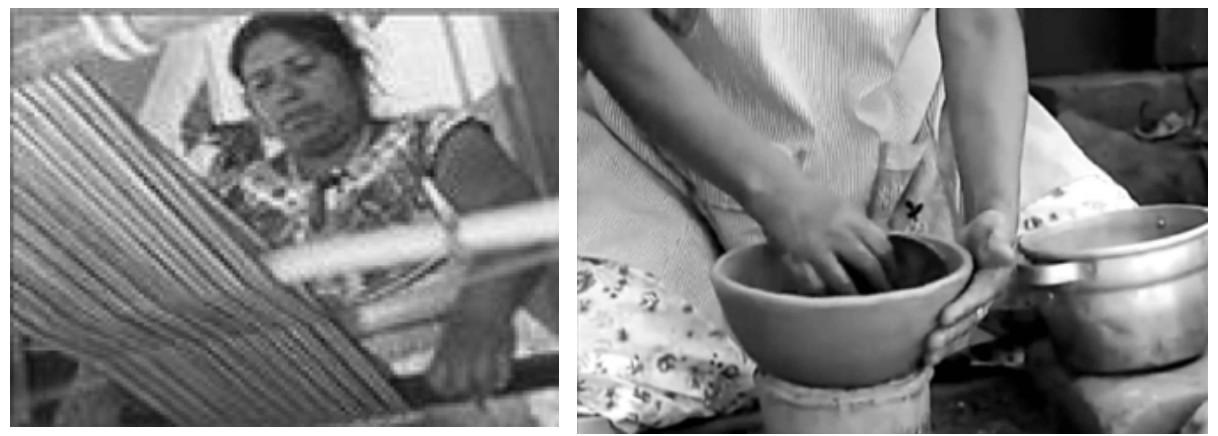

Tejedora y ceramista chatinas. (Fotos: Dir. de Turismo Estatal y CELCI)

ARTESANIAS; La ocupación artesanal mayoritaria ha sido siempre la relacionada con los textiles y los bordados, principalmente huipiles, fajas y servilletas. La costura, el bordado y la manufactura de cerámica, ha sido una actividad fundamentalmente femenina. Algunos hombres han comenzado a desarrollar labores de carpintería, albañilería, plomería y herrería.

ORGANIZACIÓN SOCIAL: La sociedad Chatina mantiene una gran cohesión social. Es patrilocal, patrilineal, monogámica y endogámica. Los hijos varones mayores heredan porciones de la tierra paterna. A la familia nuclear ( padre, madre e hijos) se agrega la familia extensa, que comprende todos los demás parientes, y desde el punto de vista afectivo los compadres, los cuales tienen gran importancia ya que desempeñan un papel fundamental 
en las bodas y bautizos, así como en la protección de las nuevas parejas y de los ahijados que van adquiriendo. El matrimonio entre parientes próximos hasta el tercer grado no es visto con buenos ojos, porque se considera que personas del mismo apellido pueden estar más emparentadas. Gabriel de Cicco, en su artículo sobre Chatinos publicado en el Manual de los Indios Mesoamericanos, señala que este rasgo puede ser el vestigio de la existencia de clanes exogámicos.

Tiempo atrás, en la concertación del matrimonio participaban activamente los padres o los padrinos del novio, los cuales iban a pedir a la novia a veces sin que el muchacho lo supiera, pero con mayor frecuencia ya con el consentimiento y la selección del joven. La aceptación de los padres de la novia se solía realizar en la tercera semana de tratos, cuando ya podían intervenir los futuros padrinos de la boda. Entonces se acordaba qué correspondía aportar a los parientes de la novia para la celebración del matrimonio. Este se realizaba con una fiesta y gran parte de la comunidad participaba en la construcción de la casa para la nueva pareja. En algunas comunidades el matrimonio recién formado debía abstenerse de tener relaciones sexuales durante "los trece días", so pena de posibles problemas. Asimismo, y hasta la actualidad, cuando una persona muere, su cuerpo es colocado en el piso de la casa, sobre una cruz de cal, con la idea de que la tierra lo reciba. El cuerpo se enrolla en un petate, es llevado al cementerio y depositado en una tumba, con la cabeza al occidente, en la cual se coloca una ofrenda consistente en pequeñas vasijas con comida y algunos implementos en miniatura que se considera servirán al difunto para usarlos en su viaje al más allá, que es considerado como el lugar de los muertos. Los familiares rezan el novenario y existe la abstinencia sexual y alimenticia durante ese tiempo, así como la continencia hacia el baño. Desde hace poco tiempo se recurre a los ataúdes, tanto metálicos como de madera.
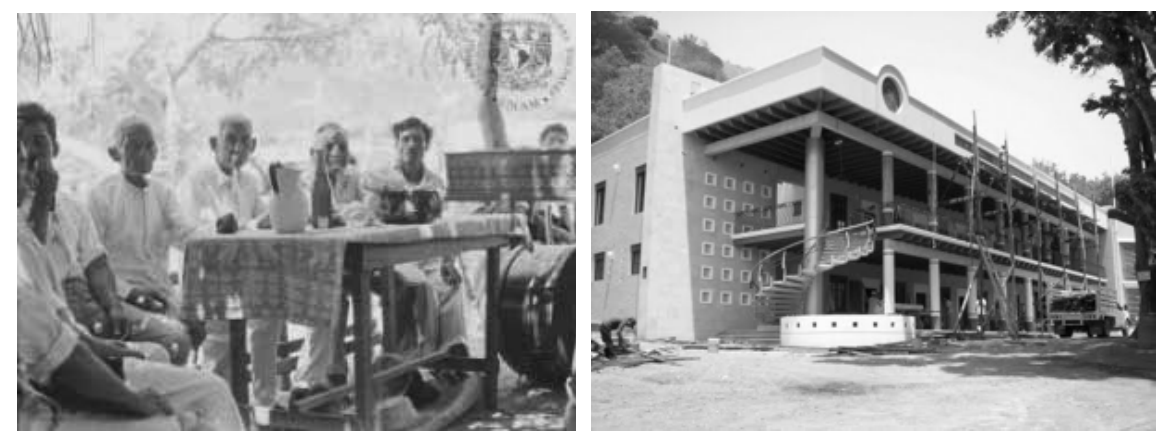

Reunión de ancianos y Palacio municipal de Santa Cruz Zenzontepec. (Fotos IIS-UNAM y Ayuntamiento de Santa Cruz Zenzontepec.)

GOBIERNO. Independientemente del aparado jurídico, político y constitucional del gobierno mexicano, en la región chatina han subsistido formas tradicionales de gobierno indígena, en las que existen jerarquías y cuyos miembros las van ocupando conforme a un escalafón definido por la edad y la experiencia, las que van estableciendo un orden de méritos. Sin embargo, en el grupo también subsiste una fuerte integración entre las 
actividades religiosas y las políticas, subsistiendo el Tequio, no obstante que el proceso de aculturación al que se ven sometidos los indígenas es muy fuerte. La actual televisión plantea situaciones y retos económicos absolutamente inalcanzables para la mayor parte de los televidentes indígenas. Eso puede ayudar a la conservación del grupo.

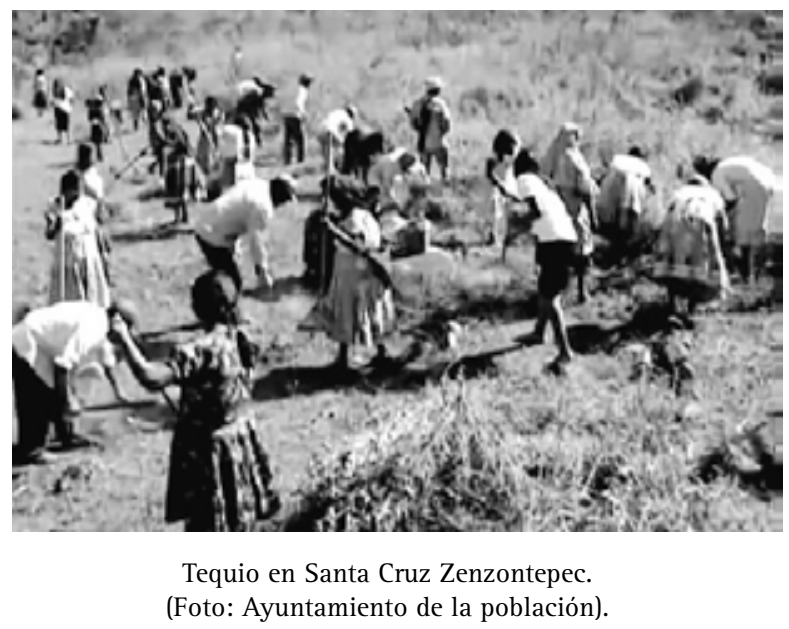

FESTIVIDADES. Las festividades de la región están relacionadas con los ciclos agrícolas y con el calendario ritual católico. Este substituyó en la época colonial al calendario ritual prehispánico y en la actualidad rige las festividades de los Santos patrones de cada población o de barrio dentro de cada una de ellas. La principal festividad religiosa del área es la correspondiente a la Virgen de Juquila, que se celebra el día 8 de Diciembre de cada año. Unos de los Santos más venerados son San Antonio Abad y Santiago Apóstol, como clara supervivencia de la labor catequizante de Fray Jordán de Santa Catarina y de los que lo sucedieron.

ORGANIZACIÓN RELIGIOSA. En la región chatina subsisten dos sistemas religiosos distintos, que operan traslapados. El primero conjunta rasgos de cristianismo con la antigua mitología indígena: El segundo conserva rasgos estrictamente indígenas. En el primero subsiste la institución de la Mayordomía, que está relacionada ampliamente con el festejo del Santo Patrón de cada comunidad. Esta mayordomía está apoyada por la comunidad, pero no reviste tanto fausto como en otras regiones del estado. La imagen religiosa más venerada es la de la Virgen de Juquila, en cuyo culto actual ya también intervienen varios otros elementos culturales importados a la región. Este culto tal como se practica actualmente, surgió en la época colonial.

El segundo sistema atribuye a los elementos de la naturaleza su propio espíritu. El principal de ellos es el viejo Dios del Maíz, existiendo también la vieja mujer del temascal, que bien puede ser una advocación local de Tlazoltéotl, la diosa devoradora de inmundicias de la mitología prehispánica nahua y mixteca, ya que el temascal es el lugar de la limpieza y la purificación por excelencia. 

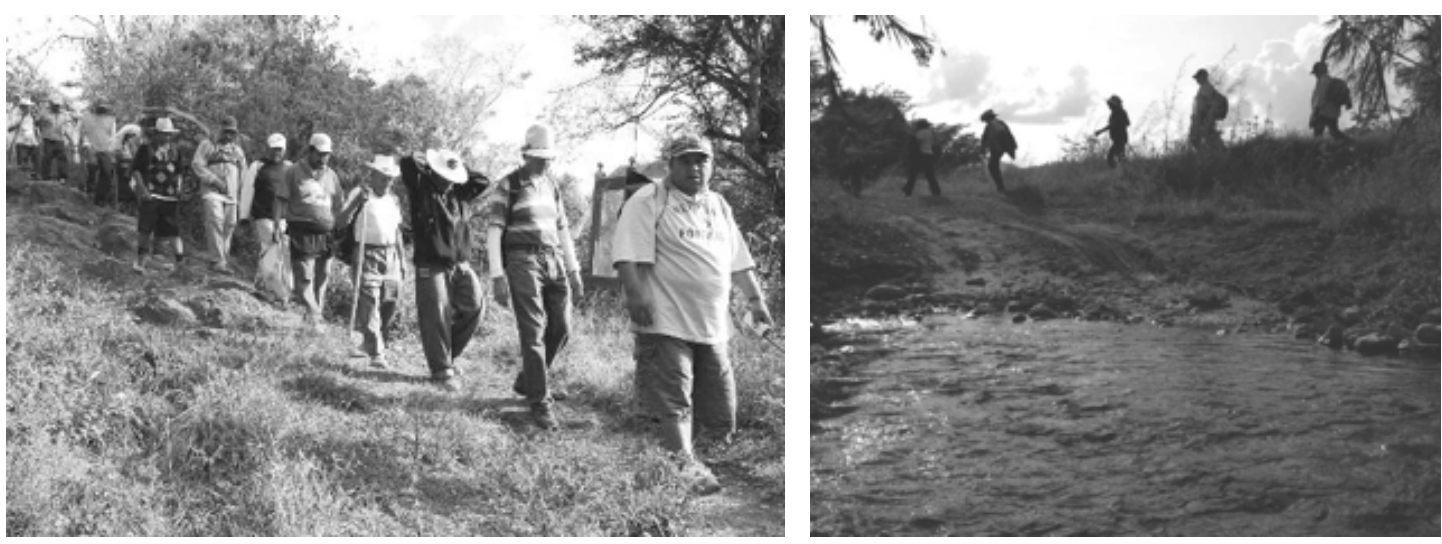

Peregrinación. (Fotos: Diario Marca)

Asimismo, y como se señaló, existió el concepto de un propietario o amo de los animales silvestres y se considera que cada especie tiene su propio espíritu guardián. De igual modo se considera que cada especie de animal doméstico está protegido por los santos (por ejemplo, las gallinas por San Antonio Abad y las yuntas por San Isidro Labrador). Una vez que cada fiesta ha terminado, la comunidad designa nuevo mayordomo para el siguiente año. Puede observarse que el alcoholismo se ha incrementado considerablemente en el grupo debido a que la penetración de las empresas productoras de bebidas embriagantes, ha ido aumentando, y la depauperación ha ido minando anímicamente a parte importante de sus individuos

MEDICINA Y MAGIA. En las diferentes poblaciones existen brujos o Shamanes considerados capaces de inducir la enfermedad. Algunos de ellos se inspiran mediante la ingestión de hongos alucinógenos o de semillas que contienen substancias químicas que hacen ese efecto. Subsisten gran cantidad de prácticas mágicas y de ritos de fertilidad consistentes en la decapitación de guajolotes para que su sangre contente al espíritu de la tierra, las lluvias sean abundantes y la tierra otorgue buenas cosechas. Algunos hechiceros recurren a la invocación de los Santos Cristianos para curar. En los casos en que una persona es afectada por la acción malévola del algún otro hechicero del grupo, siempre habrá otro hechicero que pueda deshacer el conjuro echando mano también de la imagen de los Santos Cristianos.

SALUD. Existen en la región varios Centros de Salud establecidos en diferentes períodos gubernamentales, y posteriormente, en Juquila, un Hospital de Zona, Éste cuenta con varias especialidades. Se registra que, debido a la penetración de productos industrializados de bajo índice nutricional, la obesidad se está incrementando.

EDUCACIÓN. Existen en las poblaciones chatinas escuelas primarias de bajo nivel académico. Los programas que se incrementaron en la región hace 40 años contemplaban un programa educativo de mayor envergadura. En Juquila existen ya Instituciones de ense- 
ñanza media y escuela para indigenas, ya que son pocos los jóvenes del grupo que pueden estudiar a un mayor nivel. En Santa Catarina Juquila y en Huaxpaltepec, existen ya planteles del Colegio de Bachilleres, pero es la pobreza el mayor limitante para el desarrollo individual de los jóvenes del grupo. Muy pocos muchachas y muchachos de la etnia logran realizar estudios profesionales, aunque ya existió una diputada, la Lic. Cirila Sánchez y en el grupo ya existe una fuerte emigración.

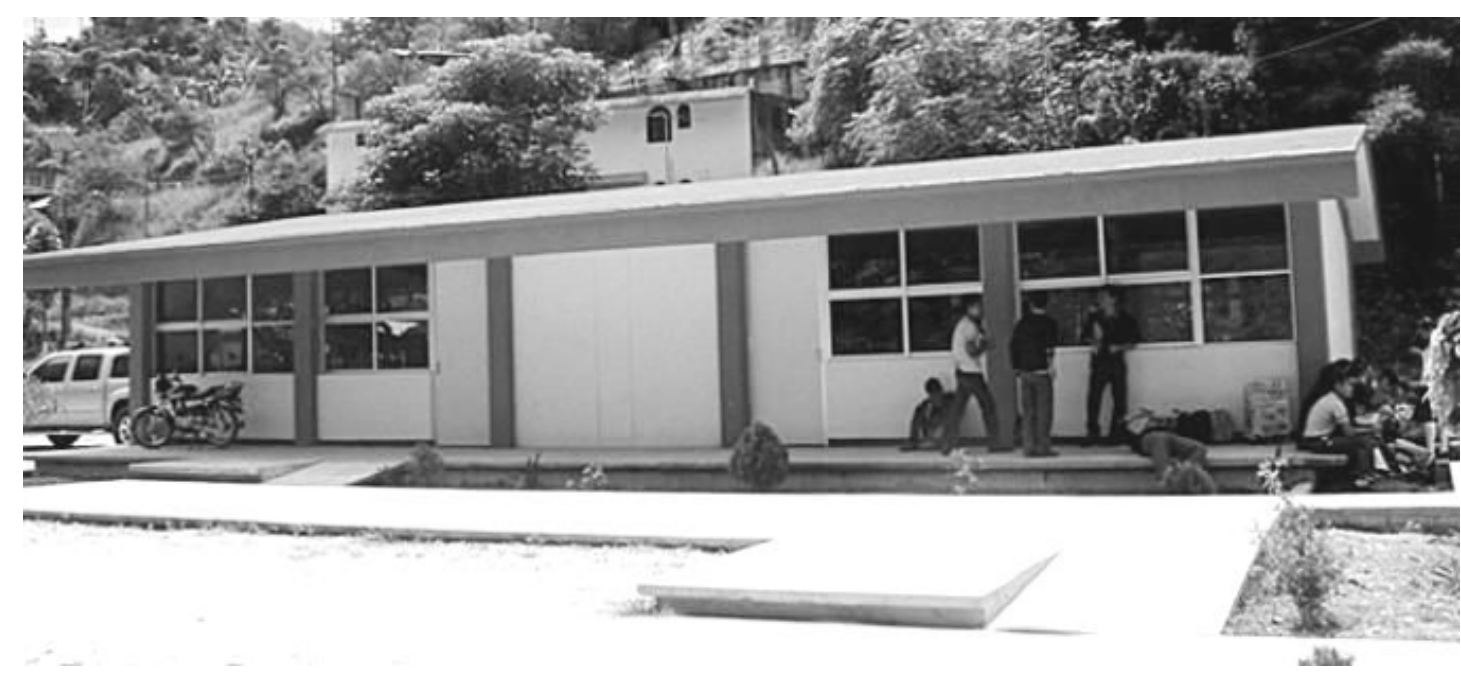

Aulas del COBAO número 31 de Juquila. (Foto: Gobierno del Estado).

\section{BIBLIOGRAFÍA}

Bartolomé, Miguel, Barabas, Alicia Mabel. 1982 TIERRA DE LA PALABRA. Historia y Etnografía de los Chatinos de Oaxaca. Colección Científica. № 108. INAH. México. D F.1982.

Basauri, Carlos, 1940 Reed 1990 "los Chatinos". En: LA POBLACION INDIGENA DE MEXICO. Tomo 2. Instituto Nacional Indigenista. SEP. México, D F. 1990.

Belmar, José Antonio. 1961 BREVE RESEÑA HISTORICA Y GEOGRAFICA

DE OAXACA. En: Homenaje a William Cameron Towsend. Sociedad Mexicana de Antropología. México, D F. 1961

Berlin, Heinrich. 1947 FRAGMENTOS DESCONOCIDOS DEL CODICE DE YANHUITLAN Y OTRAS INVESTIGACIONES MIXTECAS. Antigua Librería Robredo de José Porrúa e Hijos. Edición Particular. México. D F. 1947.

CODICE BODLEY. Lord Kingsborough. 1831 Reed, 1974 ANTIGUEDADES DE MEXICO. Edición de la Secretaría de Hacienda y Crédito Público. México. D F. 1974.

CODICE CHIMALPOPOCA. 1945 Anales de Cuauhtitlán y Leyenda de los Soles. Instituto de Investigaciones Históricas. UNAM. México, D F. 1945

Dalhgren. Bárbara. 1966 LA MIXTECA. SU CULTURA E HISTORIA PREHISPANICAS. 
2a Ed. UNAM. México. D F. 1966. De Cicco, Gabriel. 1969 “The Chatino”. En: HANDBOOK OF MIDDLE AMERICAN INDIANS. Vol. 7.

Díaz del Castillo, Bernal. 1970 HISTORIA DE LA CONQUISTA DE LA NUEVA ESPAÑA.8 ${ }^{a}$ Ed. Editorial Porrúa. México. D F. 1970

ENCICLOPEDIA DE MEXICO. 1988 “Los Chatinos”. Editorial Enciclopedia de México. México, D F. 1988.

Gay, José Antonio. 1950 HISTORIA DE OAXACA. Vol. I y II. Ed. Jacobo Dalevuelta. 3a Ed. Talleres Venero. México, D F. 1950.

Gerhard, Peter. 1986 GEOGRAFIA HISTORICA DE LA NUEVA ESPAÑA. Instituto de Geografía. UNAM. México. D F. 1986.

Jijón. Octaviano. 1883 “Cuadro Sinóptico y Estadístico del Distrito de Juquila”. En: CUADROS SINOPTICOS DE LOS DISTRITOS DEL ESTADO DE OAXACA. Vol. II. Colección. Manuel Martínez Gracida. Sala de Autores Oaxaqueños de la Biblioteca Pública Estatal. Oaxaca. Oax. México. D F. 1883.

Martínez Gracida, Manuel. 1826-27 ESTADISTICA DEL DEPARTAMENTO DE JAMILTEPEC, COMPUESTA DEL PARTIDO DEL MISMO NOMBRE Y EL DE JUQUILA. Manuscrito de la Colección Martínez Gracida, existente en la Sala de Autores Oaxaqueños, de la Biblioteca Pública Central Estatal. Oaxaca, Oax. 1926. (Póstumo). 1907 RESEÑA HISTORICA DEL REINO DE TUTUTEPEC. 2 Tomos. Sala de Autores Oaxaqueños. Biblioteca Pública Central. Oaxaca, Oax. 1907.

Paso y Troncoso, Francisco del. 1905 PAPELES DE NUEVA ESPAÑA. Vols. I y IV. Imprenta Sucesores de Rivadeneyra, Madrid, España. 1905.

Rodrigo Álvarez, Luis. 2004 GEOGRAFIA GENERAL DEL ESTADO DE OAXACA. 4ª Edición Aumentada. Carteles Editores. Oaxaca, Oax. 2004.

Ruiz y Cervantes, José María. 1991 MEMORIA DE NUESTA SEÑORA DE JUQUILA. Edición de la Parroquia de Juquila. Juquila, Oax. 1991.

Scheffler, Lilian. 1986 CHATINOS. En: GRUPOS INDIGENAS DE MEXICO. Panorama Editorial. México, D F. 1986.

Smith, Mary Elizabeth. 1973 PICTURE WRITING FROM ANCIENT SOUTHERN MEXICO. The Civilization Indian Series. Vol. 124. University of Oklahoma Press. Tulsa, Okl. U S A. 1973.

Spores, Ronald, Saldaña, Mateo. 1975 DOCUMENTOS PARA LA ETNOHISTORIA DEL ESTADO DE OAXACA. Índice del Ramo de Indios del Archivo General de la Nación. Vanderbilt University. Publ. 5. Nashville, Tenn. U A. 1975.

Vázquez Cruz, Leovigildo. 1944 LOS CHATINOS. Manuscrito inédito. México, D F. 1944. Winter, Marcus C.Gaxiola, Margarita.1978 “ Archaeology of the Otomanguean Area”. En: ESSAYS IN OTOMANGUEAN CULTURE HISTORY. Vanderbilt University. Publication in Anthropology No 31. Nashville, Tenn. U S A. 1978. 



\section{MIXTECOS}

Autodenominación: nuu savi, ñuu savi, to'on savi.

Sinónimo en su Lengua: hñuu davi, tnu'u, to ò nda.

Significado: Pueblo de la lluvia. Pueblo de las nubes.

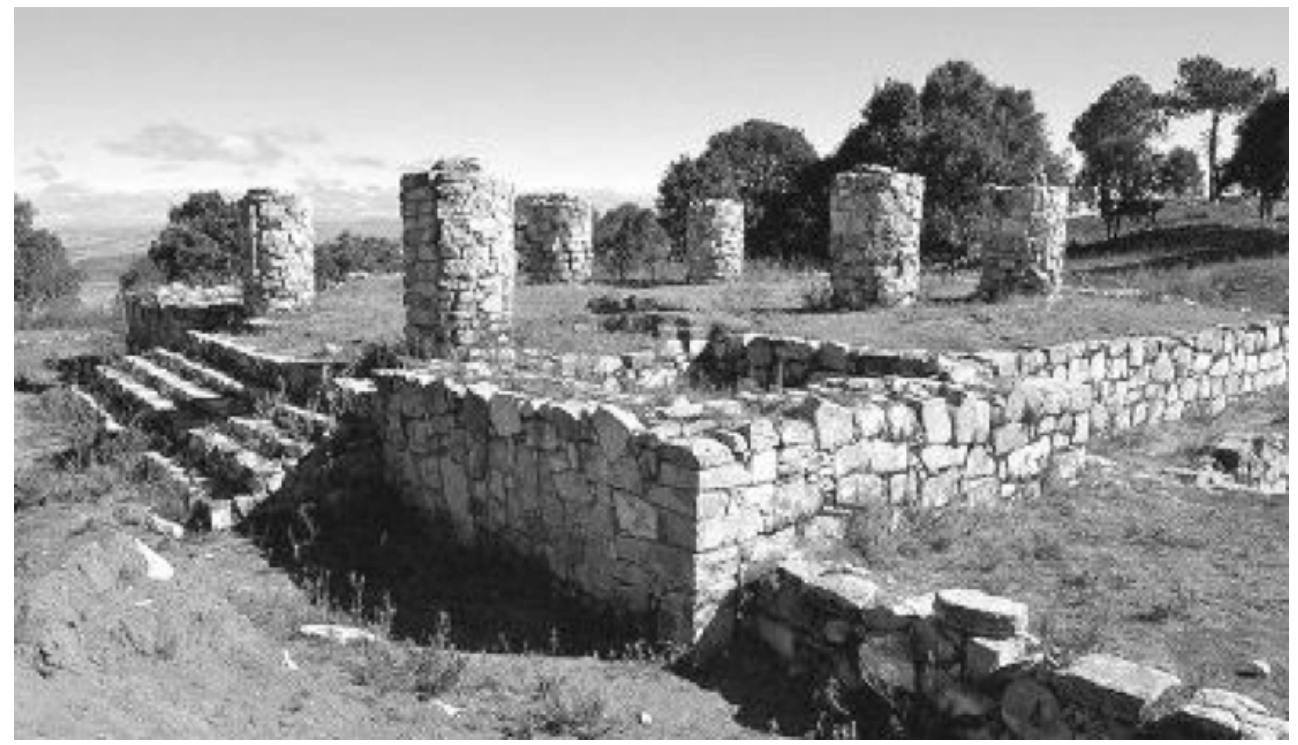

Zona arqueológica de Monte Negro, Tilantongo. (Foto: Arql. Lorenzo Gamio).

\section{GRUPO MIXTECO}

UBICACION GEOGRAFICA. La etnia Mixteca se distribuye en extensas zonas del norte y occidente del Estado, así como en una gran área de la región occidental de Guerrero y una pequeña región del Estado de Puebla colindante con Oaxaca. En total 203 municipios, de los cuales 189 son oaxaqueños. Su área ocupacional la inscribe en un cuadro situado entre los paralelos $16^{\circ} 10^{\prime}$ y $18^{\circ} 15^{\prime}$ de Latitud Norte, y los meridianos $96^{\circ} 15^{\prime}$ y $97^{\circ} 45^{\prime}$ de Longitud Occidental. En esta amplia región, de más de 40000 kilómetros cuadrados, coexiste con varios otros grupos, no solamente de los emparentados lingüísticamente con ella, sino también con algunos de los que dista, desde el punto de vista lingüístico y cultural, considerablemente.

Los distritos en que se ubica este grupo son: Cuicatlán, Etla, Huajuapan, Jamiltepec, Juxtlahuaca, Nochixtlán, Putla, Silacayoapan, Sola de Vega, Tlacolula, Teposcolula (en 
mixteco: Yucudaa), Tlaxiaco y Zaachila, pero en tiempos históricos ha establecido enclaves tales como la población de la Mixtequilla en el Distrito de Tehuantepec y en las zonas ocupadas por el territorio de los Estados de Puebla y Veracruz, así como en territorio mixe bajo, éste último donde también han sido recientemente relocalizados. La Mixteca presenta tres zonas climáticas que existen desde las altas montañas de la Sierra Madre del Sur y de la Sierra de Oaxaca hasta la planicie costera del pacífico. Dos de ellas ocupan la parte alta de la Sierra Madre del Sur en los Distrito de Tlaxiaco, Tesposcolula, Nochixtlán, Huajuapan y Juxtlahuaca, diferenciadas por una mayor sequedad de la parte próxima al parteaguas continental. La otra parte está constituida por la zona baja próxima al mar del Distrito de Jamiltepec y por algunas zonas medias de la cuenca del Río Mixteco, el cual a su vez es una fuente principal del Río Balsas. El área ocupada por el grupo es de topografía muy quebrada, abrupta y desigual en la que se alternan montañas escabrosas con valles relativamente largos, pero muy estrechos cuyas únicas excepciones se dan en Huajuapan y Nochixtlán. La vegetación de casi toda el área ha estado compuesta principalmente de bosques de coniferas, los que actualmente se encuentran muy depredados en muchas partes de la región. Geográficamente se ha considerado como Mixteca Alta la región oriental ocupada por dichos bosques.
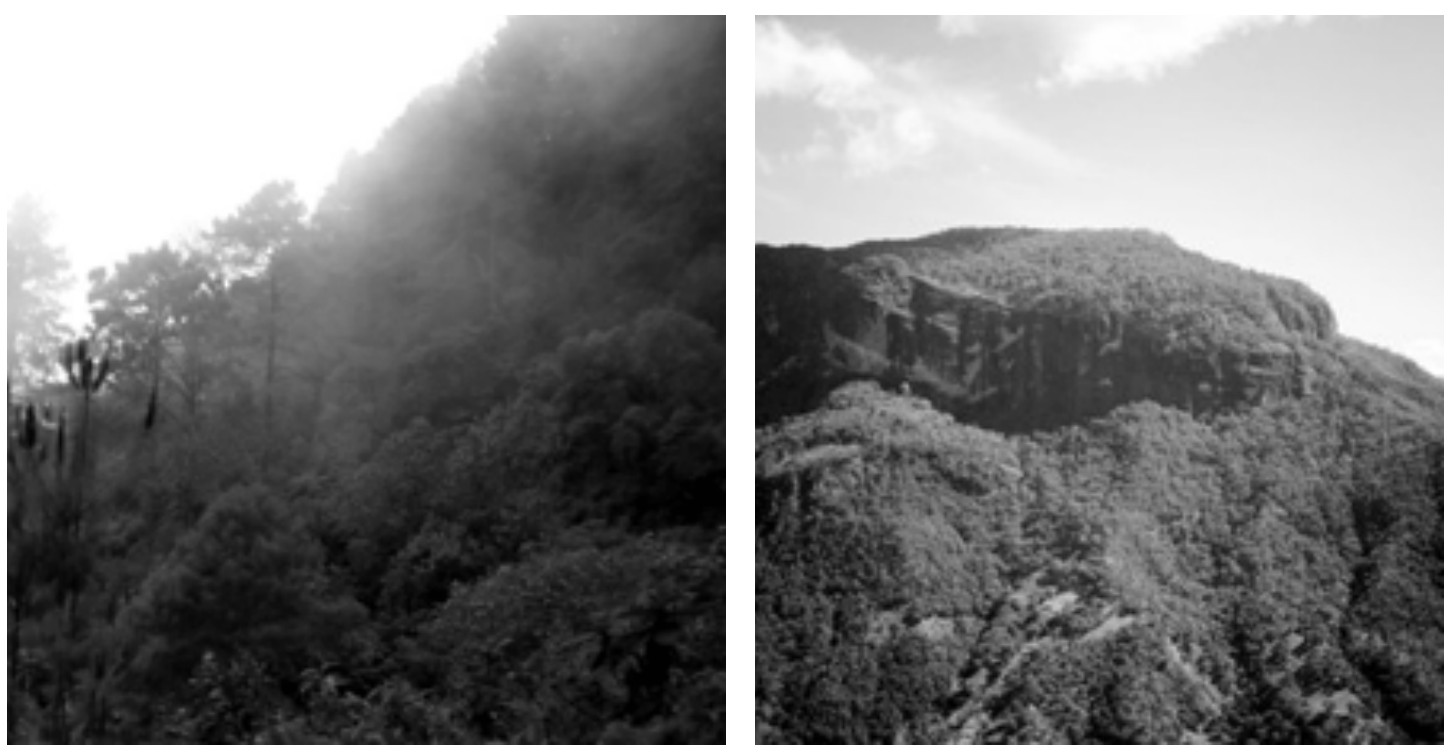

Bosque de coníferas y montaña de San Sebastián Yutanino. (Fotos: Wikipedia).

En las partes de altura intermedia, el bosque de coníferas derribado ha sido substituido por diferentes tipos de monte medio caducifolio y por algunas pequeñas praderas con diferentes variedades de pastos; Estas áreas, además, se han sembrado y siguen sembrando activamente. En algunas porciones de los distritos de Huajuapan y Silacayoapan, colindantes con los Estados de Puebla y Guerrero, existen áreas densamente cubiertas de vegetación xerofítica. 

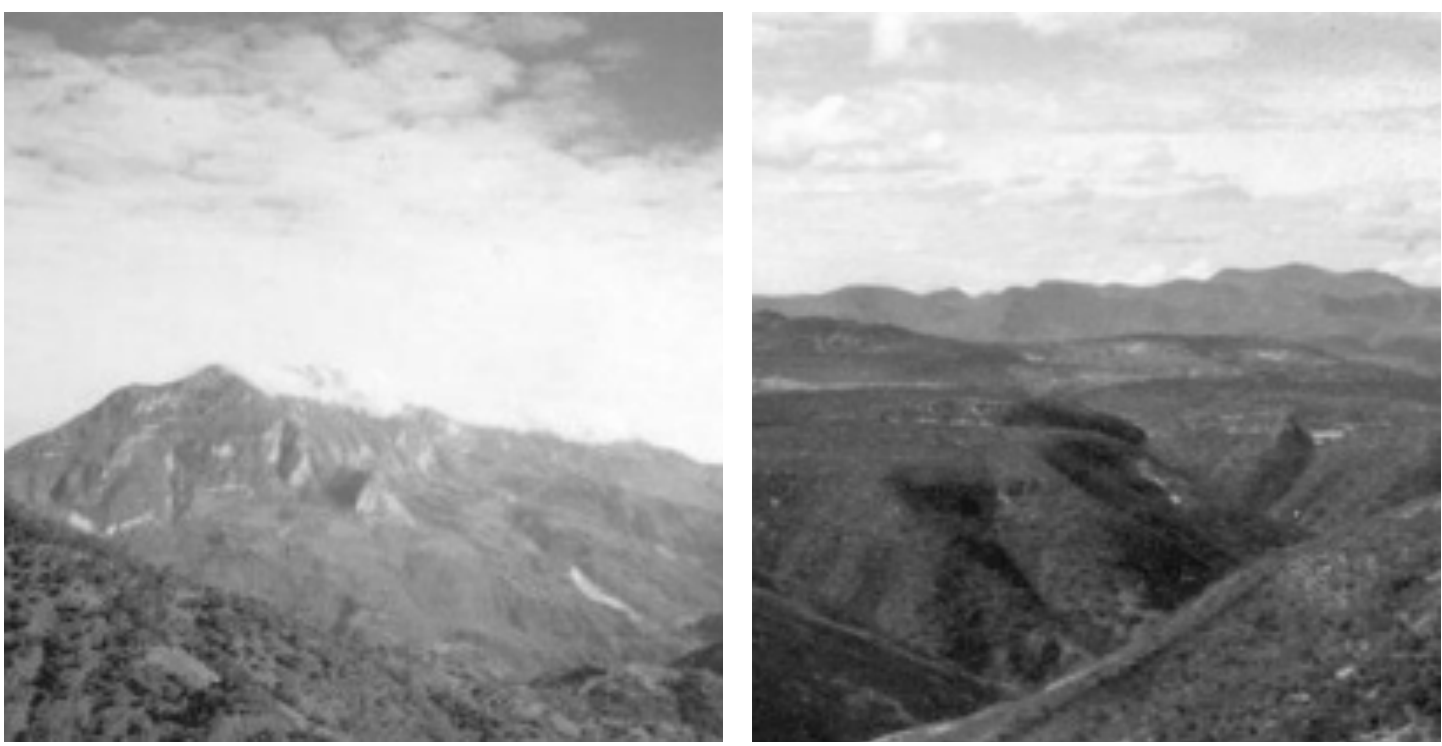

Sierra (Monte Yucucasa y altiplano mixtecos. (Fotos: David Hernández y del autor).

La enorme gama de alturas sobre el nivel del mar, así como el mosaico fisiográfico y las muy peculiares condiciones de humedad, que varían mucho en el territorio, cuya máxima altura rebasa los 3200 metros, hacen que los índices de precipitación pluvial también sean bastante cambiantes en las diferentes regiones. Grandes zonas en los Distritos de Tlaxiaco. Putla y Jamiltepec, así como porciones de Juxtlahuaca, Silacayoapan y Huajuapan, están consideradas como parte de la Mixteca Baja, y reciben una precipitación que fluctúa entre los 1000 y los 550 milímetros. El territorio es rico en una amplia variedad de suelos debido a que su formación orogénica permitió el afloramiento de gran cantidad de compuestos minerales. Muchos de estos suelos tienen origen volcánico terciario, y por lo mismo, presentan texturas medias y contienen mucho sílice. Es frecuente encontrar otros que proceden de la desintegración de rocas calcáreas originadas en las formaciones fosilíferas marinas del Jurásico y los Cretácicos Inferior y Superior. Algunos otros son arcillosos de color negro, también de formación terciaria, producto de muchos años de deposición de materia orgánica, y los últimos, de bastante antigüedad, son suelos sumamente oxidados e intemperizados, que presentan una amplia gama de colores y que proceden de la desintegración de rocas metamórficas, principalmente gneis del Paleozoico. En general los suelos del área han ido adquiriendo gradualmente capas humíferas producto de la descomposición de los desechos de su cubierta vegetal, pero se han ido destruyendo por erosión a medida que ésta han sido eliminada.

En los distritos de Nochixtlán, Coixtlahuaca, Teposcolula y Tlaxiaco, la erosión ha llegado a niveles muy críticos con el perjuicio consiguiente para la población y la productividad de esas áreas. Los climas de las regiones se inscriben dentro de una amplia gama de los tropicales subhúmedos y semisecos con lluvias en verano, y se están radicalizando hacia una mayor sequedad, sobre todo en las zonas depredadas, donde el viento la induce. Aunque la nubosidad es muy alta (la palabra náhuatl "Mixtecapan" significa precisamente 
"El país de las nubes"), la precipitación pluvial varía por zonas. En algunas porciones de los distritos de Huajuapan, Teposcolula y Nochixtlán no rebasa los 600 milímetros anuales, un poco arriba del límite inferior que hace posible el cultivo del maíz; mientras que en pequeñas zonas de la Mixteca Baja de Putla Tlaxiaco y Jamiltepec suele rebasar los 1200 milímetros, y algunos años, hasta los 1 300. Prácticamente la mitad de la región se encuentra dentro de la cuenca del Río Balsas, que en las áreas de Silacayoapan y el occidente de Huajuapan recibe el nombre de Río Mixteco. La cabeza de esa cuenca es el parteaguas continental, y la otra vertiente, en la región chocho-mixteca, lo hace en la cuenca del Río de Coixtlahuaca, el cual, a su vez descarga, a través del Río Carrizo, en el Río Salado de la Cuenca del Papaloapan. El resto de las aguas del área vierte, ya sea a la Cuenca del Atoyac-Verde (en la zona de Santiago Tenango), o en algunos ríos de la Costa del Pacífico, principalmente en el Verde, existiendo únicamente ocho presas en la región, siendo la mayor la de Yosocuta. El régimen de vientos en los distritos del Norte del área establece un sistema convectivo en el que la nubosidad sobre las sierras se diluye con frecuencia restringiéndose la precipitación. En muchas zonas de los Distritos de Tlaxiaco y Putla la nubosidad generada por el aire caliente de dicho sistema convectivo se resuelve en forma de llovizna densa, y en la costa, en los distritos de Putla, Jamiltepec y parte de Juquila, los vientos que determinan las mayores precipitaciones, en los meses de verano, soplan del sur.
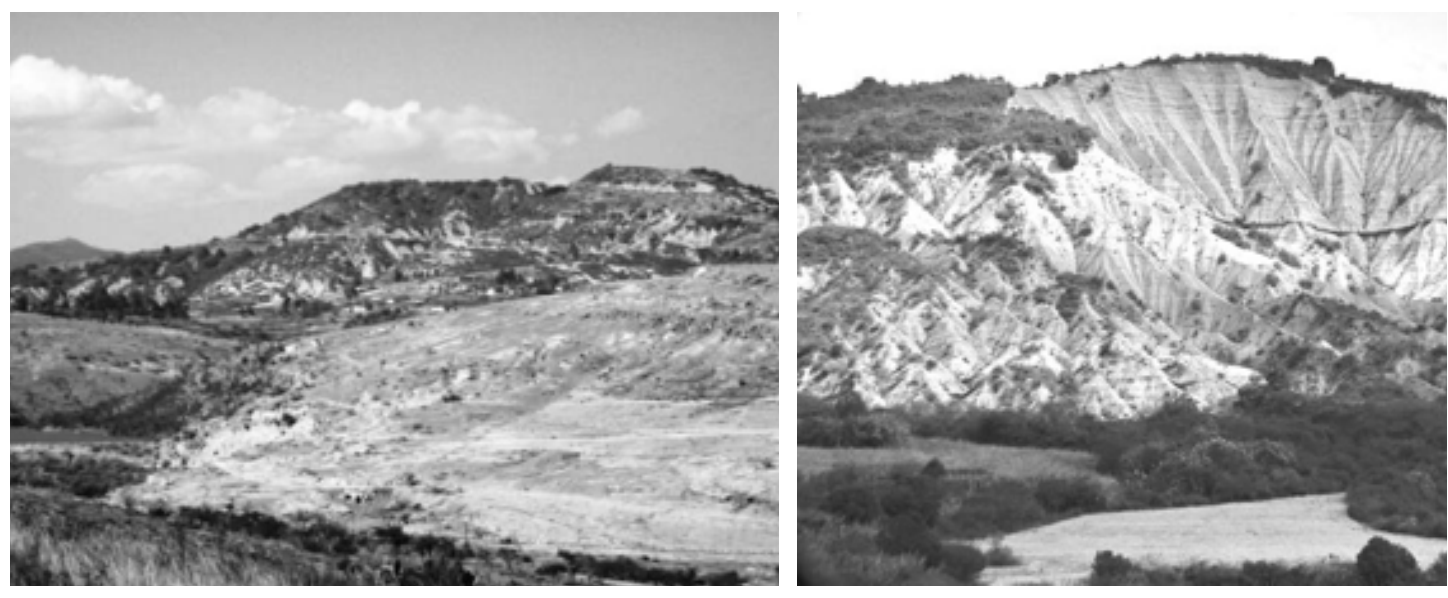

Zonas mixtecas erosionadas gravemente. (Fotos: UNAM y Javier Cruz Morales).

IDIOMA La lengua Mixteca pertenece al Grupo Otomangue, Tronco Savizaa, Familia Mixteca. Es un idioma tonal, con lo que el significado de las palabras cambia según el tono de su pronunciación. En el año 2000 era hablada aproximadamente por unas 510000 personas distribuidas en el territorio, y que en ocasiones solían no entenderse debido a que, desde muy antiguo en la época prehispánica, surgieron variantes dialectales generadas en factores geográficos y políticos. Dentro de los distritos de Tlaxiaco y Tesposcolula se han dado las mayores diferenciaciones, aunque no se conoce con certeza a cuantas ascienden, habiéndose estudiado solo seis. Ha sido tradicional que el grupo presente un porcentaje 
mayor de monolingües en las personas de corta edad, así como también lo ha sido que en las regiones en las que el grupo colinda con otras, y tal es el caso de los amuzgos, triquis y chochos, se han dado algunos casos de trilingüismo, con el español como lengua común. Es característico que cuando dos hablantes se encuentran en un área ajena a su región, se traten de "hermanos". El Censo Poblacional del 2010 da trescientos setenta y ocho mil (378 000) personas como hablantes monolingües del mixteco.

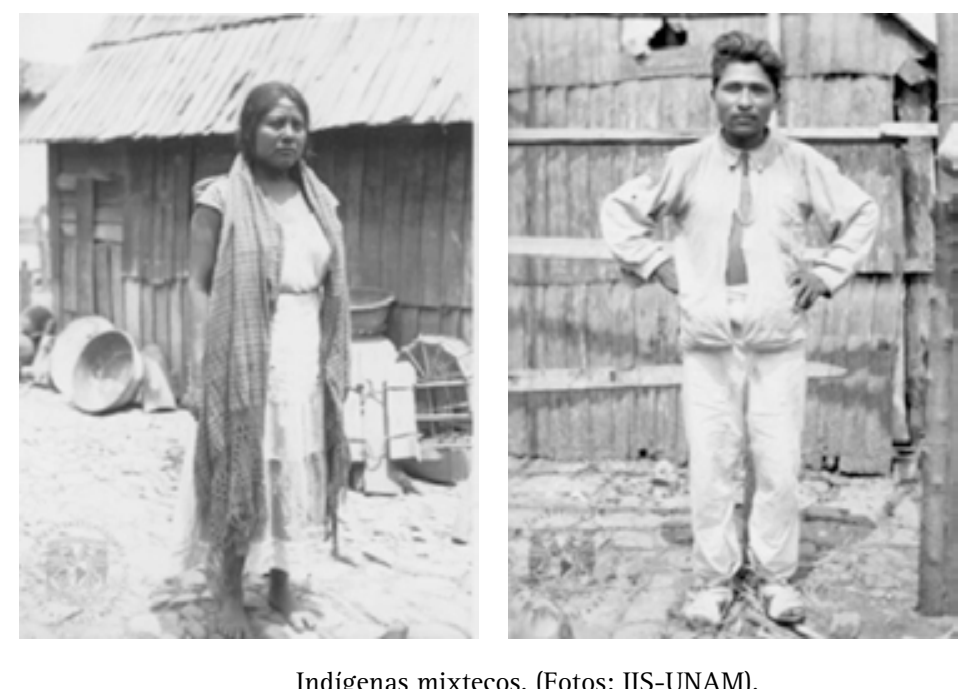

DEMOGRAFÍA. En 1984 las áreas ocupadas por el grupo estaban pobladas por un total aproximado de 480000 personas, lo que en el 2010 había aumentado a cerca del doble, más de 900 000. Dentro del grupo el mestizaje ya era muy frecuente, tanto con tipos de procedencia europea como con mestizos y gentes de los grupos colindantes. En las regiones que cuentan con ciertas riquezas naturales, particularmente bosques de coníferas o sembradíos de frutales, el mestizaje reviste particular interés, tal es el caso por ejemplo, de las poblaciones de las zonas de Juxtlahuaca y Tecomaxtlahuaca, donde pueden observarse tipos físicos rubios apiñonados, descendientes de españoles, soldados y gambusinos franceses, gambusinos alemanes, mineros ingleses e inmigrantes árabes, los cuales hablan la lengua mixteca y se escapan a los conceptos habituales de los que es un indígena-mestizo mexicano. Dentro del grupo, las variantes físicas de complexión y estatura se han ido radicalizando; esto debido a que la alimentación es más deficiente en algunas zonas que en otras debido a la depauperación y a que han cambiado los hábitos de vida, la estructura familiar, las tradiciones religiosas y las costumbres físicas y sociales de los pobladores de muchas localidades, particularmente de las cabeceras distritales. Al aumento del consumo de alimentos poco nutritivos, ampliamente distribuidos por una red de vehículos de empresas comerciales, ha contribuido en no poco grado el sistema desinformativo de la televisión comercial. Un importante número de maestros normalistas intenta luchar contra esta situación, pero es necesario que en esto también intervengan autoridades municipales, que lo deben tener como actividad prioritaria. 

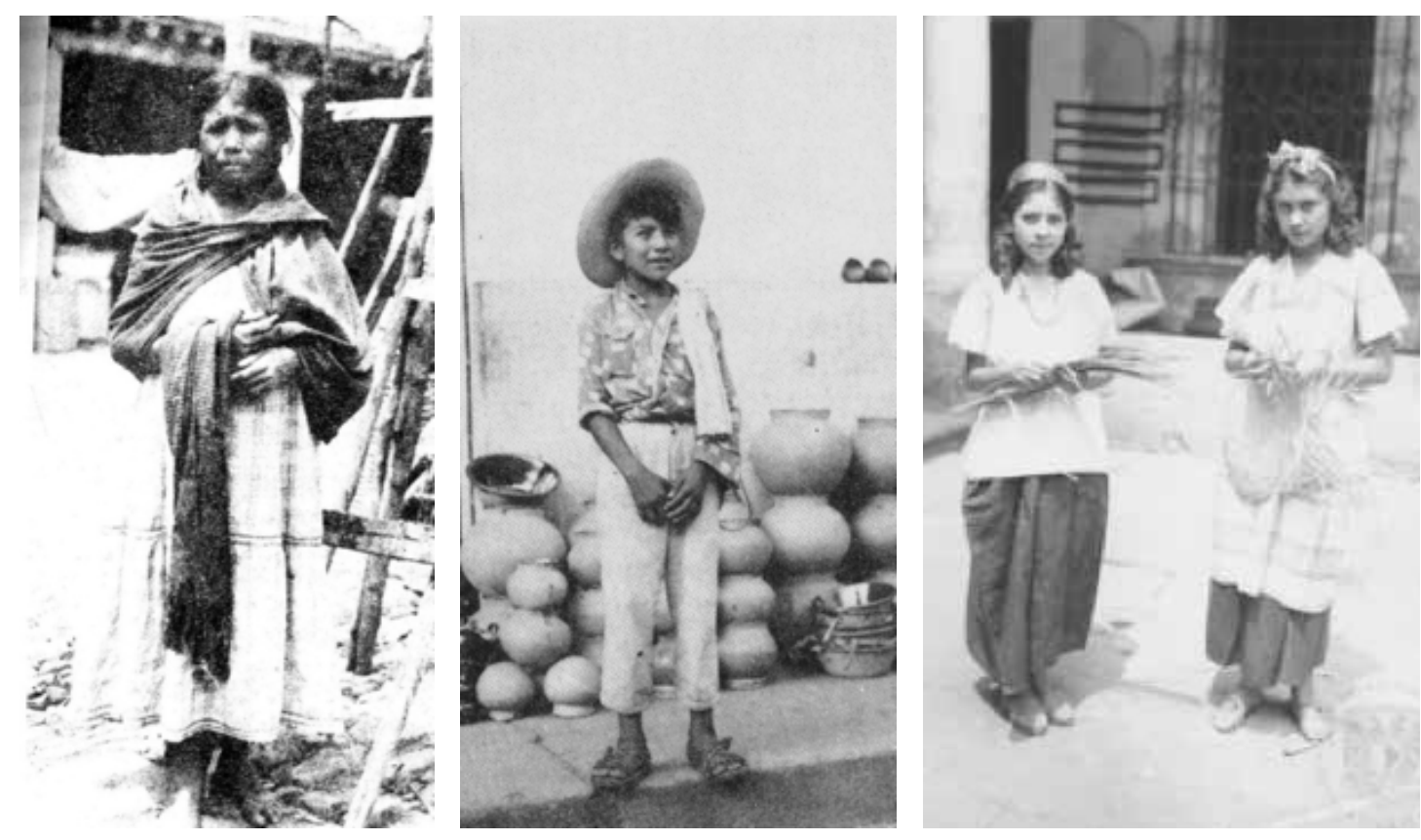

Mujer, niño y jóvencitas mixtecas. (Fotos: Carlos Basauri e IIS-UNAM).

En el grupo puede observarse que la población mestiza cuenta con mayores recursos e impone su dominio. En el caso de la costa, puede verse también que la población afromestiza intenta, y a veces lo logra, actuar con superioridad sobre los indígenas.

ANTECEDENTES ARQUEOLÓGICOS E HISTÓRICOS. Hasta el presente es imposible señalar con exactitud la trayectoria histórica del grupo mixteco dentro del Estado de Oaxaca. Ello obedece a una gran carencia de exploraciones arqueológicas, antropológicas y lingüísticas controladas en gran parte del área, si bien algunos arqueólogos y arqueólogas jóvenes ya están poniendo atención a ese problema. El territorio ocupado por el grupo presenta una muy alta densidad de vestigios arqueológicos correspondientes a todos los períodos culturales registrados para todo el territorio mexicano desde hace poco más de 8000 años. No se han documentado hallazgos anteriores debido a que el área no ha sido sistemáticamente explorada con un criterio de prospección absolutamente prehistórico, y aunque se han encontrado restos de megafauna pleistocénica y por consiguiente de proboscídeos (algunos de mamuts y todos no destazados), que revelarían una ocupación anterior, nada revela en ellos intervención humana. Los hallazgos culturales más antiguos corresponden a una etapa de cazadores-recolectores tempranos que vivieron en el momento en que todavía no se producían los cambios climáticos y botánicos que darían la actual configuración a los ecosistemas de ese territorio montañoso. De esta etapa solamente tenemos algunos hallazgos, en el Valle de Nochixtlán, de implementos líticos, principalmente raederas, raspadores y puntas de proyectil, fechables hacia el 7000 a C., así como algún material de molienda de semillas. La proximidad del área con el Valle de Tehuacán y con el proceso cultural que 
ahí tuvo lugar desde el 8000 a C., que incluyó la domesticación de las plantas del maíz, el frijol, el chile y la calabaza, permite suponer que en la Mixteca Alta debió desarrollarse un conjunto de rasgos culturales que desembocarían en una etapa proto-agrícola, que es de la que ya tenemos documentación. En la localidad de Yuzanú, también del valle de Nochixtlán, en la cercanía de Yanhuitlán, se encontró un campamento estacional de cultivadores correspondiente más o menos al año $2000 \mathrm{aC}$, con maíz y amaranto. Trascurrieron 500 años más para que en el territorio surgiesen las primeras pequeñas aldeas sedentarias, algunas en el Valle de Nochixtlán, con población casi totalmente dedicada al cultivo del maíz, la calabaza y algunas variedades de leguminosas (frijoles), el chile, el tomate, el aguacate y el amaranto, actividades agricolas que significaron inmensa seguridad y el surgimiento de un franco proceso civilizatorio.

Durante el período Formativo dichas aldeas sedentarias, tal como en el caso de Huamelulpan, Yucuita, Etlatongo y las situadas en la costa en la cuenca media y baja del Río Verde, fueron aumentando de tamaño y recibiendo aportaciones culturales de otros grupos situados en los valles centrales y en la costa de Oaxaca, con tradición Olmeca-Arqueológica, de los Valles de Tehuacán, del valle Poblano Tlaxcalteca y de la Depresión de Morelos. Para el momento del surgimiento y el desarrollo de los grandes centros ceremoniales, se observa sobre la región marcada influencia del grupo teotihuacano y del incipiente grupo zapoteca (el caso de la zona arqueológica de Monte Negro), que surgía en los Valles Centrales de Oaxaca. Gran parte de la Mixteca Alta y casi toda la Baja recibió de Teotihuacan un importante volumen de su acervo cultural, tal como también ocurrió en el área ocupada por los Popolocas y los Zapotecas. Estos datos y algunos semejantes en el utilaje inicial, han hecho pensar en un origen común para todos esos grupos, el cual debe retrotraerse a varios miles de años.
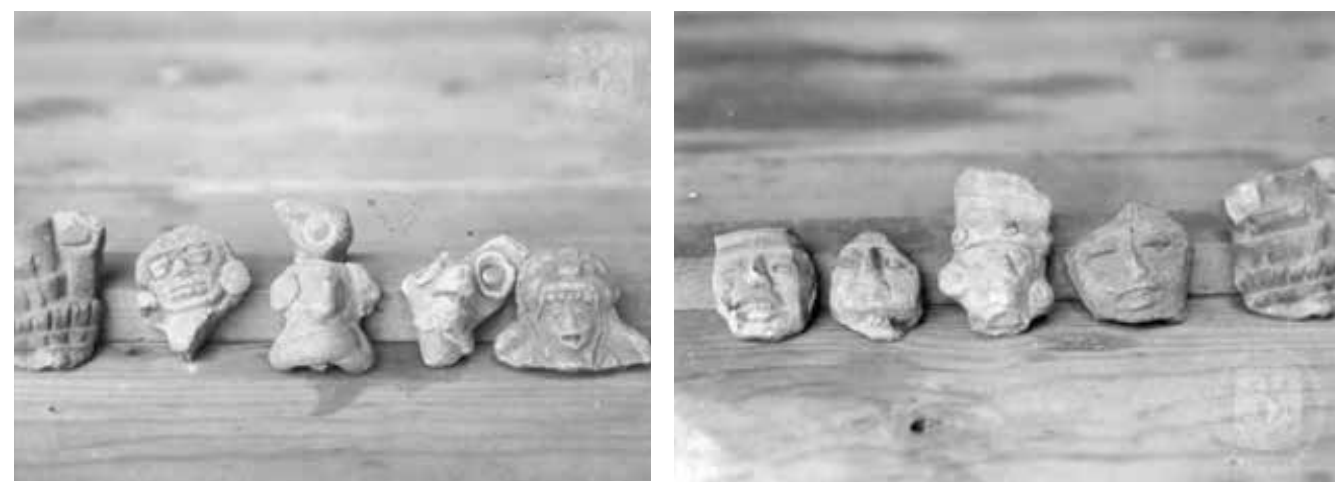

Figurillas de influencia teotihuacana. (Foto: IIS-UNAM).

A la luz de la poca información de que se dispone, ya que muchas partes del área no han sido investigadas, la etapa Clásica o de los Centros Ceremoniales tuvo en la región una particular brillantez, principalmente porque hubo contactos con los teotihuacanos y además la población mixteca terraceó muchos miles de hectáreas, con lo que dispuso de mucha tierra plana y una productividad muy alta. 


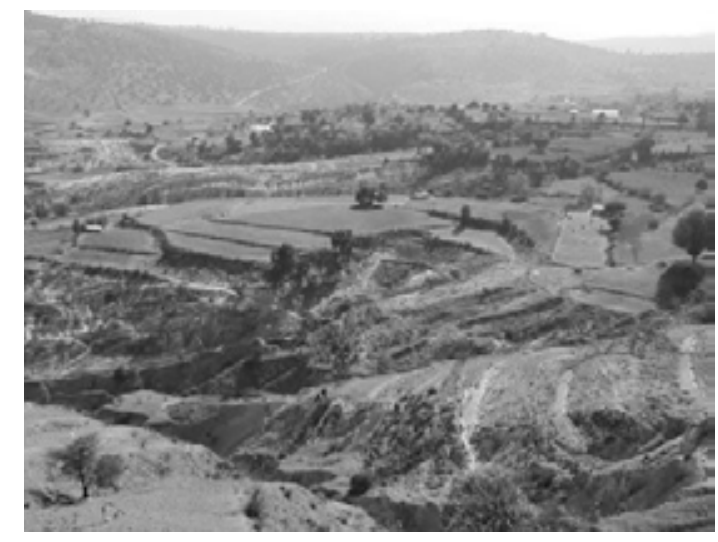

Terrazas mixtecas. (Foto del autor).

Los terraceos pueden verse y recorrerse por casi todo el territorio. Durante el período Clásico y sobre todo en su parte tardía, (entre los años 500 y 1000 de la era cristiana), la mixteca contenía una gran cantidad de centros ceremoniales que eran respectivas capitales de pequeños y medianos principalatos que comenzaron a disputar la supremacía Entre ellos se cuentan Etlatongo, Diquiyú, Tindú, Cuquila, Achiutla, Cerro de las Minas, Cerro de la Codorniz, Cuananá, La Muralla, Teozacoalco, Tilantongo y Chalcatongo. En esos momentos debió surgir la idea del origen mítico del grupo, surgiendo el concepto de que las dinastías de Principales habían surgido de la pareja que se formó en los árboles de Apoala. Entre los caudillos más importantes conocidos se cuenta a $\widehat{o} 5$ Lagarto "Tláloc-Sol" y a $\widehat{\sigma}$ 8 Venado, "Garra de Jaguar", Principales de Suchixtepec, Tilantongo y Tututepec. La causa de estas luchas bien pudo ser la ya respetable concentración de riqueza que iba presentando la región, comercialmente muy activa; las disputas por sucesiones hereditarias y el hecho de que ya existía una muy importante tradición lapidaria que producía objetos de jade, jadeíta, obsidiana, serpentina y turquesa, altamente estimados, y poco después una orfebrería, entonces de reciente introducción, que permitió el aprovechamiento del oro y la plata regionales (que se obtenían en placeres) para el adorno de Principales y dignatarios, los cuales dieron a esos metales tal valor estimativo que a partir de ese momento los hicieron constituir, convertidos en joyas, la ofrenda principal de muchos de sus enterramientos delimitados o en tumbas. Esta enorme división de los principalatos quedó ampliamente registrada en los Códices, casi todos los cuales presentan carácter histórico-genealógico, lo cual revela la importancia de tuvo en el grupo la división social emanada de la creencia en un origen mítico (el surgimiento en los árboles de Apoala), que dio supuestamente origen a genealogías que, esas sí, terminaron siendo dominantes, algunas de las cuales llegaron a tener, sucesivamente, más de 30 parejas gobernantes.

Al sobrevenir la Etapa de las Ciudades-Estado, o Etapa Militarista, el grupo mixteco había extendido sus dominios y relaciones dinásticas hasta el valle Poblano-Tlaxcalteca, la Depresión de Morelos (Xochicalco), las áreas que actualmente ocupan otros grupos étnicos en el estado, gran parte de la sección central del Estado de Veracruz (la Mixtequilla) y un importante sector de las áreas oaxaqueñas ocupadas por el grupo zapoteco incluyendo los 
Valles Centrales. En esa etapa se comenzaron a dibujar los códices informando sobre personajes y dinastías, no sólo en pieles de venado y papeles de amate e ixtle, sino también (por lo menos en un caso), en las paredes (un friso) de una cueva en el Estado de Guerrero. Códices prehispánicos mixtecos son el Colombino o Nacuaa I, el Bodley o Qhcuaa, el Nuttall o Tonindeye, el Vindobonensis o Ñuu Tnoo, el Beckker I o Nacuaa II, y el Selden o Sicuañe, entre otros.
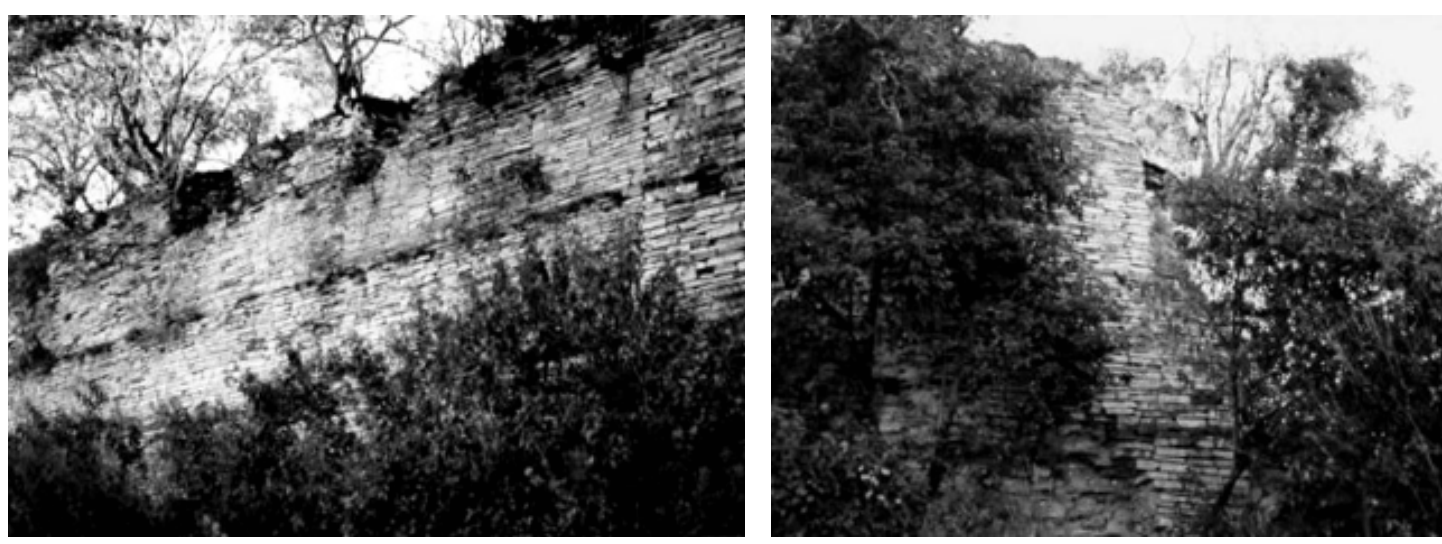

Zona arqueológica de La Muralla, Silacayoapan, Oax. (Fotos del autor).
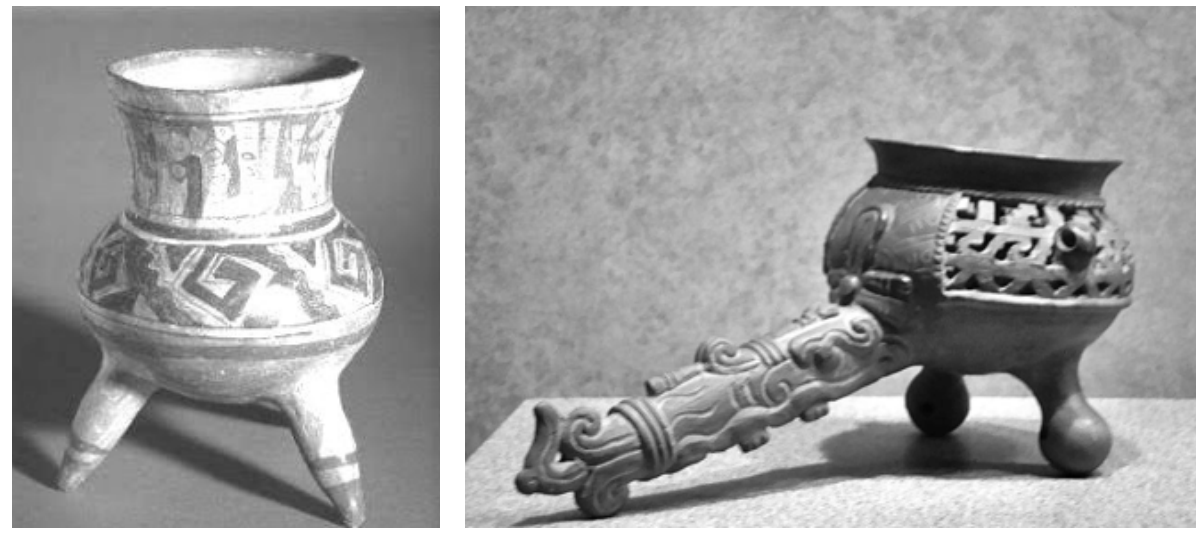

Postclásico. Vasija polícroma y sahumador mixtecos. (Fotos: INAH)

Hubo momentos en que su interrelación con los zapotecos fue muy alta, lo cual no está suficientemente estudiado y conocido, y momentos en que los desplazó o combatió totalmente.

Algunas crónicas documentan contactos entre los Mixtecos y grupos de origen toltecoide en el desarrollo cultural de todas las regiones ocupadas por el grupo en un período que va del año 1000 al 1300 de nuestra era. Parte importante de los principalatos mixtecos estuvieron ampliamente relacionados con los grupos Olmecas-Xicalancas Históricos, y con los Popolocas, con los que guardan una notable identidad. El Valle de Puebla-Tlaxcala, y particularmente la ciudad de Cholula, era la sede de gobernantes considerados "Tolte- 
cas”* 4por su linaje, su sapiencia y sus asesores ancianos. Multitud de los rasgos culturales del grupo fueron exportados, recibidos y aprovechados por los grupos nahua-culhuas que establecieron su hegemonía en la Cuenca de México desde alrededor del año 1150 hasta la Conquista Española.

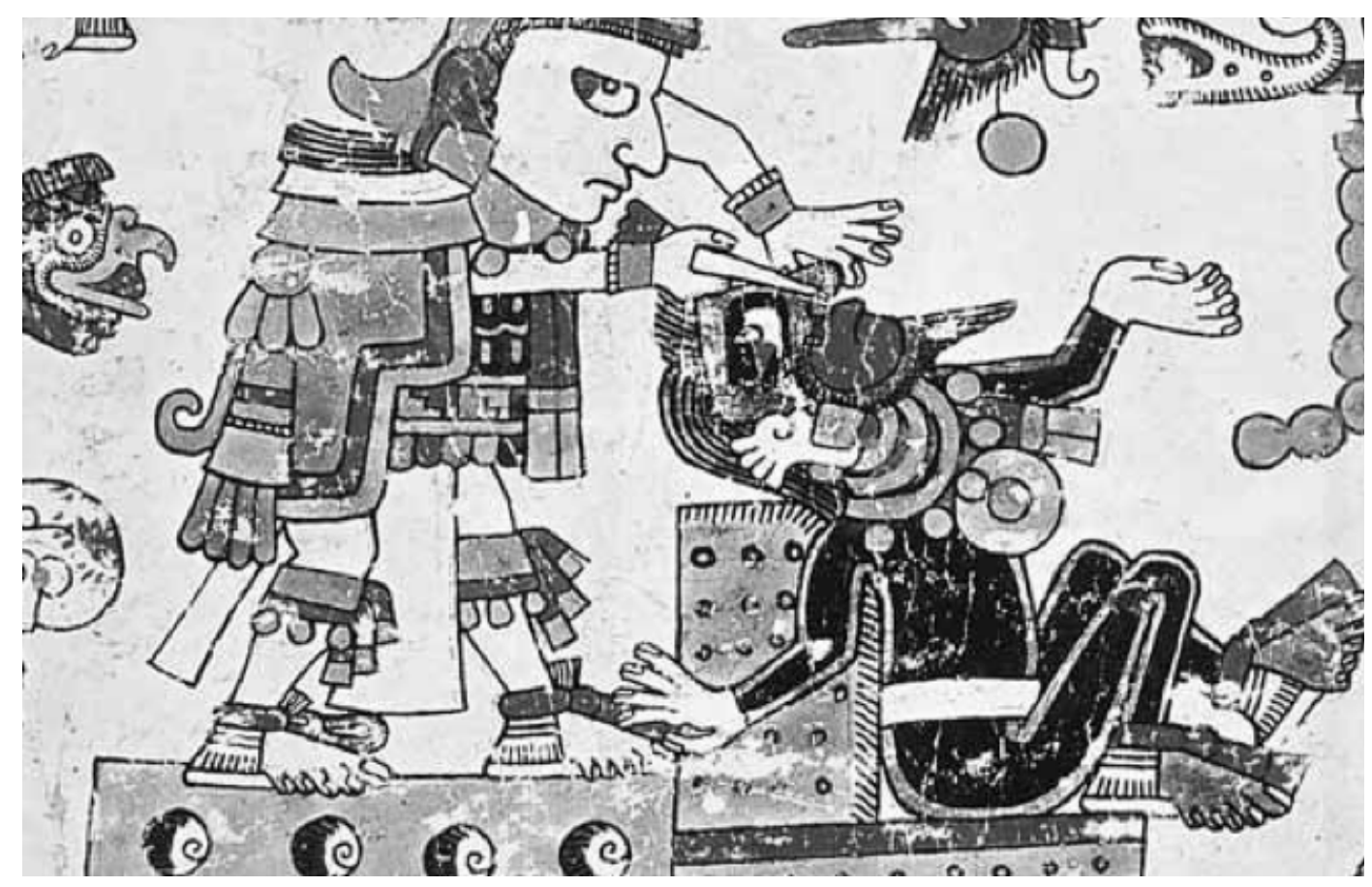

En Cholula, §̋ 8 Venado “Garra de Jaguar” es hecho “Tecuhtli”. (Códice Nuttall o Tonindeye).

Cuando convino a los intereses expansionistas del grupo Azteca el abrir rutas hacía el Istmo de Tehuantepec y el Soconusco para obtener arena abrasiva, algodón, mantas, grana-cochinilla, oro, plata, objetos de cobre, cacao, semillas, plumas de aves preciosas y pieles, la mixteca fue invadida y gradualmente sojuzgada por los ejércitos de la Triple Alianza, comandados por la dinastía gobernante azteca, proceso que se inició con la conquista del principalato chocholteca de Coixtlahuaca por las tropas de Moctezuma I Ilhuicamina en los años de 1458 a 1462. Años después, la conquista del sitio arqueológico situado en el punto elevado de Peña de Armas (San Juan Sosola), hacia 1487, tras derrotar al Principal Nahui Xóchitl (4 Flor), dio a los aztecas el acceso a los Valles Centrales de Oaxaca y a gran parte de la sección occidental del territorio mixteco. Esas conquistas permitieron el establecimiento de guarniciones estables.

La región permaneció tributando a Tenochtitlan, en unión de las zonas ocupadas por las demás etnias, hasta la conquista española, si bien en varias ocasiones algunos señoríos intentaron infructuosamente sacudirse el dominio tenochca, salvo algunos principalatos ubicados en la costa.

4 Conocido es el episodio, narrado en el Códice Nuttall, de la visita de ô 8 Venado "Garra de Jaguar" al Principal Tolteca 4 Jaguar, al Centro Ceremonial de Cholula, con el objeto de ser ungido "Tecuhtli”, o sea "Señor Principal”, para lo cual se sometió al acto de perforar su séptum nasal. 
La conquista española fue muy cruenta y se inició con una expedición jefaturada por el Capitán Gonzalo de Umbría a la región de Teposcolula, Poco después, las crónicas señalan que la resistencia que se ofreció a los capitanes Alonso de Ávila, Juan Núñez Cedeño, Gonzalo de Sandoval y Pedro de Alvarado ocasionó terribles pérdidas en vidas para ambos grupos contendientes y principalmente para los indígenas, (que formaban parte de ambos bandos. Baste recordar el episodio de la conquista de Tututepec y el sojuzgamiento de su Principal đ̃ Usia andoo (7 caña). Sin embargo, hacia 1530 la casi totalidad de la región estaba bajo control colonial. Se sabe poco del proceso de cristianización. Hubo frailes indiscutiblemente muy hábiles que rápidamente aprendieron el idioma y sus variantes y pudieron catequizar amplias zonas en poco tiempo. Entre ellos se encuentran misioneros como Fray Benito Lucero, un dominico que dejó amplia huella en los Distritos de Silacayoapan, Juxtlahuaca, Putla y Tlaxiaco fundando iglesias y conventos con particular empeño. Francisco Marín, Pedro Fernández Beteta y Domingo de Santa María, autor de este último de un "Vocabulario en Lengua Mixteca". Hacia fines del siglo XVI ya existían importantes edificios religiosos pertenecientes a la orden dominica (varios de ellos diseñados y construidos por Fray Francisco Marín y por el Lego Antonio de Barbosa) en Juxtlahuaca, Tonalá, Tlaxiaco, San Miguel Achiutla, Huajuapan, Yanhuitlán, Coixtlahuaca, Nochixtlán, Tilantongo y Tututepec, que posteriormente serían ampliados hasta su monumentalidad actual siendo, precisamente en Achiutla y Yanhuitlán, donde mas tarde Fray Francisco de Burgoa escribió su obras. La "Geográfica Descripción del Polo Ártico...” y la "Palestra Historial de Virtudes Apostólicas...”. De esa época se conservan pictografías, mapas y lienzos, y entre otros los que acompañaron a las Relaciones Geográficas del Siglo XVI y además los de Yolotepec, Zacatepec, Coixtlahuaca, Antonio León, Filadelfia, Yucunama y Cuquila, y anteriores, casi la totalidad de los códices prehispánicos, con excepción de algunos nahuas y de los mayas.

Durante todo el período colonial, la etnia mixteca presenció la explotación y degradación de su medio ambiente, la muerte de su gente por las epidemias y los trabajos extenuantes en el campo y las minas, el despojo de sus tierras para la formación de varias Haciendas y Estancias de Ganado Mayor y Menor de la región y la acción destructiva de Haciendas Volantes, autorizadas por el gobierno virreinal, y compuestas de grandes manadas de borregos y cabras, particularmente de éstas últimas; política que casi no varió mucho a partir de la Independencia: No obstante, indígenas mixtecos formaron parte de las tropas insurgentes a las órdenes de Dn. Antonio Valdés, Dn.Valerio Trujano, Dn. Juan de la Vega, Dn.Víctor Bravo, los hermanos Manuel y Juan Mier y Terán, Dn. Juan Sesma, Dn. Ramón Ramírez Sesma y de Dn. Chepito Herrera, quienes causaron descalabros a los realistas en combates como el del Cerro Encantado (Tlaxiaco) y el del Cerro del Faisán (Santa Gertrudis Cosoltepec). Un indígena mixteco de excepción pasó a la historia por su extraordinaria capacidad personal como espía, correo y combatiente. Remigio Sarabia Rosas, conocido como el "Indio de Nuyoo", de brillante actuar como decisivo en la terminación del Sitio de Huajuapan, al poner sobre aviso y hacer intervenir a las fuerzas de Dn. José María Morelos. En el bando realista, ya tan temprano como 1811, también hubo 
soldados mixtecos huajuapenses en las tropas de Dn. Nicolás Régules. Durante la Guerra de Intervención Norteamericana (1847-1848), muchos indígenas mixtecos combatieron y cayeron a las órdenes del Gral. Antonio de León y otros jefes, sobre todo en la Batalla de Molino del Rey. Más tarde, durante las guerras de Reforma y de la Intervención Francesa, muchos formaron parte de las fuerzas de los grupos contendientes y principalmente de las de los Generales Republicanos Porfirio y Félix Díaz Mori e Ignacio Mejía. En las tropas de Dn. Porfirio Díaz, los correos fueron mixtecos, y entre ellos descolló Dn. Julián Martínez, quién fue el hombre clave (el que logró introducir la cuerda) para su evasión del Colegio Carolino, en Puebla. Como consecuencia de la Ley de Desamortización de los bienes del clero, y a pretexto de ser terrenos baldíos, durante el porfiriato el grupo continuó siendo fuertemente despojado, principalmente por mestizos codiciosos y notarios inescrupulosos, por lo cual prosiguió su lucha por su tierra, la que continúa hasta la actualidad.

En la Revolución Mexicana los mixtecos participaron activamente y en el territorio se libraron multitud de encuentros armados entre Soberanista-Zapatistas y Constitucionalistas. La llegada a Oaxaca de las fuerzas constitucionalistas del General, entonces ex-villista, José Isabel Robles y su posterior defección, dio oportunidad a uno de los desplazamientos de caballería mas importantes de todo el período revolucionario, tocando a uno de los subordinados de Robles, el General Canuto Reyes, realizarlo, atravesando, al frente de los restos de su regimiento (alrededor de 380 jinetes), la Sierra Juárez, la Mixteca con breve estancia en Tlaxiaco y varios estados de la república, para reunirse en el norte del país con fuerzas villistas. Lamentablemente, en la región de mantuvieron varios cacicazgos.

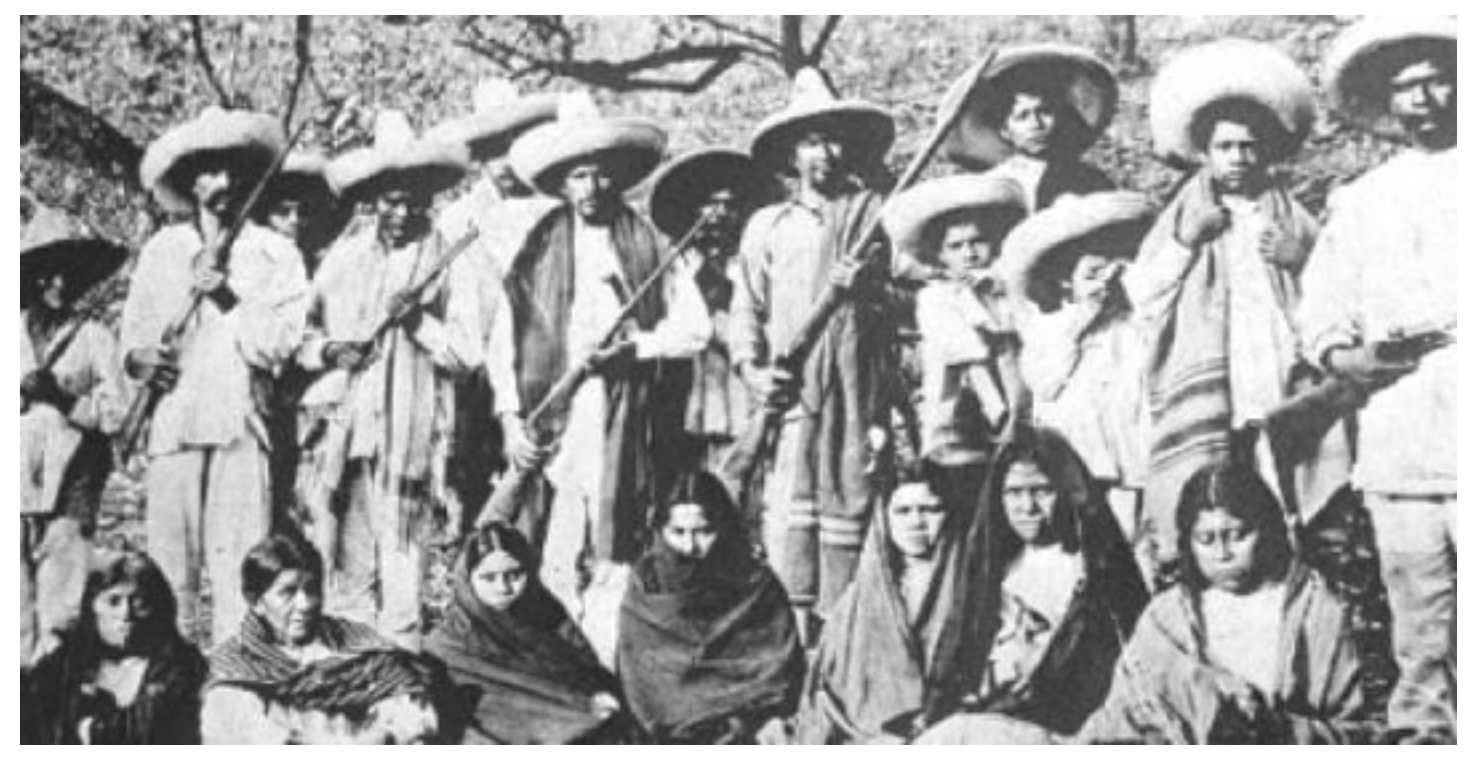

Mixtecos en la Revolución Mexicana. (Foto: Colección García Barcena).

Durante la década de los sesentas del Siglo XX, parte de la región (la Cuenca del Río Balsas) se vio beneficiada por un plan de desarrollo que estuvo a cargo de una Vocalía Ejecutiva, la de la Comisión respectiva, jefaturada por el General Lázaro Cárdenas del Río. 
Lamentablemente, después de 1970, año de la muerte del General, ya en manos de funcionarios de ideología derechista y contrarrevolucionaria, el programa no tuvo continuidad y se vio drásticamente interrumpido. Durante los últimos cuarenta años se han sucedido varios planes de desarrollo, desgraciadamente siempre fallidos, debido a que las instituciones indigenistas encargadas de la realización no han tenido acceso directo a los fondos, muchos de los cuales han sido transferidos por funcionarios corruptos, o sin conocimiento de la problemática indígena, a otras esferas de la inversión pública. Los últimos años, desde la década de los 40s, han visto una constante depauperación del grupo, lo que ha incrementado la emigración que se inició con el "Programa Bracero" que se instrumentó con la $2^{a}$ Guerra Mundial, época en que los Estados Unidos necesitaron hombres para substituir a sus propios ciudadanos que eran enviados a los frentes de batalla, y que después hizo desplazarse a miles de indígenas a campos agrícolas de Nayarit, Sinaloa y Sonora, y a multitud de localidades de los EE UU y Canadá, donde ya hay fuerte presencia mixteca. Así pues, en la mixteca la pobreza y la consiguiente emigración son una constante y en su territorio se asientan muchos de los municipios más pobres del país.

ACCESOS. Divide la región la carretera Federal 190 o Panamericana, totalmente pavimentada y de la cual parte como ramal la Federal 125 que une a Huajuapan de León con Tehuacán, en el Estado de Puebla, y que se continúa dentro de nuestro estado y rumbo al sur a partir de Yucundá o Yucudaa para pasar por San Juan Teposcolula, San Pedro y San Pablo Teposcolula, Yolomécatl, Huamelulpan, Tlaxiaco, Santa María Cuquila, San Andrés Chicahuaxtla y Putla con rumbo a Pinotepa Nacional. Otra importante vía troncal es la carretera que parte de Huajuapan de León, pasando por la presa de Yosocuta, Tonalá, Juxtlahuaca y San Juan Copala, hasta donde llega el revestimiento, y que, ya de terracería, se une a la anterior cerca de Putla.
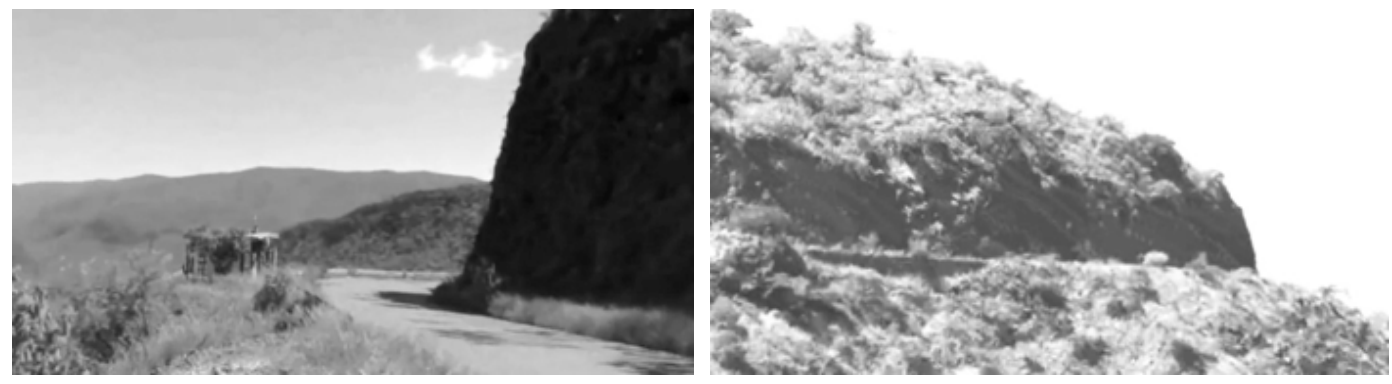

Carretera a Juxtlahuaca y Espinazo del Diablo. (Fotos: Baldemar Rodríguez).

De muy reciente construcción (1993-94) es la supercarretera que une la Ciudad de Oaxaca con el entronque de Cuacnopalan, situado sobre la autopista Puebla-Orizaba, y que une ambos puntos con las poblaciones de Tehuacán, Tepelmeme y Coixtlahuaca, con ramales a Tamazulapan del Progreso, Santiago Tenango y San Juan Sosola-Faustino G Olivera. 


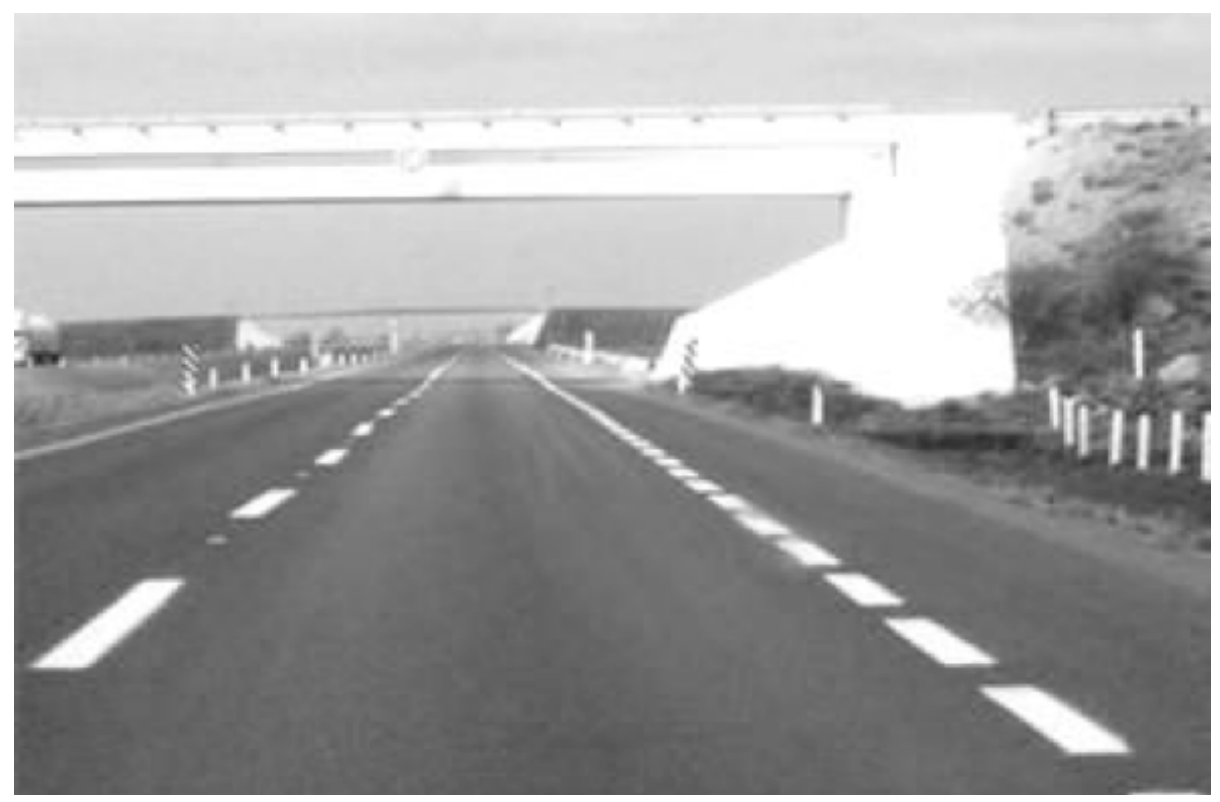

Carretera a Cuacnopalan. (Foto: Dirección de Turismo Estatal).

Recientemente pavimentado (sexenio del Lic. José Murat Casab) y de bastante importancia económica, es el camino que une a Huajuapan de León con Silacayoapan a través de Mariscala de Juárez , Tacachi de Minas, Santiago Tamazola y Calihualá.

De la carretera Panamericana parten varias rutas troncales de terracería; entre ellas las que llegan a las poblaciones de Tezoatlán de Segura y Luna, Santos Reyes Tepejillo, San Juan Diquiyú y Santa María Tindú, Coixtlahuaca, Tilantongo, San Jerónimo Sosola, San Juan Sosola y El Parián-Faustino G. Olivera, poblaciónes unidas situadas a la orilla de la vía del ferrocarril. A partir del 2011 ya llegan caminos de terracería y brechas a casi todas las comunidades.

En las diferentes áreas ocupadas por los mixtecos se encuentran pistas de aterrizaje de diferentes características y longitudes. Entre las poblaciones dotadas con esta facilidad de transporte se encuentran Huajuapan de León, Tlaxiaco, San Pedro Teozacoalco, Tonalá, Putla, Coicoyán de las Flores, Cacahuatepec, Jamiltepec, Tututepec y Pinotepa Nacional. Sólo la de esta última población puede recibir aparatos bimotores tipo C-47 o DC-3. La de Huajuapan de León solo avionetas bimotores y el resto solo aparatos monomotores, aunque los terrenos en que se asientan las de Tlaxiaco y Huajuapan ya están en la mira de fraccionadores. En el caso de Tlaxiaco allí se pretende construir un hospital, situación que demuestra el abandono en que se tiene a la región.

VIVIENDA. Debido al mosaico de climas que presentan las regiones ocupadas por el grupo, las casas varían en cuanto a los materiales empleados, el tamaño, el número y la disposición y casi nunca en cuanto a la forma, la casa mixteca es una construcción de planta, ya sea circular o rectangular, cuyos muros y castillos suelen ser de adobes entrelazados troncos superpuestos o traslapados y raramente de horcones de madera labradas de tron- 
cos de árboles. La estructura es de madera, y según la zona, el techo será de pasto, paja de trigo, teja, tejamanil o lámina metálica o de asbesto. Habitualmente no hay ventanas y la puerta se encuentra al frente, en el centro y ocasionalmente frontera a la de la otra casa. En algunas ocasiones las puntas laterales del techo son protegidas mediante una gran olla de barro para evitar que por ahí se cuele el agua. Este rasgo sobrevive en Yutanduchi de Guerrero y en San Pedro Teozacoalco.

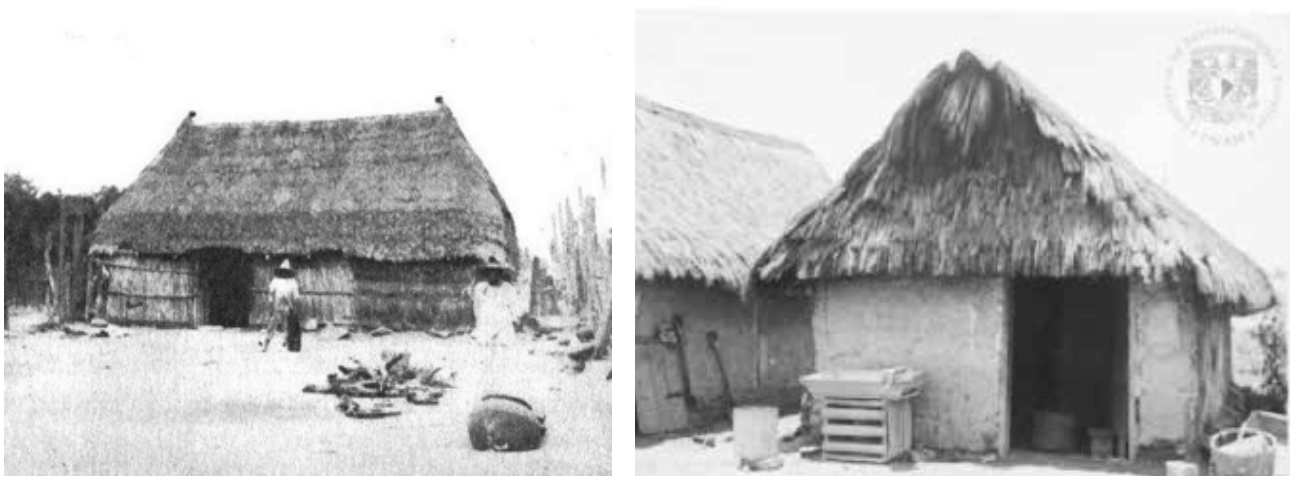

Casas mixtecas. (Fotos: Frederick Starr en 1906 y Raúl Estrada Discua en 1952).

En algunas poblaciones sobreviven el temascal y el cuescomate o troje. Los asentamientos, según la región, pueden ser compactos, dispersos o libres. Según la topografía de las poblaciones se estructura la distribución de los lotes, los cuales en ocasiones son muy pequeños y en otras rebasan los dos mil metros cuadrados.

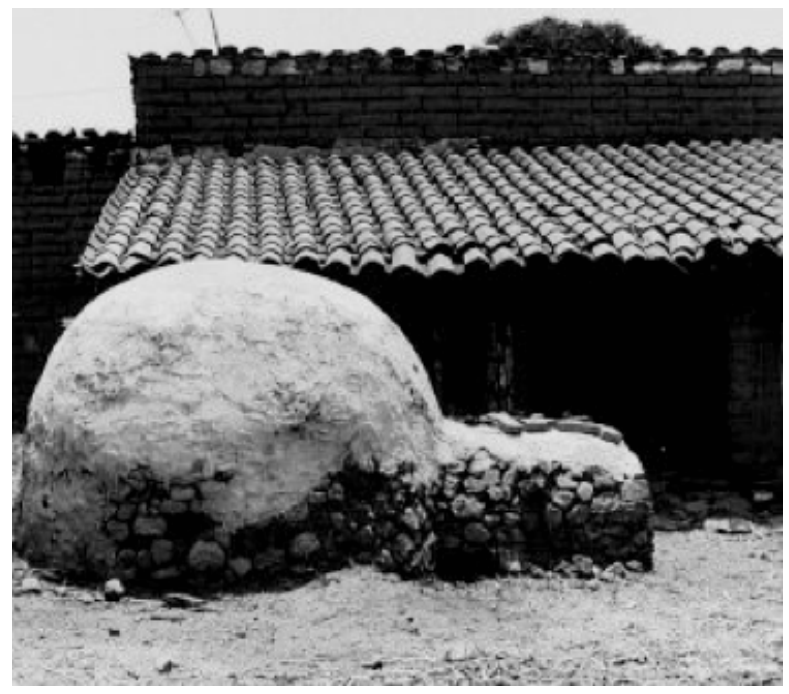

Temazcal Mixteco (Foto: IIS-UNAM).

En las poblaciones asentadas en los valles el reticulado de lotes es más uniforme habiendo casos en que la distribución es longitudinal a lo largo de un camino. En las poblaciones situadas en las laderas, las casas o sus agrupamientos están colocadas a mayor 
distancia en función de las dimensiones de los terrenos de cultivo. La población procura asentar sus viviendas relativamente cerca de una fuente de agua. En ocasiones y principalmente en los terrenos más quebrados, las casas dispersas quedan colocadas en lo alto de las laderas.
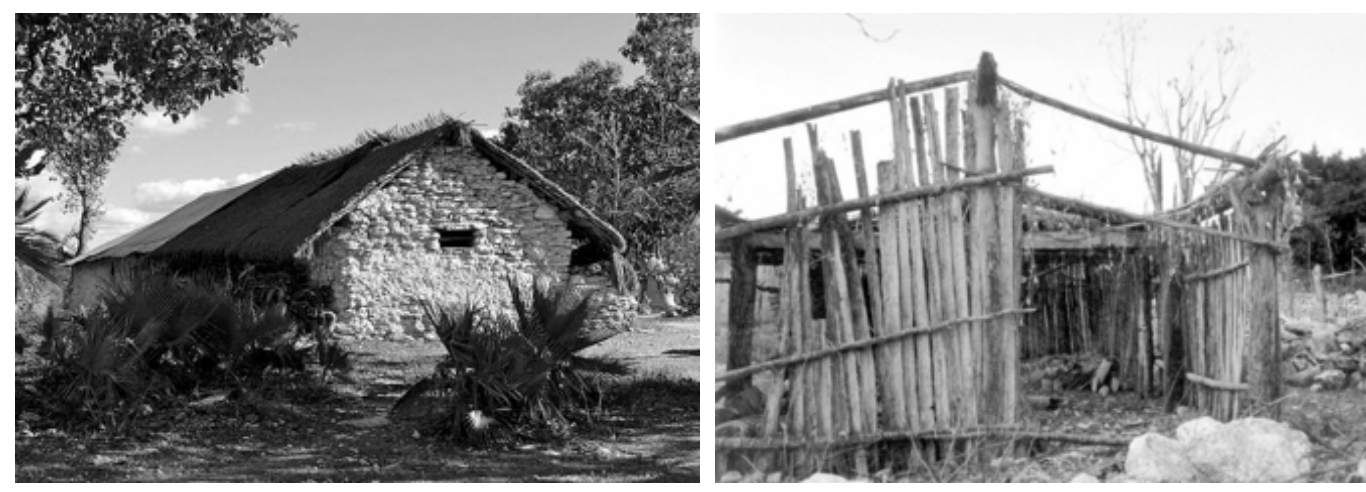

Casa Mixteca y la última tradicional en Zapotitlán Lagunas, Silacayoapan. (Fotos: Juan Zoniga y del autor).

Es habitual que en las poblaciones mixtecas, como en muchas de la República, la iglesia se encuentra en la zona central de la población, y casi invariablemente sobre una plataforma prehispánica, así como hecha con piedras que formaron parte de edificios de esa época, y es frecuente que, por ser zona de influencia dominica, tenga su portada mirando al occidente. En ese sector también se ubica el Ayuntamiento o la Agencia Municipal. También es frecuente que existan solares vacíos que se emplean para fines comerciales o ceremoniales. Con suma frecuencia el cementerio se encuentra alejado poco menos de un kilómetro, y en muchas poblaciones se trata de un sitio con un entorno particularmente bello o sumamente escénico.

Las casas suelen estar agrupadas en conjunto de dos, tres o cuatro, una de las cuales es cocina. En las zonas bajas algunas casas tienen una hendidura con traslape en el techo, que permite la salida del humo, pero no la entrada del agua de lluvia.

En casi todos los solares hay pequeños corrales para guardar cabras y borregos, así como también suele haber porquerizas. Con mucha frecuencia ha habido una troje o cuescomate redondo hecho de piedra, ramas o adobe, con una cubierta o techo de pasto o lámina de cartón. El menaje de casa ha sido relativamente limitado, consistiendo en metate y mano, muebles de madera, cerámica y canastos.

En algunas casas de la costa se construye un pequeño tapanco para guardar herramientas. Desde hace poco tiempo se ha generalizado la construcción con concreto y lámina acanalada, producto de las remesas de los migrantes, y sólo en abundantes casos de extrema pobreza, pueden verse construcciones de láminas de cartón. 

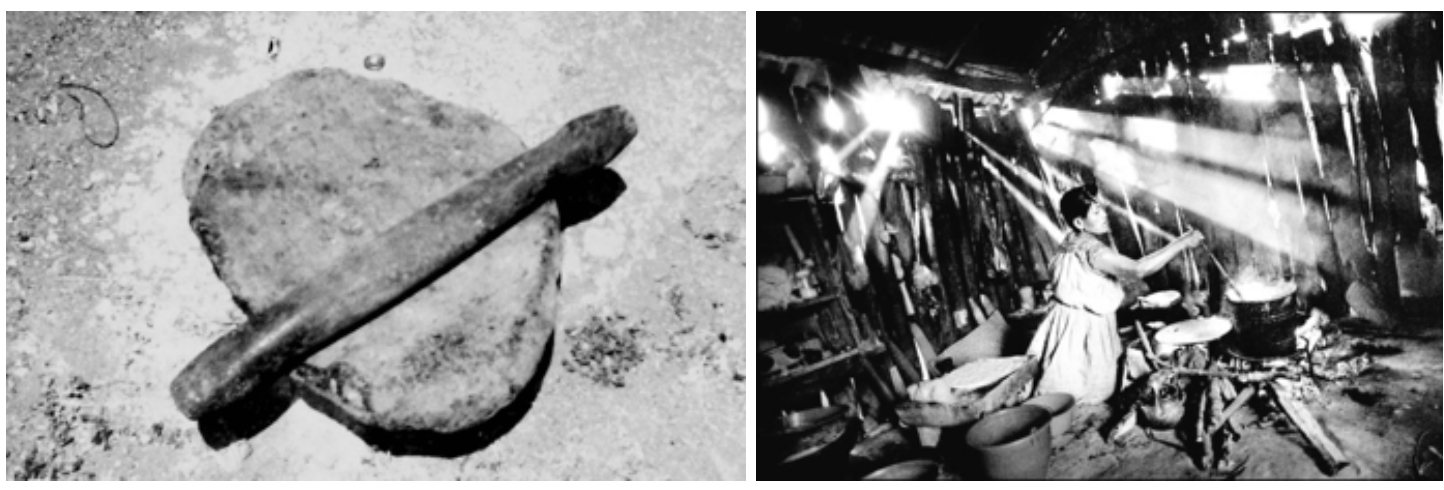

Metate y mano de principios del Siglo XX. Zapotitlán Lagunas, Silacayoapan y cocina mixteca. (Foto del autor y Matt Black ).

INDUMENTARIA. Aunque varía por zonas, y en algunas poblaciones se ha perdido casi totalmente, en parte por el proceso que durante decenas de años implementó el Gobierno Federal para imponer la castellanización, la indumentaria del grupo fue ampliamente distintiva y se tejía en telar de cintura. Tradicionalmente el hombre ha usado ropa de algodón blanco consistente en camisa y pantalones, a veces rectos y en otras ligeramente acampanados, estos últimos sostenidos por una banda tejida que se colocaba alrededor de la cintura. La camisa de algodón tradicional contenía algunos bordados. En la zona ocupada por los Tacuates el pantalón de tela de algodón solamente llega a la rodilla.

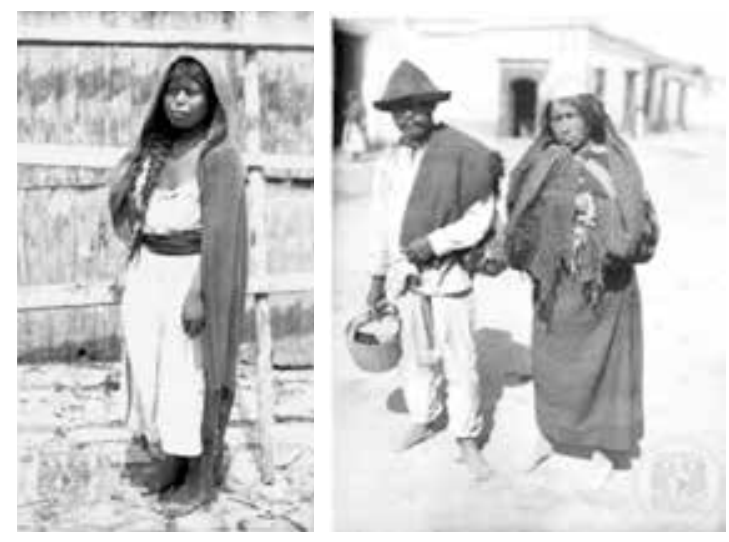

Mujer y matrimonio mixtecos. (Fotos: IIS-UNAM)

La indumentaria femenina ha sido más tradicional y conservadora; consiste en huipil y falda, así como blusa, hechas de algodón y en ocasiones bordadas con figuras de animales, Se incluye soyate y ceñidor, frecuentemente de color rojo, para sostener la falda. En algunas localidades se usa la falda enrollada que cuelga hasta un poco debajo de la rodilla. En la costa algunas mujeres desarrollaban sus actividades domésticas con el torso descubierto, si bien esta costumbre ha tendido a desaparecer a partir de "sugerencias" de autoridades "indigenistas" que propusieron el uso de mandiles o corpiños, y a medida que la lencería comercial se va difundiendo. 

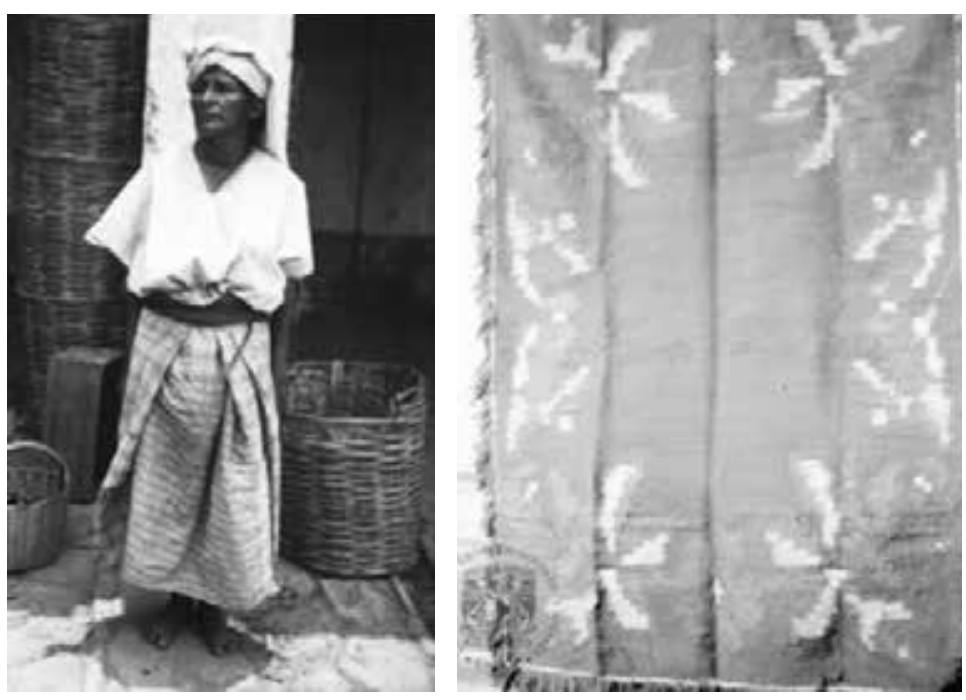

Mujer y un sarape mixteco del principio del Siglo XX . (Fotos: IIS-UNAM).

En muchas localidades persiste la tradición del uso de una capa que suele cubrir el vestido. En las zonas frías se usan rebozos y ponchos y en la costa, rebozo ligero. Frecuentemente las mujeres usan arracadas o aretes de bisutería. El peinado varía según las regiones y en la costa se suele preparar en forma de atadura sobre la cabeza. No obstante que los mixtecos constituyen arqueológicamente un grupo que practicó continuamente varios tipos de mutilación dentaria, en la actualidad ésta, debido al proceso de cristianización y aculturación, ha desaparecido totalmente. Recientemente se ha realizado el bordado de los trajes y vestidos con hilo de inferior calidad, y sólo en la costa de conservan trajes tradicionales, pero sólo en posesión de ancianos con cargos de jerarquía. En gran parte del área se ha perdido el uso del capisayo, que ha sido substituido por capitas de polietileno.

ECONOMÍA. En el grupo la economía presenta varios aspectos debido al mosaico de regiones y a la diferencia productiva y de potencialidades entre ellas. Por tanto, no puede ser vista como una economía desarrollada en términos de costo-beneficio, y tiene que ser analizada con limitaciones y de manera zonal. En la mayor parte del territorio mixteco la economía es de subsistencia basada en el cultivo estacional de maíz, fríjol, calabaza y chile, sujeta al temporal y con tecnología que no ha rebasado, salvo en contados casos, el arado de palo y la coa. También en algunos pueblos se recolecta maguey, y se está haciendo mezcal artesanal, un producto de excelente calidad.

En la mayor parte de las comunidades la población casi no produce excedentes, teniendo que adquirir artículos que no puede producir. Por ello tiene que dedicarse a otras actividades y destinar a esas adquisiciones parte de sus bienes de subsistencia. Esta situación ha provocado una depauperación en el grupo y ha obligado a muchos indigenas a dedicarse a algunas otras ocupaciones. Entre las principales están la manufactura de sombreros de palma, tenates, sopladores y petates, la preparación de carbón y la explotación de la madera, habiendo también quienes, en las zonas bajas, se dedican estacionalmente 
a la producción de piloncillo y panela a partir de pequeñas cantidades de caña de azúcar obtenidas en pequeñas parcelas próximas a arroyos. Como colofón, a esta situación, desde la década de los 80s, y como ya se expuso, otra válvula de escape ha sido la emigración al centro del país, a Sinaloa, Baja California, Nayarit o Sonora, o a los EE UU y Canadá.
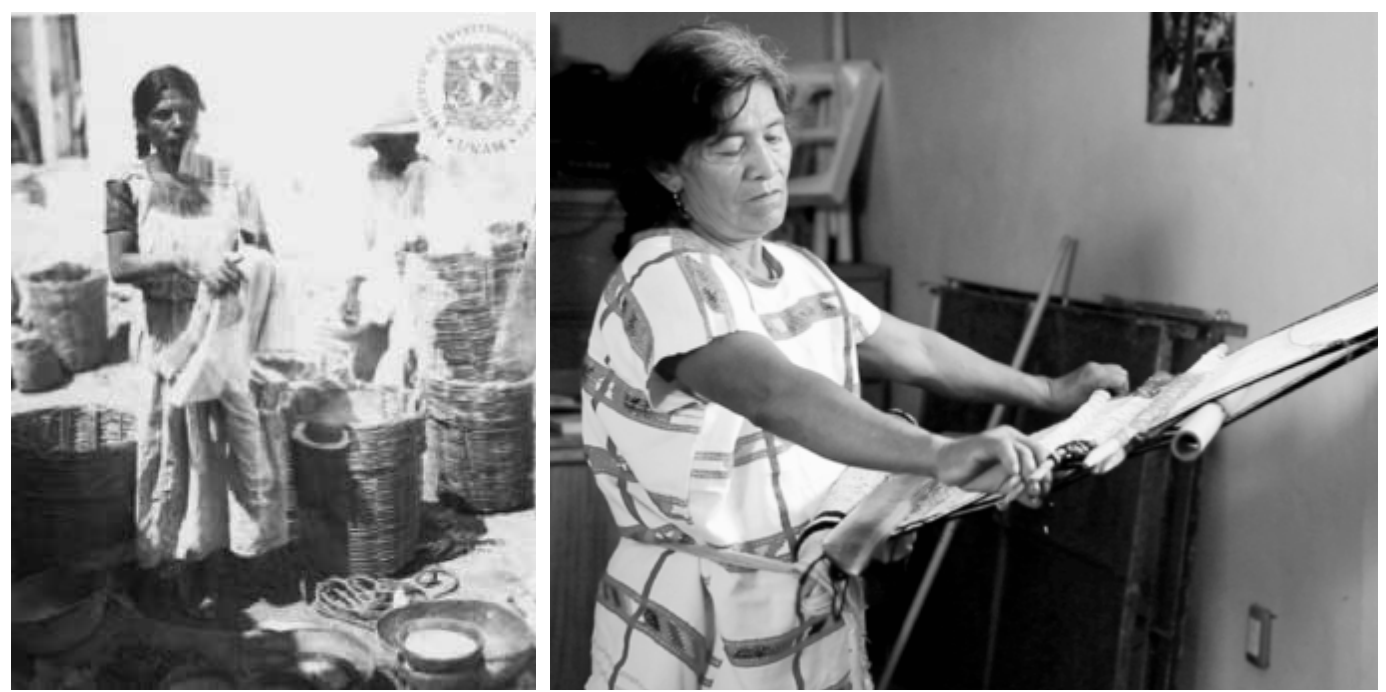

Vendedora de Canastos y Tejedora Mixtecas. (Fotos: IIS-UNAM y Felipe Santiago)

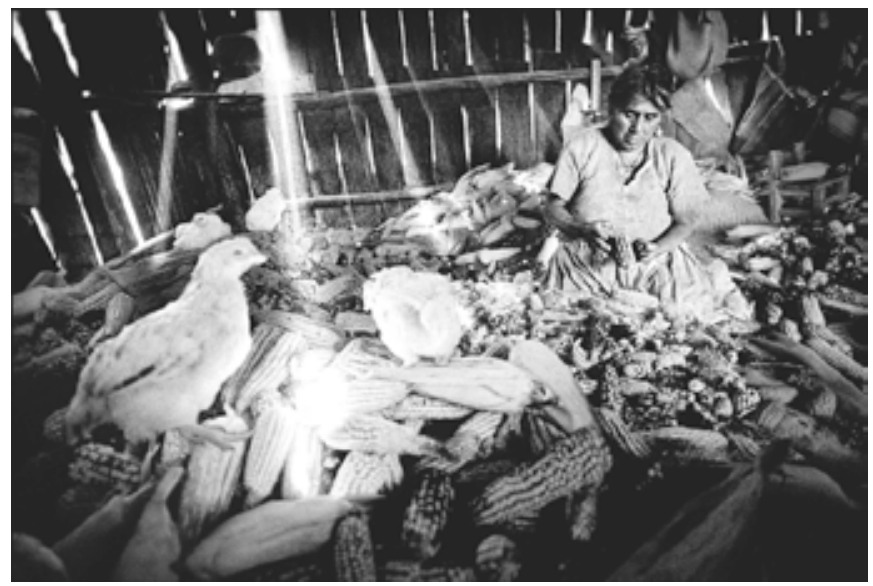

Mixteca desgranando. (Foto: Matt Black)

Dentro del grupo la división del trabajo está ampliamente defınida, sí bien ambos sexos han colaborado en un sinnúmero de actividades, sobre todo en las agrícolas, en las que las mujeres ayudan a sembrar y participan muy activamente en el levantamiento de la cosecha. Ambos sexos también participan en la construcción de casas, aunque es el hombre quien realiza la estructura. Tanto el tejido de sombreros y petates, como la elaboración de canastos y cerámica, son realizados por ambos sexos y por los niños, si bien son las mujeres quienes más se dedican a estas actividades, existiendo cuevas excavadas ex profeso para realizarlas. En el grupo existen pocos especialistas, aunque desde la década de 
los 70s comenzó a haber algunos técnicos que realizaron estudios por correspondencia. Ha sido tradicional que los principales especialistas hayan estado relacionados con la magia y el curanderismo. Asimismo, en algunas comunidades existen especialistas en pirotecnia o coheteros. Por otra parte, gran parte de la región está dedicada al pastoreo de ganado menor, lo cual es un importante rasgo y un problema.

La Mixteca presenta, por lo menos en una gran parte de su territorio, buenas posibilidades de desarrollo, ya que en ella se puede implementar una fruticultura, una avicultura de traspatio, una silvicultura, una ganadería de especies menores y una cría de especies de caza de carácter intensivo y de alta productividad. Es importante implementar pronto programas de este tipo porque tanto la mortalidad infantil como la emigración están provocando una pérdida de arraigo entre la población, Esto último ya está dejando semi-abandonadas algunas poblaciones, por eso urge implementar pequeñas agroindustrias a cargo de grupos de mujeres.

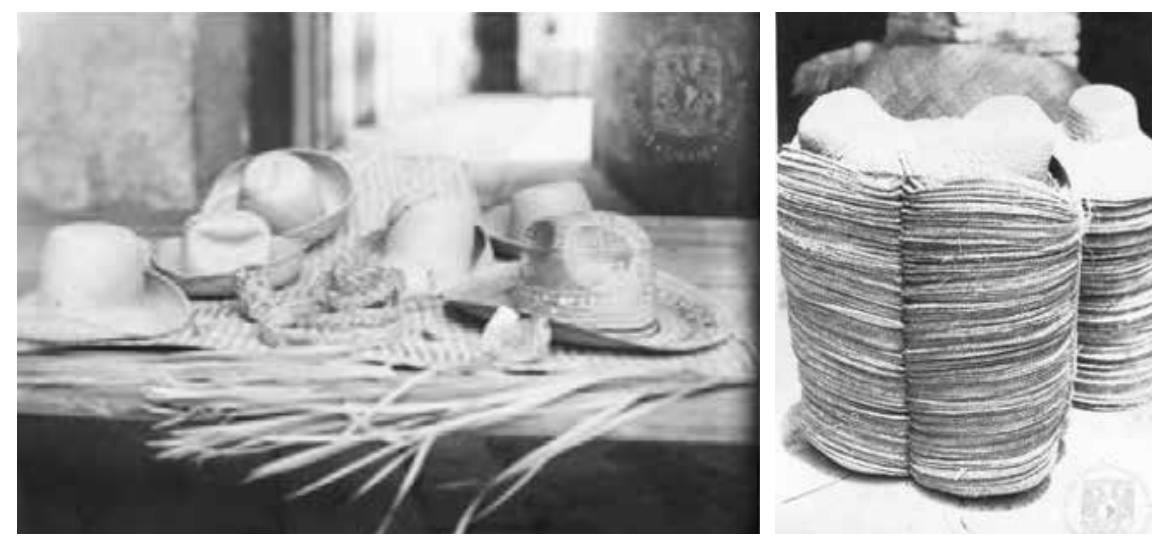

Sombreros de palma y gruesa de sombreros de palma. (Fotos: IIS-UNAM)

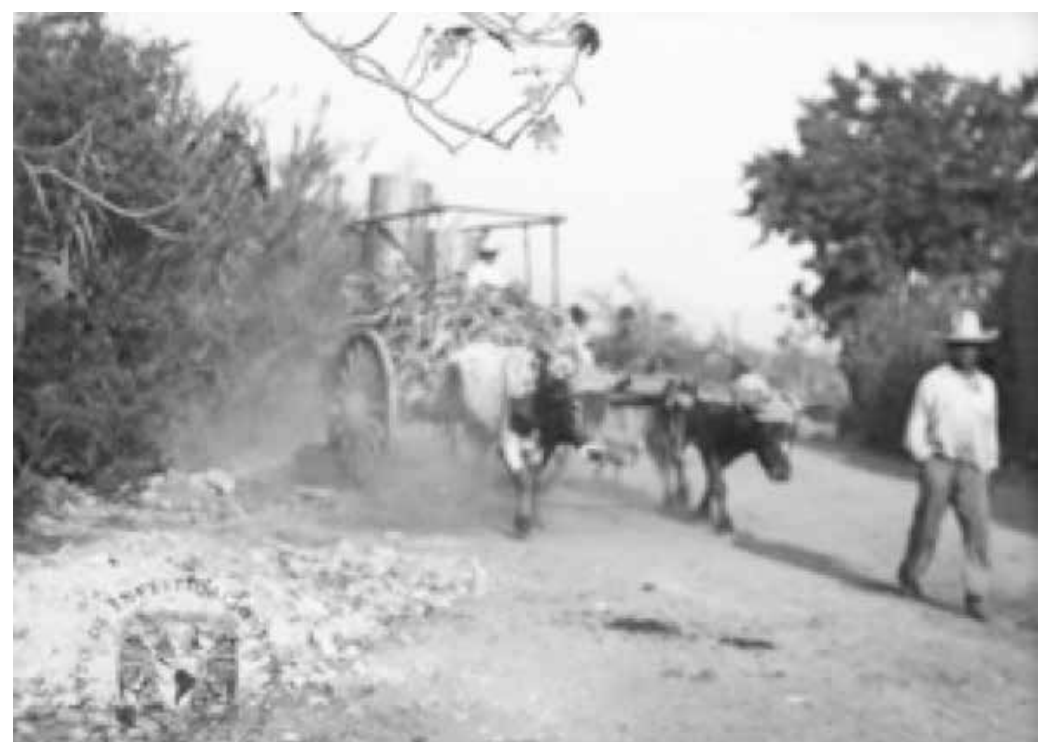

Carreta (Foto: IIS-UNAM) 
ARTESANIAS. La principal artesanía regional es el tejido de sombreros: actividad permanentemente mal pagada y que, habitualmente, se realiza en cavidades excavadas exprofeso. Además en algunas comunidades, tales como Cuquila, se elabora cerámica y en otras se trabaja sobre textiles elaborados en telar de cintura.

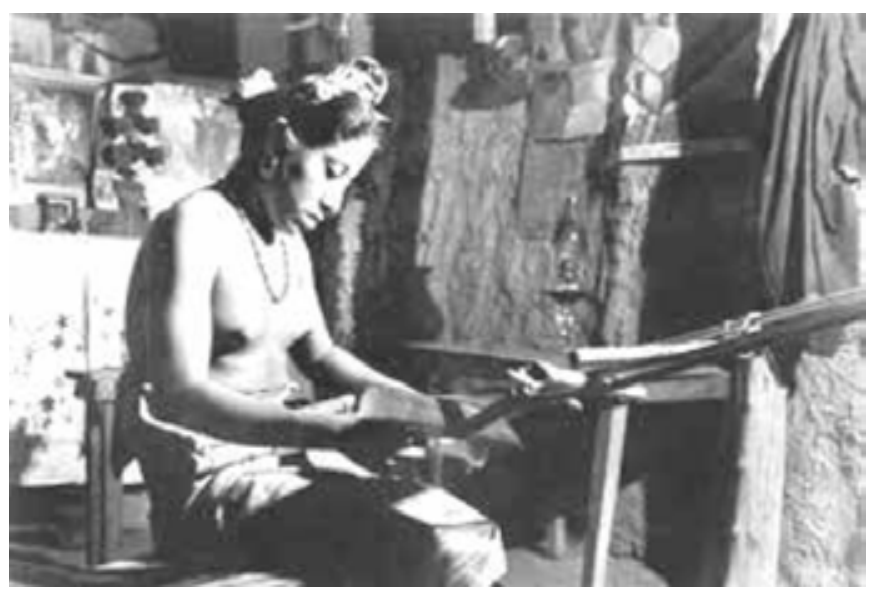

Tejedora. (Foto: Frederick Starr. 1906)

Cerca de Tlaxiaco, y como remanente del trabajo organizativo de los frailes, se hizo cuchillería, algo de jarciería, mantas y sarapes, y en algunos otros lugares, trabajos de hojalatería. En algunas zonas persiste la jarcería, la talabartería y el curtido de pieles. La tradición cerámica prehispánica se ha conservado porque una importante parte de la cerámica mixteca de los últimos años anteriores de la conquista sintetizó las formas de prácticamente toda la cerámica prehispánica mesoamericana, agregando una importante tradición de decoración bícroma y polícroma, presentando alta funcionalidad. La jarcería, la talabartería y el curtido de pieles son actividades que datan de la época virreinal y que han revestido mucha importancia durante los dos últimos siglos, ya que por la región pasaban varias rutas de tránsito para el ganado bovino y porcino producido en la costa, el cual era llevado a sacrificar y procesar al altiplano. Esta artesanía, jarciería y talabartería, hizo famosas a varias poblaciones, principalmente a Tlaxiaco, Huajuapan, Mariscala de Juárez y Juxtlahuaca, siendo muy importante que tal tradición no se pierda en esa región, la cual, infortunadamente, está sucediendo.

GANADERÍA. En las áreas ocupadas por el grupo las actividades ganaderas son extensivas y la calidad del ganado bovino es muy baja. Existen pequeñas cantidades de vacas de cría, y se documenta que, mayoritariamente, las yuntas de bueyes han pertenecido a mestizos. En muchas localidades se practica la ovicapricultura de una manera también extensiva y sin programas de mejoramiento genético. Un importante número de las cabras de la Mixteca Alta pertenecen a comerciantes establecidos en las ciudades de Huajuapan y Tehuacán, los cuales sólo dejan a los miembros de la etnia las responsabilidades del cuidado y el pastoreo a cambio de una retribución muy limitada. 
En toda la región se crían caballos, burros y mulas; estas últimas son utilizadas en los caminos agrestes que unen poblados aislados y en la extracción de madera y minerales, aunque su número se ha reducido.

CAZA Y PESCA. El área ocupada por los Mixtecos presenta, debido a los mosaicos climáticos, vegetal y de elevaciones sobre el nivel del mar, una fauna silvestre particularmente rica, muchas de cuyas especies, y principalmente el venado cola blanca, el jaguar, el ocelote y el puma, están en vías de desaparición. La caza en el grupo se ha practicado siempre con escopetas, originariamente con escopetas de chispa o chispetas, rifles de pequeño calibre y trampas, utilizándose solo los animales necesarios para el consumo familiar. Fue muy característico que los cazadores pidiesen al "amo de los animales" la pieza deseada, y en la punta de muchos cerros se conservan las piedras frente a las cuales de realizaba ese rito, así como los ritos de fertilidad. Desde hace aproximadamente 60 años se inició la explotación del recurso por parte de cazadores deportivos y profesionales, los cuales han depredado grandes áreas de la Mixteca Alta reduciendo la densidad de población del venado cola blanca y pecarí a niveles muy bajos y con él a los animales a los que dan sustento. Los grandes desmontes y talas practicadas en los Distritos de Nochixtlán, Teposcolula, Tlaxiaco, Silacayoapan y Juxtlahuaca han reducido la fauna silvestre a una posición cerca de la extinción, si bien especies como la zorra gris, el conejo montés y la codorniz común han aumentado su población con el incremento de las áreas de pastizal. Las trampas para conejo se hacen con varas y una piedra pesada, la que cae sobre el animal cuando éste acciona las ramitas que la soportan. En algunas áreas de la costa se capturan palomas huilotas y de alas blancas mediante trampas de carrizo sumamente efectivas, muy similares a las cacaxtles del altiplano, utilizando granos de maíz o ajonjolí como cebo. Como contraparte, en la región de Tonalá, desde hace pocos años, existe un exitoso programa de reproducción del venado cola blanca, que se está extendiendo a municipios vecinos con tal éxito que ya se tiene un registro de varios pumas, y su fauna dependiente, en una superficie que ahora abarca cuatro municipios. Esta es una acción que debiera implementarse también en municipios como San Pedro Teozacoalco, San Mateo Sindihui y otros, que presentan montes con pinares adecuados para ese fin, particularmente el primero.

Aunque en la región corren arroyos y ríos que, juntos, configuran el Mixteco y el Verde y existe una amplia variedad de especies de peces y crustáceos, no existen actividades piscícolas sistemáticas y racionales, pescándose solo mediante nasas y explosivos, y muy raramente con anzuelos, con el resultado de erradicar los peces en ciertos tramos de ríos. Algunos arroyos de las partes más altas de la Sierra Madre del Sur, en los Distritos de Juxtlahuaca y Silacayoapan, reúnen características muy favorables para establecer criaderos de trucha, tanto Arco Iris como Parda. En muchos arroyos de montaña existen especies de cangrejos y chacales endémicos, únicos en la fauna nacional y ya estudiados por los biólogos de la UNAM. 
MERCADOS. Las poblaciones de la Mixteca presentan mercados de diferentes características. La mayor parte de las transacciones comerciales se realizan en las poblaciones en un área destinada para tal fin. Los productos comerciales suelen ser transportados a larga distancia porque existe un ciclo mercantil semanal, dándose casos en que de manera periódica, bienes comerciales son vendidos a más de 300 kilómetros de su población de producción. En algunos mercados del área subsiste un intercambio elemental con características de trueque y en ellos se reciben artículos procedentes de varios grupos indígenas, llegando cerámica zapoteca o de Atzompa y algunos artículos amuzgos, triques, cuicatecos y mazatecos. Tlaxiaco fue la ciudad mercado por excelencia. En los mercados, en los días de intercambio, se práctica todo tipo de relaciones humanas incluyendo la prostitución.
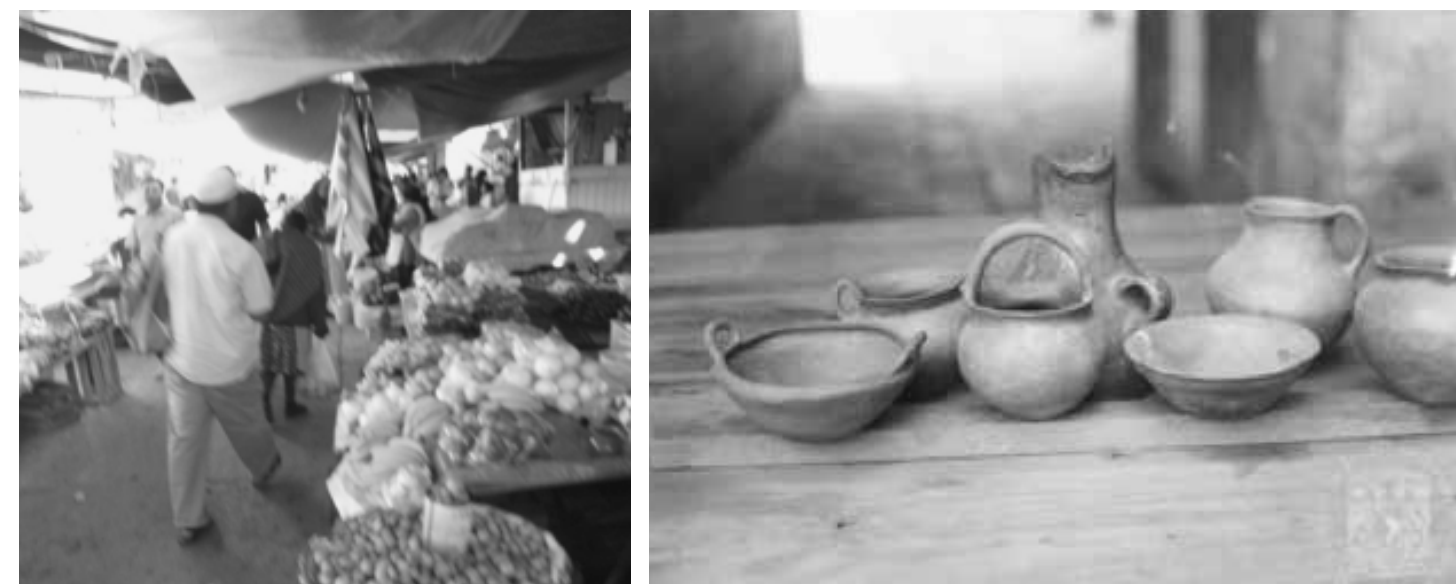

Mercado y muestrario de cerámica reciente mixtecos. (Fotos: TEDAVI y UNAM).

En las poblaciones comerciales, en las que el comerciante acaparador suele ser un español, un mestizo o un indígena aculturado, ya se ven los primeros norteamericanos ejerciendo esa función. El indígena proveedor suele llevar la peor parte porque sus productos nunca son pagados en su valor justo. Es frecuente que muchos productores artesanales sean comerciantes en los lugares y en los días en que se desarrolla esta actividad. Durante el período de la vocalía ejecutiva del General Lázaro Cárdenas del Río, se creó un organismo regulador del comercio de productos de palma, el Fideicomiso de la Palma, FIDEPAL, desarticulado poco tiempo después de la muerte del General.

ORGANIZACIÓN SOCIAL. La sociedad Mixteca es bilateral, con relativa patrilinealidad, patrilocalidad, matrilocalidad, monogámica y endogámica. La familia es nuclear. Los apellidos se trasmiten por línea paterna y con frecuencia algunas mujeres retienen su apellido paterno. Entre los varones son frecuentes los apodos, aunque también comienza a haberlos entre mujeres. La familia nuclear, compuesta por el padre, la madre y los hijos solteros, es la unidad fundamental de subsistencia pero se apoya en la familia extensa en todas las actividades productivas. En las actividades domésticas, tanto el hombre como la mujer se consultan entre sí, teniendo las mujeres una cierta autoridad matrimonial. 

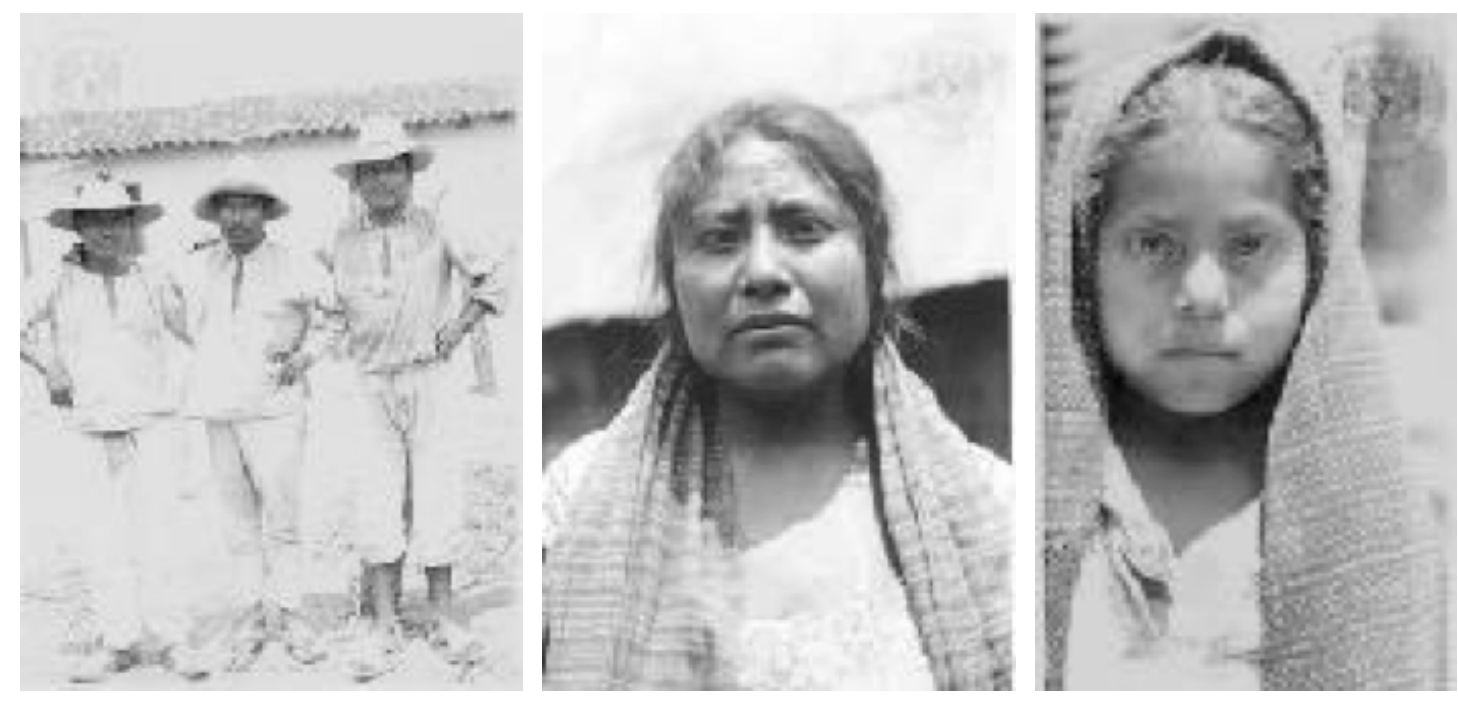

Hombres, mujer y niña mixtecos. (Fotos IIS-UNAM).

En la inmensa mayoría de las poblaciones se manifiesta una organización que agrupa dentro de la estructura política del estado a diferentes dimensiones de tamaño y autoridad. La comunidad menor es la Ranchería, seguida por las Agencias Municipales o de Policía, el Municipio y el Distrito. Las relaciones entre las localidades dependen del comercio, los mercados, los lazos de parentesco, los compadrazgos, las peregrinaciones religiosas e incluso hasta las muertes producidas en disputas por fronteras municipales o por la posesión de áreas de cultivo. En muchas poblaciones se conserva el barrio como una institución-agrupamiento remanente de la organización prehispánica; y en muchos casos como un gran conjunto que aglutina a varias familias extensas.

En el grupo existieron varios patrones de matrimonio. El más antiguo de ellos contemplaba la selección de la muchacha por parte de los padres del pretendiente, los que enviaban un intermediario, el Tavijaa o Huehuetloca, a hacer el pedimento formal. Era usual que esta selección se hiciese cuando los contrayentes tenían entre 11 y 8 años, pero recientemente han entrado en juego otros en los que la selección y la boda se realizan cuando los contrayentes tienen entre 18 y 17 años de edad. Actualmente, en las localidades más aculturadas, ya opera la selección de la pareja, realizada por mutuo entendimiento la cual decide cuando inicia su vida conyugal. En algunas regiones, en las bodas tradicionales se realizan diálogos chuscos en mixteco, entre la cocinera, los padrinos de la boda y el padre de la novia con el natural regocijo de los asistentes.

En gran parte del territorio mixteco, las fiestas de matrimonio son costeadas por ambas familias y los compadrazgos que crean revisten enorme importancia para la organización social de la etnia. Siempre es el padre del niño bautizado, o el padre del novio, quienes seleccionan a los padrinos, ya sea del niño bautizado o de la boda. Tan está considerado parentesco el compadrazgo, que los matrimonios entre compadres ya viudos no son aceptados. Toda ocasión bautismal de conformación en el grupo o de matrimonio implica una fiesta en al cual bailan todos los asistentes. En las áreas más aculturadas, durante el 
baile suele haber contacto corporal, lo que no ocurre en las comunidades aisladas, en las cuales hombres y mujeres bailan separadamente, pero la novia da oportunidad a varios hombres de bailar con ella. En la costa, durante ciertas fiestas de boda, algunas casadas tienen libertad de sostener relaciones sexuales con varios hombres.

$\mathrm{Al}$ morir algún miembro de la etnia, se le despide con tristeza, se le toca música, y en ocasiones se le danza. Al fallecido, colocado con la cabeza hacia el occidente, se le entierra con su ropa, sus implementos y suficiente comida para su ruta al más allá, en la que deberá alimentar a los animales que se le aproximen, algunos de los cuales fueron suyos o y él o ella mataron. Normalmente el cuerpo es depositado en una tumba, ya sea envuelto en un petate o en una caja de madera. En localidades grandes tales como Huajuapan, Tlaxiaco y Jamiltepec se introdujo en época relativamente reciente (la década de los 60s), el uso del ataúd metálico. En toda la región se rezan novenarios y en algunas localidades de la mixteca alta se siembran flores sobre la tumba, principalmente margaritas, zempoalxúchitl o borla.

GOBIERNO. Entre los mixtecos, e independientemente de la estructura política-jurídica de los municipios y de los distritos subsisten formas, de gobierno caracterizadas por una organización escalafonaria a la cual los hombres del grupo pueden acceder de manera gradual. Solo después de muchos años de servicio puede un miembro del grupo ocupar la máxima jerarquía; la de Principal, que a veces conlleva la de Presidente Municipal.
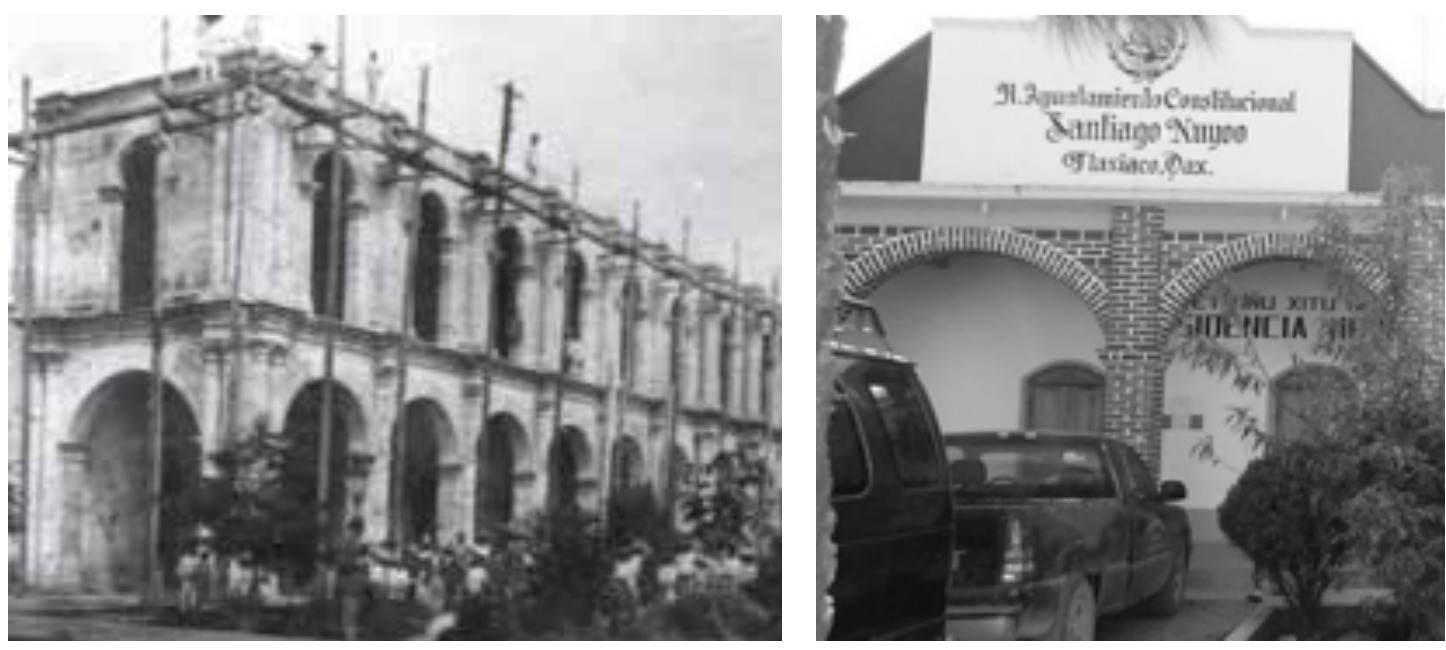

Palacios Municipales de Tlaxiaco (entonces en construcción) y de Santiago Nuyoo.

(Fotos: Archivo Municipal de Tlaxiaco y Wikimedia).

En muchas poblaciones se continúa practicando el tequio, el cual es señalado y asignado por el Principal. Debido a que muchos miembros del grupo también han recibido una politización intensa, en la zona, y principalmente en la mixteca alta, está teniendo lugar una fuerte actividad de partidos políticos, los cuales ya tienen locales sede y organizaciones filiales en las poblaciones importantes. Uno de los primeros casos fue la población 
de Huajuapan de León, donde el Partido Acción Nacional ha tenido desde hace más de 50 años una fuerte presencia, con un antecedente, un asalto de militantes derechistas a un cuartel militar, en el que brillaron en la defensa un teniente y su esposa. En el resto de la mixteca la actividad política campesina recayó inicialmente en la CNC (Confederación Nacional Campesina), y con el paso del tiempo y las divisiones, ahora tiene una fuerte presencia el Partido de la Revolución Democrática (PRD), que capitaliza el enorme cariño y respeto que dejó en esas regiones el Gral. Lázaro Cárdenas del Río.

FESTIVIDADES. El grupo se ha caracterizado desde la época prehispánica por la importancia de sus festividades. En éstas se baila y se bebe en abundancia. Es posible que el origen prehispánico del primero de estos rasgos se haya conservado hasta nuestros días y que las fiestas actuales, dictadas por el calendario católico, se encuentren superpuestas a las fiestas prehispánicas impuestas por los calendarios ritual y agrícola. En las celebraciones participan todos los miembros del grupo, y en ellas los asistentes intercambian regalos, chismes y noticias. Existe una etiqueta que señala el comportamiento de los asistentes. En ocasiones, durante las fiestas de los Santos Patronos de las diferentes poblaciones, se practica una serie de reglas que señalan el papel de cada miembro de la etnia. En estas fiestas se queman fuegos artificiales en forma de castillos y toritos, se danza y se juega la pelota mixteca. La región mixteca es rica en danzas, muchas de las cuales derivan de las de Moros y Cristianos, pero otras contienen reminiscencias de aquellos grupos de arrieros y comerciantes que transportaban mercancías y arreaban ganado desde la Costa a las ciudades de Puebla y Tehuacán, Varias poblaciones del área festejan el Carnaval, la cual da oportunidad a una notable actividad dancístico-cómica, en la que se usan máscaras de madera de magnífica calidad (El caso de "Los Rubios" y el "Macho Mula” de Juxtlahuaca), y en la que el acompañamiento corre a cargo de guitarras de diferentes tamaños, violines y tamboriles o tarolas.
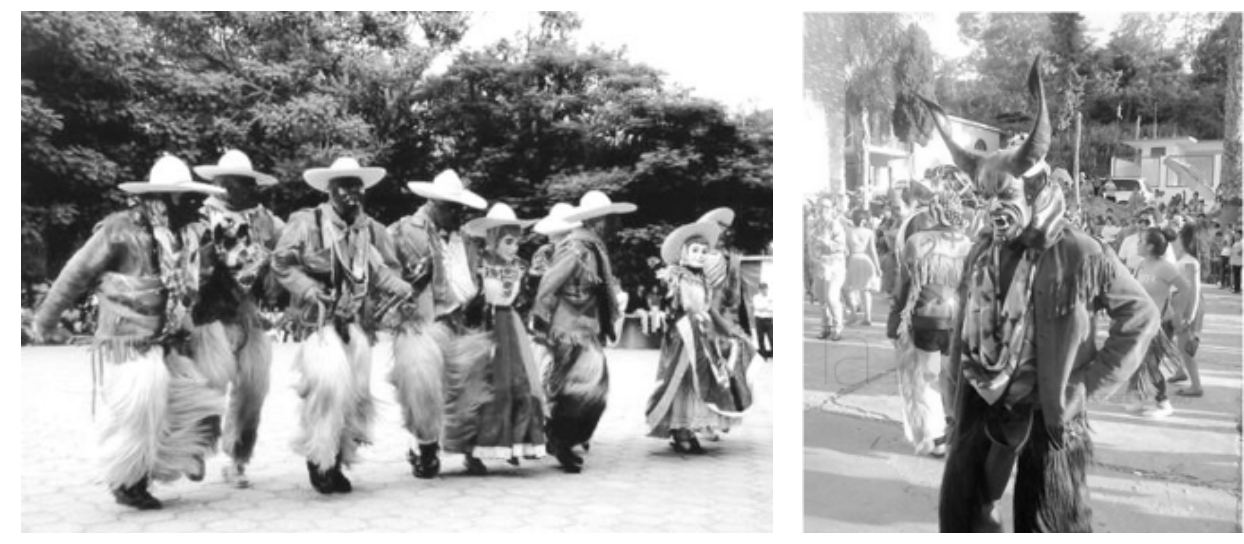

Danza de los Rubios y del Macho Mula. (Fotos: Angel Mendoza González y Semanario La Región).

Casi todas las poblaciones cuentan con una banda de instrumentos de aliento, con frecuencia insuficientemente dotadas y con instrumentos de gran antigüedad. En casi 
toda el área también se observan ceremonias los días de muertos, tanto en las visitas a los cementerios, como mediante altares en las casas. Con utilización funeraria se siguen utilizando vasijas con formas prehispánicas, principalmente sahumadores trípodes.

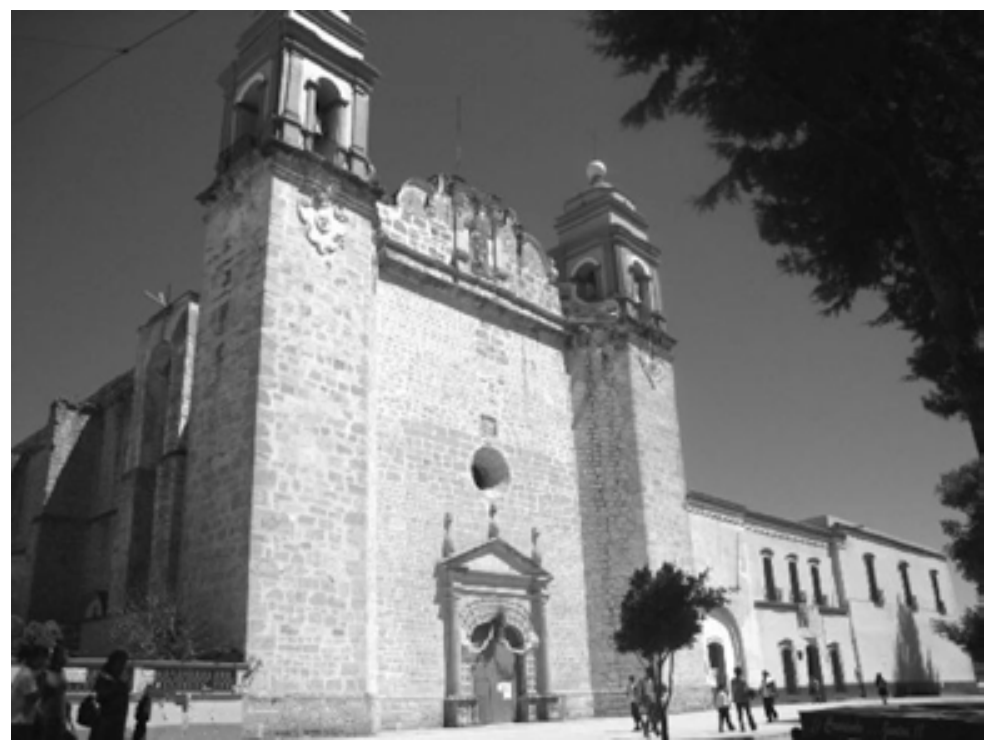

Iglesia de Tlaxiaco. (Foto del autor)

ORGANIZACIÓN RELIGIOSA. Además del sacristán, que tiene a su cargo el cuidado de cada iglesia, entre los mixtecos reviste mucha importancia el Mayordomo, que tiene que asegurarse del éxito de las festividades y que recibe la ayuda de la comunidad. En el grupo subsisten directamente conceptos emanados de la religión prehispánica, continuados en la persistencia de la brujería. A los dioses de los fenómenos naturales, y de los cuerpos celestes, principalmente al de la lluvia, Iya Dzahui, y el del Sol. Iya Nganzi, se les siguen ofreciendo sacrificios de animales, principalmente guajolotes, en una clara continuidad de los ritos prehispánicos de fertilidad. Se considera que el mundo está animado y que todos los objetos y lugares de la naturaleza tienen su espíritu. Se cree en el espíritu de las montañas, llamado Tabayucú, el cual controla el agua y los animales, y al que se considera bisexual. En los momentos de siembra y cosecha se realizan ceremonias propiciatorias que varían según las localidades, habiéndose observado casos de reutilización de figurillas femeninas prehispánicas colocadas en campos de cultivo para asegurar el éxito de las siembras. En ceremonias de este tipo participa toda la familia y todos aquellos parientes, amigos y vecinos que colaboraron para recoger el producto obtenido. En relación con el culto del agua, se siguen practicando ceremonias en cuevas, en las que, a las estalactitas y las estalagmitas se les da connotación de representaciones de los chorros de agua. Allí se depositan vasijas tetrápodas, en clara alusión a las muy similares vasijas del postclásico mesoamericano. Muy frecuentemente, en algunas ceremonias se usan rocas a las que se les asigna la representación de lazos familiares. Así mismo, con suma frecuencia también se han visto en los altares de las casas figurillas prehispánicas incorporadas al culto actual. 
Los mixtecos consideran que los manantiales, las corrientes fluviales y subterráneas y los pantanos (indudablemente turberas originadas en la putrefacción de hojas y agujas de pino y encino) son lugares sagrados e investigados con el espíritu que en ellos reside, lo cual es prueba irrefutable de las condiciones de humedad y de la densidad boscosa que la región presentó en la época prehispánica y hasta parte de la colonial.

MEDICINA Y MAGIA. En muchas poblaciones mixtecas existen brujos, hechiceros y curanderos. Ambos sexos practican el curanderismo y la magia. Se considera que las enfermedades están causadas por lo siguientes factores:

\section{Brujería y hechicerias}

2. Desajustes intestinales y estomacales por hacer comido alimentos fríos o calientes.

3. Mal de ojo. Ocasionado porque alguna persona con poderes pone atención especial en otra, la cual, por esa razón, se enferma.

4. Sustos, los que pueden ser consecuencia de una experiencia aterradora.

5. Aire, concepto relacionado con los sustos, que está caracterizado por incluir un enfriamiento nocturno.

6. Chipil. Esta es una forma de apatía en la población adulta provocada por un estado de ánimo.

Las curaciones de los sustos se hacen en los lugares en los que se supone que la enfermedad se inicia. Estos lugares pueden ser la casa del enfermo, un manantial o un lugar en las montañas que con frecuencia se encontraba situado frente a una estela prehispánica. En las actividades adivinatorias se usan substancias que contienen compuestos químicos de tipo alucinógeno, tales como hongos, flores y semillas. Muchos curanderos demuestran tener muy vagas nociones de lo que ocurre en la otra vida, habiéndose perdido ese importante rasgo religioso prehispánico. Sin embargo, persiste la idea de en cuales puntos cardinales sobreviven los espíritus. Se dice que los muertos, a los que ubican en el occidente, (como se hace en muchas regiones de Mesoamérica), vuelven a fines de octubre y, para que no se sientan a disgusto, en las entradas de las poblaciones se les ponen flores de bienvenida.
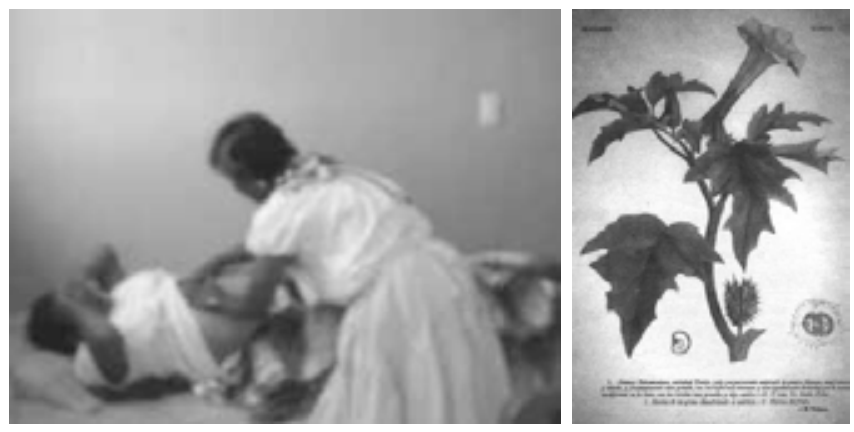

Curandera mixteca y dibujo de la planta de toloache. (Foto: Julio César Del Río Lozano y dibujo de José María Velasco) 
En muchas comunidades existen pasantes de medicina haciendo su servicio social, aunque no cuentan con equipos y medicinas en a cantidad suficiente. Recientemente en algunas se han establecido médicos titulados. Hasta 1980 algunas poblaciones contaban con clínicas, situación que se ha atendido creando muchas más, existiendo 372 en el 2013. Sólo Huajuapan de León, Tlaxiaco y Pinotepa Nacional tienen hospitales de zona. Desde hace pocos años radican en poblaciones importantes varios médicos recibidos que desarrollan su labor. Casi ninguno era indígena hasta hace muy poco tiempo.

EDUCACIÓN. Casi todas las localidades en las Mixtecas cuentan con escuelas preescolares y primarias. Hacia 1980 las cabeceras distritales y algunas poblaciones importantes contaban con una o varias secundarias, existiendo además preparatorias, si bien a varias poblaciones se les atendió dotándolas de telesecundarias. Desde esa época se han creado gradualmente diecisiete planteles del Colegio de Bachilleres, y varios CECyTES en Huajuapan de León, Santiago Chazumba, Putla, Pinotepa Nacional, Silacayoapan, Nochixtlán, Chalcatongo de Hidalgo, Mariscala de Juárez, Juxtlahuaca, Tamazulapan, Tlaxiaco, Bajos de Chila, Teposcolula, Santiago Yosondúa, San Pedro Mixtepec, Pinotepa de Don Luis y Río Grande, Santiago Yolomécatl, Jamiltepec y San Pedro Siniyuvi. En Tamazulapan existe una Escuela Normal Rural; pudiéndose realizar estudios de nivel medio superior, incluidas algunas carreras cortas, en algunas de las mencionadas poblaciones. Esta opción está resultando manejable para jóvenes de familias de muy bajos recursos, que lamentablemente son la absoluta mayoría y que suelen estudiar becados.
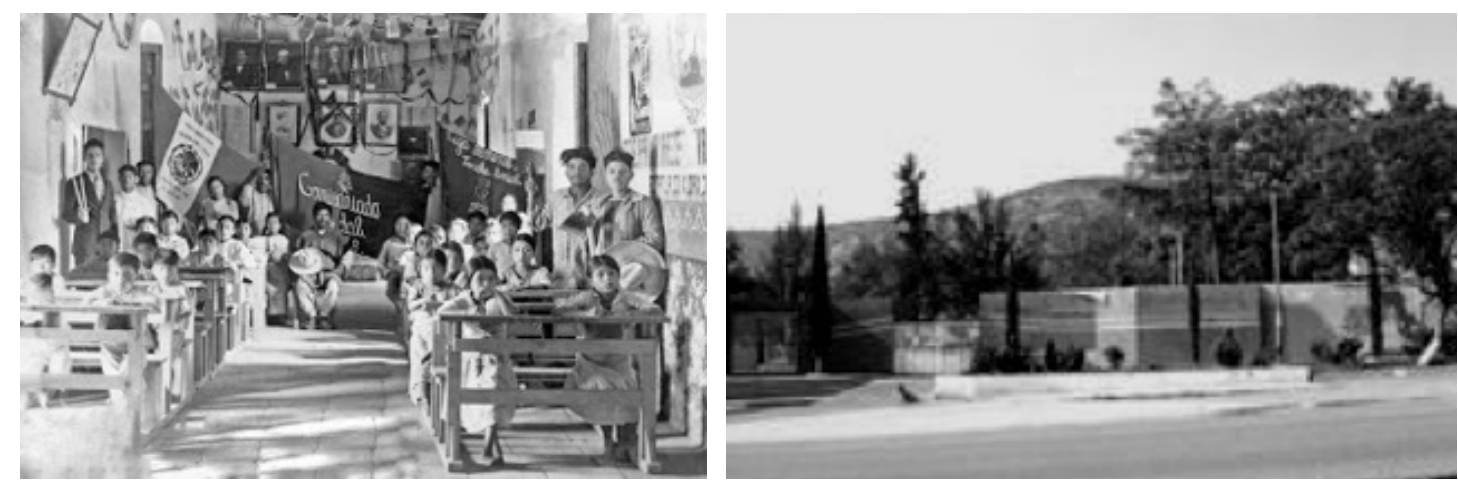

Aula en 1930 y acceso a la EscuelaNormal Rural "Vanguardia” de Tamazulapan. (Fotos: Archivos de la Institución)

Ante la enorme reviste la diseminación de la educación superior, Huajuapan de León ya cuenta con una Universidad, la Tecnológica de la Mixteca, la cual desarrolla sus actividades desde el año de 1991 con diez carreras profesionales (varias ingenierías) y con un nivel académico acreditado, que en el 2013 incluye 12 maestrías y 4 doctorados. En el año del 2011 contaba con aproximadamente 2500 alumnos de origen mayoritariamente mestizo-indígena, y 275 catedráticos.

La mayor parte de los miembros de la etnia tienen una escolaridad muy baja que en algunas zonas no rebasa un promedio del segundo año de primaria. La Mixteca tiene, por 
tanto, grandes contrastes educativos, y el grupo, debido a su bajo poder adquisitivo, presenta carencias educativas acusadas, las que es urgente resolver.

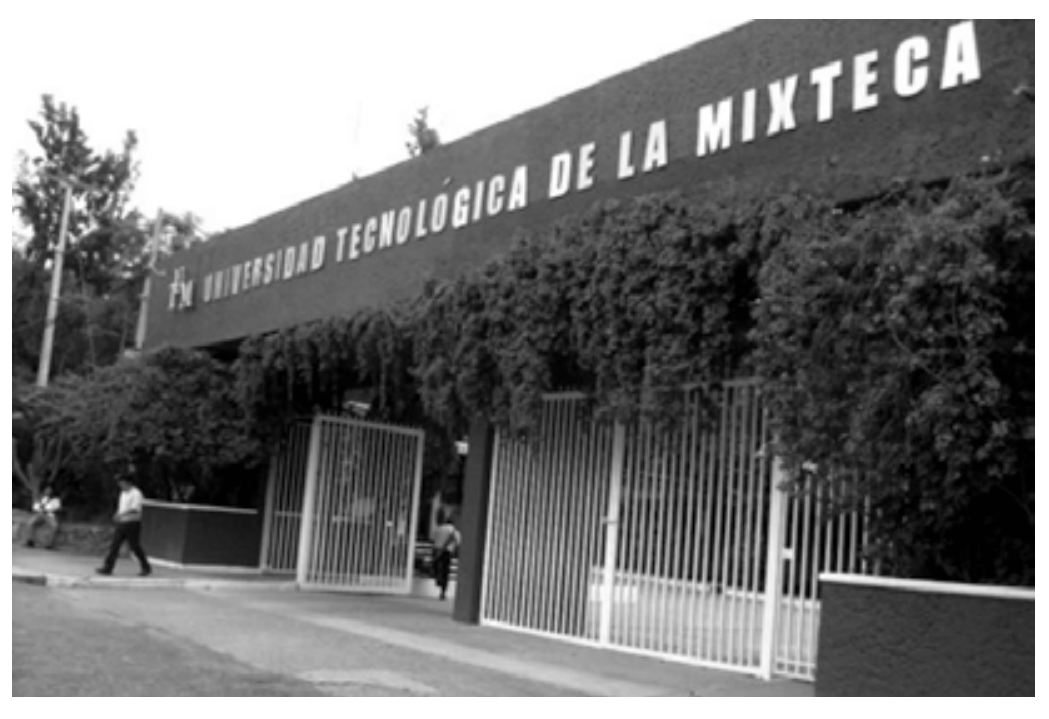

Universidad Tecnológica de la Mixteca. (Foto: UTM. Huajuapam)

\section{BIBLIOGRAFÍA}

Acevedo Conde. María Luisa, 1995 "Mixtecos”. En: ETNOGRAFIA CONTEMPORANEA DE LOS PUEBLOS INDIGENAS DE MEXICO. PACIFICO SUR. Instituto Nacional Indigenista. Secretaria de Desarrollo Social. México, D F. 1995.

2008 "Los Mixtecos”. En Revistas A CONTRAGOLPE. №s 16, 17 y 18. Carteles Editores, Oaxaca, Oax. 2008.

2011 “Un Viaje a la Montaña de Guerrero”. Revista A CONTRAGOLPE. No 27. Carteles Editores, Oaxaca, Oax.

Bartolomé, Miguel Angel. 1999 "El Pueblo de la Lluvia”. En: CONFIGURACIONES ETNICAS EN OAXACA. PERSPECTIVAS ETNOGRAFICAS PARA LAS AUTONOMIAS INI. CNCA. INAH. México. D F. 1999.

Basauri, Carlos. 1940 Reed. 1990 “Los Mixtecos”. En: LA POBLACION INDIGENA DE MEXICO. Tomo II. Instituto Nacional Indigenista. SEP. México, D F. 1990.

Benítez, Fernando. 1967 LOS INDIOS DE MEXICO. Tomo I. "En el País de las Nubes”. Editorial Era. México, D F. 1967.

Dalhgren. Bárbara. 1950 LA MIXTECA, SU CULTURA E HISTORIA PREHISPANICAS. Universidad Nacional Autónoma de México. México, D F. 1950.

De La Peña, Moisés. 1950 PROBLEMAS SOCIALES Y ECONOMICOS DE LAS MIXTECAS Instituto Nacional Indigenista. México. D F. 1950.

ENCICLOPEDIA DE MEXICO. 1988 “Mixtecos”. Editorial Enciclopedia de México. México, D F. 1988. 
Mindek, Dubravka. 2003 MIXTECOS. Consejo Nacional de los Pueblos Indígenas. México. D F. 2003.

Ravicz S. Robert. 1980 ORGANIZACIÓN SOCIAL DE LOS MIXTECOS. Instituto Nacional Indigenista. Serie: Antropología Social № 5. México. D F. 1980.

Ravicz S, Robert, Romney, A Kimball. 1969 “The Mixtecs” En: HANDBOOK OF MIDLE AMERICAN INDIANS. Vol. VII. University of Texas Press. Austin \& London. 1969.

Reyes de la Cruz, Virginia Guadalupe, Ramírez Izúcar, Claudia. 2005 LA NIÑEZ JORNALERA. EDUCACIÓN Y TRABAJO. Instituto de Investigaciones Sociológicas de la UABJO. Carteles Editores. Oaxaca, Oax. 2005.

Rodrigo Álvarez, Luis. 2004 GEOGRAFIA GENERAL DEL ESTADO DE OAXACA. 4a Ed. (Aumentada) Carteles Editores. Oaxaca, Oax. 2004

UABJO. CIESAS 1989 PRIMERAS JORNADAS DE ESTUDIOS MIXTECOS (Mecanuscrito). Oaxaca, Oax. 1989 (Contiene:

Víctor de la Cruz. "Relaciones entre Mixtecos y Zapotecos".

Marcus Winter. "Arqueología de la Mixteca. Avances y Perspectivas”.

$\mathrm{M}^{\mathrm{a}}$ de los Ángeles Romero Frizzi. “La Mixteca Alta y el Comercio Mundial. 1519-1720.

Ortiz Gabriel, Mario. "Los Campesinos de la Mixteca y los Cambios en la Estructura

Económica Regional”. Acevedo Conde, María Luisa. “Los Mixtecos. Bosquejo para un Estudio de los Impactos de la Migración en la Mixteca Oaxaqueña”.

Weitlaner, Roberto. 1961 DATOS DIAGNOSTICOS PARA LA ETNOHISTORIA DEL NORTE DE OAXACA. Sociedad Mexicana de Antropología. INAH. SEP. México D F. 1961 



\section{TACUATES}

Autodenominación: inyú, marañuu o nuchipela.

Sinónimo en su lengua: tacuate.
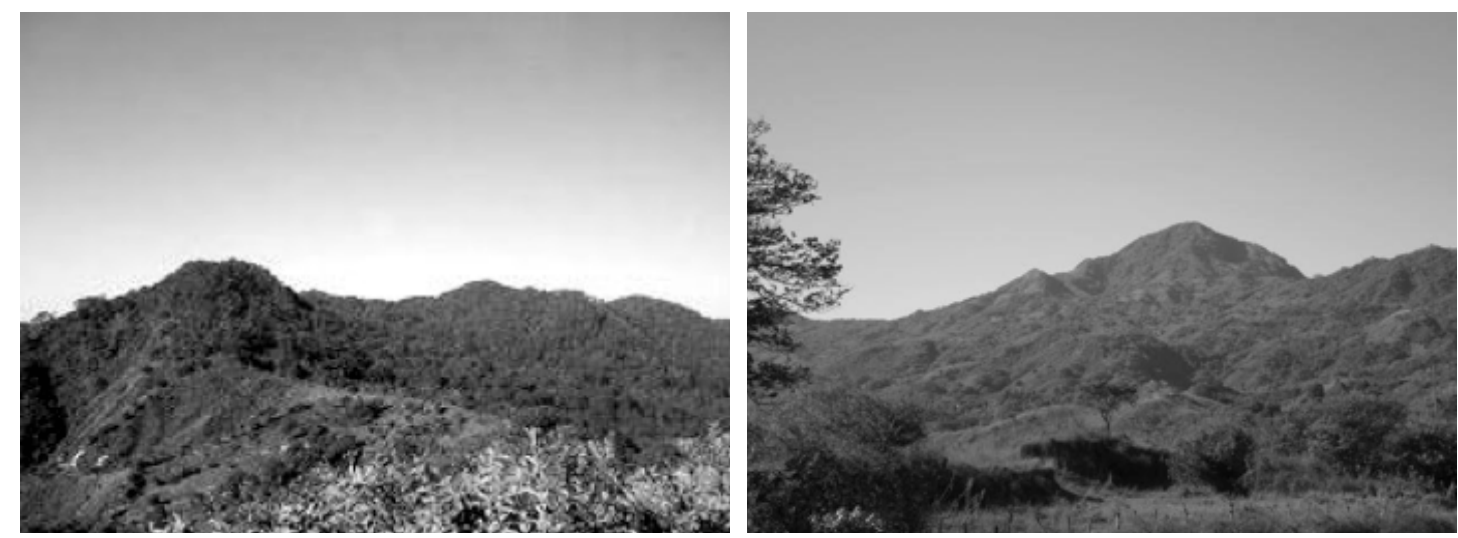

Paisajes de Santa Maria Zacatepec, Jamiltepec. (Fotos: Antonio Torres Rodríguez y Francisco García).

\section{GRUPO TACUATE}

UBICACIÓN GEOGRÁFICA. El Grupo Tacuate se encuentra ubicado en las estribaciones occidentales de la Sierra Madre del Sur oaxaqueña, en dos localidades muy distantes entre sí, de los distritos de Putla y Jamiltepec: Santa María Zacatepec (Yucusaduta o Pueblo Viejo) y Santiago Ixtlayutla, respectivamente. La primera a los $16^{\circ} 53^{\prime}$ de latitud norte y a los $97^{\circ} 19^{\prime}$ de longitud occidental y la segunda a los $16^{\circ} 14^{\prime}$ y los $96^{\circ} 56^{\prime}$ de latitud norte y longitud occidental respectivas. Originalmente ocuparon un territorio mayor, del que gradualmente fueron siendo desplazados, hasta el siglo XIX y la primera mitad del XX, en que quedaron constreñidos a su actual ubicación Su territorio es de lomeríos bajos con pequeños valles, originalmente de selva media caducifolia compuesta de ceiba, roble o rosamorada, guanacaxtle, primavera, caoba y multitud de especies, todas ellas muy útiles, que al ser depredada derivó en pastizales. Ambas localidades se encuentran, respectivamente, a 350 y 460 metros sobre el nivel del mar y cuentan con un clima semicálido, subhúmedo, con lluvias en verano, que suelen comenzar en el mes de mayo y alargarse hasta el de octubre. Sus suelos son básicos y sólo en las artes altas colindantes los hay más ácidos donde hubo o subsisten bosques de coníferas. El principal régimen de vientos es sur en el verano con relativa nubosidad. 
IDIOMA. La lengua es una variante muy cerrada del idioma mixteco, del que debió separarse hace, por lo menos, 2000 años, hablada en la actualidad por alrededor de unas 6500 personas de las 8500 que ocupan ambas poblaciones. Desde hace mucho tiempo mixtecos y tacuates no pueden entenderse entre sí. Los tacuates designan su lengua como Tu'un Va'a.

ANTECEDENTES ARQUEOLÓGICOS E HISTORICOS. De enorme interés resulta la historia tacuate. En los cerros y las laderas que rodean ambas poblaciones se encuentran vestigios arqueológicos del grupo y mixtecos, sin que hayan sido estudiados apropiadamente. La historia oral, y la recopilada por Dn. Manuel Martínez Gracida, hablan de que esa área perteneció a los señoríos de Tlaxiaco y Tututepec, para después caer bajo el dominio azteca, a quienes tributaban maíz y algodón.

Así, hacia el año $700 \mathrm{~d}$ C, los principalatos de Tilantongo y Tututepec ya pretendían el dominio regional, el cual se lograría más de 200 años después con las campañas de $\widehat{\delta} 8$ Venado "Garra de Jaguar", sus alianzas matrimoniales y los asesinatos a conveniencia de opositores, aún siendo parientes. Santa María Zacatepec tuvo una dinastía que fundó đo 4 Viento "Serpiente de Fuego" (Yya Chi Huidzo), casado con una de las hijas de 8 Venado. El Lienzo I de la población, que inicia aproximadamente en el año 1068, y que se guarda celosamente en el Museo Nacional de Antropología, narra que ${ }^{\wedge} 4$ Viento "Serpiente de Fuego" designó a su hijo đ̂ 11 Jaguar “Tlaloc-Muro de Fuego" como el primer Principal en Zacatepec. 13 fueron las poblaciones que enseñorearon ese personaje y sus sucesores. Uno de ellos, ô 3 Caña “Xiuhcóatl”, el tercero de la dinastía, tuvo una adecuada vida de guerrero, conquistando varios poblados, y entre ellos Poctla (lugar del humo o de la neblina), es decir, Putla.

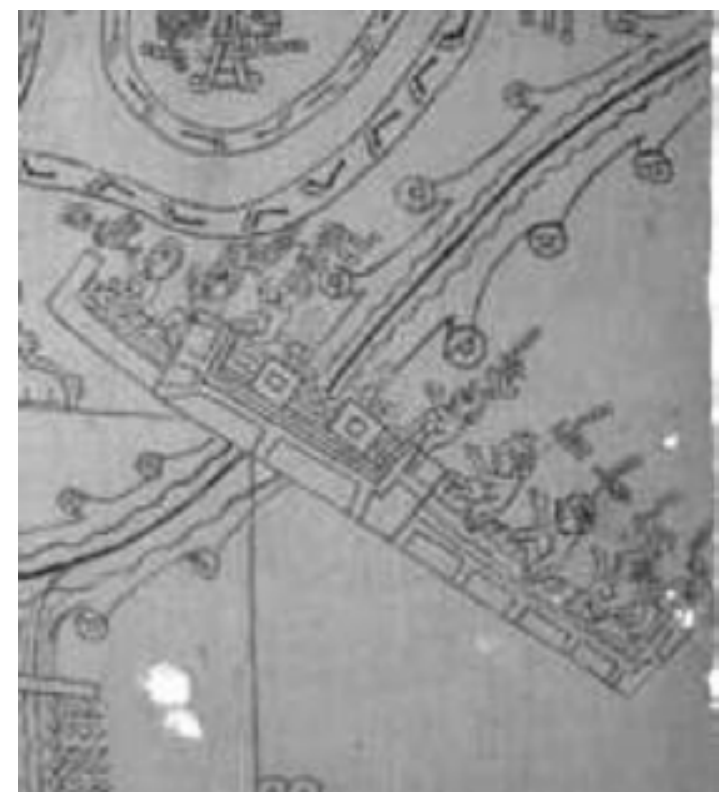

Procesión de personajes visitantes. Lienzo de Zacatepec 2. (Foto:INAH) 
El Lienzo consigna que Zacatepec fue fundado en otro lugar, posiblemente entre los ríos Atoyaquillo y Reforma y plantea que a resultas de la acción de una gran águila bicéfala (de dos cabezas) que causaba daños a las familias, los tacuates se dividieron en los dos grupos hoy conocidos. Tomando en cuenta que el águila real mexicana no existe en esa región, y el símbolo del águila bicéfala corresponde a la Casa Real Española de los Austrias, ese mito indica la posesión española poco después de la conquista, cuando sucesivamente Carlos V y su hijo Felipe II, importantes miembros de la Casa de Austria, eran Reyes de España. Además, en los recuerdos de la tradición oral figura el hecho de que los conquistadores aztecas estaban jefaturados por guerreros de la cofradía Caballero Águila, los que obviamente sujetaron y mataron dejando una impresión terrorífica.

El grupo de Zacatepec, que resultó en su actual ubicación, tuvo un mayor desarrollo económico, lo que lo volvió codiciable. Por ello hacia 1288 fue atacado por gente de Tilantongo, perdiendo territorio, y luego por la de Atoyaquillo, la que en 1333 le causó grandes pérdidas en vidas humanas, para luego realizarse una unión. En esas condiciones recibieron hacia 1463 la invasión azteca, que no ocupó ni substituyó, pero que impuso una red tributaria y dejó guarniciones que con la conquista española no fueron retiradas ni exterminadas. Esa es la razón por la que en esa zona quedaron pequeñas poblaciones hablando náhuatl.

El eje central de la conquista española en esa región fue la ocupación de Tututepec por Pedro de Alvarado en 1523, el cual se impuso al Principal. đ̊ Usia andoo (7 Caña) con extremas crueldad y codicia y con su total nulificación. Poco después, esa zona densamente poblada comenzó a perder gente debido a una serie de cuatro epidemias, entre las que estuvieron las de viruela de 1534 y la de sarampión de 1544. A partir de 1522 ya existieron encomiendas en esa región, siendo la primera la de Pedro de Alvarado, seguida por la de Zacatepec, la cual fue adjudicada en 1533 al Corregidor de Tututepec, y años después al conquistador Rafael de Trejo. Ya para 1550 se había extendido la catequización, iniciada en 1519 y realizada por frailes dominicos, al comienzo por Fray Benito Fernández y continuada principalmente por Fray Diego de Monroy. Sin embargo, en ambas poblaciones, las iglesias no quedaron establecidas en su forma y tamaño actuales, sino hasta el Siglo XVIII, mientras que en 1550 el área de Zacatepec tenía 550 tributarios, los cuales aportaban, según la Suma de Visitas, 30 pesos oro, 115 piezas de ropa (enaguas y camisas), una carga de miel cada 80 días y la labor de 34 indios. Los tributarios y el tributo se habían reducido en 1579 a cerca de la mitad. Para entonces el encomendero era Rafael de Trejo Carvajal, hijo del funcionario Rafael de Trejo, dotado desde 1536, y la región era gobernada por un Corregidor, el cual se auxiliaba con Principales indígenas. Por ello en Zacatepec gran parte del Siglo XVI gobernó Cuetzpallintzin, (uno lagartija) uno de los hijos de Usia andoo ô (7 caña), llamado en español Alonso de Castilla y Alvarado.

Hacia el año de 1600, ya con el establecimiento de "haciendas volantes" de ganado cabrío, los pobladores regionales de habla náhuatl aumentaron al iniciarse el traslado (arreado) de los rebaños que se comenzaron a llevar al área poblana (Tehuacán) para su matanza y beneficio. 
Durante el Siglo XIX hubo tacuates formando parte de las tropas realista e independiente, de estas últimas principalmente de las de Dn. Miguel Bravo, y en la Guerra de Reforma un Principal de la etnia, Lorenzo Cruz Rivera "Tata Lencho", adquirió especial relevancia como amigo, protector y colaborador del entonces muy joven militar liberal y republicano Porfirio Díaz Mori, a quien auxilió en los días del combate de Ixcapa (1857) salvándole la vida, mediante un aviso, y coadyuvando a su reposo y parcial recuperación, en un momento particularmente difícil. "Tata Lencho" llegó a ser tratado como compadre por Díaz, de tal suerte que logró llegar a ser económicamente muy poderoso, al grado de que pudo obsequiar, varias veces, a Díaz, ya siendo presidente, un ciento de cabezas de ganado de un mismo color.

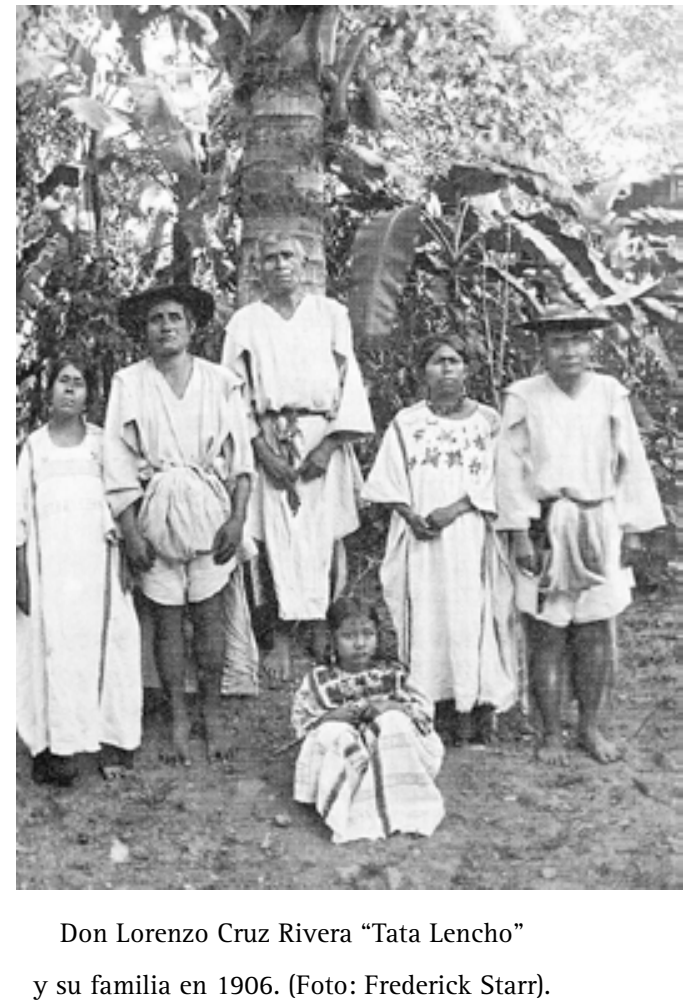

Los pastos de la zona ocupada por la etnia han sido siempre codiciados. A partir de la muerte de Dn. Lorenzo varios ganaderos españoles y mestizos de Putla han venido invadiendo esos terrenos, válidos de las Leyes de Reforma, con el subterfugio de considerarlos terrenos baldíos. En el Siglo XX, durante la Revolución Mexicana, la zona estuvo controlada por la brigada constitucionalista "Plan de Guadalupe", mandada por el General Juan José Baños, y sólo hubo pequeños combates contra fuerzas de la Soberanía Oaxaqueña (zapatistas jefaturados por el Gral. Fidel Baños, sobrino de Dn. Juan José)), en los que hubo pocas bajas entre los contendientes. Después hubo alternancia entre la defensa de sus tierras comunales (los tacuates unidos a los agraristas), y el acoso de personajes externos que han llegado, incluso, a promover el asesinato a sueldo. Esta situación se ha acrecentado al 
grado de que el grupo está limitado a las poblaciones mencionadas y ha perdido casi todas sus tierras, mientras que, jurídicamente, las tierras siguen siendo comunales, aún pese a la reforma salinista de 1988. Hoy los tacuates siguen luchando por conservar tradiciones, cultura, dignidad e historia, y lo hacen denodadamente.

DEMOGRAFIA. De acuerdo al Censo de Población y Vivienda del 2010, la población tacuate, incluyendo la mestizada con mixtecos, asciende a poco menos de 7000 personas, de las que alrededor de 3500 hablan el idioma. Este dato señala que ya existe una fuerte emigración.
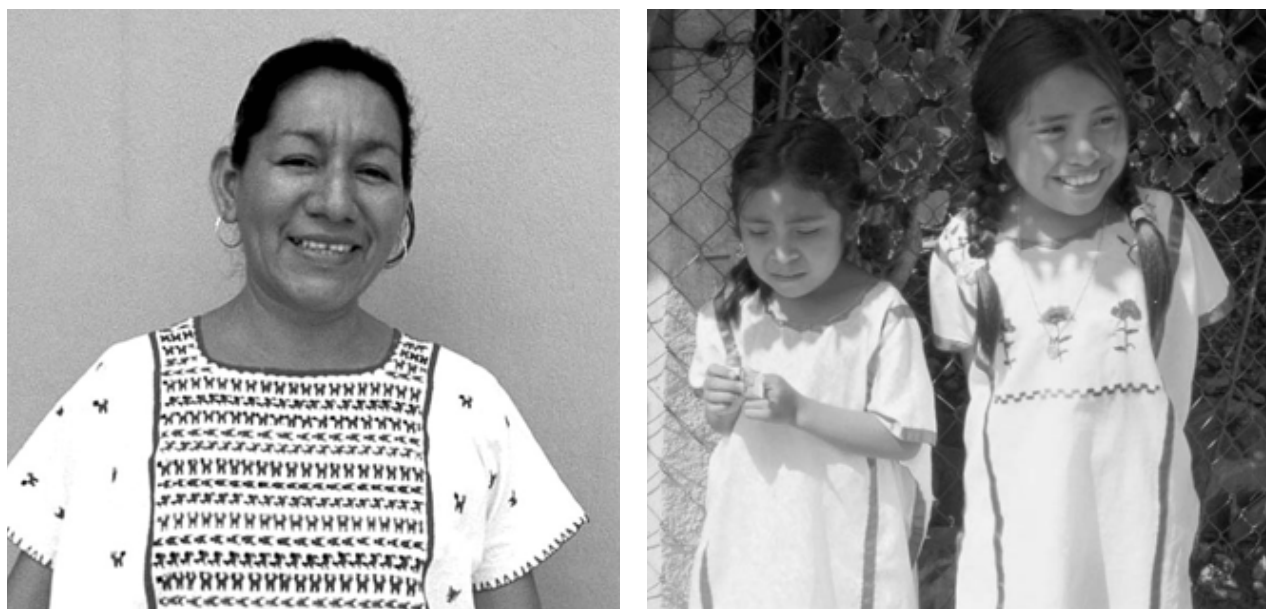

Mujer y niñas tacuates. (Fotos: CDI)
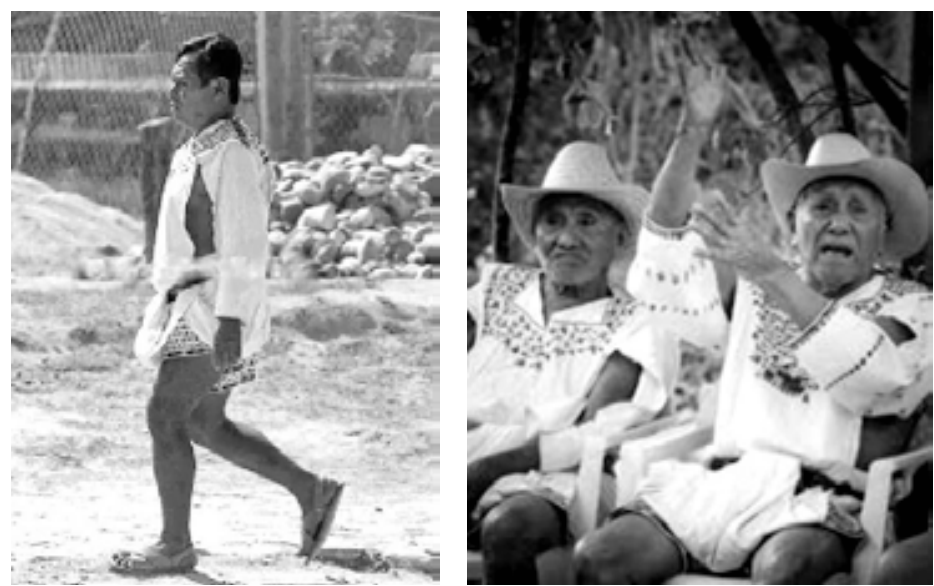

Hombre y autoridades tacuates. (Fotos: Eliseo Bravo y CDI)

ACCESOS. Santa María Zacatepec se encuentra sobre la carretera federal $N^{\circ} 125$, entre Putla y San Juan Cacahuatepec. Santiago Ixtayutla se comunica con Santiago Jamiltepec por un camino de terracería que se continúa hasta Santiago Yosondúa. Salvo la carretera federal $N^{0} 125$, todos los caminos son de terracería, en ocasiones revestida. 


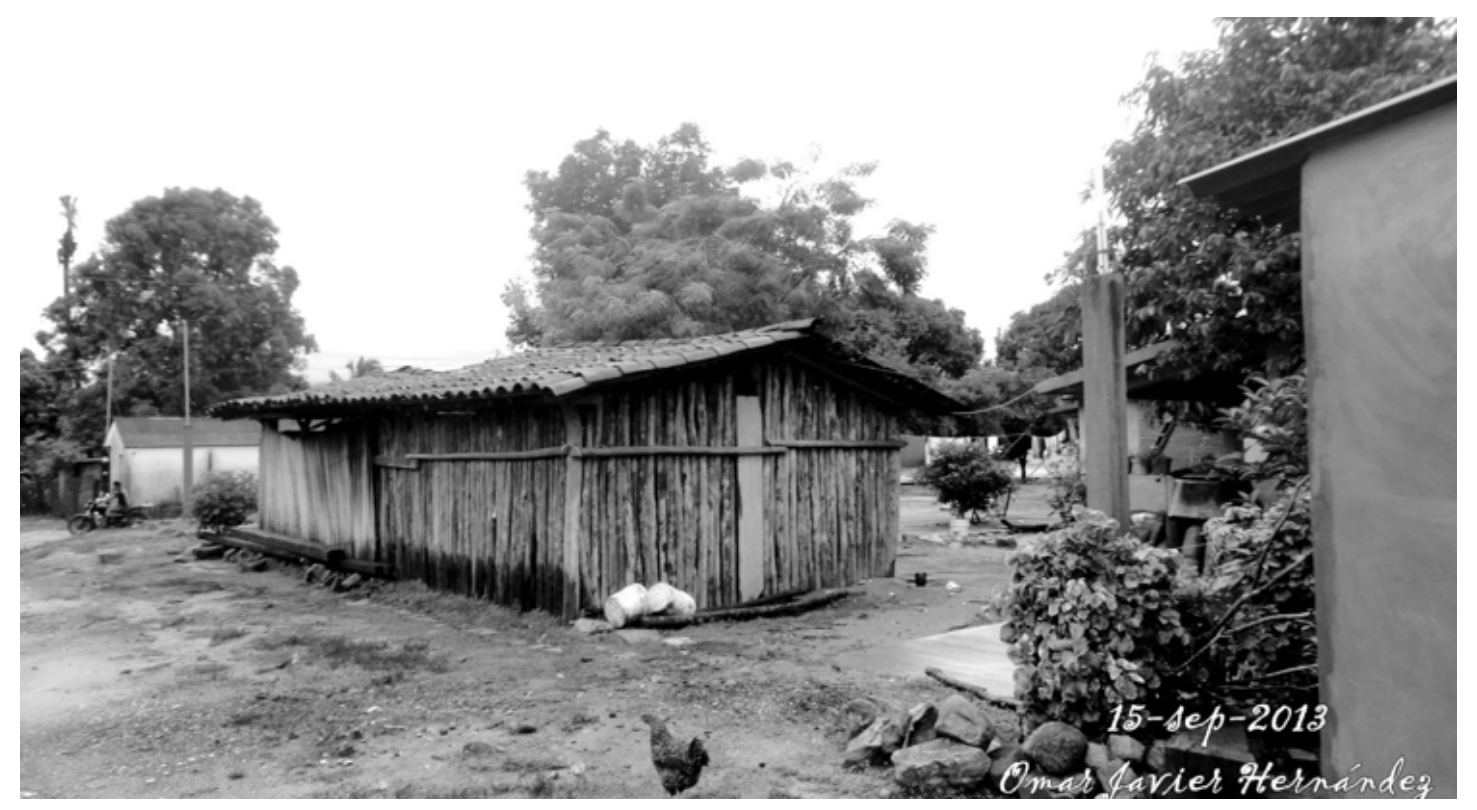

Casa tacuate. (Foto: Omar Javier Hernández).

VIVIENDA. Por encontrarse el grupo inmerso en una de las regiones mixtecas, no existe una diferencia sensible entre la casa tacuate y la mixteca. Lo que no existe en la casa tacuate son las grandes ollas que se colocan en las esquinas del vértice del techo, y ello revela la mutua independencia. El menaje fue prácticamente el mismo que en las familias amuzgas o mixtecas, el fogón con su soporte de piedras y lodo, la mesa de madera y la cama con emparrillado de carrizo o ramas rectas. Con las remesas de los emigrados ahora se hacen construcciones de material y se adquieren mesas más elaboradas, así como electrodomésticos, incluyendo el principal factor que provocará pérdida de identidad, las televisiones.

INDUMENTARIA. La indumentaria tacuate es muy característica y en alto grado de sigue usando. En Ixtayutla el hombre viste calzones de algodón blanco y un metro de largo, con una franja de dibujos entretejidos que representan la estilización del bule. La camisa es de algodón blanco con mangas semi-largas. Usan huaraches de cuero con suela de llanta sujeta con tiras de cuero de res. El atuendo de las mujeres incluye enredo, bandas un cinturón de petate y una faja azul. Un paño de algodón tejido en la comunidad, doblado en la espalda complementa el tapado e integra el huipil.

Ahora las mujeres usan calzado o sandalias de plástico. Con suma frecuencia la ropa tiene bordados fito y zoomorfos que tienen significados.

ECONOMÍA. Le economía tacuate es de subsistencia, basada en el maíz, el frijol, la calabaza y el chile, con algunos árboles y plantas de mango, tamarindo chirimoya, papause y plátano. Todo ello se complementa con pastoreo de ganado cabrío y vacuno y, desde hace algún tiempo, con la elaboración de los textiles ya descritos, los cuales a su venta repre- 

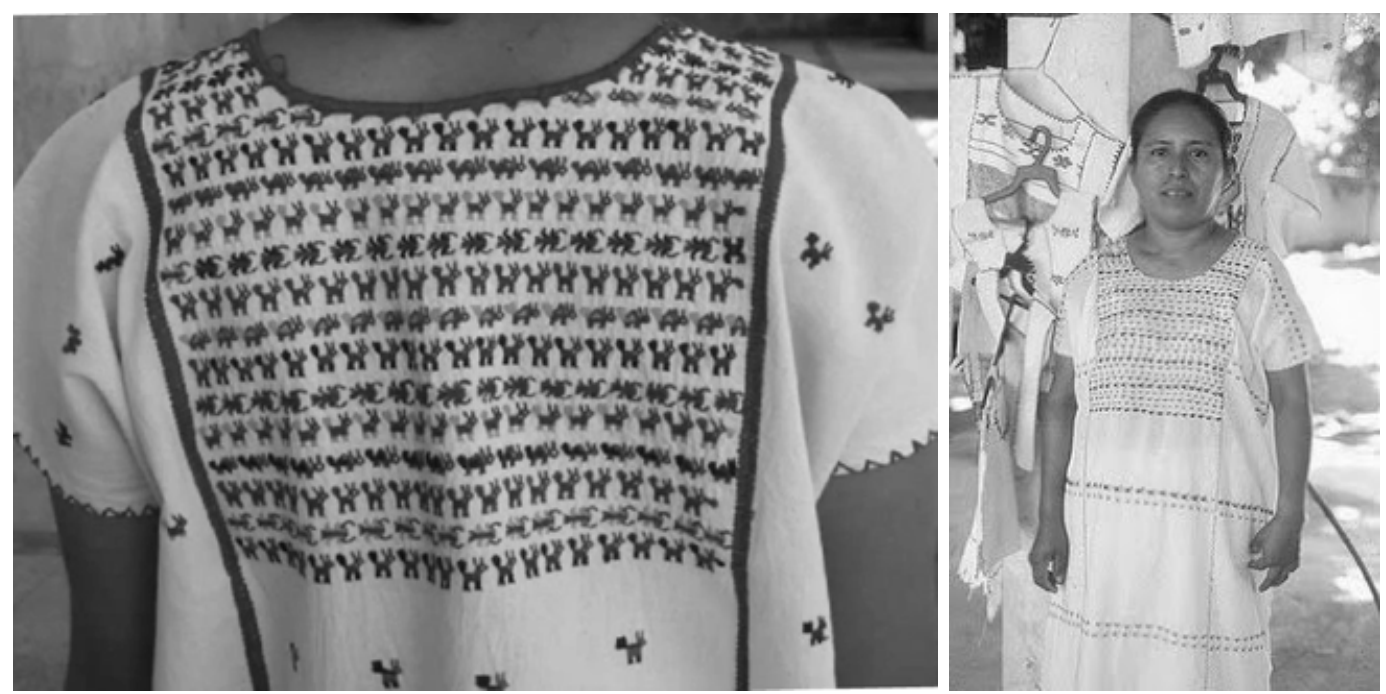

Huipiles. (Fotos: Eliseo Bravo y Antonio Torres Rodríguez).

sentan un refuerzo a los ingresos. Dicha economía no puede ser tratada en términos de costo-beneficio, puesto que en sus transacciones comerciales, los indígenas llevan la peor parte por los bajos precios con que sus productos son pagados. Además de guisos locales, en el grupo se consumen las chicatanas.

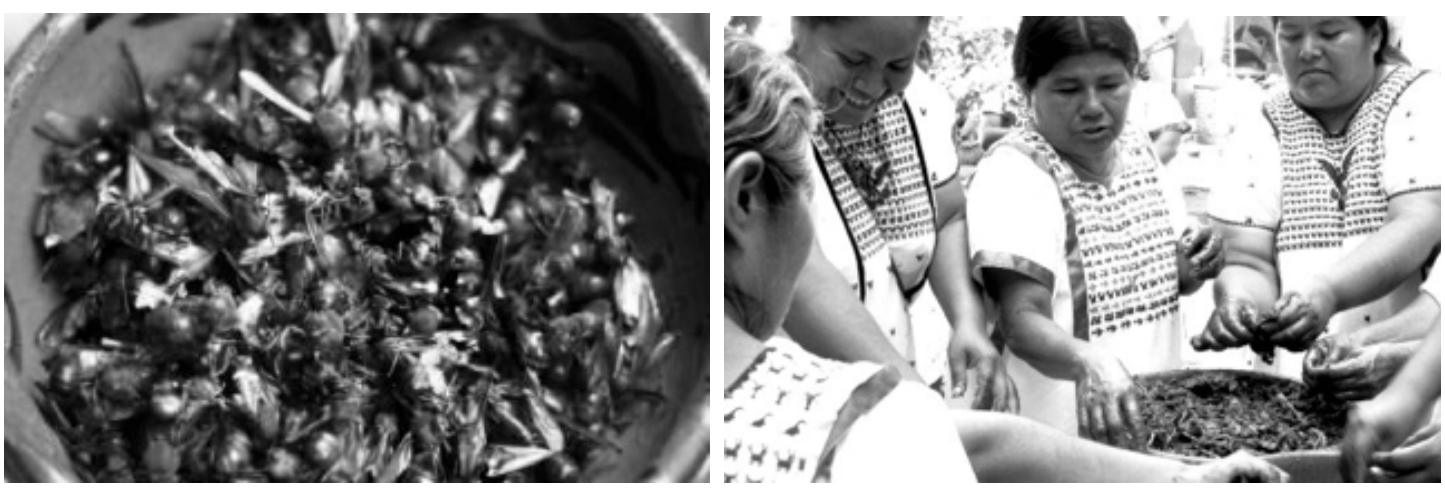

Chicatanas y mujeres preparando la salsa. (Fotos: Deni Álvarez y Antropóloga Carmen Castillo Cisneros).

CAZA Y PESCA. Por sus condiciones geográficas la región es rica en fauna neo tropical, habiendo por tanto tigrillo, ocelote, pecarí, oso hormiguero, zorra gris, venado cola blanca, conejo rabo de algodón, tejón solitario o mapache, tejón de manada, puerco espín, zorrillo y muchas otras especies. Además, recibe fauna migratoria, particularmente aves. Por estar en zona de poca contaminación los ríos contienen una ictiofauna de importancia, existiendo cangrejos, langostinos (chacales), bagres y mojarras, todo lo cual es poco pescado por miembros del grupo.

MERCADOS. Tanto Zacatepec como Ixtayutla tienen sus días de mercado. En Zacatepec el mercado es permanente. Subsiste el trueque, sobre todo entre población depauperada. 
ARTESANIAS. La principal es el tejido, que todavía se elabora en telar de cintura.

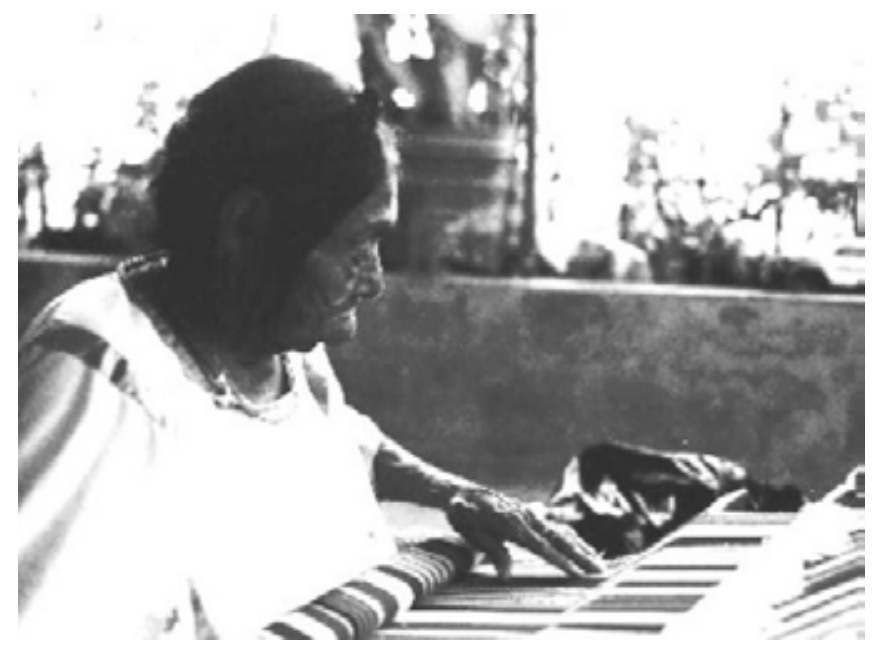

Tejedora en telar de cintura. (Foto: Antropóloga Carmen Castillo Cisneros).

ORGANIZACIÓN SOCIAL. La familia es patrilocal, patrilineal y compacta, pero la mujer tiene importancia en la toma de algunas decisiones. El matrimonio establece un vínculo social muy importante entre dos familias. El acto hace surgir una relación estrecha y de ayuda mutua que ambas familias deben cumplir. En el grupo ha sido tradicional la elección de la novia, las visitas a la casa de sus padres, el pedimento (o dar el sí), la preparación de los alimentos, la elección de los padrinos y la fiesta de bodas. Todo ello, como en muchos grupos de nuestro país conlleva un ritual. En el grupo, el compadrazgo adquirido por bautizo o boda significa una serie de alianzas encaminadas a hacer posible la supervivencia, aún en situaciones difíciles, dándose casos de actos de este tipo realizados entre mestizos e indígenas.
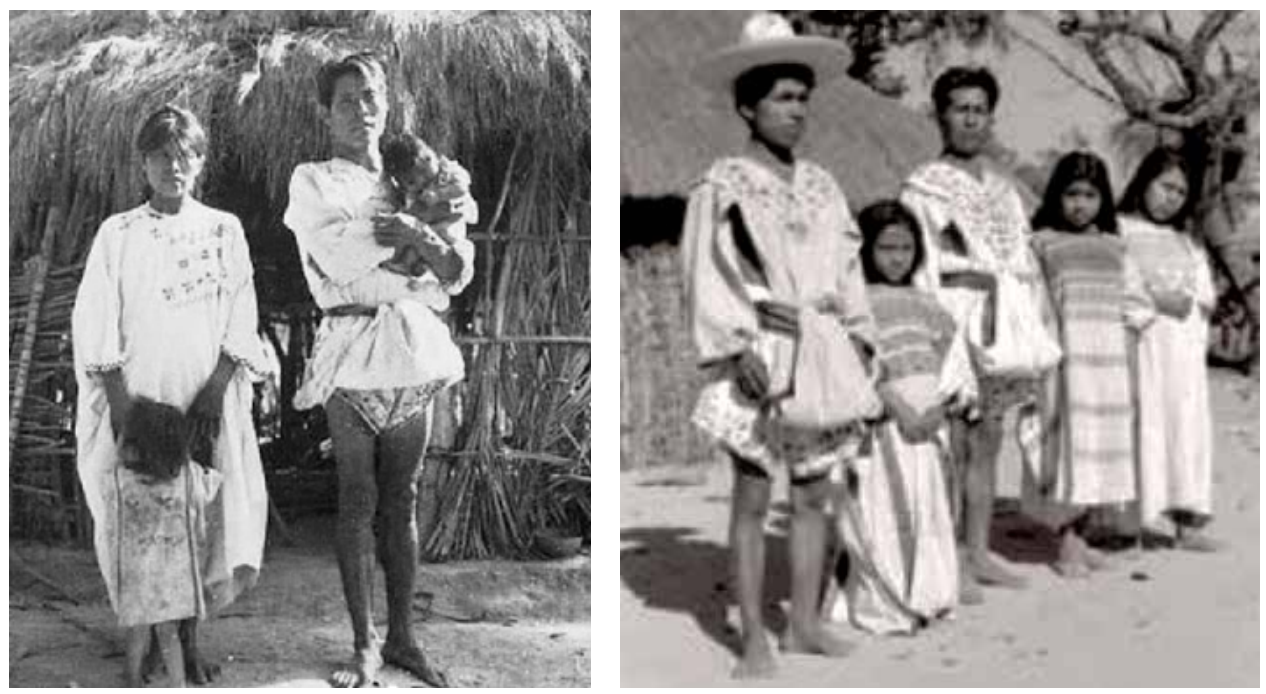

Familias Tacuates. Fotos: Eliseo Bravo). 
El grupo presenta también el hermanazgo de pila, entre los bautizados y los hijos de sus padrinos. Hay además compadrazgos con un origen ritual, que abarcan aspectos como la bendición y el aportar bienes en especie (música o vestidos, por ejemplo).

GOBIERNO. Además del gobierno municipal, en la etnia existió un autogobierno, y de ello da fé la relación que tuvo uno de sus Principales, Don Lorenzo Salazar Cruz, "Tata Lencho" con el presidente de la república en la época porfirista. Actualmente, y en razón de coexistir con mixtecos y amuzgos en esa región, están sujetos a las condiciones políticas imperantes.
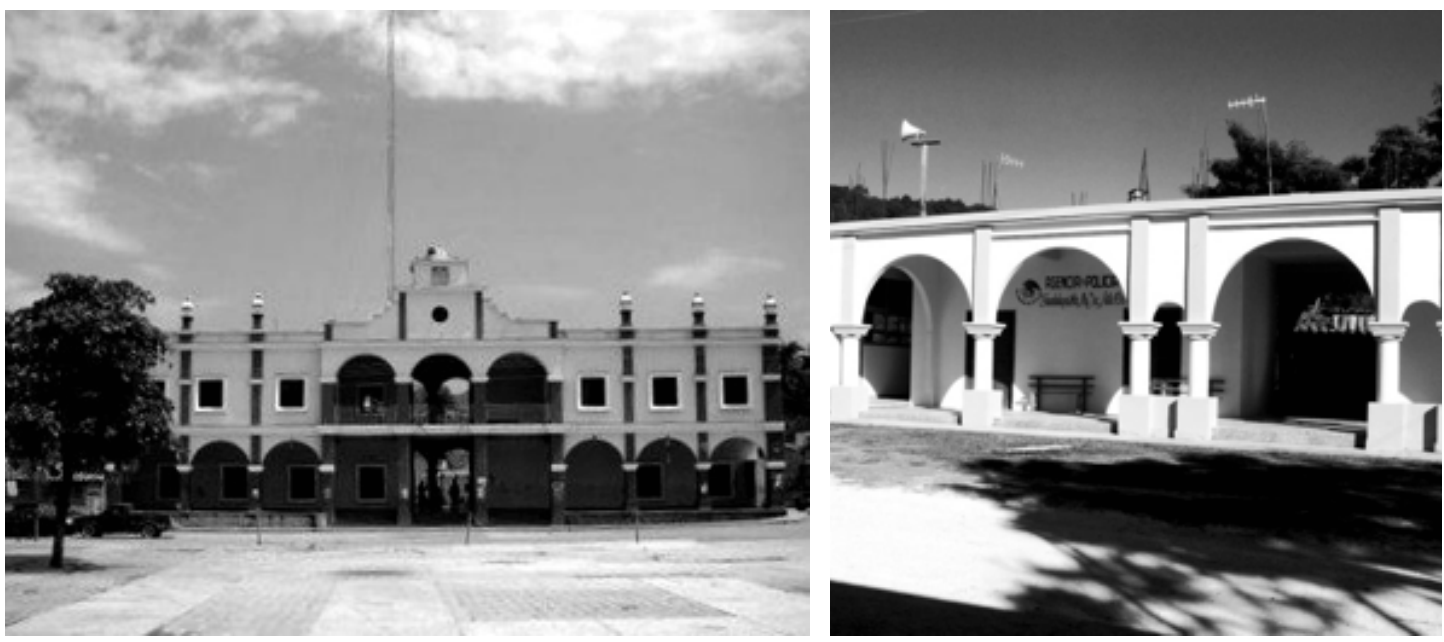

Palacios Municipal de Santa María Zacatepec y de la Agencia Municipal de Guadalupe, Zacatepec. (Fotos: Sheila Clarke y

Tierras Medievales).

FESTIVIDADES. Cada población celebra su fiesta patronal. En ella hay fuegos artificiales, música, comida y bebida. Otras fiestas son las de Todos Santos y la Vírgen de Guadalupe.

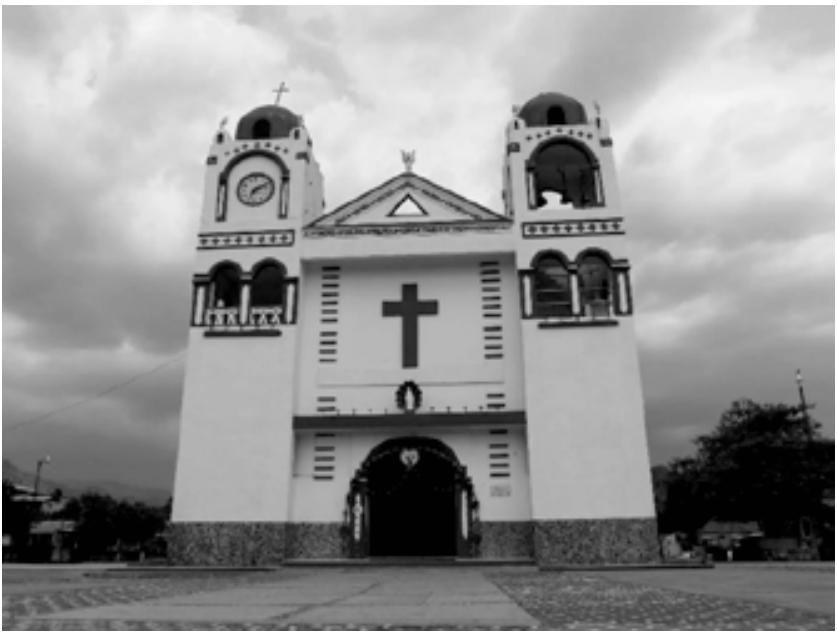

Iglesia de Atotonilco, Zacatepec. (Foto: Ayuntamiento de Zacatepec). 
ORGANIZACION RELIGIOSA. Los tacuates mantienen algunas de sus ancestrales creencias, todo dentro del catolicismo, y así se mantiene el creer en el Señor del Cerro, el Amo de los Animales y las deidades de la lluvia y el viento. En el culto católico existe la mayordomía, en la que el titular y el sacristán jefaturan el desempeño y la festividad, ya que la realización debe ser colectiva en función de su costo.

MEDICINA Y MAGIA. Las enfermedades han sido siempre atribuidas a causas sobrenaturales, tales como el susto o la pérdida del alma. Existen brujos en las comunidades, quienes utilizan yerbas medicinales, sortilegios y baños de temazcal.

EDUCACIÓN. Existen jardines de niños, escuelas primarias y un CECYTE en Zacatepec. Para acceder a niveles superiores, los jóvenes del grupo se desplazan la población de Putla de Guerrero, o bien a Santiago Pinotepa Nacional.

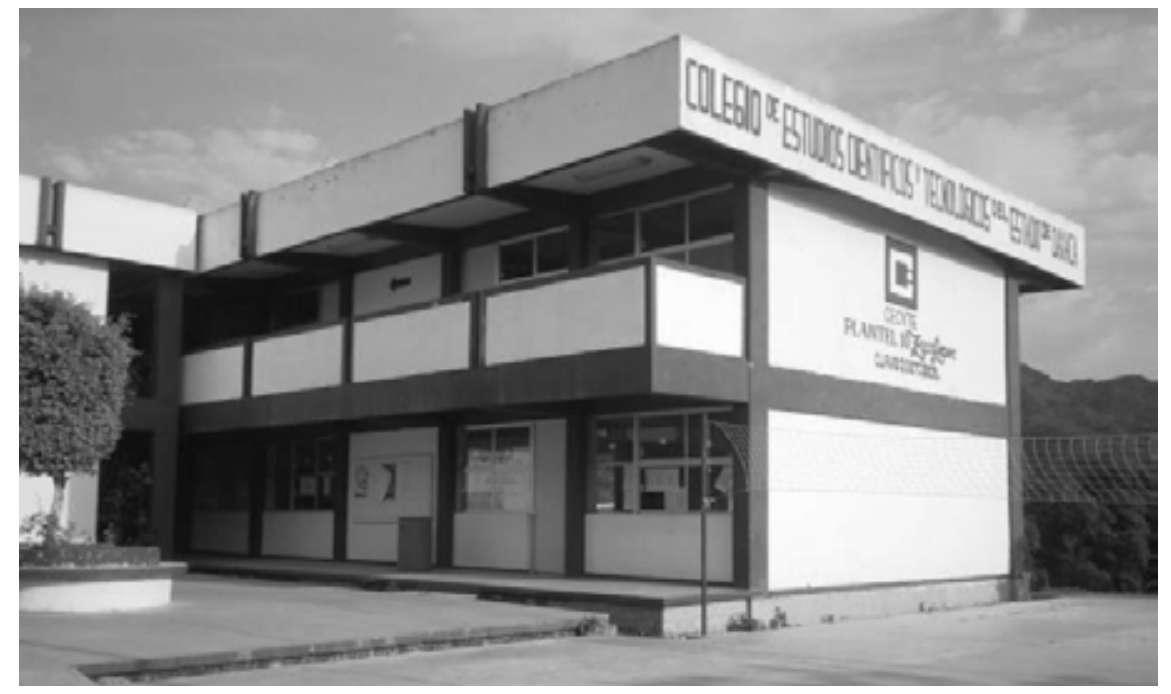

CECYTE. Santa María Zacatepec. (Foto: Ayuntamiento)

\section{BIBLIOGRAFÍA}

Burgoa Francisco de. (Fray). 1989 GEOGRAFICA DESCRIPCION DEL POLO ARTICO E INDIAS OCCIDENTALES... Editorial Porrúa. México, D F. 1989.

Caso Andrade, Alfonso. 1979 REYES Y REINOS DE LA MIXTECA. 2 Vols. Fondo de Cultura Económica. México, D F. 1979.

Castillo Cisneros, María del Carmen. 2004 TACUATES. Comisión Nacional para el Desarrollo de los Pueblos Indígenas. México, D F. 2004.

Cordero Avendaño de Durand. Carmen. 1992 EL COMBATE DE LAS LUCES: LOS TACUATES. Museo de Arte Prehispánico "Rufıno Tamayo" y Biblioteca Pública de Oaxaca. Oaxaca, Oax. 1992. 
Esparza Camargo, Manuel. 1985 GILLOW DURANTE EL PORFIRIATO Y LA REVOLUCION EN OAXACA. Archivo General del Estado de Oaxaca. Oaxaca, Oax. 1985.

Gay, José Antonio. 1950 HISTORIA DE OAXACA. Vols. I y II. Ed: Jacobo Dalevuelta. Talleres Venero. México, D F. 1950.

Gerhrard, Peter. 1986 GEOGRAFIA HISTORICA DE LA NUEVA ESPAÑA. 1519-1821. Instituto de Geografía. UNAM. 1986.

Jansen, Maarten, Pérez Jiménez, Gabina Aurora. 1986 "Iyadzehe Añute. Valor Literario de los Códices Mixtecos”. En: ETNICIDAD Y PLURALISMO. LA DINAMICA ETNICA EN OAXACA. Miguel Bartolomé y Alicia Barabas. Eds. INAH. México, D F. 1986.

Marroquín Zaleta. Enrique. 1993 HISTORIA TACUATE. Serie Historias Étnicas. № 6. INAH. FONCA. IISUABJO. Oаxaca, Oax. 1993.

Martínez Gracida, Manuel. 1883 CUADROS SINOPTICOS DE LOS PUEBLOS. HACIENDAS Y RANCHOS DEL ESTADO DE OAXACA. Oахаса, Oax. 1883. 1907 HISTORIA DEL ANTIGUO REINO DE TUTUTEPEC. Tomos 31 y 32. Libro IV. Documentos inéditos de la Colección de Dn. Manuel Martínez Gracida Sala de Autores Oaxaqueños. Biblioteca Pública Estatal. Oaxaca, Oax. 1907.

Paso y Troncoso, Francisco del. 1905 PAPELES DE NUEVA ESPAÑA. Vol. IV Relaciones Geográficas del Siglo XVI. Imprenta de Sucesores de Rivadeneira. Madrid, España. 1905.

Smith, Mary Elizabeth. 1973 PICTURE WRITING FROM ANCIENT SOUTHERN MEXICO. MIXTEC PLACES, SIGNS AND MAPS. University of Oklahoma Press. Tulsa, Okl. 1973. Tibon, Gutierre. 1981 PINOTEPA NACONAL. MIXTECOS, NEGROS Y TRIQUIS. Editorial Posada. México. D F. 1981. 



\section{MAZATECOS}

Autodenominación: ha shuta enima, chjota enna, ennda.

Sinónimo en su lengua: chota te. Ho

Significado: Gente de nuestra lengua Los que trabajamos el monte. Los Humildes. La Gente del Venado.

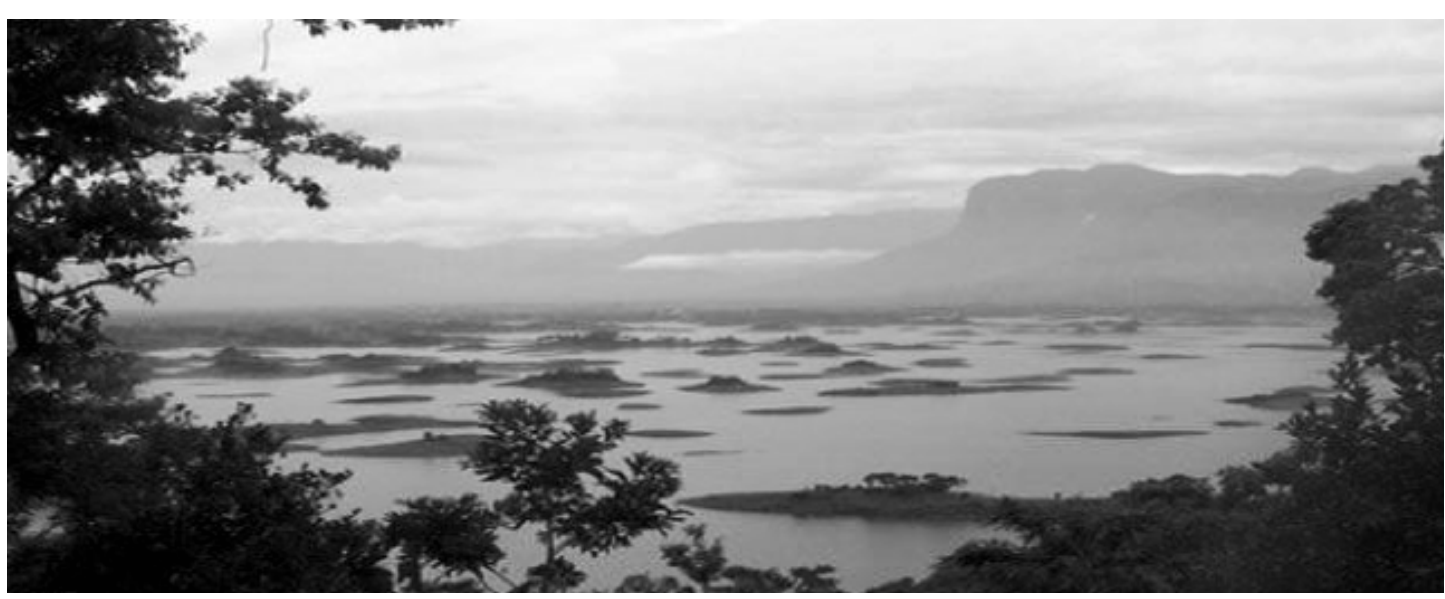

Presa Miguel Alemán o de las Cien Islas. (Foto: Dir. Turismo Estatal)

\section{GRUPO MAZATECO}

UBICACIÓN GEOGRÁFICA. La población Mazateca se encuentra localizada en la porción norte del estado, ocupando la sección de la Sierra Madre Oriental colindante con la presa Miguel Alemán, ya muy cerca del Estado de Veracruz. El grupo tiene presencia en 35 municipios de dos zonas: Alta y Baja.

Su área ocupacional se inscribe entre los $18^{\circ} 15^{\prime}$ y $18^{\circ} 30^{\prime}$ de latitud Norte y los $96^{\circ} \mathrm{y}$ $96^{\circ} 35^{\prime}$ de longitud Occidental. El territorio es de relieve muy accidentado y esa topografía irregular origina una gran diversidad de climas y, como consecuencia, de flora y fauna sumamente ricas y variadas, En la porción oriental, los lomeríos bajos se encuentran a menos de 500 metros sobre el nivel del mar y en la Sierra Mazateca, que es parte de la Sierra Madre de Oaxaca, alcanza alturas ligeramente superiores a los 2 600. Los escurrimientos de estas montañas, son las corrientes fluviales que delimitan el área por el occidente, el norte y el sur. Prácticamente casi todo el territorio ocupado por este grupo queda inscrito dentro de la Cuenca del Río Papaloapan. 

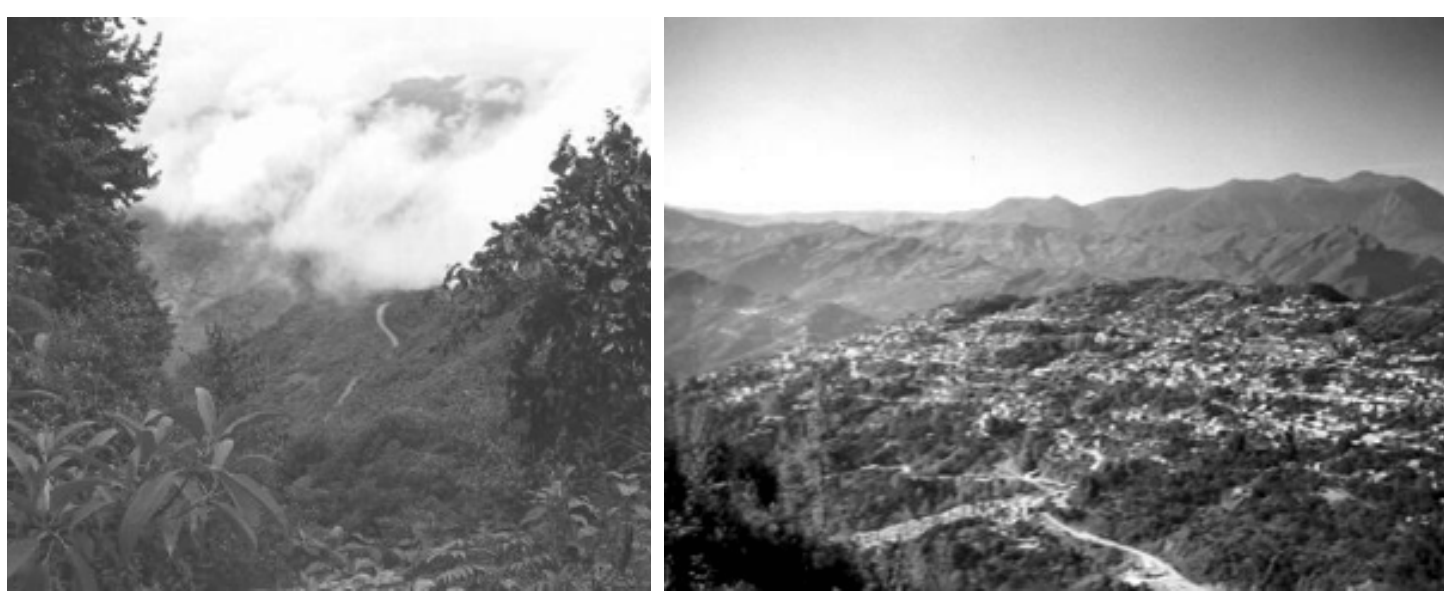

Bosque de niebla mazateco y Paisaje de Huautla de Jiménez. (Foto: UNAM y Dir. De Turismo Gbno. Del Estado de Oaxaca).

En la parte alta de la región, donde está el Cerro de la Adoración, o Nindo Chichon Tokosho, que presenta cuevas, los climas son templados subhúmedos con lluvias en verano, y la cubierta vegetal consiste en bosques de coníferas que lamentablemente están en proceso de destrucción. En esas zonas se dan también las temperaturas más frías del área, que todavía no rebasan el promedio anual de $15^{\circ} \mathrm{C}$. En zonas de altura intermedia, donde se encuentra el Cerro Rabón, otra montaña sagrada (en ella viven los dioses de la lluvia y el trueno), la cubierta vegetal ha ido cambiando de los bosques de confieras con predominio del encino y pino, al chaparral medio caducifolio que en ciertas zonas contiene ya una amplia variedad de vegetación xerofítica. Los suelos de la región suelen ser gumíferos y de color negro, o bien rojizos muy oxidados, y en general son muy delgados existiendo solo en las altas montañas capas de regular profundidad. El régimen de precipitación pluvial varía según las vertientes, existiendo una mayor cantidad (1 200 a 1400 milímetros) en la porción oriental del área.
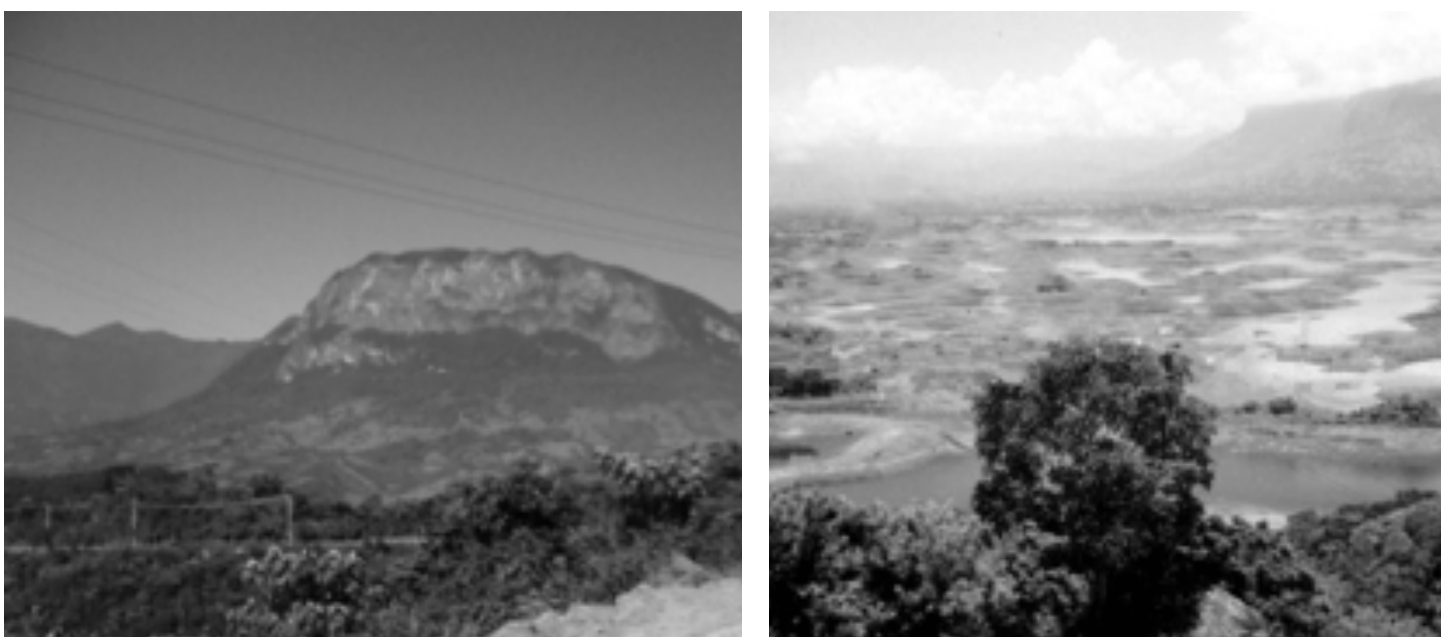

Cerro pelón y presa de temazcal o de las cien islas desde el Municipio de San Pedro Ixcatlán.(Fotos: UNAM) 
En la occidental la nubosidad es muy inferior y hay puntos donde la precipitación pluvial llega a ser inferior a los 500 milímetros anuales. La Sierra Mazateca, junto con su vecina veracruzana de Zongolica, se caracteriza, además, por la gran concentración de cuevas y oquedades que presenta, con galerías subterráneas que alcanzan varios kilómetros de longitud. En la zona el término "nita” designa a las oquedades o cavernas.

IDIOMA. La Lengua Mazateca pertenece al Grupo Otomangue, Tronco Savizaa, Familia Mazateca, y en la actualidad es hablada por aproximadamente ciento setenta mil (170 000) personas. Es una lengua profundamente emparentada con el Chocho, el Popoloca y el Ixcateco, y en menor grado con el mixteco, con el cual debió tener relaciones muy estrechas hace más de 2000 años. Además, es característico del grupo un lenguaje de chiflidos, absolutamente funcional y de enorme importancia cultural.

ANTECEDENTES ARQUEOLÓGICOS E HISTÓRICOS. No obstante que el área ocupada por el grupo contiene gran cantidad de vestigios arqueológicos, las exploraciones sistemáticas han sido muy pocas y circunscritas a la Cuenca Baja del Río Salado, a contados puntos en lo alto de las montañas y a no más de dos cuevas. La proximidad de la porción occidental con el valle de Tehuacán revela utilaje lítico del primer período de cazadores-recolectores que se extendió los primeros 7000 años, Después la sierra mazateca presentó varias pequeñas aldeas y, poco mas tarde, hacia el $800 \mathrm{aC}$, algunos asentamientos de mayor tamaño. Un muestreo en Soyaltepec reveló una aldea nucleada con cerámica y figurillas olmecas del período aproximado a los 500 a C, en plena Etapa de las Aldeas, y una Cueva de San José Tenango contuvo un interesante material del Período Militarista o Postclásico, que incluyó muchas vasijas cerradamente emparentadas con tipos mixtecos y algunas con el tipo "tres picos" de la costa veracruzana. Todavía desconocemos con exactitud las razones históricas mediante las cuales el grupo mazateco quedó marginado en la región que actualmente se encuentra. Sin embargo su importancia en varios períodos de la historia prehispánica en el Estado es muy grande. Mantuvo relaciones muy estrechas con gran parte de los grupos mesoamericanos, principalmente con los chocho-mixtecos, registrándose influencia (registrada históricamente) de un grupo nonoalca y en su territorio tuvieron lugar varias importantes aportaciones culturales. Durante el período posclásico o militarista tuvo relevancia política y económica, de la que dan fé varias fuentes históricas, así como fuertes contactos, con los popolocas y con grupos del centro y occidente de Veracruz. De hecho, coexistió con los mixtecos hasta el grado de permitir su paso hacia la porción baja de media altura central de Veracruz, lo que se conoce como "La Mixtequilla". Subsiste una población de origen mixteco inmersa en su territorio, San Juan Coatzospan y una colonia de ese origen en Huautla de Jiménez. 


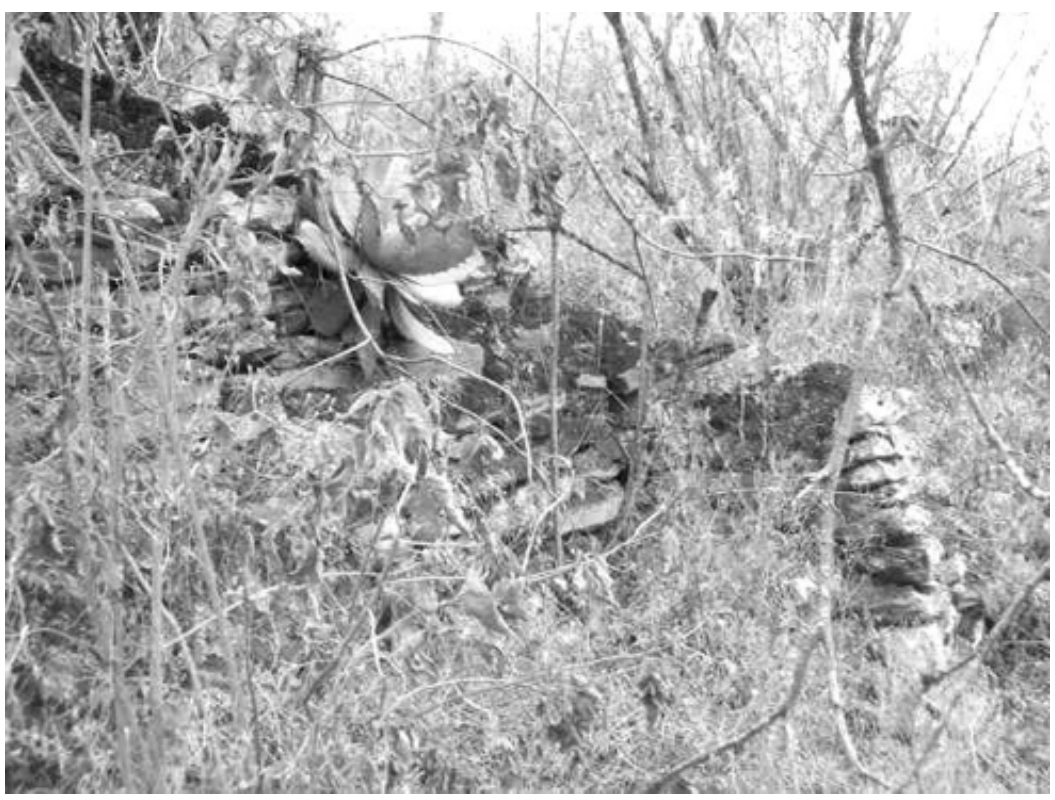

Zona arqueológica de Tepeuxila. (Foto:UNAM).

De la porción de la cuenca del Río Salado, colindante con del Valle de Tehuacán, se tiene un pilar estratigráfico casi completo, predominando principalmente datos de los períodos Clásico Tardío y Postclásico. Por estos estudios se saben las similitudes etnográficas que unen a los Mazatecos con los Chochos, Ixcatecos, Popolocas y Mixtecos. Durante el período postclásico la región fueron dos Principalatos independientes de influencia olmeca-xicalanca que se establecieron en las partes alta y baja, y que tuvieron dinastías de hasta seis y nueve Principales sucesivos. Al fin del período la mazateca (con un importante asentamiento en Matza-Apatl, situado cerca de Jalapa de Díaz), fue conquistada por el Imperio Azteca en 1455 a través de los culhuas, y convertido en tributario por ser ruta comercial de paso hacia las regiones del sureste del país y los Valles Centrales de Oaxaca, por la que pasaba parte de la tributación que se recogía en la región de Coixtlahuaca y que, en una fase tardía, hacia el año de $1500 \mathrm{dC}$, provino de la ruta de Xaltepc Candayo, con origen en Xicalanco. Al sobrevenir la conquista, el grupo mazateco fue uno de los primeros en quedar sujeto a los regímenes tributarios de la colonia, pero rápidamente sufrió una merma-poblacional debido a que fue uno de los grupos que recibieron enfermedades epidémicas tales como el sarampión, la viruela y el tifo, al grado de que al terminar el Siglo XVI la población se había reducido a menos de 5000 personas.

La catequización de estas etnias se atribuye a uno de los primeros franciscanos que llegaron a Nueva España, Fray Martín de Valencia. Este estableció su primera misión en Teotitlán (hoy del Camino), y más tarde, al llegar frailes predicadores, gestionó su transferencia a Villa Alta. Sin embargo el grupo mazateco ha seguido practicando sus ritos y ceremonias en cuevas prácticamente hasta la actualidad, y a ello ha contribuido que en su territorio se encuentra una de las mayores concentraciones de oquedades, cuevas y cavernas de todo el continente americano. 


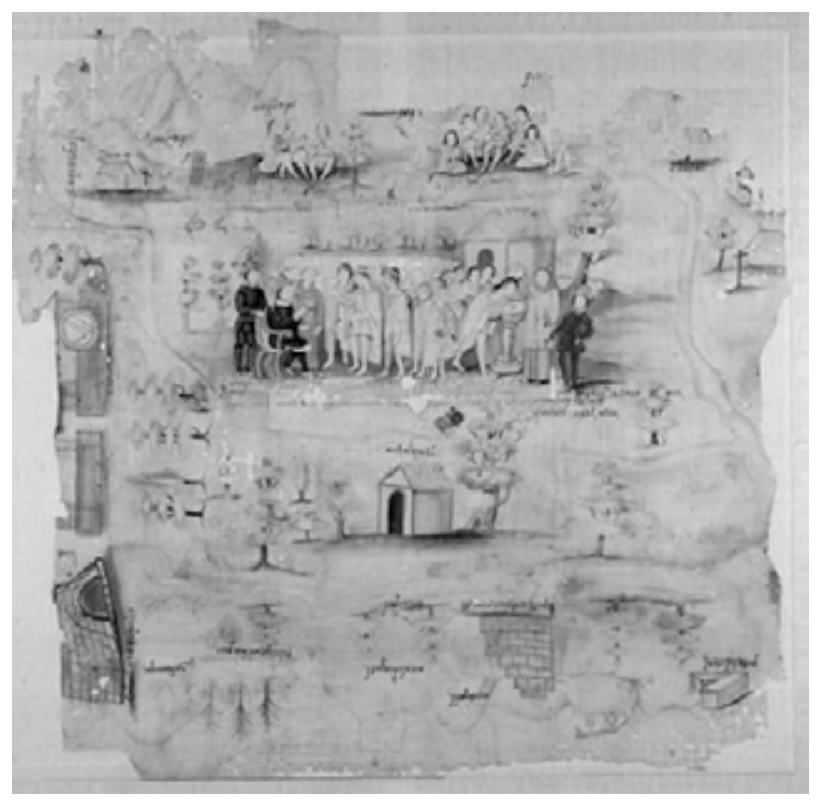

Lienzo mazateco de San Pedro Ixcatlán. (Foto: Robert Garrett )

Hacia 1531 los pueblos mazatecos ya estaban sujetos a Encomenderos, Corregidores y a la Primera Real Audiencia, con la consiguiente explotación, y muchos acontecimientos y decisiones de la época tuvieron lugar en Teutila, población designada sede para ejercer tal función. Del periodo de dominación colonial quedó la Relación Geográfica de Teotitlán del Camino y copias de lienzos, tres de los cuales son el Mapa de Huautla y el Lienzo de Ixcatlán-Soyaltepec, ambos del Siglo XVI, y el Lienzo de Chilchotla, que señala mojoneras y es del XVIII. A fines del Siglo XIX hubo un notable estudioso-cronista del grupo. El Profr. Mariano Espinosa.

La etnia mazateca ha participando activamente en todos los procesos que se han generado en el país a partir del movimiento de Independencia Nacional. En la Guerra de Independencia combatieron como insurgentes y en varias ocasiones apoyaron el paso de las fuerzas del Gral. Manuel Mier y Terán. En 1815 defendieron exitosamente Teotitlán del Camino del ataque de un batallón realista. Años mas tarde, como soldados republicanos del Gral. Luis Pérez Figueroa fueron conocidos por los húsares austríacos imperialistas como los "Guatecomacos” , consignándose que su desempeño en combate fue muy bueno y recibieron felicitaciones y reconocimientos del mismo Dn. Benito Juárez García. Uno de sus comandantes, el Coronel eloxochitleco de origen nahua Teodoro Flores, sería después el padre de los hermanos Flores Magón, Desde fines el siglo XIX se introdujo el café en la región y con él se incrementó en número de haciendas, lo que aceleró el poblamiento de mestizos y españoles en varias poblaciones, que se fueron adueñando de tierras. Esto ha provocado problemas por posesión de las mismas, los que se continuaron durante el período soberanista oaxaqueño, lo cual provocó incursiones de fuerzas carrancistas en la región, una de las cuales fue jefaturada por el General, originalmente villista, Rodrigo Pa- 
liza, y a la que se opusieron mazatecos que le hicieron guerra de guerrillas usando cuevas como refugios estacionales.

En la década de los 30s (1933) tuvo lugar en la región una tragedia que devino en acontecimiento periodístico, al caer el avión español militar "Cuatro Vientos”, procedente de Camagüey y La Habana y en vuelo de amistad, cuyos tripulantes, los pilotos Mariano Barberán Tros de Llarduya y Joaquín Collar Serra, que lograron sobrevivir a un aterrizaje forzoso en un cafetal, fueron asesinados en un cerro llamado "La Guacamaya" por fascinerosos (Bonifacio Carrera y Romualdo Palancares), relacionados con un cacique regional, para robarles lo que habían salvado y portaban, entre ellos algunos objetos de valor (regalos para funcionarios mexicanos y las pistolas reglamentarias de los oficiales de la aviación española, incluyendo la de propiedad del Teniente Collar, la cual llegó a manos de un comerciante de la ciudad de Oaxaca, lo que reveló el hecho).

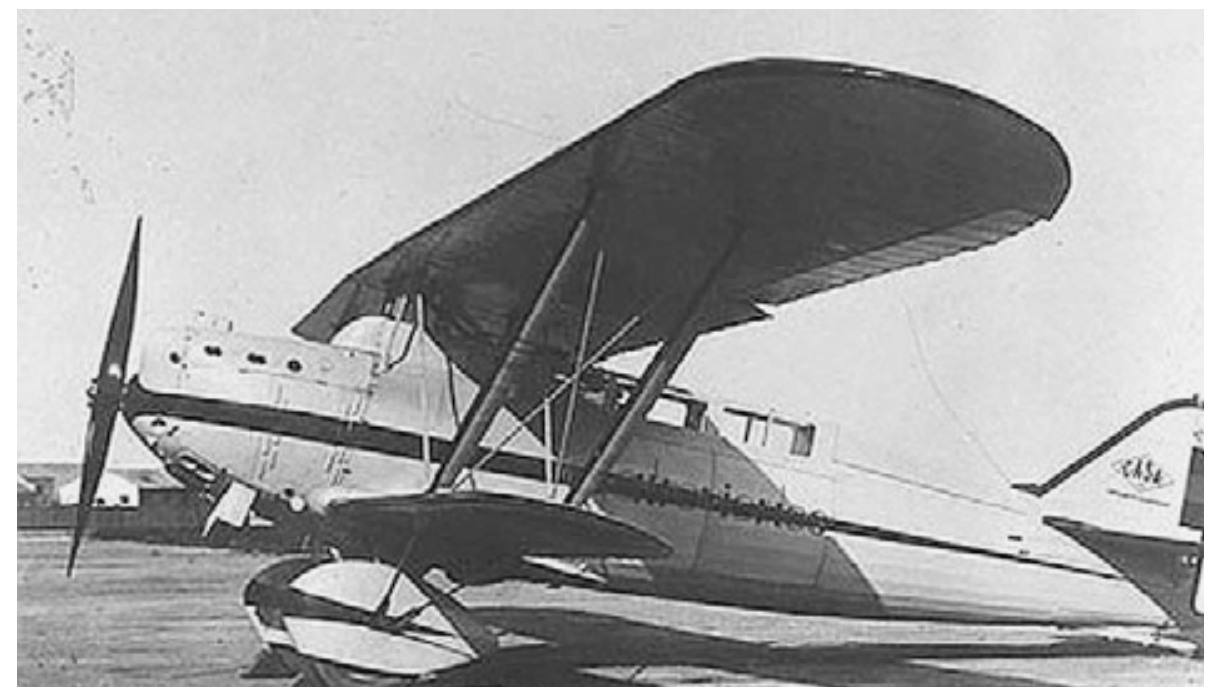

El avión Cuatro Vientos. (Foto: Wikipedia)

A instancias de la Embajada Española, en 1995 los esqueletos fueron encontrados en una cueva, rescatados y trasladados al cementerio de Guadalajara, España, ciudad natal del Capitán Barberán, donde se les hizo un monumento.

Posteriormente y del mismo modo, la construcción en 1947 de la Presa "Miguel Alemán” ocasionó el desplazamiento de varias poblaciones de ésta etnia, que, con una población total de 22000 personas, quedaron reubicadas en los Distritos de Choapan, Mixe y en el Estado de Veracruz, acción que documentó la fotógrafa Cora Van Shilling y el Antropólogo Roberto Weitlaner, seguida de otra cuando quedó terminada e inundada la Presa "Miguel de Lamadrid" o Cerro de Oro. Esas relocalizaciones afectaron las formas de vida del grupo, la relación afectiva y liga emocional con los antepasados sepultados y abandonados, su imagen del mundo y su sentido de pertenencia grupal. En la actualidad la etnia confronta problemas económicos y sociales de bastante gravedad. Hay, y ha habido constantes fricciones de carácter político (originadas en cacicazgos) entre miembros del 
Partido Revolucionario Institucional y sucesivamente, del Partido Popular Socialista y del Partido de la Revolución Democrática, algunos de cuyos miembros han sido asesinados, y la emigración, desde hace poco más de 30 años, es un problema muy presente.
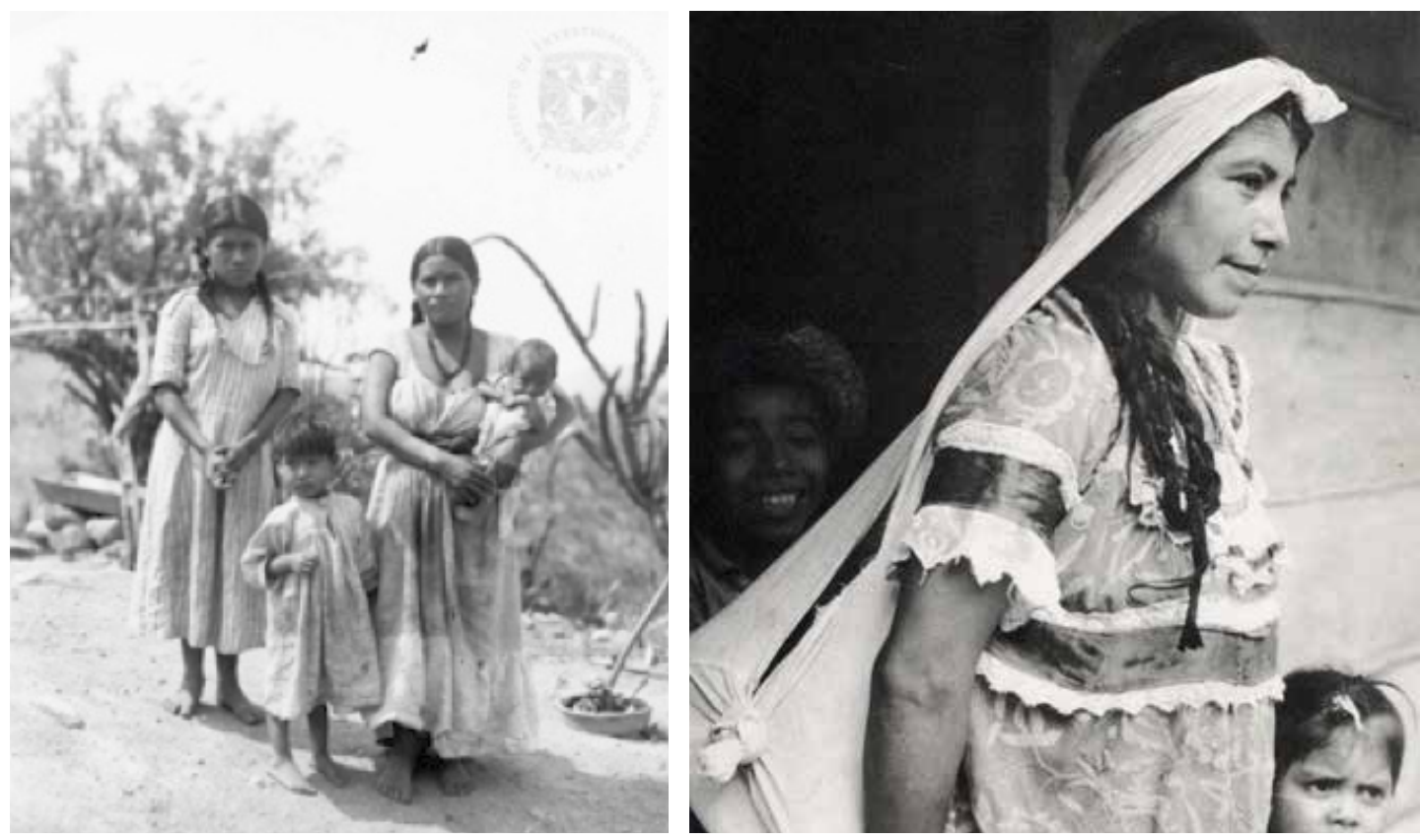

Familia y Madre e hija mazatecas. Ayautla. (Fotos: IIS-UNAM y Mtro. Roberto Weitlaner).

DEMOGRAFÍA. Debido a lo agreste del territorio y el hecho de que varias veces no fue censado con propiedad, los registros de población para el grupo son totalmente incompletos. Una cifra tentativa, aportada por el Instituto Nacional Indigenista en 1970, asignaba al grupo una población de 255,000 habitantes distribuidos en un territorio que forma parte de los Distritos de Cuicatlán, Teotitlán de Flores Magón y Tuxtepec. En el Censo de Población y Vivienda del año 2000 los pobladores dentro del Estado de Oaxaca eran aproximadamente 300 000, habiendo también que tenían como segunda lengua el mazateco, distribuidos en ciudades y poblaciones tales como Tehuacán y San Sebastián Tlacotepec en el Estado de Puebla, y Córdoba, Playa Vicente, Tezonapa y Tres Valles, en el Estado de Veracruz. En el Censo del 2010, se consignan poco menos de 550 000, incluyendo los emigrados que se ostentan de la etnia en varias ciudades. 

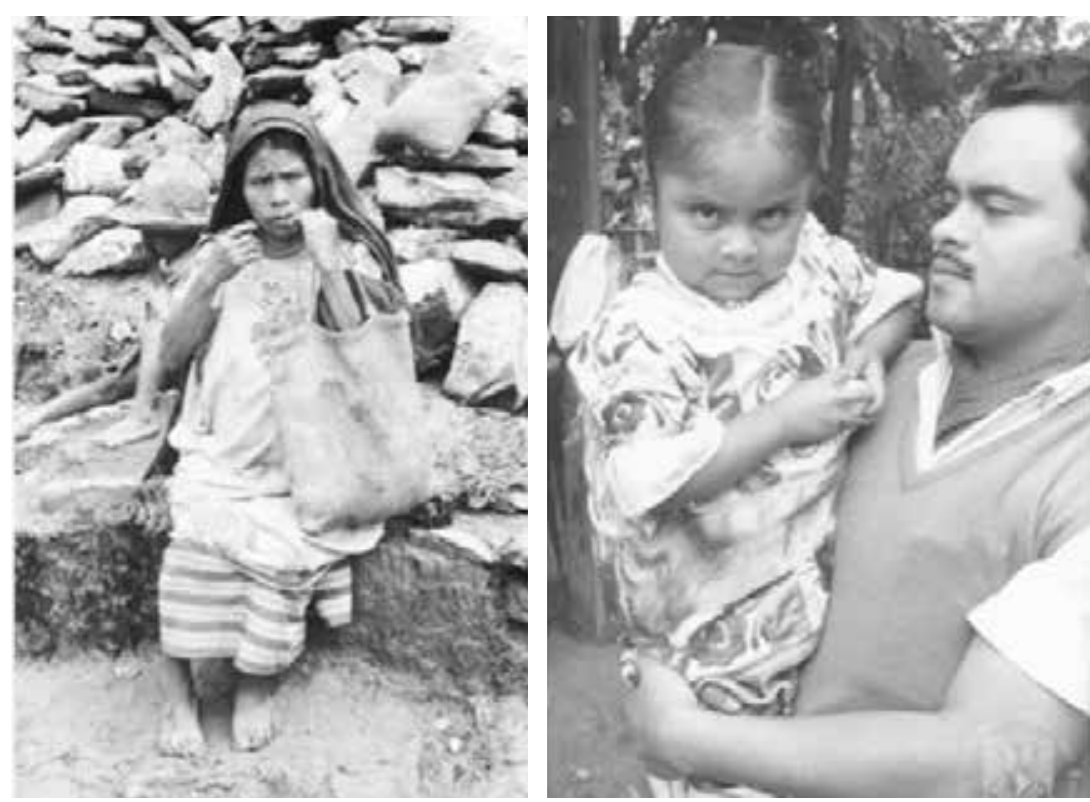

Jóven y Niña Mazateca con el Sociólogo Jorge Martínez Ríos. (Fotos: IIS.UNAM)

VIVIENDA. Casas tradicionales y cocina mazateca. (Fotos: IIS-UNAM). Existieron dos tipos de vivienda de acuerdo con la altura de la zona en que se ubican las poblaciones. La casa de las tierras altas ha sido de horcones con estructura de madera, vigas horizontales, paredes de varas entrelazadas enlucidas con barro y techos de zacate o tejamanil, entrelazados, que terminan en una pequeña proyección inclinada $45^{\circ}$ hacia el cielo, la cual recibe el nombre de oreja.

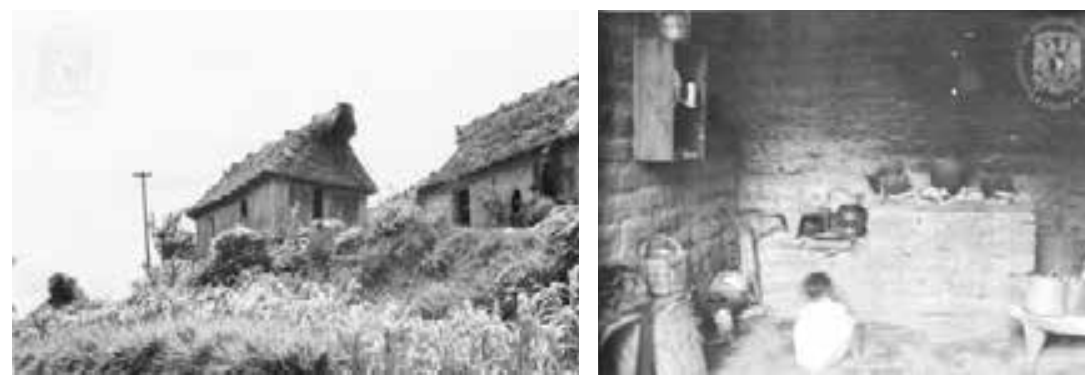

Casa y temazcal mazateco. (Foto: ISS-UNAM).

Los pisos solían ser de tierra y la casa solía estar colocada dentro de la población en un terreno que recibía el nombre de solar. Desde hace aproximadamente 30 años, se introdujeron las construcciones de adobe con techos de lámina metálica, de cartón o de asbesto, las cuales, aunque no son de un estilo agradable, han sido adoptados porque en algún momento se consideró que su propietario adquiriría prestigio. En las comunidades puede observarse que hay pocos agrupamientos, y fuera del área de solares hay muchas casas aisladas y los asentamientos son muy dispersos. Algunas tienen Temazcal. 
Las casas en las zonas bajas son muy similares, con la única excepción de que sus techos predominantes son de palma y carecen de oreja.

El menaje de la mayor parte de las casas consiste en mesas y sillas de madera, algunos anaqueles y abundancia de artículos de cestería y cerámica. Subsiste el metate, aunque ya ha sido casi totalmente desplazado por el molino de mano y la licuadora, y el fogón consiste en tres piedras formando un triángulo equilátero en un extremo de la habitación. En algunos casos de la zona alta, a la casa se le ha adosado otra habitación destinada a cocina. Una costumbre relacionada con ritos de aseguramiento y fertilidad consiste en el sacrificio de un pollo y la colocación de su sangre en un agujero en el piso, en el cual también se pueden depositar granos de cacao y huevos. Esta práctica se realiza en las casas nuevas o en aquellas que son reusadas por una nueva familia, y ostensiblemente es un ritual de reminiscencia prehispánica.

La población mazateca habitualmente dormía en promiscuidad sobre petates o en hamacas, según las zonas, y con suma frecuencia junto con animales domésticos.

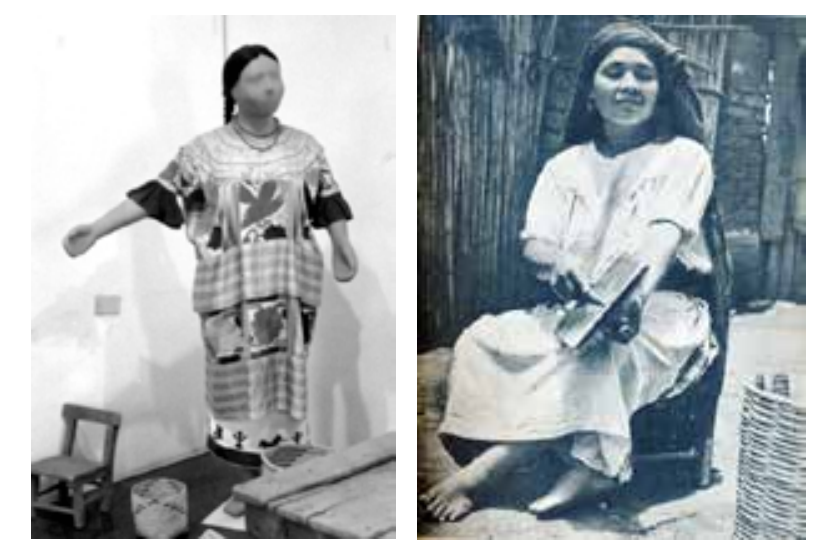

Huipil mazateco . Colección. Sra.María Luisa Jóven mazateca con huipil.

Audiffred. (Foto del autor). (Foto: Berenice Kolko).

INDUMENTARIA. La indumentaria Mazateca es una de las más ricas del estado de Oaxaca. Las mujeres usan huipil de cuello redondo y manga corta en forma de olán, hecho en telar de cintura y profundamente adornado de cintas multicolores y con diferentes tipos de telas, variando el adorno según la población de procedencia. En ocasiones portan también un rebozo y con frecuencia la indumentaria está complementada con adornos, tales como arracadas y collares con piedras o vidrios de varios colores.

En los casos de mujeres de relevancia dentro de la comunidad, los huipiles son, aún, mas elaborados. La indumentaria masculina se perdió desde hace bastantes años. En la actualidad también la femenina corre ese riesgo, sobre todo porque el huipil es distintivo del estado civil y de la población de origen de la mujer portadora, de tal manera que en las comunidades más aculturadas el huipil distintivo ha desaparecido casi totalmente para ser substituido por ropa comercial. Ambos sexos usan sandalias y los hombres, que ahora visten ropa comercial y sombrero de palma y de polietileno, están en ese sentido muy lejos 
de las tradiciones del grupo. Hace más de 30 años las mujeres usaban el "pistle" o "pixtle" hecho de hueso de mamey, con lo que preparaban un emplasto aceitoso con el que se suavizaban el cabello. Esa costumbre ya casi no se practica.
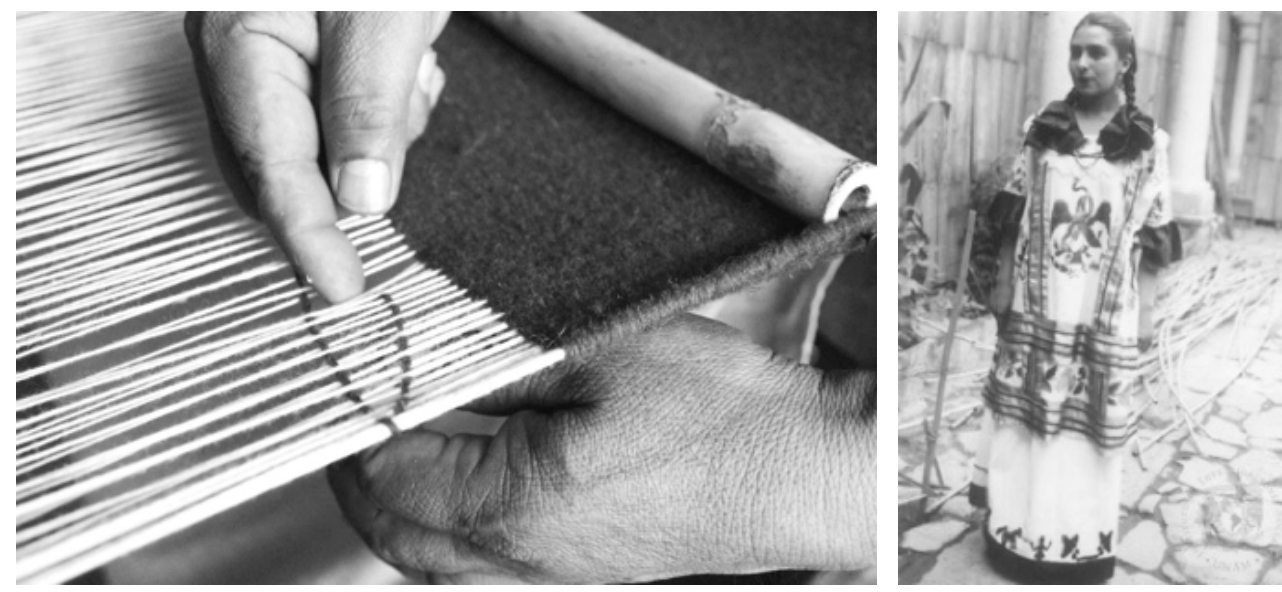

El pespunte en el tejido y huipil de ceremonia mazatecos. (Fotos: Internet e IIS-UNAM).
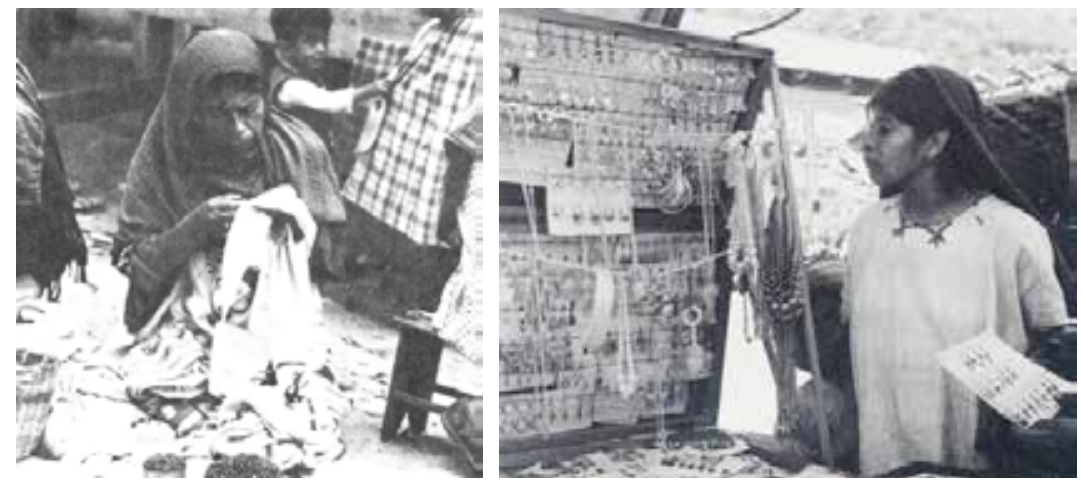

Mazateca bordadora y Jóven escogiendo aretes. (Fotos: Mtro Roberto Weitlaner).

ECONOMÍA. La economía de la etnia Mazateca lo es de subsistencia que se encuentra enmarcada dentro de la organización integral del grupo, el cual mantiene mecanismos de adaptación, cada vez más frágiles, a las condiciones económicas del país. Como ocurre en casi todas las zonas depauperadas del mismo, la explotación inadecuada de los recursos del medio ambiente ha llevado a la inmensa mayoría de los mazatecos a una situación de extrema pobreza que se agudiza porque el grupo ya no puede satisfacer sus necesidades básicas debido a que no produce lo suficiente y casi no tiene excedentes para poder adquirir los artículos que no se fabrican en su región. No obstante eso, la población se ve obligada a vender parte de aquello que produce, generalmente café maíz, frijol, calabaza o chile, con el objeto de obtener aquellos bienes que le hacen falta. Al entrar en este proceso, entran en juego los desiguales sistemas de comercialización. Puesto que la mayor parte de los indígenas mazatecos dependen de una economía de subsistencia, basada en el cultivo de roza con coa o espeque, o en los ingresos que obtienen en las plantaciones de 
café, y puesto que parte importante de las tierras van siendo gradualmente incorporadas al régimen de la propiedad privada, en abierta contraposición con la tradición grupal de la propiedad comunal, el choque cultural ha hecho perder terreno el grupo. En las tierras bajas solo en un pequeño sector es posible tener dos cosechas al año y los cultivos están más diversificados, sembrándose también cantidades limitadas de tabaco, arroz y ajonjolí. Como complemento a las actividades económicas algunas familias desarrollan algunos oficios o artesanías, entre ellas se encuentran los fabricantes de canastos, bordadores, tejedores e hilanderos, carpinteros, albañiles y algunos músicos que tocan marimbas o instrumentos de banda. En localidades reubicadas, algunos indígenas se están dedicando con éxito al cultivo de la caña de azúcar.
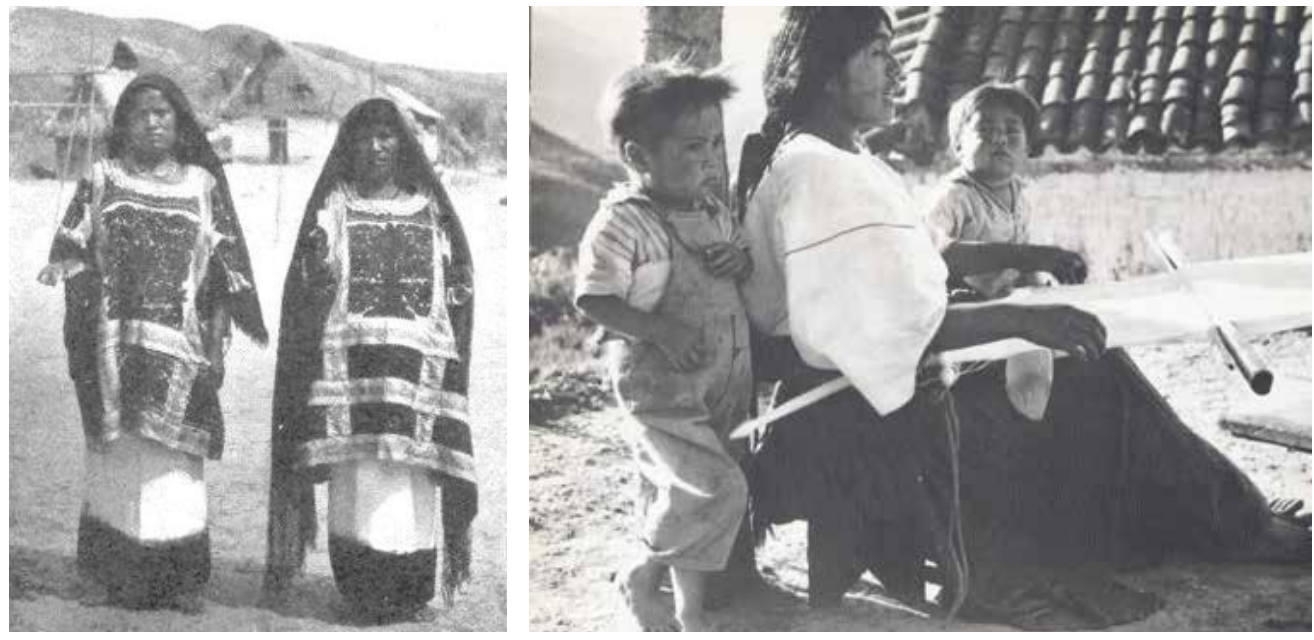

Mujeres. niños y tejedora mazatecos. (Fotos: Frederick Starr 1906 y Maestro Roberto Weitlaner).

El grupo indígena Mazateco ha tenido problemas casi permanentes para la extracción de su café, el cual, mientras existió, no pudo ser totalmente comercializado por el Instituto Mexicano del Café, ya que nunca existieron los transportes en la cantidad adecuada o porque en ocasiones se dependió de caminos que no permitían adecuadamente dicho transporte, ni había suficientes recuas. Se estuvieron implementando programas para ayudar a resolver esta situación. Hoy, con intermediarios privados, es mayor la problemática para el grupo y mayor el proceso de desvalorización de sus recursos.

ACCESOS. La principal ruta troncal de acceso consiste en la carretera federal número 131 que une a la población de Telixtlahuaca con la ciudad de Tehuacán pasando por Cuicatlán y Teotitlán de Flores Magón. Con esa carretera entronca la carretera estatal que une Teotitlán con Tuxtepec a través de las poblaciones de Huautla de Jiménez y Jalapa de Díaz. Hace 30 años, excepto la Federal 131, que estaba pavimentada, todas las demás carreteras eran de terracería con mayores o menores posibilidades de tránsito en el tiempo de lluvias continuas, Posteriormente el gobierno estatal logró la pavimentación de varios de los caminos zonales y la terminación de la de Huautla de Jiménez-Jalapa de Díaz, aunque no con buen 
pavimento. En las poblaciones de Huautla de Jiménez y Teotitlán de Flores Magón, existen pequeñas pistas de aterrizaje. La de Huautla es, quizá, una de las más cortas y escénicas de toda la república. Cada aterrizaje o despegue es un reto y un pequeño susto.

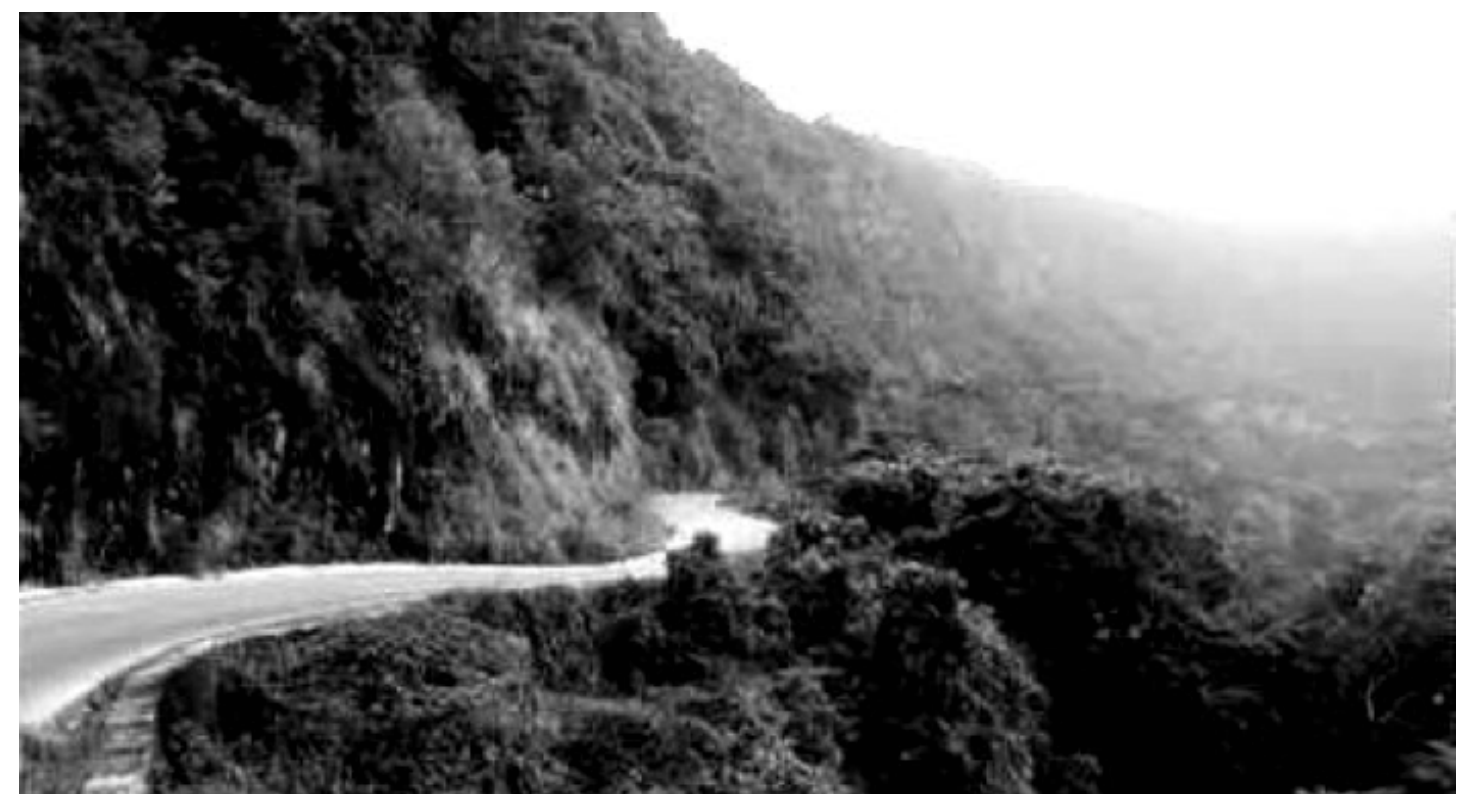

Carretera a Huautla.(Foto: Dirección de Caminos. Oaxaca.).

CASA Y PESCA. La variedad climática y vegetal del área de la región Mazateca presenta una importantísima gama de posibilidades para la explotación de fauna silvestre. La población indígena siempre manejó este recurso como un complemento de su alimentación y desarrollo, solicitando la "pieza" al "Amo de los animales". La destrucción de los bosques de coníferas ha roto el equilibrio provocando una drástica disminución en el número de animales. Tanto en las zonas altas como en las bajas ya se práctica la caza indiscriminada de tal manera que la distribución de algunas especies se ha visto afectada. Aún cuando los recursos piscícolas del área pueden ser adecuadamente aprovechados, a excepción de las capturas de mojarra que se hacen en las Presas Miguel Alemán y Cerro de Oro, la pesca en la región, por ser de arroyos altos de montaña se practica en muy pequeña escala; Esto plantea la necesidad de establecer criaderos de mamíferos, aves y peces de la fauna silvestre en la región.

MERCADOS. La actividad comercial en las zonas bajas se circunscribe a algunas tiendas en pequeñas poblaciones. Las zonas altas solo cuentan con un mercado importante en la población de Huautla de Jiménez. En él subsistió el intercambio de productos hasta la década de los 70s, pero ya la mayor parte de las transacciones se realizan en moneda nacional. Puesto que la actividad comercial se encuentra mayoritariamente en manos de mestizos, casi invariablemente la población indígena lleva la peor parte en el las transacciones con lo cual su poder adquisitivo disminuye. 

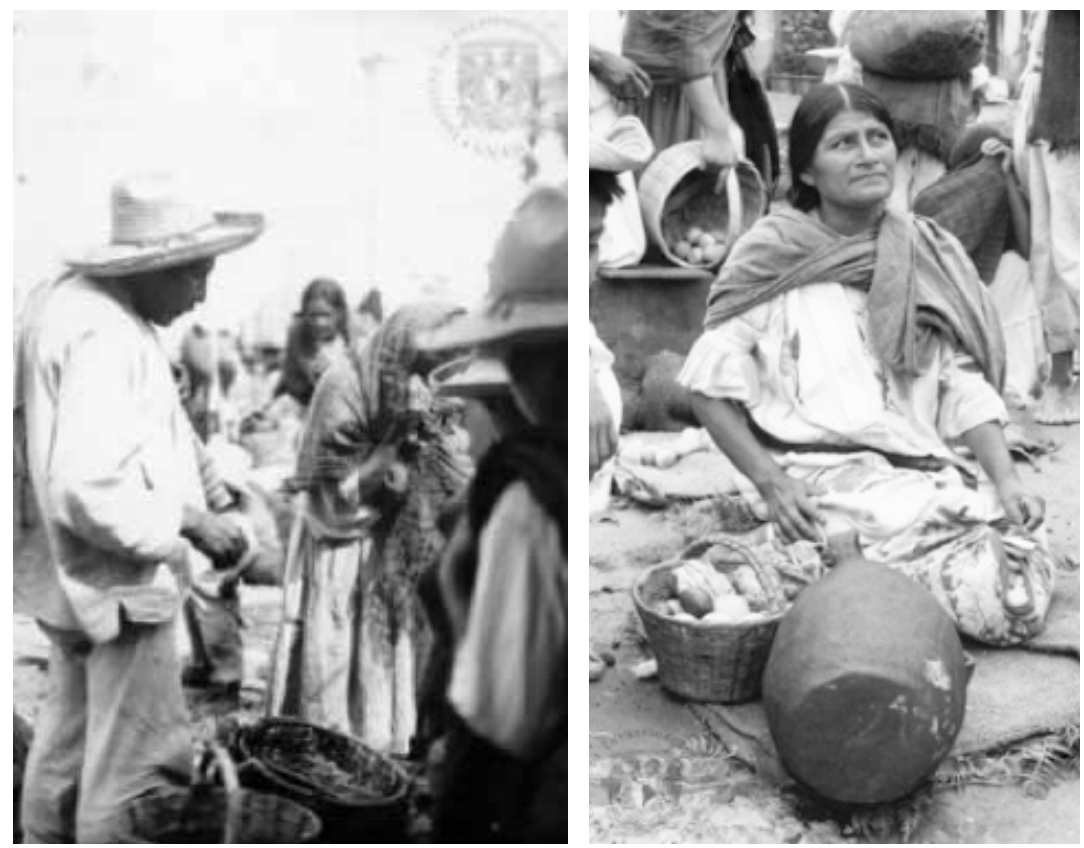

Mercado y mujer vendedora en la mazateca. (Fotos: IIS-UNAM).

ARTESANIAS. Además de la labor familiar de tejido bordado existen en la región alfareros que fabrican platos y vasijas trípodes que recuerdan algunas formas de la cerámica prehispánica en toda la región. Dichos alfareros fabrican también ollas globulares de barro rojo y café claro. Asimismo, los artesanos que se dedican a la elaboración de canastos logran formas cuyo uso utilitario consiste en la trasportación de mazorcas y granos de maíz.
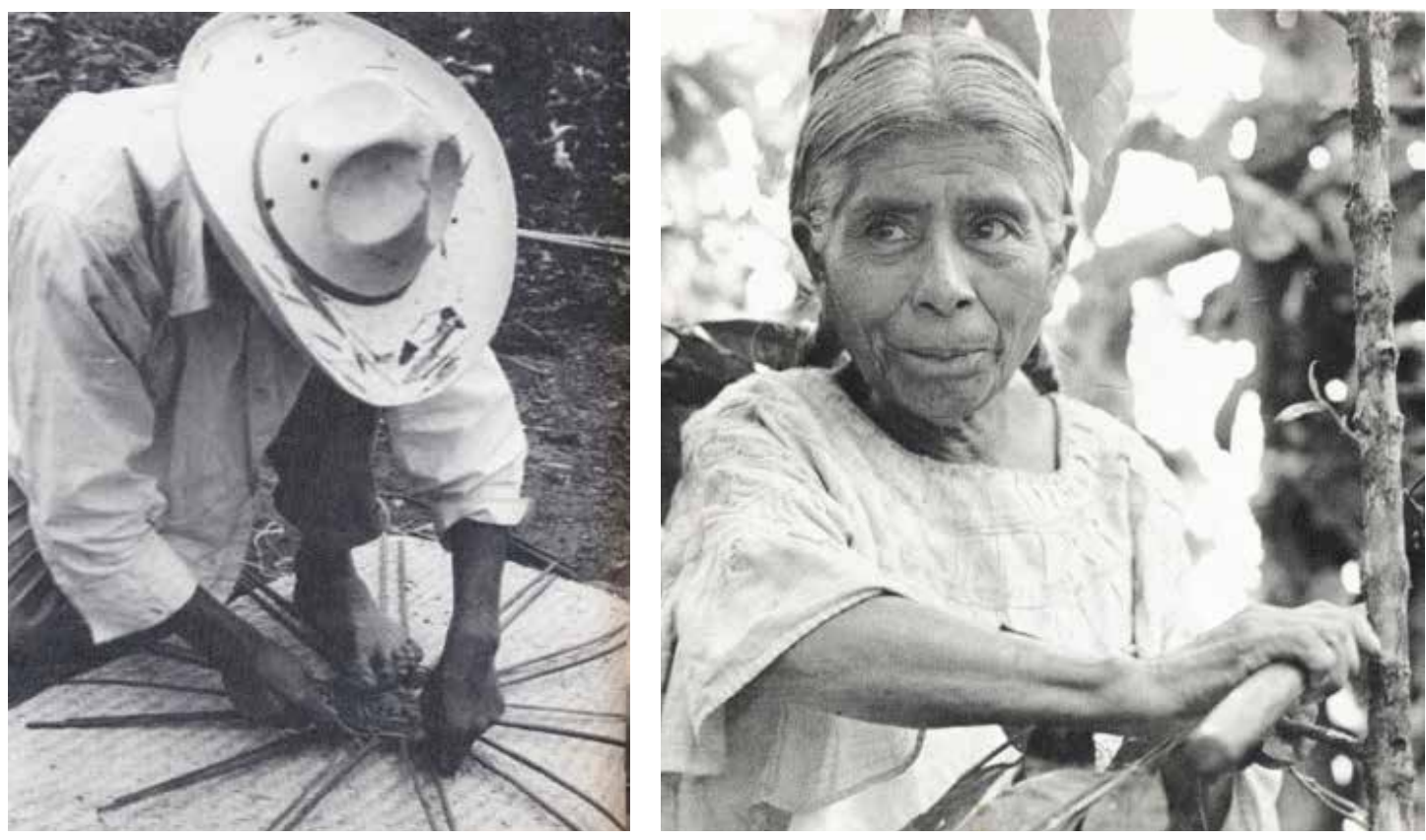

Mazatecos tejiendo carrizo y cosechando café. (Fotos Mtro. Roberto Weitlaner). 
ORGANIZACIÓN SOCIAL. La sociedad Mazateca está basada en la familia nuclear, la cual es patrilineal, patrilocal, exogámica y monogámica. Los términos de parentesco revelan que desde hace por lo menos dos siglos los indígenas del grupo tomaron en cuenta el patrón europeo de denominación familiar, y lo adaptaron de una manera tal que el hijo llevará como apellido el patronímico de su padre. En el grupo la familia es la célula y se divide en nuclear y extensa. La nuclear, compuesta por el padre, la madre y los hijos solteros, quedando inscritos en la extensa todos los hijos que se hayan casado y todos los abuelos, tíos primos y sobrinos en cualquier grado de consanguinidad. En el grupo existe la institución de compadrazgo, siendo el principal lazo de unión el compadrazgo por bautismo.

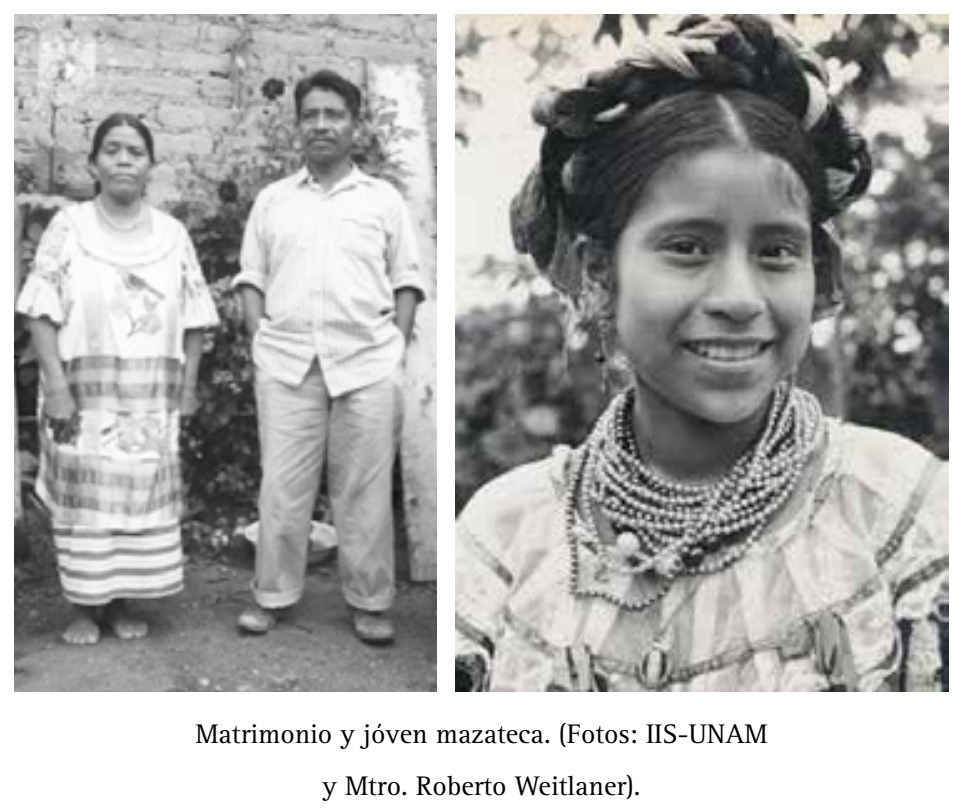

Los matrimonios se concertaban cuando la edad de los contrayentes fluctuaba entre los 16 y los 18 años. Siempre era el joven el que señalaba su elegida. Previamente a muchacha había sido informada y entrenada por su madre. En la petición de mano intervenía un anciano no pariente del novio que actuaba como intermediario peticionario y que visitaba a los padres de la novia en tres o cuatro ocasiones llevándoles regalos y aguardiente, y que advertía de las intenciones de su protegido. A la cuarta visita se fijaba la fecha de la boda y el tiempo que el muchacho permanecería en a casa de sus suegros realizando trabajos. La noche anterior a la boda, la muchacha era bañada en un manantial por varias mujeres ya casadas que actuaban como sus madrinas y al día siguiente la boda se verificaba en el Ayuntamiento de la población. Cuando algún sacerdote visitaba la Parroquia, se realizaban varias bodas en una ceremonia colectiva. Recientemente muchos jóvenes rompieron el esquema y ya hay uniones por mutuo consentimiento, aprovechando las ventajas del matrimonio civil.

Cuando algún miembro de la comunidad fallece, las campanas lo anuncian a la población. El cuerpo es bañado y vestido con ropa limpia y colocado en el piso o sobre un 
petate. A continuación se realiza un velorio en el que se reparte comida, bebida y tabaco. Al día siguiente el cuerpo es llevado al cementerio en una caja de madera, (en la actualidad las personas de recursos son enterradas en un ataúd metálico). Y una banda de música va tocando aquellas melodías que fueron sus favoritas en vida. Al sepultar, con la cabeza al oriente, se colocan como acompañamiento los implementos de trabajo, agua un peine y una vasija con amaranto o bledo, semilla conocida como "alegría". Posteriormente se coloca una cruz o un monumento y se practica el novenario.

Debido a que la sociedad de mayor importancia a la imagen paterna, habitualmente los hijos varones heredan la tierra del padre. El resto de los bienes se reparte entre todos los hijos.
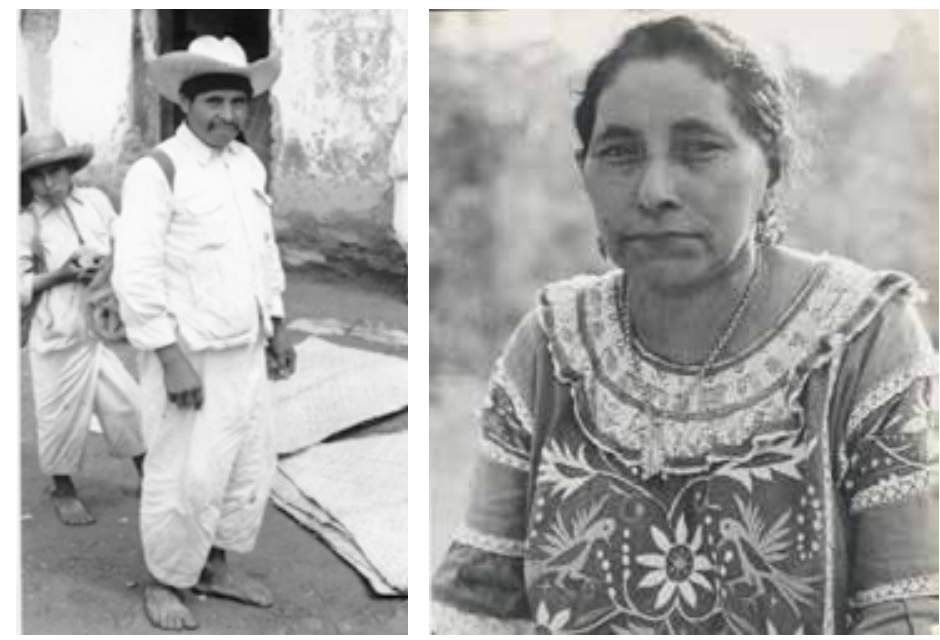

Hombre y mujer mazatecos. (Fotos: IIS-UNAM

y Mtro. Roberto Weitlaner).

GOBIERNO. Además del aparato jurídico, político -administrativo del país, que ha subdividido el territorio con intereses políticos, en la región Mazateca subsiste un Gobierno jerárquico tradicional de la misma etnia. Los Presidentes Municipales son electos por la población. Los Consejos de Ancianos deciden también todas las acciones que se tomen en las comunidades. Estas están divididas en barrios, y estos a su vez son una supervivencia de la organización política anterior a la conquista. Ha sido tradicional que el Presidente Municipal de Huautla de Jiménez informe cada día de mercado a la población cual es la situación que guarda el Municipio y cuales son las noticias más importantes del país. Subsisten el tequio y el Consejo de Ancianos, conservándose, sobre todo en la parte alta, un alto grado de sentido de pertenencia étnica. Eso deberá ayudar para una adecuada conservación cultural.

FESTIVIDADES. La substitución del calendario ritual prehispánico mesoamericano por el calendario ritual católico cambió por completo la sucesión de festividades del grupo, quedando todas dentro del calendario ritual de la religión católica. Las fiestas más importantes 
son la celebración de muertos y aquellas relacionadas con los Santos Patrones de las comunidades, así como el Carnaval; en éste se bailan en Huautla varias danzas sumamente relacionadas con los de moros y cristianos del altiplano.
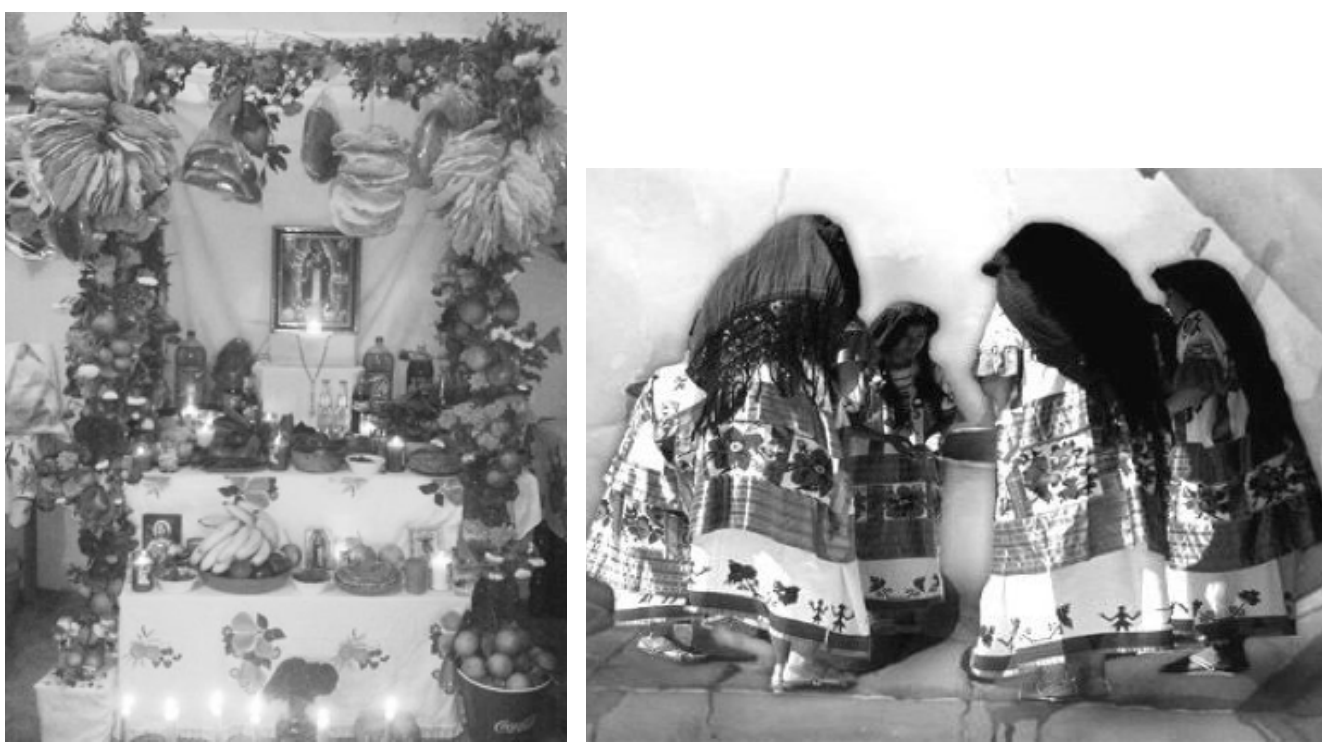

Altar de Muertos Mazateco y Danzantes de son. (Foto: Macario Matus y Prof, César Palacios).

Los mazatecos son muy aficionados a la música y existen en la región bandas de alientos con un número considerable de integrantes. Las festividades de mayor costo ahora se realizan mediante un patronato encabezado por un sacerdote. En Semana Santa, mientras en la iglesia se realizan los oficios, las mujeres se sientan frente a la puerta de su casa y golpean con palitos unas jícaras colocadas boca abajo, considerando que ese sonido ahuyenta a los demonios, lo cual tiene su expresión máxima en el templo cuando se celebran "las tinieblas", pues los asistentes golpean fuertemente el piso, gritan y chiflan.

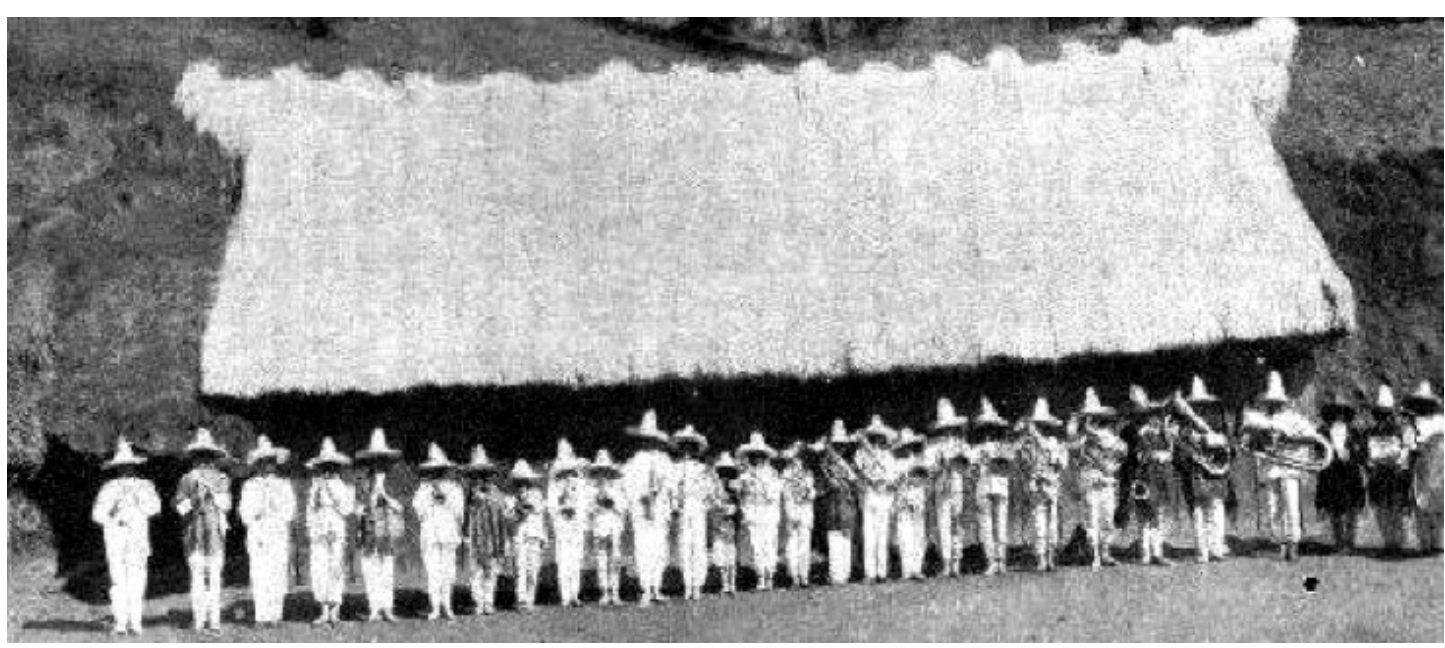

Banda de jóvenes mazatecos en 1906. (Foto: Frederick Starr). 
ORGANIZACIÓN RELIGIOSA. Además del culto regular católico, las iglesias parroquiales están a cargo de su respectivo sacristán. Pero el personaje más importante es el Mayordomo. Este tiene como función cuidar el santo durante todo el año y asegurarse de que la fiesta tenga la relevancia adecuada. Para la organización, el mayordomo cuenta con gran número de auxiliares. En la etnia ya está presente la acción de grupos religiosos de otros orígenes. Hasta hoy se siguen realizando rituales agrícolas encaminados a lograr la máxima productividad en las parcelas. Subsiste el recurrir a brujos y curanderos y el concepto del "Mal de Ojo", "Mal de Aire" o la Pérdida del Alma".

MEDICINA Y MAGIA. La región mazateca es un verdadero mosaico de mitos y tradiciones. En la zona subsistió un gran número de hechiceros y curanderos, entre los que se encontró la Sra. María Sabina, "La Sacerdotisa”, quién utilizó recursos silvestres y la aplicación de diversas clases de hongos, muchos de los cuales tienen carácter alucinógeno y que por lo mismo pueden ser usados en la terapéutica de ciertas enfermedades de carácter psicológico o pueden ser utilizados también como enervantes y estupefacientes. Similar objetivo logran administrando parte de una planta, el "manto de la vírgen (ololiuhqui). Esto ha provocado una mala interpretación del uso que les dan los curanderos de la región. Habitualmente es el curandero, y no el paciente, quien ingiere los hongos con el objeto de inspirarse y poder aplicar el tratamiento adecuado en base a la "información" que los hongos le han aportado, pero se dan casos de administración a pacientes para observar más reacciones durante el "viaje".
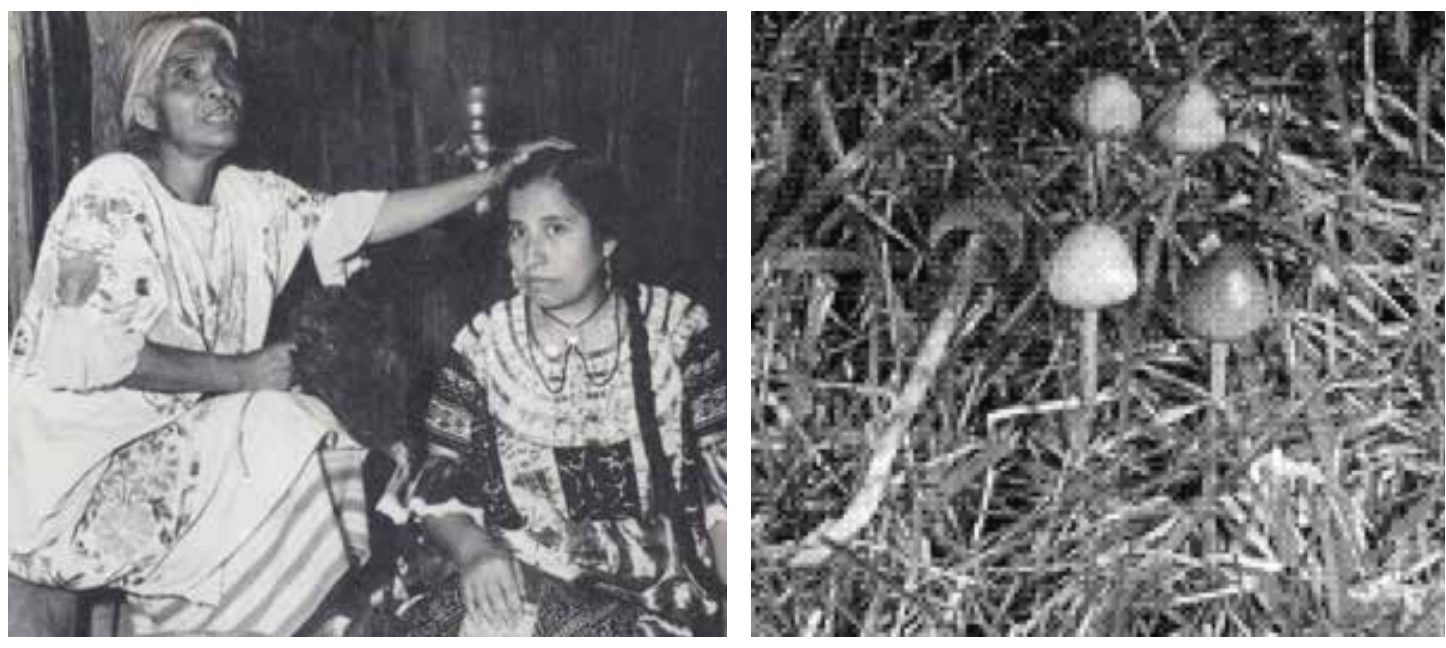

María Sabina curando, y Hongos alucinógenos (santo nanacate). (Fotos: Roberto Weitlaner e INI)

Muchas veces los hongos son utilizados solamente como estímulo, pero el concepto principal de su utilización tiene que ver con la idea prehispánica de que la divinidad y las fuerzas sobrenaturales puedan ser invocadas mágicamente y se pueden hacer presentes a través del hombre y fortalecerlo. Del mismo modo, en la región se considera muy activos a los espíritus de los “dueños” de las montañas, los manantiales, las cuevas y las barrancas, 
y asimismo, los indígenas se refieren a los astros y a las manifestaciones de la naturaleza con el calificativo respetuoso de "Padre" o "Madre": "Padre Rayo", "Madre Luna", etc., varias investigaciones también documentan la existencia de nahualismo y de ceremonias propiciatorias que se realizan cuando los cultivos, y principalmente el maíz, inician su desarrollo. Esto explica hallazgos de figurillas de barro femeninas de origen prehispánico en campos de labor.

Los curanderos utilizan habitualmente toda una gama de objetos y productos para desarrollar sus funciones. Entre estos objetos se encuentran: papel de amate, monedas, adornos, huevos, copal, cintas de colores y algunas hierbas (pequeñas ramas) que son aplicadas a los pacientes bajo múltiples formas. En ocasiones, y en casos particularmente difíciles, algunos recurren al sacrificio de aves y al uso de maíz y piedrecillas para adivinar el desenlace de la enfermedad. Estos rasgos revelan de algún modo una aproximación con el grupo chocho o chocholteca.

$\mathrm{Al}$ nacer un niño recibe la atención de una comadrona o partera empírica. Ésta amarra el cordón umbilical con un hilo, lo corta y posteriormente lo cauteriza con un machete caliente. Se suele enterrar el cordón junto con dos semillas de cacao. Desde hace algún tiempo se han enviado pasantes de medicina que así realizan su servicio social en los sucesivos Centros de Salud a medida que han ido siendo instalados.

EDUCACIÓN. Aunque existen escuelas elementales (jardines de niños, primarias y secundarias), en varias comunidades de la región mazateca, el nivel de escolaridad es sumamente bajo y similar al de las demás zonas depauperadas del estado. Muchos de los profesores son indígenas bilingües que han tenido como objetivo la castellanización El grueso de la población indígena no tiene acceso a niveles de enseñanza superiores a la primaria, aunque existen Secundarias y Telesecundarias. En Huautla de Jiménez y Teotitlán de Flores Magón, existen Colegios de Bachilleres, y por tanto es posible, para algunos miembros jóvenes de la etnia, cursar algunas áreas de enseñanza media. En Teotitlán de Flores Magón ya existe una universidad, La Universidad de la Cañada, del Sistema Estatal, con estudiantes indígenas becados.

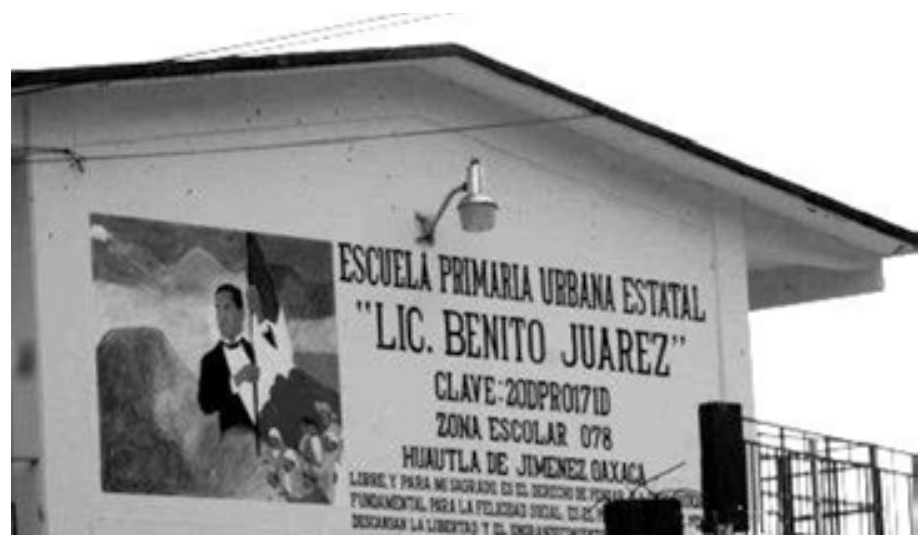

Escuela Primaria e Huautla de Jiménez. (Foto: SEP) 


\section{BIBLIOGRAFÍA}

Acevedo Conde, María Luisa. "Los Mazatecos". En: Revista A CONTRAGOLPE. No 14. Carteles Editores. Oaxaca, Oax. Basauri, Carlos. 1940 "Los Mazatecos”. Reed 1990. LA POBLACION INDIGENA DE MEXICO Instituto Nacional Indigenista. S E P. México, D F. 1990.

Boege, Eckart. 1988 “Los Mazatecos ante la Nación”. En: CONTRADICCIONES DE LA IDENTIDAD ETNICA EN EL MEXICO ACTUAL. Siglo XXI Editores. México, D F. 1988.

Herrera M. María del Carmen. Ruiz M. Ethelia. 2000 "El Códice de Tepeucila, una prueba de Escritura”. EN: CODICES Y DOCUMENTOS SOBRE MEXICO. Tercer Simposio Internacional. INAH. SEP. Colección Científica. México, D F. 2000.

Incháustegui Díaz, Carlos. 2000 "La Cosmovisión de los Grupos Indígenas de México". REVISTA CUATRIMESTRAL DEL CIESAS. México, D F. 2000.

López Cortés, Eliseo. 1996 "Los Mazatecos”. En: ETNOGRAFIA CONTEMPORANEA DE LOS PUEBLOS INDIGENAS DE MEXICO. Instituto Nacional Indigenista. México. D F. 1996.

Mac Mahon, David. 1985 ANTROPOLOGIA DE UNA PRESA. Instituto Nacional Indigenista. México, D F. 1985.

Mendieta y Núñez, Lucio.1957 ETNOGRAFÍA DE MÉXICO. UNAM. México, D F. 1957.

Neiburg, Federico G. 1988 IDENTIDAD Y CONFLICTO EN LA SIERRA MAZATECA. (El caso del Consejo de Ancianos de San José Tenango). DIVULGACIÓN. INAH. ENAH. México. D F. 1988.

Quintanar Miranda, María Cristina, Maldonado Alvarado, Benjamín. 1999 "La Gente de Nuestra Lengua. El grupo etnolingüístico chjota énna (mazatecos). En: CONFIGURACIONES ETNICAS EN OAXACA. PERSPECTIVAS ETNOGRAFICAS PARA LAS AUTONOMIAS. Vol. II. INAH. INI. México D F. 1999.

Rodrigo Álvarez, Luis. 2004 GEOGRAFIA GENERAL DEL ESTADO DE OAXACA. 4ª Edición aumentada. Carteles editores, Oaxaca, Oax. 2004. 2008 HISTORIA GENERAL DEL ESTADO DE OAXACA. Siena Editores. Puebla, Pue. 2008.

Villa Rojas, Alfonso. 1955 LOS MAZATECOS Y EL PROBLEMA INDIGENA DE LA CUENCA DEL PAPALOAPAN. Ediciones del Instituto Nacional Indigenista, México, D F. 1955.

Weitlaner, Roberto. 1961 DATOS DIAGNOSTICOS PARA LA ETNOHISTORIA DEL NORTE DE OAXACA INAH. SEP. México, D F. 1961. 



\section{CUICATECOS}

Autodenominación: nduudu yu, dbaku, dubaku.

Sinónimo en su lengua: nduudu vu.

Significado: Los que cantan (¿al hablar?). Los del lugar del canto.

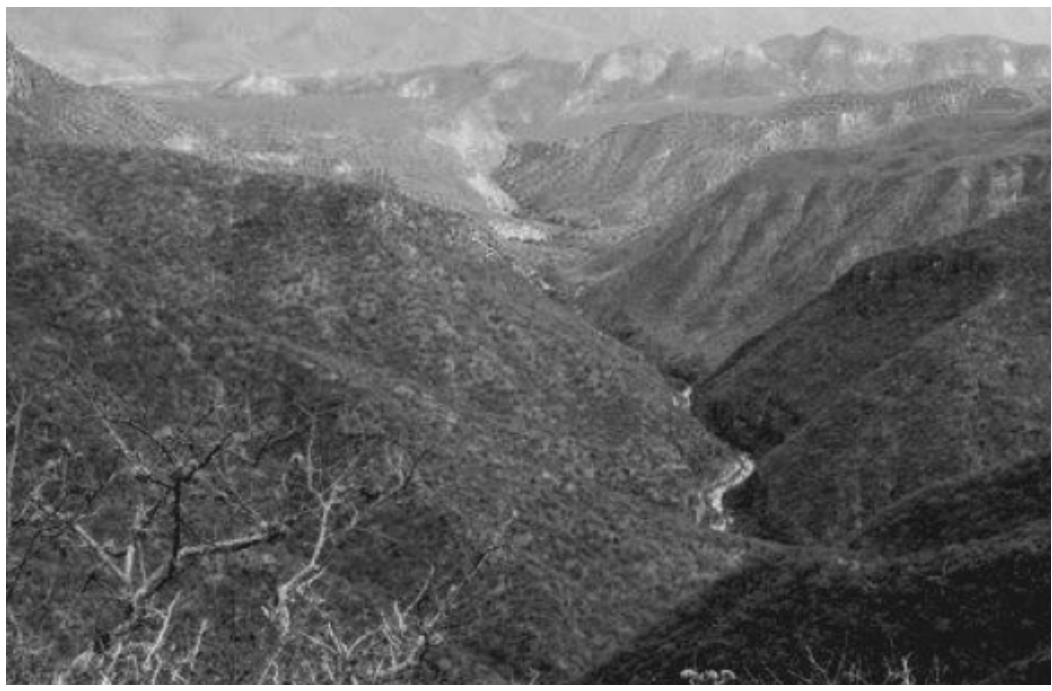

Paisaje cuicateco fronterizo. Cañón de Tomellín. (Foto: Dirección de Turismo Estatal).

\section{GRUPO CUICATECO}

UBICACIÓN GEOGRÁFICA. Esta etnia ocupa parte importante del Distrito de Cuicatlán y una porción del Distrito de Teotitlán de Flores Magón, entre los $17^{\circ} 45^{\prime}$ y los $18^{\circ} 15^{\prime}$ de Latitud Norte y los $95^{\circ} 5^{\prime}$ y los $96^{\circ} 20^{\prime}$ de longitud occidental, Su área ocupacional abarca los municipios de Concepción Pápalo, San Juan Tepeuxila, Santa María Tlalixtac, Santa María Pápalo, San Pedro Teutila, San Francisco Chapulapa, San Juan Bautista Cuicatlán. Santos Reyes Pápalo y Santiago Nacaltepec, y presenta un relieve accidentado que comprende parte de la Sierra Madre de Oaxaca y parte importante de las cuencas de los ríos grande y santo domingo, a los que descienden abruptamente por tres lados las montañas ocupadas por el grupo. En la parte central de esas montañas se encuentran las elevaciones de mayor altitud: El Cerro de las Brujas. El Volcán Negro, El Cerro Cheve y la máxima elevación, denominada Cerro Amarillo, a la cual se le señala una altitud no comprobada de más de 3200 metros. La porción occidental del área configura una gran depresión ori- 
ginada en una falla geológica a la cual se le da el nombre de la Cañada, por la que corre el Río Grande, el que, hace varios millones de años, rompió una serie de capas calizas y de conglomerados para formar el Cañón de Quiotepec.
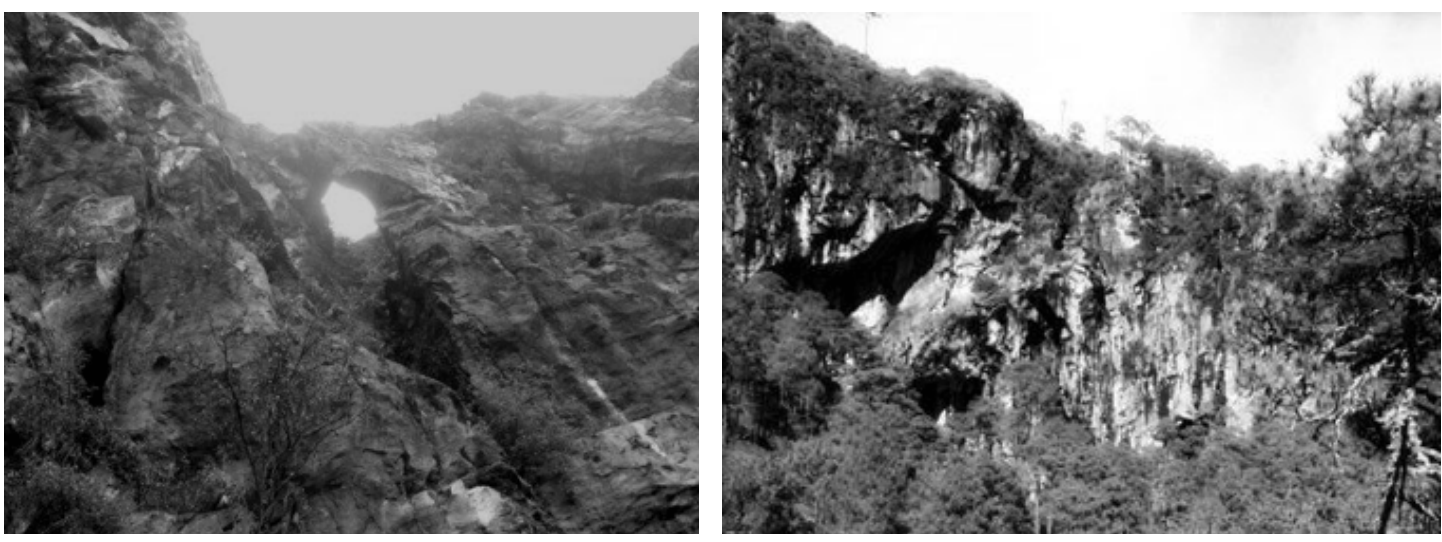

Cerro Cheve y su cueva. (Fotos: Dirección de Turismo estatal).

Debido a la agreste topografía, las alturas sobre el nivel del mar fluctúan entre los 500 metros, y las cotas superiores a 3,000 de algunas montañas. Esto genera una diversidad de climas que fluctúan en varios subtipos dentro de los tropicales subhúmedos y semisecos con lluvias en verano. En algunas altas montañas subsisten bosques de coníferas, y en la mayor parte de las laderas, cuyos escurrimientos vierten a los ríos mencionados, quedan rastros de selvas bajas caducifolias, y montes de chaparral con alta concentración de vegetación xerofítica.
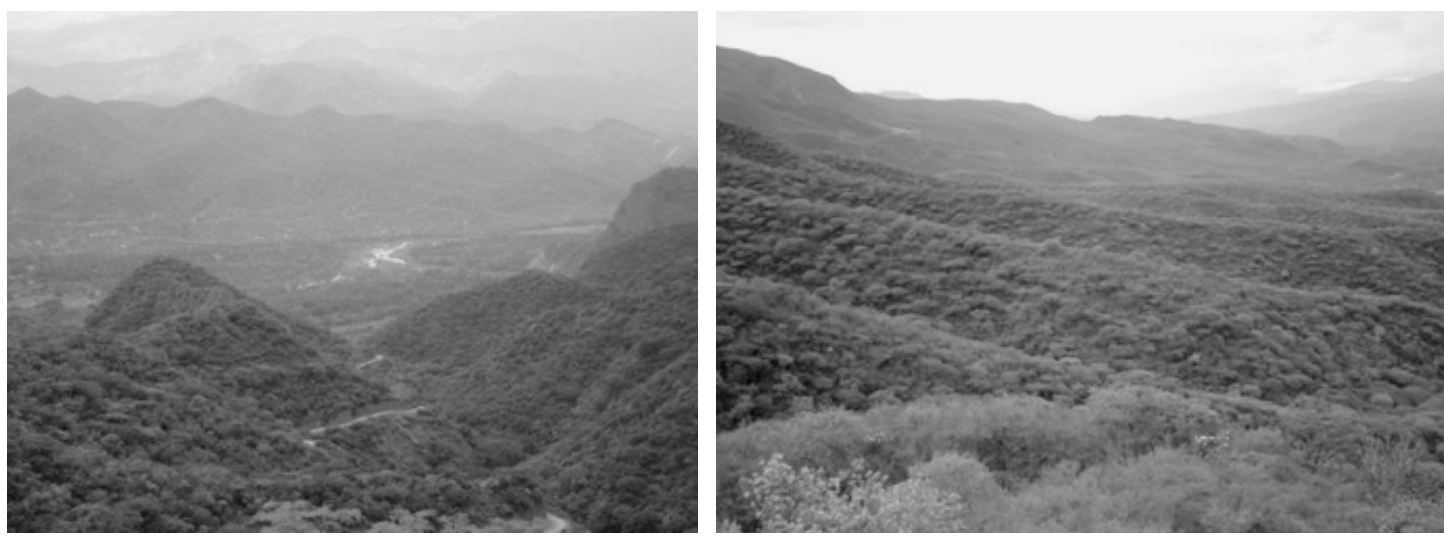

Paisaje y laderas cuicatecas. (Fotos del autor).

Los suelos de la región están generados en la disgregación de rocas volcánicas y sedimentarias, presentando migajones de color negro o gris obscuro con un adecuado contenido de materia orgánica. Los que se integraron como consecuencia de la acción natural de la formación de los bosques son los que han estado sujetos a un mayor índice de erosión. Las lluvias, la humedad ambiental y la nubosidad son mayores en las laderas orientales de 
la Sierra, y es el índice de vientos lo que determina la mayor aridez en la vertiente occidental. A los dos ríos ya mencionados vierten varias corrientes tributarias.
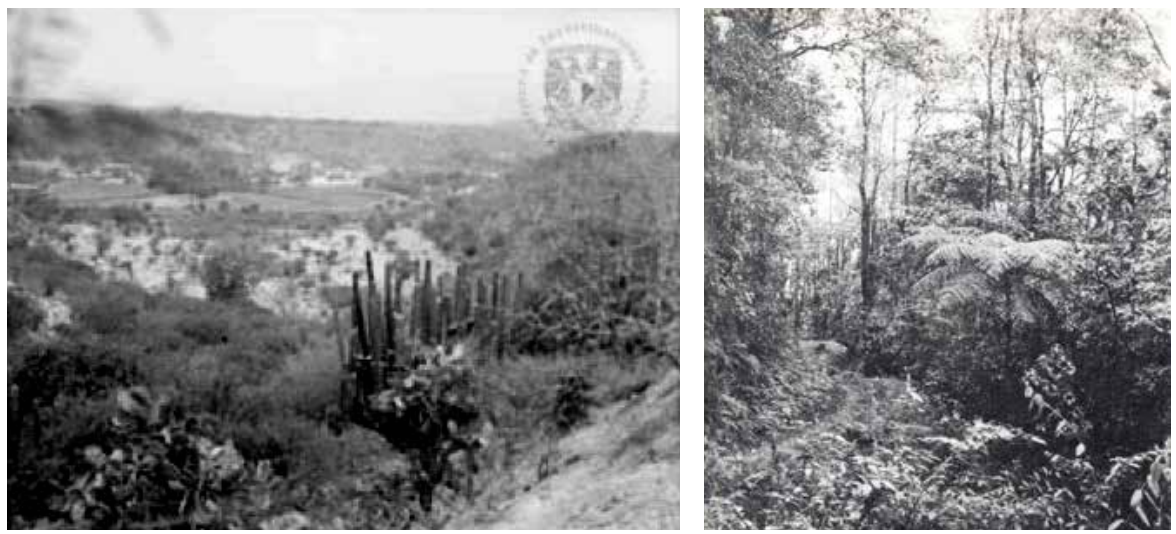

Valle Bajo de Cuicatlán y Bosque Cuicateco. (Fotos: IIS-UNAM y Mtro. Roberto Weitlaner).

ANTECEDENTES ARQUEOLÓGICOS E HISTORICOS. La porción occidental del área cuicateca, por sus peculiares condiciones climáticas, ha permitido la conservación de un alto porcentaje de los restos de materia orgánica que tuvieron algo que ver con el pasado de la acción humana en el territorio del Estado. En muchos aspectos la zona esta íntimamente relacionada con los Valles de Tehuacán y Centrales de Oaxaca y sus procesos culturales. Inicialmente esa porción debió ser asiento de microbandas del mismo tipo que las que han sido documentadas en la exploración de cuevas y sitios abiertos de esos Valles. La región contiene también algunos de los primeros tipos de cerámica conocidos en Mesoamérica y en ella se encuentran asentamientos correspondientes al comienzo de la etapa de las primeras aldeas.
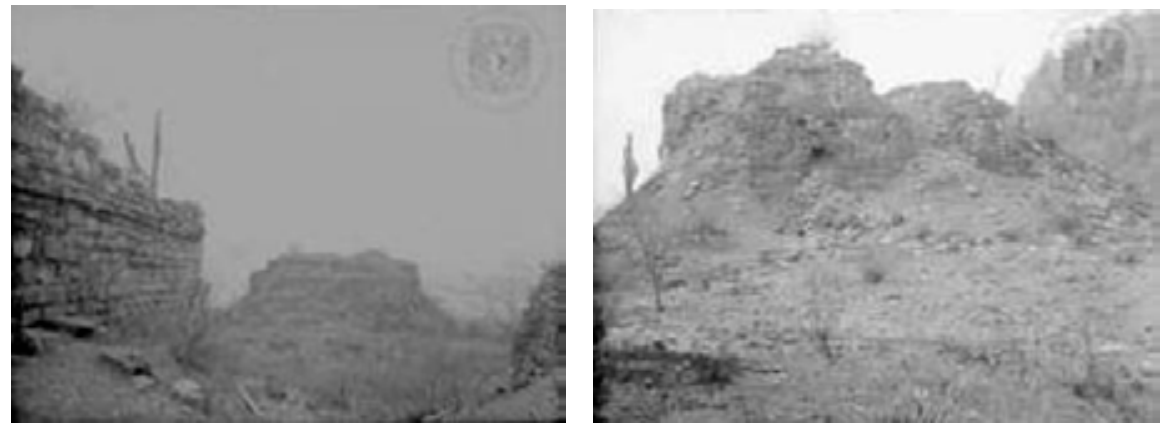

Zona arqueológica de Quiotepec y paramentos de la misma. (Fotos: IIS-UNAM).

Posiblemente desde esa etapa se utilizaron pequeñas acequias, todavía visibles, para el establecimiento de irrigación rodada Hacia el inicio del período clásico mesoamericano, el área cuicateca recibió marcadas influencias de Teotihuacan y de algunas de las áreas de la mixteca. Su posición geográfica nuevamente le hace tener importancia por encontrarse en una posición clave en el paso de las rutas comerciales del altiplano hacia los valles 
centrales de Oaxaca y hacia las regiones de Tuxtepec y del sureste del país. Al iniciarse el período postclásico, el área adoptó todas las características que la definen, estableciéndose fortificaciones y centros ceremoniales en la parte superior de las montañas, existiendo algunas evidencias (las zonas arqueológicas de Quiotepec, Santo Domingo y Jaltepetongo, por ejemplo), de las importantísimas relaciones que el grupo cuicateco mantuvo con militares procedentes de Monte Albán, algunos principalatos de la mixteca, con los grupos mixtecos que se establecieron en la región central de Veracruz y con grupos totonacos del norte-centro de ese Estado, así como con gente de filiación cultural toltecoide, procedentes del altiplano, principalmente del Valle Poblano Tlaxcalteca. La población de Cuicatlán fue tributaria de Tenochtitlan con una gran variedad de productos, incluyendo plumas de aves, y existen evidencias también de que en el área de Cuicatlán, y pese a lo cruento de la conquista, persistieron hasta mucho después de ella bastantes conceptos políticos y religiosos prehispánicos. En Jaltepetongo se han encontrado tumbas con cerámica y pintura mural que están dando información sobre Principales gobernantes. Al producirse la conquista, la cuenca de los ríos Grande y Salado fueron rutas de acceso hacía el sur y suroeste del país. Con la cristianización, los contactos del grupo cuicateco con los frailes dominicos sufrieron fluctuaciones y se registran algunas rebeliones en la época Colonial. De esa época nos quedaron algunos lienzos y códices, el Lienzo de Tepeucila y los Códices Fernández Leal y Porfirio Díaz.

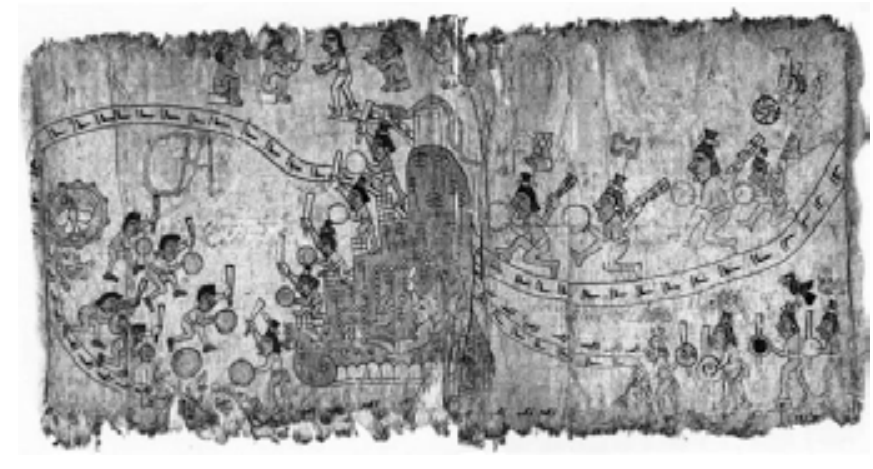

Láminas de los Códices Fernández Leal y Porfirio Díaz.

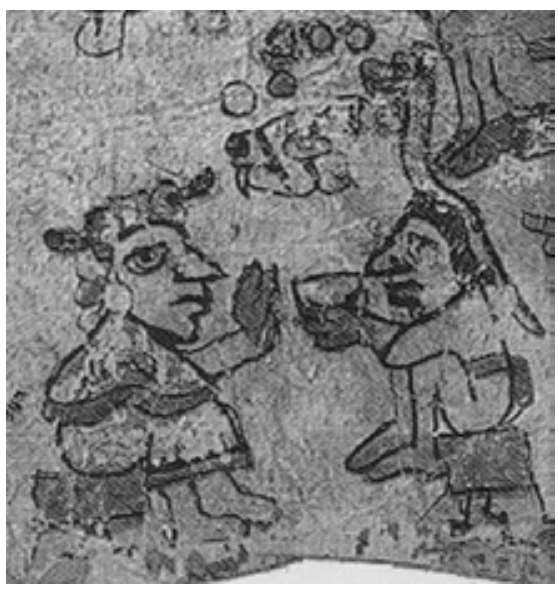

En los sucesivos períodos por los que ha pasado nuestro país, los indígenas cuicatecos han tenido participación activa, porque las rutas comerciales hacia los Valles Centrales de Oaxaca siempre se han mantenido abiertas. En la época de la colonia esa fue la ruta que permitió el transporte de mercancías entre Veracruz y Oaxaca; y en el México Independiente, de la Reforma, de la Intervención, del Porfiriato y de la Revolución, la región presenció algunos de los más importantes movimientos militares. A fines del siglo XIX la construcción del ferrocarril México-Oaxaca estableció comunicación diaria y permitió la penetración de muchos nuevos conceptos y hábitos de vida que hoy son perfectamente perceptibles en las comunidades aculturadas del área, y en ese fin de siglo el grupo fue 
estudiado y cronizado por el Profr. Mariano Espinosa. En Cuicatlán tuvo su asiento el Club Antirreeleccionista de corte maderista que jefaturó Rafael Odriozola, quién, por su tono de voz muy grave, fue conocido como "Don Retumbo". La zona continuó siendo importante por su condición de ser corredor de paso, particularmente por la existencia del ferrocarril. En ella operó, combatiendo a los carrancistas de la División 21, uno de los grupos soberanistas, el que jefaturó el Gral. Teodomiro Romero, quién varias veces tiró postes telegráficos, voló alcantarillas y enchuecó rieles para impedir los movimientos enemigos, sólo para que siempre fuera restablecida la comunicación, Se consigna que uno de los generales constitucionalistas que tuvo el mando de esa ruta, el Gral. Macario Hernández, tuvo un comportamiento tan cruel con sus prisioneros y con los campesinos del rumbo, que recibió el mote o sobrenombre de "Matario".

A principios de la década de los 50s, las necesidades de transportación obligaron a establecer la vía ancha. Posteriormente ha existido en la región cierta efervescencia política, con los partidos Revolucionario Institucional y de la Revolución Democrática como principales contendientes, y hacia 1995, por decisión gubernamental del presidente Ernesto Zedillo Ponce de León, para privilegiar el transporte de trailers por carretera, fue vendido y eliminado el ferrocarril, del cual quedan, el terraplén y algunos tramos de rieles, ya tratados como botín personal.

IDIOMA. La lengua Cuicateca pertenece al Grupo Otomangue, Tronco Savizaa, Familia Mixteca. En la actualidad es hablada por aproximadamente 38000 personas, existiendo ligeras variantes dialectales. La lengua es tonal y muy modulada, lo cual provocó que los Mexicas bautizasen al grupo con la palabra náhuatl "Cuitlatl” que significa "cantar". Por tanto los Cuicatecos son, por su lenguaje muy modulado, con mucha probabilidad, "los que cantan al hablar”, habiendo todavía poblados, tales como Santos Reyes Pápalo, Santa María Tlalixtac y San Andrés Teotilalpan, donde persiste el idioma, incluso en la vida doméstica.

DEMOGRAFÍA. Aunque no existe un censo exacto, lo disperso de los asentamientos y lo agreste de la topografía han impedido contar con datos fidedignos. Por tanto las cifras aproximadas del 2010 señalan unos 60000 pobladores, más o menos equilibrados por sexo, existiendo muchos ubicados fuera de su región de origen. Los mismos datos señalan que hay unos 12200 monolíngües. 

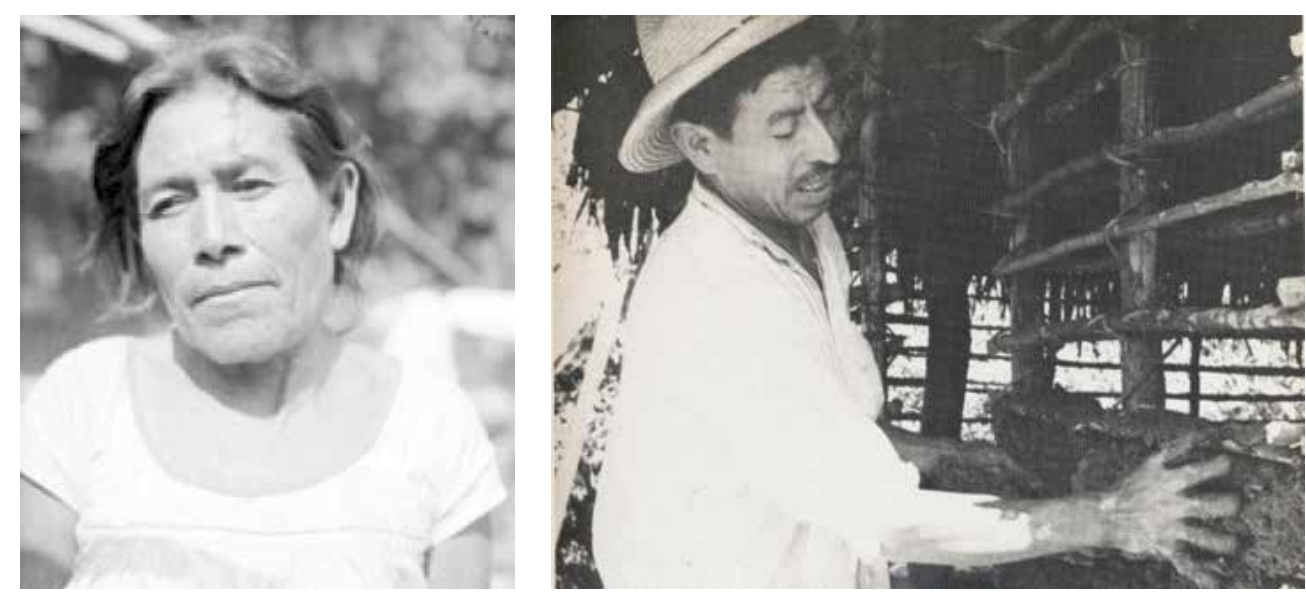

Mujer y hombre cuicatecos. (Fotos: IIS-UNAM y Mtro. Roberto Weitlaner).
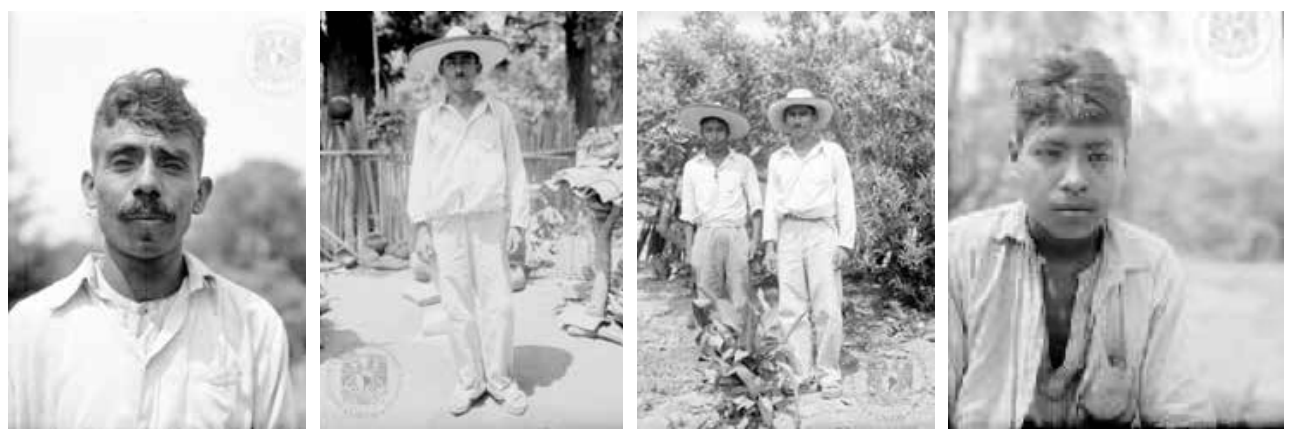

Hombres cuicatecos. (Fotos: IIS-UNAM)
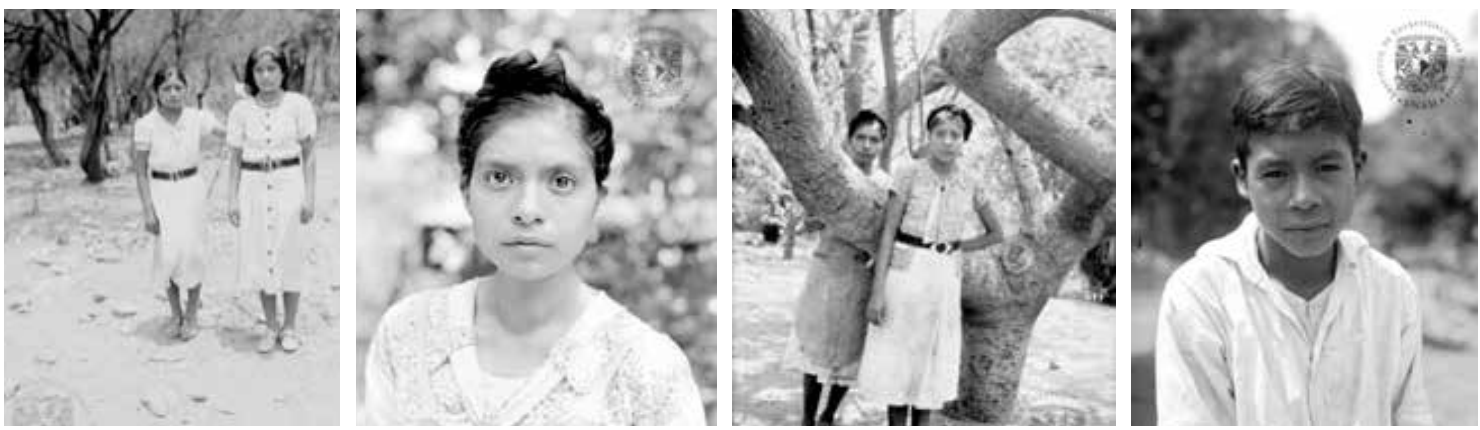

Mujeres y niño cuicatecos. (Fotos: IIS-UNAM)

ACCESOS. La población de Cuicatlán y algunas rancherías cuentan con pequeñas pistas de aterrizaje. El extremo del área Cuicateca esta recorrido por la carretera Federal número 131, llamada la carretera de la cañada y que une a la población de Telixtlahuaca con la Ciudad de Tehuacán, pasando por la cabecera distrital a 74 kilómetros del entronque con la panamericana. De esta carretera parten varios caminos de penetración de terracería que llegan a diferentes poblaciones, entre ellas Santa María Pápalo y Cuyamecalco Villa de Zaragoza. Del mismo modo, el extremo del área cuicateca estaba recorrido por el ferrocarril, el cual hacía paradas en las poblaciones de Parián, Tomellín y Cuicatlán. 

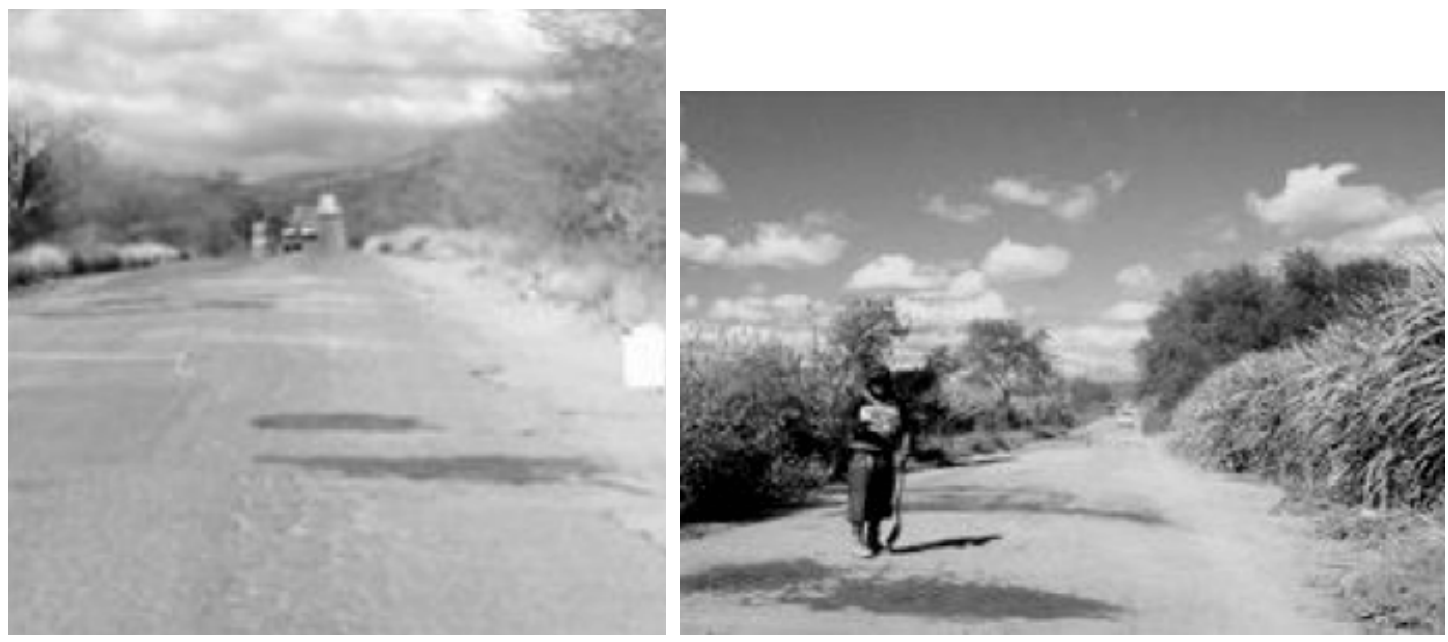

Carretera de la cañada en la zona cuicateca. (Fotos: Dirección de Turismo estatal).

VIVIENDA. Las poblaciones Cuicatecas son semicongregadas, habiendo alrededor de las casas una pequeña área de cultivo o un patio. Las casas fueron, en las partes altas, de horcones de madera con paredes de lodo, y en las bajas, de bajareque, carrizo o ramas entrelazadas y de planta rectangular. La puerta solía estar en uno de los costados y el fogón se encontraba en el extremo y se componía de las clásicas tres piedras colocadas en forma de triángulo equilátero. Los techos fueron de tejamanil, zacate o pasto, siempre de dos aguas.
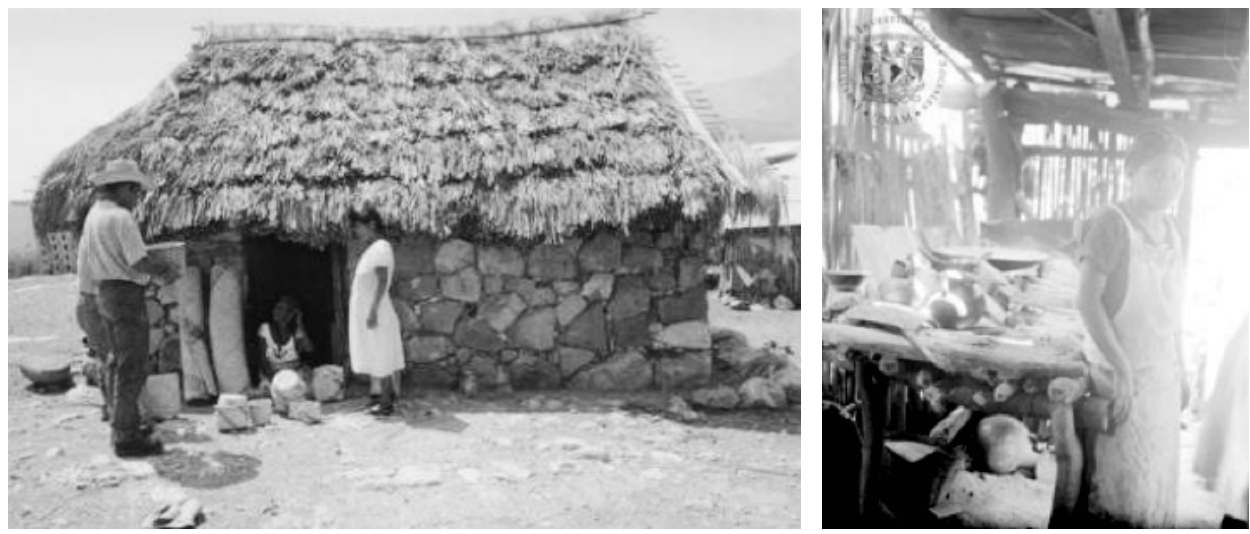

Casa e interior de casa cuicatecas. (Fotos IIS-UNAM).

Aún ahora los agrupamientos suelen consistir en dos o tres casas cuya posición varía en las diferentes poblaciones. En ocasiones una cerca de ramas protege al conjunto. Dos poblaciones, Concepción y Reyes Pápalo tienen un pequeño número de barrios y frecuentemente cerca de cada una existen pequeños agrupamientos que casi tienen el carácter de aldeas. Dentro de las casas, las familias viven en promiscuidad, y casi siempre junto con la familia duermen algunos animales domésticos. El menaje de casa consiste principalmente en cerámica y algunos muebles rústicos de madera. 
INDUMENTARIA. Tradicionalmente las mujeres cuicatecas se han tejido sus propias prendas de vestir en telar de cintura. Estas consistían en huipiles de manta blanca con bordados en el cuello y las mangas. Aunque esta actividad se ha ido deteriorando durante los últimos 40 años, todavía existen importantes huellas de ella. Las prendas tejidas, utilizando hilo de algodón, eran huipiles y enredos, así como lienzos grandes ampliamente bordados. En ocasiones, y desde hace poco tiempo, se incorporaron a la tecnología algunos elementos de tejido moderno tales como agujas y máquinas de coser. Los huipiles cuicatecos suelen estar bordados con motivos de decoración roja y en todas las poblaciones el rebozo complementa el atuendo.
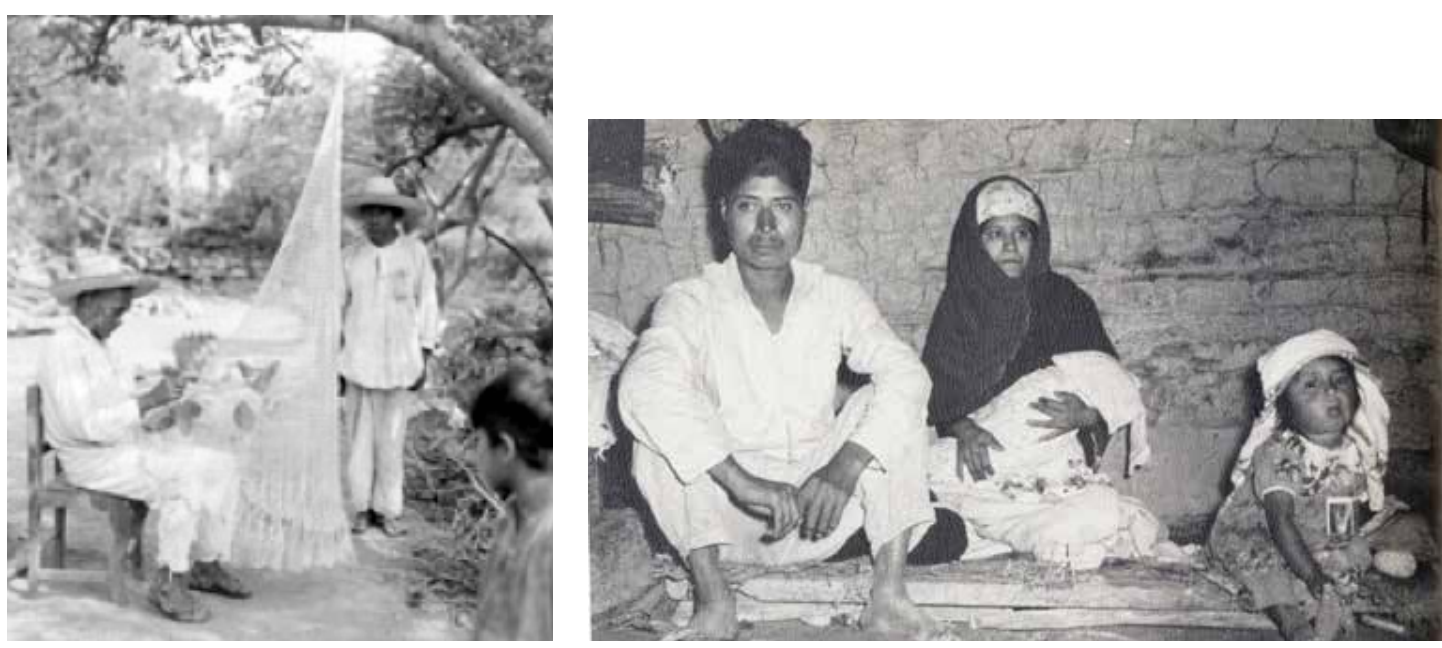

Reparador de tarrayas y mujer cuicateca en cuarentena. (Fotos IIS-UNAM y Mtro. Roberto Weitlaner).

Muy recientemente la penetración de la ropa industrial ha sido completamente lograda. El huarache y la sandalia tradicionales han sido substituidos en cierto modo por el calzado de plástico. La tradicional indumentaria masculina de algodón y manta está siendo substituida por ropa procedente de las empresas industriales. Los adornos más frecuentes entre mujeres son pequeños aretes y pequeños collares hechos de semillas de colorín.
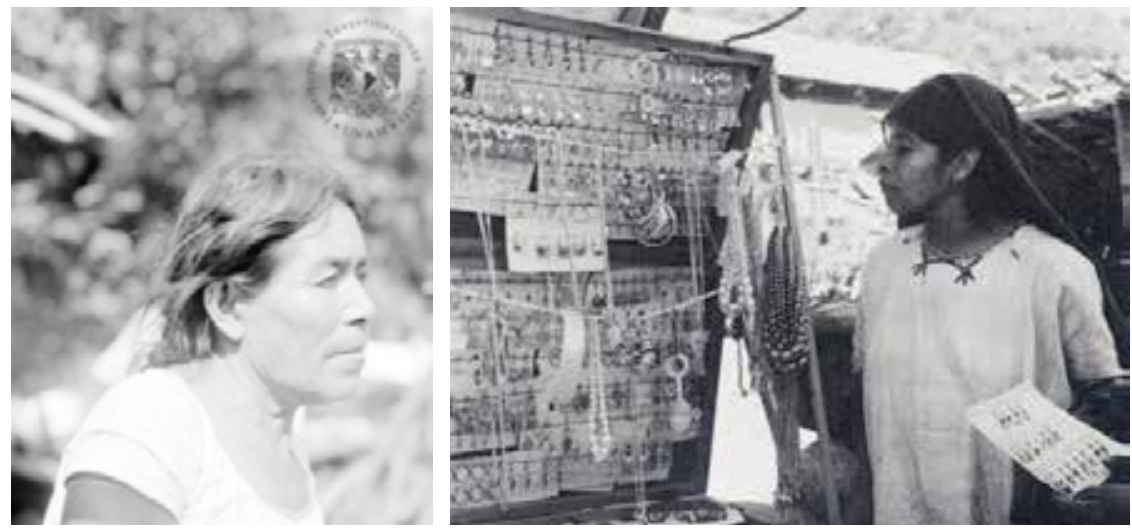

Cuicatecas. Una de ellas seleccionando aretes. (Foto IIS-UNAM y Mtro. Roberto Weitlaner). 
ECONOMÍA. La economía del grupo cuicateco puede inscribirse dentro de la organización social, política y religiosa. Por ello no puede analizársela en términos de costo-utilidad debido a que el grupo mantienen procesos de defensa, reproducción y adaptación a las condiciones económicas que vivimos en el país. En las actividades económicas de los Cuicatecos inciden una lengua, sus valores y esas tradiciones que forman una red constante de interrelaciones económicas, familiares y religiosas. Como en todas las zonas deprimidas del país la explotación inadecuada de los recursos naturales, el uso inadecuado del medio ambiente y las terribles y negativas condiciones de trabajo, están llevando a gran parte del grupo a una situación de extrema pobreza, no sólo por que los individuos de la etnia pretenden satisfacer directamente sus necesidades básicas, para lo cual tienen que explotar prematuramente los recursos naturales de que disponen, sino porque constantemente tienen que destinar parte de su producción o el pequeño excedente de la misma para adquirir aquellos artículos que no se producen en la comunidad, con lo que aparecen los desiguales sistemas de intercambio y comercialización. Al no alcanzar los recursos, la población adulta tiene que dedicarse a actividades complementarias y en ocasiones se ve obligada a emigrar. En la región se practica una agricultura de subsistencia de muy bajo índice productivo. Sólo en las zonas de migajón negro profundo las cosechas tienen una mayor garantía de desarrollo. Algunas actividades económicas complementarias son el tejido de canastas y pequeñas cuerdas de ixtle, obtenidas mediante un sistema muy elemental de obtención de fibras de maguey y la manufactura de cerámica, que se hace en horno abierto partiendo de un barro rojo al que se le pone un desgrasante en el que están incluidas pequeñas partículas de cuarzo. Algunas de las formas fabricadas son ollas, vasijas semi globulares de cuello abierto y cómales de barro de formas que están ampliamente diseminadas en toda la región. Los cultivos principales son el maíz, la calabaza, el frijol y el chile. El café es un cultivo muy extendido.
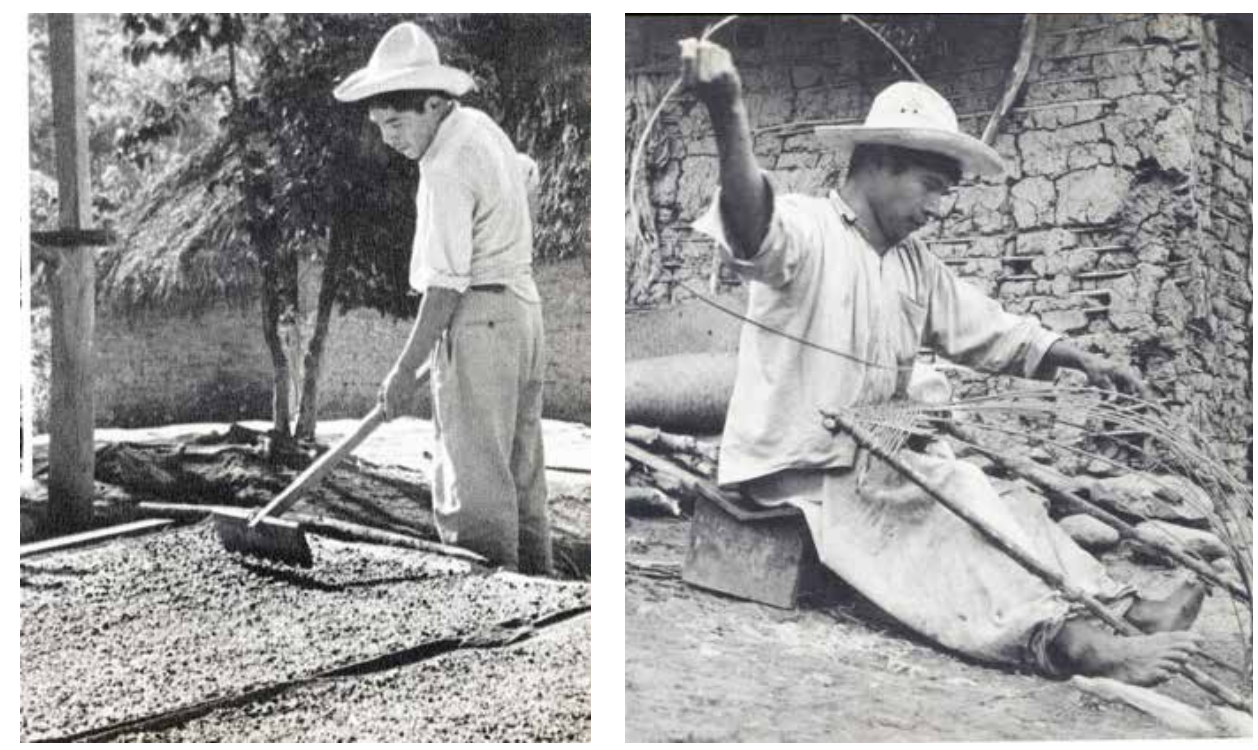

Asoleadero de café y tejiendo una cuna. (Fotos: Mtro. Roberto Weitlaner). 
CAZA Y PESCA. Debido al mosaico de ecosistemas que presenta la región, la fauna silvestre ha estado representada por multitud de especies, incluyendo el puma y el jaguar. A estos, la antigua población los consideró siempre como los mayores exponentes de la fuerza entre los animales, lo cual, cuando alguno de ellos era cazado, su carne era comida en un acto de magia simpática encaminado a dar fuerza a la persona consumidora. En las partes altas del territorio se ha cazado al venado de una manera colectiva y mediante el sistema de arreadas con el auxilio de perros. La carne del animal capturado ha sido siempre repartida en partes iguales entre los cazadores. Antiguamente el grupo Cuicateco usó cerbatanas, arcos y flechas para hacer sus capturas. En la actualidad es la escopeta el elemento principal. La fauna de las partes bajas ha sufrido una considerable merma, en parte por la disminución de sus áreas habitacionales, y parte porque en la región han operado partidas de cazadores deportivos y profesionales que han efectuado verdaderas matanzas. Aún se recuerda una cacería de arreadas organizada por ciudadanos tehuacanenses, efectuada en 1961 en que se mataron 73 venados, y quedaron 6 agónicos cuyos restos los campesinos y un custodio del INAH encontraron, que sencillamente se pudrieron en el campo.

En la región oriental, donde los escurrimientos son mayores algunos individuos han practicado la captura de pequeños crustáceos, principalmente langostinos de río. En las laderas que vierten al Río Santo Domingo, y que presentan la vegetación más densa de toda la región, ha existido la caza de ciertos cuadrúpedos mediante trampas. Para los indígenas Cuicatecos la fauna silvestre tiene un "Amo" y ha sido frecuente que, antes de emprender una cacería comunal, se realice una ceremonia de solicitud de autorización a ese "Amo de los Animales".

Aún cuando las corrientes fluviales que parten de la región ocupada por el grupo son de dimensiones importantes y contienen varias especies de peces, la pesca no es una actividad diseminada en la etnia.

MERCADOS. Los principales mercados están en poblaciones próximas a la zona Cuicateca. En Santa María, Concepción y Reyes Pápalo existen mercados esporádicos. La actividad mercantil está en manos de mestizos, y principalmente de mestizos mixtecos, quienes ejercen la distribución de mercancías desde Cuyamecalco Villa de Zaragoza. En los mercados del área se realizan intercambios, principalmente de leña o café por maíz.
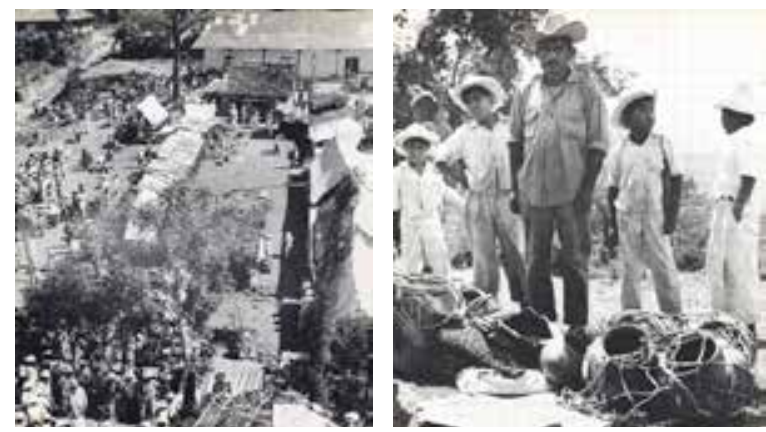

Mercado de Teotilalpan y vendedores de cántaros. (Fotos: Mtro. Roberto Weitlaner). 
ARTESANIAS. Además de los textiles sobre algodón, huipiles bordados, en algunas comunidades se ha trabajado la lana con la que se hacen sarapes y cobijas. Asimismo, la única otra artesanía regional es la cerámica. Se hacen cunas de mimbre.
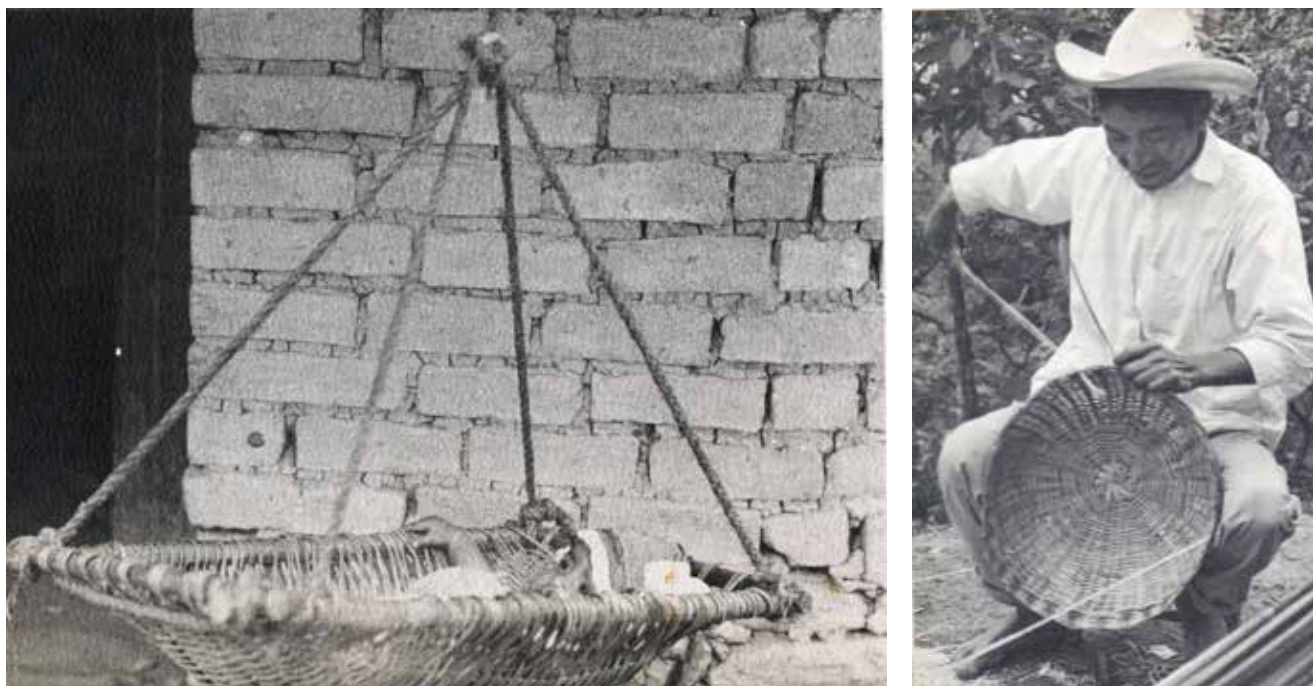

Cuna de mimbre y Tejedor de canastos. (Fotos: Mtro. Roberto Weitlaner).

ORGANIZACIÓN SOCIAL. Entre los Cuicatecos la descendencia es bilateral, pero la residencia es patrilocal. El grupo es por lo general monógamo, aunque se conocieron casos de poliginia, y principalmente de poliginia sororal que se presentaron en San Andrés Teotilalpan. Aunque el grupo es en general endogámico, se presentan también bastantes casos de exogamía. Estos se han dado entre individuos que viven en barrios diferentes.

Para la realización de un matrimonio, en la mayor parte de la zona cuicateca los padres del novio requirieron de los servicios del "Huehuetlataco", que era el encargado de pedir a la novia, la cual era otorgada después de las consabidas visitas de los padres del muchacho. En ciertas poblaciones el novio era el encargado de adquirir todo lo necesario para la novia y en Teotilalpan la persona que contestaba las negociaciones debía ser la madre de la novia. La boda fue una fiesta que no siempre culminó en la iglesia y al día siguiente los novios fueron a vivir en las cercanías de la casa del muchacho.

Dependiendo del pueblo las costumbres de enterramiento son diferentes, existiendo en la región tres tipos de ceremonias. Casi invariablemente las ofrendas consisten en pequeñas vasijas que contienen 7 granos de maíz, 7 de frijol y 7 de cacao así como un pequeño grano de chía. La ofrenda se deposita cerca del cuello, si es varón, y si es mujer se le coloca encima de una pequeña canasta. Es costumbre rezar el novenario, y, a su terminación se lleva a la tumba una cruz de madera. Los enterramientos se realizan con la cara hacía el oeste, donde se encuentra Cerro Cheve que es una de las montañas sagradas de la región. En los entierros tanto infantiles como de adultos, se suelen poner pequeños juguetes que tienen como función servir como útiles en el más allá. Se piensa que los espíritus de los muertos van al cielo y las almas permanecen en la tierra para volver a recorrer los caminos transitados en vida. 

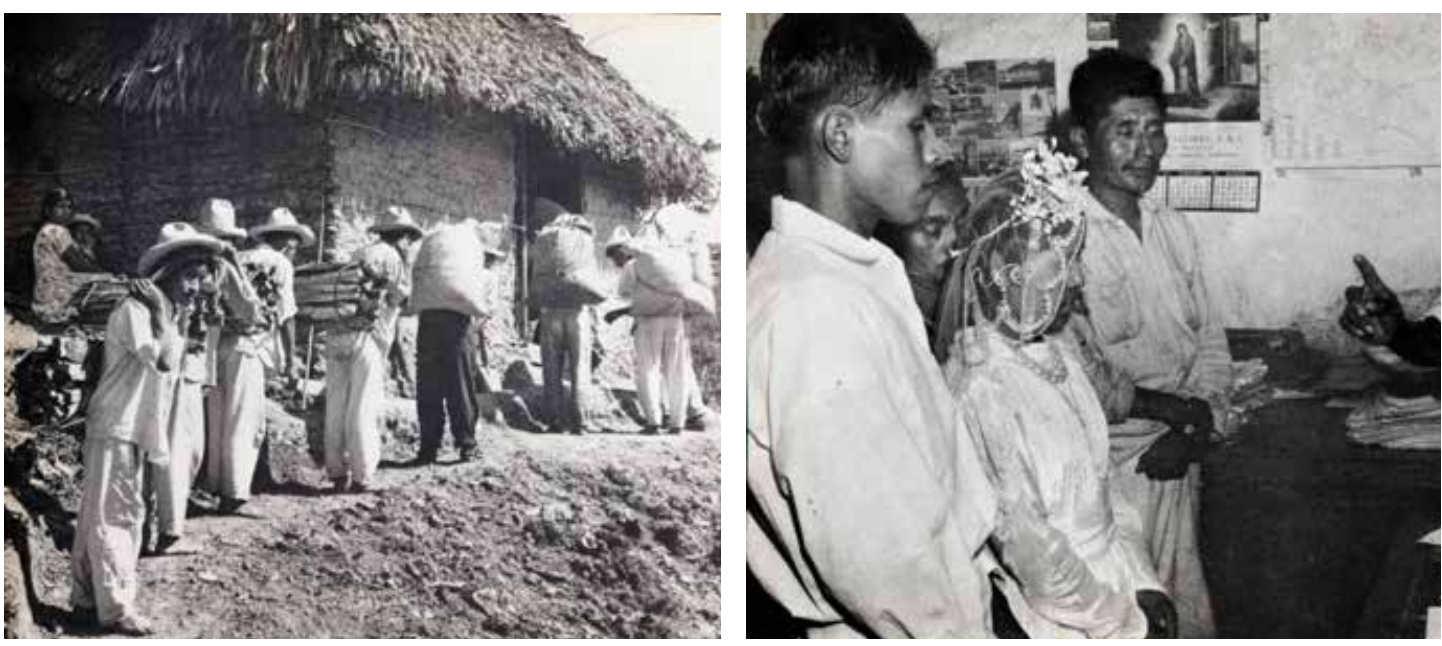

Entrega del compromiso de novia y Boda religiosa. (Fotos: Mtro. Roberto Weitlaner).

Los adornos de las tumbas se suelen hacer con arena o con flores; La primera es pintada de brillantes colores y así es utilizada. Después de este acto se erige una cruz. Existe la institución del compadrazgo, siendo los principales padrinos los de bautismo y boda.
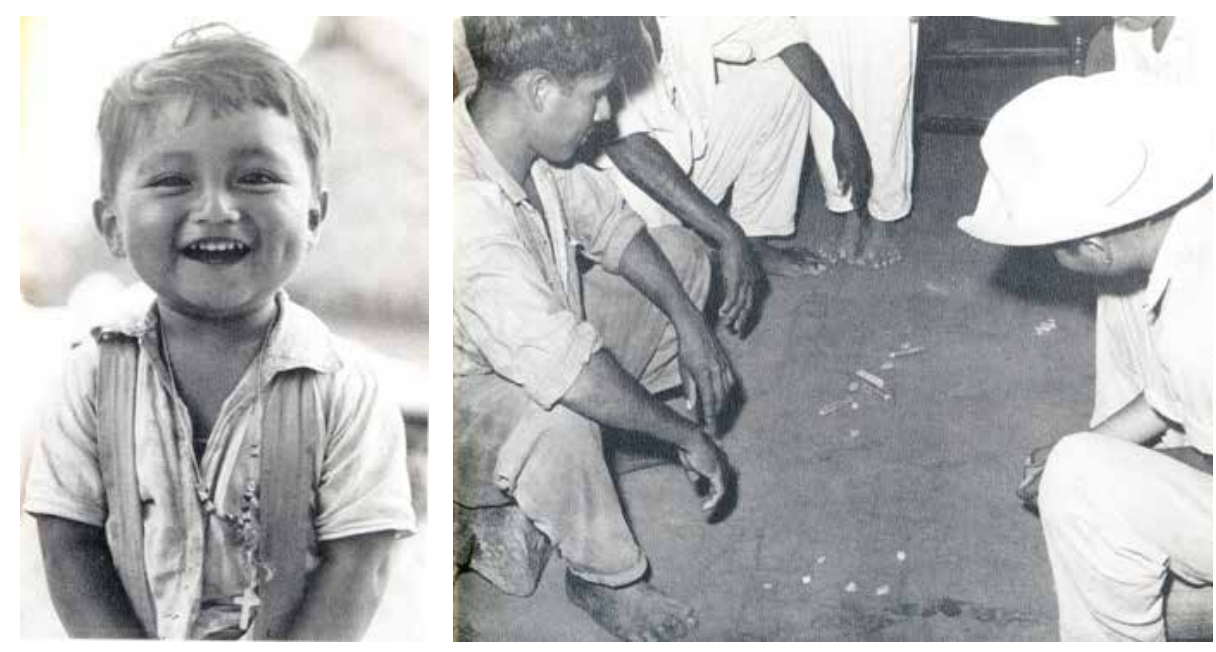

Niños cuicatecos. Uno portando su "rosario macho" y otros jugando al Patolli. (Fotos: Mtro. Roberto Weitlaner).

GOBIERNO. Además de los Gobiernos Municipales, en el grupo existe una organización jerárquica rotativa en la que se requiere ocupar una sucesión de cargos antes de llegar a presidir el Ayuntamiento. En Teponaxtla existe una manera peculiar de penalización para quienes infrinjan la ley. Esta penalización es una reminiscencia colonial, y consiste en la aplicación de una determinada cantidad de azotes, generalmente 12, aplicados al infractor en la espalda, sea cual sea su sexo. A este acto se le denomina “ dar una arroba de azotes”. 


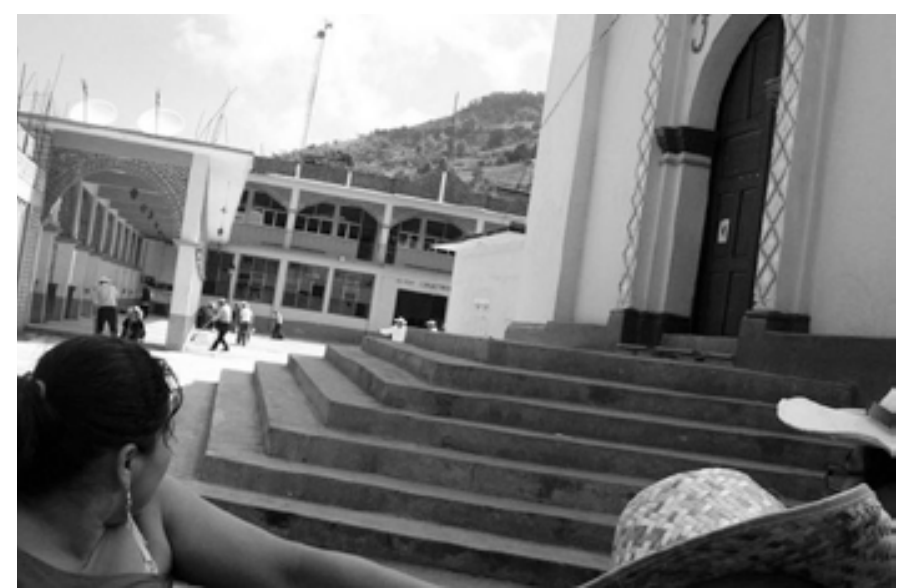

Centro de Cuyamecalco con Palacio Municipal al fondo. (Foto: Ayuntamiento de Cuyamecalco).

FESTIVIDADES. Cada población tiene su Santo patrón, además se festeja el Domingo de carnaval y la Festividad de Año Nuevo. Las personas encargadas de dirigir las festividades y de establecer los grupos actuales en cada población reciben sus cargos en Cuicatlán y esos cargos le permiten participar en asuntos de litigios. Muchas de las labores del grupo son comunales y se realizan mediante tequio. En Concepción Pápalo, en las festividades se usan chirimías, flautas, pequeños tambores y máscaras de madera y de pieles de animales. En San Andrés se ha conservado la tradición de tocar un pequeño salterio. En el carnaval de Santa María Pápalo se representa el demonio con una máscara que lleva cuernos de venado curvados hacia abajo y que va vestido de etiqueta y pantalones negros.

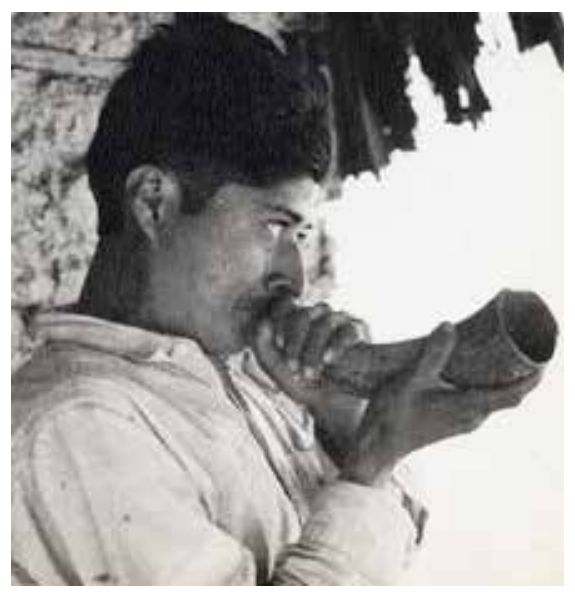

Topil cuicateco llamando a reunión. (Foto: Mtro. Roberto Weitlaner).

Los huehuetones de Concepción Pápalo son personajes vestidos de mujer que revelan una gran antigüedad. En la región se conserva tradición oral. Existen varios mitos relacionados con animales y con la creación del mundo, del sol y de la luna. 
ORGANIZACIÓN RELIGIOSA. En la región existen varias iglesias construidas en la época colonial: las más antiguas son consideradas de mayor importancia. Cada una de ellas está a cargo de un sacristán.

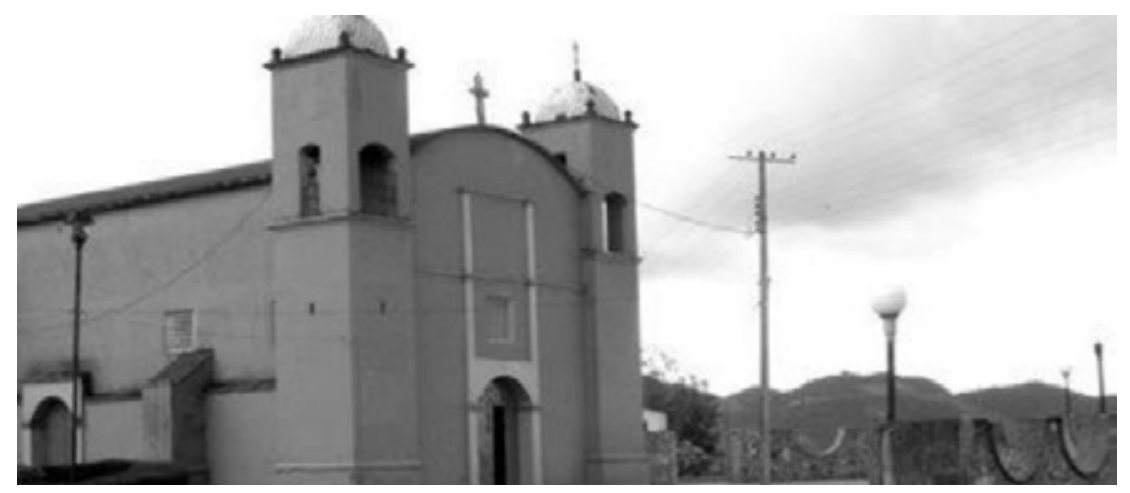

Iglesia de Concepción Pápalo. (Foto: Ayuntamiento de Concepción Pápalo)

En la mayor parte de las poblaciones se establecen Mayordomías y esos Mayordomos tienen a su cargo sacar adelante las festividades. En algunas comunidades el grupo colabora ampliamente con la persona designada a fin de asegurar la realización del evento. El cargo del Mayordomo forma parte de la vida de la persona agraciada, la cual puede también ocupar el cargo político que le corresponde debido a su edad.

MEDICINA Y MAGIA. En las comunidades cuicatecas han existido siempre hechiceros. Estos realizan las curaciones mediante buenos conocimientos de herbolaria y de psicología de los pobladores de la región. Se cree en la "pérdida del alma" y la acción de los "malos aires". En la etnia subsiste una gran cantidad de mitos; Uno de los principales se refiere a una figura mítica llamada "Señor del Cerro" que vive en el Cerro Cheve, la eminencia que domina Tlalixtac. Además, en varios lugares de la región existen cuevas en las que se practican ceremonias. En éstas los hechiceros, a los que el maestro Weitlaner consideró Shamanes, realizan ofrendas consistentes en cañas llenas de aguardiente y comida. Se considera también que en las cuevas viven duendes o chaneques y, tanto la imagen del sol como de la luna y de los planetas tienen menor importancia como apoyo a las deidades.
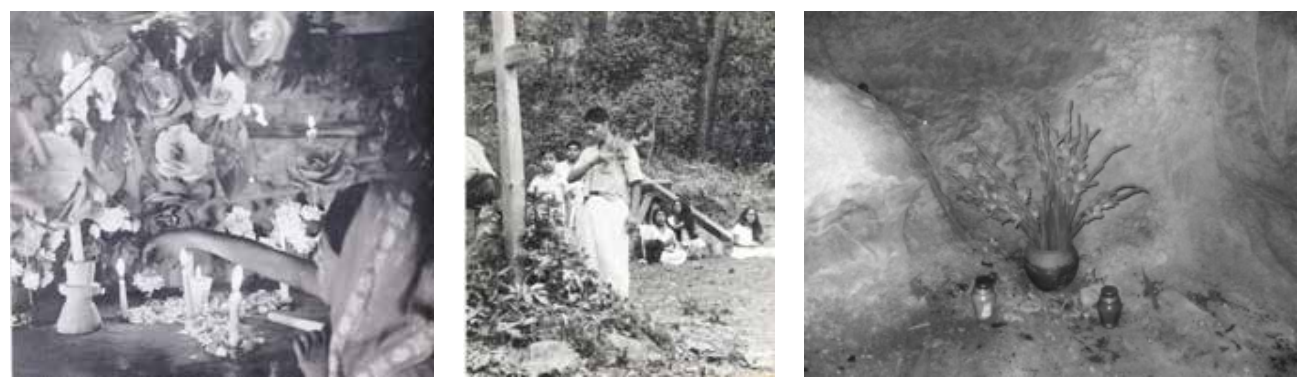

Altar y Limpia de "Mal aire" en Teotilalpan y ofrenda en el Cerro Cheve. (Fotos: Mtro. Roberto Weitlaner ). 
En prácticamente todas las ceremonias propiciatorias se sacrifican aves. Aunque existe mucha similitud en las creencias con las del grupo Chinanteco, también existen grandes diferencias. En muchas ceremonias cuicatecas los ruegos están pronunciados en una variante especial de la lengua por parte de individuos que actúan como rogadores especiales. En las poblaciones cuicatecas subsisten muy ligeramente los conceptos de tona y nahual, y sólo en el folklore de la región se les hace alusión de una manera velada. Subsiste la adivinación mediante granos de maíz.

Desde hace muy pocos años han comenzado a existir servicios médicos institucionalizados en la región. Actualmente se encuentran unos cuantos pasantes de medicina realizando su servicio social en Centros de Salud, y sólo en la población de Cuicatlán se pueden consultar médicos titulados.

EDUCACIÓN. Aunque existen escuelas primarias en muchas comunidades Cuicatecas, el índice de escolaridad no es diferente del resto de las zonas marginadas del Estado. Sin embargo, en el área existen algunas Instituciones de enseñanza media en Cuicatlán y Tecomavaca. Se considera que prácticamente es muy poca la población que puede tener acceso a niveles de enseñanza superior al cuarto año de primaria. Pocos jóvenes pueden matricularse, algunos becados, en la Universidad de la Cañada, con sede en Teotitlán de Flores Magón, y la migración juvenil es un problema constante.

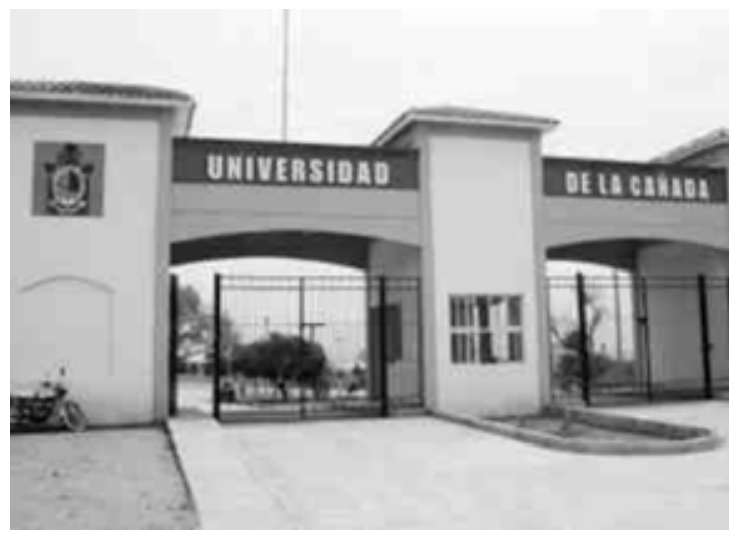

Universidad de la Cañada, Teotitlán de Flores Magón. (Foto: Sistema de Universidades Estatales).

\section{BIBLIOGRAFÍA}

Acevedo Conde, María Luisa. 2007 “Los Cuicatecos”. En: Revista A CONTRAGOLPE. № 12. Carteles Editores, Oaxaca, Oax. 2012.

Adán, Élfego. 1922 “Los Cuicatecos Actuales”. ANALES DEL MUSEO NACIONAL. 4a EPOCA. Vol. I. México, D F. 1922.

Basauri, Carlos. 1940 “Los Cuicatecos”. Reed. 1990 LA POBLACION INDIGENA DE MEXICO. Tomo II. FAMILIA MIXTECO-ZAPOTECANA. Instituto Nacional Indigenista. México, D F. 1990. 
Cerda Silva, Roberto de la. 1942 “Los Cuicatecos” REVISTA MEXICANA DE SOCIOLOGIA. UNAM. México, D F. 1942.

Gallego, Juan. 1580 "Relación de Cuicatlán”. En: PAPELES DE NUEVA ESPAÑA. Vol. 4.

Editor: Francisco del Paso y Troncoso. Imp. Sucesores de Rivadeneyra. Madrid. España. 1905.

Hernández Díaz, Gilberto. 1982 NUEVOS ESTUDIOS SOBRE LA CAÑADA. (Etnografía moderna de dos pueblos cuicatecos). Centro Regional de Oaxaca. INAH. Oaxaca, Oax. 1982.

Redmond, Elsa. Spencer, Charles. 1983 "The Cuicatlan Cañada and the Period II FrontierZapotec State”. En: THE CLOUD PEOPLE, DIVERGENT EVOLUTION OF THE ZAPOTEC AND MIXTEC CIVILIZATIONS. Eds. Kent V Flannery and Joyce Marcus. Academic Press. New York. 1983.

Sánchez, Policarpo T. 1911 “El Municipio de Cuicatlán, Apuntes Ligeros”. En: ESCUELA RURAL. Vol. 2. № 7. Mayo de 1911. Oaxaca, Oax.

Spencer, Charles S. 1982 THE CUICATLAN CAÑADA AND MONTE ALBAN, A STUDY OF PRIMARY STATE FORMATION. Academic Press. New York. 1982.

Shaffer, Elaine. 1986 GRUPOS INDIGENAS DE MEXICO. Los Cuicatecos. Panorama Editorial. Litográfica Ingramex. México, D F. 1986.

Van Doesburg, Sebastian. 2001 CODICES CUICATECOS. (Porfirio Díaz y Fernández Leal). Miguel Angel Porrúa y Secretaría de Asuntos Indígenas del Gobierno del Estado de Oaxaca. Oахаса, Oax. 2001.

Weitlaner, Roberto. 1969 "The Cuicatec". En: HANDBOOK OF MIDDLE AMERICAN INDIANS. Vol. 7. University of Texas Press. Austin \& London. 1969. 


\section{CHINANTECOS}

Autodenominación: jumi, jujmi, tsa su jmi, dza jmiih.

Sinónimo en su lengua: jau jami.

Significado en Español: Gente de palabra antigua. Gente de una misma palabra.

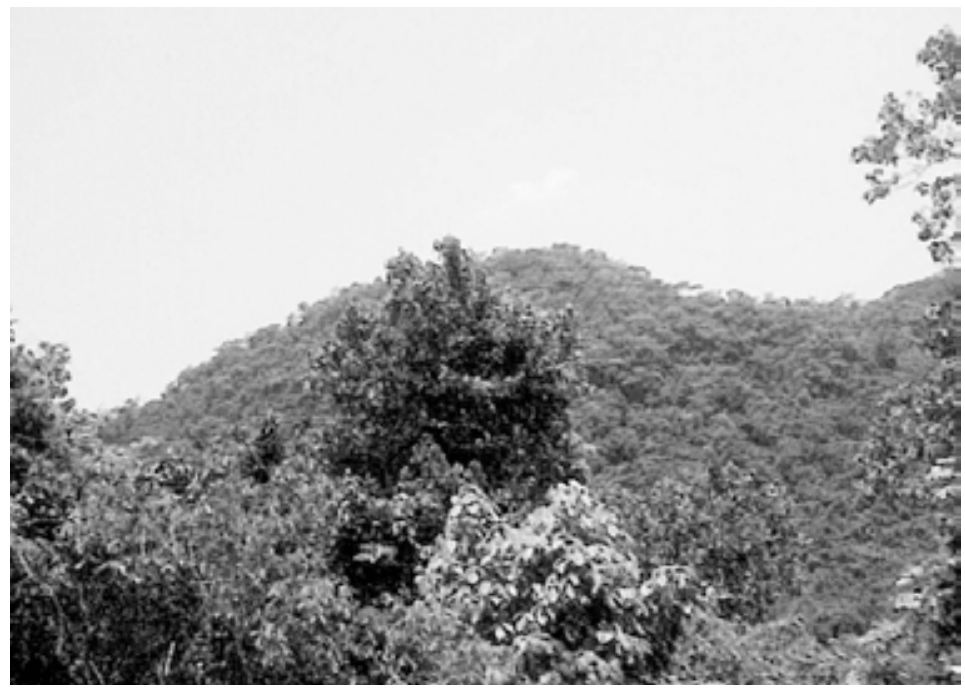

Bosque chinanteco (Foto: IIS-UNAM).

GRUPO CHINANTECO

UBICACIÓN GEOGRÁFICA. Este grupo se encuentra localizado en la porción centro norte de la Sierra Madre de Oaxaca, o sea al noroeste del estado, ubicado en 4 (cuatro) áreas. La central (municipios de Chiltepec, Jacaltepec, Ayotzintepec y Valle Nacional); La Wahmi (con los municipios de Petlalpa, Lalana y Jocotepec). La nororiental (Ojitlán, Usila, Sochiapan y Tlacoazintepec) y la de la sierra (Yólox, Comaltepec y Quiotepec). Colinda al noroeste con el grupo mazateco, el occidente con el grupo cuicateco, al sur con los zapotecos, al sureste con los mixes y al oriente con grupos del Estado de Veracruz. Con los mazatecos colindan a través de la Cuenca del Río Santo Domingo. Su posición geográfica queda inscrita entre los paralelos $18^{\circ} 10^{\prime}$ y $18^{\circ} 20^{\prime}$ de latitud norte, y entre los meridianos $95^{\circ} 40^{\prime}$ y $96^{\circ} 10^{\prime}$ de longitud occidental. La región, totalmente inscrita en la Cuenca del Río Papaloapan, es de un relieve muy accidentado que termina en lomeríos bajos y algunas llanuras en la porción oriental, y alcanza en sus máximas elevaciones en los 2725 metros 
sobre el nivel del mar. La región presenta varias subdivisiones climáticas que van desde los templados subhúmedos de los bosques de coníferas, hasta los cálidos subhúmedos de las selvas medias perennifolias. La precipitación pluvial anual de esa región se desplaza en promedio desde 650 milímetros en algunos lugares de la colindancia con los grupos cuicatecos, hasta los 3000 y aún los 4000 milímetros de las zonas húmedas de la sección oriental.

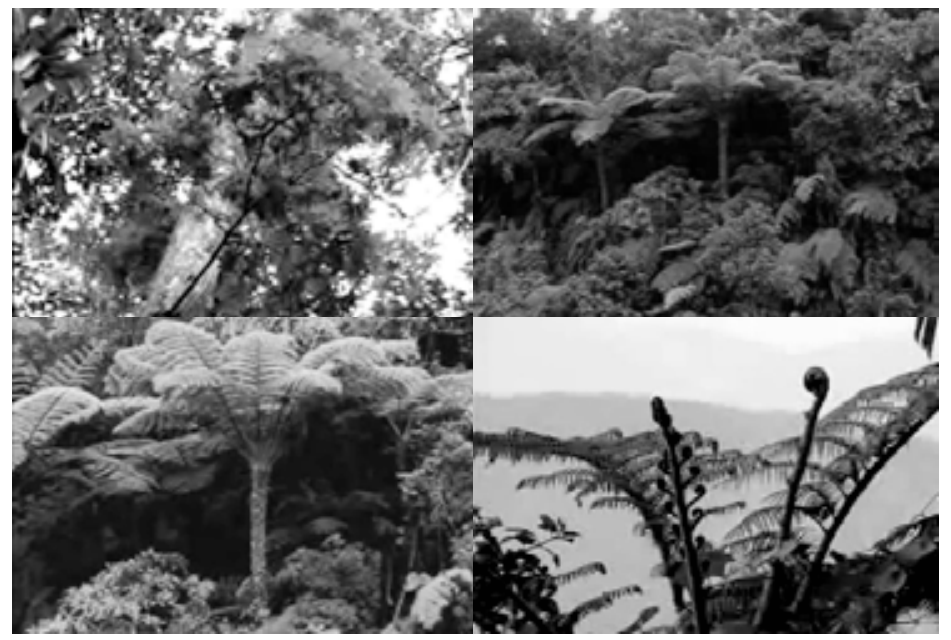

Fósiles vivientes en bosque chinanteco.

(Fotos: Coordinación General de Educación Intercultural y Bilíngüe. SEP.

La mayor parte de los suelos regionales son húmedos negros profundos, o bien suelos ácidos de color rojizo, ricos en arcilla. Las temperaturas promedio anuales fluctúan según las alturas, entre los $15^{\circ}$ y los $28^{\circ} \mathrm{C}$. La condensación en las laderas orientales es muy elevada, habiendo muy alto índice de nubosidad. Debido a las fuertes precipitaciones, muchos cerros han sido desgajados, ha habido arrastres pluviales muy graves y, por inundaciones, varios pueblos han cambiado de lugar. Chinantla, en náhuatl, significa "Donde abundan los setos o las cercas de caña”. Parte de las montañas albergan una flora superviviente de la que hace millones de años fue desplazada hacia el sur por efecto de las sucesivas glaciaciones.
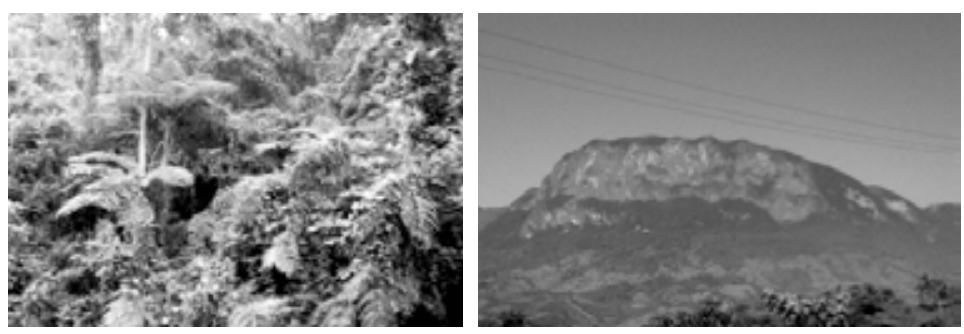

Bosque mesofilo chinanteco. (Foto: Pronatura Sur) y Cerro Pelón (Foto: Díaz Azamar).

LENGUA. La lengua Chinanteca pertenece al Grupo Otomangue. Tronco Savizaa, Familia Chinanteca y en la actualidad es hablada aproximadamente por unas 107000 personas 
debido a que las áreas de contacto con otros grupos el uso de la lengua se ha restringido. Es una lengua de gran antigüedad, puesto que existe desde hace más de 3500 años, y de la cual derivaron catorce variantes dialectales (el ojiteco, el usileño, etc.) que comenzaron a surgir hace poco más de 1500 años.

ANTECEDENTES ARQUEOLÓGICOS E HISTÓRICOS. Aunque la región contiene una importante cantidad de vestigios arqueológicos, solamente ha sido explorada sistemática, pero limitadamente, en un número muy corto de localidades: Ayotzintepec, Cerro Bobo, Yetla, Chiltepec. Paso Limón y Ojitlán, trabajos realizados, con el apoyo del Mtro. Roberto Weitlaner, por el Arql. Agustín Delgado Herrera, quien encontró grandes patios, tumbas cruciformes y cerámica decorada. Por consiguiente no sabemos sino muy pocas cosas del proceso histórico del desarrollo regional, aunque también se han producido hallazgos de osarios en cuevas, sobre todo en el área de Usila, rasgo que parece existente en el grupo desde tiempos muy antiguos, y que también puede ser un posterior y posible vestigio de epidemias tales como la de 1577. Los chinantecos fueron un grupo que elaboró una buena cerámica, tanto utilitaria como ceremonial, y que debió diferenciarse tanto de los zapotecos como de los cuicatecos al producirse la escisión de las lenguas, que en la arqueología de otras regiones de Oaxaca puede documentarse antes del período Preclásico o Formativo Inferior o Medio. De esa época existen restos de aldeas. Por su feracidad, y su riqueza de recursos, entre los cuales figura el oro obtenido en placeres, la región debió tener importancia por sus productos y su orfebrería (de la que lamentablemente conocemos muy pocos ejemplos) a partir de la iniciación del período militarista, ya que para la época tolteca era región tributaria que después sería muy codiciada por los aztecas.
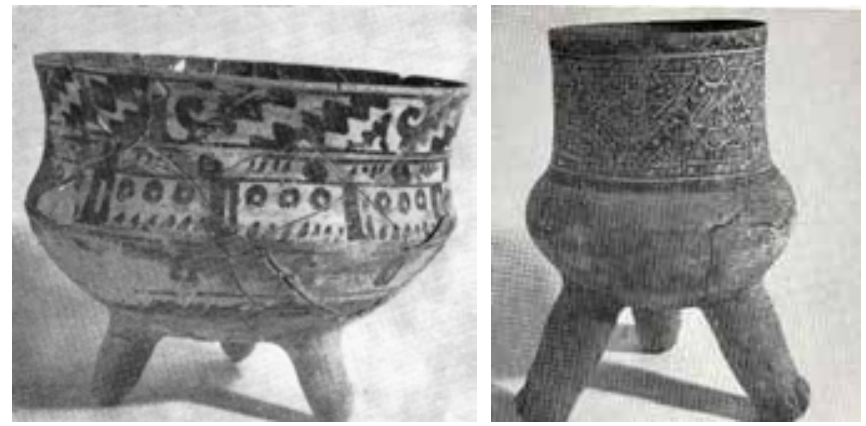

Vasijas chinantecas de origen mixteco.

(Fotos: Arql. Agustin Delgado Herrera. INAH).

Algunas tradiciones locales hablan de contactos con invasores nahuatlizados que ocuparon puntos dominantes, y a lo que parece fueron gentes conectadas con nahua-popolocas. Ya desde los tiempos de Moctezuma I Ilhuicamina los mexicas marcharon al asalto de Tuxtepec (donde existe arquitectura azteca-tlatelolca en el edificio principal del sitio arqueológico denominado "El Castillo", lamentablemente aún no restaurado), con lo que abrieron su ruta comercial cacaotera hacia Xicalanco y la planicie y los lomeríos costeros veracruzanos. 


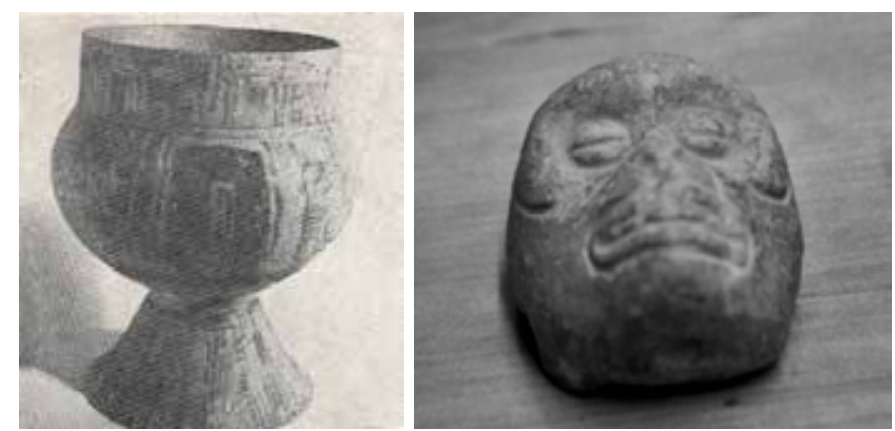

Copa chinanteca. (Foto: Arql. Agustin Delgado. INAH) y Figurilla olmecoide de serpentina. Jalapa de Díaz (Foto: Museo Regional de Tuxtepec).

Las dos relaciones geográficas del siglo XVI existentes, hechas en 1579, señalan que en las tributaciones al Tenochtitlan de Moctezuma Xocoyotzin, figuraba con suma importancia el oro y además se tributaban textiles y plumas de varios tipos de aves, incluyendo quetzales y pájaros azules del género Cotinga (Cotinga amabilis), así como pieles de ocelote, tigrillo, puma y jaguar. La población chinanteca antigua también terraceó laderas como una importante actividad. Otra tradición local habla además de un jefe y principal, Chinaam, que gobernó con acierto parte de esa zona en el Siglo XIV. Sabemos, además, que, tras la conquista mexica, un grupo de chinantecos se desprendió de Chiltepec Viejo para fundar en la zona de Choapan un principalato con varias poblaciones. Los aztecas lo conocieron como el Señorío de Coatlicámac. Este es un origen del vocablo "guatinicamanes”, con que los españoles designaron a los pobladores de gran parte de esa sierra. A fines del Siglo XIX el grupo fue estudiado ampliamente por el Prof. Mariano Espinosa.

La Conquista Española encontró a los grupos chinantecos divididos en razón de las dos subregiones del área, altos y bajos, coexistentes con dos reinos semiautónomos situados en Yoloxinequilla (Yolox) y Usila, producto de una subdivisión hecha a la muerte de un importante personaje, Quiana. Algunas fuentes hablan de un tercer reino que hubiera incluido a Malinaltepec y a Xocotepec.

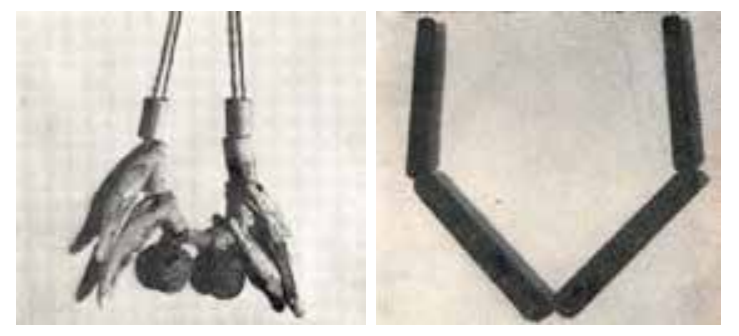

Collar de jade con cascabeles de cobre. Postclásico tardío y collar de cuentas de vidrio españolas. Período inicial de la conquista.

(Fotos: Arql. Agustin Delgado. INAH).

Se documenta que en el proceso de la Conquista los españoles subdividieron los pueblos chinantecos en varias provincias y que, por la existencia de oro, Cortés influyó 
para ser el titular de las encomiendas, en base a los informes y a la insubordinación que realizaron los primeros enviados, entre ellos el soldado Diego Pablo Pizarro "El Viejo", que fue conminado a volver ante Cortés. Poco después los indígenas regionales ayudaron a las tropas de Gonzalo de Sandoval, en un desplazamiento hasta Zempoala, Ver, portando lanzas de punta de cobre de 25 a más palmos de largo y dirigidos por el Capitán Andrés de Barrios y un soldado, Andrés Tobilla. Poco más tarde, el Capitán Gaspar Núñez Cedeño obtuvo la sumisión del grupo chinanteco serrano (1535) y en varias poblaciones permanecieron gobernando personajes que, al morir, fueron enterrados con ofrendas que incluyeron cuentas de vidrio españolas. La catequización fue realizada por varios misioneros, entre los que destacan Fray Pedro Guerrero, Fray Francisco de Saravia y Fray Mateo Daroca, quienes fueron los organizadores religiosos de la etnia, actuando en toda la región, usando la lengua náhuatl como factor de comprensión y aprovechando el gusto de la población por la música y la danza. Fray. Francisco de Sarabia, además, desde 1581 procedió a formar a los primeros catequistas indígenas. En la zona también se realizaron dos relaciones geográficas del Siglo XVI y varios lienzos ya rescatados e interpretados, el de Chinantla, el de Yetla, el de Yólox y el de Tlacoatzintepec. Durante la época independiente del país, la etnia ha participado muy poco en los sucesivos acontecimientos debido a su posición geográfica marginal. En la Guerra de Independencia hubo un combate en Ojitlán, donde el comandante insurgente fue Dn. Manuel Mier y Terán. Más tarde, sólo se documenta un pequeño contingente chinanteco en las fuerzas del ejército republicano (Ejército de Oriente del Gral. Porfirio Díaz Mori), incorporado a las tropas del Gral. Luis Pérez Figueroa, a fines de la Guerra de Intervención Francesa, así como miembros aislados de la etnia en el ejercito federal porfirista y en las pequeñas fuerzas con que Sebastián Ortíz se levantó en armas en 1911. Como consecuencia de las Leyes de Desamortización y de su aplicación por políticos y notarios inescrupulosos, que las consideraron "terrenos baldíos", durante el porfiriato se fue despojando al grupo de sus mejores tierras, lo que permitió que al comenzar el Siglo XX existiera la enorme concentración que se presentó en Valle Nacional, que fue llamado el "Valle de la Muerte", donde menos de 20 propietarios, entre los cuales descollaron los apellidos Balsa y Zamarripa, llegaron a detentar bastante más de 100000 hectáreas, en las que se sembró café y tabaco y se practicó un esclavismo sádico que costó la vida a miles de hombres, muertos de diarreas, cólera y pestes; esclavismo del que el periodista John Kenneth Turner rindió cumplido informe en su libro "México Bárbaro".

Después de 1920 la situación marginal del grupo continuó, no obstante que hubo una restitución revolucionaria de tierras, y en ellas, un posterior dominio por parte de compañías españolas, cubanas e inglesas, así como de empleados de la Standard Fruit Co, y de personajes "revolucionarios" encumbrados, tal como en el caso del Gral. Juan Andrew Almazán, quién recibió del Presidente Álvaro Obregón, como premio por su participación en la derrota de la rebelión delahuertista, 20000 hectáreas, el rancho "Las Carolinas", aunque posteriormente, a partir del sexenio del Gral. Lázaro Cárdenas del Río y de la fundación del Instituto Nacional Indigenista, se volvieron a restituir las tierras y se iniciaron programas oficiales tendientes al mejoramiento del grupo, labores en que descollaron los 
antropólogos Roberto Weitlaner y Carlo Antonio Castro. Parte de él ha sido relocalizado a partir de la construcción de las presas "Miguel Alemán" y "Cerro de Oro", habiendo ahora cerca de 50000 chinantecos en Veracruz y en la zona de los Chimalapas, con lo que ya existen nuevas diferenciaciones en el modo de vida y en la lengua.

DEMOGRAFÍA. En el año de 1982 existían aproximadamente 95000 indígenas de este grupo y de ellos, como ya se señaló hablaban su lengua alrededor de 60000 . El censo poblacional del 2010 da un total aproximado de 210 000, incluyendo los relocalizados, y presentando fuerte emigración.

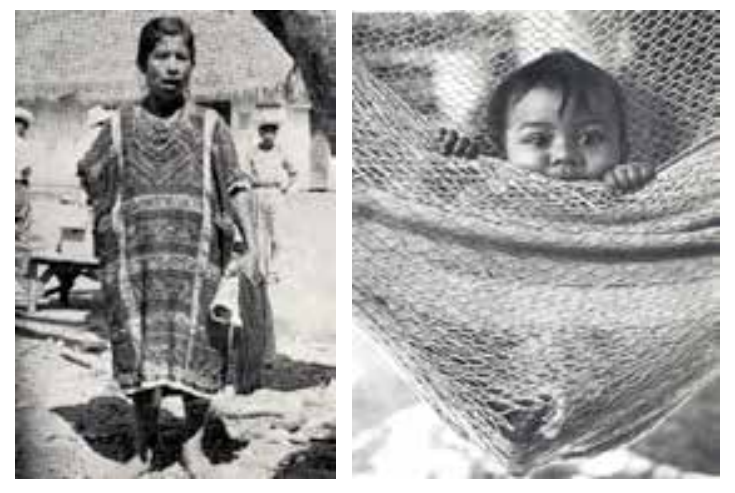

Mujer y niño chinantecos. (Fotos IIS-UNAM

y Mtro. Roberto Weitlaner).

VIVIENDA. Entre los Chinantecos se encuentran comunidades congregadas, semicongregadas y dispersas. Históricamente, en general las casas fueron rectangulares, más bien grandes, hechas de horcones con techo de pasto, con saledizo llamado "oreja" y paredes de lodo que recubrió troncos, cañas o bajareque. La base del muro estaba protegida por una línea de piedras de río. Los tipos de casa variaron ligeramente con las subregiones dependiendo de los recursos, el clima y la tradición. La mayor parte de las casas presentaban un tapanco sostenido por vigas en el que se guardaron semillas, herramientas o textiles, la cocina solía construirse aparte y hasta la actualidad el fogón suele estar en un rincón y se compone de tres o cinco piedras.
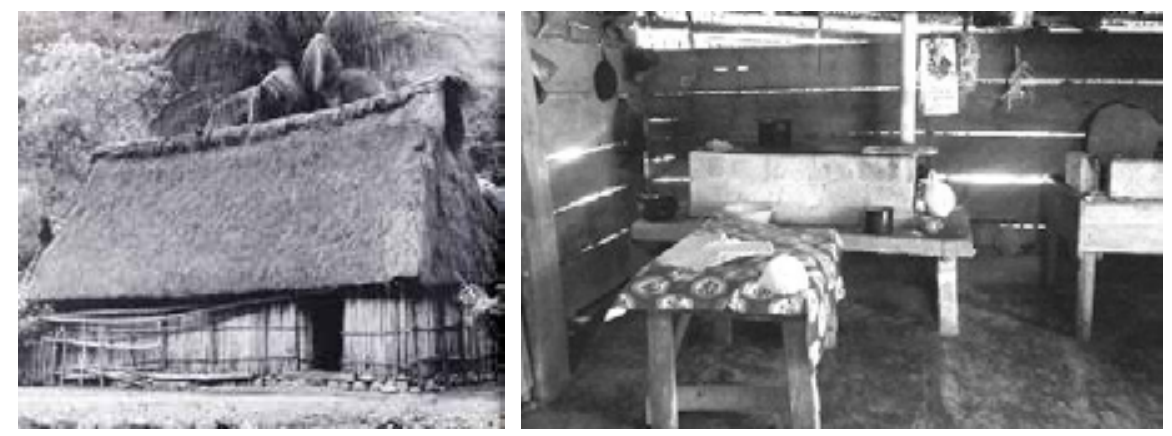

Casa en Usila. (Foto: Mtro. Roberto Weitlaner) e Interior de cocina chinanteca. (Foto:Elena Galindo). 
A medida que la familia se va haciendo más extensa, se construyen habitaciones auxiliares. Con frecuencia las casas están rodeadas por cercas de ramas o troncos. Las familias duermen en promiscuidad y con frecuencia dentro de la casa duermen también animales domésticos. Ahora, en 2014 ya son muy frecuentes las casas de materiales de construcción, máxime que muchos de los recursos aportados por las remesas de migrantes se han canalizado a la construcción de viviendas y locales comerciales.

INDUMENTARIA. Dentro del grupo existe una fuerte tradición apoyando el trabajo sobre textiles. Ha sido tradicional que las mujeres elaboren sus propios trajes, en telar de cintura, los que principalmente son huipiles de algodón y que bordan muy ricamente incluyendo además lazos y cintas de vivos colores. Es muy frecuente que los bordados sean de formas geométricas o con diseños que representan animales.
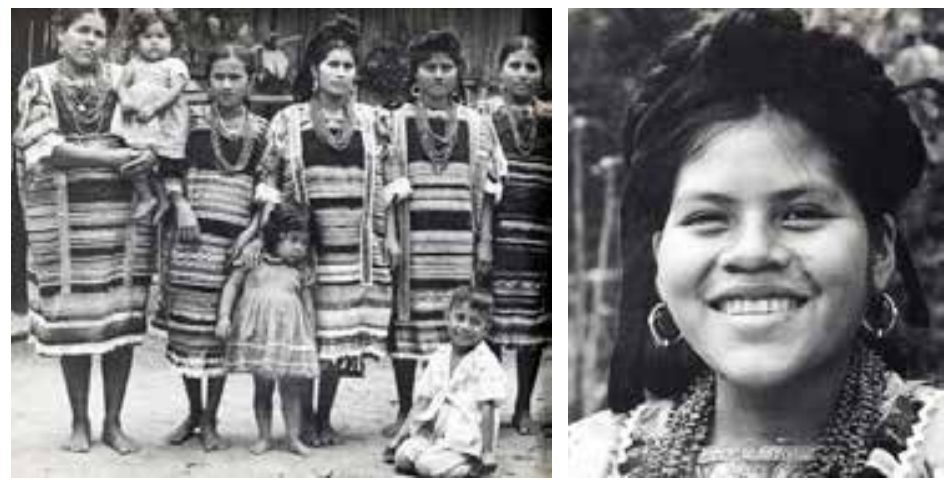

Mujeres, niños y jóven casadera en 1962. (Fotos: Mtro. Roberto Weitlaner).

Los huipiles más elaborados se fabrican en la región occidental y algunos diseños tienen significados especiales, tales como la diferenciación entre si la mujer portadora esté o no casada.

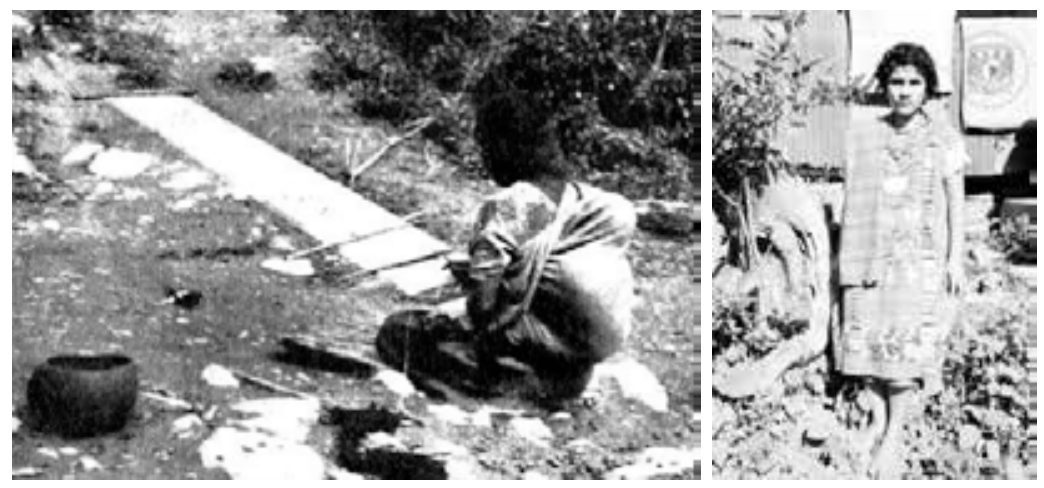

Tejedora y joven mujer chinantecas. (Fotos: Frederick Starr en 1906 e IIS-UNAM).

La población masculina ha perdido casi completamente su indumentaria tradicional y a la camisa y el calzón se manta se han agregado la camisa de algodón comercial, la camiseta 
y el pantalón de dril y de mezclilla. En algunas comunidades las mujeres llevan tocados en los que el cabello se entrelaza con cintas, de tal modo que llega a elaborarse un peinado en forma de corona. Frecuentemente la población masculina usa huaraches y la femenina suele andar descalza, aunque ya esta establecido el uso de sandalias de plástico.

ACCESOS. Por vía aérea era posible llegar a Usila, cuya pista de aterrizaje permite el acceso de aparatos poco mayores que una avioneta. Ahora, a Usila, ya existe una carretera. La porción oriental del área es tocada por la carretera pavimentada que une a la Ciudad de Oaxaca con Tuxtepec en la región de Valle Nacional. La porción norte está atravesada por la entonces carretera de terracería que une Tuxtepec con Huautla de Jiménez a través de Jalapa de Díaz, y que ahora ya está pavimen
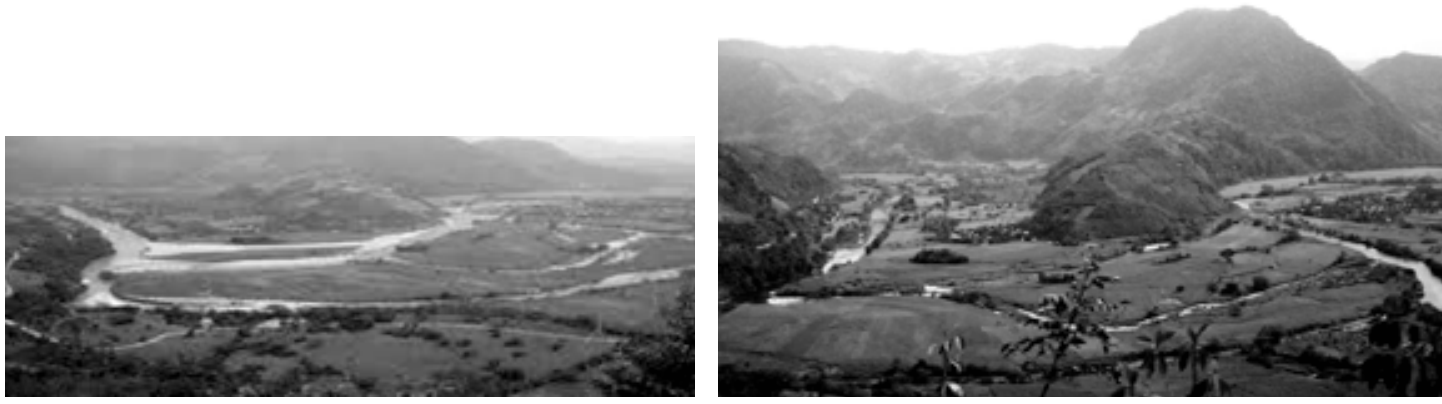

Panorámicas del Valle de Usila en 1962. (Fotos: Mtro. Roberto Weitlaner).

Una parte del área cuenta con brechas y caminos de terracería transitables con dificultad. Durante los meses de secas y cuando los ríos no están muy crecidos: éstos resultan ser vías importantes de acceso. El gran número de ríos y arroyos ha sido siempre un limitante muy importante para el tráfico mediante recuas, porque interrumpe la continuidad de las veredas y en algunos lugares se han hecho hamacas de lianas a manera de puentes colgantes.
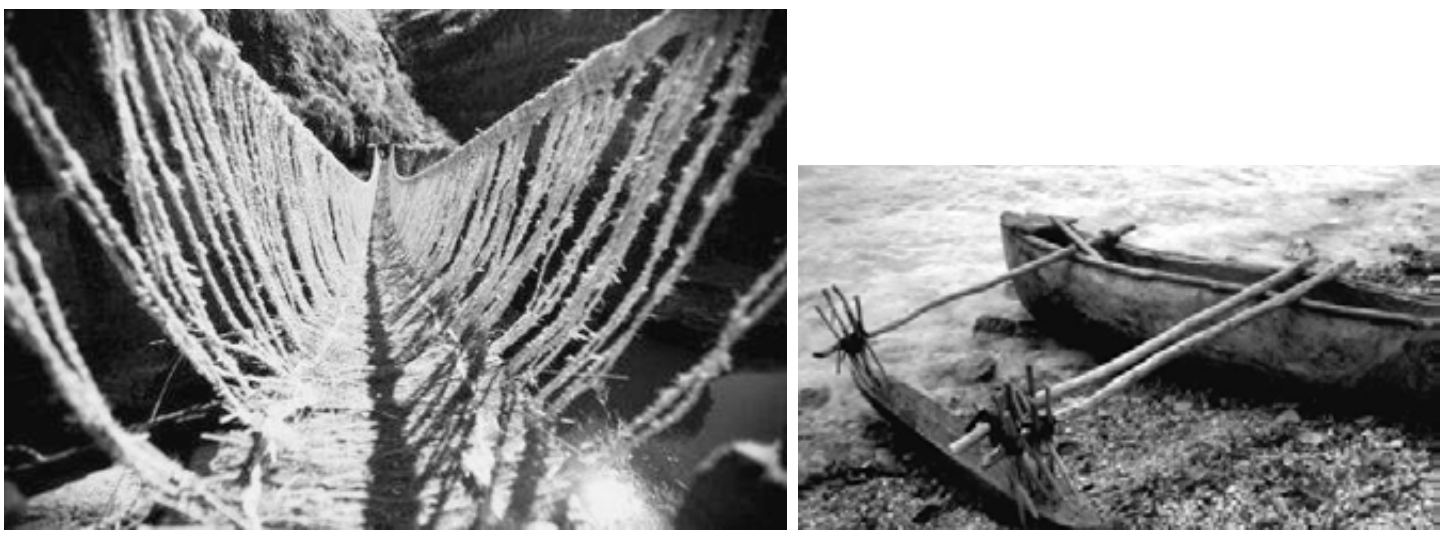

Hamaca de lianas y canoa con estabilizador chinantecos. (Fotos: Mtro. Roberto Weitlaner).

Algunas canoas de la región cuentan o contaron con estabilizador (lo cual es un rasgo importantísimo por su origen prehispánico), así como también en algunos tramos de ríos 
se usan balsas que, desde la época prehispánica, se construyen con madera ligera, muy flotante.

ECONOMÍA. La economía de este grupo parte de la organización social política y religiosa del mismo. Como la de todas las etnias del país no puede ser analizada en términos de costo-beneficio, ya que las comunidades indigenas mantienen procesos que las adaptan a las condiciones económicas nacionales. En las actividades económicas del grupo se hallan reflejadas sus características propias; y aunque el territorio tiene recursos suficientes, las relaciones comerciales y de producción están estructuradas de tal manera que es el indígena el que resulta tener menor poder adquisitivo. Como en todas las zonas deprimidas del estado. La depauperación del grupo chinanteco se agudiza, no sólo porque el grupo pretende satisfacer sus necesidades echando mano de los recursos de la región, sino porque con suma frecuencia el indígena tiene que tomar parte de su producción para adquirir bienes que no puede producir, apareciendo de esta manera los sistemas de intercambio desigual.
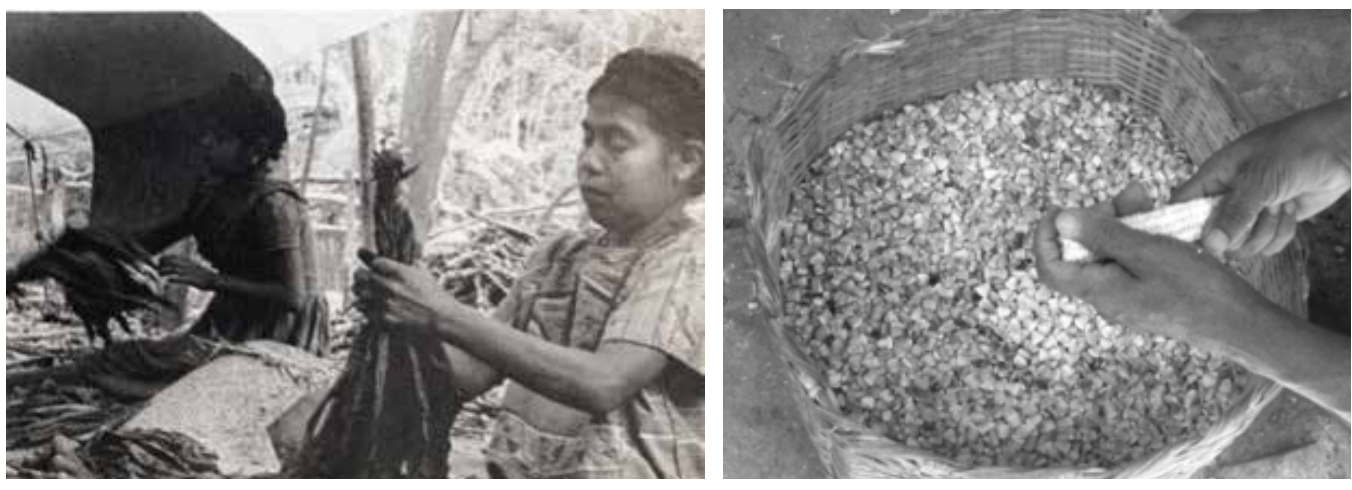

Chinanteca limpiando tabaco y desgrane de maíz.

(Fotos: Mtro. Roberto Weitlaner).

Los cultivos principales de la región, a demás de los básicos de autoconsumo (maíz, frijol, calabaza y chile) son el café, el tabaco y la caña de azúcar, con ocasional recolección de barbasco. Estos son comercializados mediante las empresas que se dedican a su distribución, y sus beneficios dotan limitadamente a la población indígena.

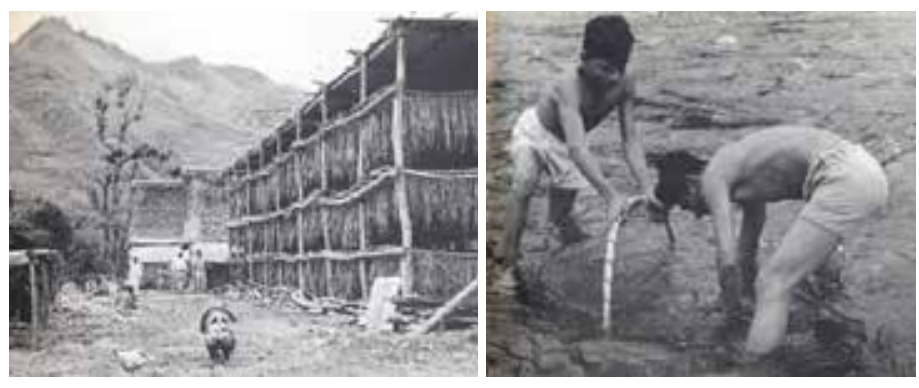

Secadero de tabaco y pesca con nasa en Usila (1962).

(Fotos: Mtro. Roberto Weitlaner). 
En gran parte del área se han explotado ya los bosques y las selvas medias, habiendo zonas en las que el daño a la cubierta vegetal es muy grande. La comercialización de la madera tampoco está beneficiando a la población indígena.

ARTESANIAS. Tradicionalmente los chinantecos se caracterizaron por la elaboración de buena cerámica. En la actualidad esta actividad ha decaído y ya se usa ampliamente una cerámica de menor calidad que procede de Ojitlán. También son característicos en el grupo los textiles, huipiles, servilletas, manteles, faldas y cobijas, los cuales se realizan sobre prendas de algodón decoradas con hilo del mismo material.
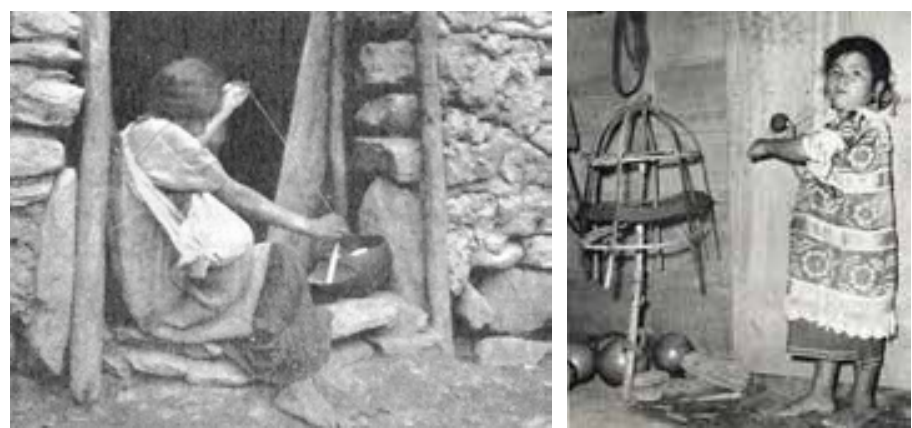

Chinanteca hilando en 1906 y Aprendiz de hilandera.

(Fotos: Frederick Starr y Mtro. Roberto Weitlaner).

Algunas mujeres hacen collares con semillas silvestres y existen hombres que elaboran redes de ixtle, metates de piedra volcánica y canoas hechas con troncos de ceiba o de guanacastle ahuecados. En regiones en que los ríos aumentan su nivel, se han realizado puentes colgantes de bejuco (jonote real). De ese mismo material también se hacen canastos y chiquihuites.

GANADERÍA. La ganadería en las regiones chinantecas es extensiva y presenta muy poco desarrollo con bovinos de baja calidad. Existe ganado menor y cerdos en pequeña cantidad, criados de manera doméstica, en zahúrdas con muy poca higiene y por ello frecuentemente sujetos a graves parasitosis (teniasis), y el principal apoyo en la alimentación para obtener proteína animal es la cría de aves de corral, principalmente guajolotes.

CAZA Y PESCA. La región es rica en especies vegetales, lo que ha permitido una fauna silvestre particularmente rica. Entre las especies características principales del área se encuentran el mono araña, el venado temazate, el jaguar, el cojolite, el hocofaisán, el agutí o paca y el tepezcuintle. En todos los casos la caza se practicaba solicitando la pieza al "Amo de los Animales". Todas las especies están sujetas a un mayor o menor grado de persecución, y por ello las posibilidades de un aprovechamiento racional se aleja cada vez más. Sería muy aconsejable lograr establecer en esa área reservas y criaderos de fauna silvestre, principalmente de los dos tipos de venado (temazate y cola blanca) y de tepezcuintle. 
Dados los recursos hidráulicos de la región, abundan diferentes especies de peces. En el grupo, el pescado ha constituido siempre parte importante de la dieta, capturándose, ya sea con red o nasa y en ocasiones, con fisga, con trampas, envenenamiento o con explosivos.

Una resultante del aprovechamiento de la pesca en el grupo es el Caldo de Piedra, en el que piedras de origen volcánico, calentadas al rojo, cuecen dentro de una olla la combinación de ingredientes encabezados por el pescado cortado en trozos.

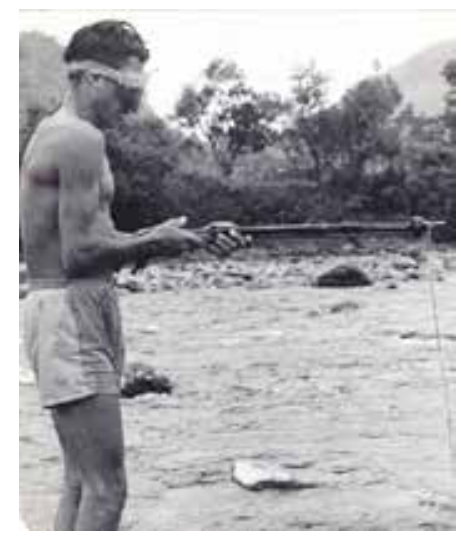

Pescador de bobos. Río de Usila.

(Foto: Mtro. Roberto Weitlaner).

MERCADOS. El único mercado regional se encuentra en Yólox. La mayor parte de la comercialización es realizada por indígenas de otros grupos, o por mestizos. El mercado de Yólox presenta los mismos procesos de intercambio de otros mercados de comunidades indígenas- Subsiste un tipo de trueque, y formas de intercambio desigual con pérdida de poder adquisitivo para la población indígena.
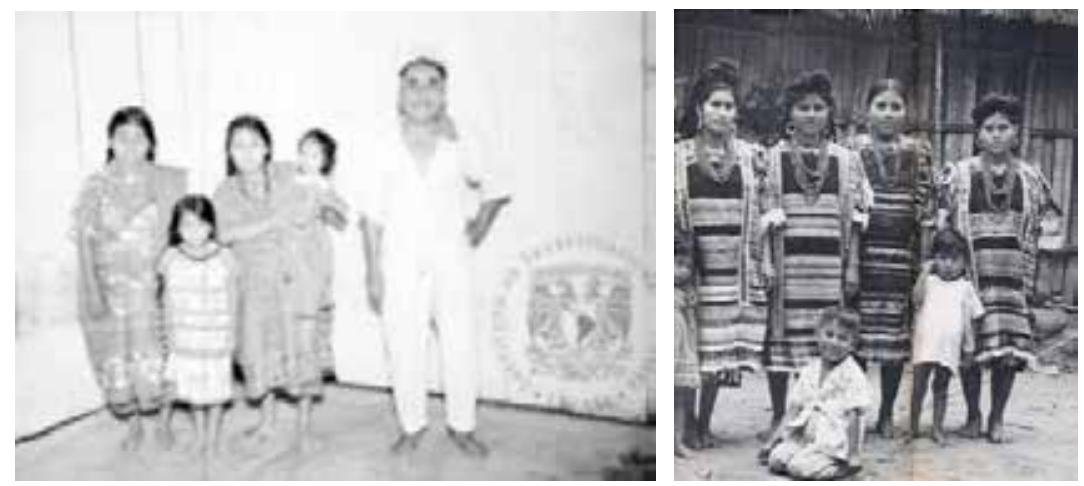

Familias chinantecas. (Fotos: IIS-UNAM y Mtro. Roberto Weitlaner).

ORGANIZACIÓN SOCIAL. La sociedad chinanteca es aglutinada y se fundamenta en la familia. Esta es patrilineal, patrilocal, monógama y endogámica. La familia nuclear está constituida por la pareja conyugal y los hijos menores, y de manera ocasional, por los padres supervivientes. Se conocen casos de poliginia aunque no son frecuentes. 
El proceso matrimonial mantiene su ritual. El joven pretendiente debe demostrar a los padres de la novia su capacidad física y económica para mantenerla. Para lograr la unión, obsequia a los padres de ella parte de sus bienes. Poco después de casados comienzan a vivir en a casa de los padres del muchacho, y no será sino hasta varios años después que pondrán su casa aparte. Para la construcción de esta intervendrán los parientes próximos y ese recibirá apoyo de la comunidad. En las zonas bajas la expansión familiar hará que crezca el número de casas en cada unidad, porque cada casa será ampliada sucesivamente. Los agrupamientos de casas van a construir los barrios y varios de ellos constituyen la comunidad. Al producirse una defunción, después del aviso con toques de campanas, se suele realizar un velorio en el que un rezador pide por el alma del difunto, y se entierra con acompañamiento de prendas de vestir, comida y una cruz de palma o un rosario. Además, se practica el novenario y la "levantada de cruz". Esta es de cal y tiene a su lado un altar familiar. Posteriormente esa cal, recogida cuidadosamente, es llevada al panteón.

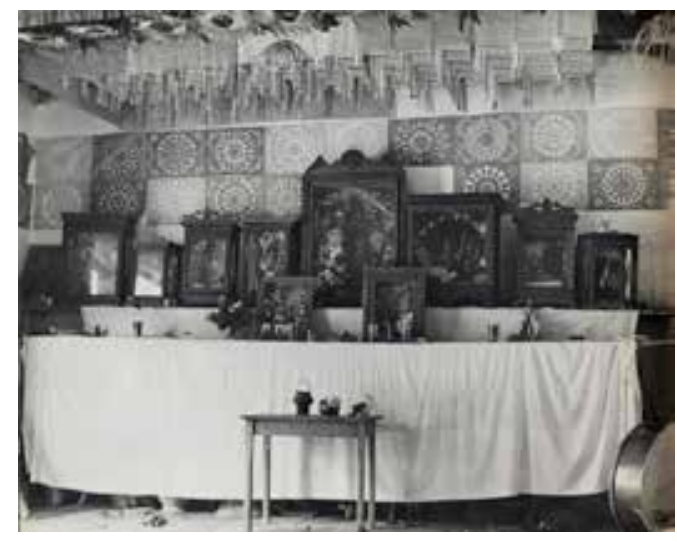

Altar de muertos. Usila. (Foto: Mtro. Roberto Weitlaner).

GOBIERNO. Al lado del aparato jurídico político del estado Mexicano subsiste la forma tradicional de gobierno. Esta está principalmente representada por el Consejo de Ancianos, el cual está constituido por las personas de mayor edad y más experiencia de la comunidad. Por tanto, para acceder a los puestos de mayor jerarquía es necesario haber ocupado antes todos los de jerarquía menor. Los hombres participan por turnos en la responsabilidad de los cargos sin otra retribución que el prestigio logrado ante la misma. Cada anciano, además, participa en la representación de los intereses de su barrio. El consejo es responsable además de las actividades socio-religiosas. Recientemente esta costumbre se ha comenzado a dejar de practicar.

FESTIVIDADES. Son muy numerosas las festividades del área Chinanteca. Además de las fiestas del Santo Patrón de cada pueblo existen las festividades religiosas-cristianas, muchas veces mezcladas con rasgos de festividades anteriores a la conquista. Se festeja el Carnaval, la Semana Santa y, el 3 de mayo, el Señor (Cristo Negro) de Otatitlán. La población chinanteca es amante del canto, la música y el baile, y por ello su cristianización no 
presentó tantos problemas como la de otras regiones del estado. Para la fiesta principal de cada pueblo se designa un mayordomo que es el encargado de organizar el festejo y la celebración. Además ese mayordomo ostenta el cargo de guardián de la fe y guardián de la divinidad. Muchas de las actividades propias de las fiestas arrancan de ritos prehispánicos.
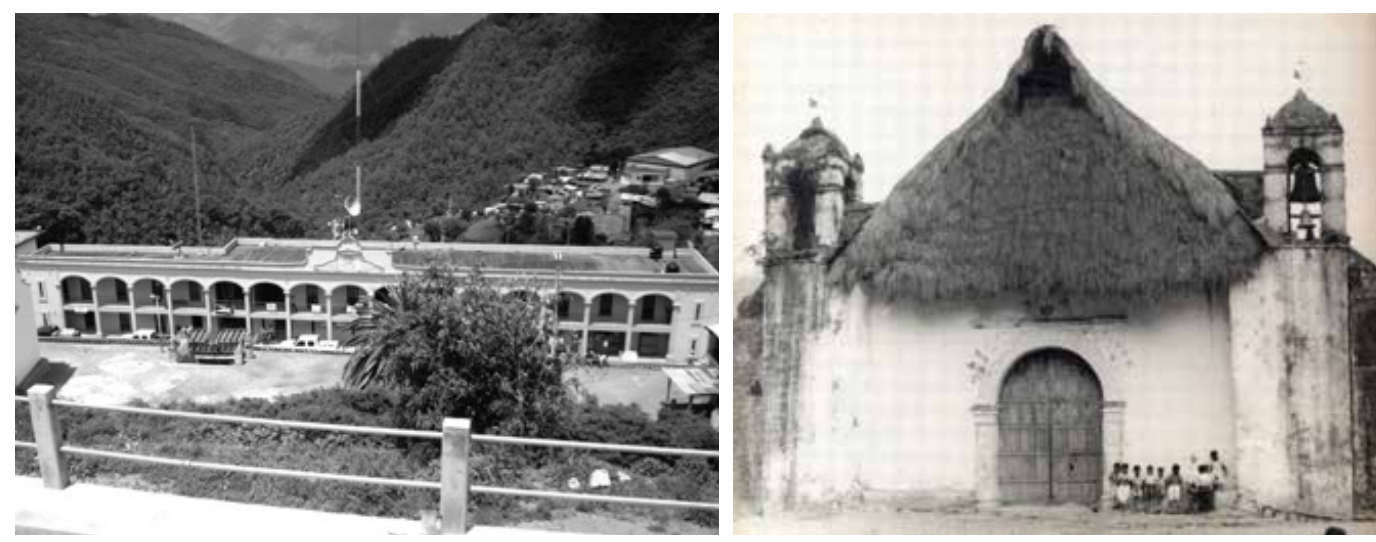

Actual palacio municipal de San Pedro Yolox e Iglesia de Usila. (Fotos: Panoramio y Mtro. Roberto Weitlaner).

ORGANIZACIÓN RELIGIOSA. Además de la mayordomía, el cuidado de la iglesia está a cargo de su sacristán, y existe una relación estrecha entre las diferentes parroquias. Durante los últimos 30 años se han infiltrado grupos protestantes que han provocado divisiones en las comunidades. Muy frecuentemente estas situaciones se iniciaron con el establecimiento de elementos del Instituto Lingüístico de Verano, los que, por ser catequistas, no actuaron, como investigadores, con la ética profesional debida.

MEDICINA Y MAGIA. Entre los chinantecos subsiste el concepto del "Amo de los Animales Silvestres", y el "Padre y la Madre del maíz". Existieron también hasta hace 40 años ritos mágicos tendientes a asegurar las cosechas, los cuales en la actualidad son recordados como parte de las manifestaciones folklóricas. Cuando las lluvias se retasan se suelen hacer procesiones. Existen mitos de la creación, y se piensa que el hombre desciende del mono y que los monos son gente antigua, que fue convertida en esa especie como castigo porque cuando apareció Cristo-Sol sobre la tierra no lo quisieron reconocer. En las comunidades existen brujos y brujas que realizan sus sortilegios y que curan algunas enfermedades mediante amplios conocimientos de herbolaria. En la zona se conservan también muchas creencias ampliamente difundidas en mesoamérica, tales como "el mal de ojo" y el "dar un mal aire", etc. Existe en las comunidades un gran número de cuentos acerca de los relámpagos, los truenos, el viento y las tempestades. Sólo en contadas poblaciones existen médicos, principalmente pasantes de medicina que están haciendo su servicio social. Hay bastantes parteras empíricas que asisten a las mujeres en ese momento crucial, en el que muchas reciben a su hijo(a) hincadas, para que luego se entierre la placenta dentro de una olla y en un rincón de la casa. 
EDUCACIÓN. En el área existen jardines de niños, primarias, secundarias y telesecundarias. Aunque pocos jóvenes chinantecos logran llegar a niveles medio-superiores, ello se ha logrado con el establecimiento de Colegios de Bachilleres en San Lucas Ojitlán, Jalapa de Díaz, Chiltepec, Estación Vicente y Loma Bonita, éste último para atender población mestiza del área. El nivel superior regional se imparte en la Universidad del Papaloapan, ubicada con dos Campus situados, respectivamente, en Tuxtepec y Loma Bonita con 12 licenciaturas, 3 maestrías y dos doctorados.

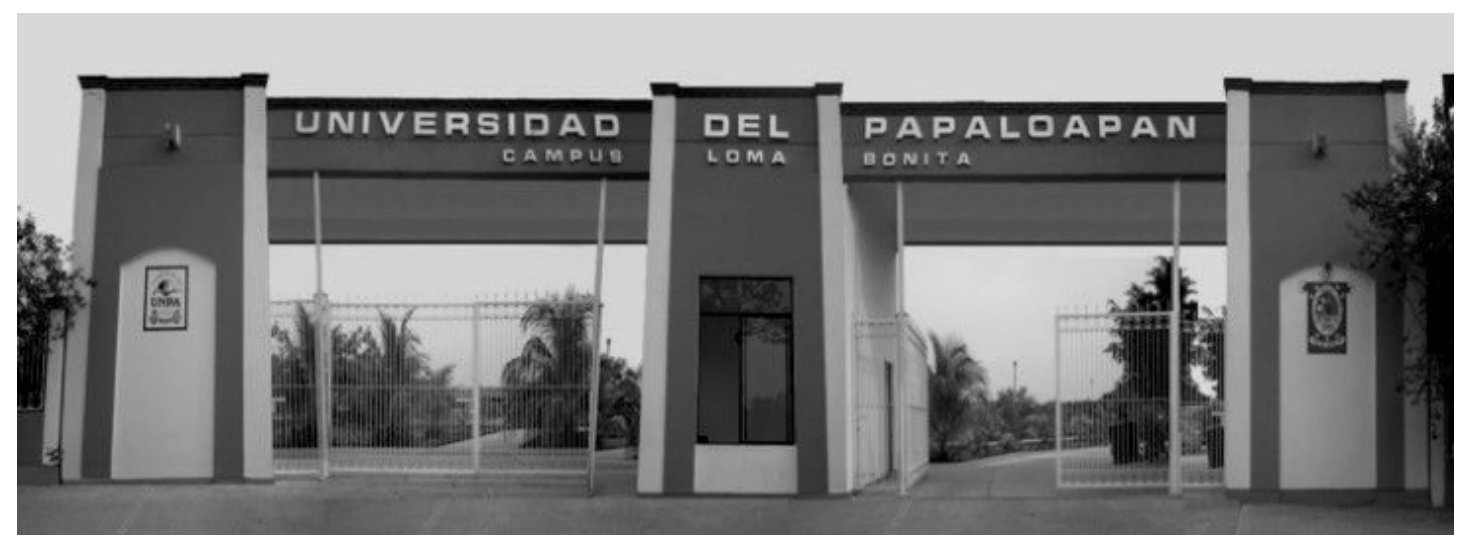

Universidad del Papaloapan. (Foto: Universidad del Papaloapan).

\section{BIBLIOGRAFÍA}

Acevedo Conde, María Luisa. 2008 “Los Chinantecos”. En: Revista A CONTRAGOLPE. No 13 Carteles Editores. Oaxaca, Oax. 2008.

Basauri, Carlos. 1940 “Los Chinantecos”. En: LA POBLACION INDIGENA DE MEXICO. T. II. Instituto Nacional Indigenista México. D F. 1940

Burgoa, Francisco de. Fray. 1934 GEOGRAFICA DESCRIPCION DEL POLO ARTICO... Publicación del Archivo General de la Nación. México, D F. 1934. 1934 PALESTRA HISTORIAL DE VIRTUDES APOSTOLICAS Y NUEVA IGLESIA DE LAS INDIAS OCCIDENTALES... Publicación del Archivo General de la Nación. México. D F. 1934.

Cline, Howard. 1955 "Civil Congregation of the Western Chinantec, New Spain. 15991603”. En: THE AMERICAS. Vol. XII, No 2. Washington. D C. U S A. 1955. 1956 "The Chinantla of Northeastern Oaxaca". BOLETIN DEL CENTRO DE INVESTIGACIONES ANTROPOLOGICAS DE MEXICO. II.

1961 "Mapas y Lienzos of the Colonial Chinantec Indians. Oaxaca, México". En: HOMENAJE A WILLIAM CAMERON TOWNSEND. Edición Particular. México, D F - 1961.

Delgado Herrera, Agustín. 1956 "La Arqueología de la Chinantla”. En: TLATOANI. № 10. Segunda Época. SAENAH. INAH. SEP. México, D F . 1956. Díaz del Castillo, Bernal. 1970 HISTORIA DE LA CONQUISTA DE LA NUEVA ESPAÑA. 8ª Edición. Ed. Porrúa. México, D F. 1970. 
Espinosa, Mariano. 1961 APUNTES HISTORICOS DE LAS TRIBUS CHINANTECAS, MAZATECAS Y POPOLUCAS. En: PAPELES DE LA CHINANTLA. Vol. III. MNAH. INAH. SEP. México D F . 1961

García Hernández, Tomás. 1989 TUXTEPEC ANTE LA HISTORIA, CNCA.- DGCPC. Club Rotario de Tuxtepec. Edición Particular. México. D F.

Gerhard, Peter. 1986 GEOGRAFIA HISTORICA DE LA NUEVA ESPAÑA. Instituto de Geografía. UNAM. México, D F . 1986. Kingsborough, Lord. 1974 ANTIGUEDADES DE MEXICO. Tomo I. CODICE MENDOCINO. Edición de la Secretaría de Hacienda y Crédito Público. México, D F. 1974.

Marquina, Ignacio. 1994 MEMORIAS. Colección: Biblioteca del INAH. Instituto Nacional de Antropología e Historia. México, D F. 1994

Miranda, José. 1968 "Evolución cuantitativa y desplazamiento de la población indígena de Oaxaca en la época colonial”. Fn: ESTUDIOS DE HISTORIA NOVOHISPANA. Vol. II. Instituto de Historia. UNAM. México. D F. 1968.

Paso y Troncoso, Francisco del. 1905 "Relaciones Geográficas de la Diócesis de Oaxaca". En: PAPELES DE NUEVA ESPAÑA. Tomos I-IV. Imprenta de Sucesores de Rivadeneira. Madrid. España. 1905.

Pérez García, Rosendo. 1956 LA SIERRA JUAREZ. 2 Tomos. Gráfica Cervantina. México, D F. 1956.

Weitlaner, Roberto. 1961 DATOS DIAGNOSTICOS PARA LA ETNOHISTORIA DEL NORTE DE OAXACA. INAH. SEP. México, D F. 1961.

Weitlaner, Roberto. Castro, Carlo Antonio. 1953. "El Lienzo de Tlacoatzintepec”. YAN. Ciencias Antropológicas No 2 Centro de Investigaciones Antropológicas de México. México. D F. 1953. 1973 USILA. MORADA DE COLIBRIES. PAPELES DE LA CHINANTLA. VII (No 7). INAH, SEP. México. D F. 1973.

Weitlaner Roberto. Cline, Howard F: 1969 “The Chinantec”. EN: HANDBOOK OF MIDDLE AMERICAN INDIANS. Vol.7. UNIVERSITY OF Texas Press. Austin \& London. 1969.

Winter, Marcus C. 1989 OAXACA. THE ARCHAEOLGICAL RECORD. Ed. Minutieae Mexicana. México, D F. 1989. 



\section{TRIQUIS}

Autodenominación: sii chian, tinujei, tindujei, kuinirkis.

Sinónimo en su lengua: nanj ni'l.

Significado: Hermano Mío. Gente que vino de abajo.

(cavernas próximas a ríos).

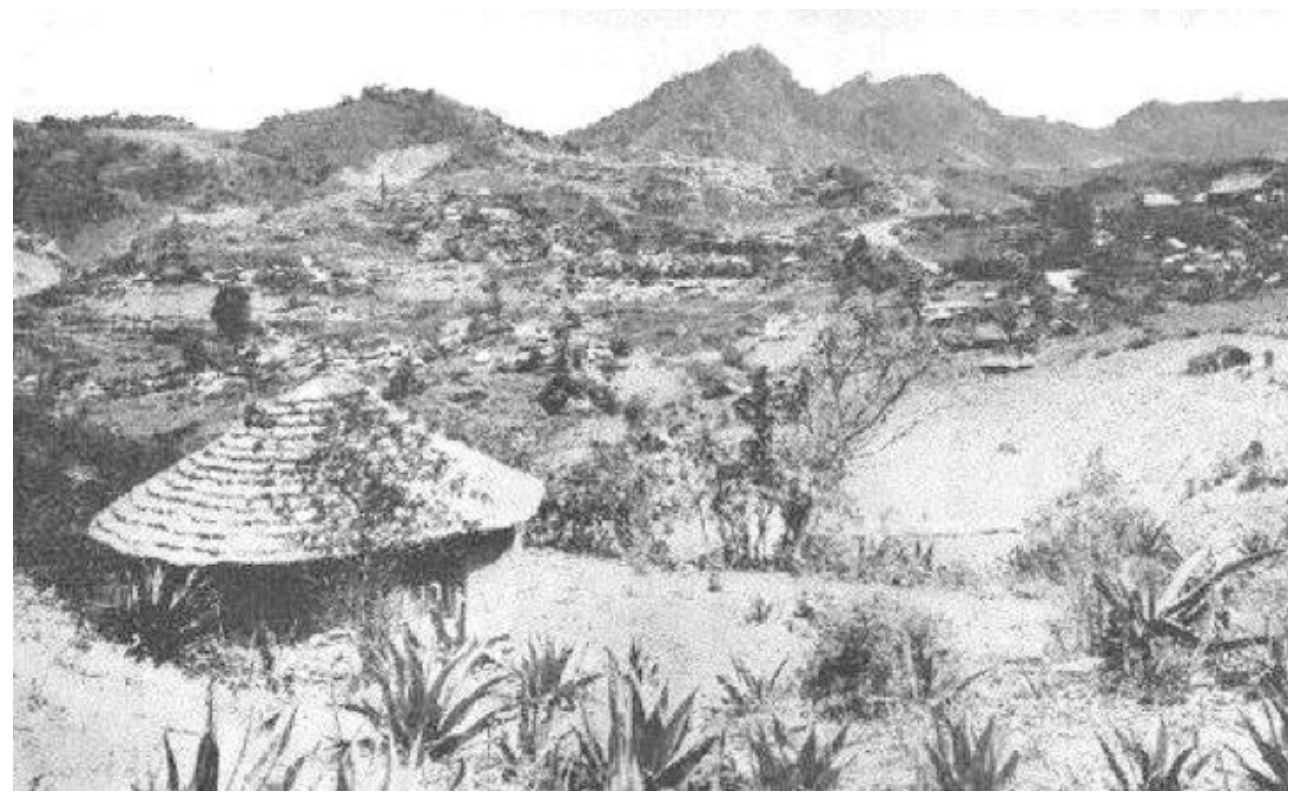

Panorámica de Chicahuaxtla en 1906. (Foto: Frederick Starr).

\section{GRUPO TRIQUI}

POSICION GEOGRAFICA. Ubicado en la porción occidental de la Sierra Madre del Sur Oaxaqueña, este grupo ocupa una pequeña región enclavada en la confluencia de tres distritos del Estado: Juxtlahuaca, Putla y Tlaxiaco, con 52 comunidades habitadas. Zona de relieve sumamente accidentado, con extensión aproximada de 50503 hectáreas, el territorio queda inscrito dentro de los $17^{\circ} 14^{\prime} 19^{\prime \prime}$ y $17^{\circ} 25^{\prime}$ de latitud Norte, y los $97^{\circ} 47^{\prime}$ 24 " y $97^{\circ} 40^{\prime} 30^{\prime \prime}$ de Longitud Occidental. El área ocupacional presenta bosques de coníferas y selvas medias perennifolias en cuya sombra se cultiva el café. La principal corriente fluvial del área es un afluente del Río de Putla que recibe el nombre de Copala. Los climas de la región son, por tanto, subhúmedas con lluvias en verano y semi cálidos subhúmedos 
en lluvias en verano con fuertes neblinas el resto del año. Salvo en las crestas, los suelos son en general gumíferos y profundos, y en su formación basal intervienen migajones formados por la desintegración de rocas volcánicas. Este tipo de suelo permitió siempre la formación de densos bosques de pinos y de pino-encinos.
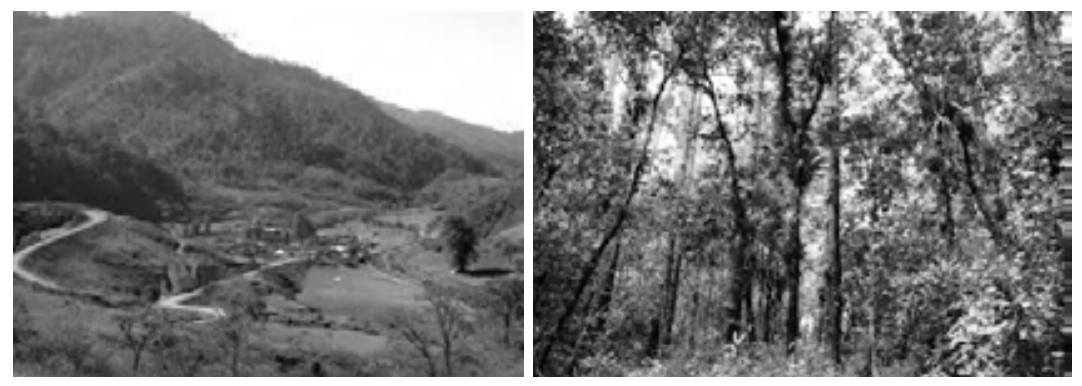

Paisaje y bosque mixto de coniferas triqui.

(Fotos: Secretaria de Turismo. Oaxaca, e Irving Castañeda Guerrero).

La precipitación pluvial media anual es, por tanto, superior a los 1200 milímetros. Las máximas elevaciones del área, la Zona Alta, se dan en la zona de los Chicahuaxtlas, con aproximadamente 3200 metros de altitud, y el resto del grupo se ubica en alturas mas bajas, en la Zona Baja, que llegan hasta los 800 metros, altura aproximada de San Juan Copala. En la zona de Chicahuaxtla se documentan cavernas, sin que se conozca su tipo y profundidad. Seis son las principales poblaciones triquis: San José Chicahuaxtla, San Andrés Chicahuaxtla, San Juan Copala, Santo Domingo Chicahuaxtla, San José Xochixtlán y San Martín Itunyoso, de ellas sólo San Martín Itunyoso conserva la categoría de municipio, y se documenta que por razones político-económicas, encaminadas a sojuzgar a la población, Chicahuaxtla y Copala fueron despojadas de tal categoría, siendo ahora Agencias Municipales de Putla y Juxtlahuaca, repectivamente..

IDIOMA. La lengua del grupo pertenece al Grupo Otomangue, Tronco Savizaa, familia Mixteca, con una antigüedad aproximada minima de 3700 años, y es hablada aproximadamente por unas 20000 personas. En la actualidad presenta tres variantes dialectales, de las que las mas antiguas, la de Chicahuaxtla y la de Copala, se debieron diferenciar entre sí hace más de 800 años, y la otra, la de Itunyoso, debió hacerlo poco después, pero todavía en tiempos prehispánicos, hace unos 600 años.

En las localidades la lengua se está conservando, hablada dentro de las casas y en los sitios públicos. En las áreas de contacto con mixtecos y con los mestizos de Juxtlahuaca la lengua se está perdiendo.

ANTECEDENTES ARQUEOLÓGICOS E HISTÓRICOS. La ubicación de ese grupo plantea uno de los problemas históricos más interesantes de todo el Estado. La región contiene una gran cantidad de vestigios arqueológicos, incluidos algunos ubicados en laderas o en lo alto de las montañas, de las que ostensiblemente, algunas tuvieron carácter defensivo. La 
cerámica prehispánica superficial de Copala, Chicahuaxtla e Itunyoso, así como la encontrada en agencias y rancherías, señala mayoritario origen mixteco, lo que hace imprescindible que se hagan los muestreos y estudios adecuados. Aunque existen pocos datos en crónicas, se señala que en el siglo XIII padecieron una ofensiva de uno de los principales mixtecos de Tlaxiaco, que expandió su poder comercial y que obligó a los triquis a remontarse a montañas más altas. En el siglo XV, la expansión azteca puso a las poblaciones de Copala y Chicahuaxtla, áreas de plumas preciosas, metales y muchas aves, en la esfera de las tributaciones a Tenochtitlán, las que se enviaban a través de Tlaxiaco, que desde 1511 fue centro de acopio de insumos para aquella ciudad. La conquista española no cambió de manera substancial esta situación, pero desde el siglo XVI todas las crónicas señalan que los asentamientos del grupo han sido dispersos, y toda esa área fue dada en encomienda a Francisco Vásquez, primero, y quizá por herencia a su hijo, Martín Vásquez, después, quien también era el encomendero de Tlaxiaco. La cristianización estuvo a cargo de frailes dominicos, entre los cuales se contó Fray Gonzalo Lucero, cuya labor catequizante abarcó una enorme región del estado. Posteriormente, los intentos de cristianización en el área de Copala tropezaron con una fuerte resistencia indígena. Estos movimientos de resistencia han continuado durante los dos últimos siglos, debido a que la explotación inmisericorde que se ha ejercido contra el grupo ha provocado constantemente intentos de liberación. En los siglos XVIII y XIX, el grupo fue despojado de gran cantidad de tierras por población mestiza, particularmente por un personaje llamado José María Carrasco, dándose las rebeliones del siglo XIX (1833-1837 y 1844-1847), encaminadas a conservar las tierras y obtener independencia. En la primera de ellas jugó un papel fundamental Hilario Medina Alonso, un "bandido social" con apoyo popular, a quien se conoció como "Hilarión", personaje importantísimo en la organización de la resistencia, y que durante varios años fue sencillamente incapturable, aunque más tarde se logró su asesinato. Poco después otra rebelión, con más de 8000 participantes, jefaturada por Dionisio Arriaga y Domingo Santiago, recibió el apoyo logístico del Gral. Juan Nepomuceno Álvarez, pero logró ser reprimida y ejecutados sus principales promotores. A fines de ese siglo se introdujo la siembra del café, y se disparó la ambición por poseer las tierras triquis, que, además, cuentan con vegetación útil y minerales. A ello coadyuvó la acción de notarios poco escrupulosos que escrituraron con una interpretación torcida de las Leyes de Reforma y las tierras fueron declaradas "baldías". Ya en el Siglo XX, se continuó con esa problemática, y debido a que algunos de los artículos que se han intercambiado por el café han sido fusiles, rifles, municiones y cantidades muy importantes de bebidas embriagantes, ha habido un índice mayor de pérdida de vidas humanas, la mayor parte de las cuales se ha generado en la represión que se ha ejercido contra los intentos de lograr una autonomía económica, existiendo el dato de que con el pretexto de la muerte, emboscado, de un teniente del ejército, de apellido Palos, y de probada culpabilidad como estuprador, traficante de rifles y municiones, la Fuerza Aérea Mexicana bombardeó en 1956, y de manera bárbara, la población de San Juan Copala matando mujeres y niños e incendiando importante número de chozas. Posteriormente, y en los últimos años, tres organizaciones políticas, de orígenes diversos y no 
siempre muy claros, el MULT, el MULTI y la UBISORT, se han enfrentado, dividiendo a la población y ocasionando conflictos y muertes. En el 2014 el MULTI pasa por ser la organización más genuina y popular, y quizá por ello sus miembros están siendo reprimidos, asesinados o encarcelados.

DEMOGRAFÍA. Aunque por lo disperso de los asentamientos es muy difícil levantar censos exactos, se considera que la población asciende a unas trescientas ochenta y cuatro mil (384 000) personas muy celosas de su identidad étnica, de los cuales más o menos 105000 son monolingües. Solo en ciertos casos algunos individuos de escasos recursos económicos se han casado con mujeres mixtecas aculturadas. En las áreas de contacto con otros grupos ya existe, por tanto, un muy ligero mestizaje.
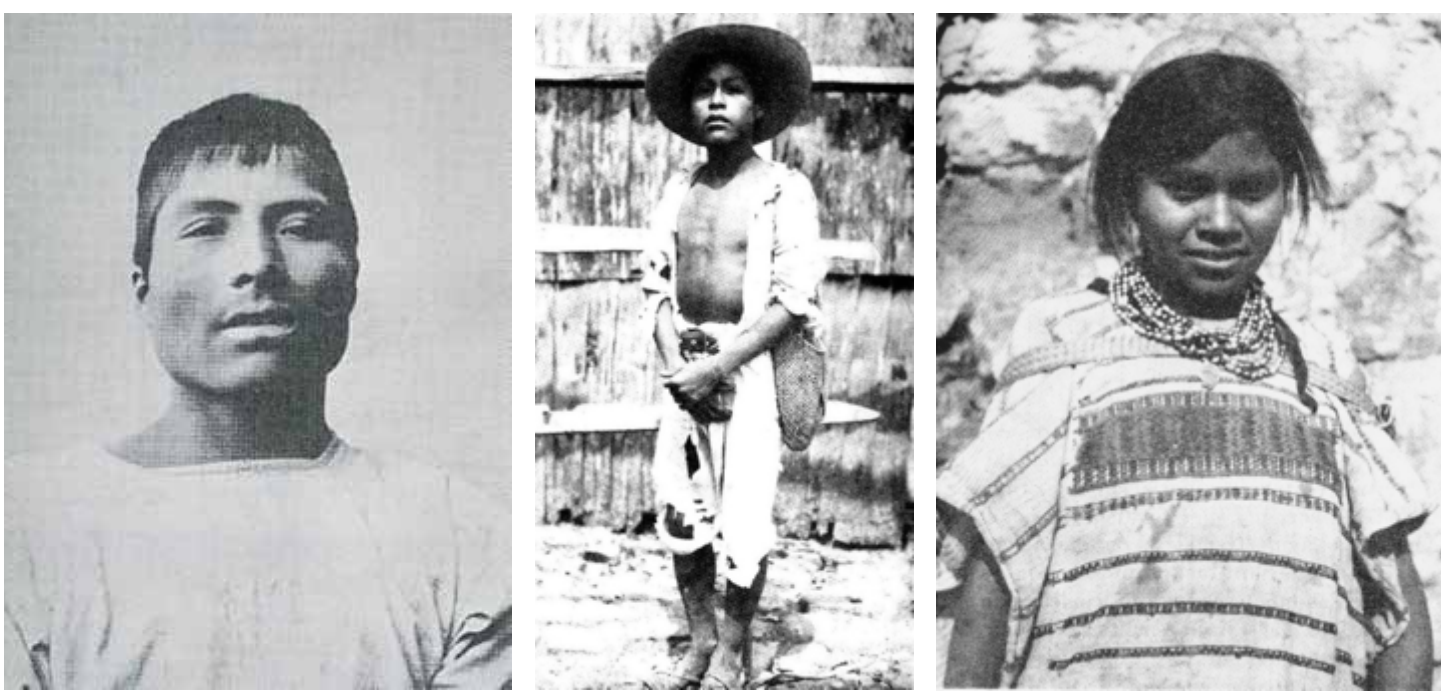

Jóvenes triquis. (Fotos: IIS-UNAM).

ACCESOS. Dos son los accesos principales a la región ocupada por este grupo: uno es la carretera de terracería que une Juxtlahuaca con Putla a través de San Juan Copala. El otro es la carretera pavimentada que une a Tlaxiaco con Putla y que pasa por las cercanías de San Andrés Chicahuaxtla, Santo Domingo del Estado y San Isidro Chicahuaxtla. San Juan Copala existe una pequeña pista de aterrizaje.

VIVIENDA. Tres tipos de casa pueden encontrarse en la región; el primero es de planta circular, con paredes de ramas de madera, estructura de horcones y techo a dos aguas, de pasto trenzado y atado.

El segundo es de planta rectangular con características similares. La tercera variante es de planta rectangular con el mismo tipo de techo, excepto que sus terminaciones son absidales. En ocasiones las paredes se enlucen con barro para no dejar pasar el frío; y este mismo rasgo se presenta también recibiendo paredes auxiliares En general existe la puerta central, y con mucha frecuencia las casas no tienen ventanas. Los techos suelen 
ser renovados cada 20 años, pero en el caso de Copala esto se suele hacer en un tiempo menor, debido a que algunos techos también se hacen de hojas de plátano, con menor durabilidad. Con relativa frecuencia suele haber adosado a la casa un temazcal o baño de vapor, el cual suele tener una estructura abovedada con una pequeña entrada lateral. El fogón se puede encontrar en un extremo de la habitación y suele estar constituido por tres piedras colocadas como los vértices de un triángulo equilátero. El mensaje de casa consiste principalmente de artículos de madera, barro y algunas canastas, documentándose que hace aproximadamente 50 años era frecuente que gran número de esas canastas contuvieran varias paradas (las laminitas-soporte en que se introducían seis) de cartuchos de fusil calibre $7 \mathrm{~mm}$, que usaban los fusiles mausser de la época., entonces reglamentarios del ejército mexicano.

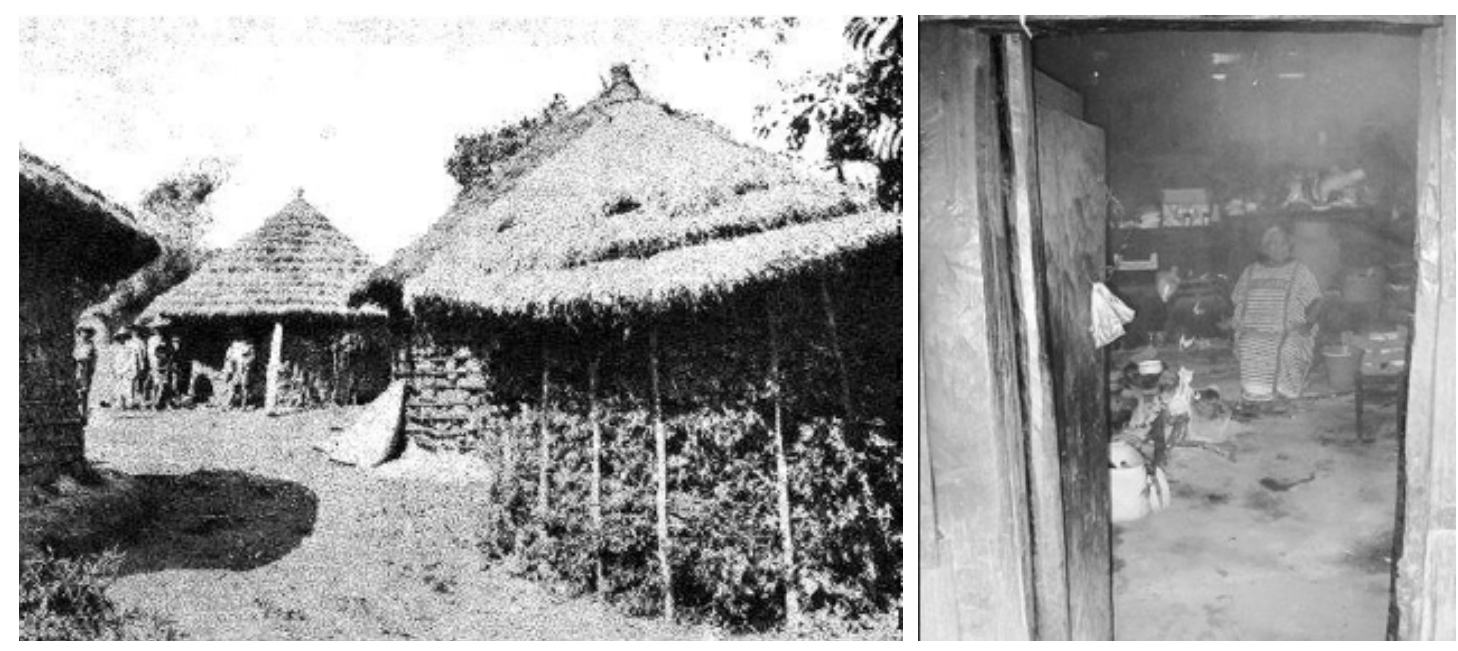

Casas triquis circulares en 1906 y Cocina en casa triqui. (Fotos: Frederick Starr y Florencio Moreno).

INDUMENTARIA. La indumentaria masculina tradicional ha sido de algodón permitiendo exponer las piernas. Ese tipo de calzón ha estado profundamente bordado. La ropa de las mujeres es el huipil brillantemente decorado con pequeñas bandas y figuras geométricas hechas con estambre de diferente color, así como de animales, mayoritariamente de color rojo, aunque también los hay blancos. También se usan faldas y enaguas. En el caso de las solteras fue tradicional el refajo de color azul marino. La mujer normalmente anda descalza y sobre la cabeza ha solido llevar una jícara o un rebozo. Los adornos femeninos han consistido en arracadas, collares y anillos. Muy recientemente se ha iniciado la penetración de la indumentaria comercial, que ahora va siendo habitual en los varones. Además, estos usan sandalias y huaraches y en ocasiones, en las partes frías, sarapes importados de la mixteca o del estado de Puebla. Sin embargo, la indumentaria femenina, hecha en telar de cintura, ha resistido muchas acechanzas. 


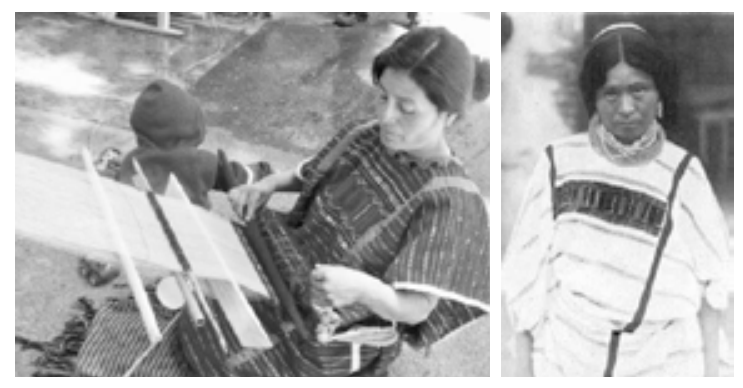

Tejedora y huipil triquis. (Fotos: Ricardo Izquierdo Ramírez y Luis Márquez).

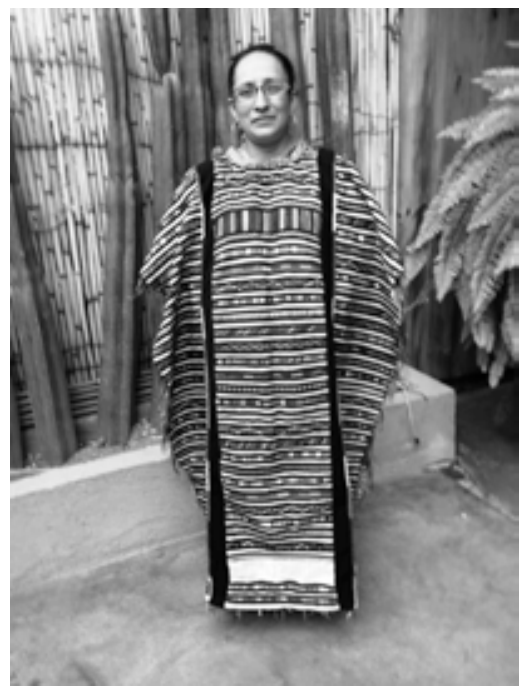

Huipil triqui. (Foto: Srta. Cecilia Juárez Flores).

ECONOMÍA. La economía del grupo se encuentra enmarcada dentro de su organización social, política y religiosa. Como la de todos los grupos indígenas del país, no se debe analizar en términos de costo-beneficio, ya que las etnias mantienen procesos de reproducción, defensa y adaptación a las condiciones económicas nacionales. En las actividades económicas de los Triquis se hallan reflejadas sus características propias, tales como el uso de su lengua y el conjunto de valores tradiciones y costumbres que forman una red permanente de relaciones familiares, económicas y religiosas, y en ocasiones biológico raciales o intergrupales reales o supuestas. Como en todas las zonas deprimidas del Estado la explotación del medio ambiente, el uso inadecuado de los recursos naturales y las inadecuadas condiciones de trabajo, están llevando al grupo a una situación de extrema pobreza, no solo porque la etnia pretende satisfacer directamente las necesidades básicas de la reproducción biológica y social, echando mano de sus pocos recursos naturales disponibles sino porque en algunos casos tiene que destinar parte de su producción, del excedente de la misma, para adquirir en el mercado otros bienes que no producen en la comunidad, apareciendo entonces los desiguales sistemas de intercambio y comercialización. Como casi siempre los recursos no alcanzan, la población masculina sale de su territorio a vender su fuerza de trabajo y con cada vez más frecuencia, la femenina se traslada a las grandes ciudades a 
vender los textiles producto de su trabajo, elaborados en talleres de cintura y con frecuencia de menor calidad que los hechos en su región.

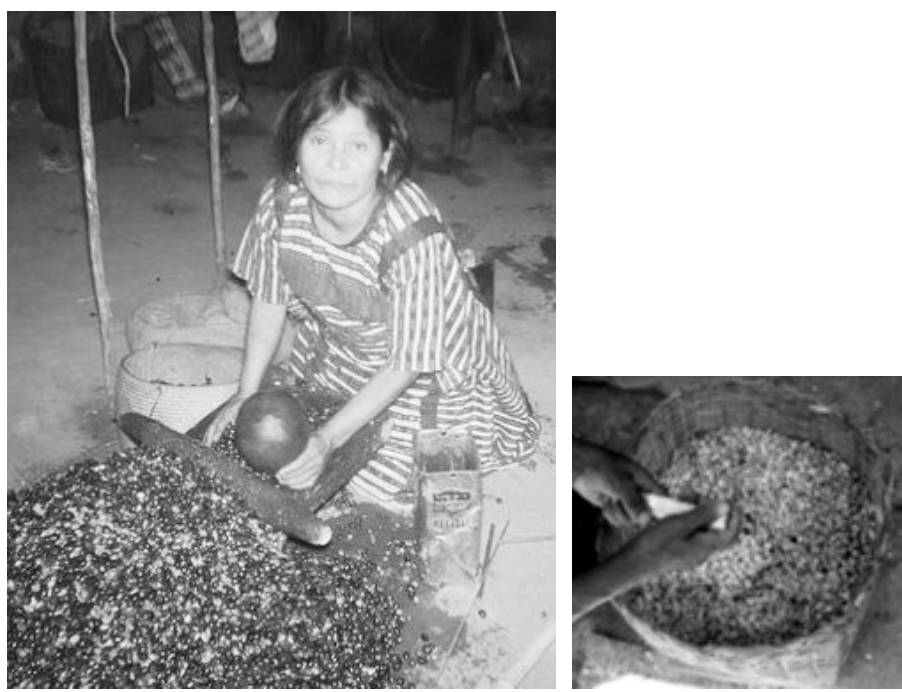

Mujeres triquis procesando café y desgranando maíz. (Fotos: Elena Erickson de Hollenbach).

En el territorio Triqui, el café es el producto comercial más cultivado. Tradicionalmente ha sido acaparado por compradores blancos y mestizos que son quienes han impuesto precios en detrimento del poder adquisitivo indígena. Además otros problemas inciden en la situación actual del grupo. Aunque el régimen de la tenencia de la tierra siempre ha sido comunal, en algunas zonas del área se han ido estableciendo fincas cafeteras privadas que han entrado en contraposición con algunas comunidades indígenas. Igualmente, el proceso gradual de obtención de mejores armas, ha ido minando la cohesión del grupo y con ello ha habido una disminución de la productividad. En la región es común la agricultura de roza de subsistencia, sembrándose maíz, frijol, chile y algunas variedades de calabaza. Exceptuando el café y un poco de tabaco, no existen más cultivos comerciales. Existe el arriendo de terrenos de pastizal a ganaderos mestizos. La explotación forestal, realizada por compañías privadas, prácticamente no beneficia a la población indígena.

CAZA Y PESCA. Para el grupo Triqui la fauna silvestre siempre fue un recurso complementario en la alimentación. Durante los últimos 30 años dicho recurso ha sido sobreexplotado y esta situación ha llevado a la virtual extinción de muchas especies, entre ellas el puma y el venado cola blanca. Algunas pequeñas especies, tales como los conejos montés y rabo de algodón, se han adaptado a nuevas condiciones y mantienen un precario equilibrio. Puesto que el área es rica en escurrimientos, las actividades piscícolas podrían ser un importante apoyo económico. Con las capturas mediante explosivos, lamentablemente han sido sobreexplotados en detrimento de la capacidad que el grupo tiene para poderlos aprovechar. Urgen, por tanto, programas de repoblación y conservación. 


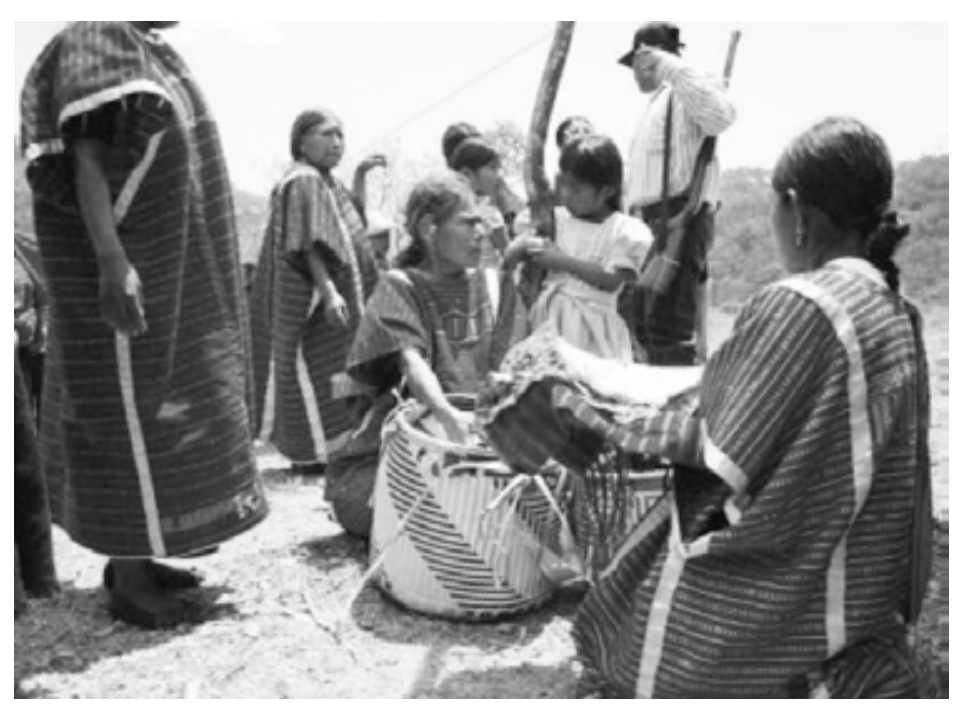

Mercado en San Juan Copala. (Foto: Francisco López Bárcenas).

MERCADOS. Los principales mercados del área se encuentran en San Juan Copala y San Andrés Chicahuaxtla, así como en San Martín Itunyoso. En ellos subsiste el intercambio de productos como reminiscencia del trueque tradicional, pero el grueso de las actividades comerciales está en manos de ladinos o mestizos, quienes controlan el movimiento económico en perjuicio de la población indígena.

ARTESANIAS. La principal artesanía del grupo es el tejido, realizado, ya sea sobre hilo de lana, o de algodón. El tejido se elabora con telar de cintura que incluye dentro de su equipo lanzaderas manuales y de trenzado. El tejido y el bordado son actividades típicamente femeninas y solo recientemente algunos hombres se han incorporado a otras actividades artesanales tales como la carpintería y la talla de madera. En la región también se distribuye una alfarería doméstica de regular calidad.
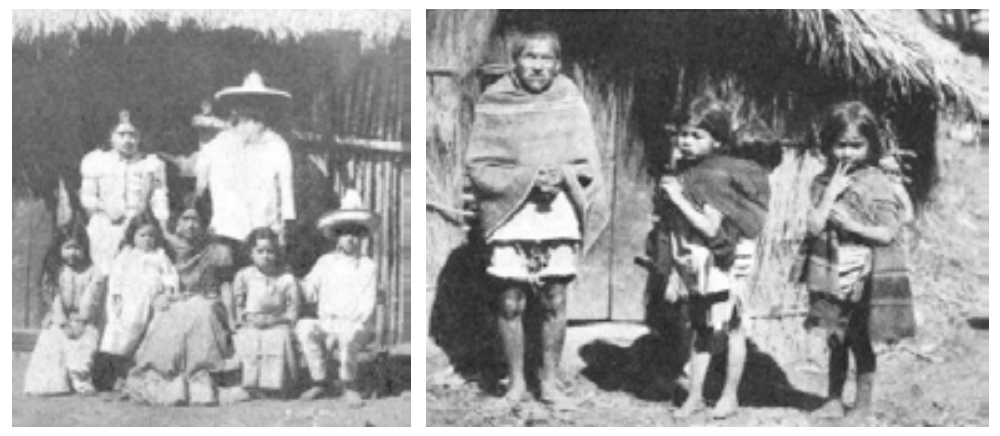

Familias triquis en 1906. (Fotos: Frederick Starr).

ORGANIZACIÓN SOCIAL. La organización social de la etnia está fundamentada en la familia nuclear. Esta está compuesta por el padre, la madre y los hijos solteros. Este órgano básico de la sociedad trique es una estructura patrilineal, patrilocal, endogámica y mono- 
gámica, aunque en al zona de San Juan Copala se han registrado casos de poliginia. El matrimonio recién formado vive en estrecha proximidad con la casa del padre del varón. Por tanto en la sociedad la patrilinealidad reviste especial importancia. En el arreglo de la boda intervienen los padres de la pareja, pero son los padres del novio los que van a la casa de la novia a hacer las visitas previas (habitualmente tres) y arreglar las cantidades de cosas que deben ser entregadas. Si posteriormente la muchacha se llega a divorciar este valor puede se devuelto. En la boda el convivió corre a cargo de los padres de la novia, pero el grupo coopera para la construcción de la casa de la pareja. El padre de la novia entrega la ropa de la muchacha al novio variando el valor de acuerdo al número de huipiles entregados. En caso de un segundo matrimonio, la mujer ya no deberá realizar estos ritos. Durante los últimos 40 años ha aumentado el índice de parejas que se pone a acuerdo para convivir y también ha aumentado el número de raptos de muchachas, los cuales con frecuencia han sido previamente arreglados por los mismos contrayentes.

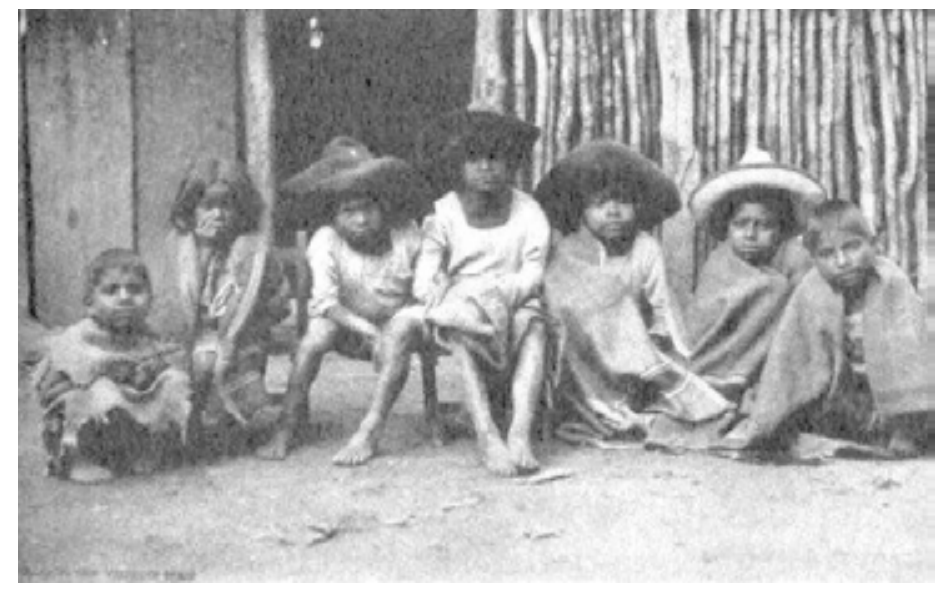

Niños triquis en 1906. (Foto: Frederick Starr).

Las prácticas mortuorias entre los Triquis conservan algunas reminiscencias prehispánicas, pero los enterramientos se realizan de acuerdo a aspectos del ritual católico. El cadáver es envuelto en un petate y se vela durante 24 horas en un acto presidido por una rezandera. Al enterrarse, el cuerpo queda con la cabeza al poniente y va acompañado de todo lo necesario para el viaje al más allá que está conceptuado como el viaje a través de varios mundos. La ofrenda consiste en alimentos, dinero, agua, frijoles, pasto y algunos implementos tales como agujas y pequeñas cuchillas. Los frijoles y el pasto están destinados a alimentar a los animales que el difunto mató en vida; y en mayor grado a aquellos que fueron domésticos y de su propiedad. En los casos en que la muerte ocurrió por asesinato o accidente, se considera que el alma queda errante y ya no llega al inframundo. A las relaciones interfamiliares se incorpora la institución del compadrazgo. Los padrinos de bautizo pueden no pertenecer a la misma familia, pero son responsables del niño tanto como los padres, a partir del momento en que éste nace. Cuando ese acontecimiento se produce, los padres de la criatura invitan a una comida a sus compadres. Si el niño llega 
a morir, es amortajado por el padrino con un traje adecuado y el funeral es también pagado por éste. En los procesos de herencia se observa la patrilinealidad. Habitualmente se heredaba solo después de la muerte del padre, pero ahora ya se comienza a hacer en vida, debido a que los hijos que se van casando, van cada vez necesitando contar con tierra para su subsistencia. El resto de las propiedades de una pareja son heredadas por reparto equitativo entre los hijos, ya sean hombres o mujeres.

Entre los triquis la familia extensa está constituida por los parientes consanguíneos y por afinidad. En las poblaciones existen barrios y en cada uno de estos radican varias familias extensas. Sin embargo, la mayor parte de la población presenta asentamientos dispersos por las razones ya expuestas en la sección de antecedentes históricos.

GOBIERNO. Además del aparato jurídico, político y constitucional que señala la política del gobierno del país, dentro del grupo triqui subsisten formas tradicionales de gobierno en las que existen jerarquías y cuyos miembros las ocupan de acuerdo a un escalafón definido acorde con la edad y la experiencia, siendo el grado máximo alcanzable el de Principal. Subsiste también una fuerte integración entre las actividades religiosas y las políticas, no obstante que el proceso de aculturación a que se ven sometidos los indígenas de este grupo es muy fuerte. Muy recientemente se ha desarrollado una importante actividad política apoyada en varios partidos registrados, PRI y PRD, como reacción a la represión, y es palmario el desinterés de los funcionarios de los sucesivos gobiernos federal y estatal para resolver la añeja problemática. Del dominio público son las evidencias del acarreo político, por razones electorales o de presión política, a que se somete a los integrantes del grupo.

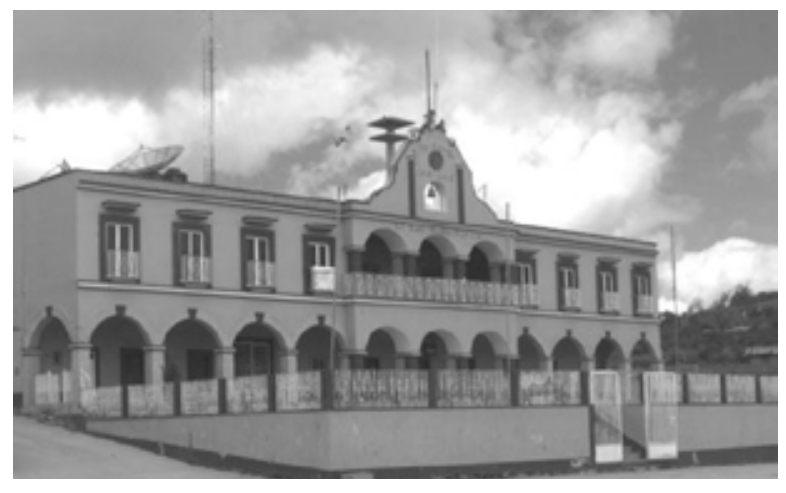

Palacio municipal de San Martín Itunyoso. (Foto: Municipio).

FESTIVIDADES. La substitución del calendario ritual prehispánico y del calendario agrícola por el calendario católico, realizada durante la primera etapa de la administración colonial del país, cambió por completo el orden sucesivo de festividades que entonces existía, por lo que las festividades que la Colonia dejó impuestas corresponden a las fechas del ritual católico, o bien a lo días en que se festeja el Santo patrón de las diferentes poblaciones esos días las iglesias y capillas son adornadas profusamente. En San Andrés Chicahuaxtla existe una banda de música ceremonial. 


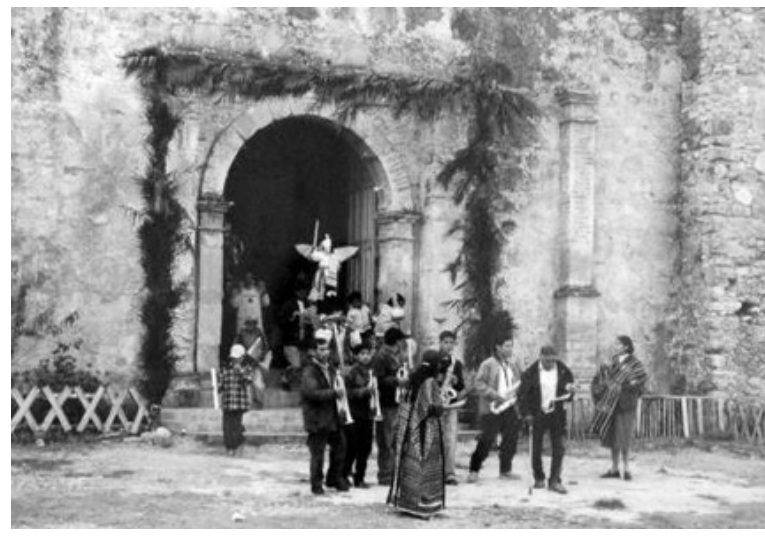

Semana Santa en Chicahuaxtla. (Fotos: Guillermo Aldana).

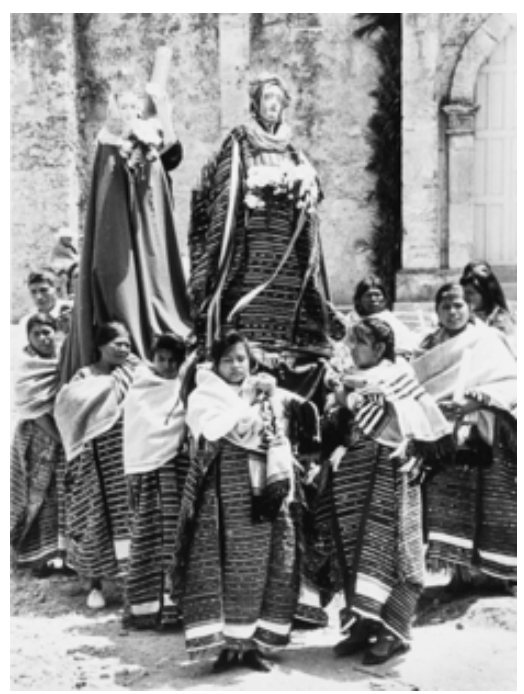

ORGANIZACIÓN RELIGIOSA. Habitualmente, las iglesias parroquiales están a cargo de un sacristán. Cuando se aproximan las festividades, la población designa un comité organizador cuya cabeza será el Mayordomo. Este comité va a asegurar el éxito de las ceremonias.

Iglesias de Chicahuaxtla y Copala. (Fotos: Francisco Ramírez y Secretaria de Turismo estatal).

Entre los triquis subsisten gran cantidad de mitos, algunos de ellos son reminiscencias prehispánicas y tienen una gran calidad literaria. Entre esos mitos se encuentran el de la Creación de los Dioses, el del origen del sol, de la luna y las estrellas, el del origen de los eclipses, de las tormentas, de la muerte, de la luna y de la construcción del mundo.

Se piensa que cada persona tiene su Nahual, que es su contrapartida y está representado por un animal. El concepto de nahual se aproxima al de otras partes de México.

MEDICINA Y MAGIA. En el grupo existen hechiceros y las curaciones se realizan de manera, tanto mecánica, como mediante baños de temascal. Algunos curanderos son también "hueseros" o arregladores de huesos. Muchos ritos religiosos se realizan en cuevas que han tenido ese uso desde a época prehispánica. Algunos curanderos tienen amplios conocimientos de herbolaria regional. Dentro de grupo existe el concepto del "espanto", el cual es interpretado como algo sobrenatural; si bien en la casi totalidad de los casos el mal estado del paciente se debe a una caída o haber sufrido una agresión física, también se considera que una causa de enfermedad es la muerte del animal representativo del nahual del individuo, es decir la Tona. Las ofensas a un elemento natural, tal como el relámpago o la lluvia, son también causa de enfermedad. Asimismo las enfermedades dentales, tales como caries o inflamación de las encías son interpretadas con la idea de que un animal se come la boca o los dientes de la persona afectada.

En el área existen muy pocos médicos, la mayor parte de los cuales son pasantes que realizan su servicio social, y que, por tanto, sólo permanecen en la región alrededor de un 
año. Los registros de sanidad en el grupo señalan graves deficiencias vitamínicas, tuberculosis, parásitos de varios tipos y en algunas zonas, paludismo, como las enfermedades de mayor dispersión, además de desnutrición crónica. En 1906 el etnólogo Frederick Starr inició estudios somatométricos, que fueron continuados en 1948 por los antropólogos Juan Comas Camps y Johanna Faulhaber.
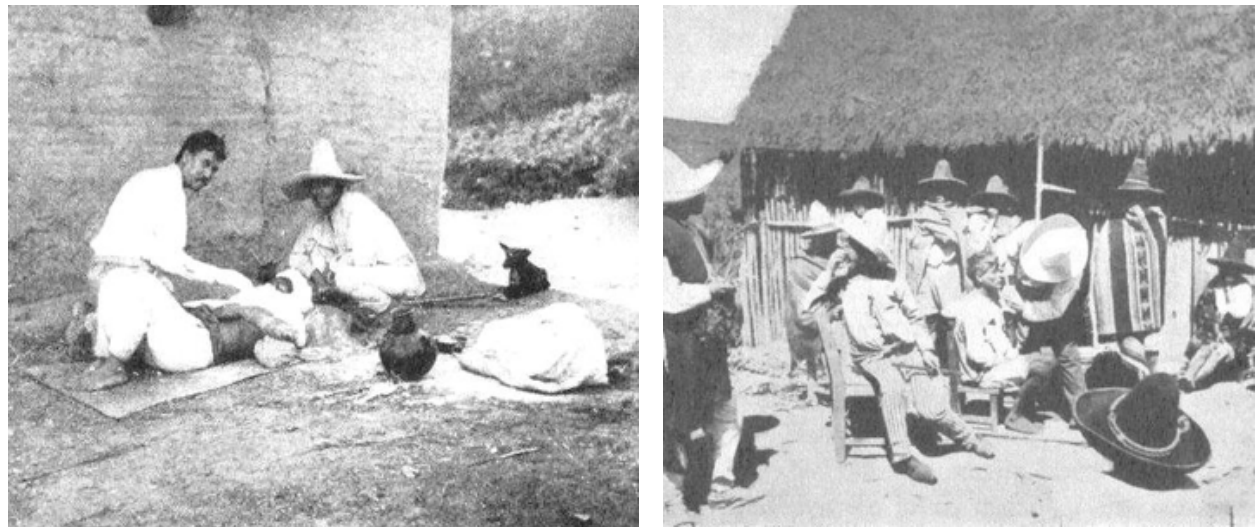

Curandero triqui y medición antropológica en 1906. (Fotos: Frederick Starr).

EDUCACIÓN. En el área existen escuelas primarias pertenecientes a varios sistemas de educación Federal y Estatal. El promedio de escolaridad, como en casi todas las zonas marginadas, es muy bajo porque los problemas económicos obligan a una gran parte de los niños a abandonar los estudios durante el ciclo primario. Algunos programas del Instituto Nacional Indigenista estuvieron incorporando a unos cuantos jóvenes a actividades educativas y productivas de mayor nivel, y aquellos jóvenes que pueden acceder a la educación superior, son canalizados generalmente a las instituciones de la ciudad de Tlaxiaco. Se consigna que, miembros del grupo que han podido estudiar, se encuentran en posiciones relevantes. La NASA, en los Estados Unidos, alberga por lo menos un científico originario de la etnia en el grupo controlador de disparos de cohetes, y mientras tanto el grupo continúa padeciendo carencias y marginación. En palabras de la Dra. María Luisa Acevedo Conde, se les mantiene "sociológicamente invisibles".

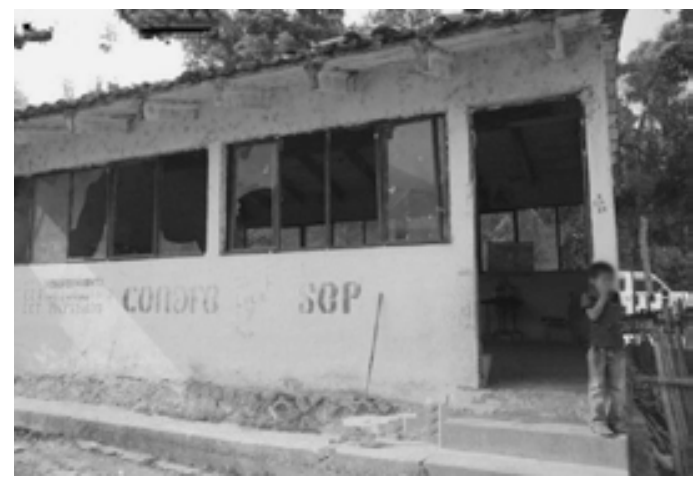

Foto de una escuela triqui. 


\section{BIBLIOGRAFIAA}

Acevedo Conde, María Luisa. 2007 "Los triquis. Un pueblo culturalmente sólido pero políticamente fragmentado”. En Revista A CONTRAGOLPE. № 11. Carteles Editores, Oaxaca, Oax. 2007.

Avendaño Ramírez, Juan. 2011 YUMAN LI. Vida comunal y conflicto agrario en una comunidad triqui (tnag ni'ing). PACMYC. Oaxaca.Oax. México.

Bartolomé, Miguel Angel. 1997 GENTE DE COSTUMBRE Y GENTE DE RAZON. LAS IDENTIDADES ETNICAS EN MEXICO. Siglo XXI Editores. México, D F. 1997.

Basauri, Carlos. 1940 “Los Triquis” Reed 1990 En: LA POBLACION INDIGENA DE MEXICO Colección: Presencias. Instituto Nacional Indigenista. SEP. México, D F. 1990.

Cordero Avendaño de Durand, Carmen. 1977 CONTRIBUCION AL DERECHO CONSUETUDINARIO DE LOS TRIQUIS. Instituto de Administración Pública de Oaxaca. Oaxaca, Oax. 1977.

Dalhgren, Bárbara. 1954 LA MIXTECA, SU CULTURA E HISTORIA PREHISPANICAS. Universidad Nacional Autónoma de México. México, D F. 1954.

Gerhard, Peter. 1986 GEOGRAFIA HISTORICA DE LA NUEVA ESPAÑA. Instituto de Geografía. UNAM. México, D F. 1986.

Gómez Levy, Enrique. 1994 “La Dignidad Humana Negada en la Mixteca”. REVISTA ESLABONES. No 8. Oaxaca, Oax. 1994.

Hollenbach, Bárbara. 1980 “Topónimos Triquis. Huellas de la Prehistoria”. En: RUTAS DE INTERCAMBIO EN MESOAMERICA Y EL NORTE DE MEXICO. Mesa Redonda. Sociedad Mexicana de Antropología. Saltillo. Coah. 1980.

Huerta Ríos, César. 1981 ORGANIZACIÓN SOCIOPOLITICA DE UNA MINORIA NACIONAL. LOS TRIQUIS. Instituto Nacional Indigenista. México, D F. 1981. 1984 "El Compadrazgo y sus Relaciones con el Caciquismo entre los Triquis de Oaxaca”. En: AMERICA INDIGENA. Vol. XLIV. № 2. México, D F. 1984.

Lewin Fischer, Pedro. 1999 "Gente de la Lengua Completa (Yi ni nanj ni' inj). El Grupo Etnolingüístico Triqui”. En: Barabas, Alicia Mabel y Bartolomé, Miguel Angel. Coords. CONFIGURACIONES ETNICAS EN OAXACA. PERSPECTIVAS ETNOGRAFICAS PARA LAS AUTONOMIAS. Vol. II. Instituto Nacional de Antropología e Historia. Instituto Nacional Indigenista. México, D F. 1999.

Lewin Fischer, Pedro y Sandoval Cruz, Fausto. 2004 TRIQUIS. Comisión Nacional para el Desarrollo de los Pueblos Indígenas. México, D F. 2004.

López Bárcenas, Francisco. 2010 SAN JUAN COPALA. Dominación política y Resistencia Popular. Centro de Orientación y Apoyo a Pueblos Indígenas. México, D F. 2a Ed. 2010. Nader, Laura. 1969 “The Triqui of Oaxaca”. EN. HANDBOOK OF MIDDLE AMERICAN INDIANS. Vol. VII. Texas University Press. Austin \& London. Austin Tx. U S A. 1969. 
Olivera, Mercedes y Romero Frizzi. Ma de los Ángeles. 1973 "La Estructura Política de Oaxaca en el Siglo XVI". En: REVISTA MEXICANA DE SOCIOLOGIA. Año XXXV, Vol. XXXV. № 2. Abril-Junio 1973 México. D F.

Parra Mora, León G. y Hernández Díaz, Jorge. 1994 VIOLENCIA Y CAMBIO SOCIAL EN LA REGION TRIQUI. IISUABJO. UABJO. Oaxaca Oax. 1994. Pastor, Rodolfo. 1987 CAMPESINOS Y REFORMAS, LA MIXTECA. 1700-1856. El colegio de México. México, D F. 1987.

Romero Frizzi, Ma de los Ángeles. 1990. LECTURAS HISTORICAS DEL ESTADO DE OAXACA. Vol. III. SIGLO XIX. Col. Regiones de México. INAH. México D F. 1990.

Spores, Ronald. 1990 "Relaciones Gubernamentales y Judiciales entre los Pueblos, Los Distritos y el Estado de Oaxaca”. En: Romero Frizzi. 1990.

Winter, Marcus C. Gaxiola G, Margarita y Hernández Díaz, Gilberto. 1984 “Archaeology of the Otomanguean Area”. En: ESSAYS IN OTOMANGUEAN CULTURE HISTORY.

Vanderbilt University. Publications in Anthropology. № 31. Nashville, Tenn. U S A. 1984. 


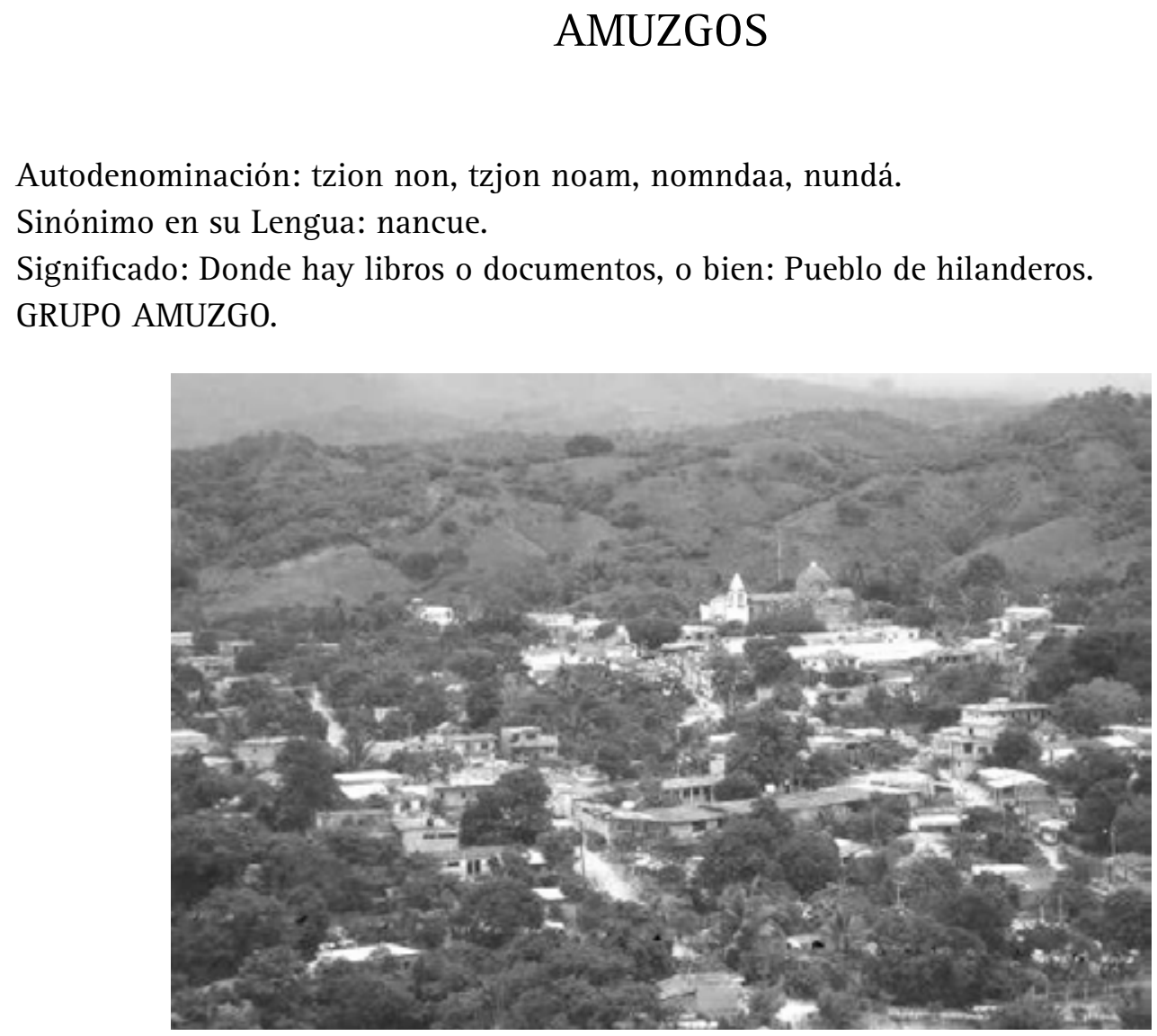

Población de San Pedro Amuzgos. (Foto: Dirección de Turismo estatal).

UBICACIÓN GEOGRÁFICA. Este grupo se localiza en la porción occidental de la Sierra Madre del Sur Oaxaqueña, en un sector de la misma dividido en dos partes por la frontera inter.-estatal con Guerrero. Su área ocupacional se inscribe entre los paralelos $16^{\circ} 40^{\prime}$ y $16^{\circ}$ $50^{\prime}$ de Latitud Norte y los Meridanos 97 $20^{\prime}$ y 97 $35^{\prime}$ de Longitud Occidental. El territorio abarca aproximadamente 3000 kilómetros cuadrados, de los que un 35\% pertenece al Estado de Oaxaca en los municipios de San Pedro Amuzgos y Santa María Ipalapa. El terreno es accidentado sobre lomeríos, con una altura máxima ligeramente superior a los 900 metros, siendo la cadena montañosa principal la Sierra de Yucuyagua, y en las cuencas de los ríos Ometepec y de la Arena. El clima es semicálido subhúmedo con lluvias en verano y la precipitación media anual presenta un promedio ligeramente inferior a los 1000 milímetros. 


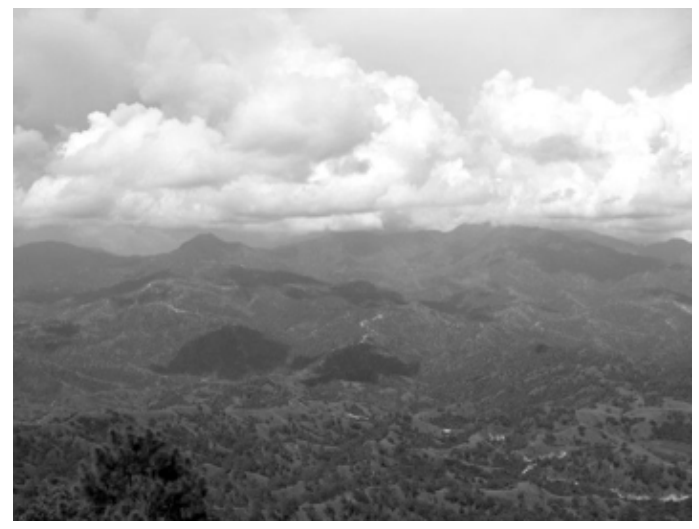

Montañas y entorno amuzgos. (Fotos: UNAM).

La región presenta características climáticas regidas por los sistemas de humedad que induce al continente el Océano Pacífico. Los suelos son arcillosos, intemperizados y con un alto índice de oxidación, lo que les da una coloración rojiza. La cubierta vegetal es una selva caducifolia con cactos columnares asociada con algunas especies de selva media perennifolia. Existen algunos pequeños valles de poca amplitud que se encuentran en mayor número en la porción oaxaqueña ocupada. Dichos valles son estrechos y productivos. En algunos desde la época prehispánica se practicó el riego rodado mediante canales.

IDIOMA. La lengua Amuzga pertenece al Grupo Otomangue, Tronco Savizaa, Familia Amuzgueana, emparentado con el Mixteco y separado de su tronco lingüístico original hace más de 5000 años, y en la actualidad es hablada aproximadamente por 4600 personas, registrándose que en Santa María Ipalapa sólo se habla dentro de las casas. Existen tres variantes dialectales de muy ligeras diferencias, por lo que todavía son mutuamente inteligibles.
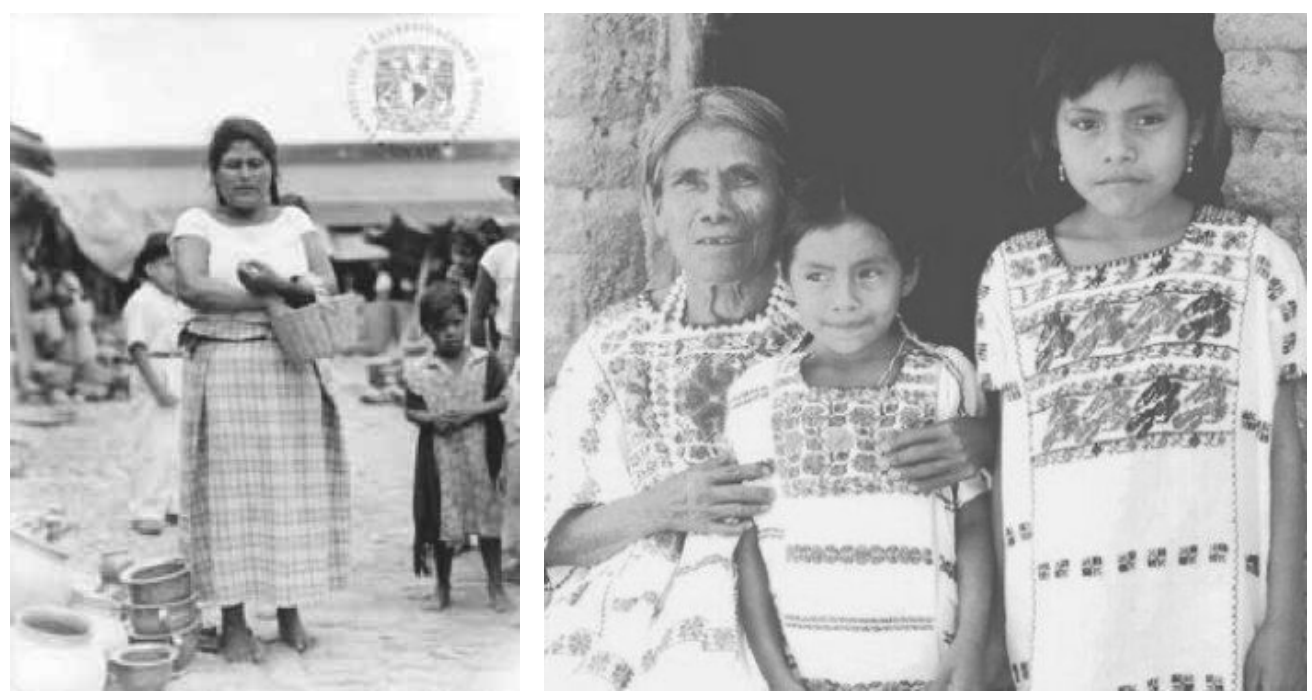

Mujeres amuzgas. (Fotos: UNAM). 
ANTECEDENTES ARQUEOLÓGICOS E HISTÓRICOS. Como grupo profundamente emparentado con los Mixtecos, los Amuzgos han presentado una cultura relacionada en algún grado con la de aquellos. El área ocupacional del grupo contiene una gran cantidad de vestigios arqueológicos, incluyendo grandes asentamientos defensivo-ceremoniales en laderas de lomas y cimas de montañas, que lamentablemente no han comenzado a ser estudiados. Son pocas las crónicas que aportan datos sobre la región, aunque se sabe con cierta exactitud que la diferenciación lingüística con los mixtecos debe haberse realizado antes o durante el segundo milenio antes de Cristo. Por sus condiciones geográficas, la región estuvo inmersa dentro de la red prehispánica de rutas de comunicación, y por ella se transportó algodón, plumas, textiles, tintes, grana y productos vegetales, principalmente maíz y cacao. Durante el período postclásico o militarista, el grupo debió haber resentido la presión de los entonces ya muy fuertes principalatos mixtecos de la Costa, que se enfrentaron en la región por el predominio comercial, y quizá ello explique su actual ubicación geográfica. Poco antes de la conquista española la región dependía, por sujección, de Tututepec, y, cercana, en Ayoxuchiquilazallan (Xochiquitzala, Gro.), había una guarnición tenochca. A partir de entonces, el grupo ha tenido a ser hermético y mantenido pocos contactos con los grupos vecinos, tanto mixtecos como nahuas, y entre los pocos Lienzos que dan información sobre ellos se encuentran los de Zacatepec I y II.
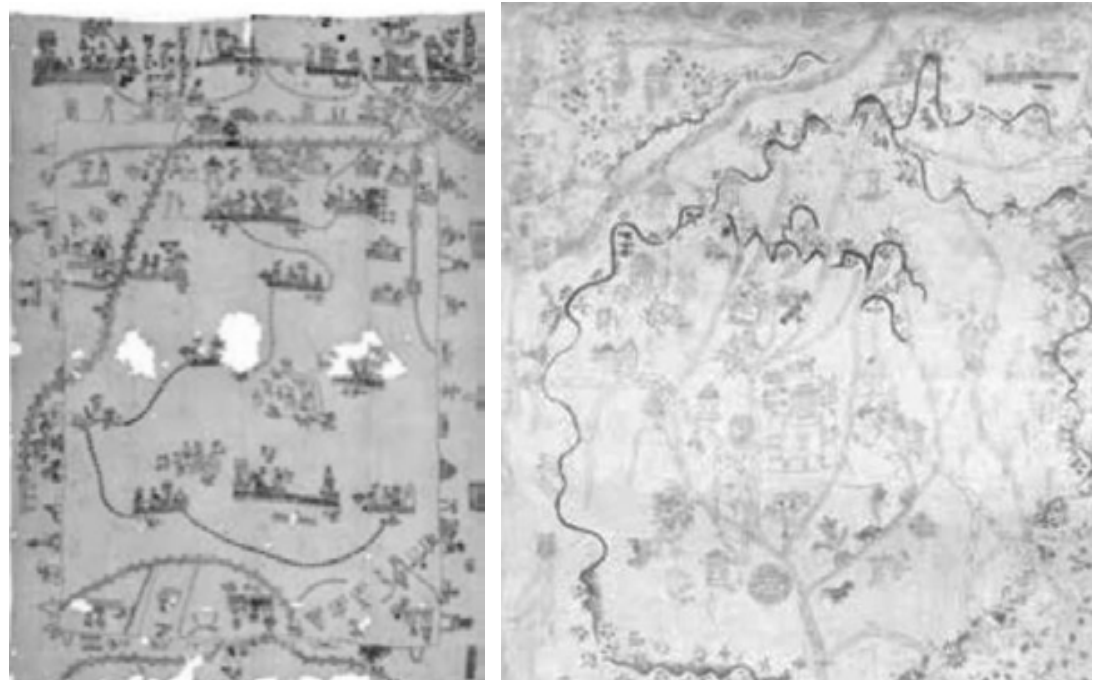

Lienzos de Zacatepec I y II (Fotos: INAH)

Se sabe poco acerca de la Conquista Española, pero cayeron junto con Tututepec después de las acciones de Pedro de Alvarado. Documentos coloniales señalan a los principales encomenderos: Francisco de Ávila en Amuchco, Francisco de Herrera en Ometepec y Bernardino del Castillo en Igualapa, cuyos actos redujeron sensiblemente la población, que, además, recibió el azote de las enfermedades introducidas. Sabemos un poco más sobre la cristianización en la región, realizada por frailes dominicos, los que también impulsaron las congregaciones. A ésta, el grupo la aceptó conservando sus tradiciones y estableciendo 
una sincronía entre sus antiguas creencias y las que los frailes impusieron. A principio del Siglo XIX en la guerra de independencia, hubo indígenas de la etnia en las fuerzas de Dn. Vicente Guerrero Saldaña, y en la de Intervención los hubo en las fuerzas del Gral. Faustino Vásquez Aldana, con el que concurrieron a la Batalla de la Carbonera, al asalto a Puebla del 2 de abril de 1867 y al Sitio de la Ciudad de México. En años recientes el grupo se ha incorporado muy lentamente al proceso de desarrollo del país debido a problemáticas similares a las que confrontan otros grupos indígenas.

DEMOGRAFÍA. La población Amuzga asciende en la actualidad a unas 20500 personas que se distribuyen en 12 comunidades dentro del Estado. Las principales poblaciones son San Pedro Amuzgos (el antiguo Amuchco) y Xochiquilazala. Casi no existe mestizaje con los grupos colindantes, registrándose unos pocos casos con afromestizos.
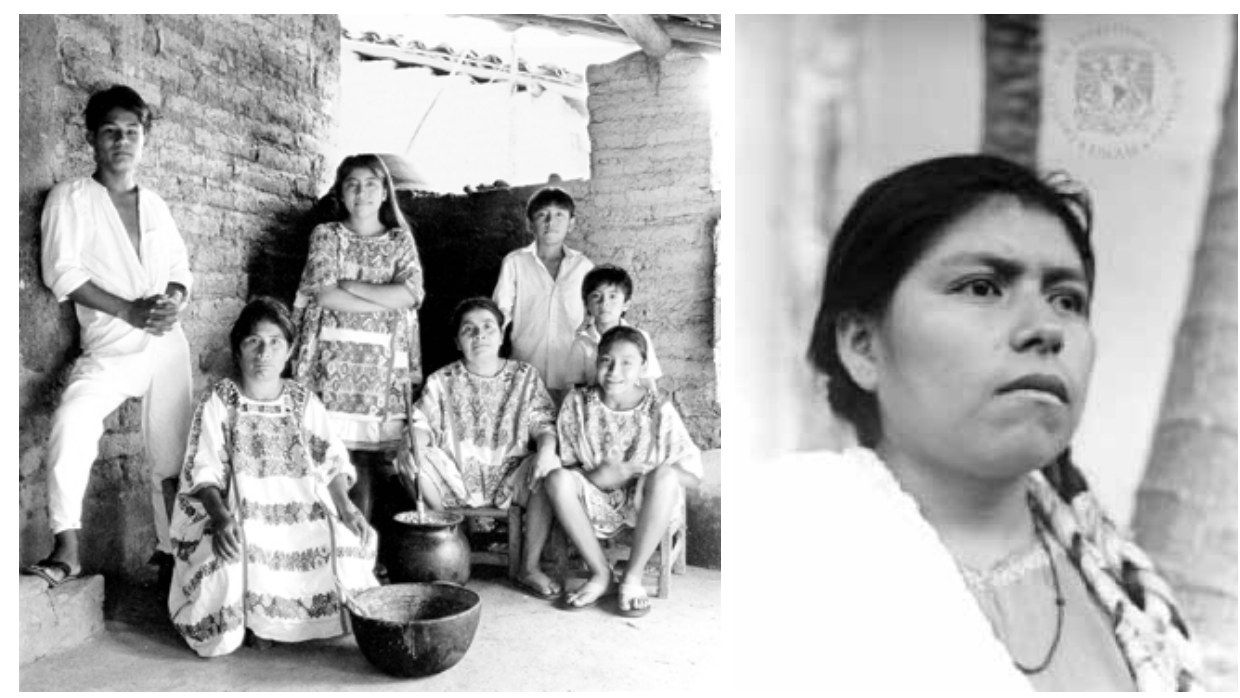

Familia y mujer amuzgas. (Fotos: IIS-UNAM.).

ACCESOS. A la región ocupada por este grupo se puede llegar a través de la carretera que une Putla con Pinotepa Nacional. Esa carretera en la actualidad se encuentra pavimentada. En San Pedro Amuzgos existe también una pequeña pista de aterrizaje.

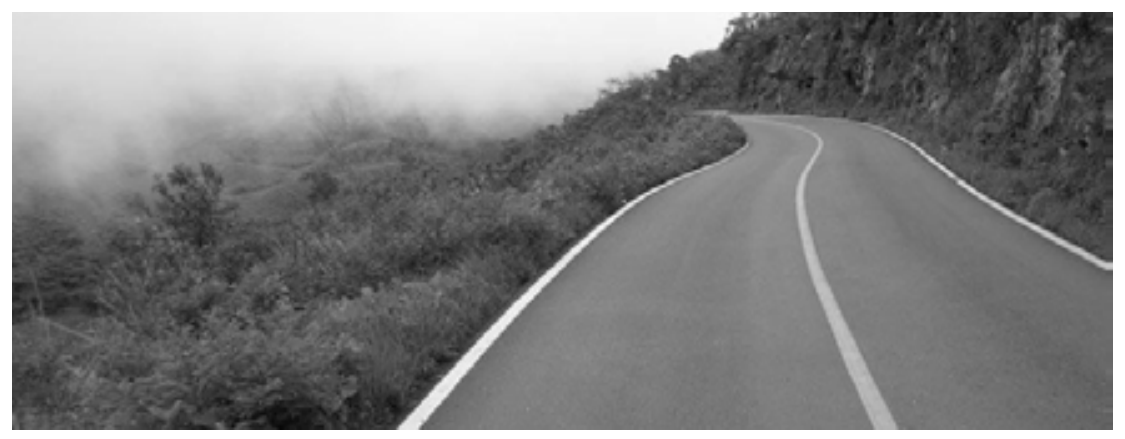

Carretera Tlaxiaco-Putla. Dir. De Turismo Estatal 
VIVIENDA. Las casas solieron ser, a veces, de planta rectangular y en ocasiones, circular, con paredes hechas con ramas, estructura de horcones y enlucido de lodo. Normalmente consistían en agrupamientos de dos; una en la que la familia cocinaba y comía y la otra en la que dormía y se almacenaba lo necesario. La familia durmió en promiscuidad y en ocasiones acompañada por animales domésticos. En la habitación destinada a cocina existía un fogón en una de las esquinas. Las casas no tenían ventanas y sólo una puerta de regular tamaño. En ocasiones, incorporado al conjunto habitacional, hubo, y en ocasiones hay, un baño de tipo temazcal.
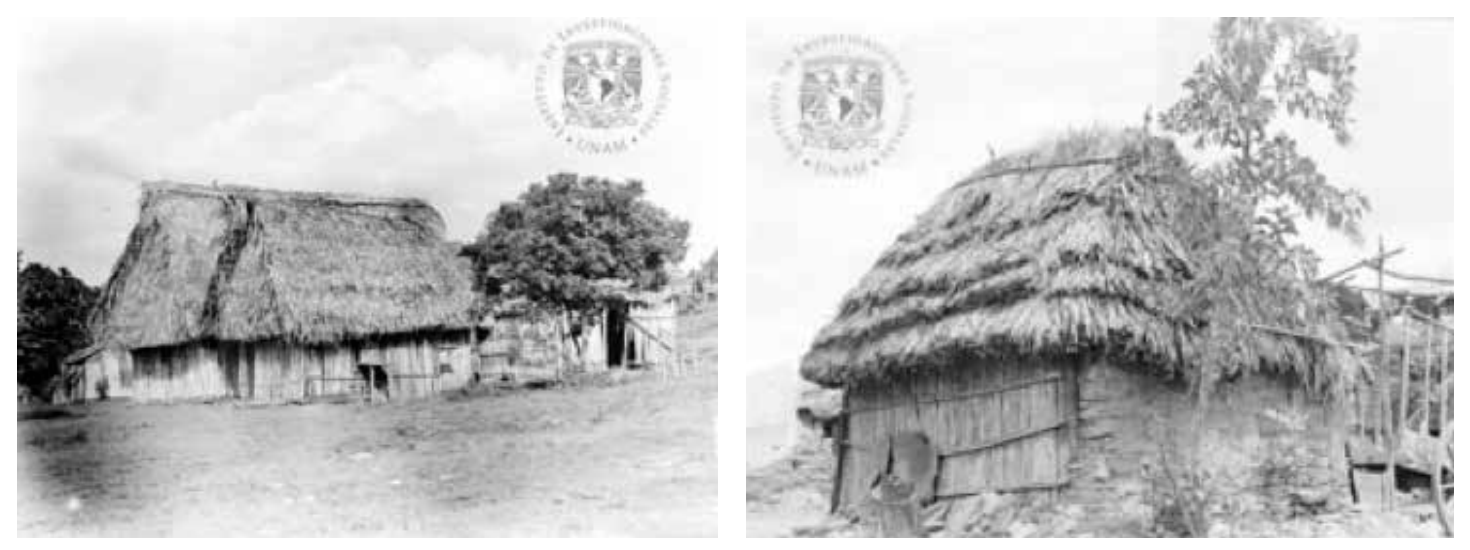

Casas amuzgas. (Fotos: IIS-UNAM).

El menaje de la casa consistió principalmente en artículos de metal, barro, madera y algunas canastas y petates tejidos. Se usaban muy pocos muebles, principalmente mesas y sillas de madera artesanales de maderas duras regionales, que han ido siendo substituidas poco a poco por mesas y sillas de madera de pino, mucho menos resistentes, llevadas por comerciantes recientes.

INDUMENTARIA. Tradicionalmente ha sido habitual que el grupo produzca sus propios textiles, los que, principalmente, se fabrican de hilo de algodón. Esta fibra es utilizada en la región en tres colores: Blanco, crema y café. El tejido se realiza mediante telar de cintura y cada pieza de tela termina por configurar, al ser cosida con otra, huipiles para mujeres (algunos extraordinariamente decorados y de excepcional belleza que, en ocasiones, son lucidos por las calles), o algunas otras prendas de ropa para los varones. Estos usan pantalón y una camisa, y ocasionalmente huaraches y sombreros de palma. En las épocas frías se suele usar un cotón de lana.

Tradicionalmente, la indumentaria característica del grupo comienza a ser usada cuando los niños cumplen seis años de edad. Recientemente se ha comenzado a introducir la indumentaria comercial y las poblaciones amuzgas se han visto invadidas por norteamericanos que compran la producción de huipiles a las tejedoras en su misma casa. 

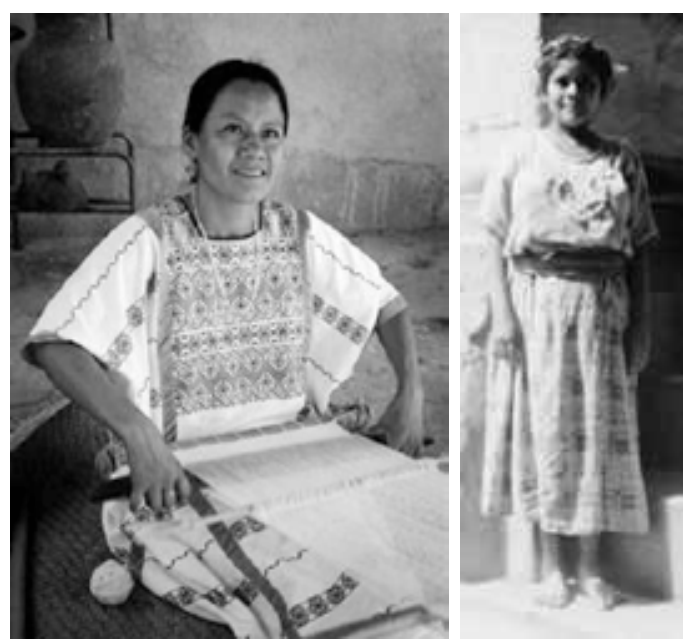

Tejedora y joven mujer amuzgas. (Fotos: IIS-UNAM).

ECONOMÍA. La economía amuzga se encuentra enmarcada dentro de su organización social, política y religiosa. Es una economía que no puede analizarse en términos de costo-beneficio, debido a que el grupo mantiene procesos de reproducción, defensas y adaptación a las condiciones económicas del país. En la actividad económica del grupo se reflejan sus características propias, su lenguaje y el conjunto de valores y tradiciones que forman una red constante de relaciones familiares económicas y religiosas.
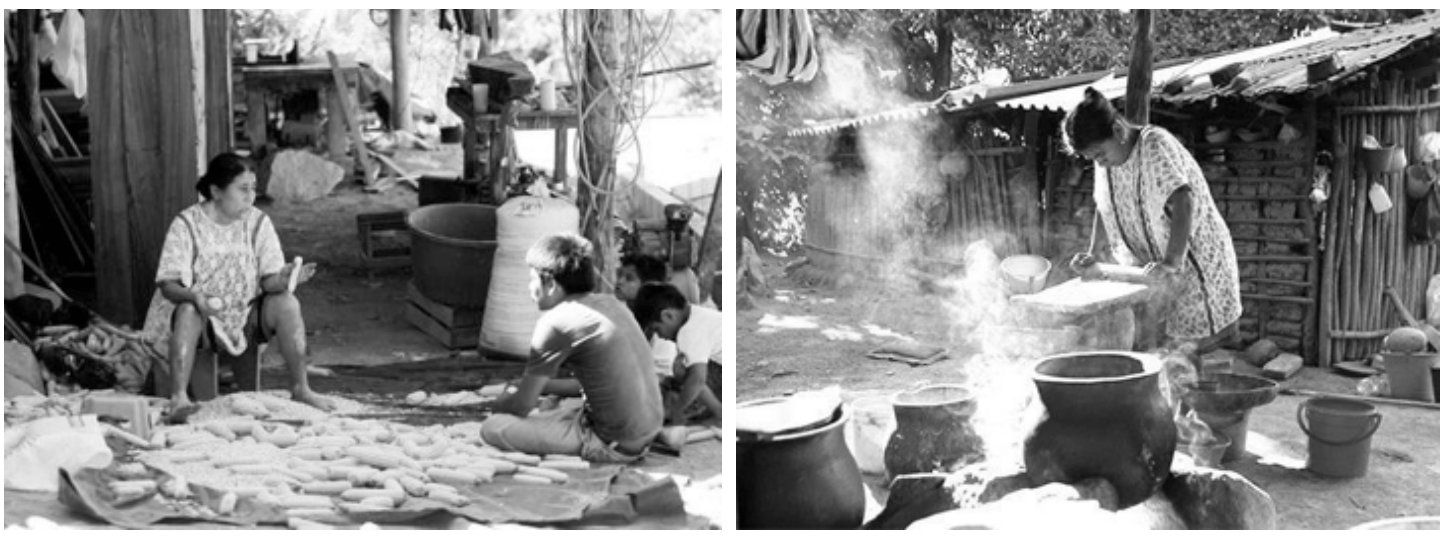

Desgranando y moliendo maíz. (Foto: Blog “Brújula Metropolitana).

Como en todas las zonas deprimidas del Estado, la sobre-explotación del medio ambiente, el uso inadecuado de los recursos naturales y las inadecuadas condiciones de trabajo, están llevando al grupo a una situación de extrema pobreza, no sólo porque el mismo pretende satisfacer directamente sus necesidades básicas, para lo cual tiene que recurrir a los pocos recursos naturales de que dispone, sino porque en algunos casos tiene que destinar parte de su producción, o del excedente de ella, para adquirir en el mercado aquellos artículos que no se producen en la comunidad, apareciendo entonces los desiguales sistemas de intercambio y comercialización. Como con frecuencia los recursos no alcanzan, la 
población adulta tiene que emigrar o dedicarse a actividades complementarias. En la región ocupada por los Amuzgos, el café y el tabaco, cultivos que requieren cierta atención, son los que se siembran en mayor grado, principalmente éste último, del que se siembran variedades de color oscuro que son las que tienen menor precio en el mercado. Además, hay poca avicultura de traspatio, así como cría de cerdos

En algunas comunidades existen individuos que elaboran cigarros y puros en bruto. Básicamente la agricultura del grupo tiende a ser de subsistencia, de roza y tumba y quema, basada en el maíz, en el fríjol y en algunas variedades de chile y calabaza, con ocasional consumo de carne, pollo y guajolote. En la región existen tres variedades de maíz, que se distinguen entre sí por su desarrollo y su tiempo de maduración. Dichas variedades son la cuarentena, que madura a los 48 días, la tecomache, del ciclo medio y la tepecente, que se siembra alrededor de los primeros diez días de Junio y madura a finales del mes de agosto. Asimismo algunos individuos siembran pequeños cañaverales con objeto de abastecer trapiches y obtener panela o piloncillo para vender. Los subproductos de esa actividad son jugo de caña, chía y miel incristalizable o melaza, la cual tiene muy poca utilización. Muy poca tierra regional está sujeta a pequeña irrigación, aunque tal rasgo existe en la región desde tiempos prehispánicos.

CAZA Y PESCA. De acuerdo al criterio puramente indígena de que los animales silvestres tienen un amo que es quien los pone al alcance del hombre, para los indígenas de esta etnia la fauna silvestre siempre fue un recurso complementario en la alimentación. En la región abundaron el venado cola blanca y el pecarí de collar, y en menor cantidad, el tigrillo, el ocelote, el jaguar, el coyote y el mono araña. Además. Hay especies pequeñas tales como el tejón de manada, el oso hormiguero, el armadillo, el mapache y la zorra gris, así como hubo grandes bandadas de loros, pericos y cotorras, actualmente muy agredidas. En los últimos años, y debido a los desmontes, varias especies de fauna silvestre han reducido su territorio ocupacional y solo algunas de ellas pueden adaptarse a nuevas condiciones. Por lo tanto, la posibilidad de recurrir a la fauna silvestre como un recurso alimenticio cada día se vuelve más problemática. De allí la importancia de establecer criaderos y proceder a una repoblación.

Las corrientes pluviales de la región presentan una existencia de especies de peces y crustáceos muy aprovechables, que no son usadas adecuadamente por la población indígena y mestiza del área. Sin embargo, sería factible establecer criaderos.

MERCADOS. San Pedro Amuzgos y Santa María Ipalapa son los principales mercados regionales. En ellos subsiste el intercambio de artículos producidos, como reminiscencia del trueque tradicional, y además se compran y se venden artículos industrializados, realizando las operaciones con dinero. El grueso de las operaciones comerciales es controlado por mestizos, de tal manera que, en el desigual proceso, es el indígena quien acaba teniendo el menor poder adquisitivo. 


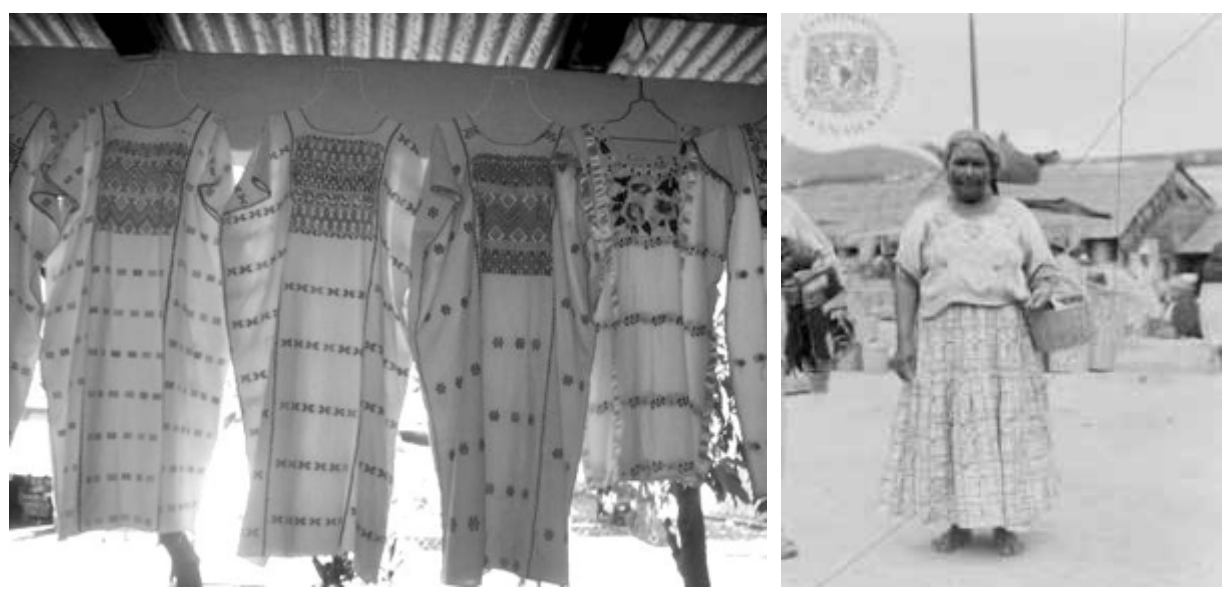

Huipiles en mercado y mujer amuzga. Otos: Dir. De Turismo Estatal e IIS-UNAM)

ARTESANIAS. El tejido y el bordado son las principales artesanías regionales. Sin embargo en algunas comunidades existen algunos artesanos que se dedican a otras actividades. En Xochiquilazala una familia fabricaba machetes y en algunas otras comunidades existen personas que elaboran cerámica y fuegos artificiales, así como cohetes.

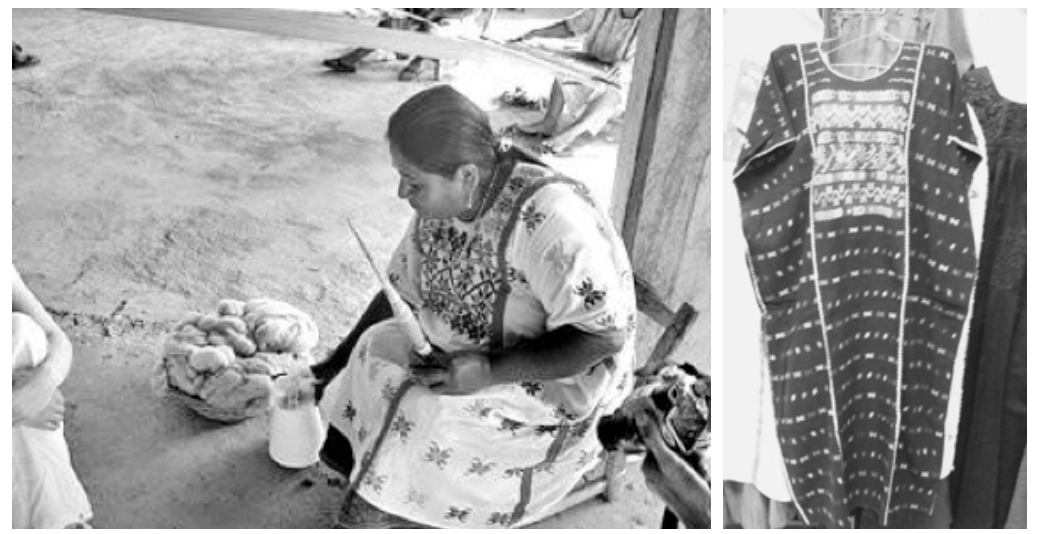

Hilandera y Huipil amuzgos. (Fotos: Blog “Brújula Metropolitana” y del autor).

Casi todos los productos artesanales son distribuidos dentro de la misma región, excepto los huipiles bordados, de los que ya hay una gran demanda por parte de los propietarios de tiendas de artesanías de las ciudades de Oaxaca y México, y del turismo internacional.

ORGANIZACIÓN SOCIAL. En el grupo Amuzgo las líneas de descendencia están fuertemente marcadas. La familia nuclear está compuesta por el padre, la madre y los hijos solteros. El nombre del individuo es impuesto por el padre, pero se observa que en algunos aspectos la madre también tiene un gran poder de decisión. Esto establece que la sociedad Amuzga es patrilineal, patri y matrilocal, endogámica y monogámica, habiendo también familias extensas. 


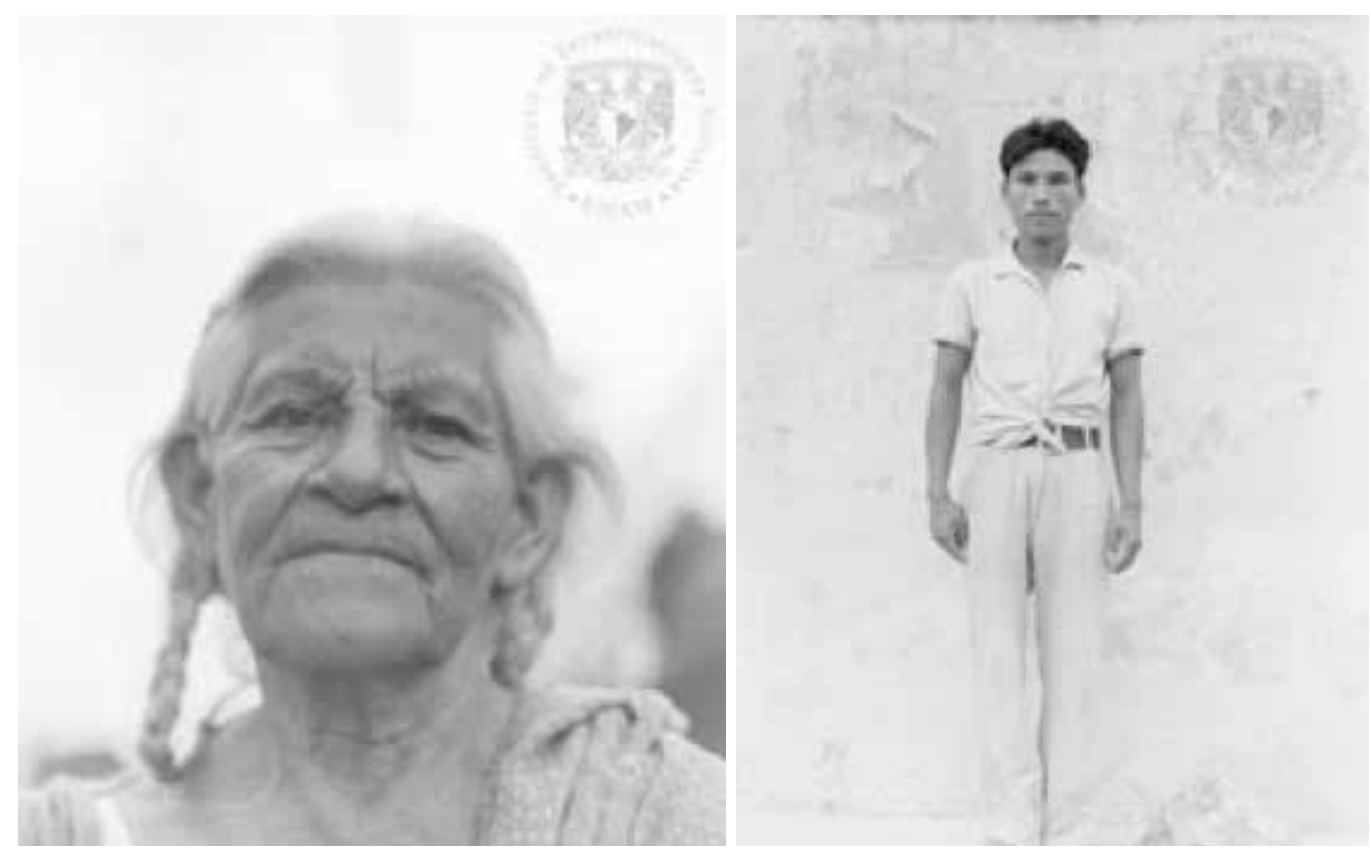

Anciana y hombre amuzgos. (Fotos: IIS-UNAM).

El matrimonio recién formado suele vivir con frecuencia cerca de la casa de la familia de la novia, y la selección de la pareja habitualmente ha sido realizada por los padres del varón desde que los niños tienen muy corta edad. Los presentes suelen consistir en animales, comida, licor y tabaco. Si la boda no llega a realizarse, lo entregado debe ser restituido. La edad de los contrayentes suele andar entre los 12 y 15 años y por ello son frecuentes los casos de desavenencia conyugal, documentándose bastantes situaciones en que las mujeres casadas han sostenido relaciones extramaritales cuando sus maridos se encuentran en sus labores. Las separaciones son frecuentes, pero no lo son los divorcios civiles. La causa de esta problemática puede encontrarse en la absoluta falta de cuidado en la selección de las parejas y en la poca edad, madurez y experiencia de los contrayentes. Ya los jóvenes actúan de otra manera.

La Institución del compadrazgo está firmemente establecida. Los principales compadres son los de bautismo y boda. Los padrinos de boda también suelen ser del primer hijo, pero los subsecuentes hijos incorporan nuevos padrinos, y por consiguiente nuevos compadres a las parejas procreantes. El matrimonio entre hijos de compadres no es visto con buenos ojos por la comunidad. Cuando un adulto muere, se le vela y entierra con música y comida. Al fallecer un niño, además de la música y de la comida, se le danza. El tipo de música en los entierros de adulto índica cual es el estado civil del fallecido. A los casados se le entierra con la cabeza mirando al occidente, los solteros y niños mirando al oriente.

Alrededor de la familia nuclear figura la familia extensa, compuesta por los parientes consanguíneos y por afinidad. Varias familias extensas pueden construir un barrio y en algunas poblaciones existen varios de ellos. Una pequeña parte de la población vive en asentamientos muy dispersos. 


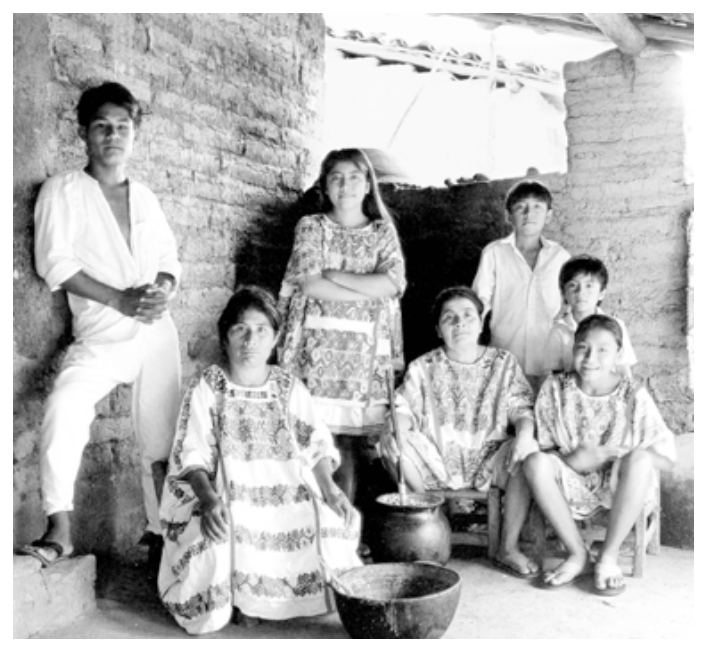

Familia amuzga. (Foto:La Jornada)

GOBIERNO. En el grupo Amuzgo, además de los gobiernos municipales existe una organización jerárquica de control social, en la que los individuos rectores ascienden por riguroso escalafón, principalmente por los ayudantes y el topilaje. Las actividades religiosas y políticas están fuertemente integradas, no obstante que en la región existe un proceso de aculturación muy fuerte. Subsiste la institución del tequio.

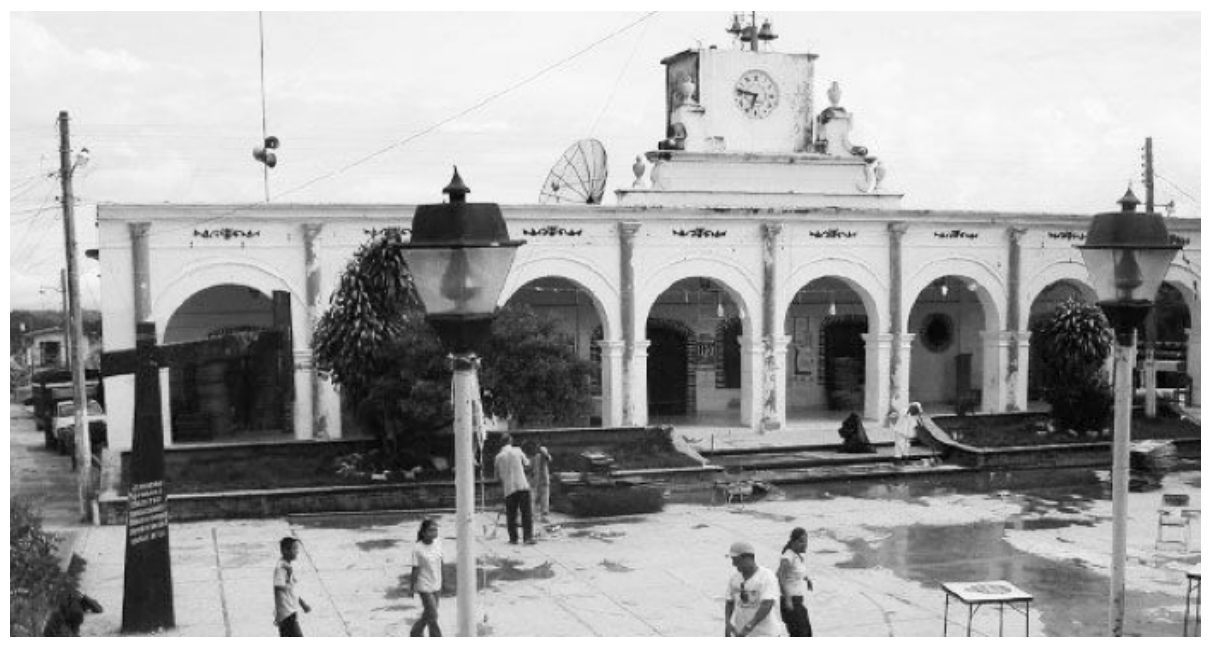

Palacio Municipal de San Pedro Amuzgos.

FESTIVIDADES. En el área ocupada por este grupo las principales festividades se dan en la fecha del Santo Patrón en cada población. En esas fiestas son habituales las danzas, gran parte de las cuales datan de la época de la colonización española, y algunas otras de períodos posteriores en los que el comercio regional fijó actitudes. Las danzas antiguas principales son las de Moros y Cristianos, las de la Conquista, la de los 12 Pares de Francia, y las de Gachupines y Apaches. Entre las danzas humorísticas se encuentra la del Macho Mula y las de Mestizos, negros y sacerdotes, existiendo también una en la que la gente 
monta en burros. Existen además otras danzas. La de los Charreos para Santiago, la de Pan de Penal, y varias danzas satíricas; la del Tigre, la del Toro y la del Macho Blanco.

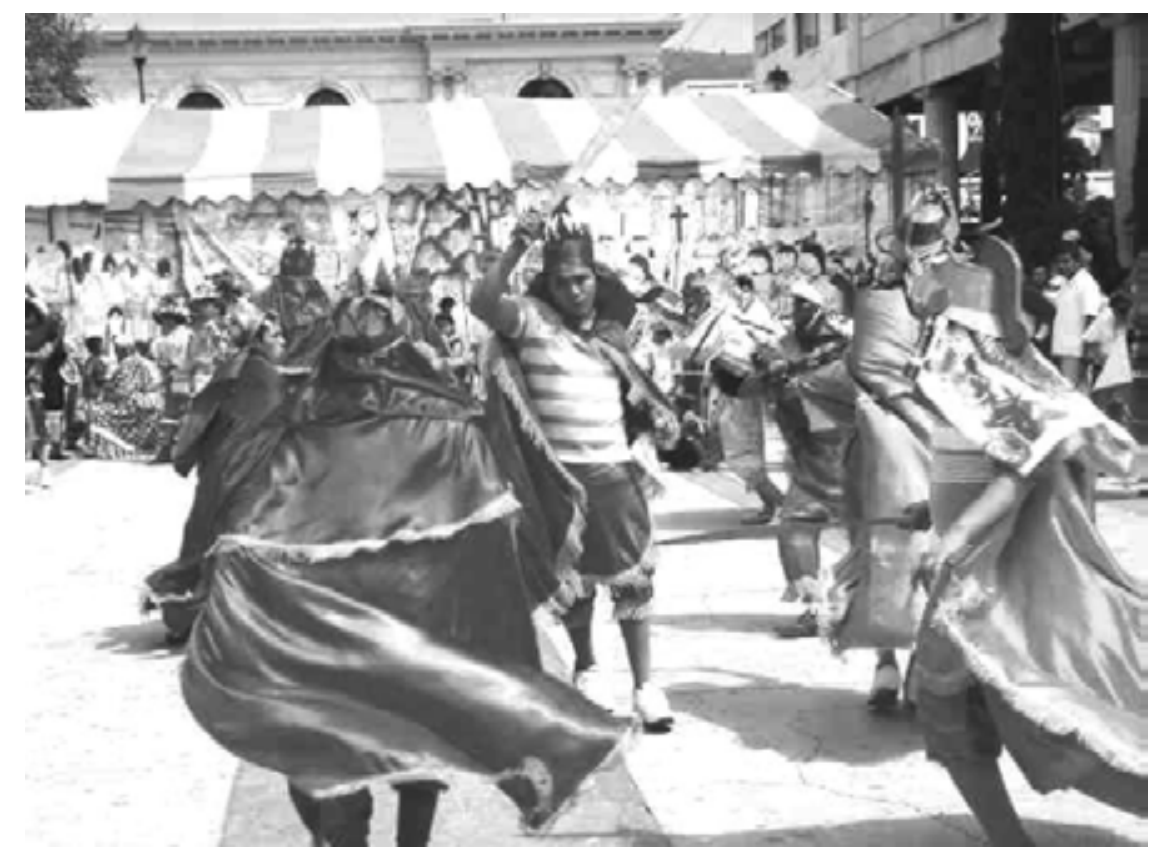

Danza de los 12 Pares de Francia en zona amuzga. (Foto: Dirección de Turismo Estatal).

La población amuzga conserva una amplia tradición oral con muchas leyendas, muchos cuentos y muchas adivinanzas. La mayor parte de las leyendas son de carácter moralístico y tienen como personajes principales al sol, a la luna, y animales tales como las serpientes, el conejo, el venado y el águila. Se cree en seres sobrenaturales capaces de crear enfermedades, y hay especialistas en detener su acción. Algunos hechiceros usan semillas de ololiuhqui, planta trepadora con semillas de propiedades alucinógenas, para conocer la causa de la enfermedad tratada, o comunicarse con lo sobrenatural.

Las fiestas familiares suelen estar nutridamente acompañadas por tabaco y bebidas alcohólicas.

ORGANIZACIÓN RELIGIOSA. Normalmente las iglesias parroquiales están a cargo de un sacristán; la institución de la mayordomía ha quedado bastante fija en la estructura del grupo. El mayordomo esta encargado de la organización de las actividades religiosas y sus funciones se entrelazan con las políticas. El mayordomo sólo puede ser electo por el Consejo de Principales. Estos son los individuos de mayor edad y de experiencia de la comunidad. Para los hombres, al servicio a ésta es uno de los mayores honores. Como las religiones prehispánica y católica se mantienen en cierto grado entrelazadas, en el grupo subsisten ceremonias de iniciación y algunos ritos relacionados con la fertilidad, por lo que hay Fiscales Mayores. En el grupo subsiste la creencia en los espíritus del agua, las montañas, los animales y la vegetación. Se pide la lluvia y las buenas cosechas. 


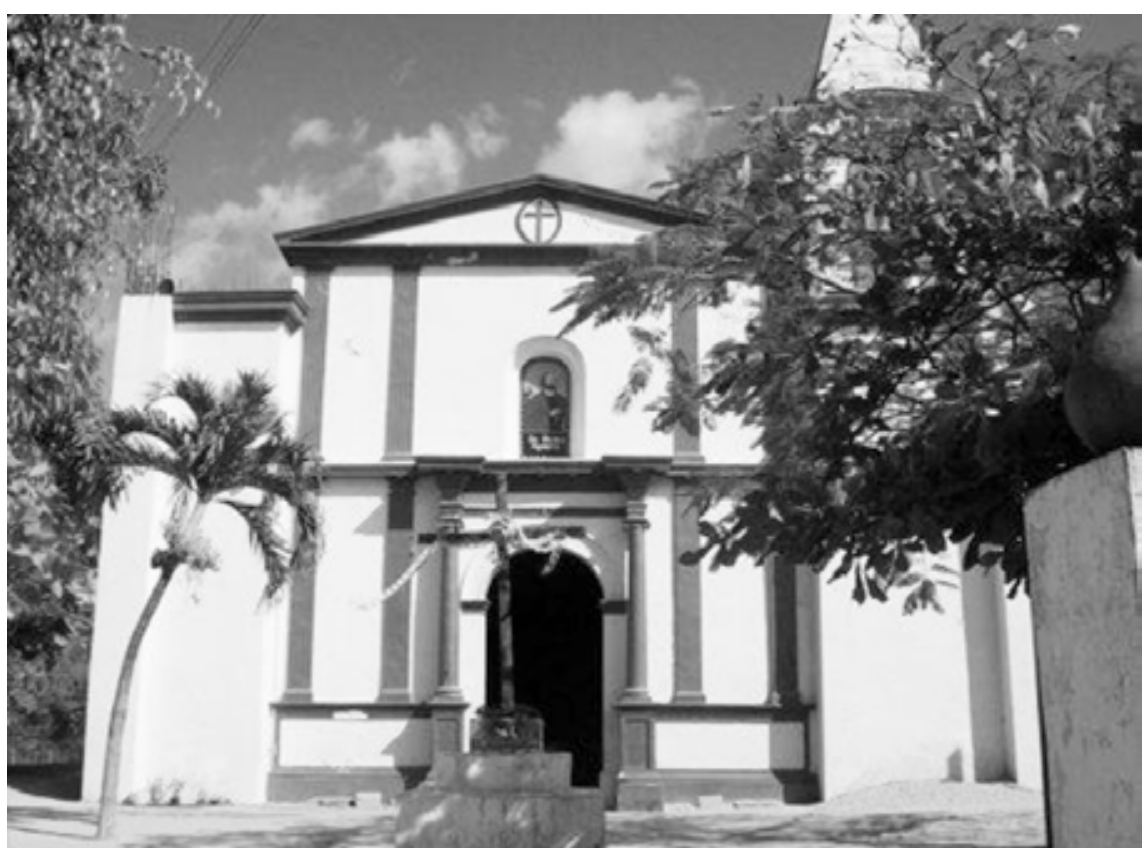

Iglesia de San Pedro Amuzgos. (Foto: Dirección de Turismo estatal).

MEDICINA Y MAGIA. En la etnia subsisten gran cantidad de las técnicas curativas prehispánicas, así como curanderos, brujos y hechiceros, considerados de amplios conocimientos, que practican ritos de enorme interés. Los sistemas curativos están asociados a la herbolaria aplicada, ya sea mediante investigación, o mediante baños. El agua constituye una muy importante parte de los sistemas curativos del grupo y su aplicación tiene por objeto modificar temperaturas en el cuerpo, aplicándosela, ya sea bebida mezclada con tierra o arena o aplicada como compresas húmedas de tierra. Muchos de los ritos de curación se realizan en puntos de que confluyen dos arroyos. Los Amuzgos creen que cada persona tiene un animal relacionado, que en el grupo recibe el nombre de "tono" y que también esta relacionado con un posible nahual. En la región existieron muy pocos médicos, quedando la actividad curativa mayoritaria en manos de brujos, curanderos y hechiceros. Los registros de sanidad revelan que durante mucho tiempo la población ha sido afectada por el paludismo y algunas otras enfermedades, principalmente disenterías. Desde hace muy poco tiempo se iniciaron los programas de sanidad que han ubicado pasantes de Medicina a realizar su servicio social. Hoy, en el 2014, la cobertura de salud es más amplia.

EDUCACIÓN. En la década de los cuarentas del Siglo XX se establecieron aulas de educación elemental en la región, no obstante, el promedio de escolaridad regional es inferior al tercer año de primaria. En el área existen varias escuelas primarias en San Pedro Amuzgos y en poblaciones guerrerenses, además de una secundaria, que dependen de los sistemas federales y estatales. Para mayor nivel, los estudiantes van al Colegio de Bachilleres de Putla, o bien al de Pinotepa Nacional. Se registran estudiantes becados en el Sistema de Universidades estatal, particularmente en la ubicada en Pinotepa Nacional. 


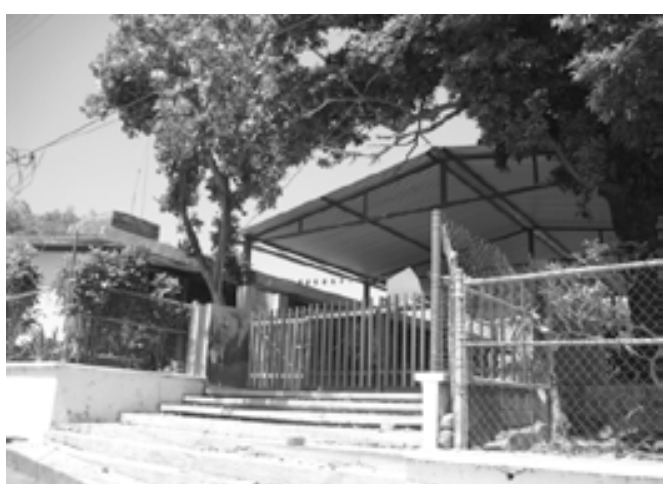

Escuela elemental en zona amuzga. (Foto: Wikipedia)

\section{BIBLIOGRAFÍA}

Acevedo Conde, María Luisa. 2007 “Los Amuzgos”. Revista: A CONTRAGOLPE № 10 Carteles editores, Oaxaca, Oax. 2007

Aguirre Beltrán, Gonzalo. 1958 CUIJLA, ESB0Z0 ETNOGRAFICO DE UN PUEBLO NEGRO. Fondo de Cultura Económica. México, D F. 1958.

Basauri, Carlos 1940 Reed. 1990 "Los Amuzgos”. LA POBLACION INDIGENA DE MEXICO. Tomo II. Instituto Nacional Indigenista. SEP. México, D F. 1990.

Caballero, Juan Julián, 1994 AMUZGOS DE OAXACA. Instituto Nacional Indigenista. SDS. Gobierno del Estado de Oaxaca. México, D F. 1994.

Egli, Walter. 1982 SAN PEDRO AMUZGOS. LA LUCHA DEL PUEBLO MEXICANO POR SU TIERRA. HISTORIA AGRARIA DE LA COSTA DE OAXACA DESDE EL PERIODO COLONIAL A SU ESTADO ACTUAL. (Edición alemana). Zurich, Suiza. 1982.

Fernández Gatica, Andrés. 1987 Tsun Noa. AMUZGOS. Editorial Cagiga, Puebla, Pue, 1987. Gay, José Antonio. 1881

Reed. 1967. HISTORIA DE OAXACA. Colección “Sepan Cuantos” No 373. Editorial Porrúa, México, D F. 1967.

González García, Carlos. 2002 "El Camino de Abajo. Autonomía del PuebloAmuzgo”. En: OJARASCA. Suplemento Mensual de La Jornada. № 69. México, D F. Enero del 2002. López Guzmán, Bartolomé. 1993 LOS AMUZGOS Y EL MUNICIPIO DE XOCHIXTLAHUACA, GUERRERO. (Programa de Apoyo a las Culturas Municipales y Comunitarias). INI, México, D F. 1993.

Mendieta y Núñez, Lucio. 1957 ETNOGRAFIA DE MEXICO. Universidad Nacional Autónoma de México. México, D F. 1957. Pericot García, Luis. 1936 LA AMERICA INDIGENA. Barcelona, España. 1936.

Rodrigo Álvarez, Luis. 1982 "Los Amuzgos”. En: ENCICLOPEDIA DE MEXICO. Tomo I. Editorial Enciclopedia de México. México, D F. 1982. 2004 GEOGRAFIA GENERAL EL ESTADO DE OAXACA. 4a Edición aumentada. Carteles Editores, Oaxaca, Oax. México. Serrano Carreto, Enrique. Embriz Osorio, Arnulfo. Fernández Ham, Patricia. 2002 INDICA- 
DORES SOCIOECONOMICOS DE LOS PUEBLOS INDIGENAS DE MEXICO. INI. México, D F. 2002.

Tapia García, Fermín. 2004 ETNOBOTANICA DE LOS AMUZGOS. Centro de Investigaciones Sociológicas. INAH. SEP. México, D F. 2004.

Tovar, María Fernanda. 1990 "Los Amuzgos". En: OAXACA, TEXTOS DE SU HISTORIA. Instituto de Investigaciones José María Luis Mora. México, D F. 1990. 


\section{POPOLOCAS}

Autodenominación: ngiwa, ngiba.

Sinónimo en su lengua: nquiveeni (chocho-Popoloca).

Significado: a) Para los nahuas: Tartamudo, Lerdo.

b) Para el grupo: El que habla lengua diferente.

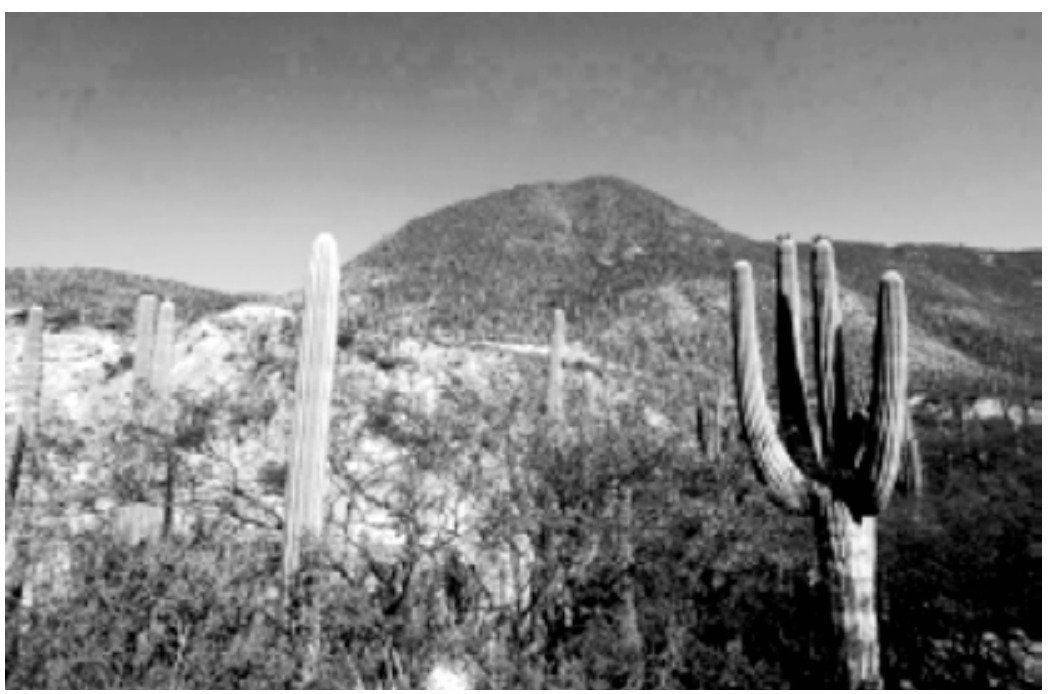

Paisaje en zona popoloca. (Foto del autor).

\section{GRUPO POPOLOCA.}

ENTORNO GEOGRAFICO. El grupo Popoloca en el Estado de Oaxaca ocupó los alrededores de una sola localidad, San Antonio Nanahuatlipan, ubicada en la frontera del Estado con el de Puebla, en el Distrito de Teotitlán de Flores Magón. Esta pequeña área se encuentra ubicada entre los paralelos $18^{\circ} 25^{\prime}$ y $18^{\circ} 27^{\prime}$ de Latitud Norte y entre los meridianos $96^{\circ}$ $30^{\prime}$ y $96^{\circ} 31^{\prime}$ de Longitud Occidental. El sector ocupado por los popolocas presenta un relieve de lomeríos bajos, en cuyas cañadas fluyen corrientes que vierten al Río Salado, el cual a su vez es uno de los afluentes del Río Papaloapan. El clima es semicálido, semiseco con lluvias en verano que casi nunca sobrepasan los 700 milímetros anuales. La vegetación es xerofítica y sólo en lo alto de algunas pequeñas montañas existe un chaparral bajo asociado con encinos o ailes. En tiempos prehispánicos la vegetación debió ser más subtropical y los bosques de coníferas debieron tener mayor extensión, aunque siempre fueron manchones pequeños. 


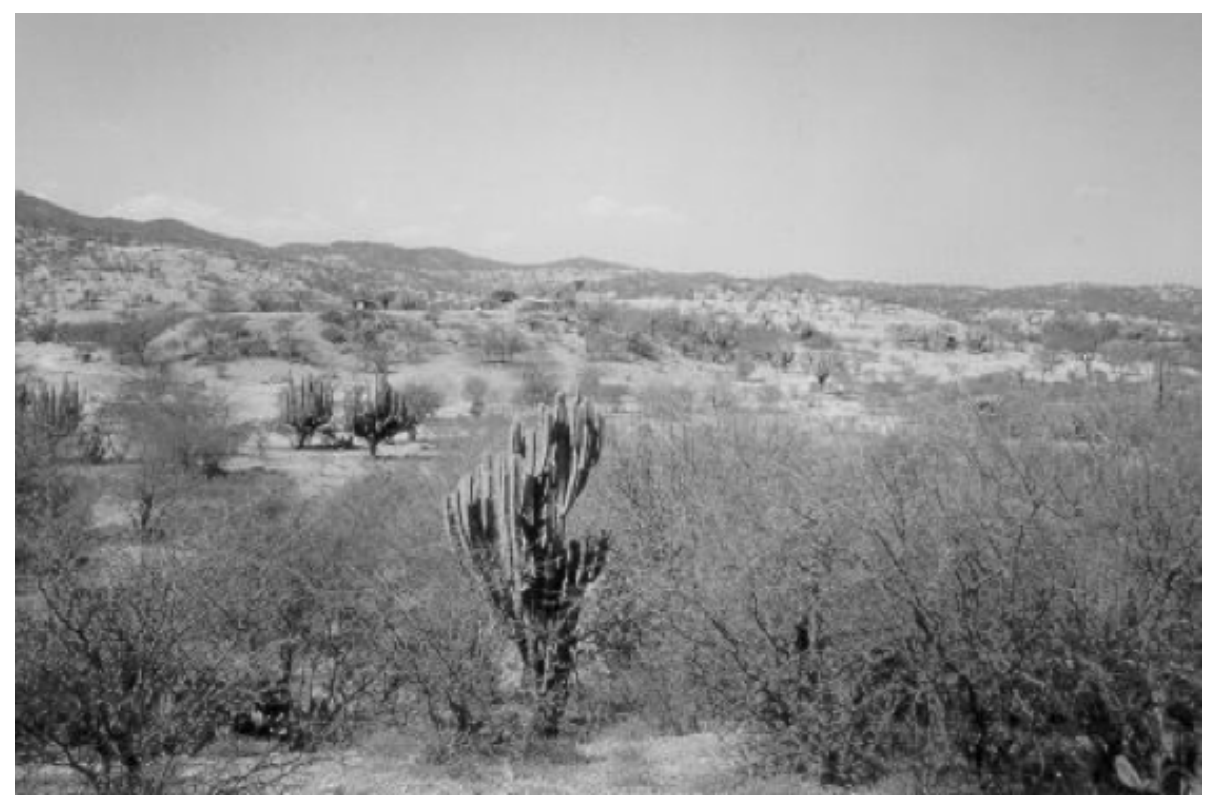

Paisaje Popoloca. Nanahuatlipan. (Foto: Gobierno estatal de Oaxaca).

LENGUA. El Grupo Popoloca habla una lengua perteneciente al Grupo Otomangue, Tronco Savizaa, familia Mazateco-Popoloca-Zapoteco, y en la actualidad en el territorio oaxaqueño, en casas aisladas, habita un poco menos de 600 personas, de las cuales más de la mitad (524) aún conservan palabras de su idioma ancestral, siendo unos pocos ancianos los que aún lo conocen.

ACCESOS. El acceso principal puede realizarse a través de la carretera que une la Ciudad de Oaxaca con Tehuacán a través de Telixtlahuaca y Cuicatlán, en tanto que el acceso a la población popoloca de San Antonio Nanahuatlipan se puede realizar mediante un camino de terracería. Por la población pasa también la vía de ferrocarril, o el terraplén que de ella queda, aunque tal medio de transporte haya desaparecido.

ANTECEDENTES ARQUEOLÓGICOS E HISTÓRICOS. Históricamente el pueblo Popoloca es una derivación de los Chocho-Mixtecos en el Norte del estado. Culturalmente parecen haber estado originalmente más relacionados con grupos del Valle de Tehuacán, con los que compartieron las primeras siembras de maíz, una de las primeras obtenciones de sal y una de las primeras cerámicas, y por ello haber tenido más contacto con grupos históricos prehispánicos del Estado de Puebla, situación que persistió durante la serie de Fases Culturales ya existentes para el Valle de Tehuacán. Hacia el epiclásico mesoamericano poseían varios principalatos en varias poblaciones, una de las cuales fue Tepexi el Viejo, otra Venta Salada y también Tehuacán Viejo (Cerro Colorado). Tiempo antes habían participado en la elaboración y distribución, en el ámbito teotihuacano, de la cerámica anaranjada delgada, llevada desde la población de Ixcaquixtla y algunas cercanas. Posteriormente tuvieron relación con nonoalcas inmigrados. 


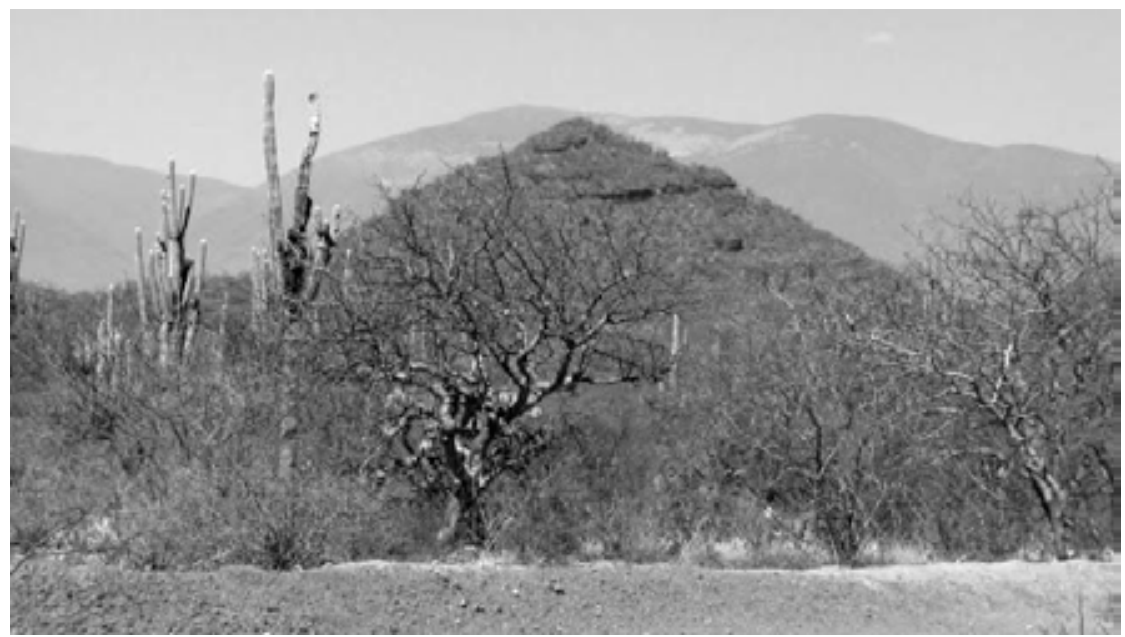

Montaña con Centro Ceremonial en culto en la parte superior.

(Foto: concienciapersonal.blogspot).

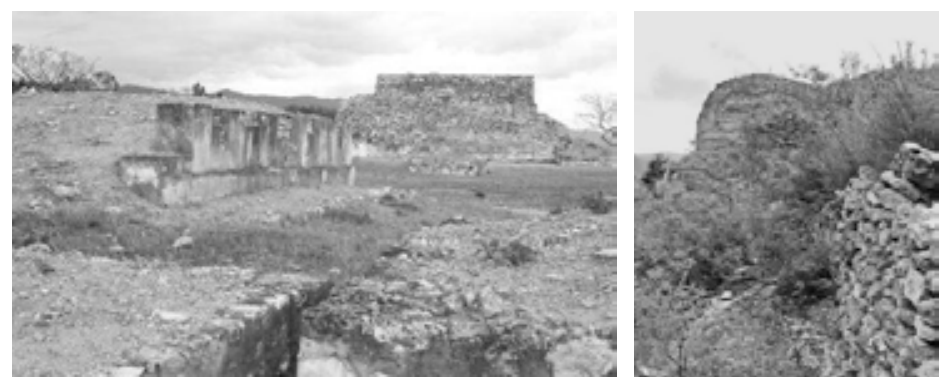

Zona Arqueológica de Cerro Colorado. (Fotos: INAH).

Hacia la época de la dominación Azteca, y con Principalatos en Tepeaca, Tlacotepec, Tecamachalco, Tzinacantepec, y Caltepec, sitios arqueológicos con rasgos culturales importantes, tales como pintura mural e implementos de uso musical (resonadores), fueron tributarios de Tenochtitlan y tuvieron relevancia como una de las regiones de apoyo para las rutas comerciales que se dirigían a Tuxtepec y a poblados de los valles y la sierra norte oaxaqueñas.

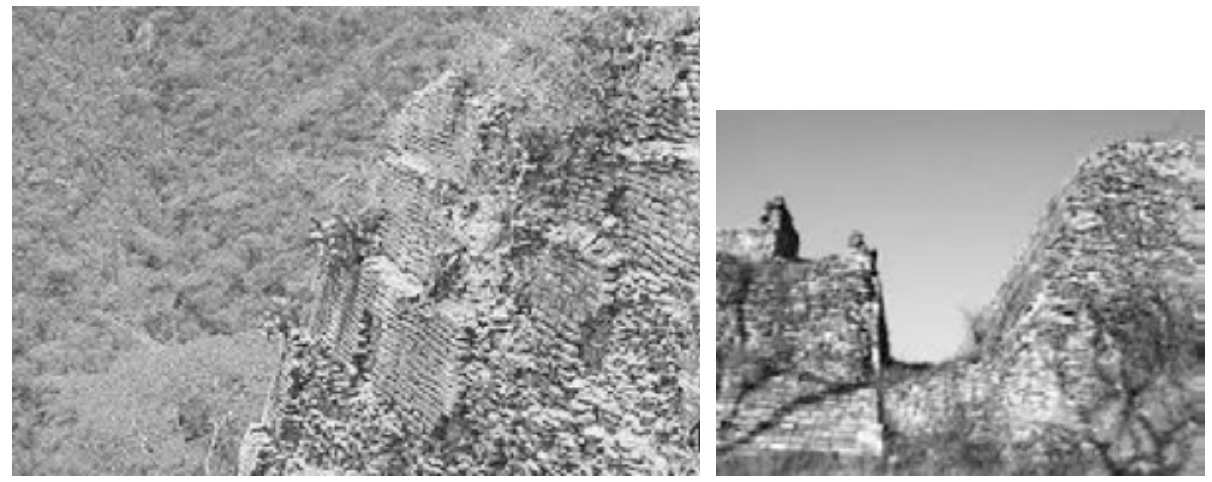

Zona Arqueológica de Tepexi el Viejo, Pue. (Fotos: Arql. Noemi Castillo Tejero). 
Los códices prehispánicos del Grupo Borgia contienen rasgos que pueden señalar la presencia popoloca entre los informantes que permitieron el dibujo de tales documentos, y en el Postclásico, la cerámica de "Fondo Sellado", con las excepciones veracruzanas, se distribuye casi exactamente sobre su área de ocupación.

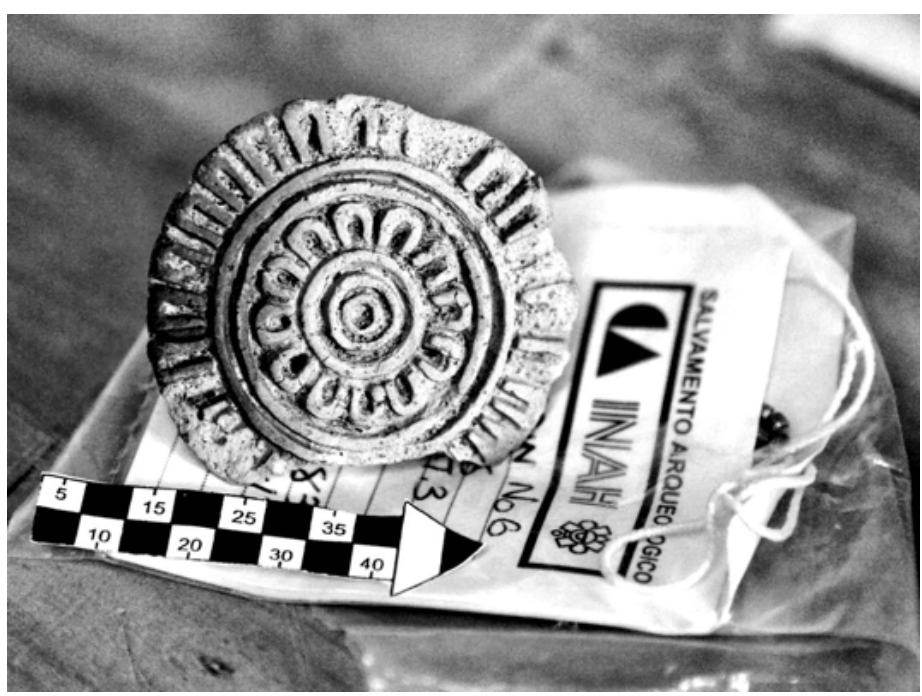

Molde de cerámica de "Fondo sellado". (Foto: INAH).
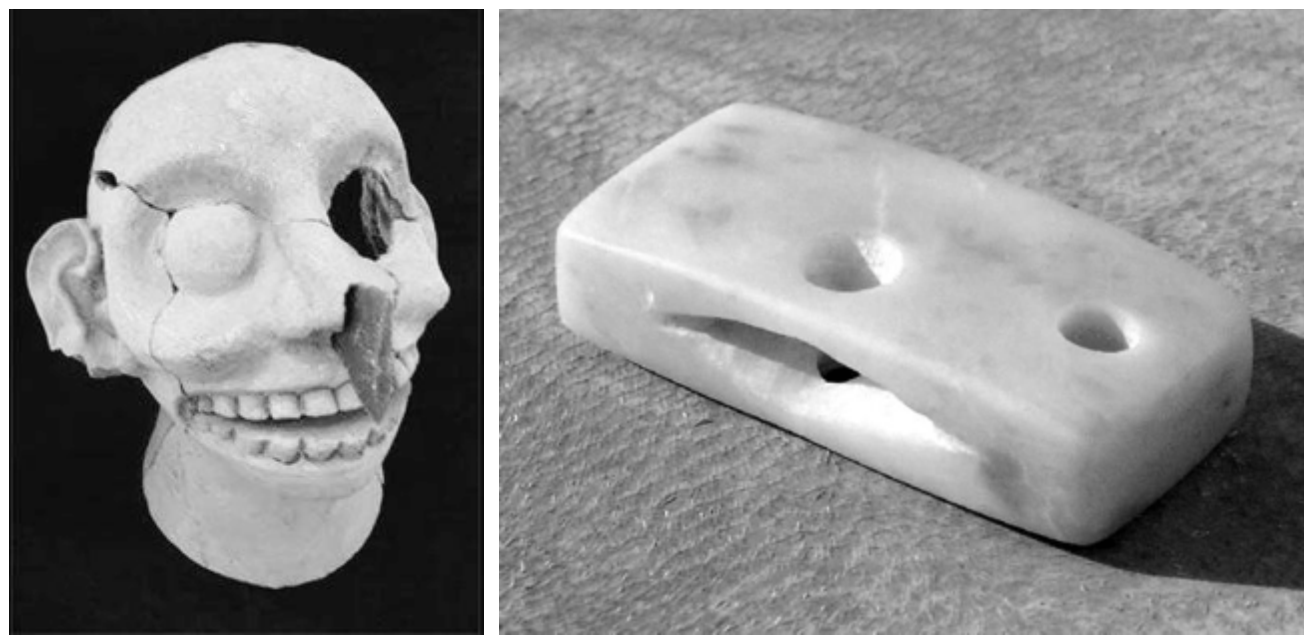

Dualidad vida-muerte, en cerámica y Resonador de ónix. (Fotos: INAH).

$\mathrm{Al}$ sobrevenir la conquista, se sometieron con facilidad y comenzaron a ser cristianizados y siempre considerados diferentes de los nahuas, con quienes colindan al occidente de su territorio. Se sabe muy poco sobre el proceso de cristianización, en el cual participaron primero frailes franciscanos (Fray Andrés de Olmos y Fray Martín de Valencia) y después algunos agustinos y dominicos, quedando bajo el control del obispado de Puebla. Más se sabe de la importancia que adquirieron en el período del Siglo XVI en que hubo cultivo de la seda en Nueva España, lo cual queda demostrado por la existencia de la po- 
blación de Tepexi de la Seda en el suroeste poblano, donde se concentró un importante acopio de ese producto, el cual se sabe que dependía de más de 100000 árboles de morera. El grupo siempre tuvo fama de ser belicoso y el nombre de Popoloca les fue asignado por los mexicanos como calificativo infamante que significa "bárbaro", "tartamudo" o "poco inteligente" y el término fue conservado y transmitido por autores como Don Nicolás León, quien los estudió a fines del Siglo XIX y a principios del XX. El valor cultural del grupo dentro del ámbito mesoamericano desmiente categóricamente esa designación, pues si algo los caracterizó fue precisamente lo capaces e industriosos, tanto que existen sus notables fortificaciones y la evidencia de ser un notable pueblo alfarero.

El área de ocupación Popoloca, antes de la conquista, presentó una serie de principalatos, con tres centros ceremoniales principales, en Venta Salada y en Cerro Colorado en el Valle de Tehuacán y, además, otro de importante tamaño en Tepexi el Viejo.

También en esa época el grupo abarcó un territorio considerablemente mayor que el que ocupaban en la década de los treintas del Siglo XX. Este territorio abarcaba parte de Puebla y porciones de Guerrero y Oaxaca.

Durante la época colonial, las epidemias, el proceso de cristianización y el de encomiendas fueron mermando su número, ya que a fines del Siglo XX sólo se contaban alrededor de 20 000. En las sucesivas crisis por las que ha pasado el país desde el fin del periodo colonial, los indígenas popolocas tuvieron una participación activa, principalmente como individuos de tropa del Ejército Nacional, y muchos de ellos combatieron y cayeron en las principales batallas que han tenido lugar desde que México es nación independiente. Las cercanías de Nanahuatlipan fueron escenario de dos combates: uno durante la Guerra de Reforma, en el que intervino, contra guerrillas republicanas del Gral. Ignacio Mejía, parte de la guarnición conservadora de Tehuacán, y otro en que las fuerzas del Gral. Porfirio Díaz Mori sorprendieron a una parte de los húsares austriacos del Conde Karl Khevenhüller, no pudiendo derrotarlos porque el refuerzo esperado del Gral. Luis Pérez Figueroa no pudo llegar. Un pequeño contingente popoloca murió casi en su totalidad cuando las tropas liberales que el Gobierno de Oaxaca envió en apoyo el Ejército del Centro a principios de 1862 fueron víctimas de una explosión en la colecturía de rentas de San Andrés Chalchicomula, actualmente Ciudad Serdán, Estado de Puebla, edificio habilitado como cuartel. Ya en el Siglo XX, y en el período de la soberanía oaxaqueña, tuvo lugar en la estación de ferrocarril de Nanahuatlipan un fusilamiento masivo, en el que cayeron soldados y oficiales maderistas nativos de Santa Catarina Ixtepeji y San Pedro Nexicho, pueblos serranos, ejecutados por soldados soberanistas igualmente serranos de las fuerzas de los Grales. Guillermo Meixueiro Delgado e Isaac M Ibarra. En ese hecho tocó a autoridades popolocas proceder a los enterramientos.

Durante el Porfiriato y casi todo el Siglo XX la etnia ha ido siendo desplazada gradualmente fuera del territorio del estado principalmente como consecuencia de la pérdida de tierras cultivables, llegando a la actual situación en que a sus últimos miembros sólo se les encuentra en una sola población con un limitado entorno agrícola, y ya prácticamente sin acceso a los pocos chaparrales y bosques de encinos y ailes próximos. 
VIVIENDA. Habitualmente, la vivienda Popoloca era de adobe o bajareque con techo de pasto o de teja a dos aguas, el piso siempre fue de tierra y el fogón se encontraba cerca de uno de los ángulos de la habitación. El hacinamiento interfamiliar y con animales domésticos fue y sigue siendo muy frecuente.

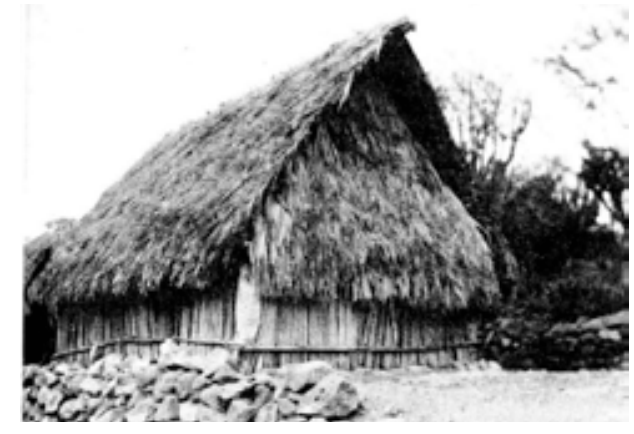

Casa popoloca. (Foto: IIS-UNAM).

INDUMENTARIA. Hasta la década de los cuarenta del Siglo XX los hombres usaron camisa y calzón blanco de manta y un sarape o cortón de lana que las mujeres fabricaban. Portaban además huaraches de correas. Las mujeres usaban enaguas y camisas de manta de color blanco, una faja hecha con un rebozo viejo y un rebozo de hilo. Habitualmente andaban descalzas y se adornaban con cuentas de vidrio y arracadas o anillos de latón o cobre. En la actualidad tanto hombres como mujeres están utilizando las camisas, los pantalones y los vestidos que se fabrican comercialmente en los establecimientos textiles del país o de importación. Se sigue usando el huarache y también los zapatos tennis, y las mujeres ya usan calzado de plástico.

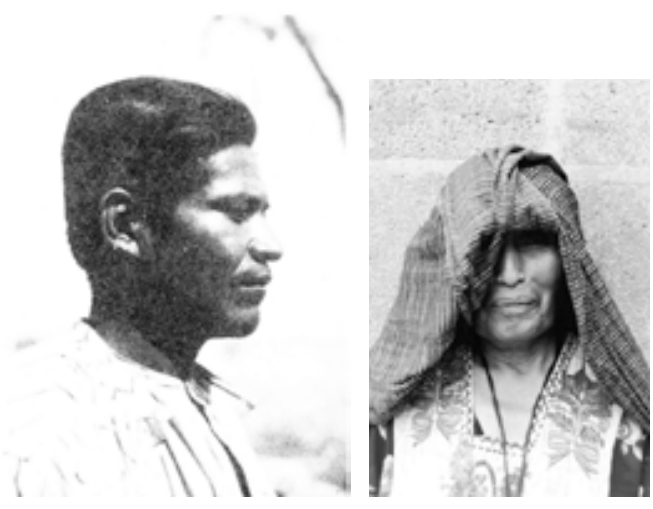

Hombre popoloca. (Foto:IIS-UNAM). Mujer popoloca (Foto: Semillas Eterno).

ECONOMÍA. La economía Popoloca es de subsistencia basada en el maíz y en la explotación de productos de plantas xerofíticas tales como el nopal y la pitahaya, y como la de todas las etnias nacionales no se debe analizar en términos de costo-beneficio, ya que la 
comunidad mantiene procesos de producción, o defensa y adaptación a los procesos económicos del País. En las actividades económicas del grupo se halla reflejado el conjunto de valores tradicionales, costumbres que forman una red permanente de relaciones familiares, económicas y religiosas. Como en todas las zonas deprimidas del Estado, la explotación se da no sólo porque el grupo pretende satisfacer directamente las necesidades básicas de la reproducción biológica y social, sino porque en algunos casos tiene que destinar parte de su producción, y muy rara vez el excedente de a misma, para adquirir en el mercado otros bienes que no se producen en la comunidad, apareciendo entonces los desiguales sistema de intercambio y comercialización. Como casi siempre los recursos no alcanzan, la población masculina se ve impelida a salir del territorio a vender su fuerza de trabajo; y la femenina comienza a abandonar su comunidad para conseguir empleos en las áreas urbanas o fabriles del país, de los Estados Unidos y Canadá. Puesto que los suelos del área son particularmente calcáreos y proceden de un fondo marino cretácico de alta salinidad, su rendimiento agrícola es muy bajo y su mejoramiento solo podría lograrse mediante la incorporación de abono orgánico, ya sea estiércol o gallinaza, en cantidades que la comunidad no puede poseer. Por otro lado, las necesidades crecientes del Valle de Tehuacán y de las empresas madereras ha motivado una inmoderada tala de los últimos bosques de coníferas del área, y los beneficios de esta explotación nunca llegaron a la etnia.

CAZA Y PESCA. Aunque el ecosistema xerofítico del área ocupada por los popolocas ha contenido una fauna silvestre específica, la destrucción sistemática de los recursos del medio había puesto el borde de la extinción a las principales especies de mamíferos del área, entre las que se encuentran el puma, el pecarí y el venado cola blanca. La decisión de establecer la Reserva de la Biósfera Tehuacán-Cuicatlán representó un importante respiro. Con altibajos, esa reserva está logrando el objetivo de la salvación, no obstante que los algunos funcionarios del Gobierno Federal y algunas autoridades de pueblos, no demuestran apoyar con entusiasmo el proyecto, lo que deriva en caza furtiva. Al principio del año del 2013, en Nanahuatlipan se ha iniciado un programa de conservación y reproducción del venado cola blanca, que comienza a dar buenos resultados. La liebre de panza blanca y el conejo rabo de algodón han logrado mantener un pequeño ritmo de reproducción, pero el espacio para la liebre es limitado y por ello no abundan los ejemplares. En el Río Salado existen solo contadas especies de peces cuyo pequeño tamaño solamente permite una captura esporádica. Los pobladores del área sólo de manera ocasional comen esas pequeñas platijas a las que dan el nombre de "mojarritas".

MERCADOS. El mercado Popoloca fue una institución importante debido a las posiciones geográficas de sus poblaciones con respecto a las rutas comerciales durante los últimos 1800 años. Hasta la década de los 50s existió el trueque y en la actualidad todas las transacciones se realizan con dinero, habiéndose perdido el antiguo sistema de pesas y medidas. 
ARTESANIAS. Los popolocas se caracterizan por la confección de textiles de algodón, de ixtle y de palma, así como por ser buenos alfareros, de lo cual quedan pocas dudas.

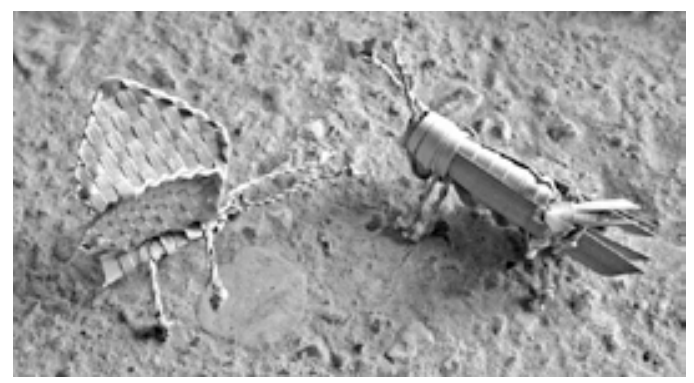

Tejido de Palma Popoloca. (Foto: Comunidad de San Juan Raya, Pue).

A principios del Siglo XX, Don Nicolás León consignó los datos de un informante que le narró la técnica que seguian, datos que transcribimos a continuación: "Asaz ruda es la tarea que la alfarería requiere: hay que traer de un lugar distante el barro y sacar de profunda mina el micasquite que se le mezcla (gránulos gruesos calcáreos que actúan como desgrasante); después preparar convenientemente ambas cosas para formar la pasta. En lugares apropiados se deposita el barro, y cuando está seco se procede a pulverizarlo. Para este fin usan un palo grueso y encorvado con el cual a repetidos golpes logran su objeto. Esta labor para un solo hombre sería demasiado pesada y como la industria no da para el pago de operarios, ni estos se encontrarían fácilmente, quienes de ellos necesitan recurren a este medio: Colocan en un lugar visible una gran botella conteniendo aguardiente de caña, y todo aquel que ayuda a esa faena tiene derecho a libar buenos tragos de ese por ellos tan apetecido licor.

Tamizadas y mezcladas las tierras en la proporción debida, proceden las mujeres al arreglo de la pasta poniéndole la cantidad necesaria de agua y malaxando con las manos”.

"Los que fabrican los comales lo hacen agradando y aplanando el barro con la palma de mano hasta obtener la figura y tamaño deseados. Estos objetos se dejan secar al sol por unos o dos días, al cabo de los cuales, con un pequeño cuchillo, los van rebajando hasta darles del grosor conveniente, y después con un pedazo de piel mojada, un fragmente de jícara y una piedra lisa, los pulen perfectamente", "Para darles mayor consistencia y cierto vidriado, los untan con el cocimiento de la corteza de un arbusto que ellos llaman cuajito (Burseva ragarcides. Engles) después de haberlos cocido al horno”. Como se señaló anteriormente, no está muy descaminada mi hipótesis arqueológica de que la cerámica postclásica de "fondo sellado" pudo tener su origen en el grupo, o que por lo menos colaboró ampliamente en su dispersión.

GANADERÍA. La casi totalidad de la región colindante entre Oaxaca y Puebla ocupada por los Popolocas está siempre sistemáticamente recorrida por hatos de ganado menor, principalmente cabras, ya que la pobreza de recursos no permite el mantenimiento de ganado vacuno y por ello sólo existen pocas yuntas y unas cuantas vacas criollas. La mayor parte 
del ganado caprino de la región pertenece a españoles radicados en Tehuacán y Puebla. Al no haber un pastoreo racional, las cabras han sido la causa de la destrucción de gran parte del monte bajo, de ciertos pastizales y de los bosques del área.

ORGANIZACIÓN SOCIAL. La estructura social popoloca es patrilineal, patrilocal y endogámica. Esto quiere decir que el matrimonio recién formado vivirá relativamente próximo a la casa del padre del varón, que la estructura dará al varón el principal papel y que los matrimonios se celebrarán dentro del grupo. Sin embargo, la mujer participa de manera importante en las decisiones matrimoniales. El noviazgo tradicional entre los Popolocas no se iniciaba por un contacto personal entre el muchacho y la muchacha, sino que el muchacho comunicaba a sus padres cual era la muchacha de su elección y entonces éstos recurrian a un casamentero, que en el grupo recibe el nombre de "xiticoxiano", quien era el encargado de comunicar a los padres de la muchacha pretendida las intenciones del joven. Antes del consentimiento de los padres de la muchacha, las visitas del casamiento y de los padres del chico debían repetirse entre cuatro y seis veces. Al final, y después de los regalos de rigor (aguardiente, granos y aves de corral), los padres de la muchacha podían dar su consentimiento, para que poco después una fiesta y el encuentro legalizaba la unión, la cual posteriormente era sancionada por un juez y más frecuentemente por el sacerdote católico.

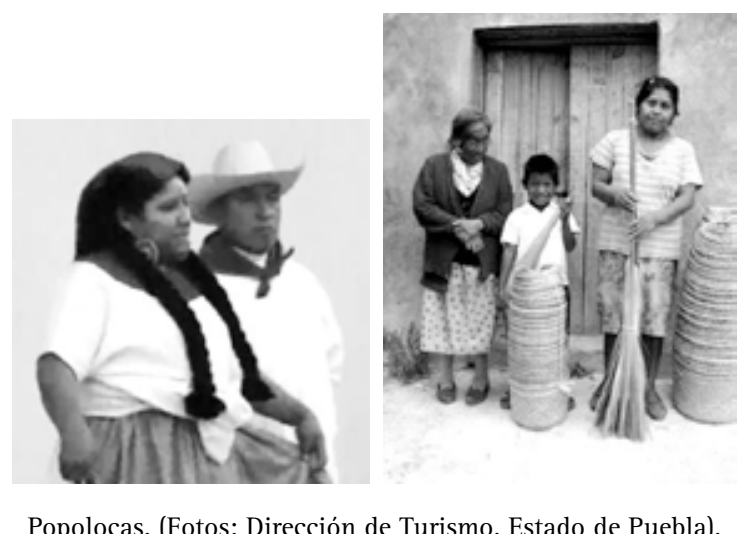

En la celebración de la boda se observaba la solidaridad del grupo, ya que parientes, amigos y vecinos contribuían con trabajo, dinero o bienes y colaboraban en la construcción de la casa para el nuevo matrimonio. La institución del compadrazgo fue y es muy importante. La población Popoloca enclavada dentro del Estado mantiene una subdivisión en barrios, en cada uno de los cuales habita un conjunto de familias.

GOBIERNO. Simultáneamente el aparato Jurídico, Político y Constitucional que rige al país, hasta hace muy poco tiempo subsistieron entre los popolocas formas tradicionales de gobierno indígena y un derecho de costumbre. La máxima autoridad recibe el mando en una ceremonia de transmisión de bastón. En el Gobierno existen jerarquías y los indivi- 
duos que van ocupando cada puesto lo hacen en riguroso orden de méritos. Sin embargo, la integración entre las actividades políticas y religiosas ha casi desaparecido a medida que ha avanzado el proceso de aculturación que la sociedad actual ha impuesto en todo el país, y como en toda el área, también en esa comunidad popoloca existe una actividad política partidaria producto de la actividad de la Confederación Nacional Campesina.

San Antonio Nanahuatlipan. Estación de Ferrocarril. (Foto: Ayuntamiento de San Antonio Nanahuatlipan).

FESTIVIDADES. Antiguamente las únicas fiestas que se celebraban en el área Popoloca eran las del Santo Patrono del pueblo y la Navidad. La escasez de recursos de los indígenas de esta etnia ha hecho desaparecer muchos de los rasgos de esas festividades. Durante el desarrollo de las fiestas y actualmente de manera habitual, el índice de alcoholismo es muy elevado, ingiriéndose pulque y aguardiente.

ORGANIZACIÓN RELIGIOSA. Dentro del grupo subsistió, hasta hace poco tiempo, la acción de depositar figurillas prehispánicas femeninas como rito propiciatorio para lograr buenas cosechas. Asimismo subsistió la Mayordomía, la cual estuvo apoyada por el resto de la población. La religión mayoritaria es la católica; profesada por la casi totalidad de la población, sin embargo, ya existen algunos fieles o sectas protestantes y algunos Testigos de Jehová.

MEDICINA Y MAGIA. A principios del siglo XX se documentaron practicas mágicas entre la población popoloca. Cada población tenía un brujo, al cual atribuían poderes sobrenaturales, considerando que podía detener o anticipar las lluvias, que podía encontrar las cosas extraviadas y que le era posible castigar a un enemigo. Todavía hasta hace poco tiempo temieron a los sacerdotes católicos y solamente escuchaban sus prédicas sin comprenderlas. Consideraban también que el brujo tenía el poder de devolver a un enfermo el alma que le había sido robada por un animal o "tona", así que la curación se efectuaba cuando el brujo lograba encontrar en el monte al animal causante de la enfermedad y después de capturarlo se lo llevaba a entregar al enfermo en medio de un ritual que presenciaban los familiares y amigos, ordenando al alma que regresase al enfermo. (Los popolocas creían que el alma era un soplo parecido al aire). Después de tal ceremonia la curación se completaba con fricciones en la parte adolorida y el hechicero, que a su vez era un hábil prestidigitador, extraía de la parte adolorida diferentes objetos, tales como espinas de maguey, alfiles, agujas, cabellos, arena y piedras.

Si este procedimiento de curación fallaba, el hechicero, para no quedar en ridículo, decía que el mal tenía otra causa y entonces repetía la curación tomando una gallina negra a la que metía en un tenate de palma, sujeto con espinas y adornado con flores de Zempoalxúchitl. A continuación el brujo lo cargaba diciendo que lo iba a dejar a un cerro para obtener que el mal desapareciese.

Otra forma de curación era la siguiente: El hechicero hacía un cerco de piedras y colocaba dentro de él la gallina negra, amontonando a continuación piedras sobre ella hasta 
formar un cono hueco, y adornando el túmulo con tallos tiernos de mezquite, los que a continuación poco a poco iba quemando y luego sahumando todo con copal. Algunos curanderos agregaban huevos y una vela de sebo invertida. En los casos de parto intervenían, además de la partera empírica, las cuñadas, y la mujer daba a luz acuclillada.

Recientemente, al hacerse un Centro de Salud, se ha introducido la presencia de Pasantes de Medicina que realizan su servicio social en esa Región, de acuerdo con los programas que el Sector Salud del Gobierno Mexicano tiene establecidos.

EDUCACIÓN: En San Antonio Nanahuatlipan existe un jardín de niños, una escuela primaria y una telesecundaria, canalizándose a los alumnos, para los siguientes grados, a los planteles de la población de Teotitlán de Flores Magón.

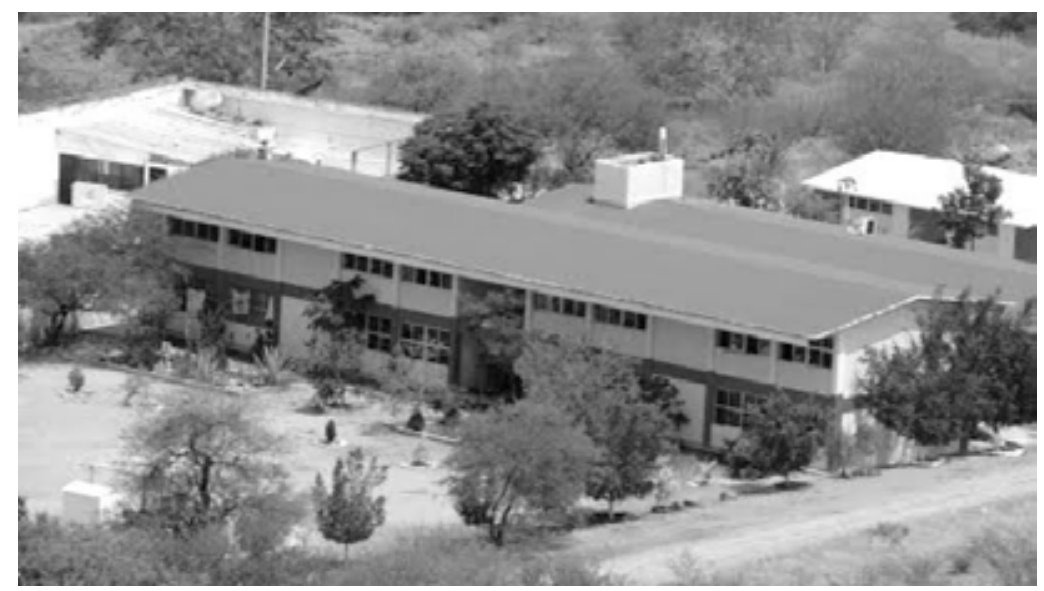

Escuela primaria en zona popoloca. (Foto: Dirección de Turismo estatal).

\section{BIBLIOGRAFÍA}

Aguirre Beltrán, Hilda. 1984 LA CONGREGACION CIVIL DE TLACOTEPEC. Cuadernos de la Casa Chata. CIESAS. México, D F. 1984. ANALES DE TECAMACHALCO. 1398-1590. 1992 (Introducción, Traducción y Notas de Eustaquio Celestino Solís y Luis Reyes García). Gobierno del Estado de Puebla. CIESAS. FCE. México, D F. 1992.

Armillas Carrasco, Pedro. 1964 "El Norte de Mesoamérica”. En: PREHISTORIC MAN IN THE NEW WORLD. Eds. Jesse Jennings y Edward Norbeck. Rice University. University of Chicago Press. Chicago, Ill. 1964. 2011 "El Norte de Mesoamérica”. Cuaderno de traducciones Mesoamericanistas № 2. Instituto de Investigaciones Sociológicas. UABJO. Oaxaca, Oax. 2011. Traducción: Mtro. Luis Rodrigo Álvarez.

Basauri, Carlos. 1940 Reed 1990. "Los Popolocas". En: LA POBLACION INDIGENA DE MEXICO. Tomo III. Instituto Nacional Indigenista. SEP. México, D F. 1990. 
Beals, Ralph L. 1969 “Southern Mexico highlands and adjacent Coastal Region”. En: HANDBOOK OF MIDDLE AMERICAN INDIANS. Vole 7. University of Texas Press. Austin \& London. USA. 1969.

Castillo Tejero, Noemí. 1997 “Tepexi el Viejo. Un Señorío Popoloca en el Sur de Puebla”.En: HOMENAJE AL DR. IGNACIO BERNAL. Serie Científica. INAH. SEP. México, D F. 1997.

Commons de la Rosa, Aurea. 1971 GEOHISTORIA DE LAS DIVISIONES TERRITORIALES DEL ESTADO DE PUEBLA. Instituto de Geografía, UNAM. México, D F. 1971.

Dalhgren de Jordán, Bárbara. 1954 LA MIXTECA, SU CULTURA E HISTORIA PREHISPANICAS. UNAM. México, D F. 1954. Reed. IIA. UNAM. 1990.

Escalante, Roberto. 1995 "El Grupo Lingúístico Chocho-Popoloca”. En: REVISTA MEXICANA DE ESTUDIOS ANTROPOLOGICOS. T. XL. Sociedad Mexicana de Antropología. México, D F. 1995.

Gámez Espinosa, Alejandra. 2003 LOS POPOLOCAS DE TECAMACHALCO-QUECHOLAC. HISTORIA, SOCIEDAD Y CULTURA DE UN SEÑORIO PREHISPÁNICO. Dirección de Regionalización. Facultad de Filosofía y Letras, UNAM. Dirección general de fomento Editorial, Benemérita Universidad Autónoma de Puebla. Puebla, México, D F. 2003.

García Cook, Ángel y Merino Carreón, Leonor. 1989 HISTORIA PREHISPANICA DEL VALLE DE TEHUACAN. Lecturas Históricas de Puebla. Secretaría de Cultura. Gobierno del Estado de Puebla. 1989.

Gibson, Charles. 1994 LOS AZTECAS BAJO EL DOMINIO ESPAÑOL. 1519-1810. Col. América Nuestra. Editorial Siglo XXI- México, D F. 1994.

Jackle, N Caus.1974 UN PUEBLO POPOLOCA. Serie Antropología Social. INI. SEP. México, D F. 1974. 1978 a "Los Popolocas de Tepexi, Puebla. Un Estudio Etnohistórico". En: INVESTIGACIONES INTERDISCIPLINARIAS MEXICO-ALEMANIA. Franz Steiner. Ed. (Fundación Alemana para la Investigación Científica). Wiesbaden. Alemania. 1978 a. 1978 b "Nuevos Datos sobre la Conquista de los Popolocas de Puebla”. En: COMUNICACIONES. No 15. Fundación Alemana para la Investigación Científica. Franz Steiner, Ed. Puebla, Pue. 1978 b.

León, Nicolás. 1906 LOS POPOLOCAS. Reed. 1991 Edición del Museo Amparo, Puebla Pue. 1991. Mac Neish, Richard S. 1964 EL ORIGEN DE LA CIVILIZACION MESOAMERICANA VISTO DESDE TEHUACAN. Cuadernos del Departamento de Prehistoria. № 16 . INAH. SEP. México, D F. 1964.

Muñoz Camargo, Diego. 1981 DESCRIPCION DE LA CIUDAD Y PROVINCIA DE TLAXCALA. Análisis y Glosa de René Acuña. Instituto de Investigaciones Filológicas. UNAM. México D F. 1981.

Paddock, John. 1987 “Cholula en Mesoamérica”. En: NOTAS MESOAMERICANAS. № 10. Universidad de las Américas. Cholula, Pue. 1987. 1997 a "Algunos Problemas Pendientes en el Valle de Tehuacán”. En: SYMPOSIUM INTERNATIONAL. TEHUACAN, BALANCE Y PERSPECTIVAS. Colección Científica. INAH, SEP. México, D F. 1997 a.

Reinoso. Louisa. 1997 "La Cerámica de Los Reyes Metzontla, Una Clave hacia el Pasado". En: SYMPOSIUM INTERNATIONAL. TEHUACAN, BALANCE Y PERSPECTIVAS. Colec- 
ción Científica. INAH, SEP. México, D F. 1997.

Seler, Eduard. 1960 GESAMMELTE ABHANDLUNGEN SUR AMERICANISCHEN SPRACH UND ALTERTUMSKUNDE. 5 Vols. Graz. Austria. 1960.

Vázquez Mendoza, Heriberto. 1982 LOS POPOLOCAS. Instituto Nacional Indigenista. México, D F. 1982. 1990 "Los Popolocas". En: OAXACA, TEXTOS DE SU HISTORIA. Tomo I. Instituto de Investigaciones José María Luis Mora. Gobierno del Estado de Oaxaca. México, D F. 1990. 



\section{CHOCHOS}

Autodenominación: ngiba, Ruxina ngiigua, rru ngigua.

Sinónimo en su lengua: nquiveeni.

Significado: Los que hablan idioma.

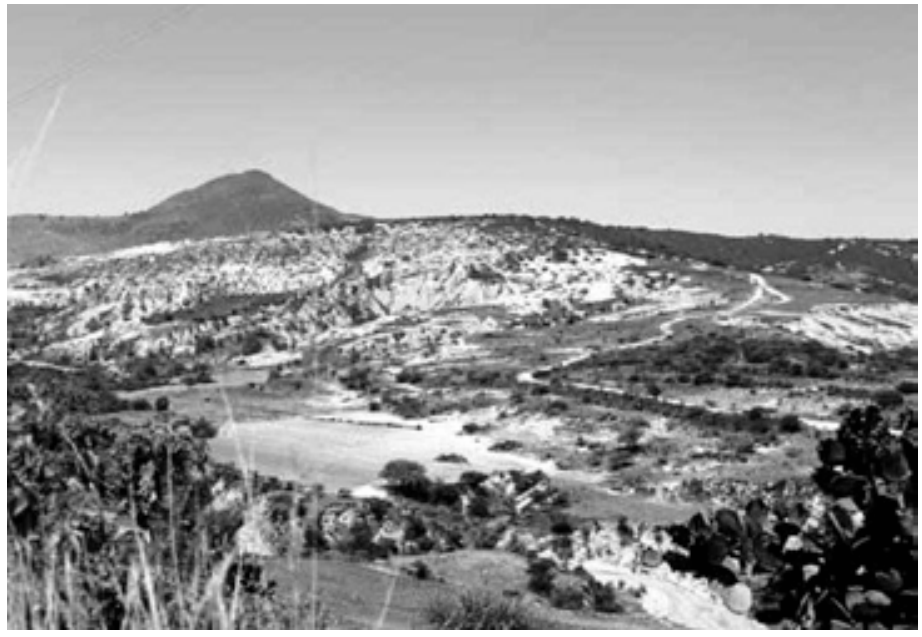

Paisaje chocholteco (Foto del autor).

\section{GRUPO CHOCHO O CHOCHOLTECA}

UBICACIÓN GEOGRÁFICA. Localizados en el Distrito de Coixtlahuaca y parte de Teposcolula, este grupo ocupa una región del altiplano terriblemente depredada desde tiempos histórico-coloniales, cubriendo trece municipios del Distrito de San Juan Bautista Coixtlahuaca, entre ellos la cabecera, y además Santa María Nativitas, San Miguel Tulancingo, San Mateo Tlapiltepec, Tepelmeme de Morelos, Teotongo y parte, (tres municipios) del Distrito de San Pedro y San Pablo Teposcolula. Su posición geográfica queda inscrita entre los $17^{\circ} 35^{\prime}$ y los $18^{\circ} 25^{\prime}$ de Latitud Norte y entre los $96^{\circ} 30^{\prime}$ y $96^{\circ} 50^{\prime}$ de Longitud Occidental. Su área ocupacional constituye parte de la Sierra Madre del Sur en su porción norte, y la región queda dividida por el parteaguas continental, que determina que parte de los escurrimientos vayan por el río de Coixtlahuaca rumbo al Papaloapan y los demás lo hagan por el río Tamazulapan hacia el Mixteco y el Balsas. El relieve consiste en montañas y pequeños valles que se alternan formando un terreno quebrado y actualmente muy erosionado cuyas máximas alturas sobre el nivel del mar alcanzan los $3000 \mathrm{~m}$. 


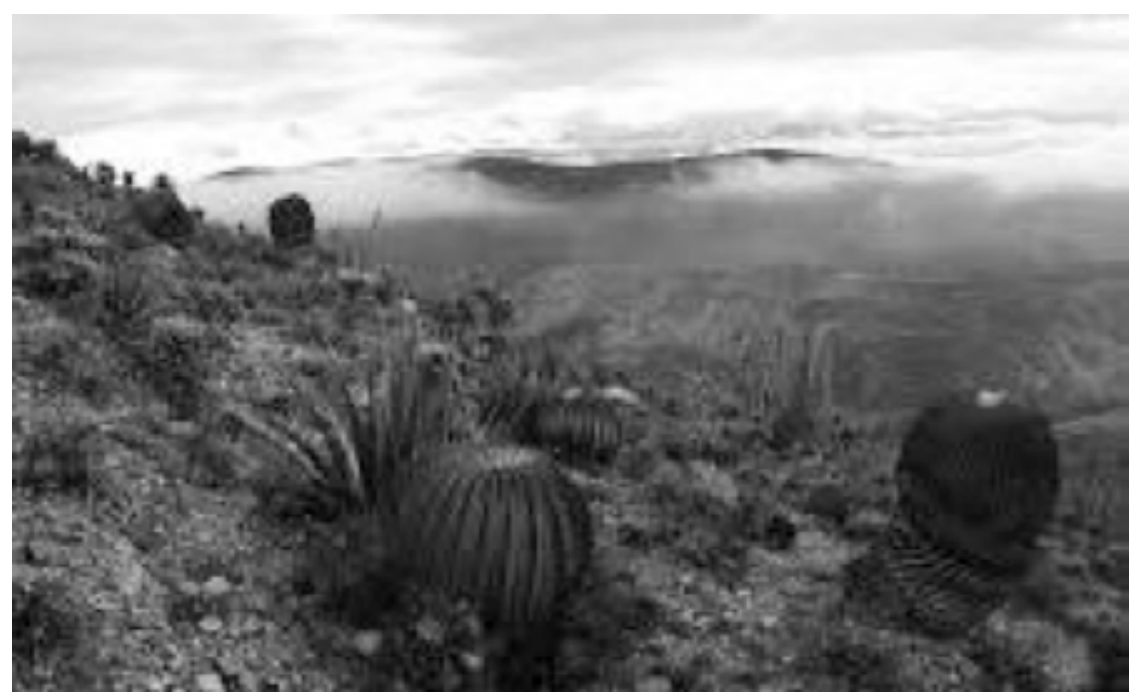

Imagen de zona chocholteca. (Foto del autor).

Aunque en las partes altas la vegetación consistió en bosques de coníferas, pinos, encinos y ailes, estos casi han desaparecido totalmente quedando pequeñísimos manchones. En las áreas intermedias y el fondo de los valles la vegetación fue de chaparral con manchones xerofíticos, que en la actualidad también han casi desaparecido. Casi toda la vegetación regional original ha sido depredada para ser substituida por un pastizal estacional poco desarrollado y pequeños manchones de matojos y monte bajo espinoso asociado con plantas xerofíticas tales como la yuca, el maguey y el cardón. En el ámbito de algunas poblaciones, desde hace pocos años, se ha implementado un programa de reforestación con pinos (ocotes) y pinabetes, siendo ahora posible contemplar bosques relativamente cerrados de algunas hectáreas de extensión.

Los climas en la región son templados semisecos con lluvias en verano, existiendo en la porción norte del territorio una pequeña sección de clima templado fráncamente seco. La precipitación media anual es del orden de los 500 milímetros (casualmente el límite de la agricultura del maíz), y sólo en algunos sectores es ligeramente más alta, esto debido a que los vientos norte, que dan precipitación alta sobre la Sierra Mazateca y la Sierra Madre de Oaxaca, pasan por encima de la zona permitiendo raramente bancos de niebla o lluvias ligeras. Los suelos del área son calcáreos, producto de estratos marinos originados en el Cretácico Superior y constituidos por capas muy delgadas de materia orgánica sobre la roca madre caliza. Debido a esta situación la cobertura de coníferas del área nunca alcanzó a crear suelos con la suficiente profundidad antes de ser destruida. La zona suele ser nubosa en ciertas épocas del año, pero sus temperaturas extremas hacen que los vientos se mantengan activos impidiendo una precipitación mayor.

IDIOMA. La lengua Chocho o Chocholteca pertenece al Grupo Otomangue, Tronco Savizaa, Familia Popoloca, siendo hablada en la actualidad por aproximadamente 524 personas, muchas de las actuales hablan también el Mixteco y el Español. Recientemente, miembros 
de la etnia, muchos de ellos maestros bilingües, residentes en la Cuenca de México (Valle de Chalco y Ciudad Nezahualcoyotl), han creado la Academia de la Lengua Chocholteca y realizan bastantes esfuerzos para su conservación. Ojalá ese esfuerzo logre su objetivo. DEMOGRAFÍA. La etnia contó hacia el año 2000 con aproximadamente unas 19000 personas, en su inmensa mayoría sometidas a un fuerte mestizaje tanto físico como cultural, al grado de que prácticamente, en el ámbito familiar, ya no se enseña Chocholteco a los niños

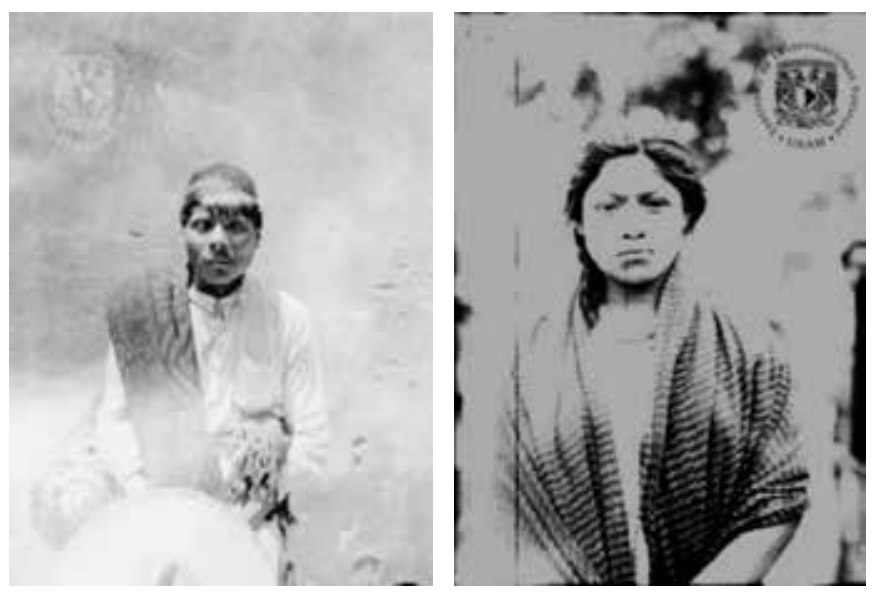

Hombre y mujer chocholtecas. (Fotos: IIS-UNAM).

La mayor parte de las hibridaciones se han realizado con individuos de las poblaciones de las regiones mixtecas colindantes. El censo del 2010 reporta 34 000, incluyendo mucha población flotante que constantemente se desplaza a la Cuenca de México, los estados de norte y noreste, los EE UU y el Canadá.

ANTECEDENTES ARQUEOLÓGICOS E HISTÓRICOS. La región ocupada por la etnia Chocholteca presenta una alta densidad de vestigios arqueológicos, de los que un porcentaje mayoritario pertenece a los períodos Clásico y Postclásico mesoamericanos, aunque hay sitios con ocupaciones muy anteriores. Han aparecido osamentas de animales pleistocénicos, principalmente mamuts, pero ninguna ha sido hallada en un contexto arqueológico, por lo que no se sabe que alguno haya sido destazado por el hombre. Prácticamente no existe municipio que no tenga en su territorio un sitio, una concentración superficial de tepalcates, con frecuentes objetos líticos asociados, unas ruinas, compuestas de grupos de montículos que, en varios casos, incluyen juegos de pelota* ${ }^{*}$ y en todo el territorio Chocho los terraceos de lomas y montañas son bastante densos y hay algunos puntos con pinturas rupestres, lo que revela una ocupación estable durante períodos prolongados.

Debido a diferentes factores, la región ha sido muy poco estudiada desde el punto de vista arqueológico. El área revistió importancia desde la época de apogeo de los centros ceremoniales porque ocupó un lugar transicional y de contacto entre los grupos que poblaban el valle de Oaxaca, los del valle de Tehuacán y grupos de las mixtecas alta y baja. 
Aunque desconocemos el origen de la actual población chocholteca en el área en que se encuentra, y hay evidencias de que allí está un poblamiento humano bastante antiguo, suponemos que de algún modo fueron movidos en la época del principio de la expansión de los principalatos mixtecos, (hacia el año 800 de la era cristiana), iniciándose con ello el desarrollo histórico del principalato de Coixtlahuaca. Los datos históricos documentan que Coixtlahuaca fue un principalato independiente, aunque considerado mixteco, y que como tal tuvo enfrentamientos con vecinos alcanzando un alto grado de desarrollo, y siendo centro comercial y artesanal de mucha importancia, cuya expansión abarcó hasta Tochtepec (Tuxtepec). Ello, como ya señalé, puede comprobarse por la existencia de terraceos muy densos en ese valle. Durante la expansión azteca, convino a la economía de Tenochtitlan establecer en Coixtlahuaca un centro comercial de recepción tributaria que captase parte importante de los productos (principalmente algodón, cacao y plumas preciosas), del territorio oaxaqueño y del Soconusco. Con ese fin la población fue conquistada y convertida en tributaria por las tropas de Moctezuma I Ilhuicamina poco antes de 1462 debido a que su rey, Atonal o Atonaltzin, había, aparentemente, ordenado la muerte de unos comerciantes (pochtecas) tenochcas o aztecas. Al consumarse la conquista, la región quedo marginada y su poder económico vino a menos, pero sin embargo siguió estando densamente poblada, lo que interesó al poder colonial español, el cual estableció el régimen encomendero ${ }^{1}$ e inició la catequización (1529) a través de Fray Jerónimo Abrego. Este demostró un alto celo cristianizador destruyendo una gran cantidad de objetos y figuras de culto indígena, a los cuales persiguió hasta el interior de ciertas cuevas. Poco después se estableció en Coixtlahuaca un importante enclave dominico (1550), del que se conservan la Iglesia, Monasterio y Capilla Abierta, donde puede verse la mano maestra constructora de Fray Francisco Marín.
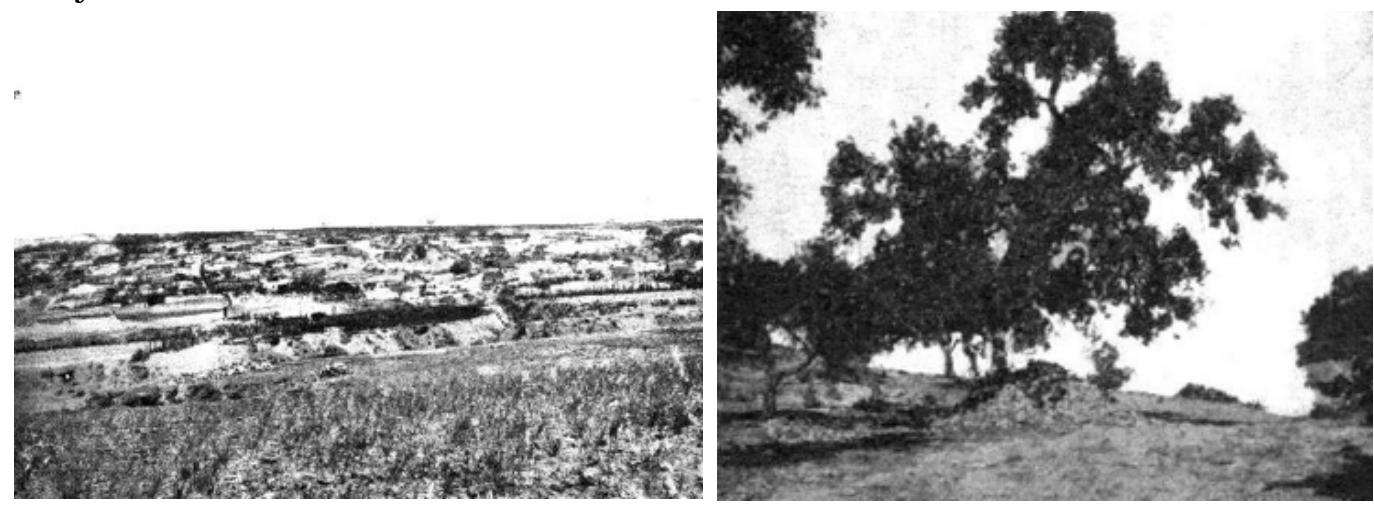

Terrazas y montículo de Inguiteria, Coixtlahuaca en 1906. (Fotos Frederick Starr).

1 Por ejemplo: En Santa María Nativitas se encuentra la zona arqueológica de Cerro del Rosario, la cual aportó cerámica antigua diferente de la mixteca y con fechamiento cercano a los 2500 años, o sea de la Etapa Media de las Aldeas. La cerámica encontrada permitió fijar una da las fases culturales que forman parte de la cronología arqueológica de ese valle, La Fase Ramos. En Teotongo se conserva el nombre antiguo de la población, que, situada en las cimas de unos cerros cercanos, era conocida como Xade-Duxo y en Santa María Nativitas se sabe que su antiguo asentamiento, también en la cima de un cerro próximo, es la zona arqueológica de Tizaltepec. De gran importancia, pero aún no estudiada, fue la zona arqueológica de Tlapiltepec, llamada zonalmente "Cunatexa". Lo revela la antigüedad del asentamiento con población muy densa en el momento de la conquista, dadas las terrazas que ese cerro presenta. 
Durante el resto del periodo colonial en muchos pueblos se elaboraron mapas y lienzos referentes a las tierras y sus personajes principales, lienzos que en muchos casos han logrado conservarse (el de Tlapiltepec, el de Otla, los tres de Coixtlahuaca, el de Tequixtepec, el de Nativitas, el de Yanhuitlán y el de Ihuitlán, por ejemplo), y que nos dan cuenta de dinastías (el de Santa María Nativitas nos informa de 17 (diecisiete) parejas, padres, hijos y nietos, que ejercieron poder) y de aspectos de la vida colonial. Durante la Colonia, también, la región, que por su monte bajo con algún pasto basal, reunía cualidades excepcionales para la cría de ganado menor, fue dedicada a este uso creando Estancias de tal ganado, y pastoreada de manera tan intensiva que ya a principios del Siglo XX se encontraba semidestruida y prácticamente despoblada. A esto también ayudaron las epidemias de 1520, 1531 y 1576 de viruela y tifo, el hambre varias veces presente durante cuatro siglos y las reconcentraciones decididas por personajes novohispanos tales como el Arzobispo Pedro de Moya y Contreras. Se documenta que poco después de la Guerra de Independencia, varias comunidades chocholtecas fueron siendo despojadas de sus tierras por ganaderos criollos y mestizos, lo que se agudizó al declarar terrenos baldíos todas esas tierras comunales y fundos legales, de acuerdo con la aplicación, a conveniencia, por parte de notarios inescrupulosos, de las Leyes de Reforma. De la actuación de indígenas chocholtecos en las guerras de Reforma e Intervención Francesa casi no se tienen noticias. Hubo algunos oficiales y soldados de ese origen en las fuerzas del Ejército de Oriente del Gral. Porfirio Díaz. Durante la Revolución Mexicana, ya en el Siglo XX, los pobladores del área tuvieron que soportar el paso y la acción de grupos de filiación soberanista, con infantería zapatista (el caso de las fuerzas de los Generales Tedomiro Romero, Julián José Arreola Calvo y Manuel Martínez Miranda, este último nativo de la región), que se mantuvieron activos hasta el año de 1919, y durante los años de hambre, recurrir al consumo de cactos, cogollo de maguey y limitadas cosechas de maíz como casi único sustento. Hacia el principio de la década de los años 40 se inició el fenómeno de la migración, la que casi desde el principio se canalizó hacia la Cuenca de México, sus grandes poblaciones y los ingenios veracruzanos. Con ello se agudizó el proceso del abandono y la pérdida del idioma. Los años posteriores, aunque han permitido una subsistencia, han presenciado una situación dramática para el grupo, el cual ha tenido asignados algunos programas de ayudas federales y estatales, sin haberse podido impedir una fuerte emigración. El trazo y la realización de la Supercarretera Cuacnopalan-Oaxaca, sin haber incrementado el bienestar de la población regional, salvo por algún empleo ocasional, ha agudizado la retirada de la gente. Sin embargo, pueblos como San Miguel Tequixtepec, en su afán de no perder su memoria histórica, han implementado su museo comunitario, donde se exhiben los restos de mamuts y megafauna, con el apoyo del INAH, además de su artesanía de textiles de palma, que es de alta calidad. 

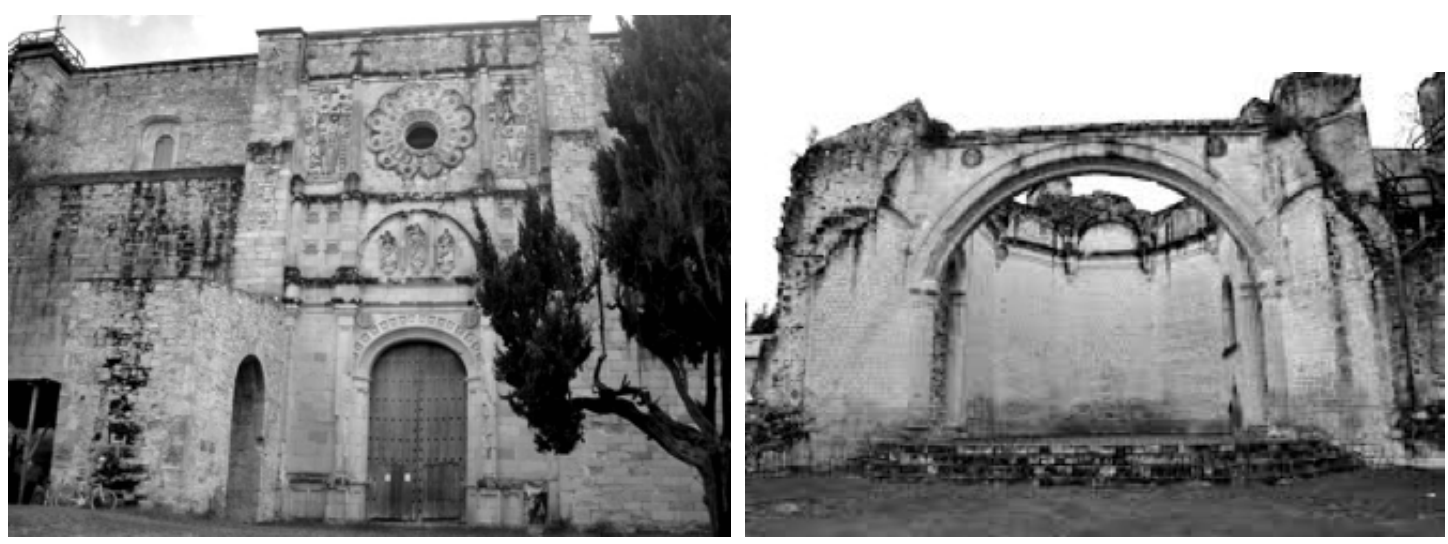

Fachada lateral y Capilla Abierta de la iglesia de Coixtlahuaca. (Fotos del autor).

ACCESOS. La región queda dividida en dos por la carretera de terracería que parte de Tejupan, donde entronca con la panamericana y llega a Coixtlahuaca, continuando después rumbo a la Cañada, (previo paso por Santa María Ixcatlán), con cuya carretera, la Federal número 131, entronca al lado del puente de Cuicatlán. De Coixtlahuaca parte una carretera, también de terracería, que pasa por Tequixtepec, Tepelmeme de Morelos, Ihuitlán Plumas y Teotongo, llegando después a Tamazulapan. La obra carretera más reciente (1994) es la Supercarretera Cuacnopalan-Oaxaca, que corta el Valle de Coixtlahuaca pasando muy próxima a las poblaciones de Coixtlahuaca y Tepelmeme de Morelos. En la región sólo existe una pequeña pista de aterrizaje, ubicada precisamente en Tepelmeme.

VIVIENDA. Las casas tradicionales se han construido de diversos materiales, todos ellos regionales, las columnas suelen ser de horcones, pero también de ángulos de placas de adobe o de lajas de piedra caliza entrelazadas. La estructura es de madera y el techo, de dos y a veces de cuatro aguas, está sostenido por morillos a los que amarran morillos o varas largas de menor tamaño, sobre los cuales se monta el emparrillado. Sobre él va un techo que suele ser de pasto o en ocasiones palma entrelazada o penca de maguey, ahora reforzado con láminas acanaladas en la parte alta. La duración de los techos no es nunca mayor de 10 años por lo cual tienen que estarse reponiendo.

Muy frecuentemente el parteaguas del techo tiene una hendidura oculta que es la que permite la ventilación. No hay ventanas y cuando las hay se hacen pequeñas y muy altas. Las puertas suelen ser frontales. Con mucha frecuencia la cocina está adosada a la casa principal. Gran parte del utilaje se obtiene del maguey pero también hay bancos de madera, mesas del mismo material y metates de piedra. Antiguamente también se empotraban cuernos de venado de los que se suspendían las tiras de palma, varias formas de cerámica y algunos canastos. En las poblaciones los asentamientos son semiconcentrados. Muy frecuentemente rodean los solares cercas de cactos, y este rasgo también se encuentra en algunas casas aisladas. Últimamente se ha incrementado la construcción de casas de lajas de piedra caliza entrelazada, o bien de material (ladrillo, blocks y concreto). 

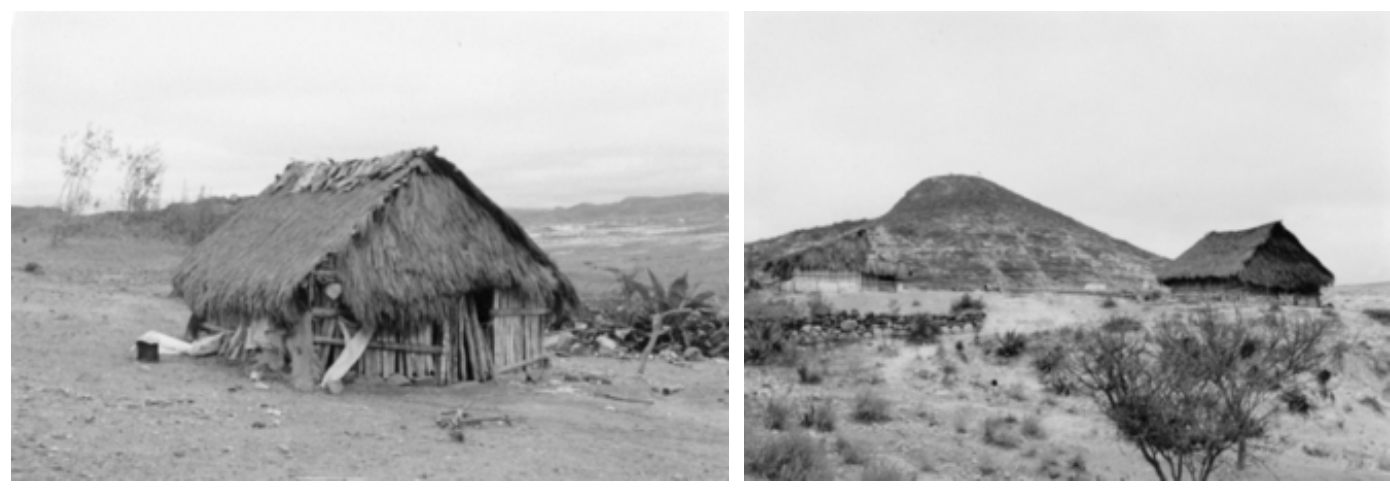

Casa y ranchería chocholtecas. Tepelmeme 1983. (Fotos del autor).

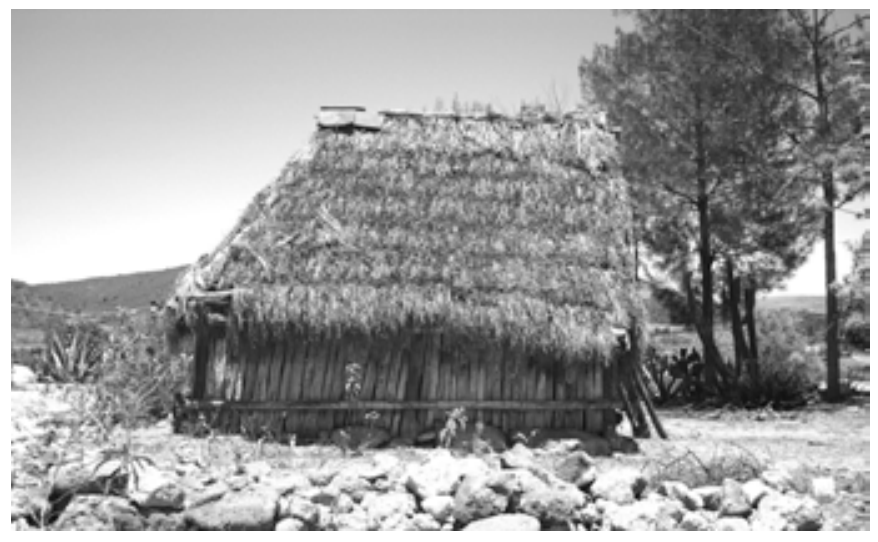

Ultima casa tradicional. San Miguel Tequixtepec.

Coixtlahuaca. (Foto: Dr. José Antonio León Ruiz).

INDUMENTARIA. La indumentaria se ha perdido en su casi totalidad. Los hombres usan ropas de dril, de algodón y chamarras comerciales. Las mujeres blusas blancas y faldas de colores tenues.

Hasta hace poco menos de 30 años la mujeres usaban blusas, faldas, vestidos de algodón y enaguas caracterizadas por tener dos bandas azules, así como un rebozo y un mantón triangular que cubría la cabeza y la espalda, ropa que se elaboraba en telar de cintura. Ambos sexos usan sandalias y huaraches. Algunas mujeres comienzan a usar calzado de plástico. En los días fríos algunos hombres usan ponchos multicolores comerciales.

ECONOMÍA. La economía del grupo ha sido de subsistencia basada en el maíz y sujeta al temporal, con tecnología que no va más allá del arado de palo. Por ello los rendimientos son muy bajos, practicándose la pequeña irrigación en muy pocos lugares. Por esta razón no puede ser analizada como las economías desarrolladas. Además del maíz se siembra frijol, calabaza y pequeñas cantidades de jitomate, tomate, chile y cebolla, así como nopal. Como el grupo casi no produce excedentes y necesita adquirir artículos que no puede producir, tiene que dedicarse a otras actividades y destinar a ello parte de los de subsistencia. Una de las principales actividades es la fabricación del sombrero de palma, y algunas 
ocupaciones estacionales. Parte importante de algunas comunidades continua dedicada al pastoreo menor. La región todavía tiene posibilidades de recuperación siempre y cuando se maneje bien la poca tierra vegetal existente, tanto para hacer agricultura en terrazas, como para fruticultura de riego debido a que las condiciones climáticas lo permiten. Quizá esto permita arraigar a una parte de la población, ya que el índice de emigración es muy alto, al grado de que hay poblaciones casi vacías.

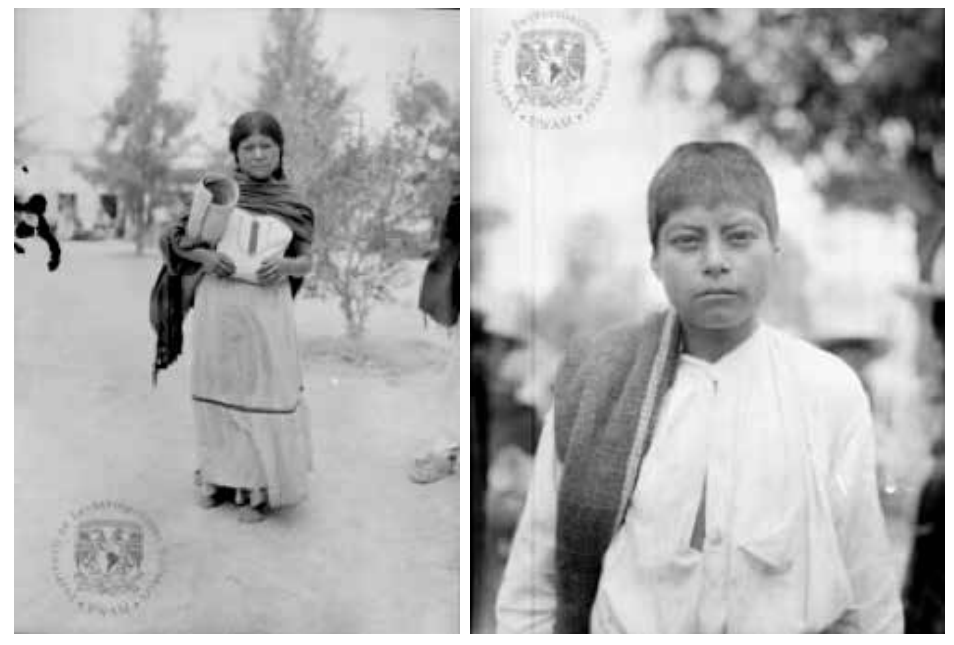

Chocholtecas con vestimenta tradicional (1962). (Fotos: IIS-UNAM).

ARTESANIAS. El tejido de sombreros es la principal artesanía regional. Ha sido tradicional que quienes se dedican a esta actividad excaven en el patio de su casa una cueva destinada a mantener un grado de humedad adecuada en la palma que se usa para tejer, porque al secarse es muy quebradiza se documenta que en la población de Santa María Nativitas la calidad de los sombreros es extraordinaria. En algunas poblaciones existen personas que practican diferentes oficios. Principalmente el bordado y la carpintería sobre madera y pencas de maguey.

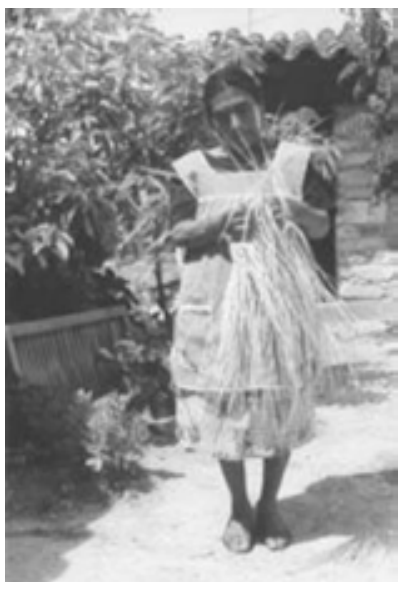

Tejedora de sombreros.

(Foto: La Jornada). 
GANADERÍA. Como ya se ha señalado, la cría de ganado menor es mayoritaria en el grupo. Parte importante de las cabras de la zona sólo son pastoreadas por indígenas chochones porque pertenecen a comerciantes de la Ciudad de Tehuacán. Por ello no existe ningún programa de mejoramiento genético.

En la región existen muy pocas vacas y pocas yuntas de ganado criollo y, además, cantidades muy limitadas de caballos, burros y mulas. Estas últimas han sido siempre utilizadas como medio de transporte entre localidades aisladas. En los siglos XIX y XX, hubo un importante camino para recuas entre San Francisco Teopan y la zona de Chazumba, y otro con valor estratégico que siguió el curso de los ríos Carrizo y Calapa. Ese camino permitió dos veces un rápido desplazamiento de tropas republicanas durante las Guerras de Reforma e Intervención y sólo fue explorado por oficiales franceses.

CAZA Y PESCA. Como en el resto de las regiones de sus características, donde existió el bosque de coniferas hubo una fauna neártica bastante extensa. En la actualidad, a excepción de unas cuantas especies de roedores, de marsupiales como el tlacuache y de pequeños carnívoros tales como el cacomixtle, la fauna ha desparecido casi totalmente. Sólo el conejo montés y la liebre continúan ocupando el área y sólo pueden ser cazados en poca cantidad. En la zona de Tepelmeme se documentan venados cola blanca y la presencia ocasional de cazadores que disparan desde helicópteros. Aunque la región cuenta con cuatro pequeños ríos de relativa importancia, el Coixtlhuaca, el Xiquila, el Carrizo (Calapa) y el Tamazulapan, son de corriente muy exigua y no se observan especies de peces que permitan cualquier género de captura. Sin embargo, posiblemente sea factible desarrollar algún programa que permita introducir Carpa de Israel y Mojarra Tilapia en pequeños estanques.

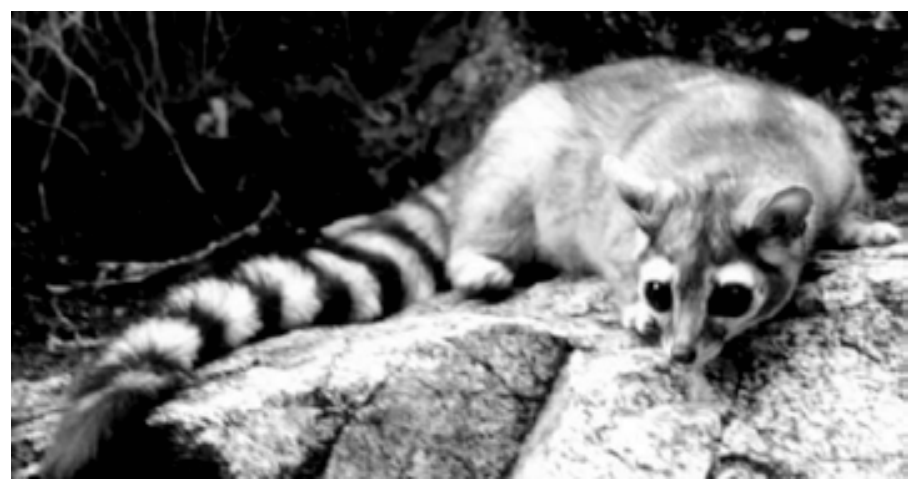

Cacomixtle. (Bassariscus astutus.) (Foto: Instituto de Biología. UNAM).

MERCADOS. Aunque prácticamente todas las localidades cuentan con tiendas, sólo tienen importancia comercial Coixtlahuaca e Ihuitlán Plumas, aunque las actividades mercantiles se han visto considerablemente reducidas. En esos dos mercados aún subsiste el intercambio de productos. Debido a que el comercio es practicado principalmente por mestizos, en las transacciones los indígenas llevan la peor parte. 
Como señalé anteriormente, la tradición histórica del siglo XV señala a Coixtlahuaca como un gran centro mercantil. La zona arqueológica de Ingüiteria, con sus concentraciones de cerámica superficial, procedente de varias regiones, incluso del sureste de mesoamérica, lo revelan.

ORGANIZACIÓN SOCIAL. La sociedad Chocholteca es patrilineal, patrilocal endogámica y exogámica. El grupo da mucha importancia a la familia extensa, existiendo un gran respeto mutuo entre los miembros de la misma. Así la familia nuclear se introduce en la extensa. Los lazos de compadrazgo reafirman los parentescos y los lazos de la amistad entre el padre del niño bautizado y el padrino bautizante. Se documenta que en la ceremonia ambos se besan en las manos y los hombros.

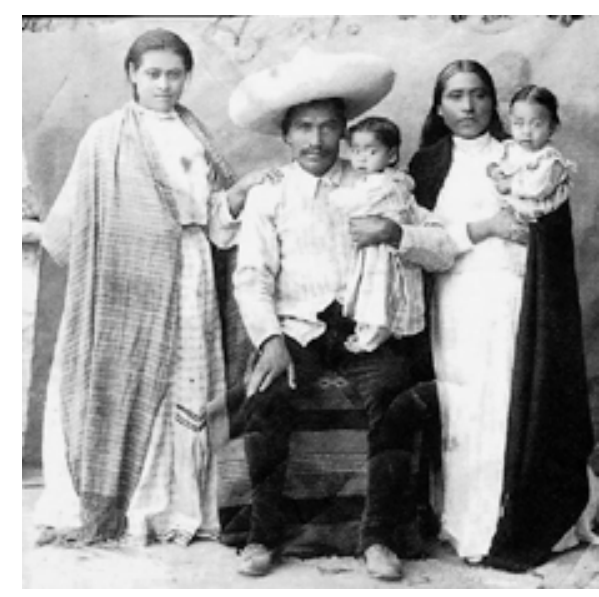

Familia chocholteca. Siglo XIX. (Foto: Dr. Edgar Mendoza García).

Anteriormente, para la celebración del matrimonio normalmente se esperaba que los contrayentes tuvieran 20 y 18 años respectivamente. Los padres del novio y sus padrinos de bautizo eran quienes a través de un intermediario llamado Tonishano, iban a ver al padre de la novia para hacer los arreglos conducentes, realizando de cuatro a seis visitas, y en caso de que alguno de ellos hubiese muerto, el pariente más próximo por consanguinidad ocupaba su lugar. La noche anterior a la boda se peinó a la novia en la casa de los padrinos de su futuro marido, acto que realizó la madrina con carácter de ritual. Después de la boda los recién casados fueron a vivir a la casa de los padres del novio hasta que se construyó la suya.

Cuando fallece un miembro de la etnia, se le viste con sus mejores ropas y se le coloca sobre una cruz de cal en el piso frente al altar de la casa. Una piedra azul de río, preferentemente de arenisca, se coloca bajo su cabeza; a continuación se le vela toda la noche y concurrentes, tanto como los parientes del difunto aportan bebidas o dinero. Al día siguiente se notifica a las autoridades y mediante papeles escritos a mano se hace llegar la noticia al resto de la población. En la segunda noche una banda toca música y en el velorio circula café, pan, mezcal y aguardiente, así como cigarrillos. 
A la mañana siguiente parte una procesión acompañada de música fúnebre y del tañido de las campañas de la iglesia, El cuerpo es llevado en una caja de madera o envuelto en un petate y se le entierra con sus efectos personales, no sin antes pasar por la iglesia en donde se le reza. Nueve días después se traza una cruz de cal sobre la tumba, previo novenario rezado, y a través de la intervención del Tonishano, la persona que trazó la cruz queda relacionada mediante compadrazgo con los parientes próximos del fallecido.

En las poblaciones de la etnia se observa una cierta organización por barrios, Teotongo y Tamazulapan son las localidades en que se nota más este rasgo, si bien Tamazulapan está dividida por el hecho de que uno de sus barrios es mixteco. En los siglos XVI y XVII este rasgo se presentaba también en varias poblaciones más.

GOBIERNO. Independientemente de la estructura político-jurídica del gobierno Mexicano, el grupo Chocholteca presenta formas de Gobierno Indigena, que se entrelazan con la organización política estatal. Las unidades territoriales son las cabeceras municipales, los municipios, las agencias municipales, las agencias de policía y las pequeñas rancherías. En Coixtlahuaca los barrios presentan restos de antiguas funciones religiosas. En la zona subsiste el tequio, el cual es asignado por las Autoridades Municipales y tiene que ser cumplido con el resto de la población. Para acceder a los puestos más altos de la jerarquía es necesario haber antes ocupado otros menos importantes. En Coixtlahuaca y Tepelmeme de Morelos, asimismo, se observa el principio de una actividad política partidaria, siendo los Partidos Revolucionario Institucional y de la Revolución Democrática los que tienen mayor presencia. El primero por su cercanía con la Confederación Nacional Campesina, de la que es la matriz.

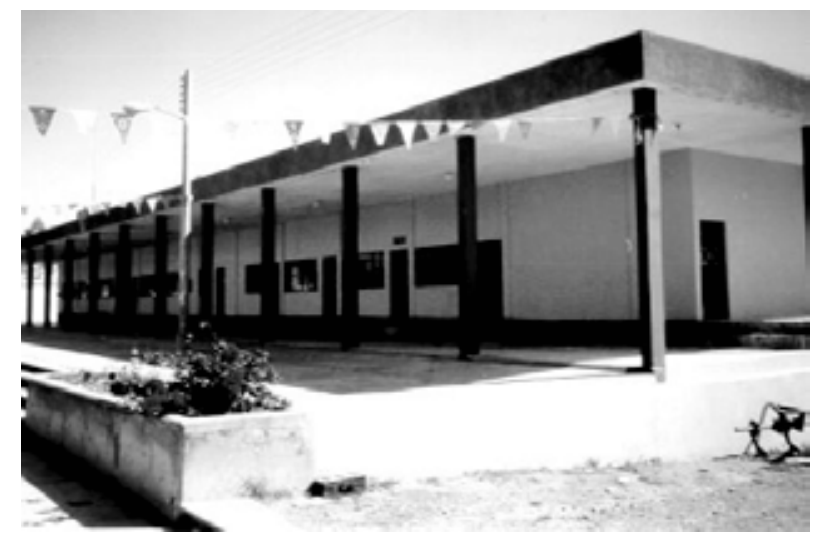

Palacio Municipal de San Mateo Tlapiltepec. (Foto: Ayuntamiento de San Mateo Tlapiltepec).

FESTIVIDADES. Desde la época prehispánica la región de Coixtlahuaca tuvo importancia por su calendario de fiestas. Estas dependían del calendario ritual y del calendario agrícola y fueron sustituidas por las festividades del Santo Patrón cuando después de la conquista los calendarios fueron sustituidos por el ritual católico. En la actualidad la festividad del Santo Patrón de las diferentes poblaciones es la más importante y en ellas tocan las ban- 
das, hay procesiones y se realizan partidos de pelota mixteca, otros deportes y espectáculos de maroma. Las bandas de música de la región poseen un amplio repertorio, y cuando en una festividad se requiere de un mayor número de músicos, cada banda se refuerza con las de las poblaciones vecinas.

ORGANIZACIÓN RELIGIOSA. Entre los chochos, además del sacristán que tiene por función cuidar de la iglesia, existen cofradías religiosas cuyo miembro de mayor jerarquía es el Mayordomo. Este cargo depende de la autoridad civil y en algunas poblaciones es voluntario, aunque en ocasiones le es impuesto a un prominente vecino. La función del mayordomo consiste en supervisar el buen desarrollo de la fiesta que la autoridad civil organiza con la cooperación económica de todos los vecinos de la localidad. En el grupo la religión mayoritaria es la católica, aunque en algunas localidades comienzan a surgir grupos protestantes que ante todo han generado una división intergrupal. Una parte importante de la etnia chocholteca conserva creencias muy importantes referentes a la influencia de la luna en la tierra y los cultivos, las que sin duda provienen de observación directa. Se implora la lluvia y se lanzan cohetes para provocarla. Se cree en los encantamientos, en el "Dueño del Lugar", en el "Señor del Cerro", y en el "Catrín" que suele ser considerado una personificación del demonio, o bien un aparecido que pena porque dejó un "pendiente" en la tierra, con frecuencia un "guardado", es decir, dinero enterrado. En los ritos de fertilidad dejan caer sangre de una gallina sacrificada (a veces un gallo negro), para que la tierra beba, y con ello produzca más.

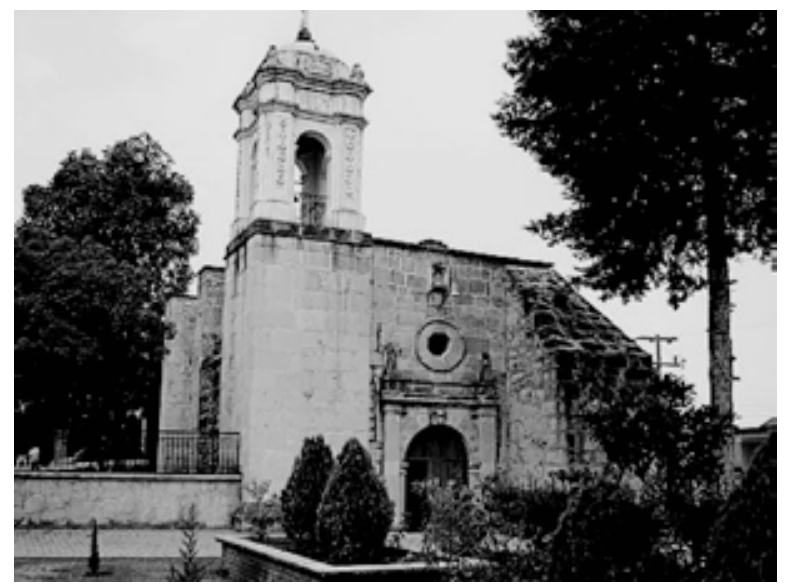

Iglesia antigua en zona chocholteca, Santiago Tepetlapa (Foto: Ayuntamiento).

MEDICINA Y MAGIA. Como reminiscencias prehispánicas, en el grupo chocho se conservan algunas actividades de carácter mágico practicadas por hechiceros que asumen funciones de curanderismo usando huevos, plantas medicinales, "levantadas de pulso" y "limpias". Como las enfermedades más comunes son de tipo digestivo y respiratorio (las infecciones intestinales son la causa principal de mortalidad infantil), son combatidas mediante el uso de hierbas medicinales, y de unciones de incienso. Parteras empíricas atienden los partos 
en los que habitualmente la mujer da a luz acuclillada. Ciertos curanderos consideran que el espíritu de una persona puede ser robado por el "dueño" de un determinado lugar, y que solo regresará a su verdadero propietario sí este deposita una ofrenda a aquel, quien en realidad funge como ladrón de espíritus.

El elemento más importante de la medicina tradicional del grupo es el baño de temazcal. Está construido especialmente y se le da temperatura mediante el calentamiento de piedras. El baño de temascal participa en muchas de las actividades importantes del grupo, y entre ellas en todo el ritual pre y post-natal.

EDUCACIÓN. Existen en el territorio chocholteco jardines de niños y primarias en todas las localidades, telesecundarias en varias y la Normal Rural "Vanguardia" en Tamazulapan, situada sobre la carretera federal № 190 o Panamericana. Esa normal tiene una historia señera en el estado, habiendo sido fundada después de su traslado desde San Antonio de la Cal y Cuilapan, en 1944, por los Profesores. Manuel Quiroz Martínez y Florentino Guzmán Cruz, éste último que entonces era autoridad educativa. Para la enseñanza superior, los jóvenes deben ir principalmente a Huajuapan o Tlaxiaco.

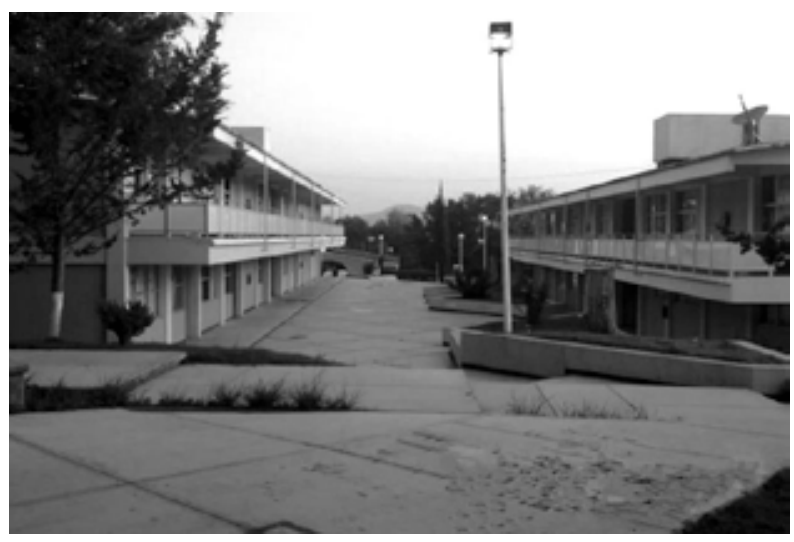

Escuela normal "Vanguardia” de Tamazulapan. (Foto: Ayuntamiento de Tamazulapan).

\section{BIBLIOGRAFÍA}

Acevedo Conde, María Luisa. 2007 “Los Chochos de Oaxaca”. Revista A CONTRAGOLPE. No 8. Carteles Editores, Oaxaca, Oax. 2007.

Basauri, Carlos. 1940 "Familia Zoque-Mixeana, Chochos”. LA POBLACION INDIGENA DE MEXICO. Tomo III. Instituto Nacional Indigenista. SEP. México. D F. 1940.

Bartolomé, Miguel. Barabas, Alicia. 1991 HISTORIA CHOCHOLTECA. Serie: Historias Étnicas. No 4. Colección Valores de Oaxaca. Casa de la Cultura Oaxaqueña. Gobierno del Estado. Oaxaca, Oax. 1991.

Bernal y García Pimentel. Ignacio. 1948 “Exploraciones en Coixtlahuaca, Oaxaca”. En: 
REVISTA MEXICANA DE ESTUDIOS ANTROPOLOGICOS. Tomo X. México. D F. 1948.

Byland, Bruce. 1948 "Boundary Recognition in the Mixteca Alta”. En: ESSAYS IN OTOMEANGUEAN CULTURE HISTORY. Vanderbilt University. Nashville, Tenn. U S A. 1948.

Caso Andrade, Alfonso. 1979 REYES Y REINOS DE LA MIXTECA. 2 Vols. Fondo de Cultura Económica. México, D F . 1979.

Dalhgren, Bárbara. 1954 LA MIXTECA. SU CULTURA E HISTORIA PREHISPANICAS. $1^{\text {a }}$ Ed. UNAM. México, D F . 1954.

Díaz Núñez, Luis Gerardo. 2006 "La Presencia Itinerante de los Dominicos en Oaxaca y la Mixteca durante los Siglos XVI al XVIII”. En: ÑUU SAVI. LA PATRIA MIXTECA. Universidad Tecnológica de la Mixteca. Huajuapan de León. Oax. 2006.

Gerhard, Peter. 1986 GEOGRAFIA HISTORICA DE LA NUEVA ESPAÑA. Instituto de Geografía. UNAM. México, D F. 1986.

Hoppe, Walter. Weitlaner, Roberto. 1969 “The Chochos”. En: HANDBOOK OF MIDDLE AMERICAN INDIANS. Vol. 7, ETHNOLOGY, Pt 1. University of Texas Press. Austin \& London. Austin, Tx. 1986.

Martínez Gracida, Manuel. 1883 CUADROS SINOPTICOS DE LOS PUEBLOS DEL ESTADO DE OAXACA. Col. Martínez Gracida.. Gobierno del Estado de Oaxaca. Oaxaca, Oax. 1983.

Mendieta y Núñez, Lucio. 1957 ETNOGRAFIA DE MEXICO. Universidad Nacional Autónoma de México. México, D F. 1957.

Mendoza García, J. Edgar. 2011 MUNICIPIOS, COFRADIAS y TIERRAS COMUNALES. (Los Pueblos Chocholtecos de Oaxaca en el siglo XIX). UABJO, CIESAS, Universidad Autónoma Metropolitana. Carteles Editores. Oaxaca, Oax. 2011.

Parmenter, Ross. 1982 "Four Lienzos of the Coixtlahuaca Valley". En: STUDIES IN PRE-COLUMBIAN ART AND ARCHAEOLOGY. No 26. Washington. D C. 1982 Paso y Troncoso, Francisco del. 1905 PAPELES DE NUEVA ESPAÑA. VOL-IV. Relaciones Geográficas de la Diócesis de Oaxaca. Imprenta Sucesores de Rivadeneyra. Madrid, España. 1905.

Rincón Mautner, Carlos. 2000 "La Reconstrucción Cronológica del Linaje Principal de Coixtlahuaca”. En: CODICES Y DOCUMENTOS SOBRE MEXICO. (Tercer Simposio Internacional). INAH. SEP. México, D F. 2000.

Rodrigo Álvarez, Luis. 2004 GEOGRAFIA GENERAL DEL ESTADO DE OAXACA. 4a Ed. Aumentada. Carteles Editores. Oaxaca, Oax. México. 2004.

Ruiz Ortiz, Víctor Hugo. Jansen, Maarten E. R. G. N. 2009 LIENZO DE OTLA. (Memoria de un Paisaje Sagrado). Universidad de Leyden. Holanda. 2009.

Pastor, Rodolfo. 1987 CAMPESINOS Y REFORMAS. LA MIXTECA. 1700-1856. Centro de Estudios Históricos. El Colegio de México. México. D F. 1987.

Romero Frizzi, María de los Ángeles. 1990 ECONOMÍA Y VIDA DE LOS ESPAÑOLES EN LA MIXTECA ALTA. Colección Regiones de México. INAH y Gobierno del Estado de Oaxaca. México D F. 1990. 
Starr, Frederick. 1901 "Notes upon the Ethnography of Southern México". En: PROCEEDINGS OF DAVENPORT ACADEMY OF SCIENCES. T. VIII. 1899-1900. T. IX. 1901. $<$ Davenport.. U S A. 1901.

Wence, Jorge. 1982 “Los Chochos”. En: GUPOS ETNICOS DE MEXICO. Tomo 2. INI. México. D F, 1982.

Winter, Marcus C. Gaxiola, Margarita. Hernández, Gilberto. 1984 "Archaeology of the Otomanguen Area”. ESSAYS IN OTOMANGUEAN CULTURE HISTORY. Vanderbilt University. Nashville, Tenn. U S A. 1984. 



\section{IXCATECOS}

Autodenominación: mero ikoba, xwja.

Sinónimo en su lengua:

Significado: Los del lugar del algodón.

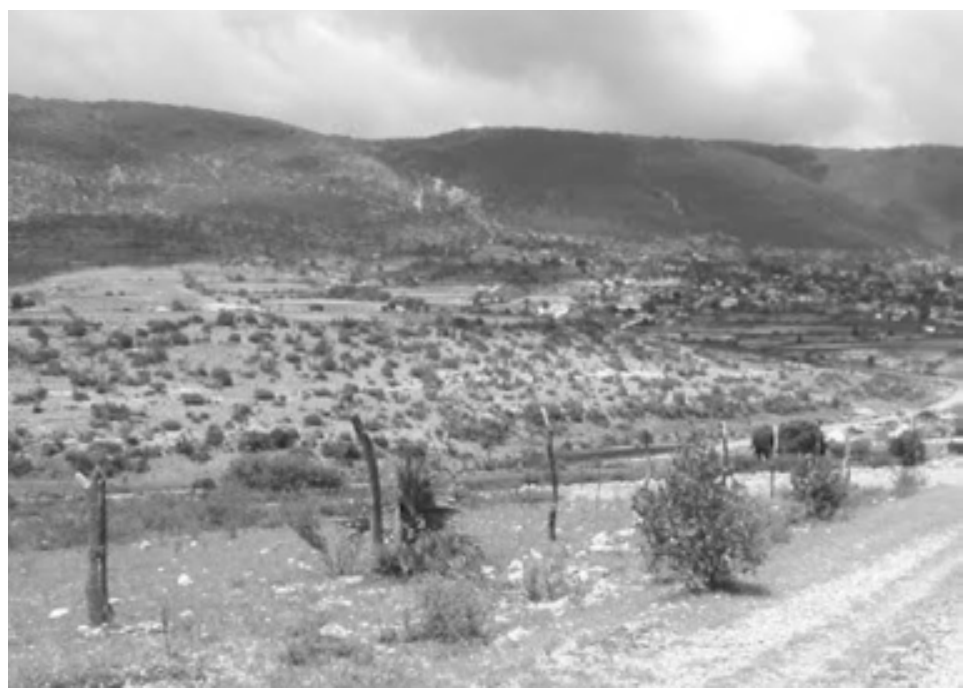

Paisaje ixcateco con terrazas visibles. Foto del autor.

\section{GRUPO IXCATECO}

UBICACIÓN GEOGRÁFICA. Es un pequeño grupo ubicado en territorio de la Mixteca Alta, en la porción nororiental del Valle de Coixtlhuaca, a la orilla del brazo norte del Río del Sabino y en las estribaciones de una de las últimas montañas que, de la Sierra Madre del Sur, dan acceso a la Cuenca del Río Papaloapan, a cuyo Río Salado el Río Sabino se une a corta distancia del Cañón de Quiotepec. Su área ocupacional es sumamente pequeña y queda comprendida entre los paralelos $17^{\circ} 55^{\prime}$ y $17^{\circ} 58^{\prime}$ de Longitud Norte y los meridianos $96^{\circ} 30^{\prime}$ y $96^{\circ} 33^{\prime}$ de Longitud Occidental. El clima regional se inscribe dentro de un contexto templado subhúmedo y semiseco con lluvias en verano, con una precipitación pluvial nunca superior a los 800 milímetros, pero que en los últimos dos siglos ha sufrido una notable disminución. Los suelos son muy delgados, en parte por la intemperización y erosión que han sufrido y en parte porque proceden de desintegración de rocas volcánicas y calizas muy duras, éstas, de origen cretácico. Pocos suelos tienen migajones de color 
negro o gris oscuro que tengan relativo potencial agrícola. La altura zonal sobre el nivel del mar fluctúa entre los 1900 y 2250 metros.

Antiguamente la región presentó una cubierta vegetal de bosques de coníferas (pino-encino-aile), la cual fue desaparecida gradualmente con el proceso de sobrepoblación que tuvo lugar en la región durante el periodo de expansión de los principalatos mixtecos, lo cual puede verse en los densos terraceos zonales. Con ese factor, y con la introducción de los rebaños de cabras, hacia fines del siglo XVIII la zona ya estaba severamente dañada $\mathrm{y}$, de este modo, los últimos dos siglos han contemplado en la región una desertificación irreversible. La ausencia de cubierta vegetal, y la existencia de las sierras mazateca y cuicateca del otro lado de la cuenca de los Ríos Grande y Salado, ha provocado que la nubosidad neblinosa que presentó la región en tiempos prehispánicos haya casi desaparecido y que en cambio las nubes sean arrastradas por el viento norte hacia otras partes de la mixteca. Lo anterior sustenta la posibilidad de que, si antiguamente se sembró algodón en Ixcatlán, debió ser con resultados limitados, porque ese cultivo se da mejor en tierras más bajas y con más humedad. Ahora el maíz sembrado en la zona es de variedades criollas blancas de ciclo medio y el de color negro, con similares características.

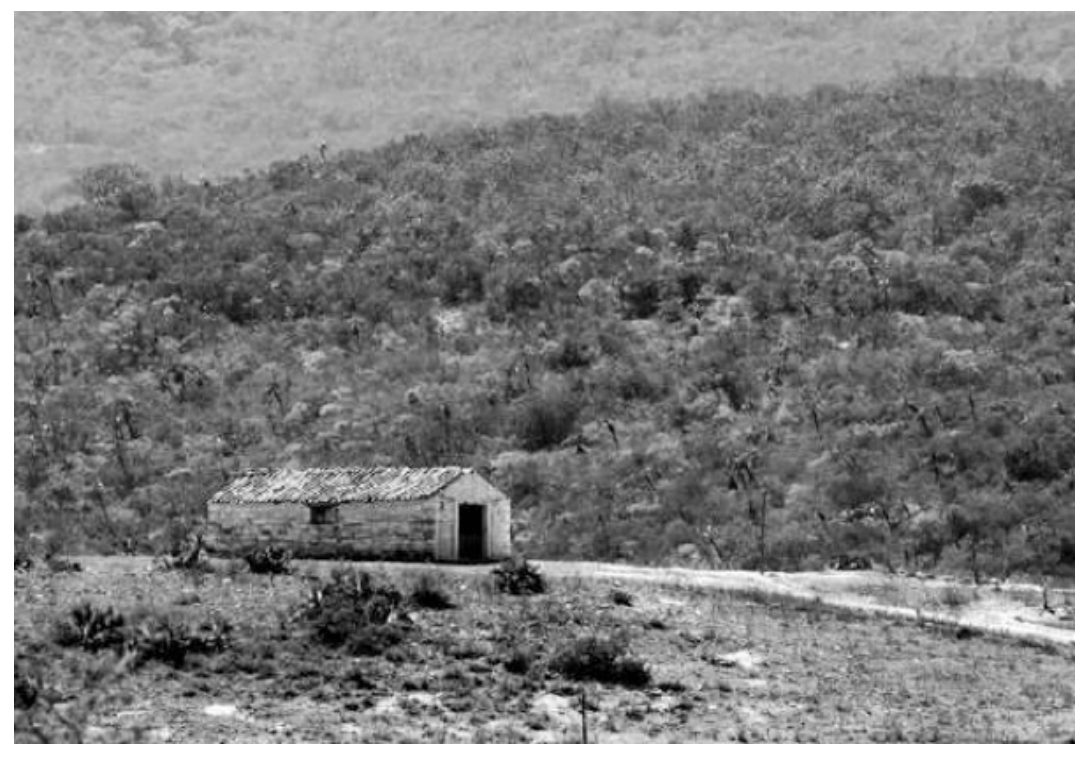

Paisaje Ixcateco (Foto: Alejandro Aquino).

ANTECEDENTES ARQUEOLÓGICOS E HISTÓRICOS. Debido a su relación con otros grupos de tronco Popoloca, los Ixcatecos debieron ser en algún momento un grupo disidente de algunos de los principalatos mixtecos del área. Esto puede observarse por algunas vasijas mixtecas encontradas. El territorio ocupado por el grupo contiene vestigios arqueológicos de importancia, con construcciones defensivas, ceremoniales y por lo menos un juego de pelota, ubicados en lo alto de varias lomas e indudablemente conectados con los existentes en las áreas de coixtlahuaca, apoala, el valle de tehuacán y cuicatlán. Aparentemente, los primeros asentamientos datan de la época clásica, aproximadamente hacia 500 años des- 
pués de Cristo, cosa que indica la cerámica superficial, aunque sin duda los hay anteriores, ya que la diferenciación de la lengua grupal data de más de 1800 años, lo que indica la necesidad de realizar investigaciones arqueológicas en el área, la cual, además, presenta terraceos densos.

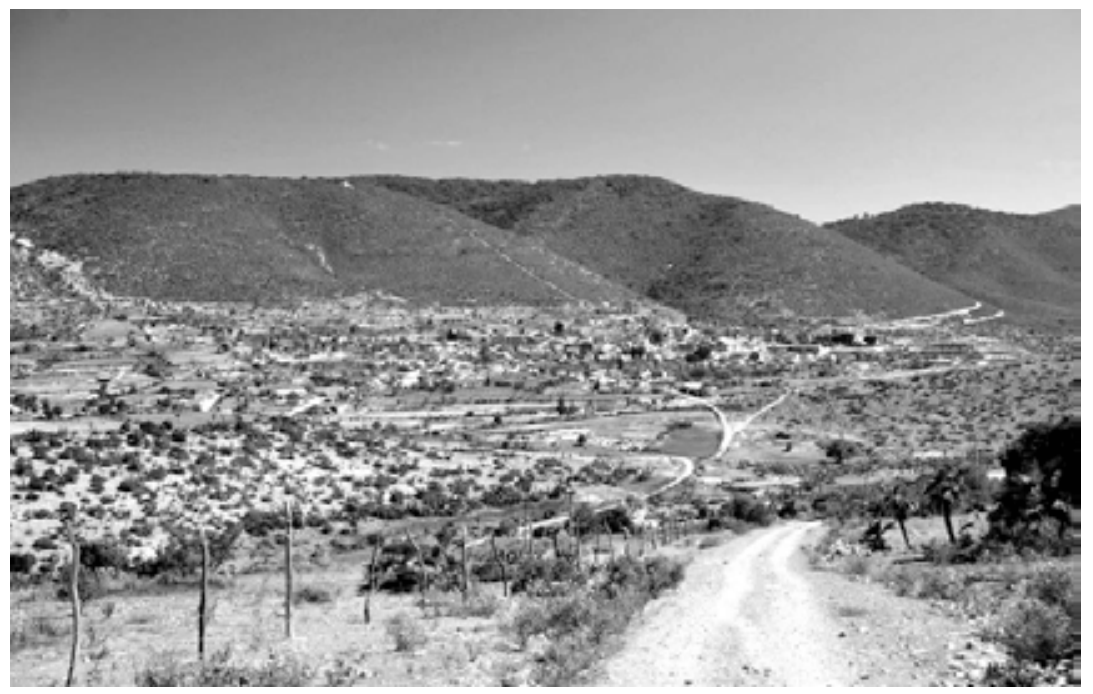

Fotografia de la población y los terraceos de Santa María Ixcatlán. (Foto del autor).

Ya para la época postclásica, esa pequeña zona presentaba una amplia ocupación un tanto periférica que solo le hizo figurar dentro de los programas tributarios del Imperio Azteca con un personaje, Tzintecuhtli, cuya descendencia tributó a través de Coixtlahuaca, después de una temprana expedición de conquista, y la agreste topografía los mantuvo relativamente desconectados de las rutas comerciales que unieron a la gran Tenochtitlán, Culhuacan y a Cholula con los Valles Centrales de Oaxaca. El grupo Ixcateco permaneció bastante aislado durante la Conquista, pero al alcance de las enfermedades traídas por los españoles, ya que una fuente señala que los Ixcatecos ocupaban siete poblados en el momento de su cristianización, entre ellos Nopala, Tecopango, San Pedro Nodón y Coyula, aniquilados debido al proceso de sequedad y a enfermedades.

Del grupo se conservan por lo menos tres lienzos coloniales, de los cuales ninguno se encuentra en México. Uno de ellos está incluido en las Relaciones Geográficas del siglo XVI, recopiladas en 1903 por Dn. Francisco del Paso y Troncoso, y otro, el Lienzo de Santa María Ixcatlán, ubicable en la Biblioteca Nacional de Paris, se refiere a un conflicto territorial con una comunidad llamada Axumulco; esto cuando jefaturaban la población los Principales

○ิ 11 Caña y 97 Jaguar, cuya fecha de enseñoramiento todavía no puede precisarse; el tercero es el Lienzo o mapa de Santa María Ixcatlán, que se encuentra en la Colección Latinoamericana Benson de la Universidad de Texas, en Austin. La cristianización fue practicada por frailes dominicos no plenamente identificados, que pusieron mayor atención en las áreas de Coixtlahuaca y Apoala, marginando aún más al grupo, aunque en la 
población de Ixcatlán se construyó durante el Siglo XVII un importante templo que, con los años, fue siendo dotado de retablos de esa época y posteriores y de pinturas de mérito entre la que destaca una "Virgen con Donador" del pintor Antonio de Lara.

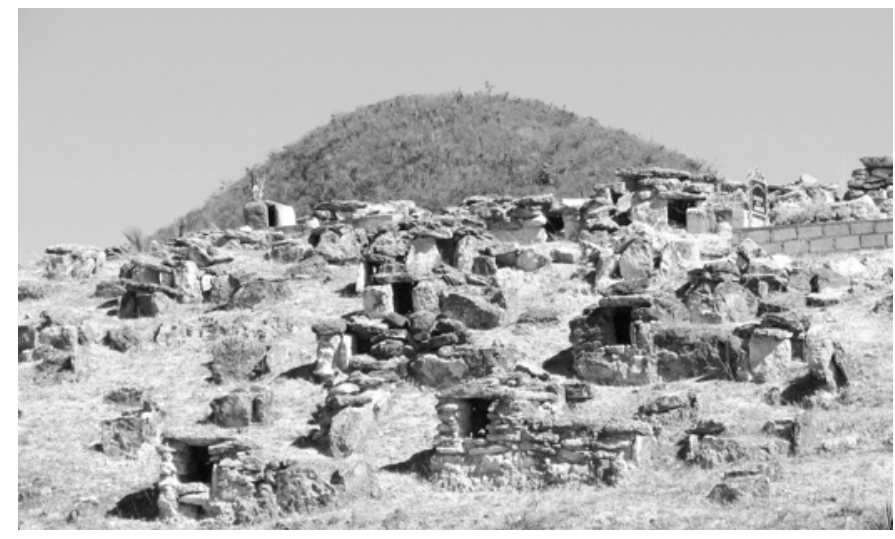

Un poco probable cementerio prehispánico superficial o el cementerio resultante de una epidemia del S. XVI. San Pedro Nodón, Ixcatlán. (Foto: Ollinzihuatl).

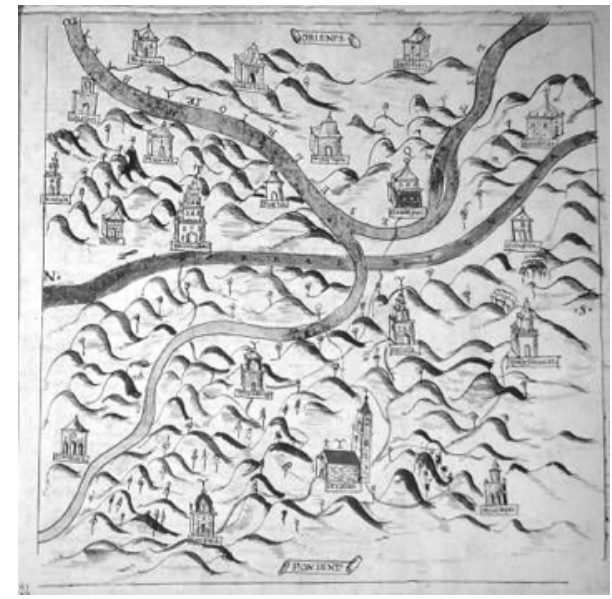

Lienzo de Santa María Ixcatlán (Foto: Colección

Latinoamericana Benson de la Universidad de Texas, Austin).

Durante la época Colonial hubo encomenderos, uno de ellos Rodrigo Segura, codicioso y causante de trabajos forzados en minas y por consiguiente de múltiples muertes. Simultáneamente, el área fue sobrepastoreada por rebaños de cabras y borregos que destruyeron irreversiblemente la cubierta vegetal. Más recientemente hubo población que requirió del uso de la madera de los muy pocos bosques existentes y hacia principios del siglo XIX la región vivía una crítica situación que determinó una carencia casi total de agua. Parte de la población debió emigrar hacia zonas circundantes, con la consiguiente desaparición de comunidades aisladas, y para los que se quedaron, el siguiente siglo y medio estuvo revestido de calamidades. Alrededor de 1915, el "año del hambre", como se le llamó en su momento, una fuerte epidemia de tifoidea ocasionó una mortalidad muy 
elevada en la Mixteca Alta y la población en Santa María Ixcatlán se redujo a menos de 1000 personas. Poco después (1919) actuó en la zona uno de los grupos armados de filiación "zapatista" (General y oficiales soberanistas y soldados zapatistas), que combatieron asociados con el movimiento soberano oaxaqueño, el que jefaturó el General Teodomiro Romero, quién llegó a la población exigiendo y obteniendo algunos recursos, con lo cual todavía más se agudizaron las carencias. El grupo del Gral. Romero fue expulsado a fines de febrero de 1920 por miembros del batallón "Miguel M Navarrete" de la División carrancista 21 al mando del Teniente Coronel Candelario Moreno, cuyos soldados se dedicaron después a saquear la población, llevándose burros y objetos. Años después, durante el sexenio del Gral. Lázaro Cárdenas del Río, se regularizó la posesión de las tierras comunales, y bajo el gobierno del Lic. Heladio Ramírez López, se dejó transitable la carretera que une Coixtlahuaca con Tecomavaca. Hasta muy recientemente, el índice poblacional comenzó a sufrir una recuperación, pero ya sin hablar el idioma, aunque ahora una constante es la emigración, tanto a la Cuenca de México, como a los EE UU.

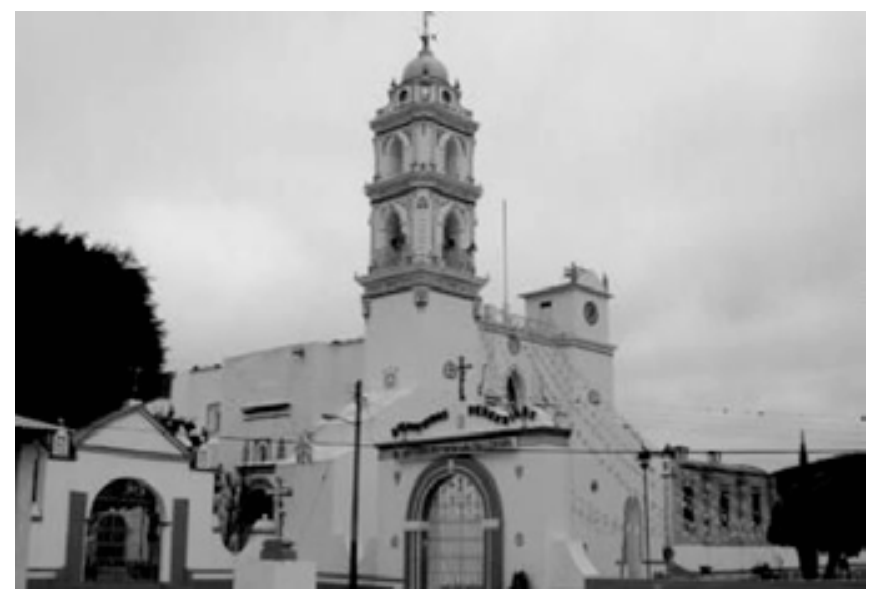

Iglesia de Santa María Ixcatlán. (Foto: Pshara).

IDIOMA. La lengua Ixcateca pertenece al Grupo Otomangue, Tronco Savizaa, Familia Popoloca, y hacia 1970 era hablada por aproximadamente 4000 personas. En el año 2009 se registró que solamente cinco personas la poseían. En 2014 se registran ocho. De los pueblos y rancherías originales de habla ixcateca solamente sobrevive Santa María Ixcatlán y en él la lengua se ha estado perdiendo rápidamente. Poco antes de 1960, la Maestra en Lingüística María Teresa Fernández de Miranda, aprovechando un buen informante, hizo un estudio fonémico de bastante profundidad y un Diccionario Ixcateco, que fueron publicados por el Instituto Nacional de Antropología e Historia, de México, D.F. en 1956 y 1959. Años después se dio el caso paradójico de que los maestros de enseñanza primaria fueran de habla mixteca, sin conocimiento de la lengua local, y aún más recientemente, alguna autoridad consideró que los niños son mas útiles tejiendo sombreros que aprendiendo su lengua, aunque algunos ancianos han intentado enseñarla, con bajísimos resultados. Sin embargo, ahora de nuevo hay un programa tendiente a evitar su desaparición. Don Cipria- 
no Ramírez Guzmán es un anciano dedicado a esa labor, dentro de un programa impulsado por la Fundación Harp oaxaqueña.
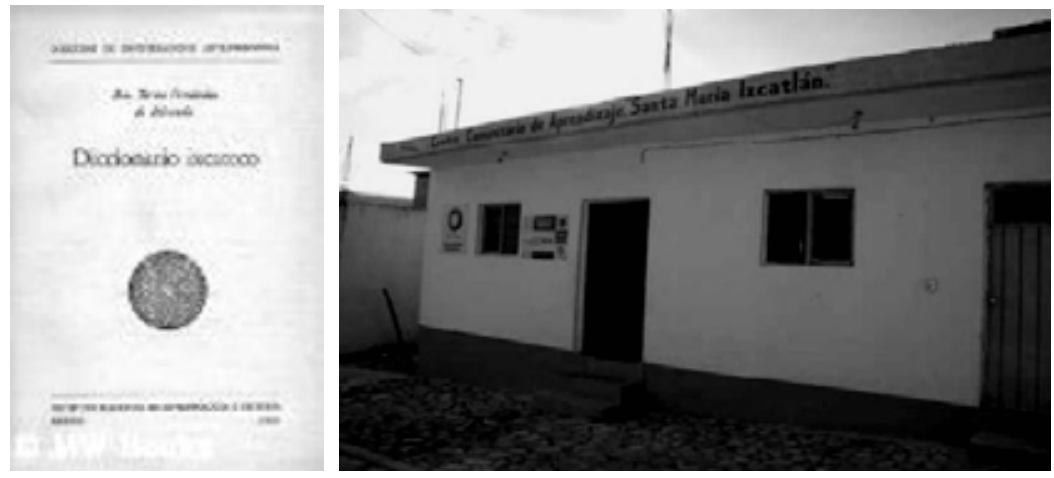

Portada del libro "Diccionario Ixcateco" y Centro del Estudio de la lengua. (Fotos INAH y Ayuntamiento de Ixcatlán).

DEMOGRAFÍA. Los registros del Gobierno del Estado de Oaxaca, que no concuerdan con los de otras fuentes, asignaron en 1970 al grupo Ixcateco aproximadamente 6500 personas. La dispersión de la población y la poca acuciosidad en los censos hacen que no exista ningún dato fidedigno.

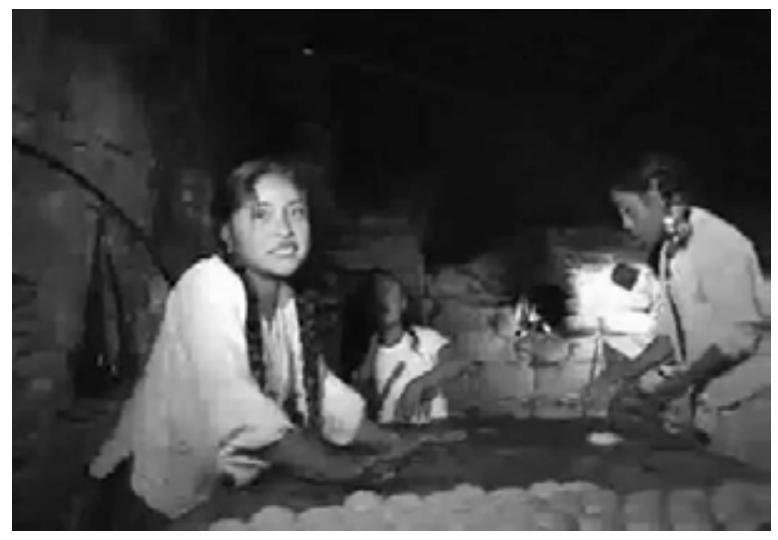

Niñas ixcatecas. (Foto: Sandino Leal).

En 1962, en el Guión Etnográfico que elaboró para el grupo, el Mtro. Roberto Weitlaner calculó 4500. Los datos del 2000 dan como resultado 549, y los del 2010, 370, casi todos ignorantes de su lengua original.

ACCESOS. A la región Ixcateca siempre se llegó a través de veredas. Hace algunos años se construyó una pista para pequeñas avionetas, en la que se apoyó el Instituto Lingüístico de Verano. En 1980 se construyó un camino de terracería que une a las poblaciones de Coixtlahuaca y Tecomavaca, el cual pasa por Santa María Ixcatlán. El primer tramo terminado fue el de Tecomavaca a Ixcatlán. Después de 1990 se abrió el camino complementario de terracería que permite llegar desde Coixtlahuaca. 

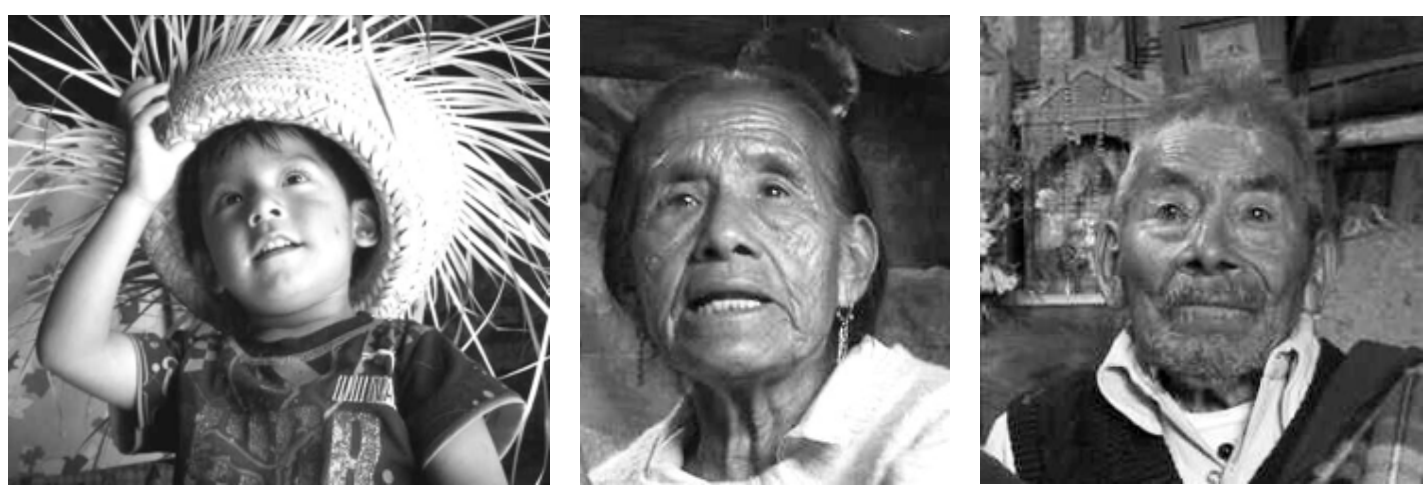

Niño y ancianos ixcatecos. (Fotos: Internet).

VIVIENDA. Existieron casas de planta rectangular con techos, ya sea de pasto o de teja y de dos aguas.. Las casas solían estar congregadas y en la población de Ixcatlán todos los grupos de casas se agrupaban alrededor de la plaza pública detrás de los edificios que rigen la vida de la comunidad. Las dimensiones de cada choza solían ser de un promedio de cinco metros de largo y el amueblado interior consistió relativamente de pocos utensilios entre los cuales descollaban mesas, sillas, vasijas y ollas de cerámica, y habitualmente una mesa de madera. El fogón se encontró en uno de los dos costados de la habitación y se compuso de tres piedras que configuraban un triángulo equilátero. En muchas casas fue frecuente el enlucido de lodo en las paredes y sólo en contados casos, hasta la actualidad, éstas son de adobe. Un importante elemento incorporado en algunas casas es el baño de vapor o temascal. Dentro de las casas, la gente duerme en petates y en promiscuidad, y en ocasiones también con animales domésticos. Pocas familias tienen cabras que venden a comerciantes de Tehuacán.

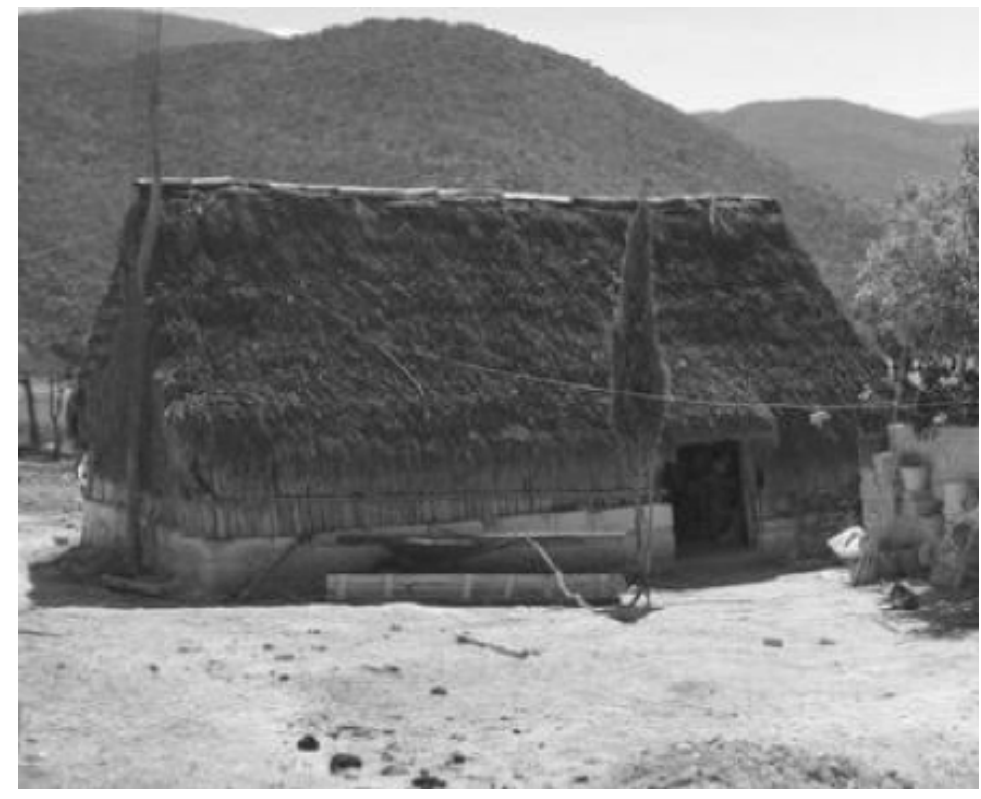

Casa en Ixcatlán en 1962. (Foto: IIS-UNAM). 
INDUMENTARIA. Casi desde principios del siglo desapareció completamente la indumentaria indigena. Se conservaron algunos huipiles que quedaron en colecciones particulares, Dicha indumentaria fue substituida por la ropa comercial de algodón y de dril, y en las mujeres por el vestido y el delantal. Se usa el huarache, la sandalia y para muchas personas actualmente el calzado de plástico. Algunas mujeres portan pequeñas arracadas y son frecuentes las medallas y los crucifijos pendientes de collares.

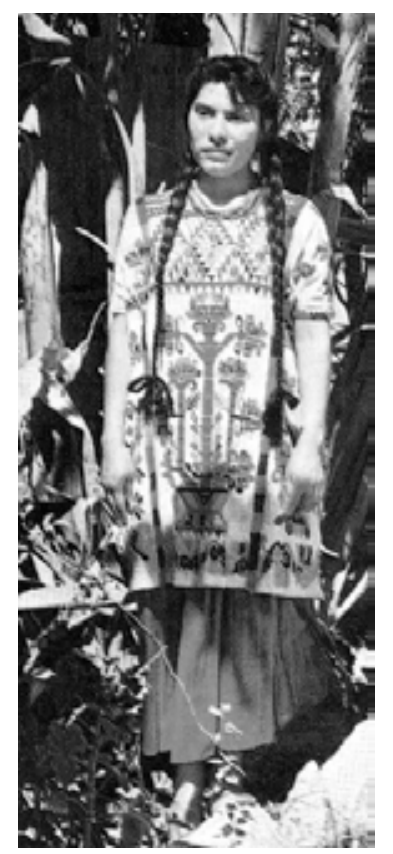

Huipil ixcateco. Colección Maria Luisa Audiffred. (Foto: INAH).

ECONOMÍA. La economía Ixcateca es de subsistencia y se encuentra enmarcada dentro de la organización integral del grupo. Este ha mantenido mecanismos de adaptación, cada vez más frágiles, a las condiciones económicas del país. Como en todas las zonas deprimidas de éste, la explotación inadecuada del medio ambiente y de sus recursos, aunada a la casi total destrucción de estos últimos, ha llevado al grupo Ixcateco a una situación de extrema miseria que se agudiza debido a que la etnia ya no produce lo suficiente, y casi no tiene excedentes para poder obtener los artículos que no se producen en su región. No obstante, la población se ve obligada a vender parte de lo que se produce, particularmente sombreros, con el objeto de obtener aquellos bienes que le hacen falta. En estas operaciones de compra venta está presente una vez más el desigual sistema nacional de comercialización.

Puesto que la economía del grupo es de subsistencia y los suelos están prácticamente agotados, existen ligeros programas de fertilización que no están resolviendo el problema. La tenencia de la tierra contempla dos de las formas existentes en el país: La primera es la propiedad privada, que se presenta dentro del casco de la población de Ixcatlán, principalmente en forma de solares. La tierra es comunal, ocupando todo el territorio y es utilizada para cultivo, pastoreo y extracción de leña y productos de cactáceas. 
El principal cultivo es el maíz, en ocasiones mezclado con fríjol, alverjón y calabaza. Los rendimientos son muy bajos, casi nunca superiores a los 300 a 400 kilogramos por hectárea. Las variedades sembradas son criollas de ciclo medio y de granos grandes, con ligera resistencia a algunas plagas. Debido a la topografía del terreno, las áreas cultivables son muy pequeñas y no existe un programa de rehabilitación de terrazas. Existe el aprovechamiento de plantas y semillas comestibles silvestres; el amaranto, la chía, el laurel y los tipos de nopal de textura más suave, de cuyas pencas se hace caldo y otros guisos. En la población se hace pan.
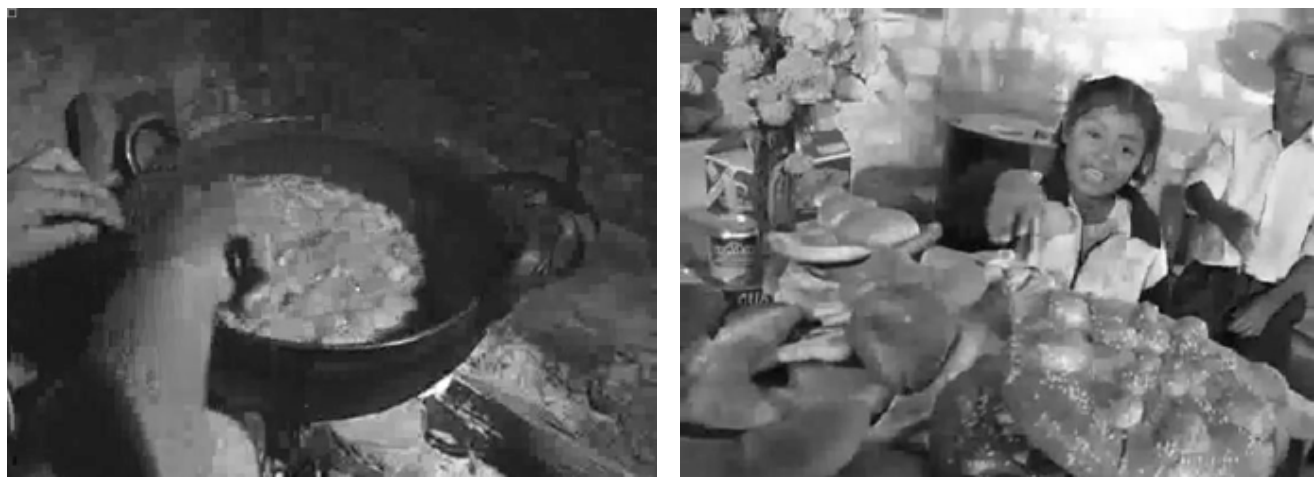

Caldo de nopal. (Foto: CDPI). Pan de muertos ixcateco. (Foto: Sandino Leal).

CAZA Y PESCA. Las características del terreno y su deforestación eliminaron por completo muchas especies de animales silvestres desde hace muchos años. Actualmente el grupo sólo tiene a su alcance de manera muy esporádica aves y algunos roedores (ardillas de la tierra o hurones, liebres y conejos), zorras grises, cacomixtles, unos cuantos coyotes y algunos reptiles (camaleones, lagartijas, víboras de cascabel y culebras). Como los arroyos son intermitentes, solo existen peces de ciclo muy corto y de un tamaño muy pequeño, que resultan casi inaprovechables. Por ser perfectamente posible, urge un buen criadero de Carpa de Israel, el que elevaría la capacidad nutricional en el grupo. Como ya se ha hecho un bordo, sería muy recomendable aprovecharlo en ese sentido.

MERCADOS. La única y por ello principal plaza es Santa María Ixcatlán, con una señera historia cultural, porque en los Siglos XVIII y XIX era centro de trueque y comercio al que acudian gentes de comunidades tan lejanas como algunas de la sierra mazateca. En ella las actividades comerciales corren a cargo de mestizos y de comerciantes ambulantes los cuales han acrecentado su acción desde que se abrieron los caminos de terracería. Existe un limitado intercambio de productos, y las transacciones suelen ser muy injustas para el productor indígena.

ARTESANIAS. En el grupo predomina el tejido sobre palma y sobre fibras sintéticas, las cuales son llevadas de otras regiones para su elaboración. En 1962 se disponía de palma regional y había varias lomas donde era abundante a las que se les llamaba "El Palmar". 

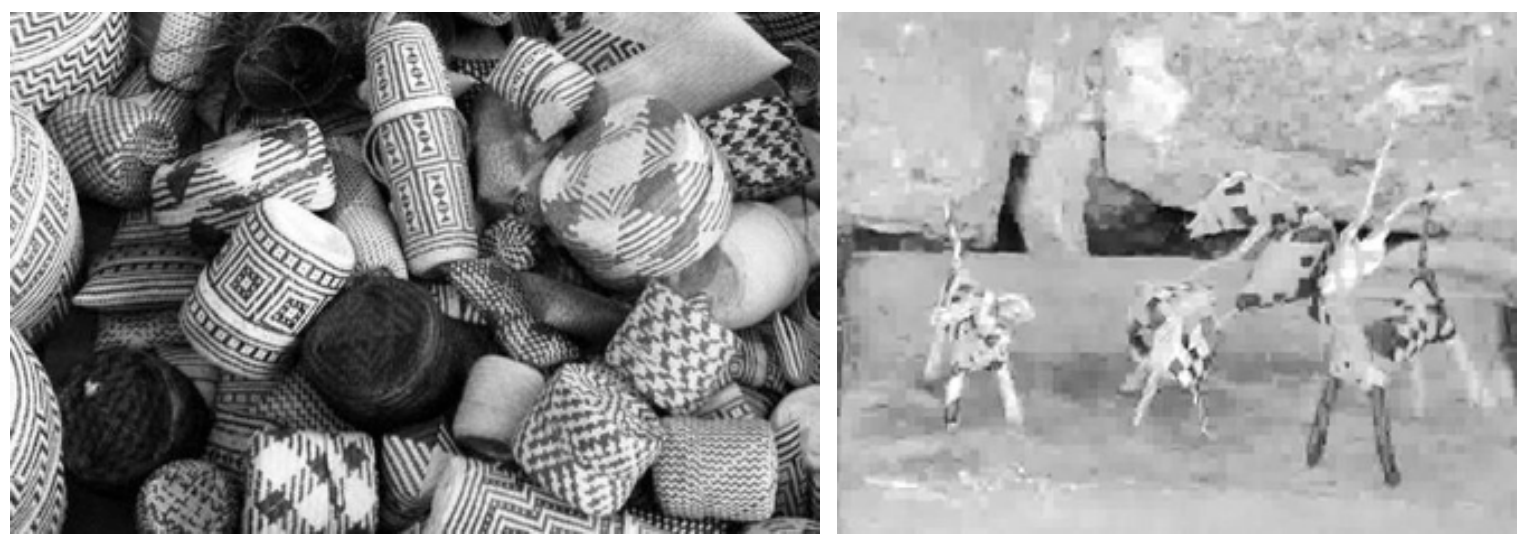

Tejidos y juguetes de palma ixcatecos. (Fotos: CNPI).

Esta actividad es realizada por toda la familia, en oquedades excavadas ex profeso para mantener la humedad de la palma y poderla moldear, y se tejen sombreros, tenates y canastos, consignándose que existió un modelo de sombrero que recibió el nombre de "Ixcateco".
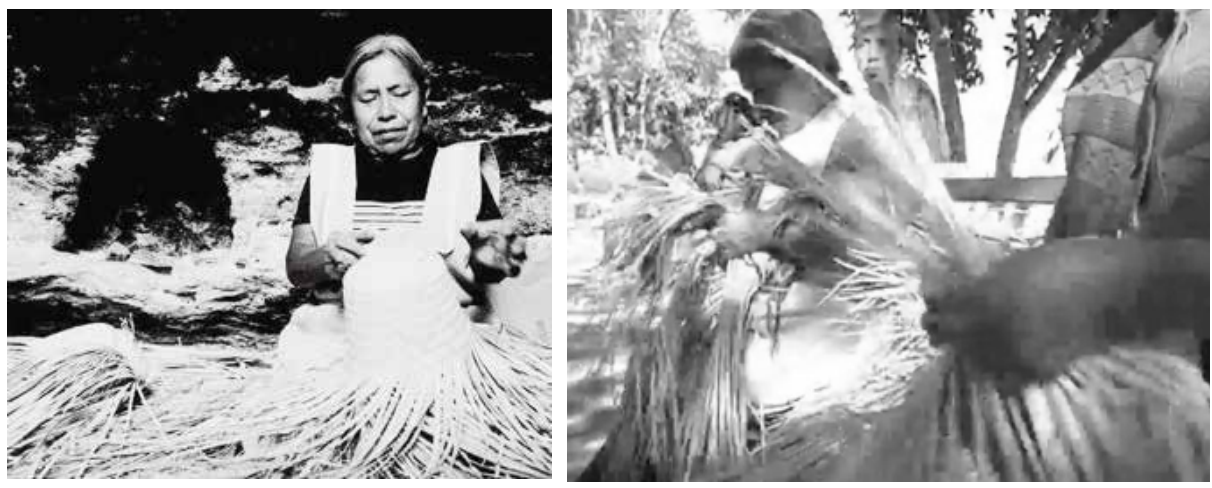

Tejedoras de palma ixcatecas. (Fotos: Alejandro Aquino).

En la comunidad existen pocos especialistas de tiempo completo en carpintería, albañilería, y peluquería. En Santa María Ixcatlán, el Maestro Roberto Weitlaner reportó un herrero dedicado a la reparación de aperos agrícolas y al herrado de animales.
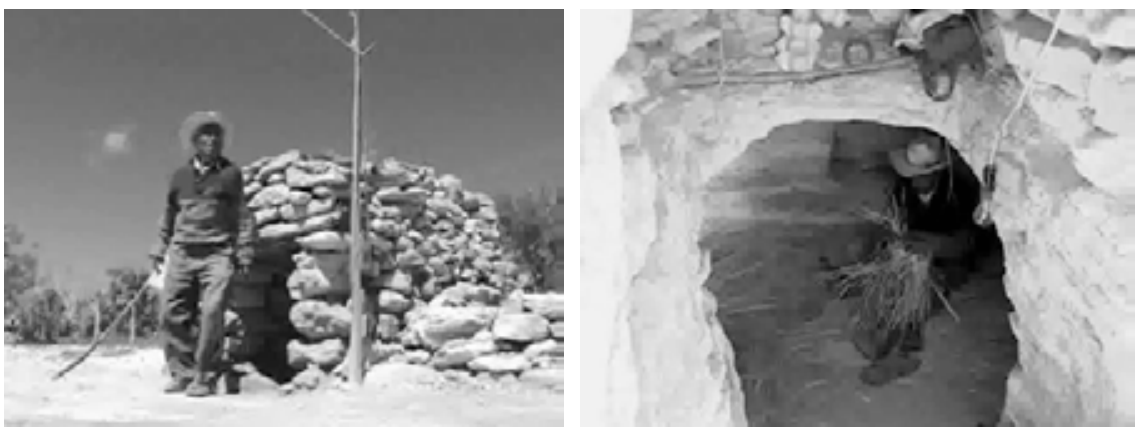

Oquedades para tejido de palma, Ixcatlán. (Fotos: CNPI). 
ORGANIZACIÓN SOCIAL. La sociedad Ixcateca es patrilocal, patrilineal, monogámica y endogámica. La familia es la célula principal: Cuando es nuclear está constituida por el padre, la madre y los hijos solteros. Cuando es extensa, a la familia nuclear se le agregan los parientes próximos y por consanguinidad. La institución del compadrazgo está firmemente implantada. Hasta hace relativamente poco tiempo, los matrimonios se concertaban cuando la edad de los contrayentes fluctuaba entre los 18 y los 20 años. Existió un intermediario, el parangonero, que era el encargado de convencer a los padres de la novia de las buenas intenciones y a solvencia del pretendiente. Las visitas de avenencia no pudieron ser menos de tres, y se les denominaba "El Rogamiento", y en ellas se entregaban regalos entre los que descollaban botellas de licor. Cuando los padres de la novia aceptaban, había una reunión con los padres del muchacho y en ella se fijaba la fecha de la boda. Al novio correspondió aportar lo necesario para el ajuar de la novia. La noche anterior a la boda, en la casa de los padrinos se celebraba una fiesta en la cual una anciana, generalmente su madrina, peinaba a la novia después de haber sido llevada ex profeso. Después de la ceremonia religiosa la fiesta se realizaba en ambas casas de los padres de los contrayentes; pero la primera noche la pasó la pareja en la casa de los padrinos de la boda y al día siguiente un hombre con experiencia los ponía en antecedentes de todo lo que debían hacer para una vida adecuada y productiva. A continuación el matrimonio se iba a vivir a la casa de los padres del novio. Durante todas las fiestas son habituales los bailes. Actualmente las relaciones entre chica y chico se inician platicando, y ya hay parejas que toman la decisión de unirse.

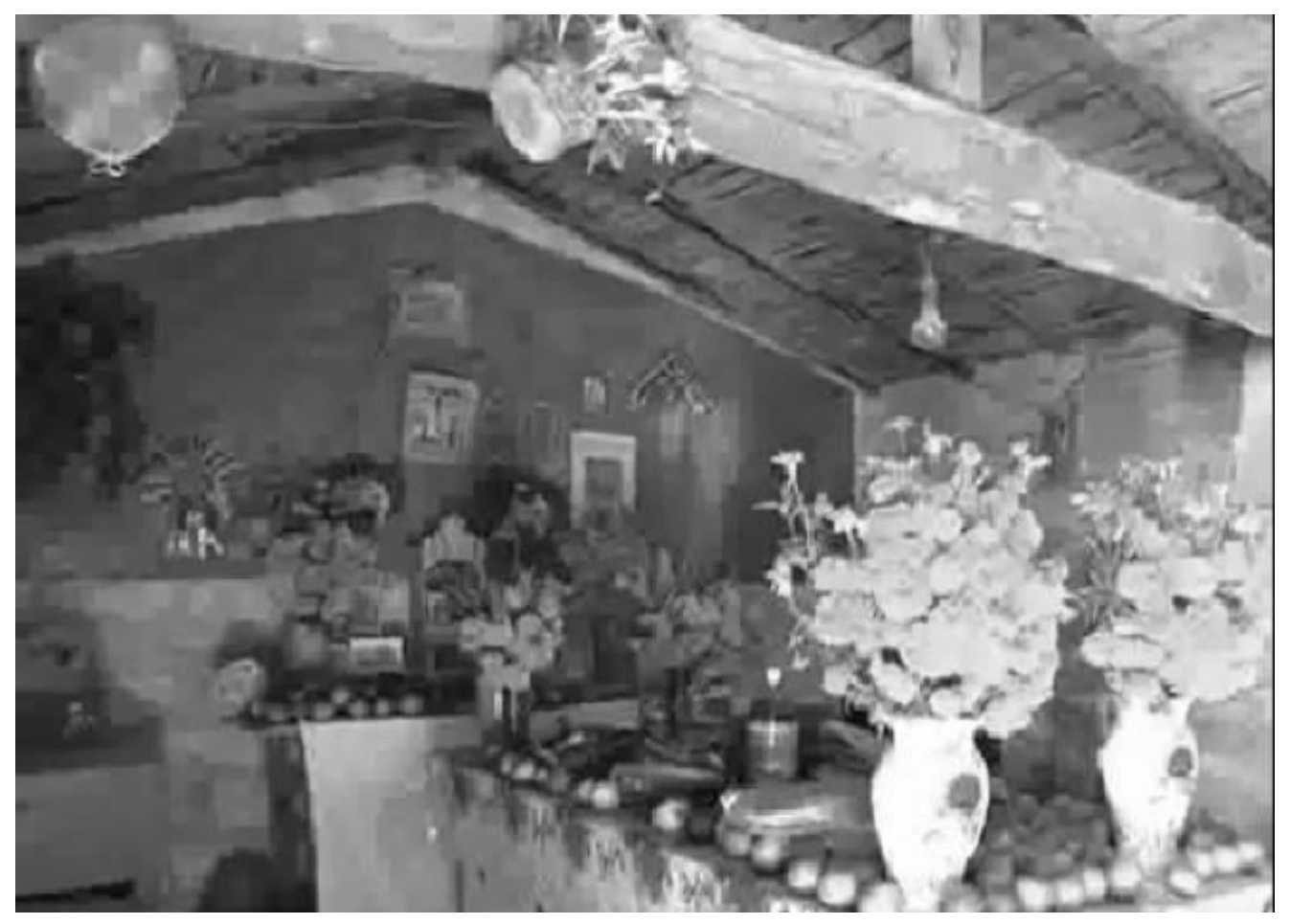

Altar de muertos ixcateco. (Foto Profr. José Demetrio Quiroz). 
Cuando se produce una muerte, el cuerpo es colocado sobre una cruz de cal pintada en el piso frente al altar de la casa. Anteriormente se le vestía con sus mejores ropas y se le ponían los mejores huaraches o sandalias posibles para que pudiera subir al cielo. Al velarlo se le colocó una piedra bajo la cabeza para que ésta pudiese descansar, un crucifijo sobre el pecho y un rosario sobre el cuello. Acto seguido se notificó a autoridades, parientes y amigos y se le llevó al cementerio en una procesión que primero lo introdujo a la iglesia, donde se le dedicaron los rezos. En la ceremonia intervenían rezadores de ambos sexos. Y al terminar fue llevado al cementerio donde se le inhumó, con la cabeza al poniente, en una tumba, sobre la que se solía poner un monumento o una cruz. Parte de esta costumbre pervive.

Los hijos varones heredaban las tierras de los padres. Sin embargo, los artículos que pertenecieron a su pareja difunta eran repartidos entre todos los hijos.

GOBIERNO. Además del aparato político que fundamenta el Estado Mexicano, en el grupo Ixcateco subsistió una forma de Gobierno Jerárquico en el que existe una fuerte relación entre las actividades políticas y religiosas. La aculturación a que ha sido sometido el grupo ha hecho que parte de esa tradición se haya perdido, y que solamente subsisten algunas de las jerarquías. Informes recientes revelan que, aunque el Municipio se rige por Usos y Costumbres, hay una fuerte penetración política en torno a la Confederación Nacional Campesina, brazo rural del PRI.

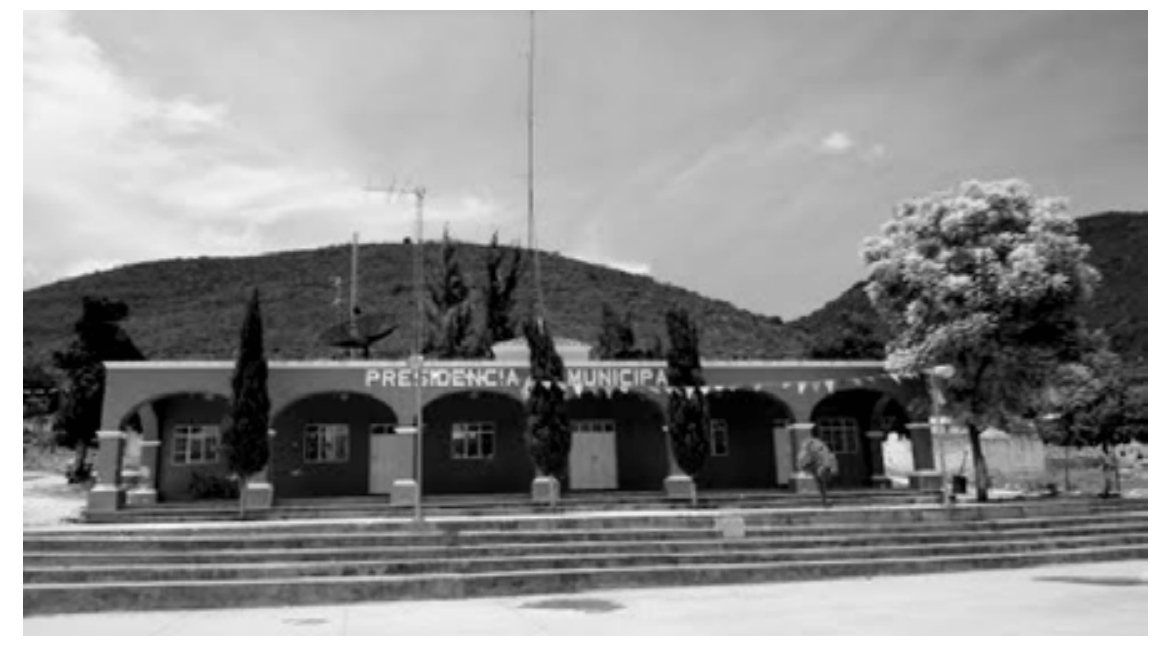

Palacio Municipal de Santa María Ixcatlán. (Foto: Municipio).

FESTIVIDADES. Como en otros grupos de las ramas Popoloca y Mixteca, la substitución del calendario ritual y del calendario agrícola, por el calendario que rige la religión católica, realizado durante la primera etapa de la administración colonial del país, cambió por completo el orden sucesivo de fiestas que entonces subsistía, por lo cual todas las festividades quedaron dentro del ritual católico. Las fechas principales de fiestas en San María Ixcatlán son: El Carnaval, en el cual se baila la danza de los Huehuetones: la danza del 8 de septiembre llamada de los Santiaguitos, a la cual se acompaña con flautas de caña, 
tambores y tamboriles, y también hay una procesión mortuoria en el día 2 de Noviembre, pero desde el 31 de octubre se inicia la conmemoración y se instalan los altares con poca comida porque se considera que entonces llegan las almas de los niños que murieron sin haber podido ser bautizados. Al día siguiente se completan los altares y se desarrolla normalmente la tradición. La fiesta más importante de la población es la del cuarto viernes de cuaresma. En ella se instala un mercado regional, al que concurren comerciantes de pueblos, ya sea próximos o distantes.

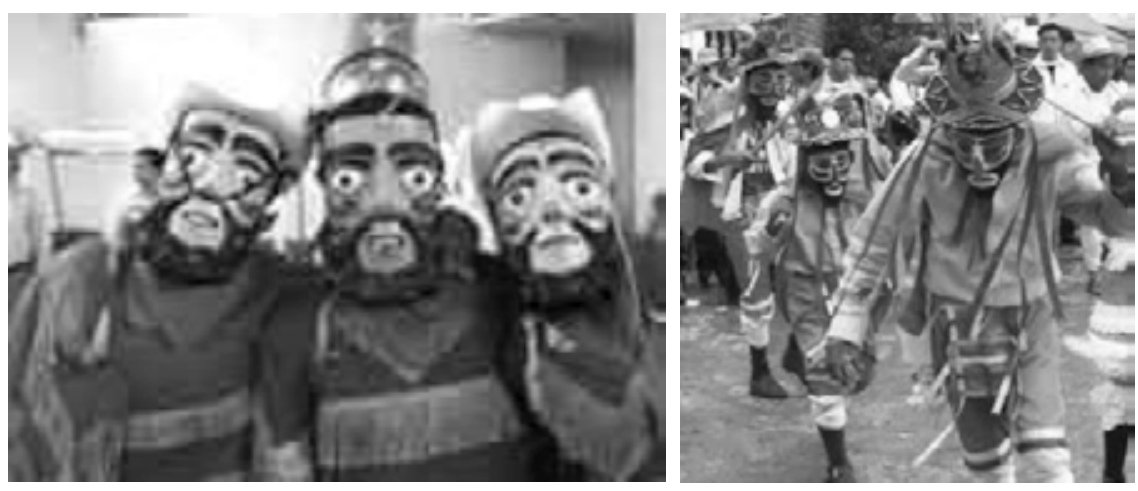

Danza de los Santiaguitos. Santa Ma. Ixcatlán. (Fotos: Profr. José Demetrio Quiroz).

ORGANIZACIÓN RELIGIOSA.: La iglesia Parroquial está a cargo de un Sacristán. Para la organización de las fiestas subsisten las mayordomía, de las que la más importante corresponde al 7 de mayo, y a la que denomina "Del Señor de las Tres Caídas”, a cuya festividad llegan, siguiendo una antigua tradición, personas procedentes de la Sierra Mazateca, de la región de Huautla de Jiménez,. En las actividades de la Mayordomía participa casi toda la población. En el grupo subsisten bastantes mitos. No todos están registrados y el más importante de los que lo han sido es el del "Dios de la Lluvia”, el cual vive en las Cañada de la Palma Blanca, y que se manifiesta porque en los amaneceres aparece una nube que cubre la cresta de ciertas montañas, rasgo que generalmente precede una buena lluvia. Para la colocación de ofrendas, en los costados de las veredas existen pequeños túmulos y en ocasiones también cruces a las que se les ponen ofrendas de flores frescas. Se piensa que los caminantes que pisan esos túmulos pueden desaparecer, pero es costumbre que el caminante se coloque al lado y se golpee los pies con ramas pequeñas, con lo cual le debe desaparecer el cansancio. Subsisten los curanderos, que eliminan los "malos aires" y "el espanto" haciendo limpias.

MEDICINA Y MAGIA. Existen hechiceros que utilizan un abigarrado conjunto de objetos para curar. Los males que ellos pueden curar con principalmente los aires y los provocados por sustos, para lo cual usan huevos, hierbas y alcohol. Las enfermedades más comunes son de tipo digestivo y respiratorio y reciben tratamiento mediante buenos conocimientos de herbolaria, así se aplican en la región una importante cantidad de hierbas medicinales. 


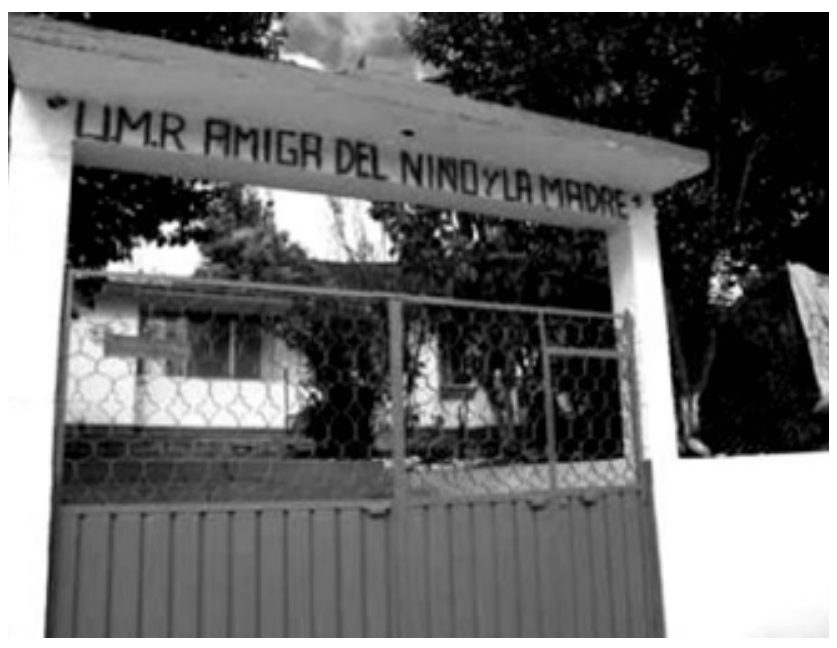

Unidad Médico Rural en Santa María Ixcatlán. (Foto: Municipio).

Desde hace poco tiempo desarrolla sus actividades en ciclo anual un pasante de medicina en la región, que de esa manera cumple con su servicio social.

EDUCACIÓN. Existe en Ixcatlán un jardín de niños, una escuela primaria, una telesecundaria y algunas aulas diseminadas en rancherías. El nivel de escolaridad promedio es inferior al segundo grado de primaria, y los jóvenes, para adquirir un mayor nivel académico, deben trasladarse, ya sea a Cuicatlán, o a Nochixtlán, donde algunos estudian becados. Se registra que, hasta poco antes de 1965, los maestros que iban a trabajar a esa escuela hacian dos días de camino desde Coixtlahuaca.

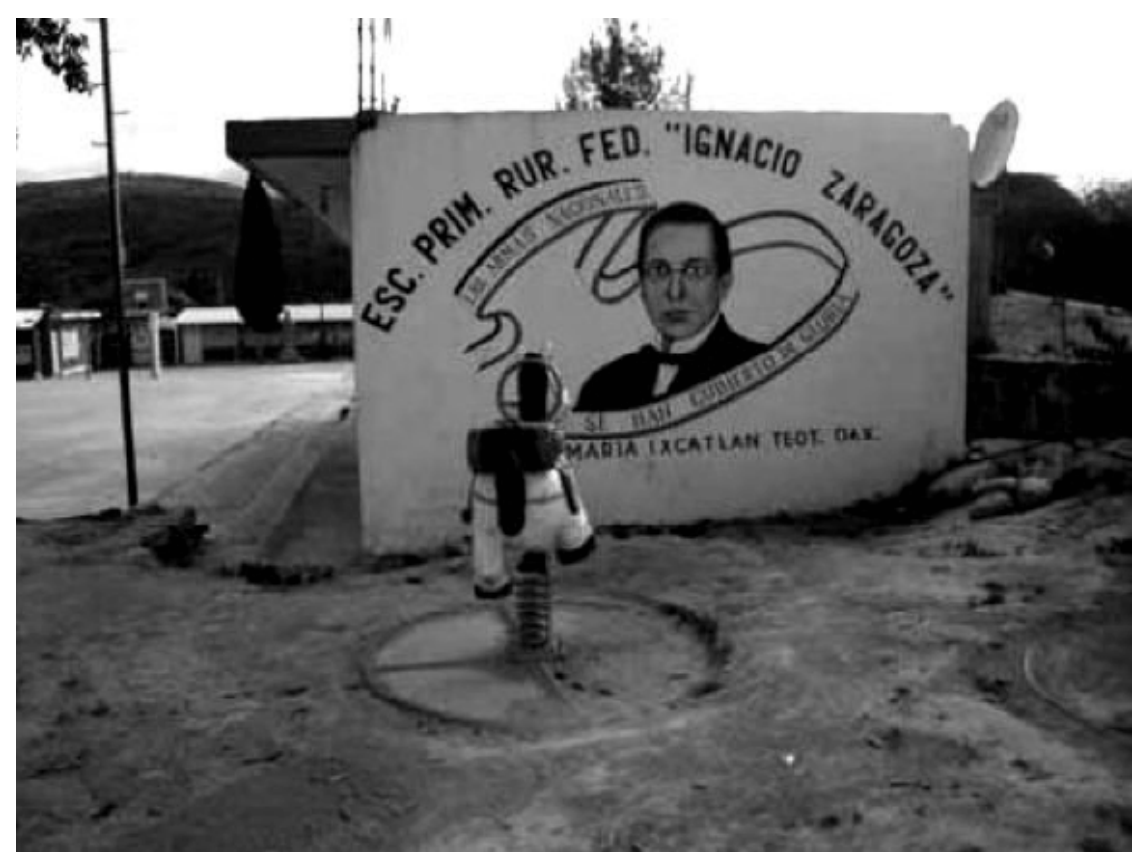

Escuela Primaria en Santa María Ixcatlán. (Foto: Municipio) 


\section{BIBLIOGRAFÍA}

Acevedo Conde, María Luisa. 2007 “Los Ixcatecos”. Revista A CONTRAGOLPE. № 9. Carteles Editores, Oaxaca, Oax. 2007.

Aguirre Beltrán, Gonzalo. 1966 "Función de la Indumentaria en el Viejo Ixcatlán”. En: SUMMA ANTHROPOLOGICA. Homenaje a Roberto Weitlaner. Instituto Nacional de Antropología e Historia. México, D F. 1966.

Bartolomé. Miguel Alberto. 1991 HISTORIA IXCATECA. Historias étnicas III. INAH. CIESAS. Gobierno del Estado de Oaxaca. Oaxaca, Oax. 1991. 1999 "¿Los últimos ixcatecos?. Entre la identidad étnica y la filiación comunitaria”. En: Barabas, Alicia Mabel y Bartolomé, Miguel. Coords. CONFIGURACIONES ETNICAS DE OAXACA. PERSPECTIVAS ETNOGRAFICAS PARA LAS AUTONOMIAS. VOL III. INAH. INI. México. D F. 1999.

Bartolomé, Miguel. Barabas, Alicia Mabel. 1996 LA PLURALIDAD EN PELIGRO. Colección "Regiones de México". INAH. INI. México. D F. 1996.

Cook, Sherburne F. 1958 "Santa María Ixcatlán. Habitat. Population. Subsistence”. En: REVISTA IBEROAMERICANA. № 41 University of California Press. Calif. 1958.

Dalton Palomo, Margarita. 1997 "Una hoja de papel arrugada". "Las ocho Regiones Geográficas”. OAXACA, TEXTOS DE SU HISTORIA. Vol. I. Instituto José María Luis Mora. Gobierno del Estado de Oaxaca. México. D F. 1997.

Hironymous, Michael 0.2003 LA GEOGRAFIA HISTORICA DE SANTA MARIA IXCATLAN. Trabajo de investigación entregado al FAMSI.

Universidad de Texas. U S A. Austin. Tx. 2003. Hoppe, Walter. Weitlaner, Roberto. 1969 “The Ichcatec". En: HANDBOOK OF MIDDLE AMERICAN INDIANS. Vole VII, University of Texas Press. Austin Ct London. 1969.

Nava Reyes, Clara. Romero Luna. Monserrat. 2007. IXCATECOS. Comisión Nacional para el Desarrollo de los Pueblos Indígenas. México. D F. 2007.

Rzedowsky, Jercy. 1983 VEGETACION DE MEXICO. Limusa. México. 1983

Tovar. María Fernanda. Bazúa Rueda. Silvia. 1982 LOS IXCATECOS. Instituto Nacional Indigenista. México. 1982. 1997 LOS IXCATECOS. En: OAXACA. TEXTOS DE SU HISTORIA. Vol. I. - Instituto José María Luis Mora. Gobierno del Estado de Oaxaca. México. D F. 1997.

Weitlaner, Roberto. 1962 Guión “Los Ixcatecos”. Para la Sala de Etnografía del Museo Nacional de Antropología. INAH, CAPFCE, México. D F. 1962. 



\section{MIXES}

Autodenominación: Ayuuk ja'ay, ayook, ayuk.

Sinónimo en su lengua: ayuuk.

Traducción: Gente del idioma de la montaña.

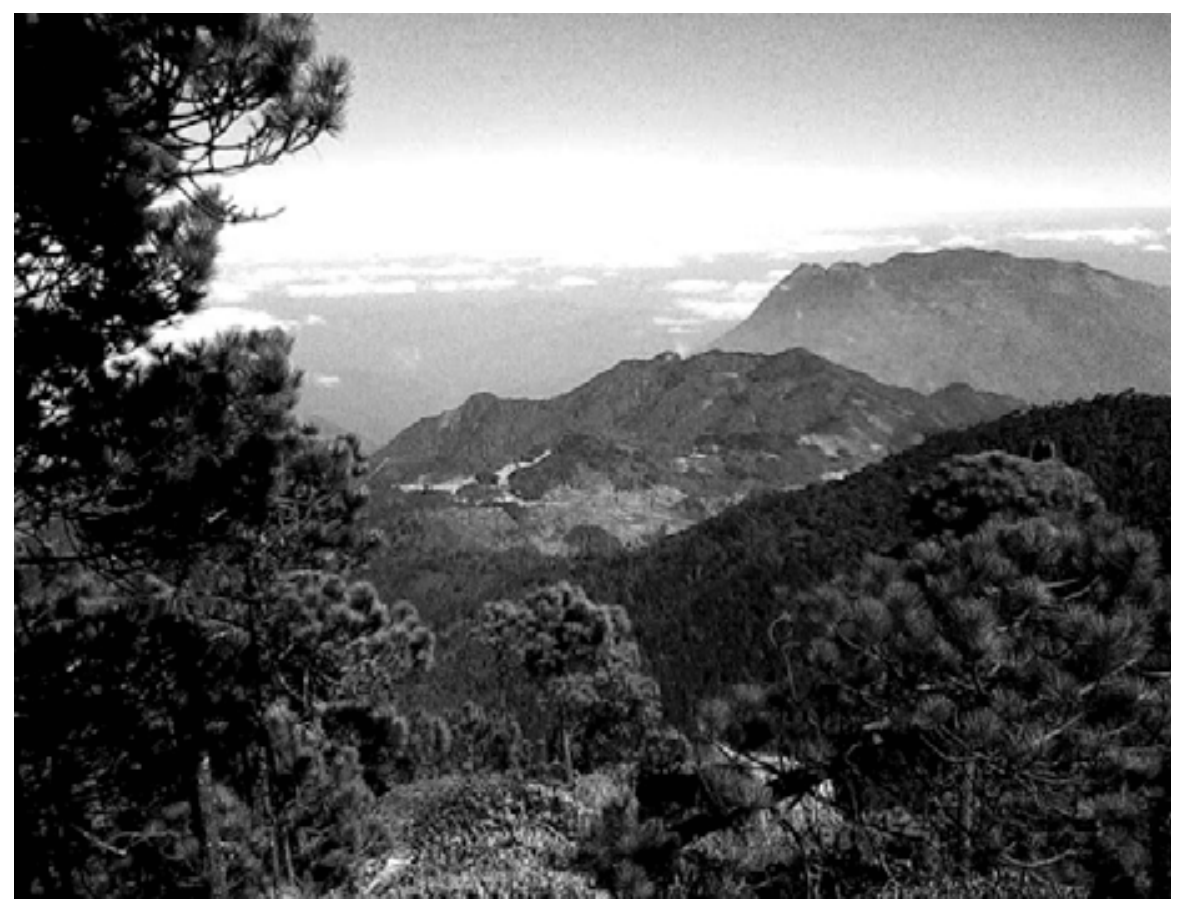

Paisaje de Tlahuitoltepec. (Foto: paisajestlahui.blogspot).

\section{GRUPO MIXE}

POSICION GEOGRAFICA. Los mixes se encuentran localizados en la porción oriental de la Sierra Madre de Oaxaca, en la sección en que ésta se une con Sierra Atravesada, limitando al norte la porción oriental de la Sierra Madre del Sur, de la cual están separados por la cuenca media del Río Tehuantepec. Geográficamente, su área ocupacional se inscribe entre los paralelos $16^{\circ} 40^{\prime}$ y $17^{\circ} 32^{\prime}$ de Latitud Norte y los meridianos $94^{\circ} 40^{\prime}$ y $95^{\circ} 31^{\prime}$ de Longitud Occidental, y abarca aproximadamente 4700 kilómetros cuadrados. Son un grupo de muy posible origen olmeca-mayense, debido a que su lengua pertenece al Tronco Mixeano de la familia Mixe Popoloca. Su área ocupacional es de relieve muy accidentado, 
siendo el macizo del Zempoaltépetl, (su montaña sagrada), la mayor altura geográfica de la región, con alrededor de 3000 metros sobre el nivel del mar y con una cobertura de bosques de coníferas, pinos y encinos. El territorio presenta tres secciones, de alturas alta, media y baja. Las alturas medias se presentan entre los 800 y 1500 metros sobre el nivel del mar y en esa zona se encuentran las precipitaciones más altas de la región (hasta 3000 $\mathrm{mm}$ ), y un medio ambiente brumoso, conteniendo dos tipos de vegetación. Los bosques tropicales y los bosques mixtos bajos. En la región baja, situada debajo de los 800 metros sobre el nivel del mar, se presenta un clima caliente, por lo que tuvo una cerrada selva alta perennifolia, conservada en pequeños manchones, e intensas lluvias en verano alternadas con estiaje de dos meses.

La hidrografía de la región presenta las dos vertientes del macizo continental: Parte de los ríos vierten al pacífico a través del Río Tehuantepec, y los otros lo hacen al Golfo de México a través de afluentes del Papaloapan y de los ríos Jaltepec, Chivela y Tolosita, de la cuenca del Río Coatzacoalcos.
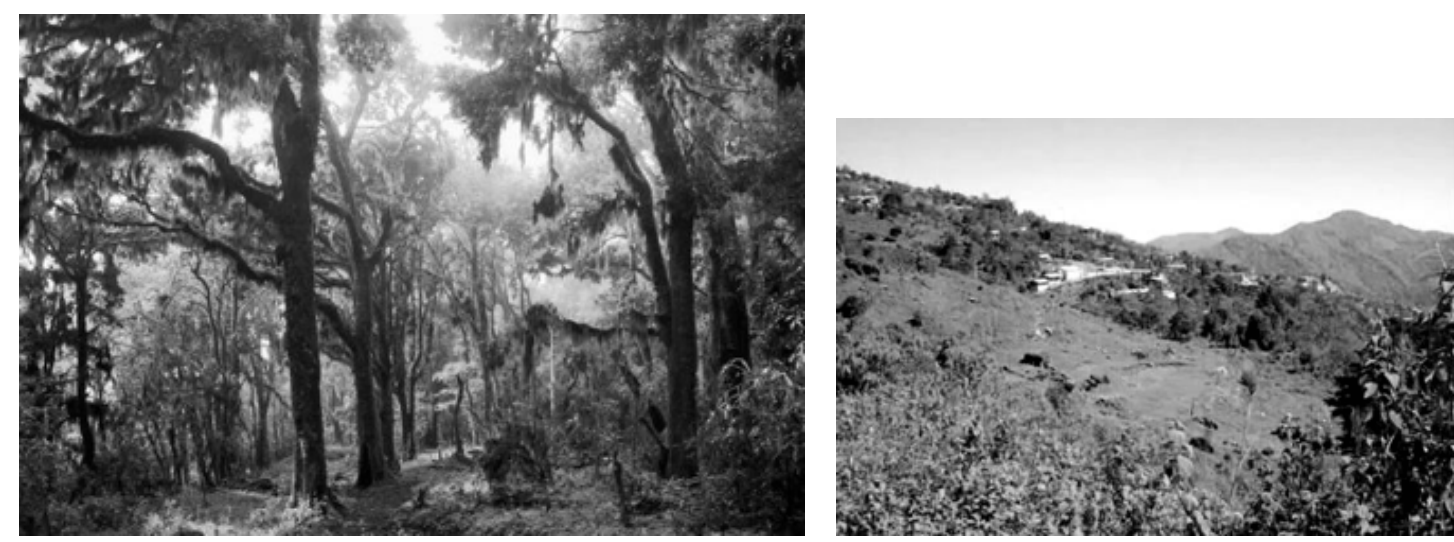

Bosque de niebla y Montañas Mixes. (Fotos del autor).

Debido a su accidentado relieve, la región presenta climas muy variados que van desde los templados con lluvias veraniegas de los bosques altos, hasta las selvas medias perennifolias, que ocupan todos los lomeríos bajos de las vertientes del río Coatzacoalcos, ahora en proceso de grave deforestación.

ANTECENTES ARQUEOLÓGICOS E HISTÓRICOS. Aunque el área mixe contiene muchos vestigios arqueológicos, se comienzan investigaciones controladas. Son muy pocos los sondeos realizados hasta ahora, uno de ellos realizado por el Arql. Scott R Hutson, que reportan cerámica y construcciones prehispánicas en varias localidades. En la zona alta, entre otras, en Moctum, Totontepec y Quetzaltepec, y en la baja en Xaltepec Candayoc, éste un importante y vital nudo de comunicaciones que se mantuvo con ese carácter durante más de 1500 años. Además, hay un dato que reporta cerámica y objetos olmecas arqueológicos en las cercanías de Zacatepec, lo que revela que el área ya tenía ocupación desde el Preclásico Medio o en la Etapa Media de las Aldeas. De hecho los actuales asentamientos 
revelan la antigüedad; asentamientos dispersos de carácter clánico. La tradición histórica del grupo consigna haber cedido pacíficamente terreno para el establecimiento de los huaves en su actual ubicación. Tal cosa no se ha comprobado. Sin embargo, la tradición oral y algunos investigadores etnográficos señalan que los mixes eran un grupo belicista cuando entraron en contacto con la conquista, momento en que estaban enfrentados con los zapotecas. Sin embargo, sus leyendas, entre ellas la del rey K’ong oy (Condoy), y su posición geográfica actual, hace suponer que en tiempos posteriores al año 800 de la era cristiana el grupo pudo haber sido desplazado por grupos Olmeca-Xicalancas hasta las montañas del Zempoaltépetl, ya que en la época de las presiones aztecas, alrededor de la segunda mitad del siglo XV, sus movimientos comerciales para la obtención de granos y sal se realizaban siempre con los grupos asentados en la costa del pacífico. A la conquista española opusieron fuerte resistencia, enfrentándose a conquistadores españoles particularmente sanguinarios, tales como Rodrigo Rangel, Luis de Barrios y Diego de Figueroa, de los que este último resultó el mas pendenciero y codicioso (se hundiría junto con el barco (bajel) que lo transportaba cuando regresaba a España con el producto de sus considerables robos y saqueos de tumbas prehispánicas, gracias a una providencial tormenta), los cuales fracasaron para lograrla. Poco después, hacia el año 1550, el grupo sufrió los estragos de la viruela y el tifo, por lo que la cantidad de población se desplomó. La recuperación vino hasta el Siglo XIX.

Debido estos factores, la evangelización se inició en 1558 con las acciones de Fray Jordán de Santa Catarina, al que siguió en 1561 Fray Pedro Guerrero, esforzado dominico que introdujo en la región los fiscales o catequistas, con lo que ya en 1570 había una doctrina en Totontepec, a la que en el siglo siguiente se agregaron las Residencias de Juquila, Quetzaltepec y Tepuxtepec, servidas por frailes como Marcos Benito, Fernando Bejarano y Agustín Quintana, todos ellos autores de libros doctrinarios, las que fueron seguidas a principios del Siglo XVIII por 18 parroquias seculares.

Prácticamente no hay datos sobre la participación del grupo en la Guerra de Independencia. Sólo fue hasta el período post-independiente que los mixes han tenido una participación activa y siempre en condiciones de desventaja y depauperación, en el proceso económico del país, si bien a fines del Siglo XIX la introducción del cultivo del café significó un importante refuerzo en las fuentes de ingreso, y un aliciente para desarrollar la codicia de algunos. Muy pocos fueron los mixes que participaron en las Guerras de Reforma e Intervención Francesa.

Como consecuencia de la acción política de los grupos soberanista y carrancista a principios del Siglo XX (1914-1919), la que permitió la elevación al máximo nivel político de personajes que fueron asignados, y aún nombrados, como oficiales o jefes, (participando en esos bandos cuando fue necesario organizar compañias de indígenas mixes que pudieran apoyar los movimientos militares), la etnia ha padecido dos fuertes cacicazgos, los de Daniel Martínez (un coronel habilitado) y Luis Rodríguez Jacob, que se desarrollaron durante las décadas de los 30s, 40s, 50s y 60s del Siglo XX. Fueron años en que ambos personajes se distinguieron, alternativamente, por su ambición y su crueldad, o por su 
trato selectivo y especial a habitantes de ciertos pueblos, siendo a la postre el primero asesinado por un pistolero del segundo, José Isabel Reyes, hecho que tuvo lugar en una calle de la ciudad de Oaxaca en las proximidades del Templo de las Nieves. De las relaciones de Luis Rodríguez Jacob con varios de los sucesivos gobernantes estatales, y particularmente con sus secretarios particulares (a quienes mantenía permanentemente sobornados, al grado de que Rodríguez conocía, vía telegráfica, el contenido de los Acuerdos antes de ser firmados), derivó la creación del Distrito Mixe en un trámite que se desarrolló entre los años de 1936 y 1939 a iniciativa del entonces gobernador, el Coronel Constantino Chapital. Poco después la zona fue erigida como vicariato apostólico, basado en San Juan Juquila y recientemente se incorporó la acción política de varios partidos.

ACCESOS. Loa accesos a la zona mixe, independientemente de la vía aérea, consisten en algunos caminos pavimentados y bastantes de terracería revestida, (ahora casi siempre transitables todo el año), de los cuales el principal es el troncal que da principio en Mitla y termina entroncando a la altura de Sochiapa con la carretera Palomares-Tuxtepec, en el Distrito de Choapan, Algunos caminos de acceso a poblaciones de la región alta también presentan esta característica, y ya solo una parte de la región mixe está comunicada solamente por veredas, brechas o por caminos transitables solo en secas. La cabecera distrital: Santiago Zacatepec, se encuentra al final de una desviación que parte de la carretera que une Mitla con Choapan. Además, cuentan con caminos las poblaciones de Santa María Tlahuitoltepec, Asunción Cacalotepec, Santa María Tepantlali, San Juan Juquila Mixes, San Pedro Ocotepec, San Lucas Camotlán, San Juan Ozolotepec, Totontepec Villa de Morelos y San Pedro y San Pablo Ayutla, población en que se construyó el Centro Coordinador del Instituto Nacional Indigenista (hoy Consejo Nacional de los Pueblos Indígenas). Se documenta que cuando se intentó introducir el teléfono, pistoleros de uno de los caciques recogieron y robaron los alambres y muchos postes. Hasta hace poco tiempo, ese servicio, ya consolidado, funcionó con normalidad.

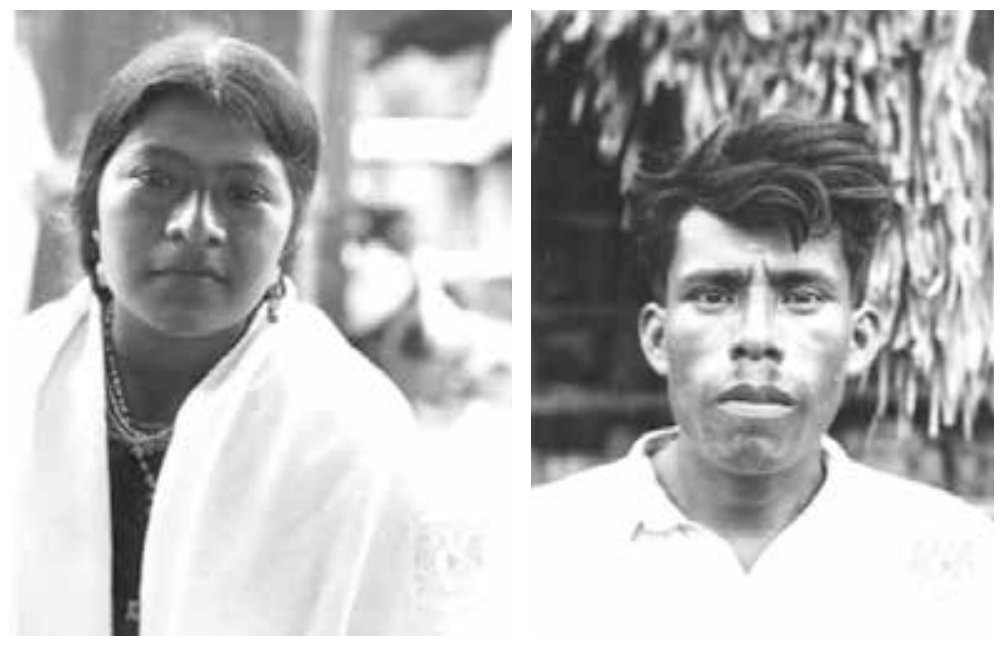

Mujer y hombre mixes. (Fotos: IIS-UNAM). 
DEMOGRAFÍA. En el año 1982 existían 90000 personas aparentemente constituyendo la etnia mixe en el Estado. En el 2000 se registraron 168 935, con 81952 hombres y 86952 mujeres, y en el 2010 se registran más de 350 000. Aproximadamente el 30\% (105 000) habla el idioma, aunque población emigrada lo está perdiendo.

VIVIENDA. Entre los Mixes existieron dos tipos de casa diferenciados por las características climáticas. Las paredes en la zona alta solían ser de adobe, madera o zacate, con techos de cuatro aguas, zacate o tejamanil. En las zonas bajas, las chozas fueron de zacate y madera. La sustentación de todos los tipos se hacía con horcones y vigas. Aún ahora se usa poco la teja porque la precipitación pluvial la satura y la hace permeable, pero muchas casas tienen un pórtico, y suele haber temazcales, a veces dentro y otras fuera. Viven en promiscuidad con animales domésticos y la familia duerme alrededor de la lumbre en el suelo, aunque quienes cuentan con mayores recursos en ocasiones usan camas. En las áreas frías colocan fogones auxiliares para aumentar el calor. Aunque con la comunicación se han introducido materiales industrializados tales como las láminas de asbesto y de metal, esos materiales no han resultado ser mejores que los tradicionales debido a su poca calidad térmica. El menaje de casa comprendía, generalmente, chalupas para conservar alimentos, camas de varas o cañas adosadas a las paredes, sillas y mesa. En algunas casas accedían al "desván" mediante un tronco colocado vertical con cortes biselados, a manera de escalones.

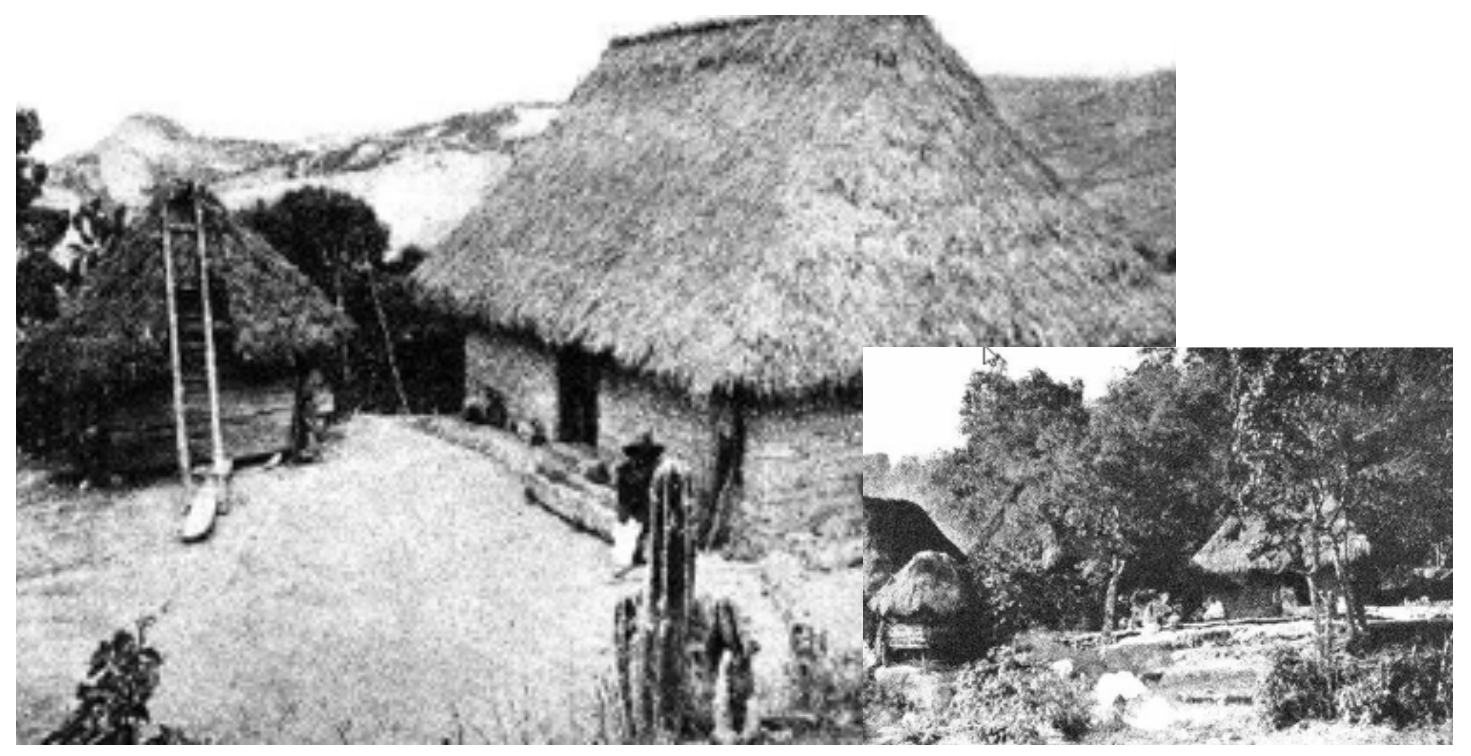

Casas y trojes mixes en 1906. (Fotos: Frederick Starr).

LENGUA. De origen mayense puesto que pertenece al grupo Mixe Popoloca. Aparentemente está subdividido en 6 variantes dialectales, aunque la escasez de datos impide saber si hay alguna más. Estas variantes son: La de Comotlán, la del sur de Coatlán, la del este de Juquila, la occidental de Tlahuitoltepec, la de Totontepec y la de Cotzocón. 

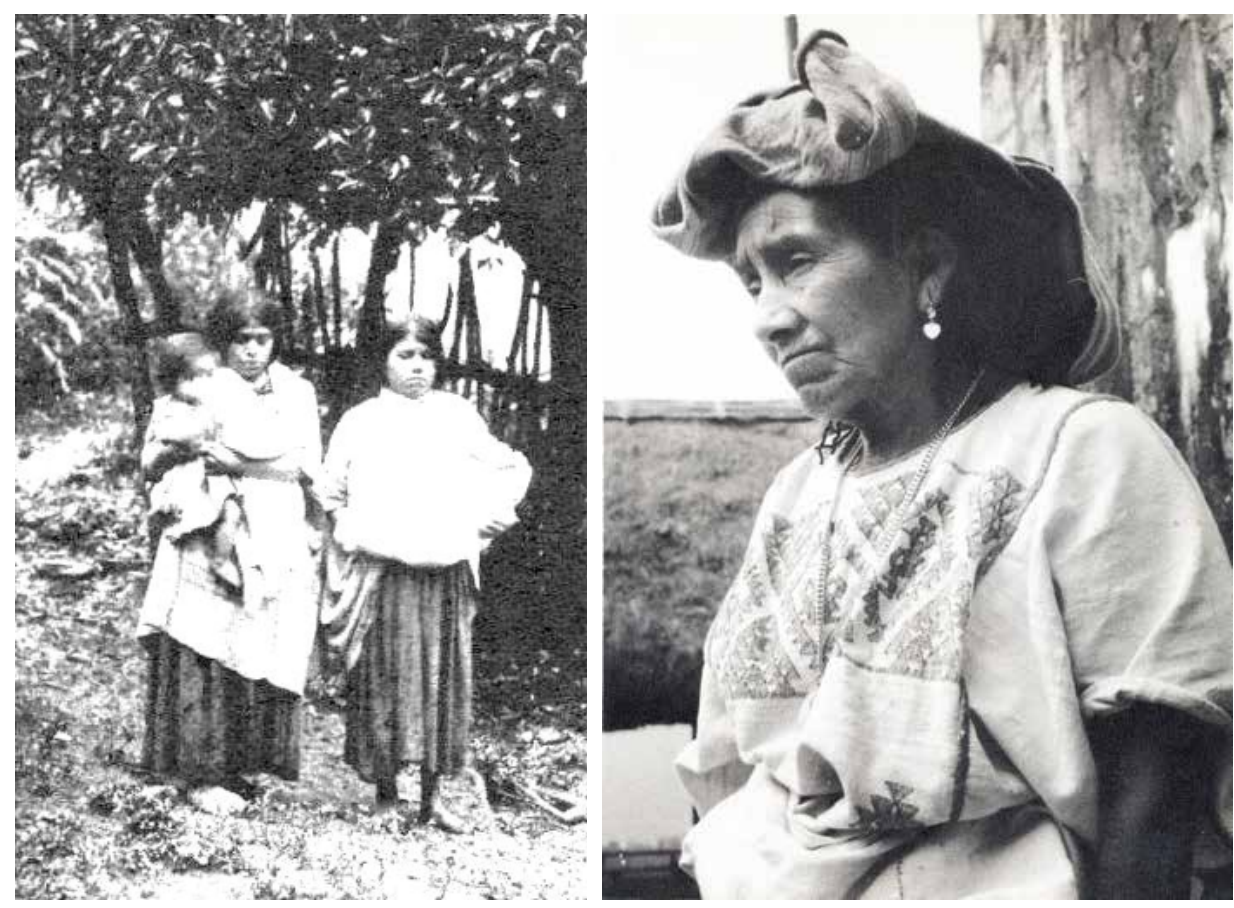

Mujeres y anciana mixes. (Fotos: Frederick Starr 1906 y Mtro: Roberto Weitlaner).

INDUMENTARIA. La indumentaria Mixe ha sufrido muchos cambios como producto del proceso de aculturación que ha enfrentado el grupo. En parte, la escasez de algodón ha ocasionado parte de estos cambios, debido a que ya no se cultiva. Son muy pocos los pueblos que conservan sus trajes tradicionales y actualmente solo se usan en ciertas ceremonias. Ello ocurre en Tamazulapan, Tlahuitoltepec, Tepuxtepec, Mixistlán, y Quetzaltepec.
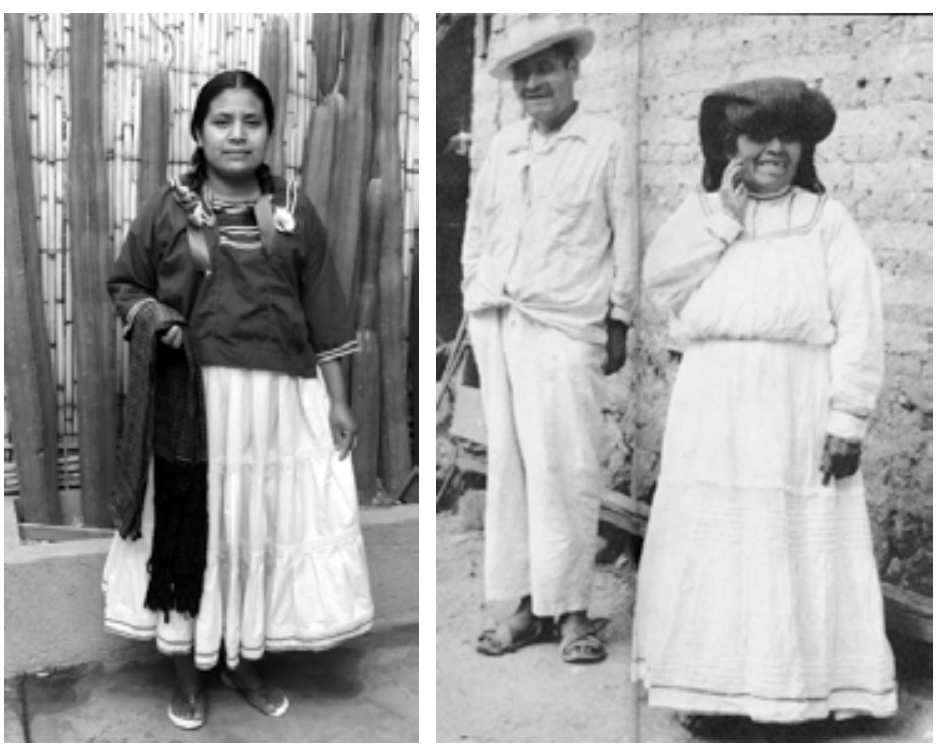

Jóven y Matrimonio Mixe. (Fotos: Srita. Leticia Marcial Domínguez originaria de Sto. Domingo Tepuxtepec y Mtro: Roberto Weitlaner). 
ECONOMÍA. La economía se encuentra enmarcada dentro de la organización social, política y religiosa. Como las de todas las etnias del País no se debe analizar solo en términos costo-beneficio, ya que las comunidades indígenas mantienen procesos de reproducción, defensa y adaptación a las condiciones económicas nacionales. En las actividades económicas del grupo se hallan reflejadas sus características propias, tales como el uso de una lengua y el conjunto de valores, tradiciones y costumbres que forman una red permanente de relaciones familiares, económicas y religiosas y en ocasiones biológico-raciales o intergrupales reales o supuestos. Como en todas las zonas deprimidas del estado, la explotación del medio ambiente entre los mixes los ha llevado a una extrema pobreza no solo porque el grupo pretende satisfacer directamente las necesidades básicas de la reproducción biológica y social, sino porque en algunos casos tienen que destinar parte de su producción o excedentes de la misma para adquirir en el mercado otros bienes que no se producen en la comunidad, apareciendo entonces los desiguales sistemas de intercambio y comercialización. Como con frecuencia los recursos no alcanzan, la población masculina se ve impedida a salir del territorio a vender su fuerza de trabajo.
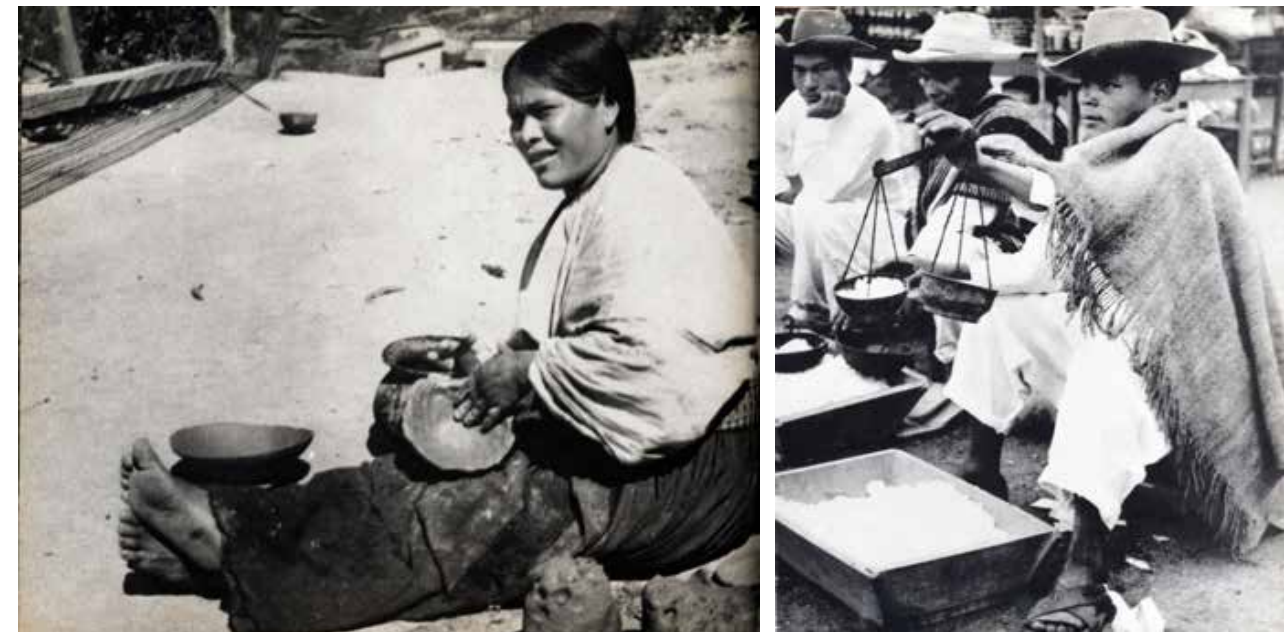

Ceramista y vendedores de sal mixes. (Fotos: Mtro. Roberto Weitlaner).

Entre los mixes el producto comercial más cultivado es el café. Este fruto tiene como problema principal su sanidad, su limitado período productivo y su terriblemente difícil comercialización, ya que no existe la infraestructura caminera ni de transporte adecuada que permita mejores precios fuera de las comunidades, debido a que los recursos del Instituto Mexicano del Café, cuando existía, fueron insuficientes y no pudo cubrir toda el área.

En el área mixe también se explotan algunos conjuntos de colmenas y algunos sembrados de maguey, así como la agricultura de subsistencia basada en el maíz, el fríjol, el chile y la calabaza y practicada mediante el sistema de roza tradicional, que consiste en el desmonte y quema de una porción de bosque, monte o selva, en la que se siembran esos productos en el intento, no siempre efectivo por depender del temporal, de satisfacer las necesidades alimenticias anuales de una familia. 

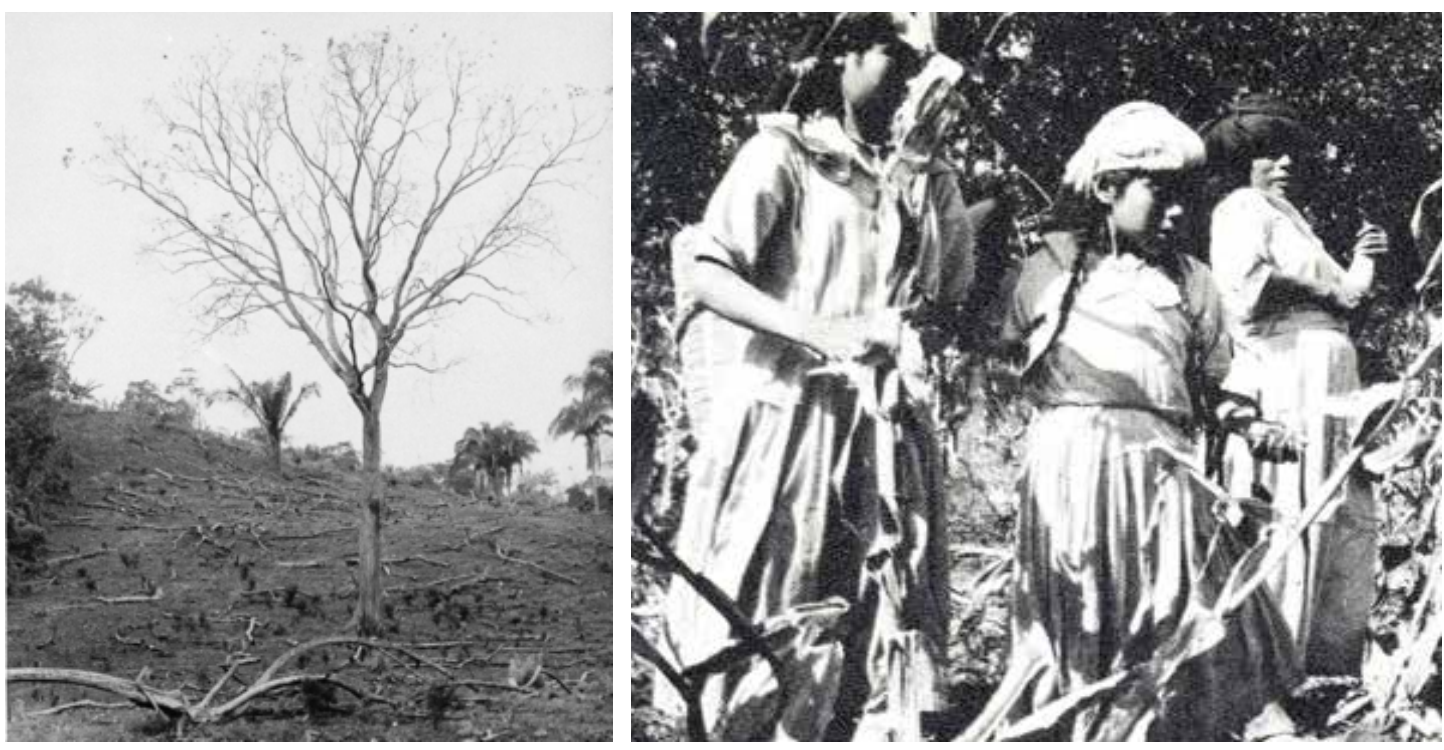

Campo después de roza y mujeres mixes cosechando. (Fotos: Mtro. Roberto Weitlaner).

Por otra parte, en a región mixe, gran parte de la explotación de los bosques se realiza de manera irracional y completamente a espaldas de las comunidades indígenas. Estas acciones implican un grave problema para el país, ya que es una de las regiones de mayor precipitación pluvial, donde la pérdida de suelos y el azolvamiento de ríos. crearán a la larga situaciones problemáticas de importancia capital.

ARTESANIAS. Existe en poco volumen trabajo artesanal en textiles y en cerámica, la cual conserva algunas formas de cerámica prehispánica. Tal ocurre en Yacoche. Los productos son vendidos en los mercados locales principalmente los de Cotzocón. Izcuintepec. Totontepec, San Juan Mazatlán y Santiago Zacatepec. Los textiles elaborados en Tlahuitoltepec y Tamazulapan se realizan con hilos de hilaza. Hay, además, carpintería en Tlahuitoltepec, redes en Tepuxtepec, herrería en Cacalotepec, curtiduría y talabartería en San Juan Juquila, cestería de bejuco en Zacatepec y tenates en Alacrancito. Como un intento de proyectar su cerámica y sus artesanías ya existe una pequeña tienda en El Tule, en Valles Centrales.

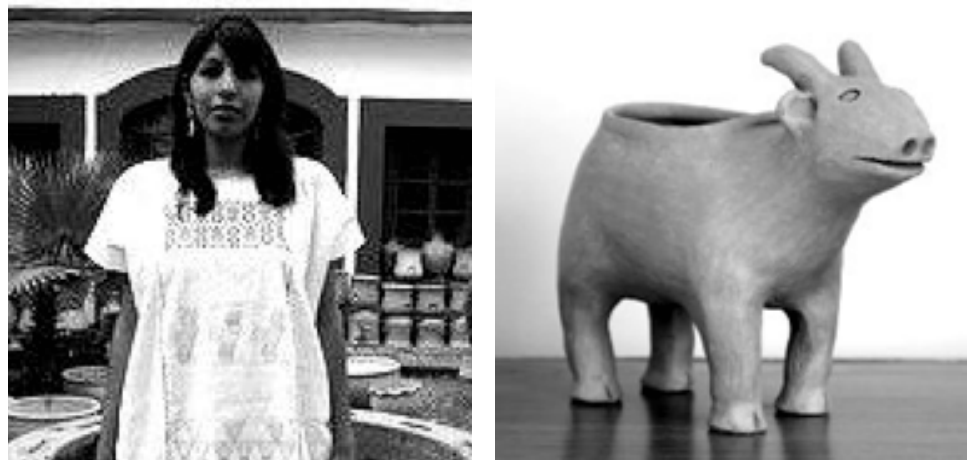

Huipil de San Juan Cotzocon y cerámica mixe. (Fotos: Instituto Oaxaqueño de las Artesanías y “Artesanos Mixes”). 
GANADERÍA. Aunque existe ganado vacuno en la región, en las zonas altas predomina el ganado menor, y en las bajas una ganadería extensiva sumamente raquítica. Los únicos ranchos importantes de la zona de San Juan Mazatlán pertenecen a la población ladina o a personas de otro origen que han ido adquiriendo tierras durante los últimos cuarenta años. Algunos de ellos ganaderos radicados en Matías Romero o la Colonia Istmeña.

CAZA Y PESCA. Aunque los ecosistemas de la región han sostenido una riquísima fauna silvestre, un manejo irracional y los desmontes indiscriminados, han extinguido o puesto al borde de la extinción muchas especies. Para la población indígena, la fauna silvestre siempre constituyó un recurso complementario en su alimentación. Lo realmente grave es que la destrucción del bosque, el monte o la selva, implica dejar al descubierto especies que entonces pueden ser cazadas con linterna o con faro buscador en cantidades que no permiten una recuperación natural, tal es el caso de los monos, los venados, los pecaríes el tepezcuintle, el jaguar, el ocelote, el puma y el tigrillo.

En toda el área mixe los recursos acuiferos han permitido siempre una vida animal también excepcionalmente rica. Algunas de las comunidades indígenas pueden así tener acceso a la captura de más de 20 especies de peces y crustáceos que abundan en la región. Lamentablemente, las necesidades han obligado a introducir prácticas inadecuadas de obtención. Tales como el empleo de dinamita o bombas de pólvora, las que permiten el capturar gran cantidad de animales, pero matan a la totalidad de los que pueblan las sección correspondiente de la corriente, los que, por irse al fondo, no pueden ser aprovechados, puesto que flotan cuando ya están en descomposición.

MERCADOS. Los mercados en la región presentan, desde la compra masiva de bienes de artículos industrializados, hasta el trueque de artículos entre pequeños productores. Estos mercados presentan formas de intercambio desigual, con la extracción del producto de su trabajo o de sus recursos por parte de la sociedad urbana-industrial, que es la máxima beneficiaria de ellos en el país. Casi todas las poblaciones que son cabeceras de municipios tienen mercado un día de la semana, el cual es rotativo. Quetzaltepec y Juquila tienen tianguis los domingos. Cacalotepec y Tlahuitoltepec a media semana.

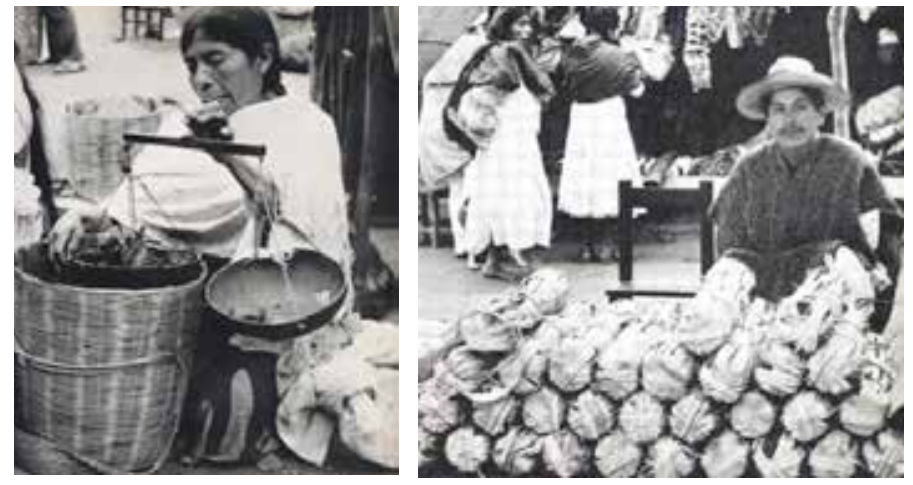

Mercado mixe. Pesando chile y vendiendo piloncillo. (Fotos: Mtro. Roberto Weitlaner). 
ORGANIZACIÓN SOCIAL. La sociedad Mixe es patrilineal, patrilocal, monogámica. Su unidad es la familia, que está constituida por los padres y los hijos solteros, y está apoyada por la familia extensa que se constituye con la agregación de los parientes consanguíneos y por afinidad. En la selección de los esposos los padres tienen gran importancia, utilizándose los servicios de un intermediario que recibe el nombre de Chagola y que es quien conviene los términos del matrimonio con los padres de la novia, entregando a continuación cigarrillos y aguardiente. En ocasiones la aproximación entre los jóvenes se practica mediante la substitución de un cántaro que el muchacho lleva al lugar donde la muchacha va por agua; si la muchacha lo acepta, recoge el cántaro nuevo y el día siguiente lo lleva adornado con flores. En la celebración de la boda se observa con claridad la importancia de la solidaridad y de la reciprocidad dentro del grupo, ya que parientes, amigos y vecinos ayudan con trabajo, dinero o bienes; y lo mismo durante la construcción de la casa para el nuevo matrimonio, la cual tendrá relativa proximidad con la casa de los padres del novio.
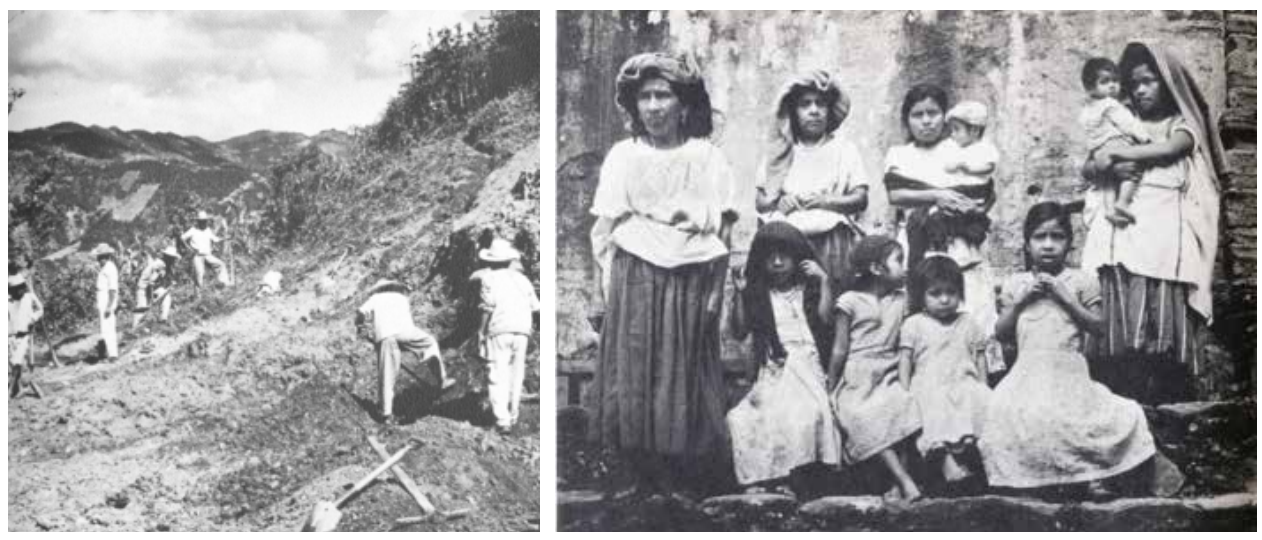

Abriendo un camino y tres generaciones de mujeres mixes. (Fotos: Mtro. Roberto Weitlaner).

En la sociedad Mixe el compadrazgo actúa como integrador y la relación de compadrazgo es tan importante como el parentesco. Un barrio está constituido por un conjunto de familias, y todas ellas reconocen su identidad con ese pequeño sector de la comunidad. Por tanto, ésta consiste en la agrupación de varios barrios. De este modo, entre los mixes es más fuerte el sentido de la comunidad que el de la etnia, y esto se refleja en las diferencias entre las poblaciones; algunas de ellas generadas durante los cacicazgos.

GOBIERNO. Al lado del aparto jurídico-político constitucional, entre los mixes coexisten formas tradicionales de Gobierno Indígena y un derecho de costumbres. Estas formas tradicionales han permitido la estabilidad y el desarrollo de la etnia mixe. En el sistema de gobierno, los poderes civiles y religiosos guardan estrecha relación, de tal manera que los cargos civiles y religiosos se ordenan en una jerarquía indistinta. Para acceder a los puestos de mayor jerarquía, es preciso primero ocupar los puestos menores. Los hombres participan por turnos en las responsabilidades de los cargos, sin otra retribución que el prestigio aportado ante la comunidad, si bien algunos individuos nunca pueden llegar a 
los puestos más altos. Dentro del grupo existe un sistema de grado de edad, y cada grado constituye un grupo bien definido con distintas funciones en la vida política y ceremonial. Sin embargo, la integración entre las actividades políticas y religiosas tiende a desaparecer a medida que avanza el proceso de secularización en los asuntos del gobierno, lo cual revela el índice de aculturación que está teniendo lugar en la región. En las comunidades pequeñas los agentes municipales y de policía son elegidos mediante asambleas y constituyen la máxima autoridad. Comienza a existir en la región mixe una actividad política partidaria, con mayor presencia del PRI y el PRD. Cada partido tiene su sede en la cabecera distrital. Santiago Zacatepec.
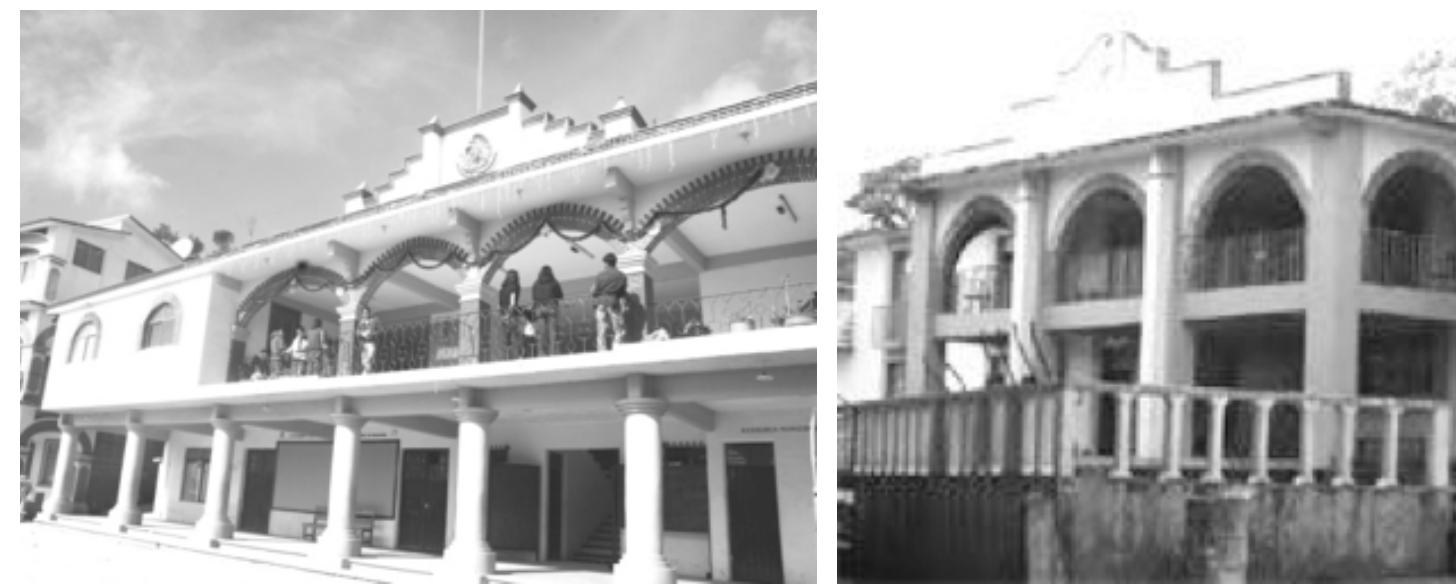

Palacios municipales de Tlahuitoltepec y Zacatepec Mixes.

(Fotos: Ayuntamientos respectivos).

FESTIVIDADES. Los mixes llevan la música por dentro, son uno de los grupos étnicos del estado de Oaxaca con mayor interés musical, y lo manifiestan con la extraordinaria dedicación hacia el estudio de la música, que les permite tener un Conservatorio y una Escuela de Música en dos de sus poblaciones y prácticamente maestros y una o más bandas en cada una de las cabeceras municipales. El calendario ritual prehispánico y el calendario agrícola, que aún persiste, fue substituido en a época colonial por el calendario católico, de tal forma que en la actualidad la mayoría de las festividades ligadas al ciclo agrícola, o al calendario ritual prehispánico, han sido interpretadas en términos del santoral y el ritual católico, tales como el Carnaval, la Semana Santa, el Día de Muertos, las Festividades del Año Nuevo, etc. Además, en cada pueblo se celebra la Fiesta del Santo Patrón y en buena parte de ellas persisten vestigios de creencias prehispánicas que se manifiestan en rezos, danzas y ritos. Entre los mixes existen también formas de reciprocidad manifestadas por la cooperación otorgada por unas comunidades con respecto a otras; éstas son las gozonas, que consisten en invitaciones de pueblo a pueblo para asistir a la fiesta patronal.

El pueblo invitado debe corresponder con una invitación similar. La mayor parte de las danzas presentan origen español y entre ellas se encuentran las de Negritos, Moros y Cristianos y las de San José. 

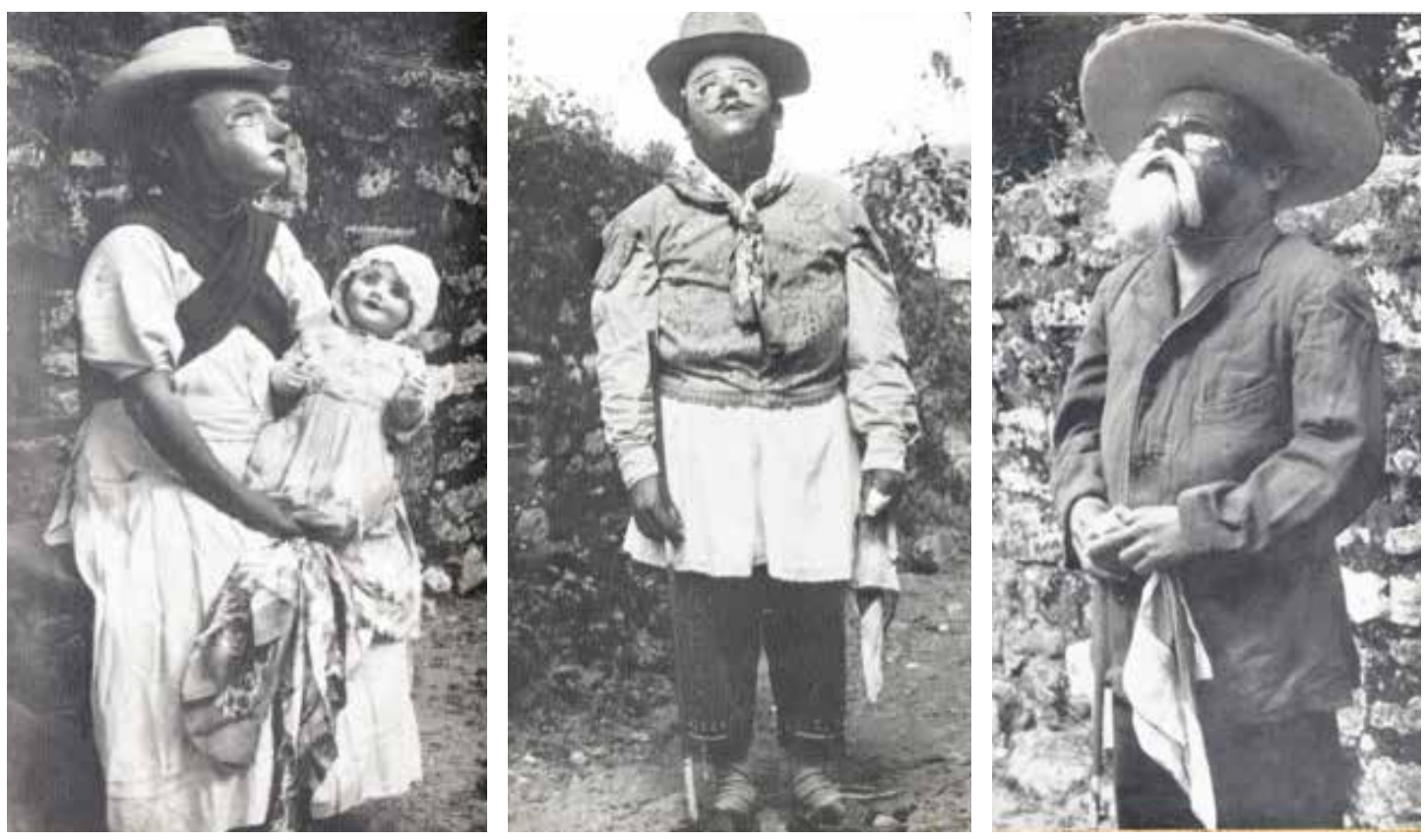

Danzantes mixes de la Maringuilla. (Fotos: Mtro. Roberto Weitlaner).
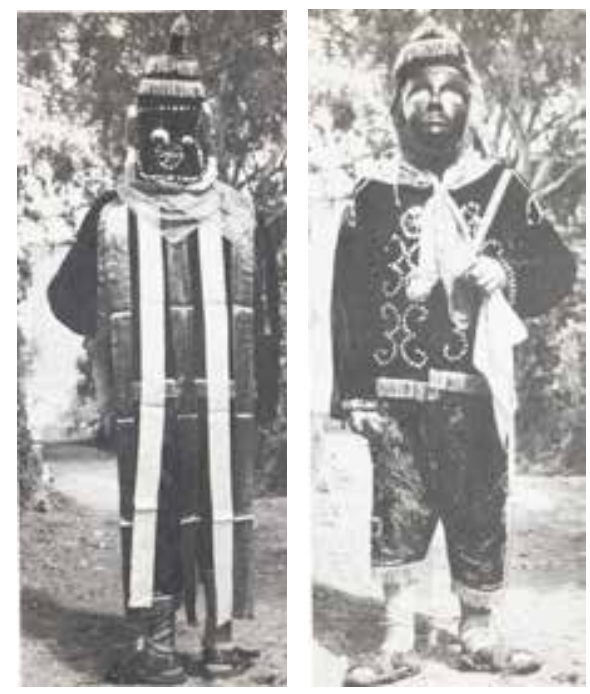

Danzantes de los Negritos. (Fotos: Mtro. Roberto Weitlaner).

Entre los instrumentos musicales autóctonos figuran varios tipos de tambor y de sonaja, así como chirimías, pitos de carrizo y varas ahuecadas, y también algunas flautas de barro. Las bandas de la región están perfectamente dotadas de oboes, clarinetes, saxofones, tubas, trombones, cornos, trompetas y flautas de diferentes tonalidades y diferentes tipos. Hay también gran número de unidades de percusión compuestas de tambores, bombos, tamboriles o tarolas y platillos. En el Mixe Bajo hay conjuntos juveniles que conservan la tradición del son, en las variantes que caracterizan su región, y que es diferente del jarocho. 
ORGANIZACIÓN RELIGIOSA. Entre los mixes la organización religiosa presenta la institución de la mayordomía apoyada por un número variable de fiscales, acólitos y sacristanes. La religión mayoritaria es la católica, con aproximadamente unos 80000 fieles, pero durante los últimos 30 años algunos grupos protestantes se han infiltrado en las comunidades, habiendo ya presbiterianos, congregacionales, adventistas del séptimo día y testigos de jehová. Esto ha planeado divisiones en varias poblaciones, y como consecuencia de ellas, tensiones intergrupales súmamente lamentables porque han redundado en falta de cohesión del grupo. Tradicionalmente se ha creído en seres espirituales, tales como los "Dueños del Maíz", los animales, los huracanes y la lluvia, por lo que se aún se realizan rituales en cuevas. Subsiste la creencia en nahuales y en la región persiste el calendario ritual prehispánico (tonalpohualli) que permite establecer los días nefastos y los favorables. Hay especialistas que determinan fechas en que es favorable establecer rituales. Además, también subsiste el Tonalámatl.
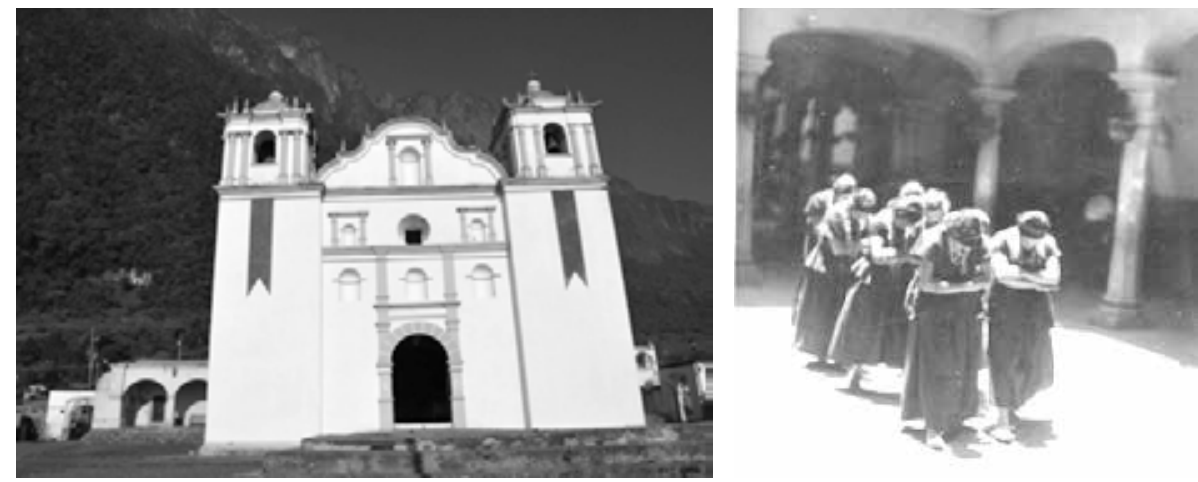

Iglesia de Sta. María Alotepec y Procesión Ritual. (Fotos: Jonatan Lopez e IIS-UNAM).

MEDICINA Y MAGIA. Como reminiscencias prehispánicas y coloniales, se conservan algunas actividades de carácter mágico practicadas por brujos y brujas que actúan de curanderos en base a muy importantes conocimientos de herbolaria. Asimismo, se usan hongos alucinógenos con propósitos adivinatorios y terapéuticos

Muchas veces las brujas se declaran incompetentes para curar, porque los días jueves y viernes suelen ser fatídicos, en los que la medicina tradicional tiene poco poder. En la región existen pocos médicos y unos cuantos pasantes de medicina comisionados por los programas del Instituto mexicano del Seguro Social, que de este modo realizan su servicio social. Se documentan Centros de Salud de la Secretaría de Salubridad y Asistencia en Santiago Zacatepec, Tamazulapan, Tlahuitoltepec y Juquila.

EDUCACIÓN. Existen en casi todas las poblaciones de la Región Mixe escuelas de diferentes niveles, desde los jardines de niños y la primaria hasta el nivel medio inferior y normal. En Santiago Zacatepec, Tlahuitoltepec y Tamazulapan hay escuelas de Música, y en Tlahuitoltepec un Conservatorio y un Centro de Bachillerato Agropecuario. Sin embargo, aún es muy bajo el nivel promedio de escolaridad. Muchos jóvenes emigran una vez 
terminada su secundaria y muy pocos logran acceder a niveles superiores. Algunos están en las Universidades de Tuxtepec y Loma Bonita.

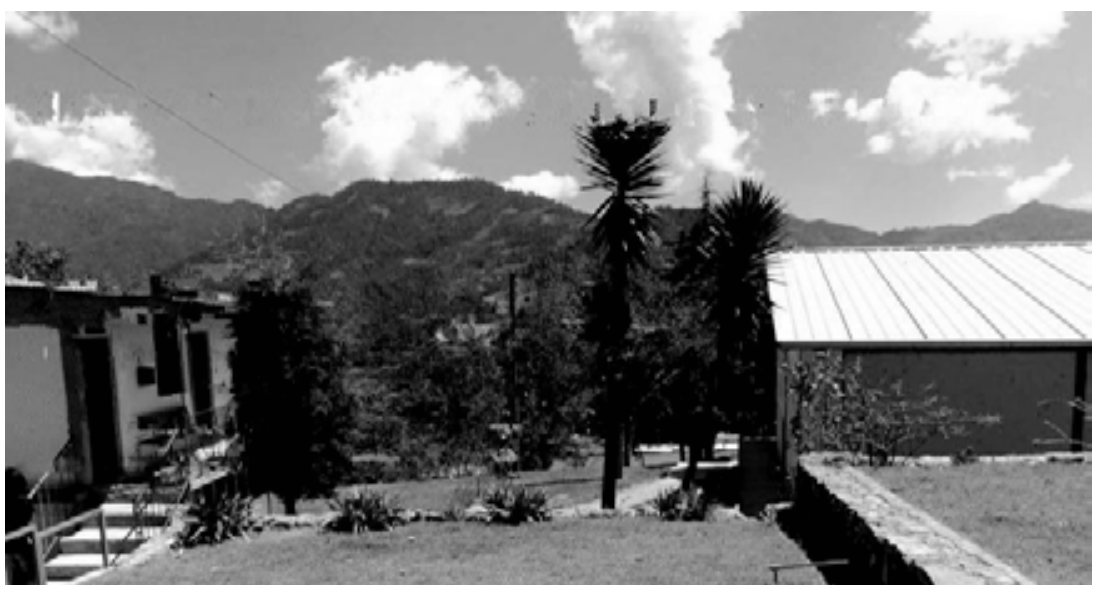

Instalaciones del CECAM, Tlahuitoltepec. (Foto: CECAM).

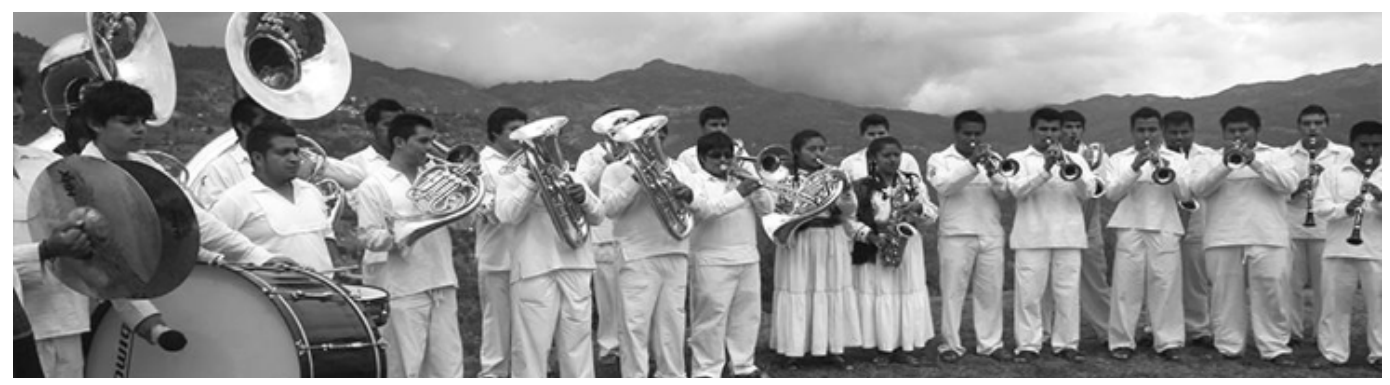

Integrantes del Conservatorio Mixe. (Foto: CECAM).

BIBLIOGRAFÍA

Acevedo Conde, Mará Luisa. 2008 “Los Mixes”. En: Revista A CONTRAGOLPE. № 15. Carteles Editores. Oaxaca, Oax. 2008.

Barabas, Alicia Mabel. Bartolomé, Miguel Angel. 1984 "El Rey Cong Hoy. Tradición Mesiánica y "Privación Social entre los Mixes de Oaxaca”. INVESTIGACIONES SOCIALES № 1. Instituto Nacional de Antropología e Historia. México, D F. 1984.

Basauri, Carlos. 1940 “Los Mixes”. Reed. 1990 En: LA POLACION INDIGENA DE MEXICO. Tomo III Instituto Nacional Indigenista. SEP. México, D F. 1990

Beals, Ralph Leon. 1945 "Ethnology of the Western Mixe”. En: UNIVERSITY OF CALIFORNIA PUBLICATIONS IN AMERICAN ARCHAEOLOGY AND ETHNOLOGY. Vol 42. № 1. University of California Press. Berkeley \&t Los Ángeles. California. U S A. 1945. Chance, John 1989 THE CONQUEST OF THE SIERRA. SPANIARDS AND INDIANS IN COLONIAL OAXACA. University of Oklahoma Press. Norman \& London 1989. 
Foster, George M. 1969 “The Mixe-Zoque-Popoluca”. En: HANDBOOK OF MIDDLE AMERICAN INDIANS. Vol 7. Part 1. University of Texas Press. Austin \&t London. 1969.

Kraemer Bayer, Gabriela. 2003 AUTONOMIA INDIGENA. REGION MIXE. RELACIONES DE PODER Y CULTURA POLITICA. Universidad Autónoma de Chapingo. Plaza y Valdés. Editores. México, D F. 2003.

Kuroda, Etsuko. Van Zantwijk. 1993 BAJO EL ZEMPOALTEPETL. LA SOCIEDAD MIXE DE LAS TIERRAS ALTAS Y SUS RITUALES. CIESAS. Instituto Oaxaqueño de las Culturas. Oaxaca, Oax. 1993.

Laviada, Iñigo. 1978 LOS CACIQUES DE LA SIERRA. Editorial Jus. México, D F. 1978.

Miller, Walter. 1956 CUENTOS MIXES. Biblioteca del Folklore Indígena. № 2. Instituto Nacional Indigenista. México, D F. 1956.

Nahmad Sitton, Salomón. 1965 LOS MIXES, ESTUDIO SOCIAL Y CULTURAL DE LA REGION DEL ZEMPOALTEPETL Y DEL ISTMO DE TEHUANTEPEC. Memorias del INI. Instituto Nacional Indigenista. México, D F. 1965. 1994 FUENTES ETNOLOGICAS PARA EL ESTUDIO DE LOS PUEBLOS AYUUK (MIXES) DE OAXACA. CIESAS. Instituto Oaxaqueño de las Culturas. Oaxaca, Oax. 1994.

Regino Montes, Adelfo. 2003 “El Pueblo Mixe. Una Mirada sobre el Pueblo Ayuuk”. Ed: SERVICIOS DEL PUEBLO MIXE. Oaxaca, Oax. 2003.

Rodríguez E, Mauro. Ballesteros, R. L. 1974 LA CULTURA MIXE. SIMBOLOGÍA DE UN HUMANISMO. Editorial Jus. México, D F. 1974.

Schmieder, Oscar. 1930 THE SETTLEMENTS OF THE ZAPOTEC AND MIXE INDIANS. STATE OF OAXACA, MEXICO. University of California Press. Berkeley, Calif. U S A.

Torres Cisneros, Gustavo Adolfo. 2004 MIXES. Consejo Nacional para el Desarrollo de los Pueblos Indígenas de México. México, D F. 2004. 



\section{HUAVES}

Autodenominación: mero ikool, mero ikoots, ombeyajts.

Sinónimo en su lengua: ombeayaran, mareño.

Significado: Los que viven en extrema humedad.

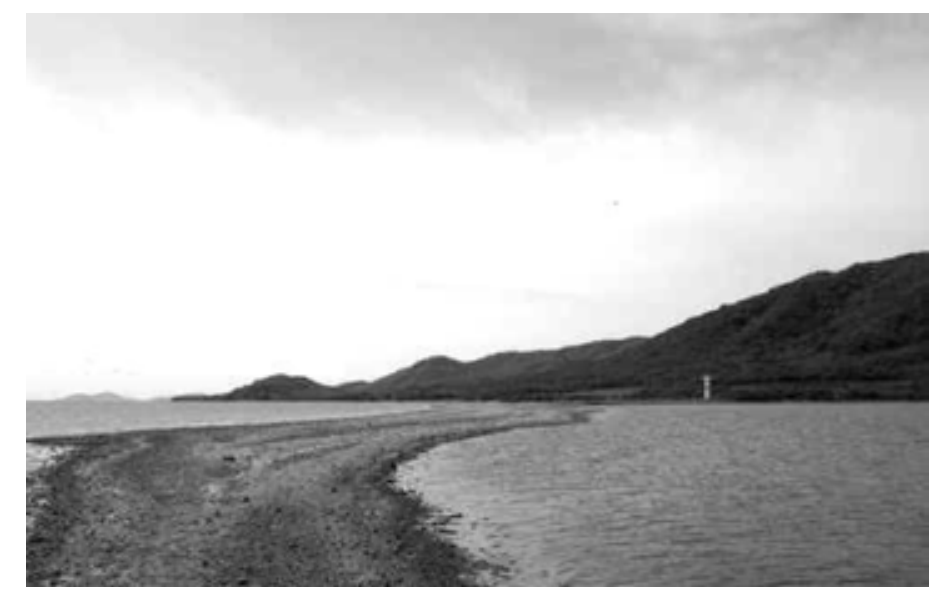

Playa de San Dionisio del Mar. (Foto: Fernando Estudillo).

\section{GRUPO HUAVE}

UBICACIÓN GEOGRÁFICA. Este grupo tiene sus asentamientos en las secciones terrestres que rodean las lagunas Superior e Inferior ubicadas en a porción costera del Distrito de Juchitán y principalmente la península arenosa que divide la Laguna Inferior del Golfo de Tehuantepec. Su posición geográfica los inscribe entre los paralelos $16^{\circ} 10^{\prime}$ y $16^{\circ} 35^{\prime}$ de

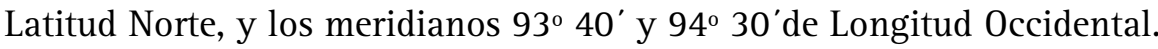

El territorio huave consta de tres zonas bien diferenciadas; una de monte bajo con algo de madera y propia para la caza, otro de sabana apta para el pastoreo, y otra más pantanosa, poblada de manglares y abundantes salinas.

El terreno es poco accidentado, considerando en su mayoría de terrenos planos de tierra arenosa poco fértil, en los que predominan chaparrales bajos de selva baja caducifolia, y pastizales naturales de zacate grama y rabo de zorra en los que se ha inducido, desde tiempo atrás, zacate privilegio o zacatón. Prácticamente, exceptuando las islas ubicadas en las lagunas, no existen elevaciones. Las aportaciones de agua dulce de la región están dadas por la desembocadura de los ríos Tehuantepec. De los Perros, de San Vicente. De Santo Domingo, el Cazadero y el Niltepec. El clima es cálido semi-seco, dentro de un 
contexto subhúmedo con lluvias en verano, y la precipitación pluvial promedio anual es ligeramente superior a los 500 milímetros, la cual es el límite de aportación de agua para el desarrollo de los maíces de ciclo corto (zapalotes), lo que explica la precaria agricultura regional. La temperatura media anual es de aproximadamente $28^{\circ} \mathrm{C}$, y el régimen de vientos, los cuales corren de norte a sur entre los meses de noviembre a mayo, y de sureste a noroeste de junio a octubre, actúa decisivamente en el proceso de sequedad de la región (debido a su alta velocidad), la cual se incrementó como consecuencia del desmonte, primero de miles de hectáreas situadas al occidente de la carretera transístmica y después, principalmente de las selvas medias y bajas caducifolias, de las 56000 hectáreas del distrito de riego de Juchitán, más las que rodean al ingenio de Santo Domingo. Estas características regionales han determinado que gradualmente, desde hace varios siglos, el pueblo huave sea una comunidad de pescadores con un entorno de sabana prácticamente seco, lo que se agudizó con los desmontes recientes.
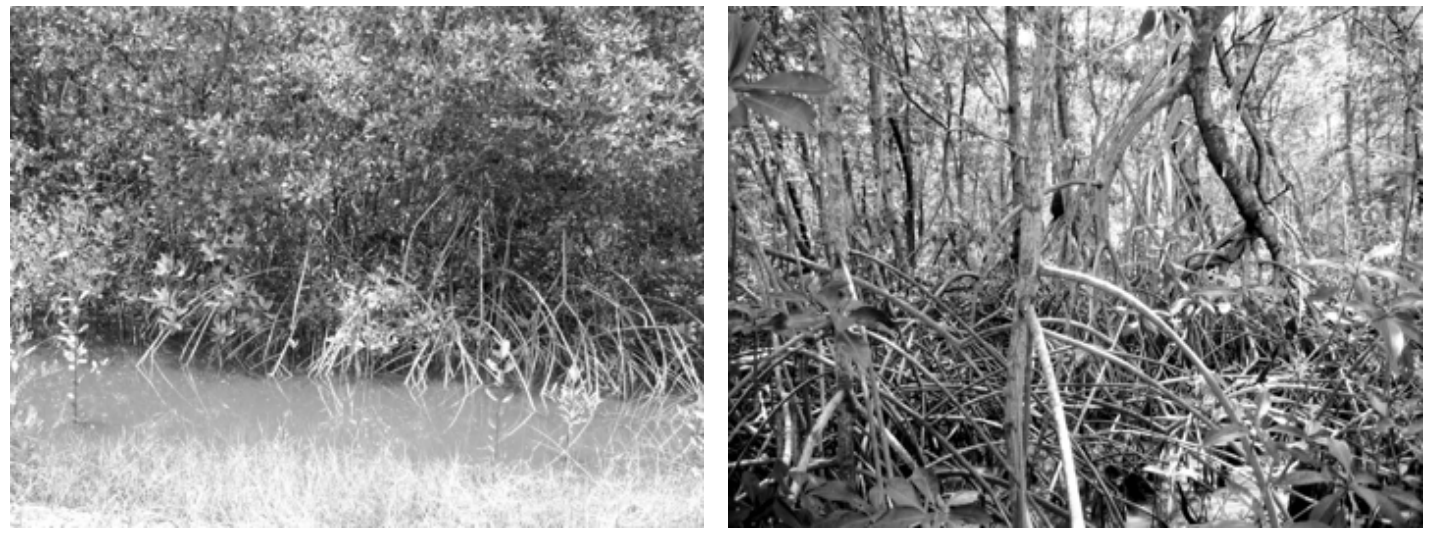

Manglares huaves. (Fotos: Dirección de turismo estatal.).
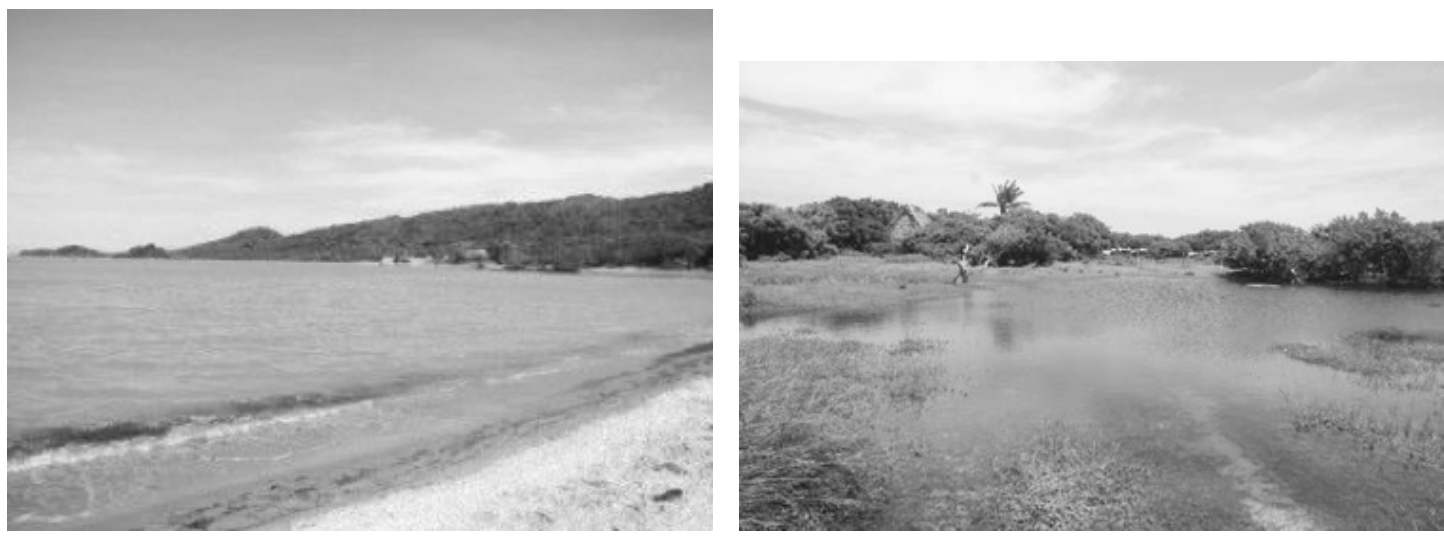

Costa de San Dionisio e Isla de Pueblo Viejo. (Fotos: Direción de turismo estatal).

ANTECEDENTES ARQUEOLÓGICOS E HISTÓRICOS. Siendo una etnia cuya lengua pertenece al grupo Otomangue, tronco Huave, tuvieron un desarrollo histórico diferente del de sus 
vecinos Zapotecas y Zoques. Algunas crónicas (y entre ellas la del Padre Burgoa) los hacen proceder de Sudamérica a través de Nicaragua, sin que hasta el momento esto esté arqueológicamente documentado, como tampoco lo está que haya habido enfrentamientos con los mixes, o que estos les cedieron el área, aunque ello funciona como hipótesis. El área huave presenta bastante antigüedad, no precisada, en la ocupación humana, lo que revelan concheros, muy posiblemente precerámicos, ubicados a lo largo de las playas interiores y exteriores, vistos por quien esto escribe en 1975 en prospección aérea en helicóptero. Sin embargo, de acuerdo a los estudios del arqueólogo Enrique Méndez Martínez, primer explorador-excavador del área, el territorio que rodea las lagunas muestra evidencias de una ocupación prehispánica correspondiente al primer milenio anterior a Cristo y a las etapas subsecuentes, es decir, desde la etapa Media de las Aldeas hasta la etapa Militarista. Hubo una cerámica local y un utillaje que en algunos diseños todavía persiste, y en la zona se detectan influencias de los olmecas arqueológicos, los teotihuacanos, los mixtecos y una especial aproximación a un grupo de origen mayense, muy posiblemente los zoques, para, finalmente, y desde el Siglo XIV, haber una relación proximal con los zapotecos y con los chontales, con quienes se encontraron pescando. Está documentado que la cosmogonía del grupo, con especial énfasis en los dioses del agua, está relacionada con las estelas encontradas en un sitio arqueológico ubicado en la Costa de Chiapas, Cerro Bernal, lugar que tuvo especial relevancia como punto intermedio en la ruta costera de la sal y el cacao, de acuerdo a estudios del Arql. Carlos Navarrete Cáceres. Las crónicas se refieren a ellos como un pueblo pacífico pero en la época inmediatamente anterior a la conquista parecen haber sido tributarios de los zapotecas, primero y posteriormente de los aztecas, puesto que algunas fuentes mencionan las cargas de pescado y camarón salado que llegaban a Tenochtitlán procedentes del Istmo de Tehuantepec a través de Juchitán y Tehuantepec. Además, de esa dominación quedan vestigios, porque los asentamientos huaves recibieron, por ejemplo, los nombres en náhuatl de Huazontlán (El caso de San Mateo del Mar), Ocelotlán (Santa María del Mar) y Tepehuazontlán (San Dionisio del Mar).

A partir del siglo XVI las poblaciones Huaves fueron infiltradas por los frailes, inicialmente franciscanos, para proceder a la cristianización. En San Mateo, Santa María y San Dionisio del Mar hubo cierta resistencia, cosa que puede verse en las iglesias, que en su totalidad fueron construidas en los Siglos XVII y XVIII. La primera iglesia dominica fue erigida en San Francisco del Mar. El mal trato de los españoles provocó rebeliones durante los tres siglos de dominación, y debido a las condiciones topográficas (terrenos prácticamente llanos) y a la existencia de pastizales, se establecieron en la zona grandes haciendas de ganado mayor, principalmente pertenecientes a la orden dominica. En 1777, año de redacción de una Relación Geográfica, un cura de San Francisco del Mar, Juan Basilio, informaba de áreas despobladas o con muy poca población. Debido a sus transacciones, sus entregas comerciales y sus relaciones con los Zapotecos del Istmo, con quienes coexisten desde hace más de cinco siglos, algunos individuos huaves han visitado periódicamente comunidades tales como Juchitán y Unión Hidalgo, este hecho les debió haber permitido participar, o ser testigos, de algunos de los acontecimientos políticos que han tenido lugar 
en esa región. Enternecedora y muy bella fue la contestación de las autoridades huaves de San Mateo del Mar al oficio en que el Presidente Benito Pablo Juárez García advertía a todos los pueblos de México de la inminencia de la Intervención Francesa en 1861:

“Señor Presidente:

Pierda usted cuidado. Si los enemigos vienen y los divisamos, itomaremos nuestras canoas y los iremos a combatir!".

En 1899 el grupo fue visitado por el etnólogo Frederick Starr, quien lo documentó en una serie de históricas fotografías.

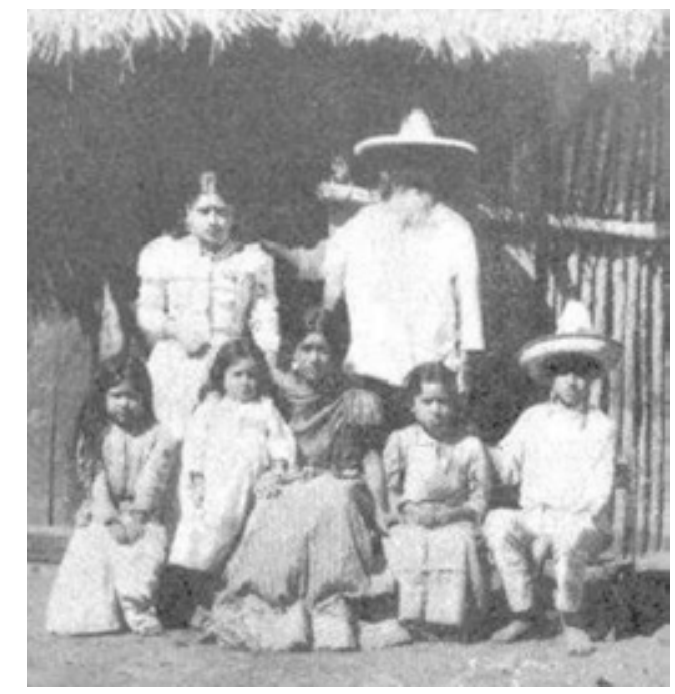

Huaves de san Mateo del Mar en 1899. (Foto: Frederick Starr).

Durante la Revolución Mexicana la participación activa de los huaves fue tan importante como la de las comunidades zapotecas. Muchos miembros de la étnia fueron agarrados de leva por el ejército federal porfirista y huertista cuando se encontraban en los mercados del ístmo. En la época, el acceso a sus poblaciones era fráncamente problemático, y sin embargo, posteriormente hubo soldados huaves, primero en las fuerzas que lidereó el líder juchiteco José Facundo Gómez, y más tarde en las fuerzas constitucionalistas, en las soberanas y en las obregonistas. Soldados huaves combatieon en el 13 Batallón, mayoritariamente juchiteco, que jefaturó el Gral. Heliodoro Charis Castro, enfrentando la rebelión delahuertista. Desde poco antes, es decir, fines del Siglo XIX, la indumentaria femenina zapoteca ha sido en alto grado adoptada por las mujeres del grupo. Posteriormente, cabe mencionar el trabajo del antropólogo Ítalo Signorini sobre la étnia y su realidad en los años 50 del siglo pasado.

ACCESOS. La península en que se ubican San Mateo y Santa María del Mar cuenta con una carretera de terracería transitable todo el año que une a Santa María con San Mateo y 
a San Mateo con Tehuantepec, a través de San Pablo Huilotepec. Ya existen pequeños poblados intermedios, surgidos en las invasiones recientes realizadas por mestizos zapotecos.

San Dionisio y San Francisco del Mar están unidos con la Carretera Panamericana mediante un camino de terracería que entronca con ésta a la altura de Puente Guamol. El antiguo San Dionisio del Mar se encuentra en una península, la de la bocana de Santa Teresa. Entre las diferentes comunidades huaves existe un tráfico canoero de bastante importancia, sujeto estacional y solamente a la fuerte intensidad de los vientos del norte, de manera que es posible llegar navegando a cualquiera de ellas.

IDIOMA. En el año 2000 la población huave ascendía a 16000 personas, de las cuales aproximadamente 14000 hablaban el idioma. Este es una lengua de Grupo Otomangue. Tronco Huave, que desde principios del siglo XX presenta variantes dialectales que la hacen ininteligible entre algunas poblaciones. En el censo del 2010 los pobladores huaves son poco más de 34000 y ya no todos hablan el idioma. Los hablantes son 13800.

VIVIENDA Las casas de este grupo son jacales rectangulares con estructura de horcones y paredes de madera, cañas de otate o palma con que tapan los intersticios. Los techos son de caballete con morillos atravesados y vigas. Generalmente están agrupados en un gran espacio rectangular techado y abierto a los cuatro vientos. Los conjuntos están circundados por bardas de cañas. Las casas son de forma cuadrangular, bien ventiladas y de una sola pieza, aunque a veces tienen un cuarto anexo que sirve de dormitorio.
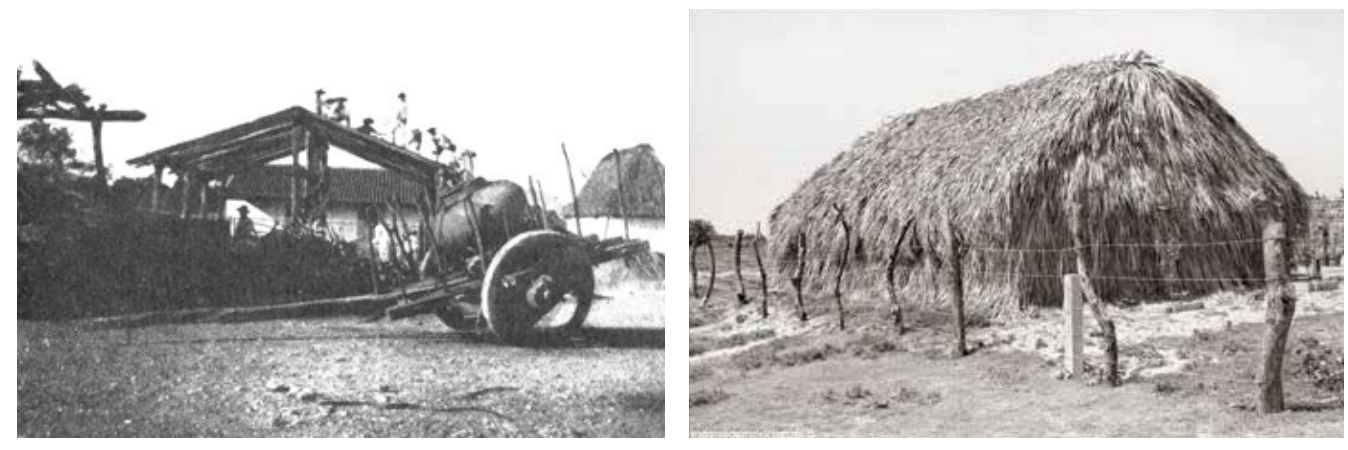

Carreta y casas huaves en 1899. (Fotos: Frederick Starr).

Habitualmente la cocina está separada del resto de la casa con el objeto de evitar el humo y el calor y en ella come toda la familia. Las áreas circundadas constituyen corrales en las que encierran sus animales domésticos y dentro del corral también suele existir una troje compuesta de una base de entortado de lodo, separado del suelo como cuarenta centímetros, la cual sustenta una estructura del mismo material, de forma cilíndrica que presenta una ventanita en la parte inferior para poder extraer el maíz cada vez que es necesario, volviendo a cerrar a continuación para que "no se pique", o no sea afectado por los insectos, en especial el gorgojo. 


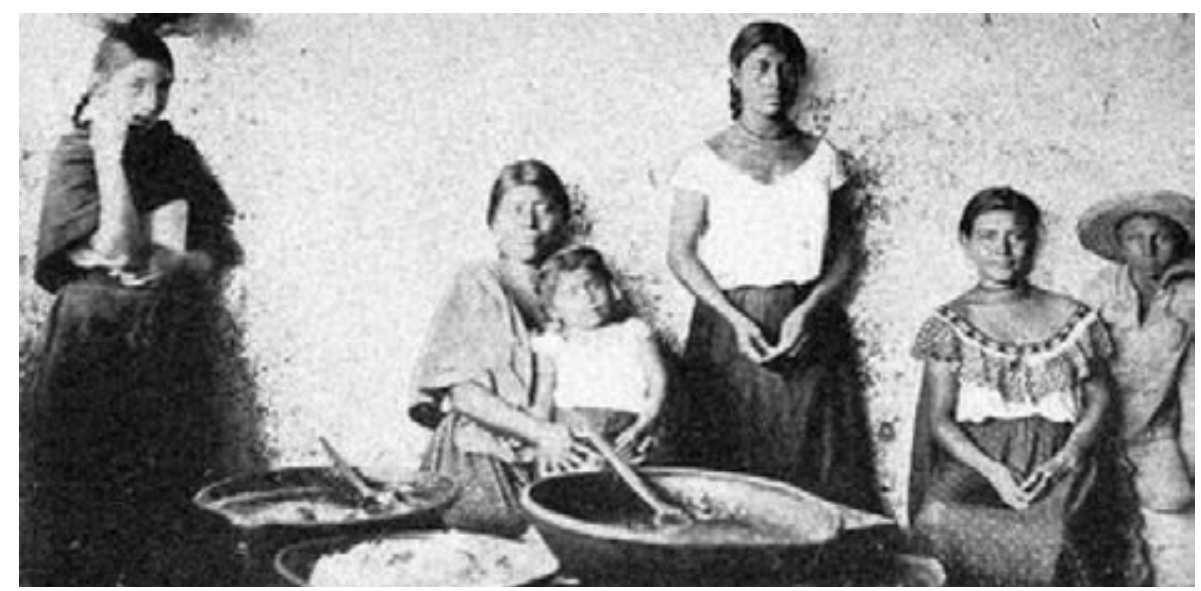

Familia en cocina huave en 1899. (Foto. Frederick Starr).

INDUMENTARIA. La indumentaria masculina consistió en camisa con mangas largas y calzón blanco. Hasta hace poco tiempo usaron un ceñidor negro o blanco con fajas azules o moradas. Cubrían su cabeza con un sombrero de lana negra. Las mujeres usaban un cotoncillo sin mangas o un huipil blanco con labores en la apertura del cuello, así como una enagua de manta azul o morada. El teñido del hilo para los bordados se extraía del caracol púrpura marino y en ocasiones cubrían su cabeza con otro huipil: éste posiblemente tomado de los zapotecas de Tehuantepec.
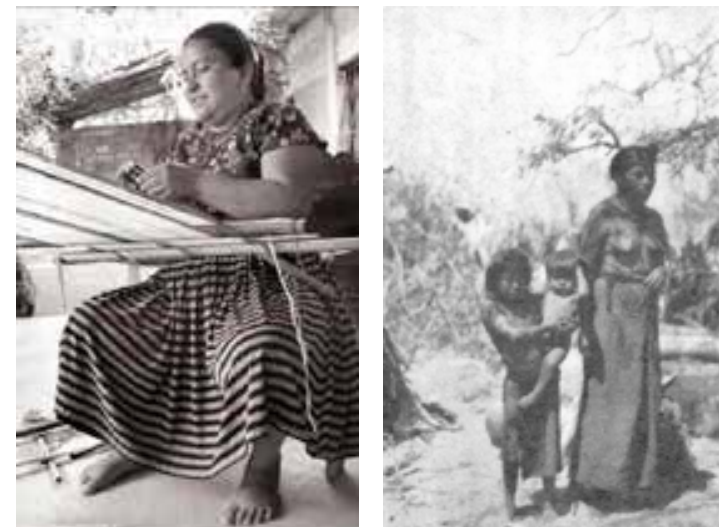

Tejedora y mujer (1906) huaves. (Fotos: lugaresdemexico.com y Frederick Starr).

Durante el desempeño de sus labores domésticas algunas mujeres preferían andar desnudas de la cintura para arriba. En los últimos años la indumentaria ha variado, introduciéndose los pantalones de dril o mezclilla y los vestidos de algodón o de lino. El sombrero de palma ha tenido durante el siglo XX amplia difusión.

ECONOMÍA. Entre Los Huaves existe una agricultura muy precaria y por ello la ocupación mayoritaria es la pesca. Algunos individuos de la comunidad obtienen madera de los manchones de monte medio caducifolio que aún se observan. Hay una fruticultura constreñida 
a la proximidad de las viviendas y limitada a algunos cítricos, mangos, tamarindos, papayos y almendros. La variedad de maíz cultivada es principalmente el zapalote pequeño, de ciclo muy corto y de rendimiento muy bajo, que madura a los sesenta y dos días de sembrado y del que no es posible obtener más de 300 kilos por hectárea. Pero el principal recurso con que se cuenta es el obtenido de las lagunas, ya sea mediante redes, tarrayas o pequeñas trampas de captura. Dentro de las especies de peces de aguas someras, las más pescadas son la lisa, la liseta, el bocadulce y la mojarra, y, como crustáceo, el camarón, y ocasionalmente se capturan ejemplares, principalmente hembras, de las especies que entran a las lagunas a desovar, mayoritariamente corvina, robalo y pargo blanco. Además, algunos individuos se han dedicado a la obtención de sal, en base a la evaporación. La economía del grupo no se debe analizar sólo en términos de costo-beneficio, ya que las comunidades mantienen proceso de reproducción, defensa y adaptación a las condiciones económicas del país. En las actividades económicas huaves se encuentran reflejadas sus características propias, tales como su lengua y el conjunto de valores, tradiciones y costumbres que forman una red permanente de relaciones familiares, económicas y religiosas. Aunque los huaves constituyen una etnia que tiene ciertos recursos naturales, no cuentan con los sistemas adecuados de intercambio y comercialización, ni ha existido en la zona ninguna instalación para conservar los productos capturados; por lo que gran parte del pescado y el camarón obtenidos son vendidos a acaparadores de Juchitán o del puerto de Salina Cruz. En fechas muy recientes las canoas de madera de ceiba o parota y guanacastle, cuyo diseño guarda estrecha relación con otros de la costa del golfo y sudamericanos, y que estuvieron ampliamente difundidas durante, por lo menos, dos siglos y medio, han sido substituidas por lanchas de fibra de vidrio y la locomoción con remo o pértiga ha recibido la innovación del motor fuera de borda.
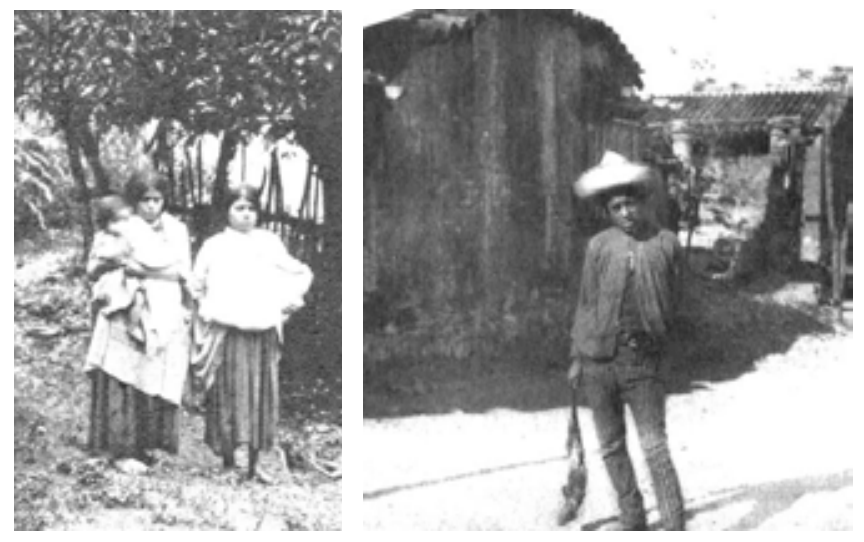

Mujeres y hombre con iguana huaves en 1899. (Fotos Frederick Starr).

ARTESANIAS. Existen en pequeña cantidad algunas labores textiles y de bordado, aunque de exquisita factura, pequeños trabajos sobre conchas de moluscos o sobre espinas de pescado y se conoce un caso de un fabricante de máscaras que usa, o usó como materia prima, caparazones de armadillo. 

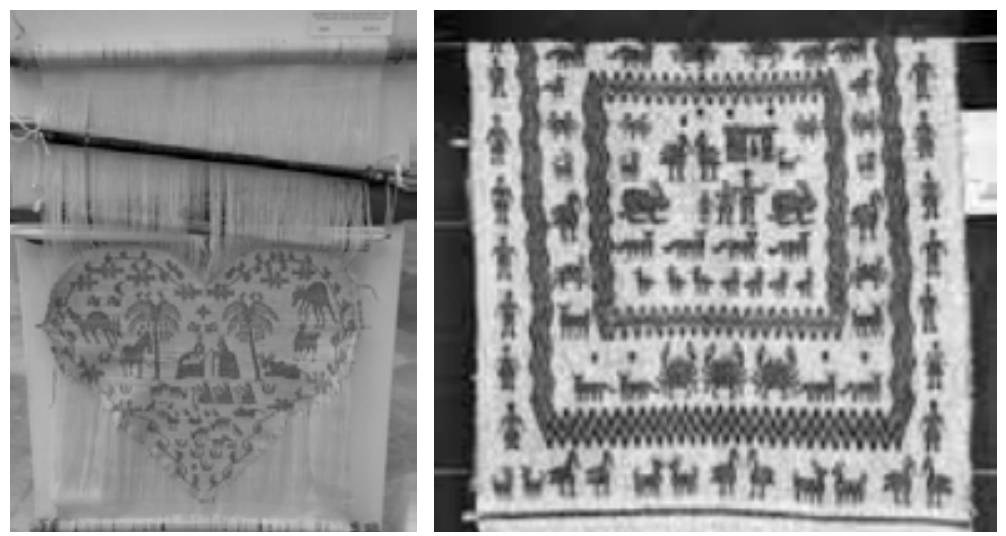

Textiles huaves. (Fotos: Karen Elwell).

GANADERÍA. Durante el último siglo se desarrolló una raquítica ganadería caprina. En la década de los ochentas el Banco Nacional de Crédito Rural ha iniciado un programa de introducción de borregos pelibuey en las zonas de pastizal natural y en algunos potreros de la región de San Mateo del Mar sembradas con zacate privilegio. Se intuye que el borrego pelibuey, por sus características, su rusticidad y su capacidad de conversión cárnica, es un animal que va a tener un notable desarrollo en toda la porción seca del Istmo de Tehuantepec, siempre que no sature los pastizales.
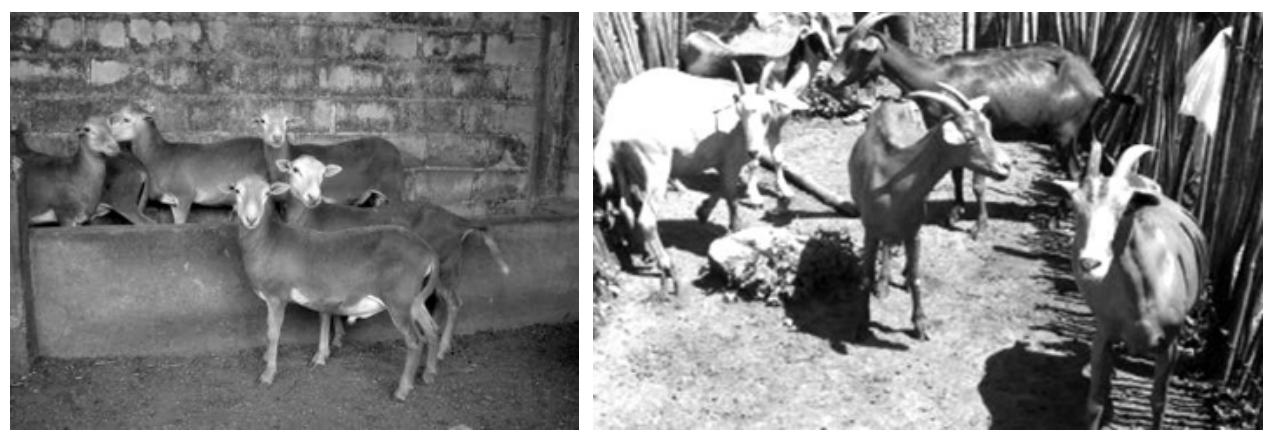

Borregos pelibuey y Cabras en la zona huave. (Fotos: Dirección de GANADERÍA. Gobierno del Estado)

CAZA Y PESCA. La región ocupada por los Huaves contuvo hasta hace poco tiempo un equilibrio entre especies animales y vegetales. En la actualidad la fauna silvestre, cuyos principales exponentes en la región eran el ocelote, el venado cola blanca, el oso hormiguero, la liebre, el pecarí, el mapache, el conejo y el armadillo, han sufrido un proceso gradual de extinción. Tradicionalmente el armadillo formó parte de la dieta de la población huave, pero su captura se ha incrementado y ha visto reducido su número. El armadillo se captura cuando, estando encuevado, el cazador agranda el agujero con una coa hasta poderlo sujetar de patas traseras y cola. El animal siempre ha sido localizado con un buen perro. Caso especial es la liebre zonal (Lepus callotis), especie única en el país, en el continente y en el mundo, que ha sido cazada con faro buscador desde camionetas.. El conejo está resistiendo. 


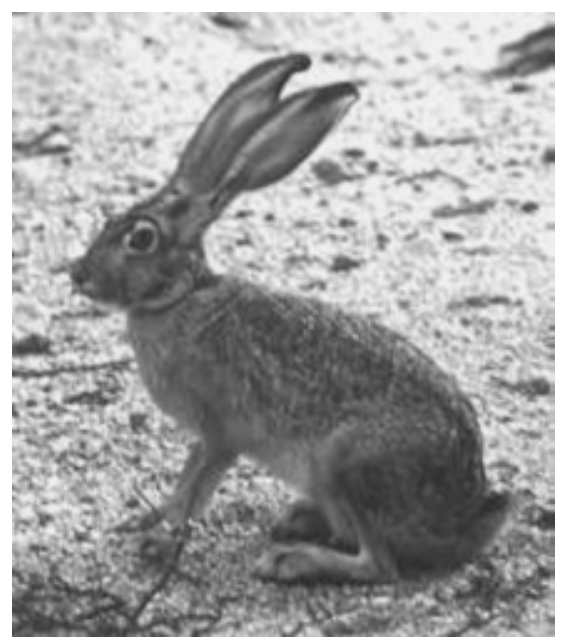

Liebre del İstmo. (Lepus callotis). (Foto: Instituto de Biología UNAM)

Siendo la pesca la principal actividad del grupo, en los últimos 40 años se introdujo el chinchorro, una red anclada en el fondo en la que se atoran por las agallas los peces que van en tránsito; del tamaño de la malla del chinchorro depende el de los peces capturados.
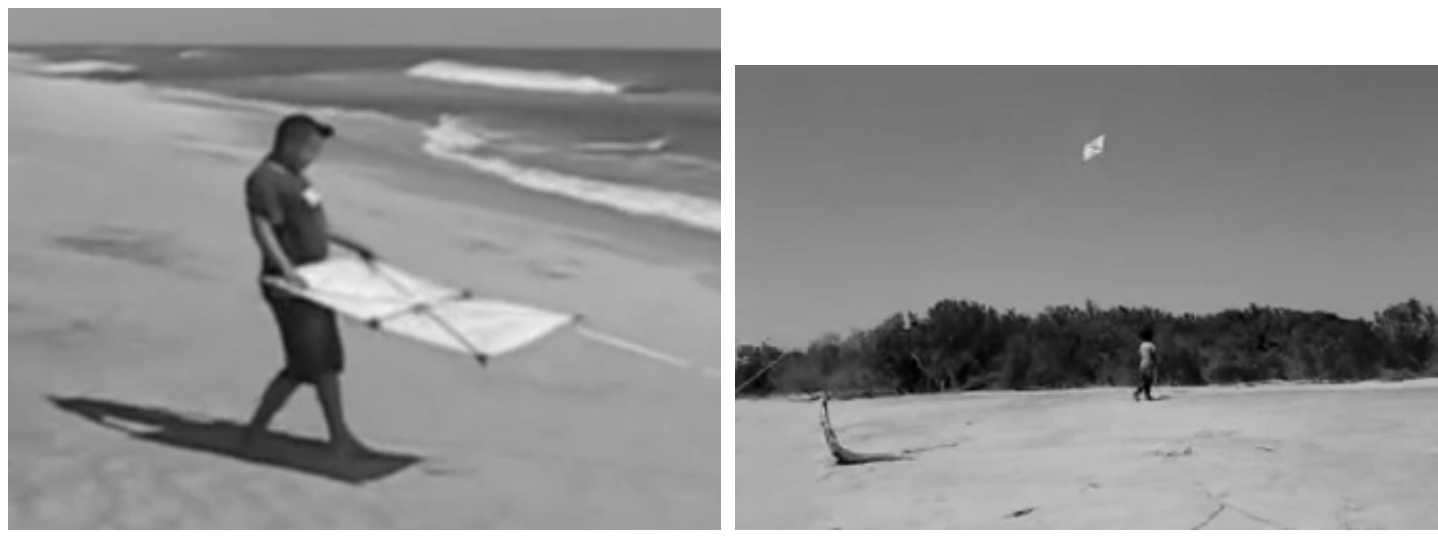

Pescadores con papalote y palangre. (Fotos: Internet)

Una variante muy interesante de la pesca de playa en el mar consiste en la colocación de un palangre con varios anzuelos aprovechando el fuerte viento invernal. Un papalote es el aparato que hace volar y coloca varias decenas de metros dentro del mar la línea del palangre. Con ese sistema se capturan peces mayores, y en ocasiones, jureles o dorados.

El camarón se captura colocando un mechero en la orilla del agua en horas de la mayor obscuridad nocturna. El crustáceo es atraído por la luz, y cuando se supone que se han reunido bastantes, el pescador arroja una tarraya fina, la cual captura todos los animales en un diámetro de dos a cuatro metros. Algunos pescadores han desarrollado habilidad para capturar jaibas y lenguados ensartándolos con una fisga. En algunos esteros, y cuando las condiciones han sido propicias, algunos individuos capturan ostiones de pequeño tamaño retirándolos de las raíces de los mangles, a las que están adheridos. En 
algunas playas, sobre todo frente a mar abierto, también se capturan almejas excavando en la arena hasta su localización, dado que allí suele haber varias en distancias cortas. La cucaracha de mar y la calapa o chocalopa fueron abundantes y se les capturó hasta casi la extinción.
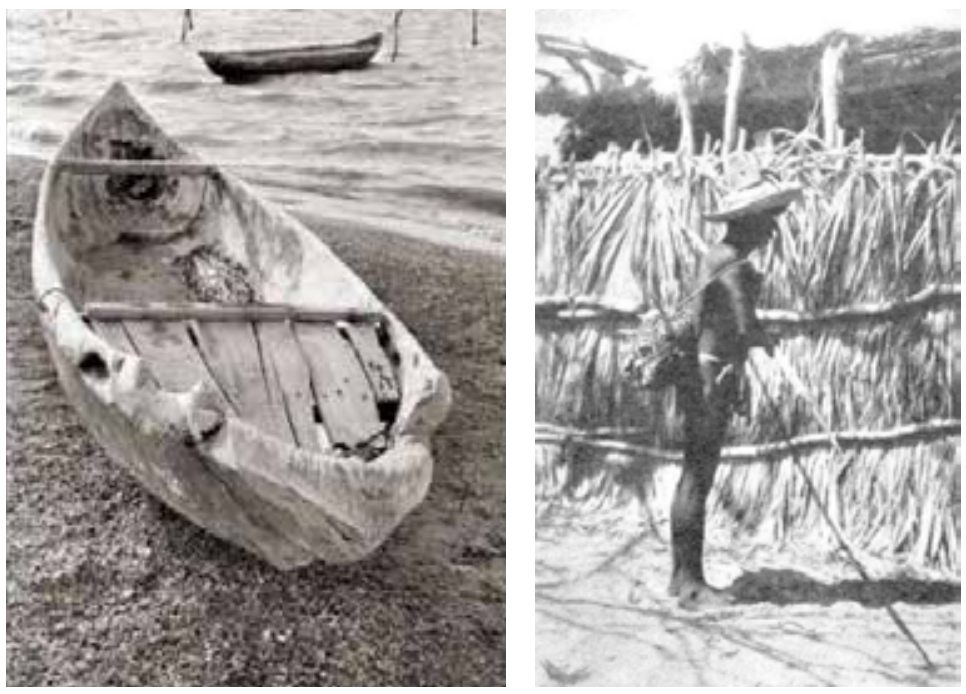

Canoa de parota y pescador huaves. (Fotos: Anne Bonnefoy y Frederick Starr).

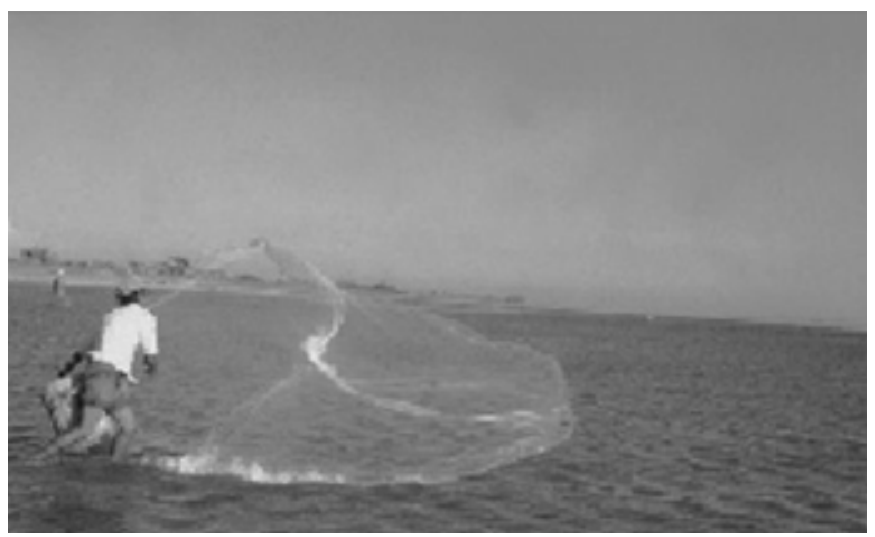

Huave pescando con tarraya (Foto: Alberto Becerril).

MERCADOS. Los principales mercados de la región se encuentran en San Mateo del Mar, Santa María del Mar, San Francisco del mar y San Dionisio del Mar. Los compradores de pescado que van de Salina Cruz y Tehuantepec llegan a esos mercados a recoger la mercancía, y a ellos llegan también algunos comerciantes ambulantes a bordo de camionetas ofreciendo gran cantidad de artículos de uso diario.

ORGANIZACIÓN SOCIAL. La sociedad Huave es patrilineal, patrilocal y endogámica, habiendo la familia nuclear y la extensa, designándose los parientes no tan próximos como akwalaac, dándose al matrimonio una importancia primordial, concertándose éstos entre 
los padres desde que los pretensos tienen corta edad. En los casos en que los jóvenes se entienden, los padres del muchacho van a pedir a la muchacha. La familia tiene como máxima autoridad la figura del padre y la figura materna solo adquiere relevancia en los asuntos mercantiles y de carácter económico. Varias familias constituyen un barrio y pocos barrios constituyen la comunidad. En la celebración de las bodas se observa con claridad la importancia de la solidaridad y la reciprocidad dentro del grupo, puesto que existe contribución de los parientes, amigos y vecinos para la instalación de la nueva pareja. La casa de ésta suele tener relativa proximidad con la casa de los padres del novio.

El ritual de muerte es un tanto diferente al de otros grupos; A los moribundos se les visita llevando obsequios con los que se le despide, con lo que se piensa que ya no queda ningún lazo que pueda ser nocivo para los vivos. Además existe la costumbre que consiste en que el que se da cuenta de su cercana muerte reparte sus bienes. Al recién fallecido se le lava, viste y coloca con la cabeza mirando al sur. A continuación se le lleva al cementerio. Posteriormente se le hacen cuatro ceremonias, a los nueve días, a los cuarenta, a los seis meses y al año, y los rezos están encaminados a que el alma los aprenda y con ello pueda pasar el examen a que lo someterá San Pedro al llegar al cielo.

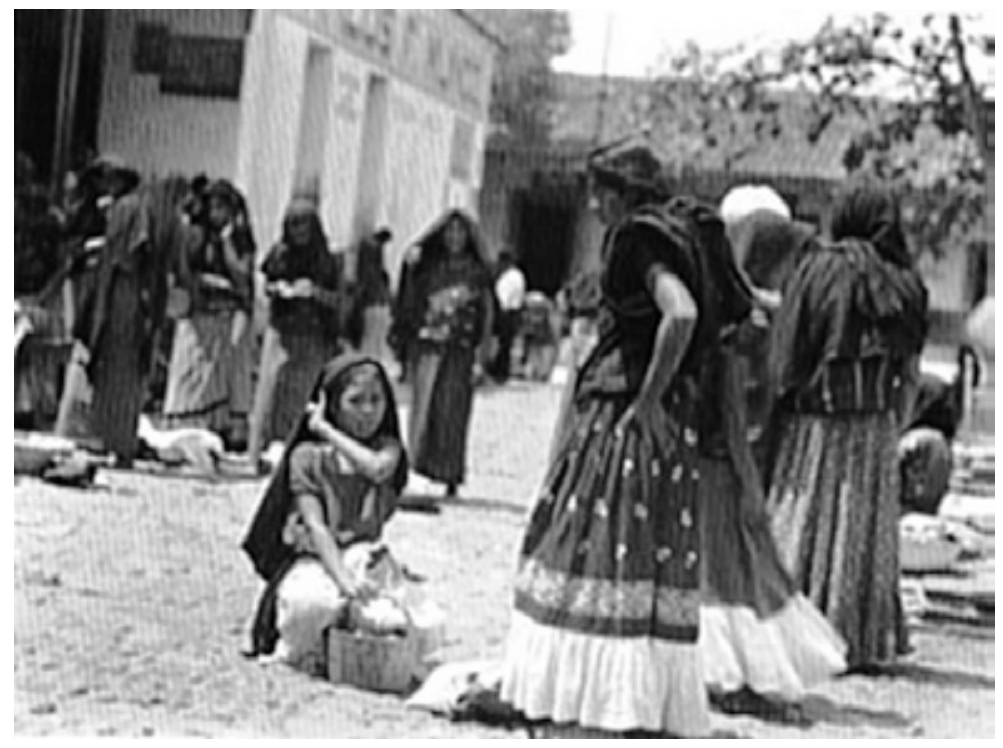

Mujeres huaves en un mercado en 1929. (Foto: Tina Modotti).

GOBIERNO. Antiguamente los Huaves eran gobernados por un jefe absoluto y en las diferentes comunidades existían caciques subalternos. En la actualidad en esta región opera el aparato jurídico, político y constitucional mexicano. Las comunidades eligen su ayuntamiento o tienen el representante o agente que responde ante la cabecera municipal. El sistema de cargos es escalafonario y a la cima llega quién ha sido Mayordomo de alguna imagen. Subsiste el tequio.

En el caso de San Mateo del Mar los integrantes del ayuntamiento son indígenas en su totalidad. No así en San Francisco y San Dionisio. En todas las poblaciones ya existe 
consenso de que Petróleos Mexicanos tiene la obligación de preservar las lagunas impidiendo que substancias nocivas y contaminantes sean vertidas en ellas.

FESTIVIDADES. Desde la época colonial se substituyó el calendario ritual prehispánico y el calendario agrícola por el calendario ritual católico. Así en la actualidad se celebra el día del santo titular, ya sea en San Mateo, San Dionisio o San Francisco y también la Candelaria, la Semana Santa y el día de Muertos. En el Siglo XX se introdujo también la celebración de velas y calendas. En la región existen bandas de música dotadas con instrumentos de aliento y de percusión tales como saxofones, trompetas y tubas, y además con bombo, platillo y tamboriles, la música huave es característica y existen danzas que tienen su origen en la época colonial. Una de ellas es una especie de pantomima relacionada con tradiciones históricas que se baila al son de chirimía y tamboril. Además hasta hace más o menos 40 años se danzaba en honor del Sol y de la Luna en un baile consistente en una serie de brincos acompañados por instrumentos de percusión, en ocasiones un caparazón de armadillo frotado. Los danzantes formaban un corro alrededor de una fogata.

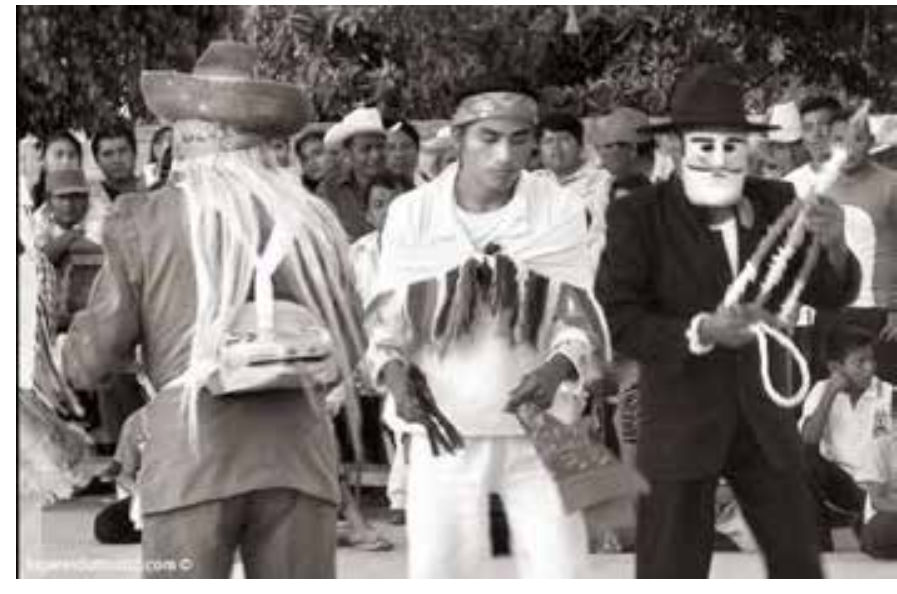

Danza huave de la serpiente. (Foto:Anne Bonefoy).

ORGANIZACIÓN RELIGIOSA. Se tiene documentada gran parte de la religión prehispánica huave. Esto debido a que el grupo, en su culto a los dioses del agua, utilizó la zona insular de Laguna Superior (Monopultiac, Monguixtla), donde existieron santuarios en culto constantemente visitados, cuyas ruinas pueden verse hasta hoy. Además, hubo un sólido culto al rayo, a la lluvia y los ciclones. Ya dentro de la religión cristiana, entre los huaves persiste la institución de la Mayordomía, pero el mayordomo suele ser ayudado por el resto de la comunidad. La religión mayoritaria es la católica la cual profesan más de 15 000 personas. Sin embargo, ya también comienza a haber grupos pertenecientes a sectas protestantes y Testigos de Jehová. Como supervivencia anímica, una pequeña parte de la población masculina efectúa ritos de origen prehispánico relacionados con la fertilidad y la posibilidad de la obtención de buena pesca. En uno de ellos la procesión camina por la orilla del agua, ya sea en la laguna, o en la playa marina. 


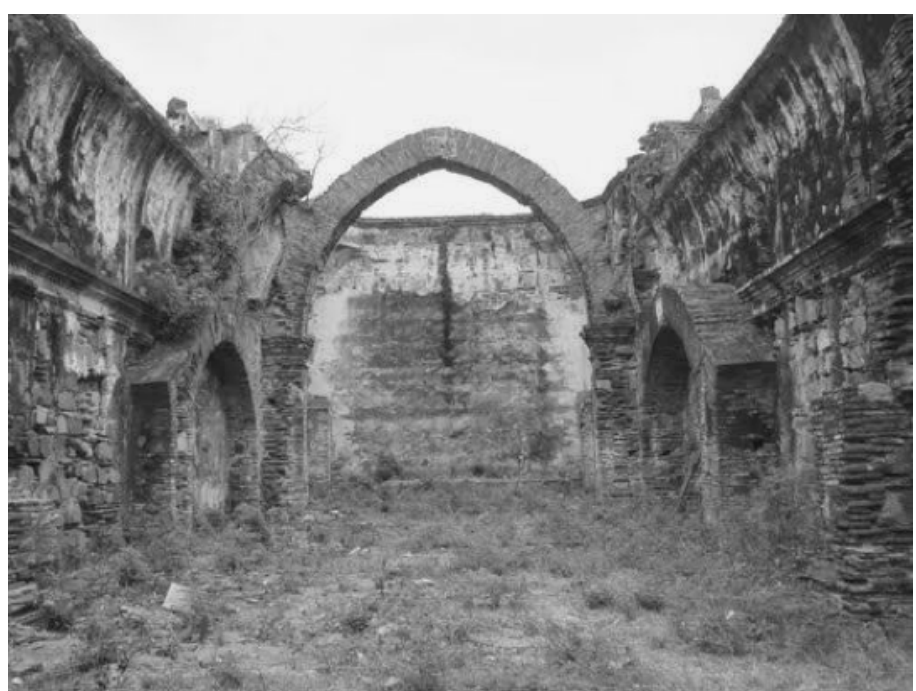

Ruinas de la Iglesia de San Dionisio del Mar. Siglo XVII.

(Foto: Dirección de Turismo Estatal).

MEDICINA Y MAGIA. En las poblaciones huaves subsisten algunos brujos, considerados capaces de convertirse en animales, encargados de curar enfermedades y de sanar el alma. Casi no se conservan ritos. En la región existen muy pocos médicos y solo unos cuantos pasantes de medicina que, en ciclos anuales y en los Centros de Salud dotados, cumplen con su Servicio Social.

EDUCACIÓN. Las comunidades cuentan con algunas escuelas primarias pertenecientes, tanto al sistema federal como al estatal. Se calcula que en edad escolar hay unas 5000 personas; los pocos estudiantes de nivel medio deben trasladarse a Tehuantepec y los de mayor nivel al Tecnológico de Juchitán o a la Universidad del Istmo en Ciudad Ixtepec, donde hay algunos estudiantes becados.

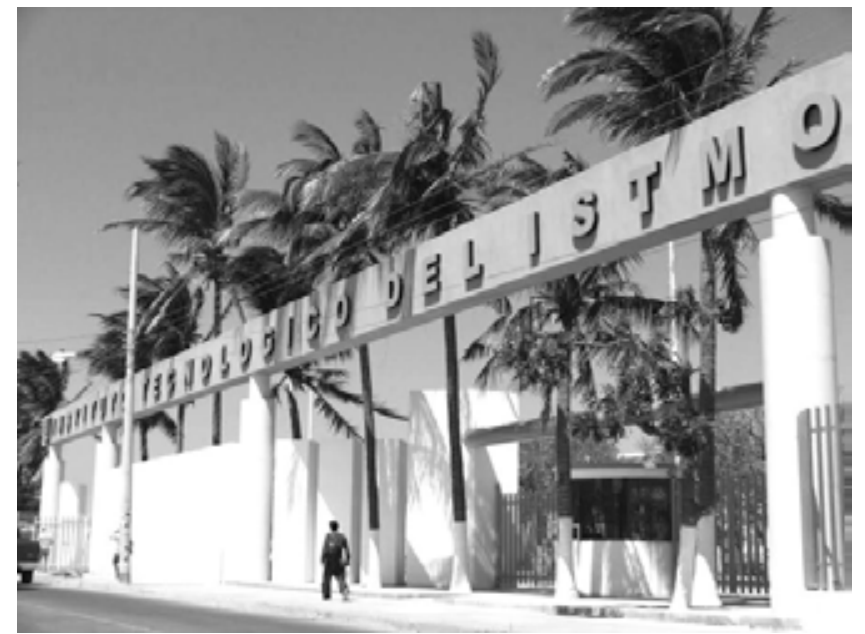

Instituto Tecnológico del Istmo. Juchitán (Foto: Expresión) 


\section{BIBLIOGRAFÍA}

Acevedo Conde, María Luisa. 2007 "Apuntes sobre los Huave”. Revista A CONTRAGOLPE. № 5. Carteles Editores. Oaxaca, Oax. 2007.

Basauri, Carlos. 1940 “Los Huaves”. En: LA POBLACION INDIGENA DE MEXICO, Tomo III. Instituto Nacional Indigenista. México, D F.

Cook de Leonard, Carmen. 1950 "Costumbres Mortuorias de los Huaves”. En: EL MEXICO ANTIGUO. Vol VII. México, D F. 1950.

Covarrubias, Miguel. 1980 EL SUR DE MEXICO Colección. CLASICOS DE LA ANTROPOLOGÍA. Vol IX. Instituto Nacional Indigenista. México, D F. 1980.

Diebold, Richard. 1969 “The Huave”. En: HANDBOOK OF MIDDLE AMERICAN INDIANS. Vol. VII. University of Texas Press. Austin \& London. Austin, Tx. U S A.

Frey, Rudolf Hans. 1982 LA JERARQUIA POLITICO-ECLESIASTICA Y LA MAYORDOMIA EN SAN DIONISIO DEL MAR. OAXACA. Instituto de Investigaciones Sociológicas. UABJO. 1982.

Gerhrard, Peter. 1991 LAS FRONTERAS MERIDIONALES DE LA NUEVA ESPAÑA. Instituto de Geografía. UNAM. México, D F. 1991. Griffın, William. 2001 "Camaronicultura en Oaxaca”. En: CUADERNOS DEL SUR. No 16. CIESAS. IISUABJO, Oaxaca, Oax. Marzo del 2001.

Hernández Díaz, Jorge. 1996 CULTURA E IDENTIDAD ETNICA EN LA REGION HUAVE. Instituto de Investigaciones Sociológicas. UABJO. Oaxaca, Oax. 1996.

León, Nicolás. 1904 CATALOGO DE LAS ANTIGUEDADES HUAVES DEL ESTADO DE OAXACA. Imprenta del Museo Nacional de México. México D F. 1904. Millán, Saúl. 1995 LOS HUAVES.

Etnografía Contemporánea de los Grupos Indígenas de México. Instituto Nacional Indigenista. México, D F. 1995.

Navarrete Cáceres, Carlos. 1976 "El Complejo Escultórico de Cerro Bernal en la Costa de Chiapas, México”. En: ANALES DE ANTROPOLOGIA. Vol XIII. Instituto de Investigaciones Antropológicas. UNAM. México, D F. 1976.

Rodríguez, Nemesio. 1992 "Los Huaves, Entre el Desarrollo Sostenido y la Hipoteca de su Futuro". En: ETNIAS, DESARROLLO, RECURSOS Y TECNOLOGIA EN OXACA. MEXICO. CIESAS, Gobierno del Estado de Oaxaca. Oaxaca, Oax. 1992.

Signorini, Italo. 1979 LOS HUAVES DE SAN MATEO DEL MAR. INI. Serie Antropología Social. No 59. México, D F. 1979.

Zizumbo Villarreal, Daniel y Colunga García Marín, Patricia. 1982 LOS HUAVES. LA APROPIACION DE LOS RECURSOS NATURALES. Universidad Autónoma de Chapingo. México, D F-1982. 


\section{ZOQUES}

Autodenominación: angpon, tsuni.

Sinónimo en su lengua. tahtza'uaay’yode, tzuni ote, tzunipil'n otowe.

Significado: Gente que habla la lengua

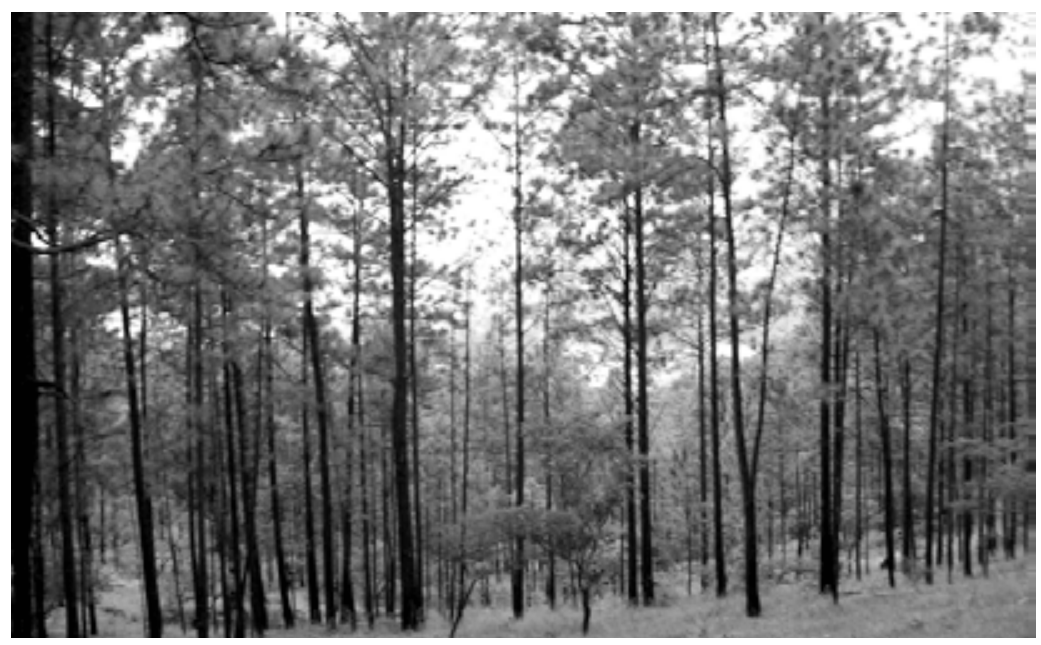

Bosque de coniferas (Pinus oocarpa) Alto Chimalapas. (Foto del autor).

\section{GRUPO ZOQUE}

En Oaxaca, ocupa aproximadamente 150000 hectáreas en la porción oriental del estado del Distrito de Juchitán, colindando con los Estados de Veracruz y Chiapas. Su área ocupacional queda delimitada por los paralelos $16^{\circ} 20^{\prime}$ y $17^{\circ} 50^{\prime}$ de latitud norte y los meridianos $93^{\circ} 30^{\prime}$ y $95^{\circ} 10^{\prime}$ de longitud occidental. Se encuentra en casi toda la cuenca oriental oaxaqueña del río Coatzacoalcos, (ríos del Corte y Alto Uxpanapa), con un relieve de lomeríos que oscilan entre 500 y los 1800 metros sobre el nivel del mar y que están cubiertos por selvas altas y medias perennifolias, y, en los lomeríos más altos, bosques de coníferas, de lo que una parte importante ya ha sido gravemente dañado. Los climas en la región son tropicales subhúmedos con lluvias todo el año, aunque en ocasiones se presentan breves temporadas de secas durante los meses de marzo y abril. Los suelos de la región tienden a ser lateríticos, es decir, ricos en compuestos de hierro, y son de baja fertilidad, existiendo en ellos la agricultura en roza tradicional sólo porque los desechos de las selvas crean una 
capa relativamente humífera y de poco grosor sobre ellos. La precipitación pluvial alcanza en algunos sectores hasta los 3000 milímetros anuales, habiendo otros sectores en lo que es menor, pero nunca inferior a los 1700 milímetros. El régimen de vientos los hace soplar en dirección norte-sur entre los meses de noviembre y abril en estratos superiores de la atmósfera, lo que determina que la condensación de vapor cree una nubosidad baja, que a su vez origina lloviznas casi permanentes.
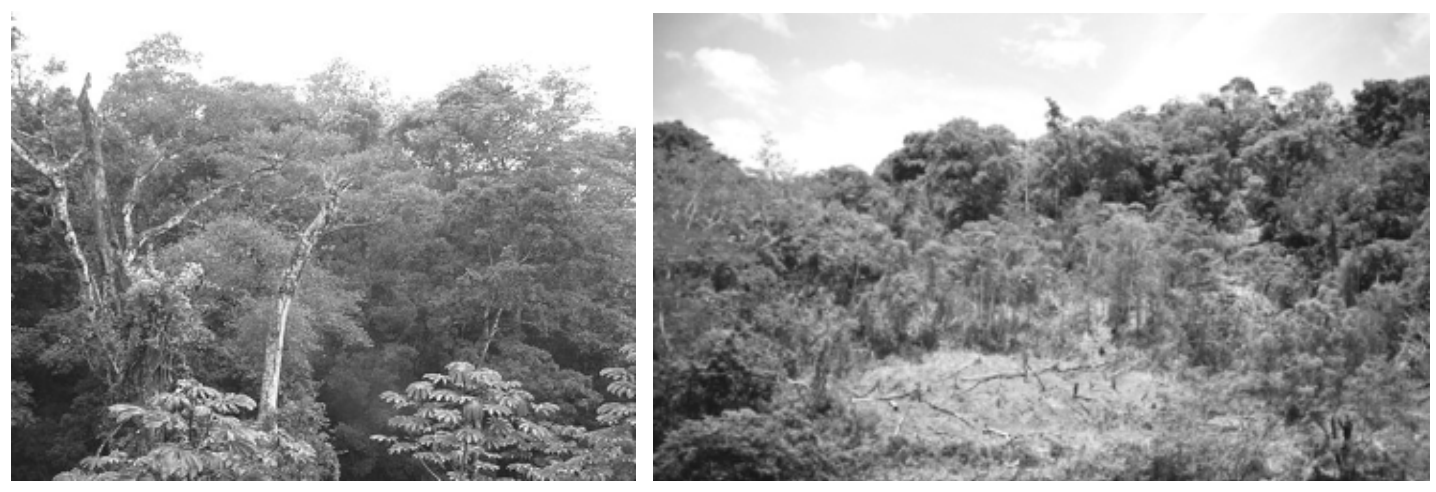

Selva alta perennifolia y Método de tumba y quema. (Fotos: Enrique Antonio Hernandez y Wikipedia).

Sin embargo, la acelerada destrucción de la vegetación y la consiguiente elevación de la temperatura y la disminución de la humedad están acelerando un proceso de desertificación, lo que llevará a que los vientos norte ístmicos en la costa del Pacífico, al no tener sobre la masa continental ese regulador térmico, desciendan e incrementen su velocidad con consecuencias impredecibles. Ya se producen ráfagas con velocidades cercanas o mayores a los 150 kilómetros por hora. El autor ha visto higos, amates y tezcalamas de $50 \mathrm{o}$ más toneladas arrancados de cuajo. Y de uno presenció el hecho.

IDIOMA. El grupo zoque tiene una lengua perteneciente al grupo Maya Totonaco, Familia Zoque-Mixeana que, según el Censo Poblacional del 2010, es hablada por aproximadamente unas 5300 personas, mayoritariamente bilingües, dentro del territorio oaxaqueño. Dicha lengua está íntimamente emparentada con el Mixe. Hace unos 4000 años, se hallaba unificada como Protomixe-zoque.

ANTECEDENTES ARQUEOLÓGICOS E HISTÓRICOS. El territorio ocupado por los Zoques contiene gran cantidad de vestigios arqueológicos, los que, debido a la casi total carencia de investigaciones controladas, no han podido ser debidamente analizados e interpretados, pero los sondeos apuntan a una primera ocupación pre-olmeca detectada en la zona fronteriza Chiapas-Oaxaca (designados como Mokaya: Gente del Maíz), confirmada por recorridos de arqueólogos en el Alto Uxpanapa. Más tarde, casos importantes son las Zonas de Chimalapilla, San Francisco de la Paz y Utlatepec, que revelan la existencia de arquitectura monumental que se remonta al primer milenio a $\mathrm{C}$, de estelas con glífica, con juegos de pelota y de una localización estratégica para rutas comerciales que debieron desarrollarse 
a lo largo de los ríos, tanto del El Corte como del Uxpanapa. El área ocupacional zoque es muy amplia, y las posibilidades de que hayan tenido que ver, como el grupo olmeca-mayense que son, con la expansión de grupos de esa afiliación, tanto en las épocas Preclásica y Clásica como en la Postclásica, son muy altas. Tanto figurillas, como cerámica de tipo olmeca y mayense correspondiente a esas épocas, he y se han encontrado hasta las costas del pacífico del Istmo de Tehuantepec, incluyendo glífica en estelas (Sol y Luna, Zanatepec), así como en una faja costera que se extiende hasta la región comprendida hasta la Laguna de Las Coloradas en la costa del Estado.
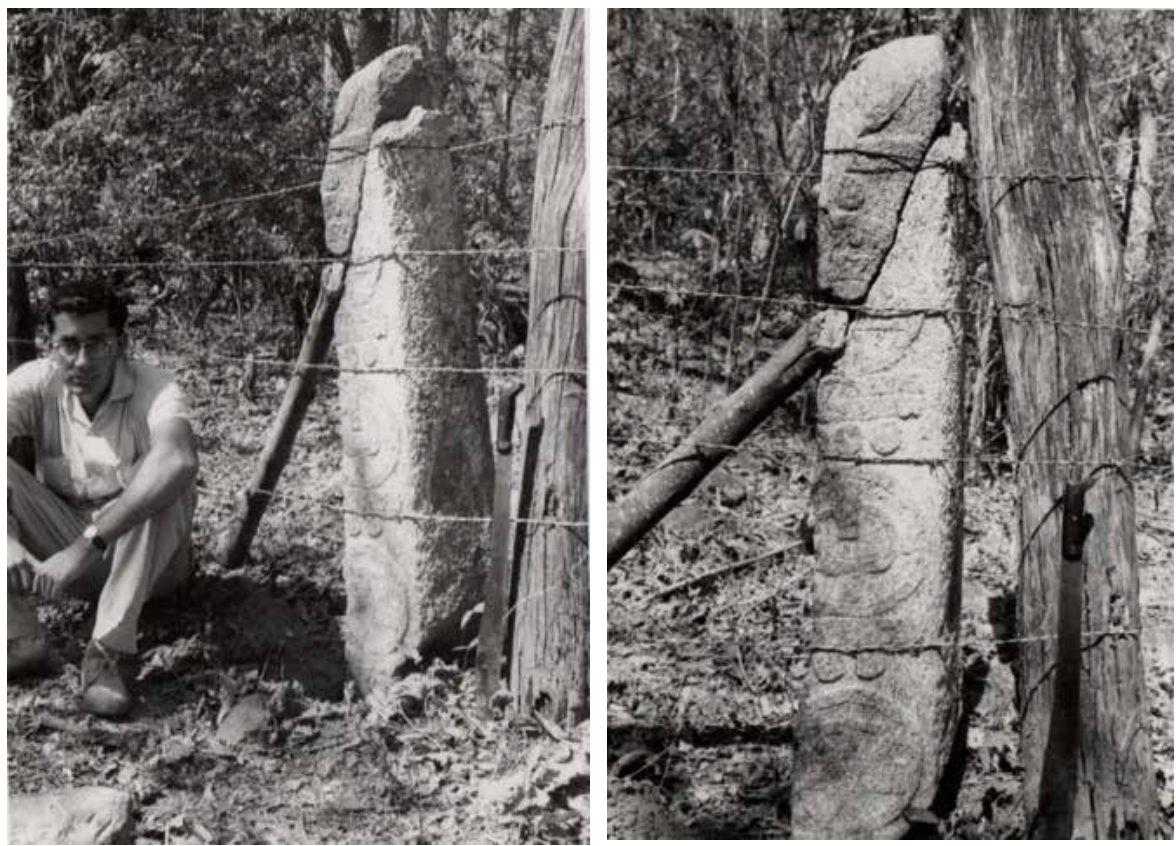

Estela zoque de Sol y Luna, en el rancho de Dn. Agapito Sánchez, Zanatepec,

Oax, Visitada en 1965 por el autor y su padre. (Fotos: Ing. Luis Rodrigo Martínez).

Algunas fuentes históricas mencionan los contactos tributarios de ese grupo con los aztecas, sin embargo, parece que en realidad las rutas de comercio mexicas atravesaban la región ocupada por los zoques para llegar a los Altos de Chiapas y al Soconusco. Esto hace suponer que por lo menos hubo entre los zoques y los aztecas una relación de cooperación comercial, ya que se trataba de principalatos muy pequeños. Al sobrevenir la conquista española, la mayor parte de la población de este grupo tuvo enfrentamientos en territorio chiapaneco, y se documenta que en el Siglo XVII (1687) compraron, mediante el pago con más de 20 (veinte) jícaras llenas de oro, a la Corona Española, los territorios que poseen, es decir, los Chimalapas, a través de un notable personaje, el Sr, Domingo Pintado. El grupo fue difícil de dominar, y su cristianización llevó bastantes años, tantos que no hay iglesias anteriores al Siglo XVII en el sector, aunque la de Santa María Chimalapa, con cimientos indudablemente coloniales, nunca fue terminada. Poco después un fraile dominico, Juan de Pozarenco escribió en 1696 una "Doctrina Christiana en Lengua Zoque" que las autori- 
dades eclesiásticas no editaron, que quedó olvidada y que apareció mucho tiempo después en la iglesia de Ocozocuautla, Chis., estando actualmente en el Fondo FAMSI. (FOUNDATION FOR THE ADVANCEMENT OF MESOAMERICAN STUDIES, INC.).
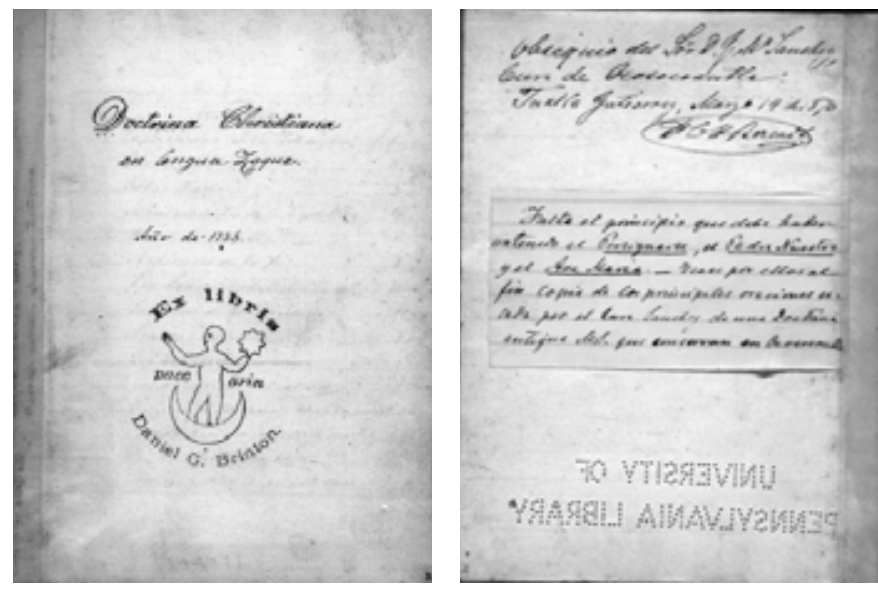

Fotos del original del libro del fraile Juan de Pozarenco.

(Foto: FOUNDATION FOR THE ADVANCEMENT OF MESOAMERICAN STUDIES, INC.).

Durante los siglos XIX y XX indígenas de filiación zoque participaron en los movimientos libertarios en Chiapas a las órdenes del general Joaquín Miguel Gutiérrez, y, posteriormente, grupos indígenas zoques participaron, unidos al bando liberal, en las guerras de Reforma y de la Intervención Francesa. Al principio del Siglo XX sostuvieron enfrentamientos por posesión de tierras con indígenas tzotziles, y algunos se vieron participando en la Rebelión Mapachista, una reacción de finqueros chiapanecos opuestos a los postulados carrancistas. Por lo anteriormente expuesto puede colegirse que la importancia histórica-cultural del grupo es particularmente grande. No obstante, los Zoques de Oaxaca han permanecido en el siglo XX en una posición totalmente marginal a los acontecimientos políticos nacionales $\mathrm{y}$, por su posición geográfica, es muy posible que sea uno de los grupos con mayor bagaje cultural, que pierde aceleradamente. Actualmente, ya en el Siglo XXI, y por ser un grupo con dispersión interestatal, confrontan la invasión de población mestiza que se ha ido asentando con motivo de la creación de superficies ganaderas y de la explotación maderera de coníferas y maderas tropicales finas, superpuesta al hecho histórico-político acordado nacionalmente, de que el límite interestatal Chiapas-Oaxaca está trazado como una línea recta de 130 kilómetros de longitud, desarrollada entre la cima del Cerro de la Gineta (Municipio de San Pedro Tapanatepec), y la del de Los Martínez, (Municipio de Santa María Chimalapa), ahora violada hasta 16 kilómetros dentro del territorio oaxaqueño. Este grave problema, ahora en el año 2014 totalmente vigente, deberá ser resuelto adecuadamente por la Suprema Corte de Justicia de la Nación. En estricta justicia, en la República Mexicana no ha lugar a despojos territoriales en el nombre de la ambición. Realmente, los Chimalapas pertenecen a la población zoque y a todos los mexicanos y deben ser un Parque Nacional. ¡Lo exigen las necesidades nacionales y mundiales!. 
DEMOGRAFÍA. De acuerdo a datos censales, a principios de 1983 existían en territorio oaxaqueño 14300 individuos de filiación zoque, los que en el censo de 1990 se contabilizaban como 5 282. En el 2010 se contaron 32 000. Ha sido muy difícil elaborar censos, debido a que los asentamientos son muy dispersos, habiendo a veces varios kilómetros entre rancherías, existiendo solamente dos poblaciones relativamente grandes que a su vez son cabeceras municipales: Santa Miguel y Santa María Chimalapa.
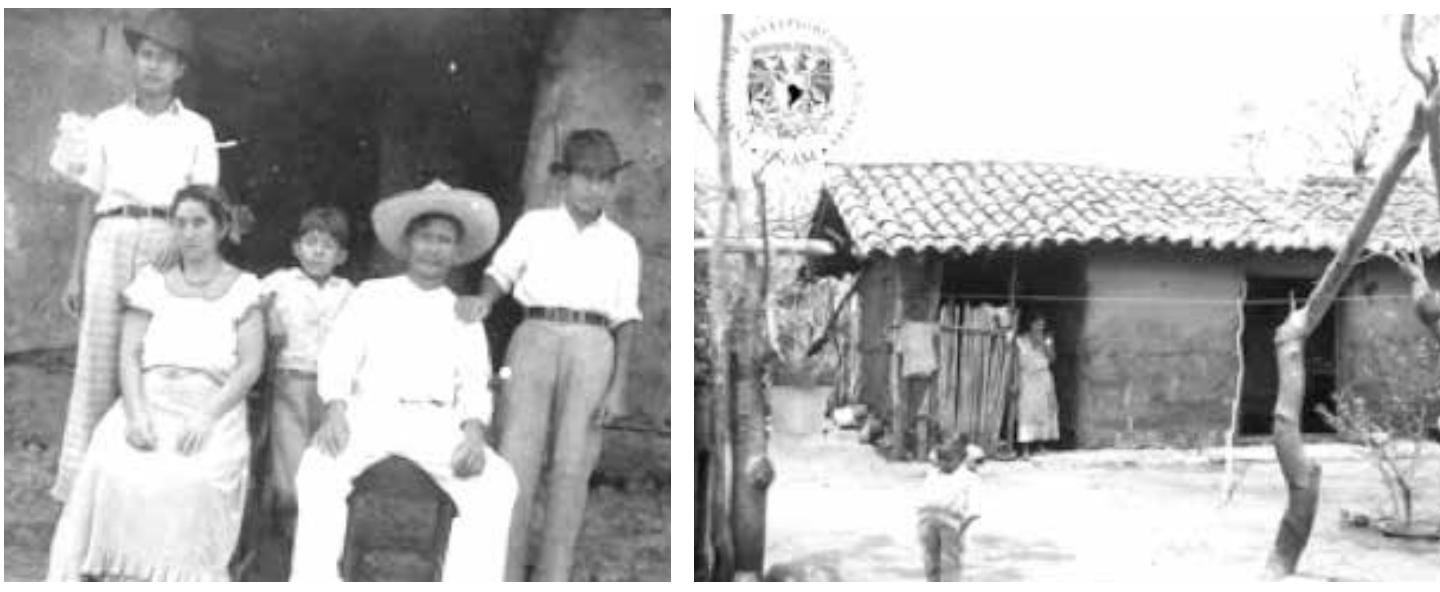

Familias zoques. (Fotos: IIS-UNAM).

ACCESOS. Penetran a la región ocupada por los zoques varios caminos de terracería que llegan a San Miguel Chimalapa y Santa María Chimalapa y otros poblados, partiendo del entronque de la Carretera Panamericana con la carretera de terracería que llega por el otro extremo hasta Chicapa de Castro. Otro camino de terracería parte de la localidad llamada Mezquite, ubicada sobre la carretera transístmica y pasa por la comunidad de Santa Inés, para luego proseguir hasta Santa María, cerca de la cual entronca con la que va de San Miguel. Actualmente se ha terminado una carretera de terracería que, partiendo de un punto situado a dos kilómetros al norte de Matías Romero, sobre la carretera transístmica, llega hasta Santa María Chimalapa después de recorrer aproximadamente 40 kilómetros. El resto de los caminos del área son brechas y caminos de muy difícil acceso, por las que sólo pasan camiones o vehículos fuertes o de doble tracción. Santa María Chimalapa cuenta con una pista para avionetas y algunos ranchos y congregaciones cuentan con pequeñas pistas que les permiten sacar algunos de sus productos y llevarlos a los mercados relativamente próximos. A algunas pequeñas aldeas se accesa navegando en lancha los ríos, tanto por el del Corte como por el Uxpanapa. 

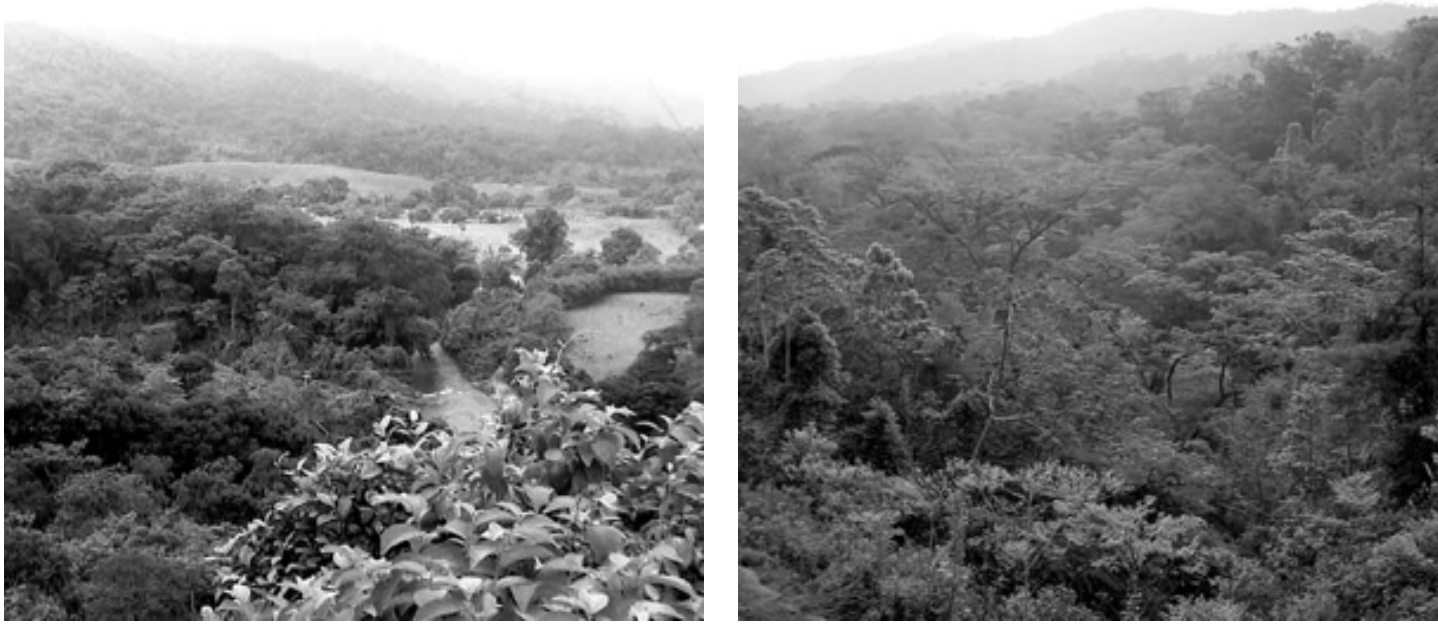

Entornos de San Miguel y Santa María Chimalapas. (Fotos: Armando Guerrero Chichino y Enrique Antonio Hernández).

VIVIENDA. Las casas son de horcones de madera unidos con vigas del mismo material. Las paredes suelen ser de bajareque y los techos, de pasto y más recientemente, de teja. Estos están diseñados a dos aguas en forma de caballete, el piso es de tierra aplanada por medio de un entorte de lodo. El tamaño de la casa varía según las necesidades familiares y es frecuente que en el interior también se almacenen las mazorcas del maíz obtenido en las cosechas precedentes.
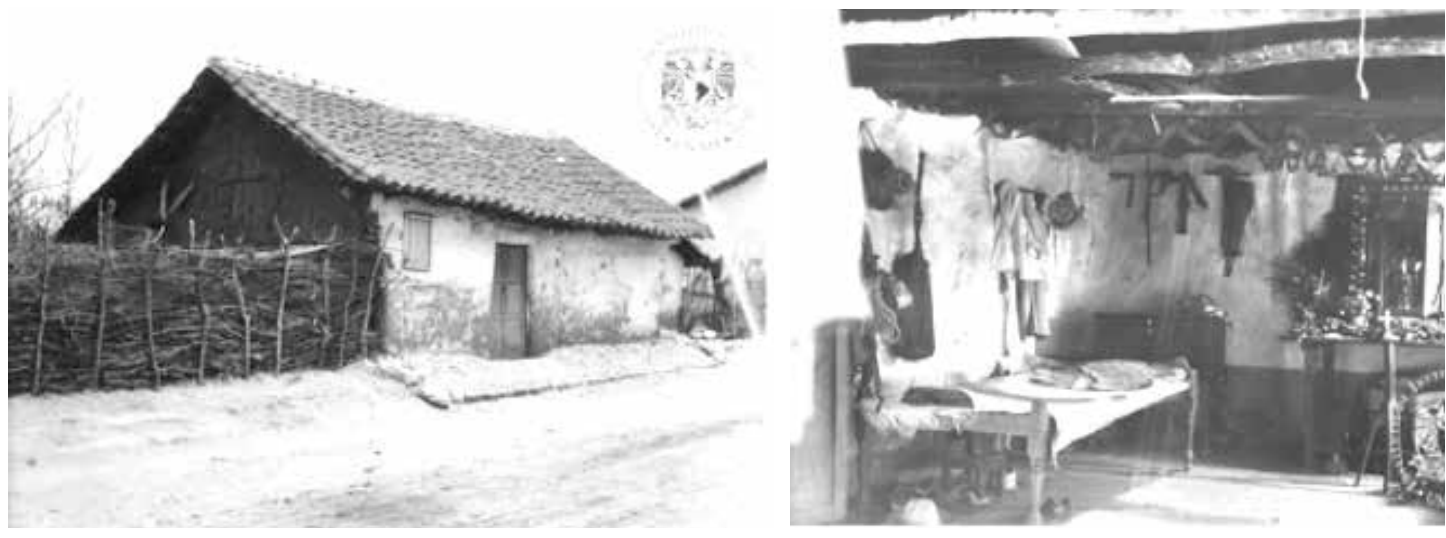

Casa e interior de vivienda zoques. (Fotos: IIS-UNAM).

El fogón suele estar en un extremo y se suele dejar un respiradero para la salida del humo. La familia suele dormir en promiscuidad y en ocasiones acompañada por animales domésticos. Recientemente se ha comenzado a introducir la lámina de cartón, metálica y de asbesto para los techos y asimismo, también se comienzan a observar casas de adobe.

INDUMENTARIA. La indumentaria Zoque original se perdió desde principios del Siglo XX. En el área oaxaqueña, ha sido fuertemente influenciada por la de los zapotecos colindantes. Los hombres usan calzón de manta y una camisa de manta de cuello cerrado. Las mu- 
jeres, huipiles de colores vivos con una enagua amplia de colores, predominando los obscuros, sujetas con un ceñidor. Ambos sexos suelen usar huaraches de correas y los adornos femeninos cuelen ser aretes y arracadas, y hasta hace poco tiempo, frecuentemente de oro.
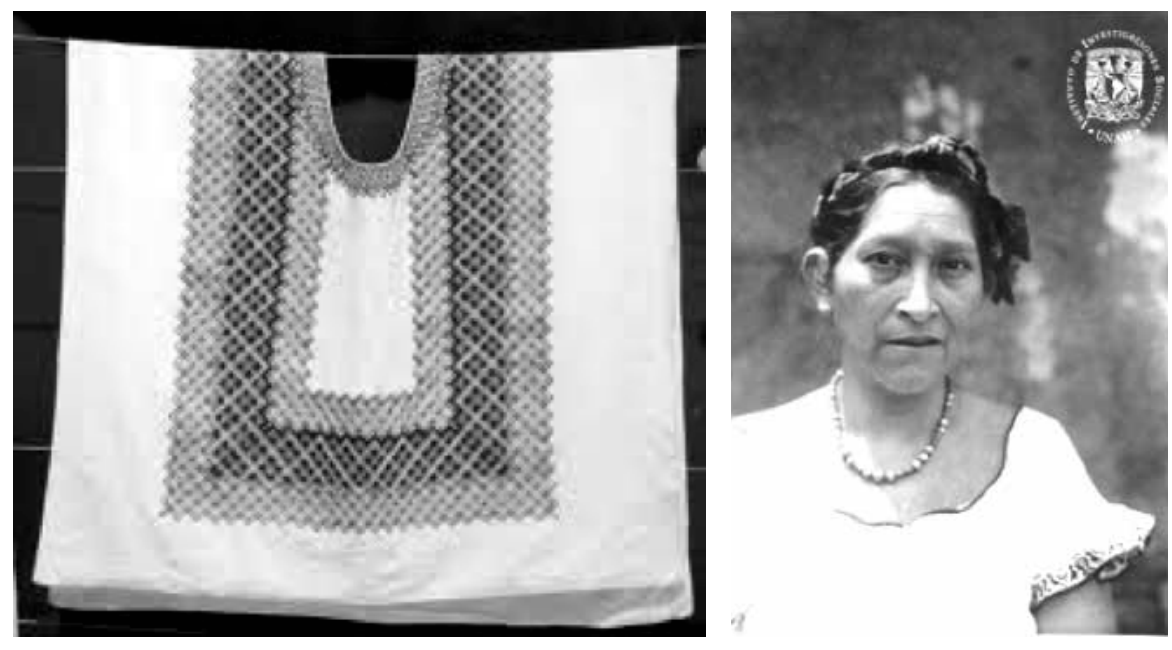

Huipil y mujer con blusa zoques. (Fotos: Karen Elwell e IIS-UNAM).

ECONOMÍA. La economía del grupo es parte de la organización social. política y religiosa. Como la de todas las etnias del país no puede ser analizada en términos de costo-beneficio ya que las comunidades indígenas mantienen procesos de reproducción defensa y adaptación a las condiciones económicas del país. En las actividades económicas del grupo zoque se hallan reflejadas características propias, tales como el uso de la lengua y el conjunto de valores, tradicionales y costumbres que forman una red permanente de relaciones familiares, económicas, religiosas y en ocasiones biológico-raciales o intergrupales reales o supuestas. Como en todas las zonas indígenas del estado, la explotación de los recursos del medio ambiente los está llevando a una depauperación, no sólo porque el grupo pretende satisfacer las necesidades básicas de la reproducción biológica y social, sino también porque en algunos casos tienen que destinar parte de su producción, o del excedente de la misma para adquirir en el mercado otros bienes que no se producen en la comunidad, apareciendo entonces los desiguales sistema de intercambio y comercialización. Aunque el área ocupada por los zoques contiene recursos naturales suficientes, (una extraordinaria región boscosa), los desmontes indiscriminados y la sobreexplotación de la madera, encaminados a crear terrenos de pastoreo, han puesto a muchas comunidades en condiciones de desventaja. Desde hace más de treinta y ocho años, los taladores de aserraderos chiapanecos han derribado bosques hasta dieciséis kilómetros dentro del territorio oaxaqueño, estableciendo inclusive núcleos de población, uno de los cuales pretende ser municipio ya reconocido, contra toda justicia, por el gobierno del estado de Chiapas.

Dentro del grupo persiste la agricultura de subsistencia basada en la obtención de maíz mediante el sistema de roza. Esta apertura de claros en la selva ha sostenido el grupo, pero también ha causado daños a la vegetación y a los suelos del área. Un pequeño 
porcentaje de la población apoya sus actividades económicas con la producción limitada de café, un café de menor calidad que el producido en otras regiones, habiendo, también, una producción no registrada de enervantes. Los beneficios de la extracción de madera no llegan a las comunidades indígenas, y en el caso de los bosques de coníferas de Sierra Atravesada, su explotación y extracción se están realizando, como ya se señaló, a través de empresas madereras chiapanecas.
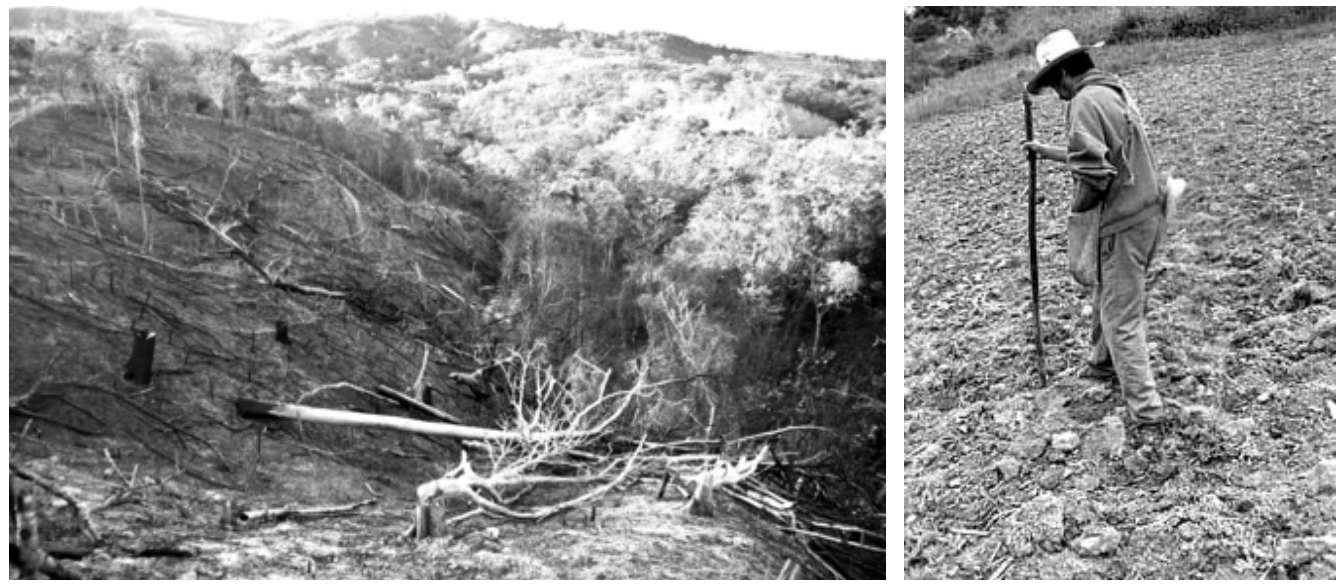

Tumba y quema, así como sembrador zoques. (Fotos: UNAM).
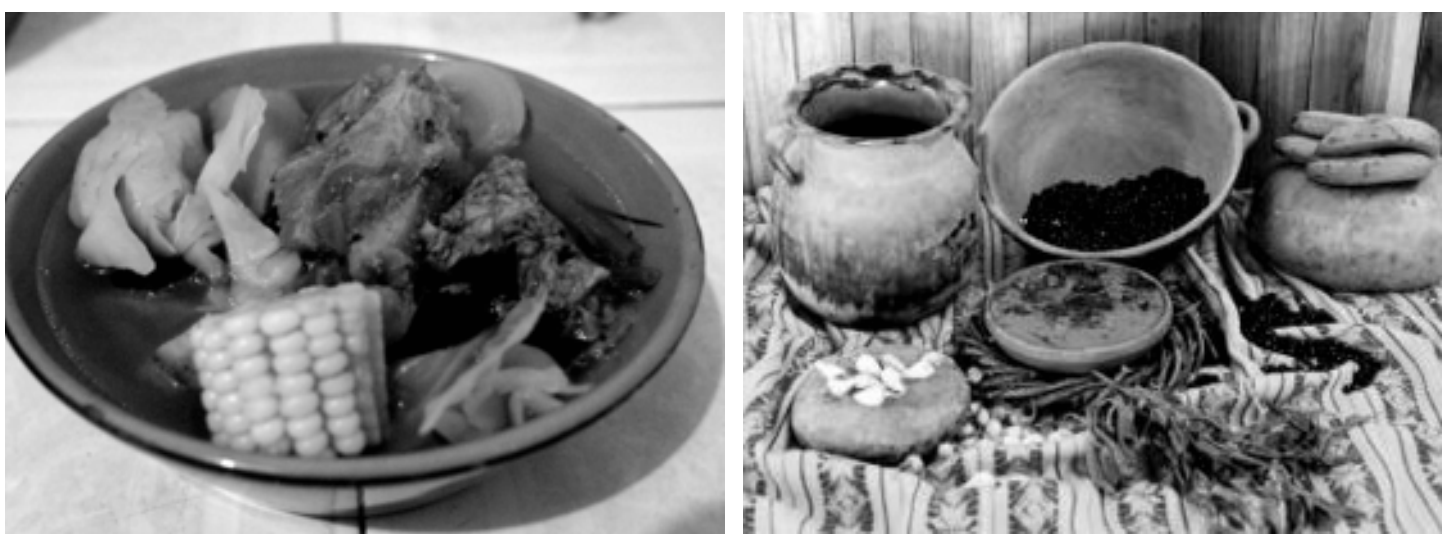

Comida zoque. Caldo de res y Tzata (platillo a base de frijol y plátano verde). (Fotos: Dirección de Turismo estatal).

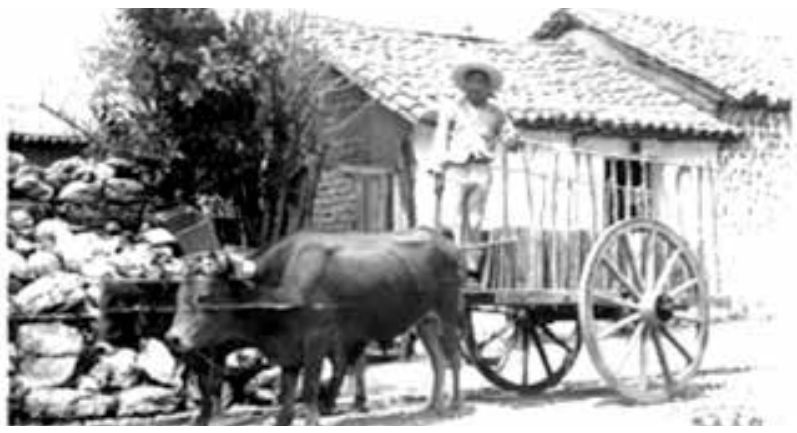

Carreta. San Miguel Chimalapa. (Foto IIS-UNAM). 
ARTESANIAS. En las comunidades Zoques persiste el bordado de huipiles sobre telas de algodón. En 1959 se registró una tejedora en telar de cintura. En ocasiones se conservan caparazones de armadillo, los que son vendidos para hacer adornos y máscaras.
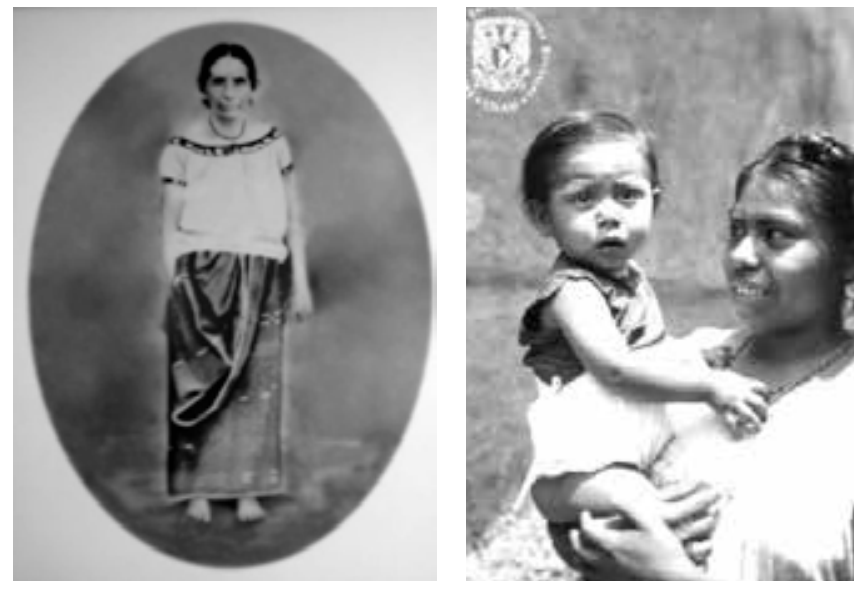

Mujeres zoques de 1890 y de 1965. (Fotos: Ayuntamiento de Copainala e IIS-UNAM).
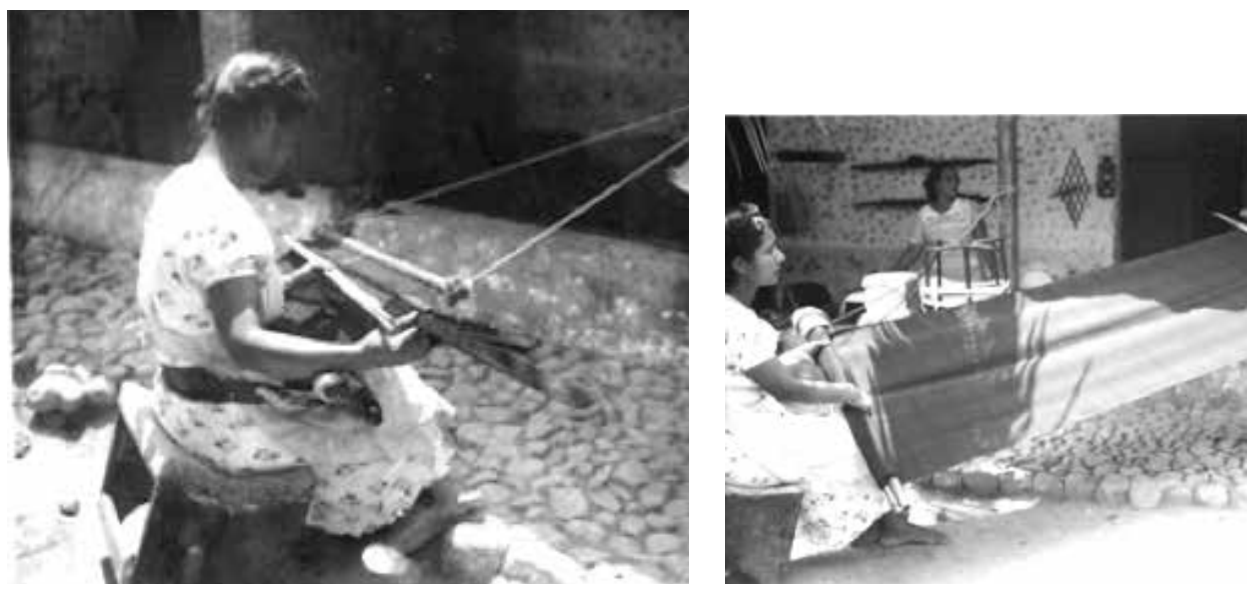

Hilandera y tejedora zoques. (Fotos: IIS-UNAM).

GANADERÍA. Hasta hace pocos años la ganadería en la región era una actividad complementaria fundamentada en muy pocas cabezas de ganado vacuno criollo. Con los desmontes practicados por las instituciones crediticias nacionales, y por los ganaderos de fuertes recursos económicos radicados en Matías Romero, la Colonia Istmeña, Jesús Carranza, Lorena y Acayucan, la ganadería extensiva ha ido adquiriendo importancia zonal. Sin embargo, los procesos de empaste han fracasado en alto grado debido al sobrepastoreo y a la ruptura del ecosistema selvático que imperaba en la región. Toda esta situación ha perjudicado gravemente a las comunidades indígenas, porque las tierras desmontadas y sobrepastoreadas perdieron su pasto inducido, se están erosionando, o bien han sido invadidas por pasto grama, el cual es perenne y absolutamente inútil, dado su bajo proteinaje, para desarrollar cualquier actividad prolongada, sobre todo ganadera. 
CAZA Y PESCA. Aunque la región ha sido particularmente rica en fauna silvestre, los desmontes indiscriminados y el manejo irracional de la cubierta vegetal, han extinguido o puesto al borde de la extinción a multitud de especies de animales. Actualmente han virtualmente desaparecido ya el mono saraguato, el tapir, el águila harpía y el senso (del que hubo manadas de más de 100 individuos), planteándose una situación crítica para el mono araña, el puma (circunscrito solamente a las crestas de Sierra Atravesada y con situación poblacional desplomada), el jaguar, el ocelote (ambos en el mismo caso), el tigrillo, el venado cola blanca, la guacamaya roja, el tucán real, el cojolite, el hocofaisán y dos especies de chachalacas. Tradicionalmente, para los indígenas Zoques la obtención de un animal para su consumo era visto como un complemento a la alimentación. La extinción de esos recursos priva a los indígenas de esa forma de sustento.

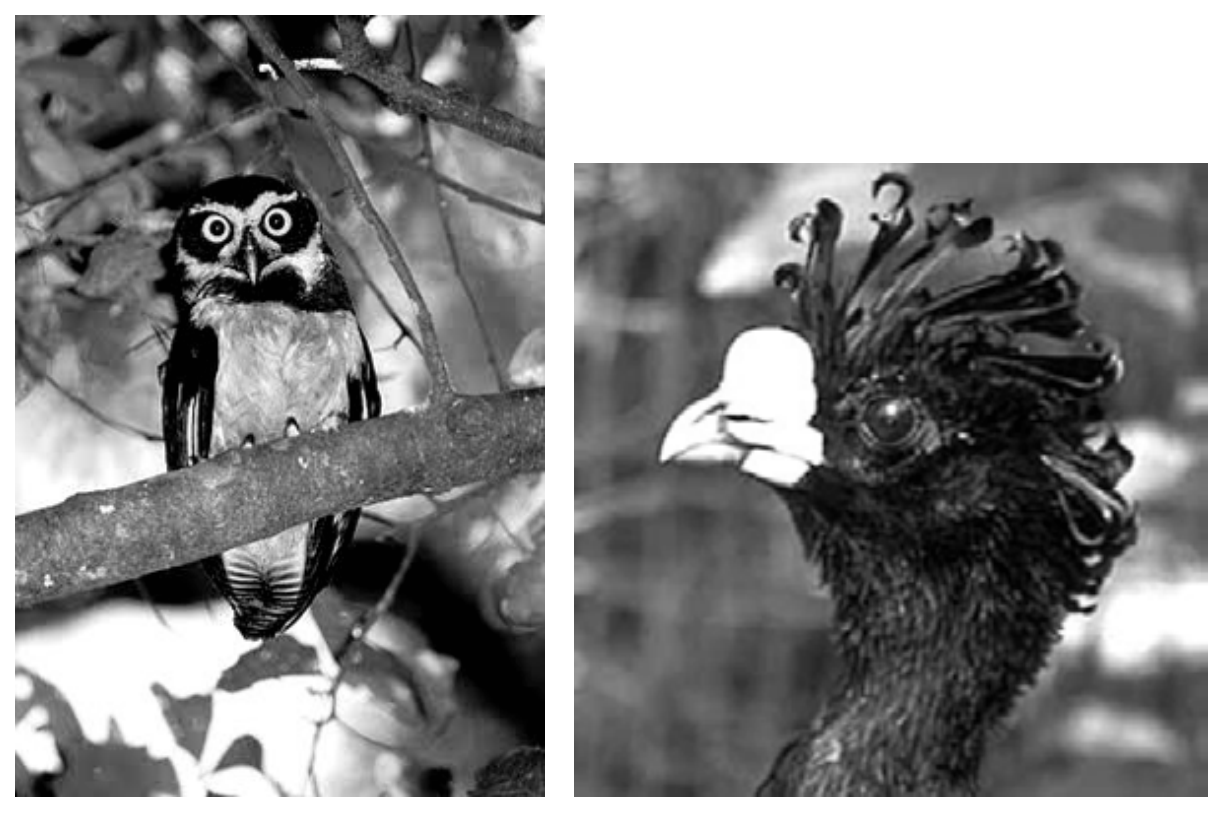

Buho de anteojos (Pulsatrix perspecillata) y Hocofaisán (Crax rubra)

(Fotos: Lorenia Tamborell e Instituto de Biología UNAM).

Puesto que la región queda inscrita dentro de una de las cuencas más ricas en escurrimientos acuíferos en todo el país, la riqueza piscícola de esos ríos es considerable. La obtención de peces mediante fisgas o pequeñas redes siempre ha sido una actividad complementaria para la alimentación regional, pero también ha sido frecuente el arrojar bombas de dinamita para obtener mejores resultados, actividad registrada desde $1955 \mathrm{y}$ que ha matado inutilmente muchos peces. La profundidad de los ríos permite el acceso de una fauna marina entre la que descuellan pequeños tiburones y rayas, a los que muy raramente se captura.

MERCADOS. Los únicos mercados regionales se localizan en Santa María y San Miguel Chimalapa. En ellos se encuentran desde la compra de bienes industrializados hasta el 
trueque de productos entre pequeños productores. Como la mayoría de los comerciantes son mestizos aculturados, con frecuencia las formas de intercambio son desiguales, con desventaja para los productores indígenas, quienes de esta manera padecen la extracción de sus productos o del producto de su trabajo por parte de los intermediarios, quienes, como parte de la sociedad urbana industrial del país son los máximos beneficiarios de los mismos.

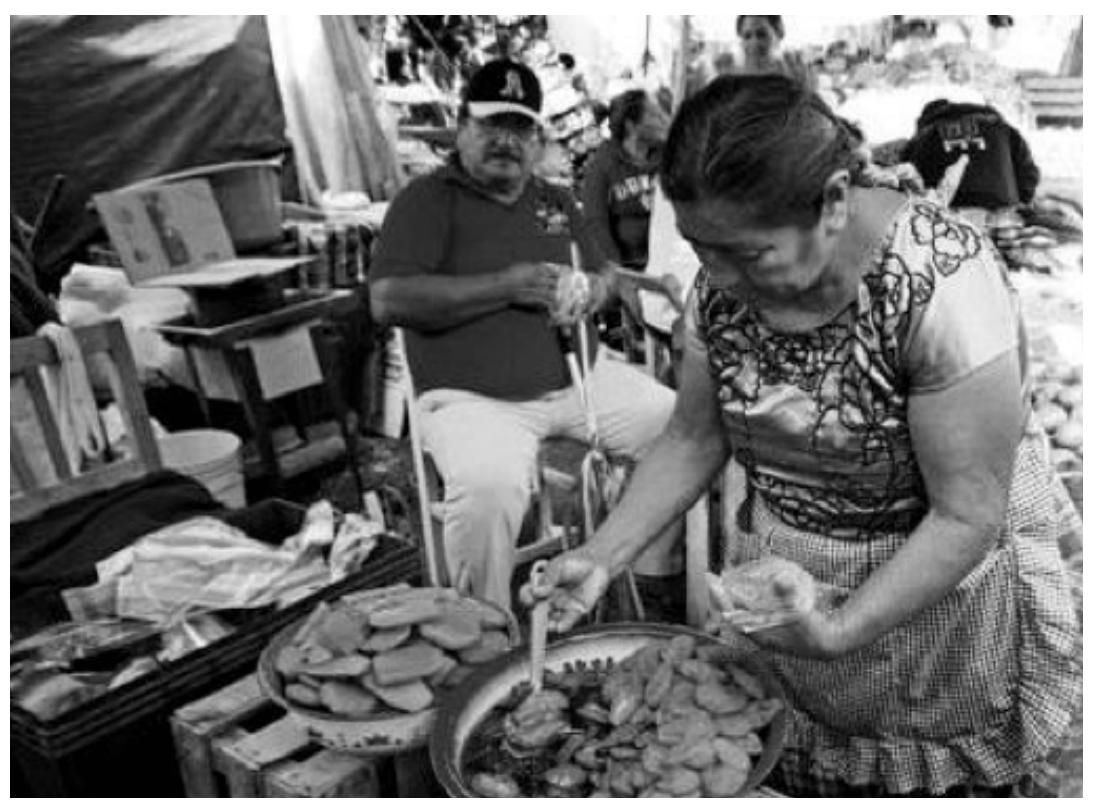

Mercado en los Chimalapas. (Foto: Ayuntamiento de San Miguel Chimalapa).

ORGANIZACIÓN SOCIAL. La sociedad zoque es patrilineal, patrilocal, monogámica y endogámica. La unidad es la familia, que está constituida por el padre, la madre y los hijos solteros: en torno a ella se encuentra una familia extensa constituida por los parientes consanguíneos y por afınidad. Para la selección matrimonial, los jóvenes entran en contacto en primer lugar (era frecuente la oportunidad de comunicarse cuando la joven iba a traer agua), existiendo un breve período de conocimiento. Cuando se formaliza el compromiso, el padre del novio, acompañado de un padrino, visita a los padres de la muchacha para solicitar su mano. Si se la dan fija la fecha de la boda y el novio compra el vestido de la muchacha. La celebración del matrimonio viene acompañada de una gran fiesta que en ocasiones se prolonga más de una semana. Los recién casados construyen una casa aparte con el apoyo de sus familiares y de parte importante de los vecinos de la comunidad. Si los padres de los contrayentes tienen recursos, les dotan con un pedazo de tierra para que la puedan trabajar. Es muy frecuente que los familiares consanguineos brinden su ayuda en los casos en que se producen nacimientos de hijos o defunciones dentro del seno familiar. La principal costumbre mortuoria entre los zoques consiste en el enterramiento extendido con la cabeza hacia el oriente, (porque es el punto cardinal de donde sale el sol) y después se practica el novenario. 


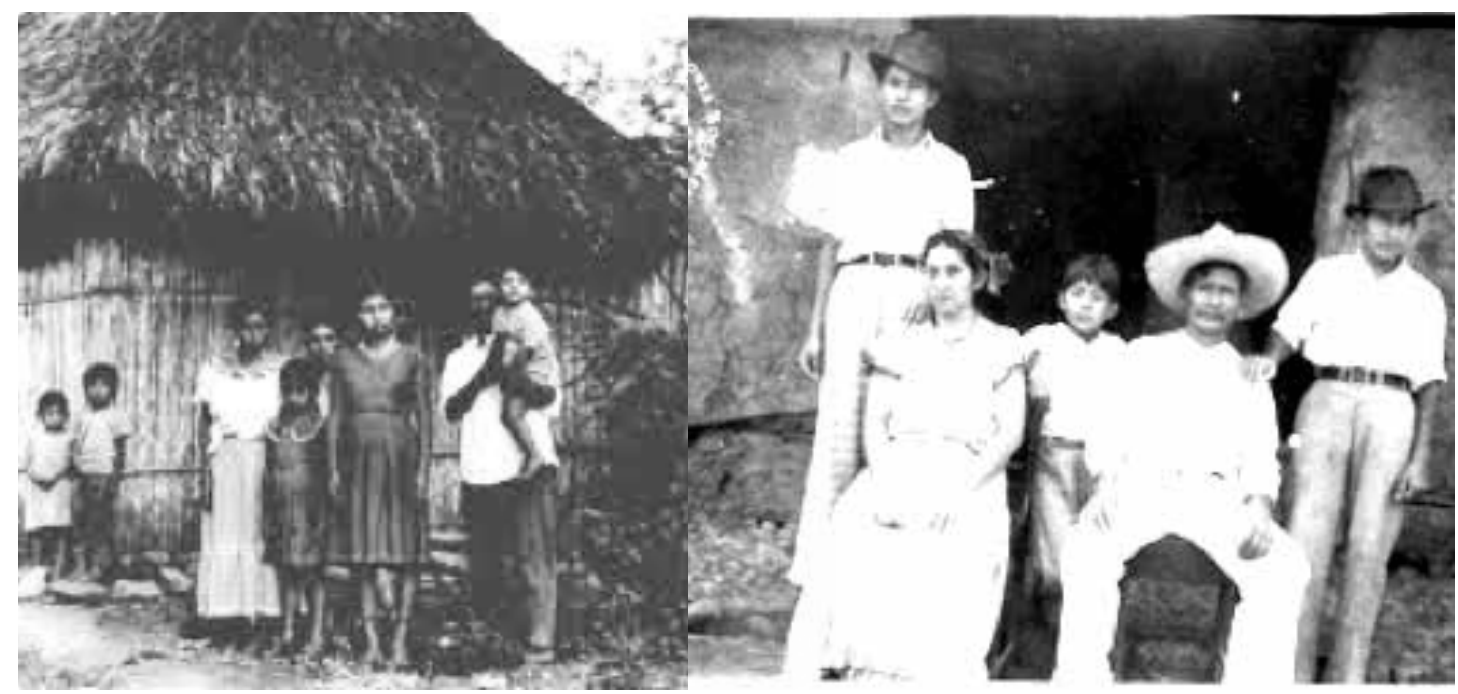

Familias zoques, tradicional y mestiza. (Fotos: IIS-UNAM).

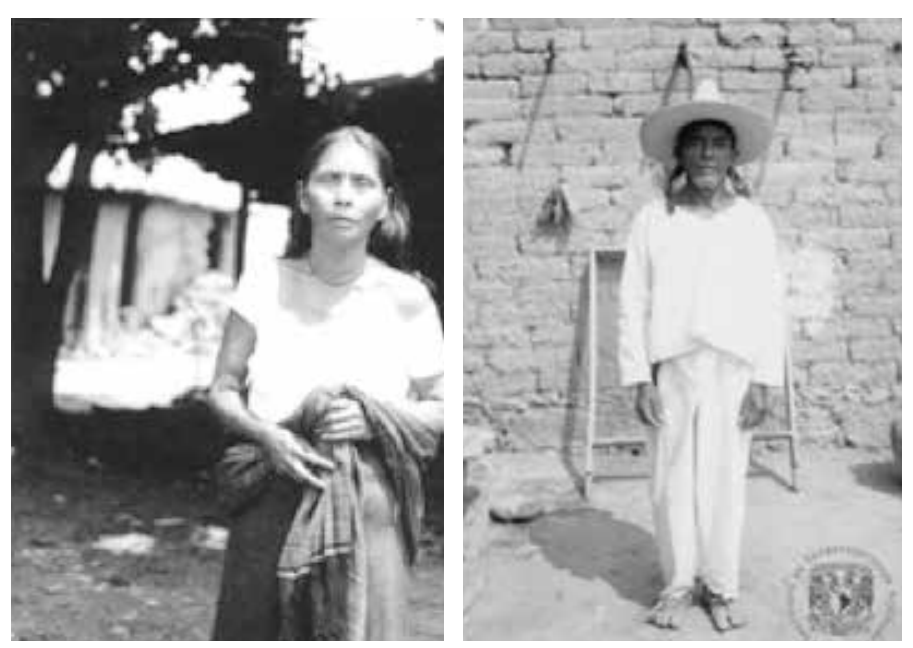

Mujer y hombre zoques. (Fotos IIS-UNAM).

GOBIERNO. Al lado del aparato jurídico, político-constitucional nacional entre los zoques coexisten formas tradicionales de gobierno indígena y un derecho de costumbre. Todas las comunidades indígenas son obedientes a las decisiones políticas que adopta el gobierno del estado, y en las Agencias Municipales y de Policía, los nombramientos recaen en las personas de mayor edad y de mayor experiencia, de quienes se considera pueden ejercer mayor control.

Existe ceremonia de transmisión de mando y el símbolo es un bastón con borla cuya representatividad es profundamente respetada.

Entre la etnia zoque, existen jerarquías por edad y se ocupan los puestos directivos sólo después de haber ocupado los de menor jerarquía. 
FESTIVIDADES. El calendario ritual prehispánico y el calendario agrícola que aún persiste en algunos grupos étnicos fue sustituido en a época colonial por el calendario católico. De esta forma, en a actualidad la mayoría de las festividades legadas al ciclo agrícola o al calendario ritual, han sido interpretadas en términos del santoral y el ritual católico. Estas festividades son el Carnaval. La Semana Santa. El Día de Muertos y el Año Nuevo. Las festividades entre los zoques no se sustraen a estas características. El 25 de Abril se festeja a San Marcos. La Semana Santa es una fiesta movible y el 12 de Diciembre se festeja la Virgen de Guadalupe. Dentro de las fiestas, en las comunidades se realizan danzas. La principal de ellas es una danza mixta denominada Yomotzé, que consiste en un zapateado ejecutado por dos filas de danzantes, una de hombres y otra de mujeres que se entrecruzan. Los hombres llevan unas espuelas especiales con los que producen un tintineo que acompaña al ritmo. Otra danza registrada es el Mequé, el cual se baila en las festividades correspondientes a la época de la cosecha. Por otra parte, se documenta que hace sesenta años, en Santa María Chimalapa existió un grave problema de alcoholismo, exacerbado por el comercio de alcohol adulterado realizado por mestizos zapotecas.

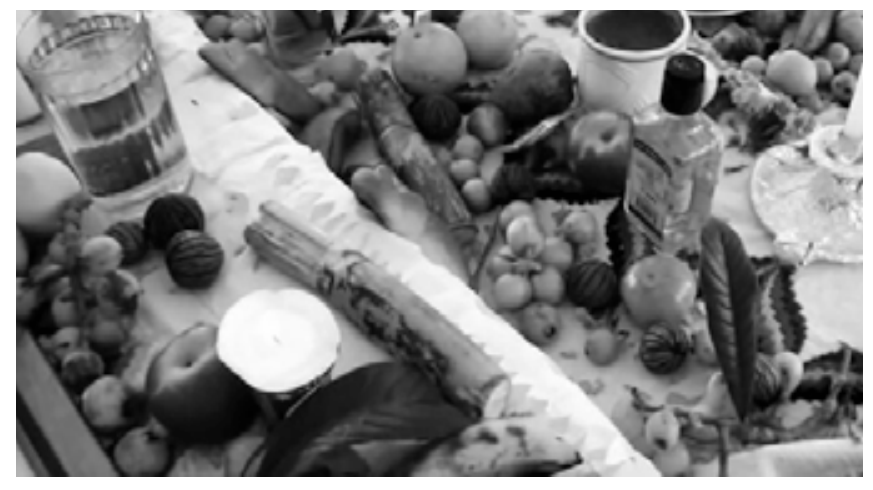

Altar de Muertos. Chimalapas. (Foto: Dirección estatal de turismo. Oaxaca).

ORGANIZACIÓN RELIGIOSA. En el grupo, la organización religiosa presenta la institución de la mayordomía. La persona que adquiere dicho compromiso suele ser ayudada por otros miembros de la comunidad. La religión mayoritaria es la católica, y la practica más del 90\% de la población, aproximadamente 13,500 personas. En los últimos 30 años ha comenzado la infiltración de pequeños grupos de religión protestante (Pentecostales), y los Testigos de Jehová. Esto ha planteado divisiones entre los indígenas, y como consecuencia de ellas, tensiones intergrupales que han hecho perder cohesión a la etnia, habiéndose dado el caso de exclusiones totales de individuos por no pertenecer a determinada religión. Ha persistido la creencia de que las enfermedades son causadas por brujería.

MEDICINA Y MAGIA. En el grupo subsisten algunas creencias mágicas, y en parte de las comunidades y rancherías subsisten brujos, brujas y hechiceros. Estos son personajes de carácter folklórico que controlan algunos aspectos de la comunidad y que rigen aspectos psicológicos de los miembros de la misma. 
Los actos de curación mágica consisten en la extracción del cuerpo del enfermo, por parte del brujo, de hormigas o gusanos como causantes de la enfermedad. Dentro del grupo se atribuye a los brujos el poder de la transformación en animales tales como gatos o perros y, así mismo, se considera que existen los espantos y que el espíritu de los muertos regresa a la tierra a perturbar a los que quedan vivos. Muchos de estos rasgos fueron aprovechados por los misioneros en el estado de Chiapas para inducirles prácticas cristianas por medio de oraciones.

EDUCACIÓN. Lo disperso de los asentamientos ha hecho que varias comunidades no hayan contado con una escuela sino hasta la década de los 20s del Siglo XX, por ello el nivel escolar de la población zoque fue siempre muy bajo, siendo muy pocos los jóvenes que pueden llegar a los ciclos medios, cuyas escuelas se encuentran en las dos cabeceras municipales y en Matías Romero, donde hay un Colegio de Bachilleres. Recientes programas han dotado de jardines de niños y escuelas primarias a las comunidades comunicadas.

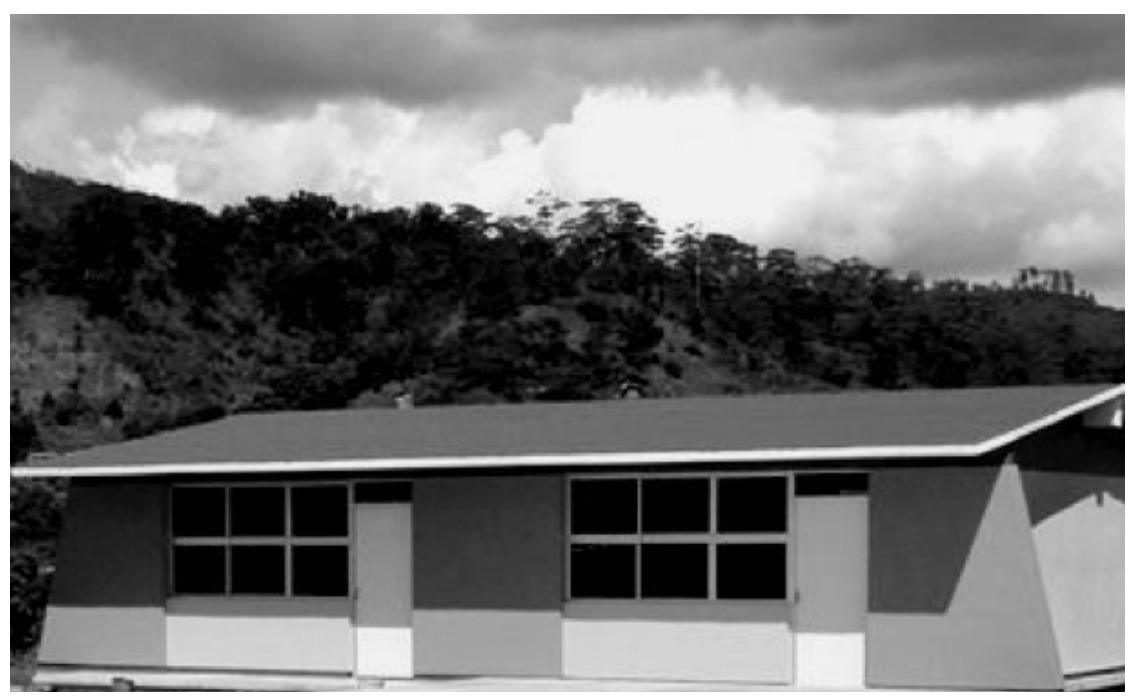

Escuela en San Miguel Chimalapa. (Foto: Ayuntamiento de San Miguel Chimalapa).

\section{BIBLIOGRAFÍA}

Acevedo Conde, María Luisa. 2007 “Apuntes sobre los Huave”. En: Revista A CONTRAGOLPE. No 5. Carteles Editores. Oaxaca, Oax. 2007.

Acuña, René. 1982 RELACIONES GEOGRAFICAS DEL SIGLO XVI. VOLS. II y III. Diócesis de Antequera. Instituto de Investigaciones Antropológicas. UNAM. México, D F. 1982. Arroyo, Esteban. 1961 LOS DOMINICOS. FORJADORES DE LA CIVILIZACION OAXAQUEÑA. T. II. "Los Conventos”. Impresión Particular. México, D F. 1961.

Báez-Jorge, Félix. 1973 LOS ZOQUE POPOLUCAS. ESTRUCTURA SOCIAL. Instituto Nacional Indigenista. Serie de Antropología Social No 18. México, D F. 1973. 
Barabas, Alicia Mabel. 1990 "Rebeliones e Insurrecciones Indígenas en Oaxaca. La Trayectoria Histórica de la Resistencia Étnica”. En: ETNICIDAD Y PLURALISMO CULTURAL,LA DINAMICA ETNICA EN OAXACA. Coords; Alicia Barabas y Miguel Bartolomé. CNCA. México, D F. 1990.

Bartolomé, Miguel. 1997 GENTE DE COSTUMBRE Y GENTE DE RAZON. LAS IDENTIDADES ETNICAS EN MEXICO. Siglo XXI Editores. INI. México, D F. 1997. 1996 La Herencia Olvidada. Los Pueblos Zoques de Oaxaca”. En: LA PLURALIDAD EN PELIGRO. PROCESOS DE TRANSFIGURACION Y EXTINCION CULTURAL EN OAXACA. INA. INI. México, D F. 1996. Bartolomé, Miguel Angel y Barabas, Alicia. 1993 HISTORIA ZOQUE. Serie Historias Étnicas, No 7. INAH. México, D F. 1993.

Basauri, Carlos. 1940 "Los Zoques”. Reed 1990 En: LA POBLACION INDIGENA DE MEXICO. Tomo I. Instituto Nacional Indigenista. SEP. México, D F. 1990.

Berthé, Jean Pierre. 1959 “Las Minas de Oro del Marqués del Valle en Tehuantepec”. En: HISTORIA MEXICANA. Julio de 1958. El Colegio de México. México, D F. 1959. Ciudad Real, Antonio de.

1993 TRATADO CURIOSO Y DOCTO DE LAS GRANDEZAS DE LA NUEVA ESPAÑA. Instituto de Investigaciones Históricas. UNAM. México, D F. 1993.

Cruz, Wilfrido C. 1982 OAXACA RECONDITA. Gobierno del Estado de Oaxaca, Oaxaca, Oax. 1982.

De Ávila Blomberg, Alejandro y García, Miguel Angel. 1997 "La Reserva Campesina en Chimalapa. La Alianza de Comuneros y Ecologistas”. En: SEMILLAS PARA EL CAMBIO EN EL CAMPO. Luisa Paré, et al. coordinadores. IIS. UNAM. México, D F. 1997.

Foster, George R. 1962 “The Mixe, Zoque, Popoluca”. En: HANDBOOK OF MIDDLE AMERICAN INDIANS. ETHNOLOGY. Vol 7. University of Texas Press. Austin \& London. 1963. Gerhard, Peter. 1986 GEOGRAFIA HISTORICA DE LA NUEVA ESPAÑA. Instituto de Geografía, UNAM. México, D F. 1986.

González Martínez, Alfonso. 1986 RELACION DE SANTA MARIA CHIMALAPA. Colección Agua Quemada. Casa de la Cultura, Gobierno del Estado de Oaxaca. Oaxaca, Oax. 1986. González R, Álvaro. 1992 "Los Zoques de Oaxaca o el Derecho a la Autonomía Regional” En: POBLACION Y FUTURO. Año 3,No 10. Junio de 1992. Oaxaca, Oax.

Muñoz Muñoz, Carlos. 1977 CRONICA DE SANTA MARÍA CHIMALAPA. (En las Selvas del Istmo de Tehuantepec). Ediciones Molina. San Luis Potosí. México. 1977.

Navarrete Cáceres, Carlos. 1970 "Fuentes para la Historia Cultural de los Zoques". En: ANALES DE ANTROPOLOGIA. VOL. VII. Instituto de Investigaciones Antropológicas. UNAM. México, D F. 1970.

Nigh, Ronald y Rodríguez, Nemesio. 1995 TERRITORIOS VIOLADOS. En: PRESENCIAS. INI, CNCA. México, D F. 1995.

Velasco Toro, José. 1975 "Perspectiva Histórica”. En: LOS ZOQUES DE CHIAPAS. Coord. Alfonso Villa Rojas. Et al. INI, CNCA. México, D F. 1975. Vocalía Ejecutiva. Chimalapas. 1989 TEQUIO POR CHIMALAPAS. Gobierno del Estado. Oaxaca, Oax. 1989. 



\section{CHONTALES}

Autodenominación: slijuala xanuc, tsame, lajltyaygi.

Sinónimo en su lengua: lalhtaiqui, tequixtlateco, huamelulteco, Significado: Los que somos hermanos.
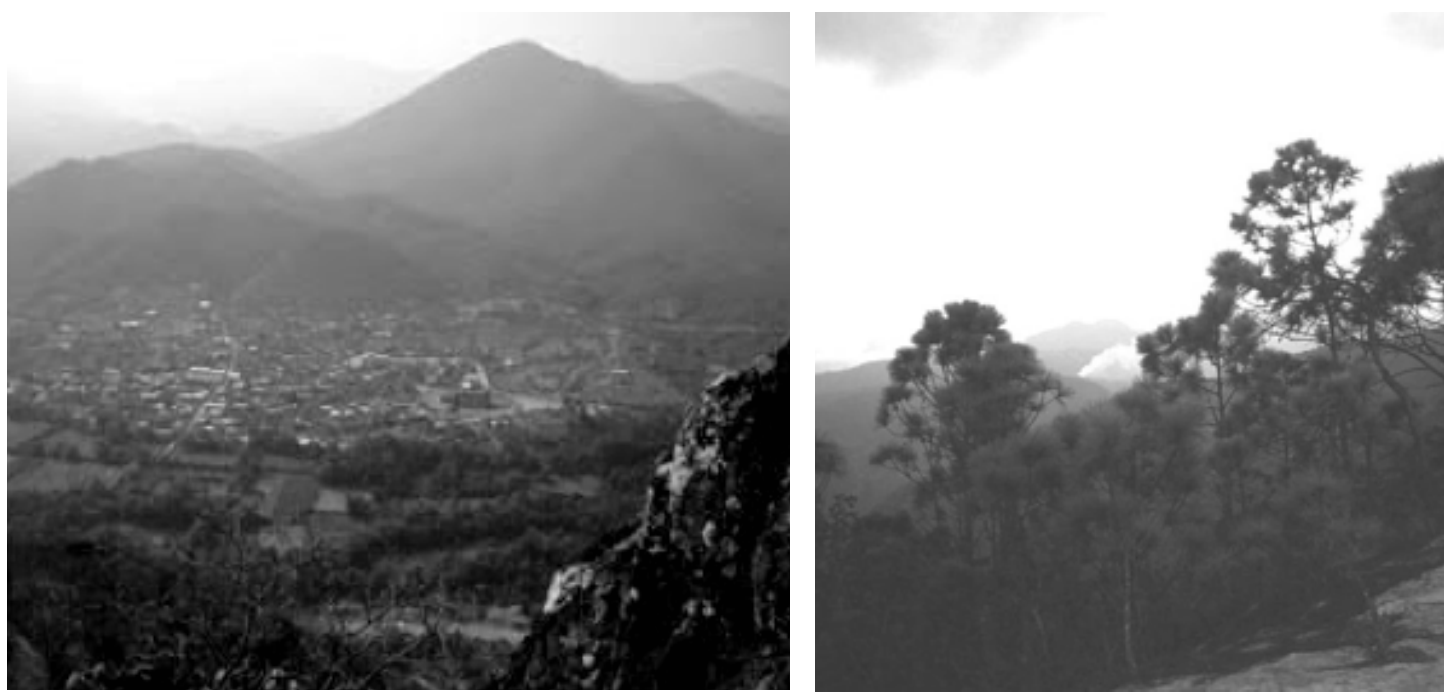

Valle de Asunción Tlacolulita y Bosque de coníferas. Zona chontal alta. (Fotos: Saul Cabrera Toledo y Ayuntamiento de Santa María Ecatepec).

\section{GRUPO CHONTAL}

UBICACIÓN GEOGRÁFICA. El grupo chontal, que algunas veces fue también llamado Tequixtlateco, sobre todo en la zona costera, se encuentra distribuido en la porción centro sureste del Estado de Oaxaca. Su área ocupacional se inscribe entre los paralelos $15^{\circ} 50^{\prime}$ y $16^{\circ} 40^{\prime}$ de latitud norte y los meridianos $94^{\circ} 45^{\prime}$ y $95^{\circ} 300^{\prime}$ de longitud occidental. El territorio es muy agreste y se compone de montañas con alturas sobre el nivel del mar, ligeramente inferiores a los 2000 metros, con muy pocas crestas superiores a esa altura. Dichas montañas constituyen el último conjunto orográfico de la Sierra Madre del Sur antes de su unión con la Sierra Madre de Oaxaca para formar la Sierra Atravesada a partir de la Cuenca del Río Tehuantepec. La totalidad de esas montañas presenta escurrimientos que vierten a dos cuencas. La mayor parte lo hace a la cuenca del Río Tehuantepec y una pequeña parte de la zona baja vierte a pequeñas cuencas cortas cuyos ríos desembocan en el Océano pacífico en el sector de Huamelula-Astata. 
La diversidad climática del área es grande pero la casi totalidad de los climas son templados subhúmedos y templados semisecos con lluvias en verano. Las partes altas presentan bosques de coníferas y en las regiones de alturas medias, así como la costera hay selva media caducifolia. La nubosidad es relativa en las partes altas debido a la condensación que se provoca por las masas de aire caliente que caracterizan la cuenca baja del Río Tehuantepec. Los suelos son producto de desintegración de rocas ígneas y metamórficas (gneis) muy antiguas y contienen alternadamente zonas de migajón negro y de arenas silíceas ricas en mica. Dichos suelos tienen muy relativo potencial agrícola pero permiten el desarrollo y la conservación de bosques.

IDIOMA. La lengua chontal, de acuerdo con estudios muy recientes, pertenece al Grupo Hokano Meridional (al que pertenecen el Cochimí y el Kiliwa), Tronco Yumapacua, Familia Chontal. Es una lengua Hokana, fuertemente relacionada con enclaves nahuas de ese origen, que parecen haber existido en la región, y en toda la costa, pocas decenas de años antes de la Conquista, ya que es visible una influencia tolteca o proto-tolteca a lo largo de casi toda la costa mexicana del pacífico. En la actualidad existen dos variantes dialectales no inteligibles entre sí, que han permitido establecer una diferenciación dentro del grupo en Chontales de los Altos y Chontales de la Costa, con el Tequixtlateco, aparentemente ya extinto, que se habló en las laderas bajas costeras de la sierra. Actualmente la lengua es hablada por aproximadamente 4700 personas distribuidas en poblaciones sumamente marginadas. En las localidades con mayor comunicación se esta perdiendo totalmente.

ANTECEDENTES ARQUEOLÓGICOS E HISTORICOS. El territorio Chontal contiene una importante cantidad de vestigios arqueológicos que comenzaron a ser estudiados en los reconocimientos de 1959 de los arqueólogos Gabriel de Cicco y Donald Brockington, los que revelaron sitios con ocupaciones diversas y cerámicas de desgrasante grueso.. Más tarde ha habido nuevas exploraciones, labor que ha estado a cargo de los Arqueólogos Roberto Zárate Morán y Peter C. Kroefges. Zárate en Tequisistlán y la parte alta y Kroefges en la zona de Astata-Huamelula, seguidos por un Proyecto de Reconocimientos Superficiales, de amplia extensión, que ha llevado a cabo el Arql. Danny Zborever, y que ha incrementado los conocimientos sobre el desarrollo cultural del área, señalando ocupaciones de la etapa Militarista y de la Colonial Temprana.

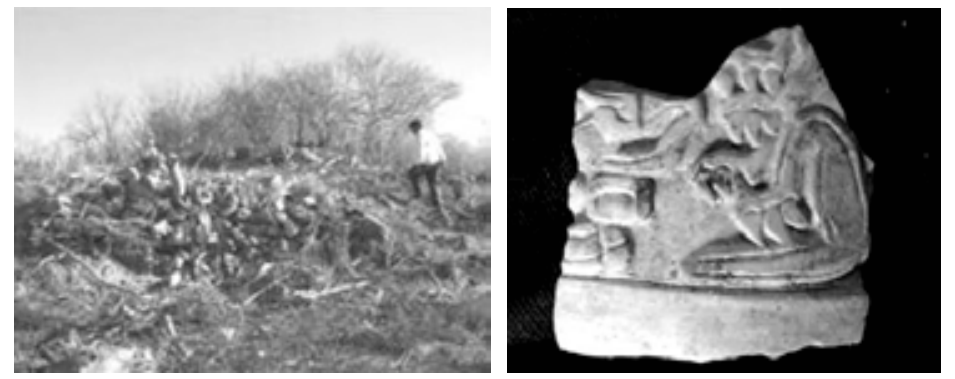

Montículo arqueológico y cerámica ceremonial chontales (Fotos: Arqls. Danny Zborover y Peter C. Kroefges). 
En el Valle de Río de Tequisistlán se han encontrado asentamientos formativos fundamentados en actividades agrícolas incipientes. En la costa, asentamientos Clásicos y Postclásicos, es decir, de las Etapas de los Señoríos Teocráticos y de los Militaristas. Durante los siglos anteriores a la conquista la región recibió influencias, muy posiblemente comerciales, tanto de los grupos de filiación mayense (probablemente zoques) como de la cultura zapoteca del centro de Oaxaca, para después, durante el periodo postclásico, y en la zona alta, ser área de choque entre los diferentes principalatos que siempre rodearon la zona, documentándose una terrible guerra chontal-zapoteca. De ese período procede la leyenda del guerrero imbatible Fane Kantsini (tres colibrí), siempre vencedor contra los zapotecos. Se desconoce el momento en que este grupo llegó a la región, pero ya participaba en alianza con los zapotecos en el momento de la intervención mexica encaminada a la conquista de Tehuantepec, y posteriormente fue junto con los zapotecas un grupo aliado de Tenochtitlan. Una tradición del grupo habla de un personaje (Cinco Garza), casado con una principal chontal, actuante en la zona y perteneciente a la nobleza tenochca, de quien señalan fue primo de Moctezuma, si bien puede haber un error porque "garza" no es nombre de día en el calendario azteca.

La Conquista del área Chontal fue difícil debido a la resistencia que ofreció el grupo. Su primer contacto con los españoles tuvo lugar en 1522 al llegar a la región las fuerzas del Capitán Pedro de Alvarado, el cual recibió una herida, se sabe que grave, en un enfrentamiento. Lo acompañaba Fray. Bartolomé de Olmedo. Posteriormente, en 1527, tuvo lugar la campaña de control por parte del Capitán Francisco Maldonado “El Ancho”, personaje muy próximo a Hernando Cortés, el cual solo pudo hacerlo de manera muy limitada. Posteriormente los españoles enviaron a un recaudador, Pedro de Piedra, con poderes extraordinarios, el cual, por su agresividad y saña, fue ejecutado, después de capturado, en acto de ajusticiamiento durante una ceremonia ritual. Este acto ocasionó que el grupo fuera considerado antropófago y por ello respetado más de 50 años, al cabo de los cuales los frailes dominicos intentaron la cristianización, siendo Fray Diego de Carranza el primero que convivió doce años con el grupo haciendo proselitismo. Sin embargo, como comprobación del interés de la orden dominica en la evangelización, el territorio chontal está constelado de iglesias, algunas de cal y canto y ahora varias en ruinas, hechas en los siglos XVI, XVII y XVIII, lo que revela la acción de varios frailes todavía desconocidos. En la costa, la primitiva población de Astata, inmediata a una bahía abierta, fue varias veces asaltada por piratas, y sus ruinas revelan la importancia arquitectónica de su momento.

En la región existieron mapas, lienzos y pictografías, dos de las cuales son el Lienzo de Tecczictlán (Tequisistlán) y Tecuatepec (Tehuantepec) y el de Jilotepequillo, que cubren un territorio chontal-zapoteco.

A partir de 1612, Diego de Álvarez quedó a cargo de la región chontal como encomendero, y a partir de ese momento hasta la consumación de la independencia el grupo mantuvo una situación de dependencia respeto a autoridades políticas de Tequisistlán y Nejapa. Durante el Siglo XIX miembros de la etnia participaron en los acontecimientos políticos y militares que tuvieron lugar en Tehuantepec y otras partes del estado. Hubo indí- 
genas de la etnia en los batallones ístmicos durante el proceso de la Revolución Mexicana. Posteriormente, en la zona alta, hubo una activa participación del Instituto Lingüístico de Verano, y en los Siglos XX y XXI muchos indígenas chontales, y significativamente dentro del magisterio, han aportado su adecuado esfuerzo en el proceso político y socioeconómico del país.

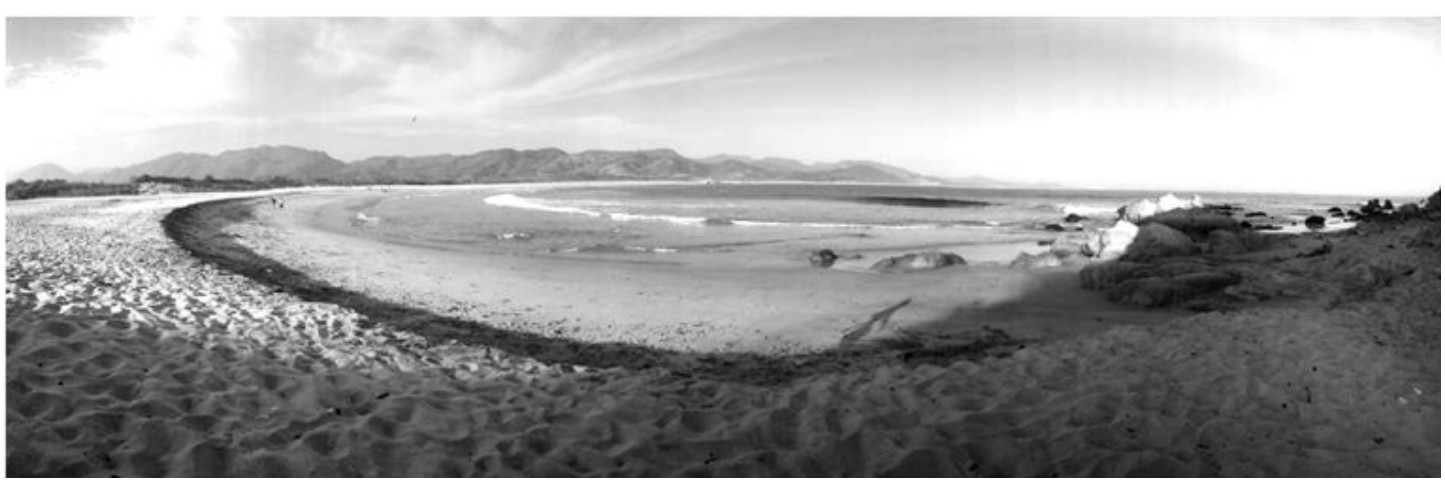

Playón de Astata. A la derecha, restos de lo que fueron los cimientos del extremo oriente del asentamiento español. (Foto: Blog de Chrisitom).

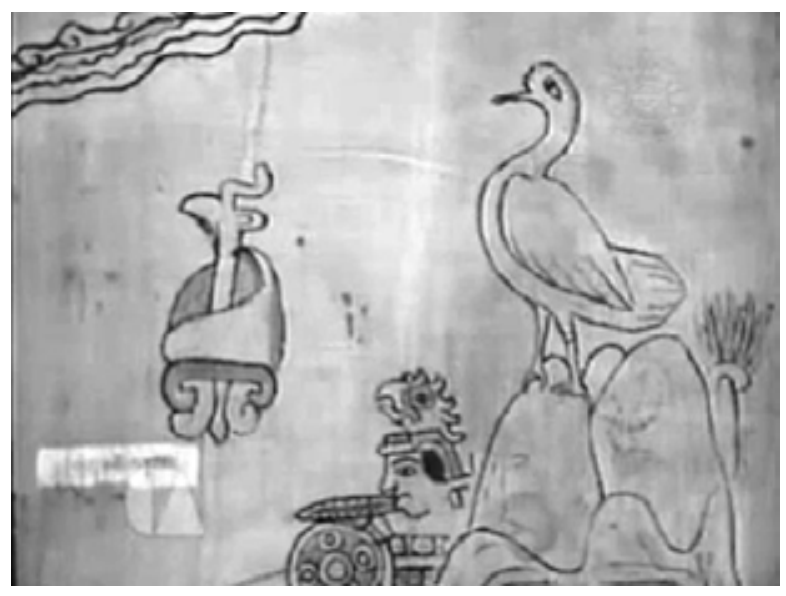

Detalle del Lienzo de Tecczictlán (Tequisistlán) y Tecuatepec (Tehuantepec), con el glifo de Astata (Lugar de garzas). (Foto: INAH).

DEMOGRAFÍA. Debido a dispersión de los asentamientos, no existe un registro exacto de la población chontal. En el momento presente (2014) se calcula que la etnia suma más de 55000 personas, y se tienen datos que la población está aumentando gradualmente. Por otra parte se produce un mestizaje con la población mestiza y zapoteca colindante, y por otro lado, existe una fuerte emigración. 

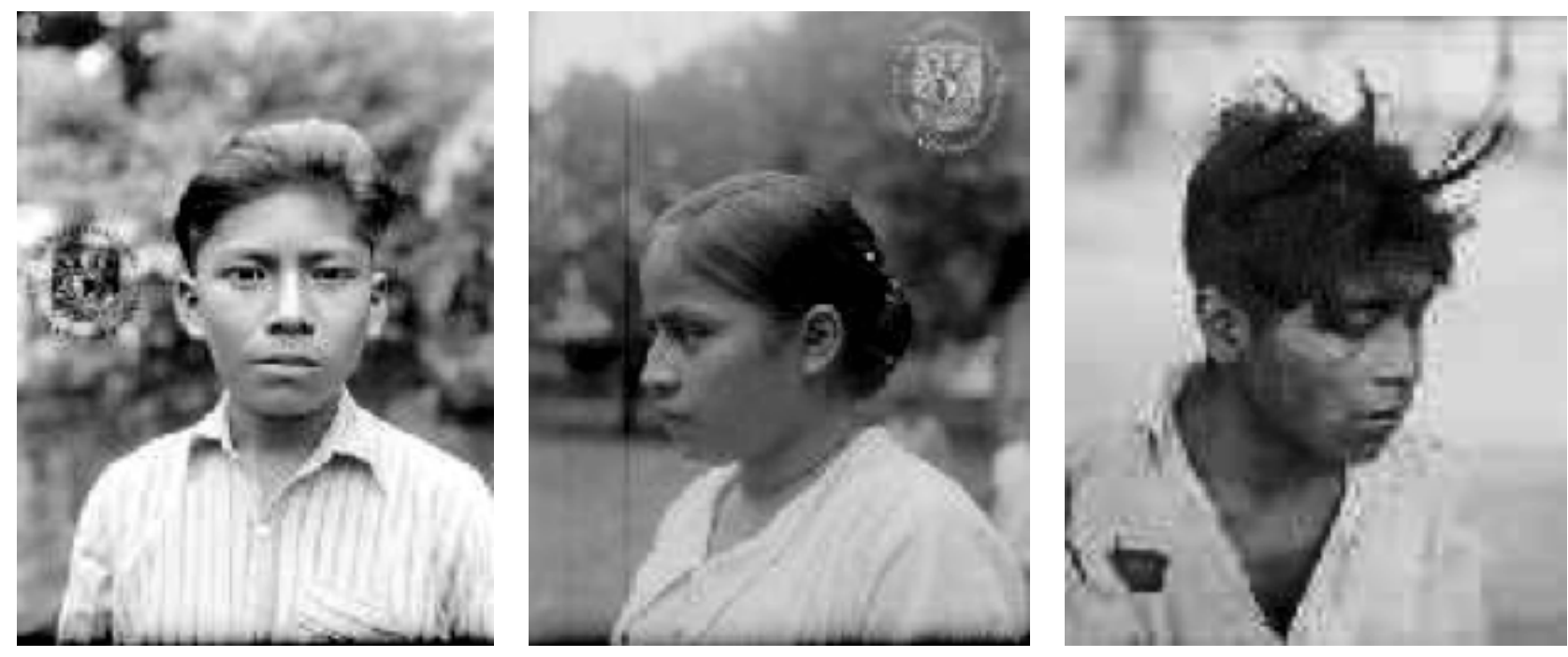

Jóvenes chontales. (Fotos: IIS-UNAM)

ACCESOS. La región alta chontal recibe su comunicación a través de la Carretera Federal $\mathrm{N}^{\circ} 190$ o Panamericana, de la cual parten caminos de terracería o reciente pavimentación hacia San Carlos Yautepec, San Bartolo Yautepec y Santa María Ecatepec. El resto de los caminos son brechas de penetración, brechas madereras y veredas.

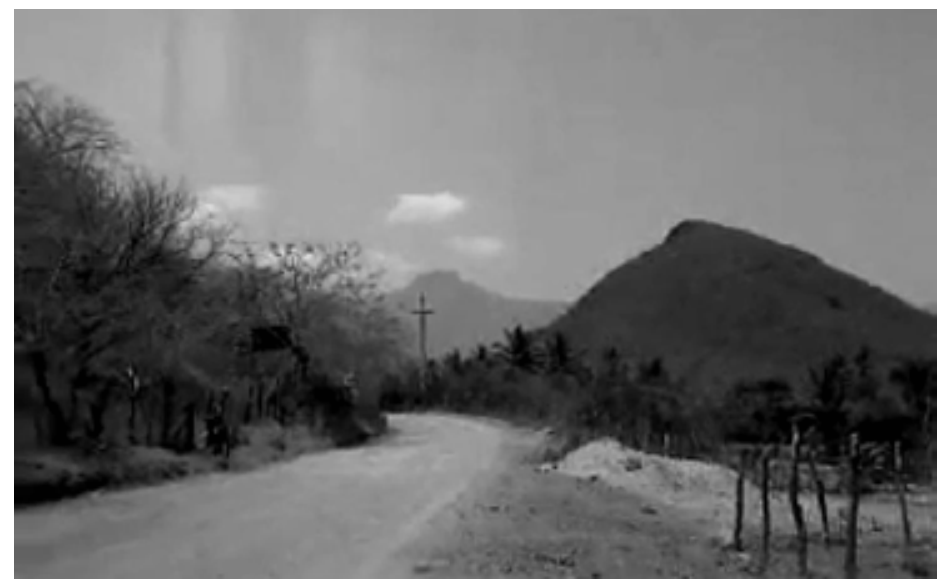

Carretera en Tlacolulita. (Foto: Dirección de turismo estatal).

La región chontal baja está comunicada por la Carretera Federal $\mathrm{N}^{\circ} 200$ o Costera del Pacífico, de la que en Astata se desvía un camino que va a Huamelula, Tlacolulita y Tequisistlán, así como a varias otras localidades. Los caminos históricos son varios. Uno unió San Bartolo Yautepec con Tequisistlán y otro San Bartolo Yautepec con San Juan La Jarcia hasta Nejapa. Ambos tuvieron afluencia de recuas. Hoy comunican ranchos.

En varias poblaciones del área existen pequeñas pistas de aterrizaje, varias de ellas gestionadas, desde hace más de 50 años, por catequistas e investigadores del Instituto Lingüístico de Verano. 
VIVIENDA. La población Chontal vivió en casas de horcones con techos de paja y pasto, de una o dos aguas y con paredes de varas trenzadas colocadas de manera horizontal, enlucidas con barro. La estructura de cada casa era de madera y las casas de agrupaban de tal manera que solía haber 4 o 5 en un solar. En las cocinas, los fogones, habitualmente de tres piedras, ocupaban una de las esquinas. En las poblaciones, los agrupamientos de casas ocupaban predios que se distribuían formando manzanas que permitían calles bien trazadas. Las casas solían ser de uno o dos cuartos, y habitualmente en cada uno vivía una familia nuclear. La promiscuidad era muy amplia y con suma frecuencia la familia dormía junto con animales domésticos. En las poblaciones mas lejanas las casas estaban más dispersas y, las casas aisladas, que se encuentran en zonas muy escabrosas de las montañas, pertenecían habitualmente a personas dedicadas a la caza o a cultivadores totalmente marginados. Desde hace unos 30 años, se hacen casas de ladrillo y últimamente de block, teja y estructura de concreto, como resultante de las remesas de los emigrados.
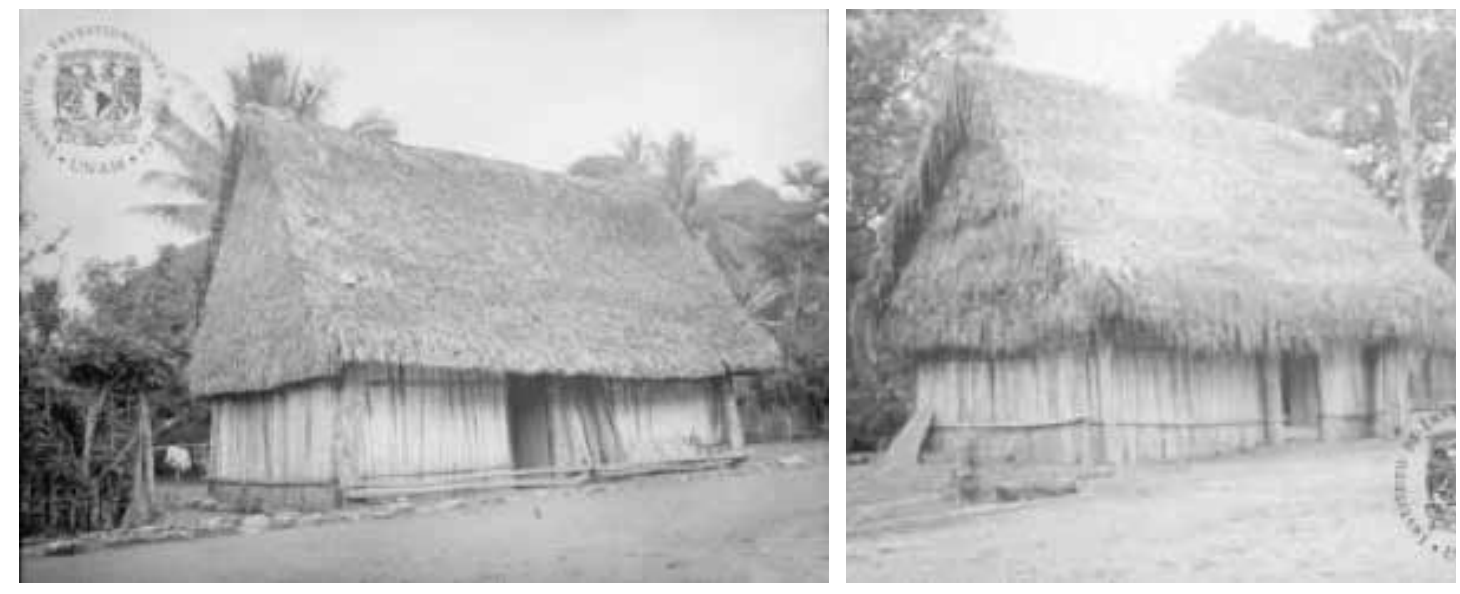

Casas tradicionales chontales. (Fotos IIS-UNAM).

INDUMENTARIA. Desde principios del siglo XX se perdió la indumentaria masculina, que se componía de camisa y calzón de manta. Las mujeres usan un huipil de colores suaves rosas o rojos, frecuentemente decorado con motivos geométricos y una falda enrollada de colores negro o azul con frecuencia muy decolorados, muy relacionado con el huipil zapoteca ístmico. Ocasionalmente las mujeres portan rebozo y un turbante blanco. Ambos sexos usan huaraches y sandalias. En la actualidad la ropa de fabricación industrial ha penetrado profundamente en el grupo y ha desplazado en alto grado a la tradicional.

Huipiles. Colección: Sra. María Luisa Audiffred. (Fotos del autor (1982) y CONACULTA).

ECONOMÍA. La economía del grupo es de subsistencia basada en el cultivo del maíz, el frijol y la calabaza mediante el sistema de roza. Es una economía enmarcada dentro de la organización integral del grupo, el cual mantiene mecanismos de adaptación, cada vez más frágiles, a las condiciones económicas del país. Como en todas las zonas deprimidas del mismo la explotación inadecuada de los recursos del medio ambiente, en su casi total 
destrucción ha llevado el grupo chontal una situación de extrema pobreza que se agudiza porque el grupo ya no puede satisfacer sus necesidades básicas debido a que no produce lo suficiente y casi no tiene excedentes para poder obtener los artículos que no se producen en su región. No obstante esta situación el indígena chontal se ve obligado a vender parte de lo que produce para obtener aquello que le hace falta. Y es precisamente en estas operaciones de compraventa en las que se hacen presentes los desiguales sistemas de comercialización. Puesto que la economía chontal es agrícola, y de autosuficiencia, la mayor parte de lo producido es consumido en el ámbito de la familia productora, y en el caso de la producción de fruta, ésta frecuentemente se destina a la venta. En general la tierra es comunal y puede usarse prácticamente una roza con el consentimiento del Consejo Municipal de Autoridades. Sólo en el caso de los cada vez más extensos sembrados de maguey mezcalero, la tierra tiende cada vez más a la privatización.
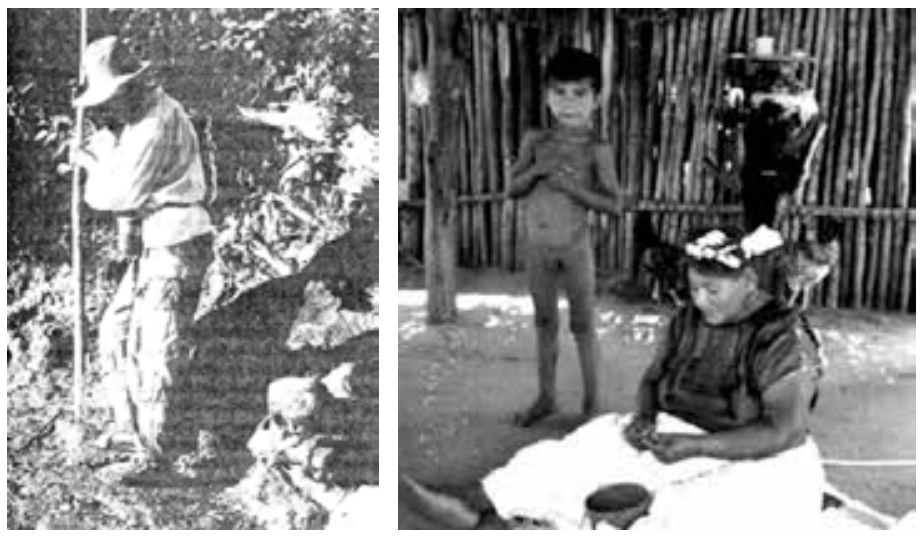

Sembrador con coa (1938) y Mujer desgranando. (Fotos: Carlos Basauri y Antonio Torres Rodríguez).

En algunas comunidades existen pocos artesanos que desempeñan algunos oficios, principalmente la carpintería, la alfarería, la manufactura de canastas y, en muy pocos casos la hechura de instrumentos musicales. El comercio se practica con el área de Tehuantepec, y en esta actividad, así como en la manufactura de cerámica, participa toda la familia. En algunos casos hombres de las comunidades han salido a trabajar a las regiones zapotecas del istmo y a otras del país, principalmente a las fincas cafeteras del Soconusco, con el objetivo de ganar dinero para poder adquirir armas de fuego y municiones, elementos que han sido importantes para desarrollar la caza como actividad complementaria, y recientemente se inició la emigración hacia el norte de México y los EE UU.

CAZA Y PESCA. Debido a las características climáticas y montañosas de las zonas chontales Alta y Baja, la región es particularmente rica en monte bajo de hojas ramoneables $\mathrm{y}$, por consiguiente, de varias especies de fauna silvestre, principalmente del venado cola blanca, del que se documentan altas concentraciones. Hasta hace aproximadamente 30 años los animales silvestres constituían un refuerzo a la dieta del indígena de la región. En los últimos tiempos la región chontal se ha visto fuertemente depredada por partidas de 
cazadores profesionales y deportivos que han ocasionado daños al proceso de repoblación de varias especies animales. Aunque la cuenca del río Tehuantepec contiene varios tipos de peces aprovechables, sólo en la zona de Tequisistlán se práctica una pesca limitada con anzuelo y pequeñas tarrayas. Los fondos de los ríos son pedregosos.
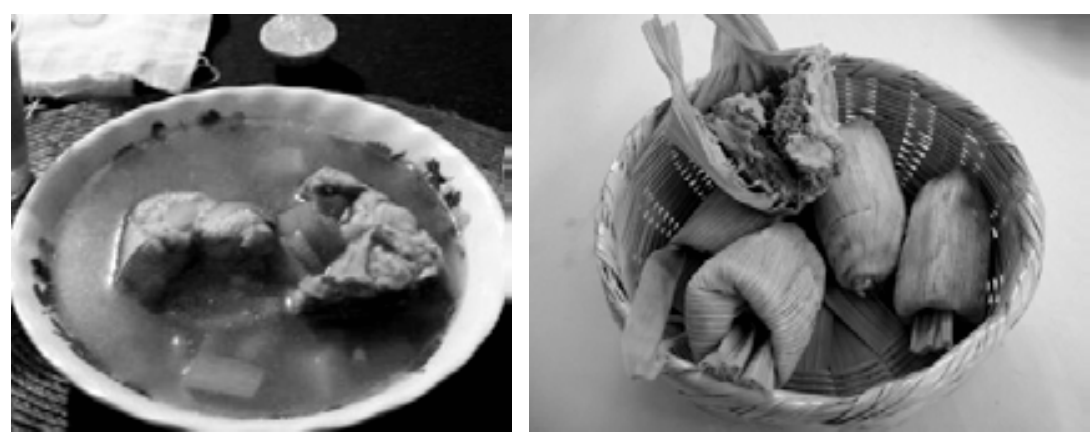

Caldo de cuatete (bagre) y tamales chontales. (Fotos: Allen García y Wikipedia).

MERCADOS. No existen mercados establecidos, pero se realizan intercambios en San Bartolo Yautepec, Santa María Ecatepec, Huamelula y Astata, y en menor grado en Tequisistlán. La mayor parte de las actividades comerciales de la región están a cargo de mestizos, que son los principales proveedores ambulantes de los artículos que se requieren en la zona. Gran parte de las adquisiciones de material que los miembros del grupo realizan, se hacen en Tehuantepec y Juchitán, o bien en la Ciudad de Oaxaca.

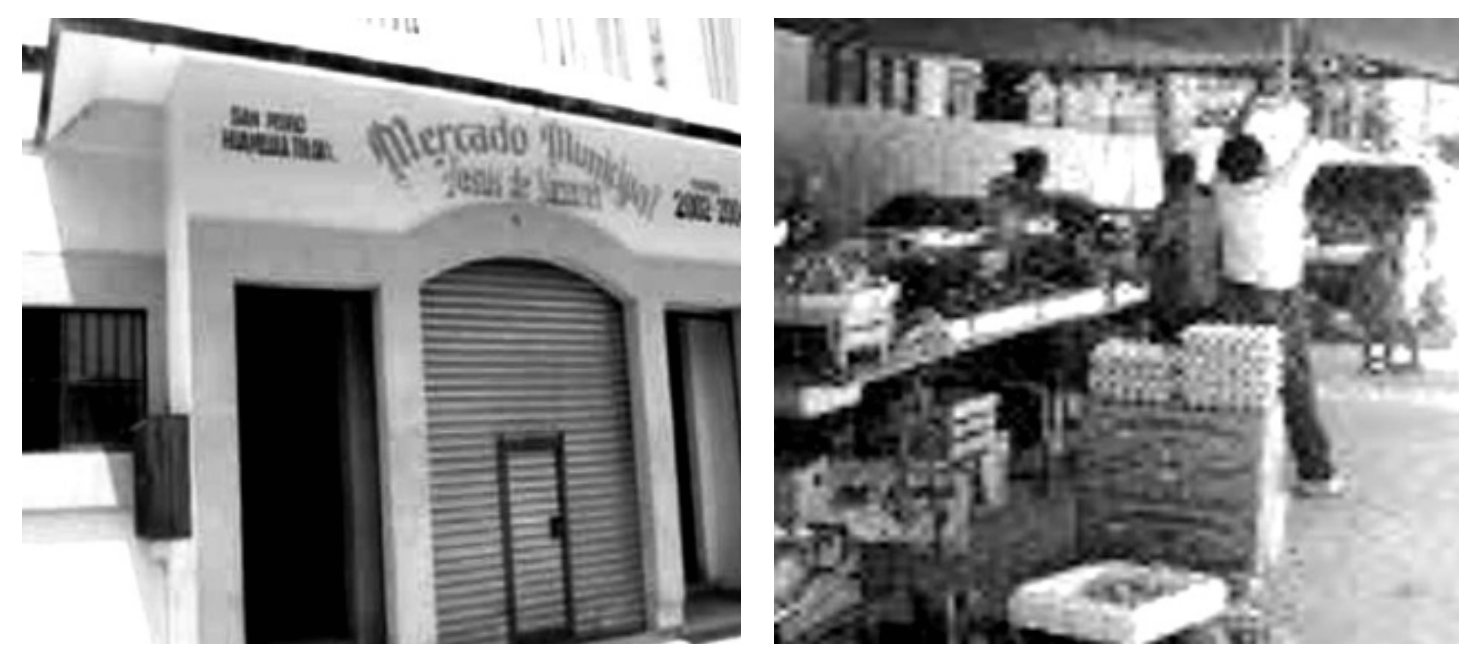

Mercado de Huamelula. (Fotos: Ayuntamiento Municipal).

ARTESANIAS. En la población de Tequisistlán existen canteras y por ello una Empresa Comunal que fabrica placas y bancos de ónix para cubrir, recubrimientos de paredes y elaboración de una amplia gama de artesanías. Esta empresa distribuye materia prima a talleres artesanales del Estado y a fábricas de muebles situadas fuera de él. En la región existen también familias que elaboran una cerámica lisa, de color rojizo y de carácter utilitario. 

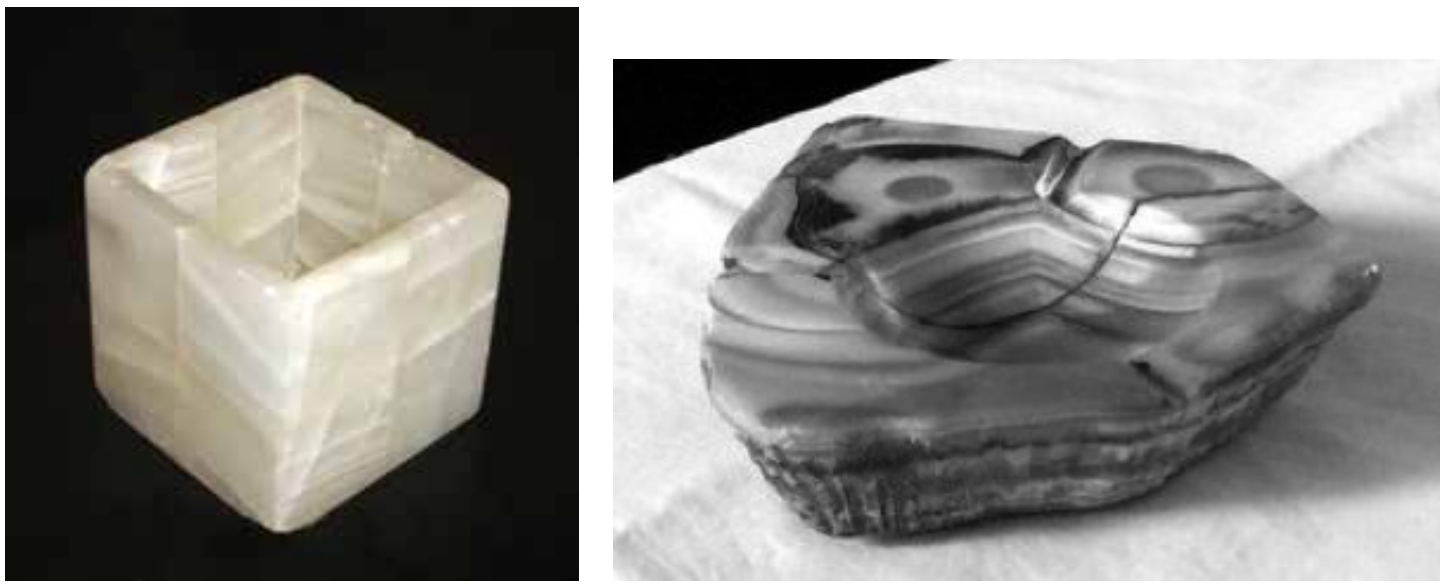

Porta velas y cenicero de ónix de Tequisistllán. (Fotos: Mármol y Ónix Primo Tapia y Dr. José A. León Ruiz).

ORGANIZACIÓN SOCIAL. La sociedad chontal es patrilocal, patrilineal y de descendencia bilateral, exogámica y monogámica, existiendo el tabú entre personas que ostentan el mismo apellido, a quienes se considera demasiado emparentados, aunque esta regla a menudo no se toma en cuenta. La familia nuclear es la célula principal de la sociedad y está constituida por el padre, la madre y los hijos solteros. Los matrimonios se realizan cuando los contrayentes tienen la edad adecuada, y es el muchacho el que informa a su padre cual es la joven de su elección. Este visitará al padre de la chica durante tres sábados consecutivos, al cabo de los cuales se fijará el precio de la muchacha. Es habitual que, si la pretensa es virgen, valga cuatro veces más que en el caso de que no lo sea, y que los artículos que el padre del novio entrega incluyan guajolotes, botellones de mezcal, botellas de vino, canastos de pan, paquetes de cigarros y billetes de banco.

Una vez acordada la boda, se fija una fecha, en promedio tres meses posterior, para la realización de la misma. Esta es una ceremonia en la, frente a la casa de la novia, se sitúan todos los parientes en semicírculo colocando en el centro un gran plato de barro que contiene mezcal, chocolate, vino, pan, cigarros y una cantidad de dinero en monedas; frecuentemente doce. A continuación cada miembro de la familia del novio entrega una flor a cada miembro de la familia de la novia. La fiesta continúa por dos días más, pero es el momento en que los invitados participan de la comida, el que fija la validez oficial del matrimonio. Este va a vivir a la casa de los padres del novio mientras se construye su casa, en cuya edificación participa colectivamente un respetable número de integrantes del grupo. Posteriormente el matrimonio recién formado visitará a los padres de la novia en un plazo que fluctúa entre pocos días y algunos meses. 

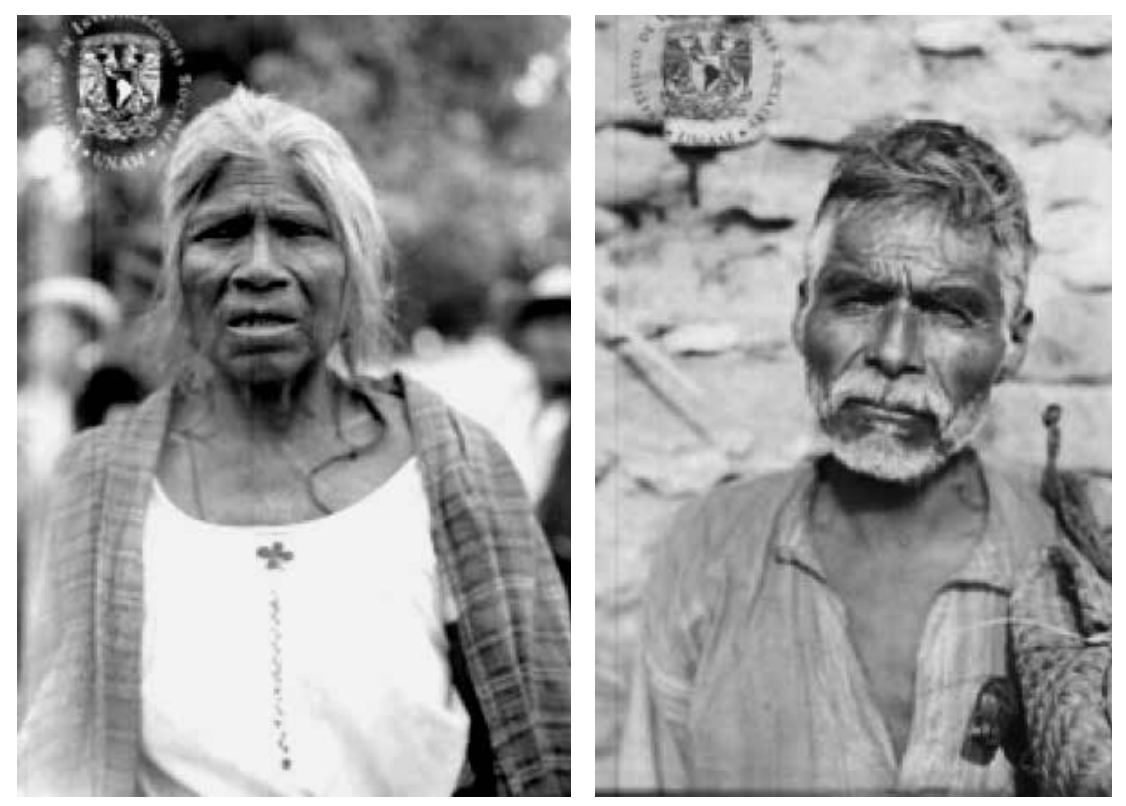

Anciana y anciano chontales. (Fotos IIS-UNAM).

El nacimiento del primer hijo da lugar a la ceremonia de la "Quema de la Leña”. Tres días de celebración con una gran fogata y ofrendas a las deidades. Los niños son educados sin infringirles castigos, y desde los ocho años comienzan a entrenarse en las labores de su sexo.
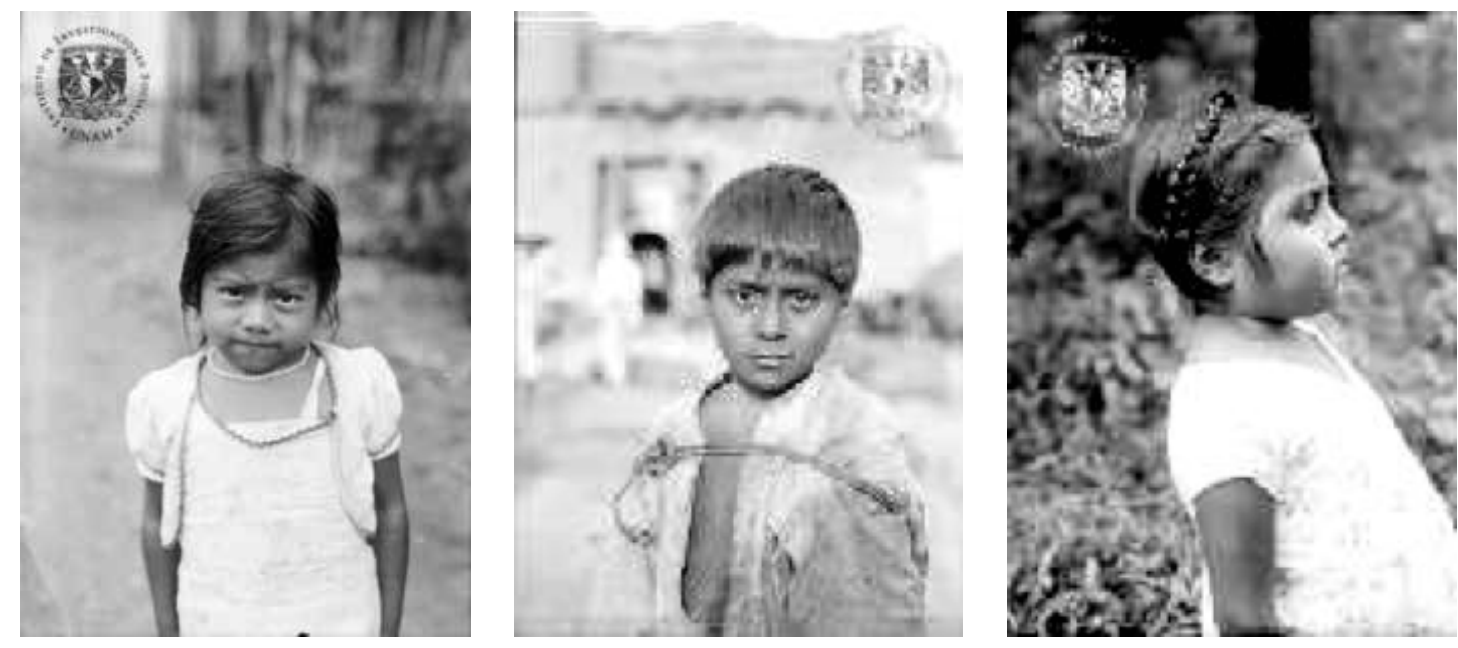

Niños chontales. (Fotos: IIS-UNAM).

Cuando muere una persona, se le lava y envuelve en una sábana blanca. A continuación se hace un velorio en el que se ofrecen alimentos y bebidas a los asistentes. Es frecuente que el entierro se realice alrededor de 24 horas después del deceso. El individuo es amortajado con toda su ropa incluyendo el sombrero y los zapatos, pero el resto de sus pertenencias son heredadas por sus familiares más próximos. 

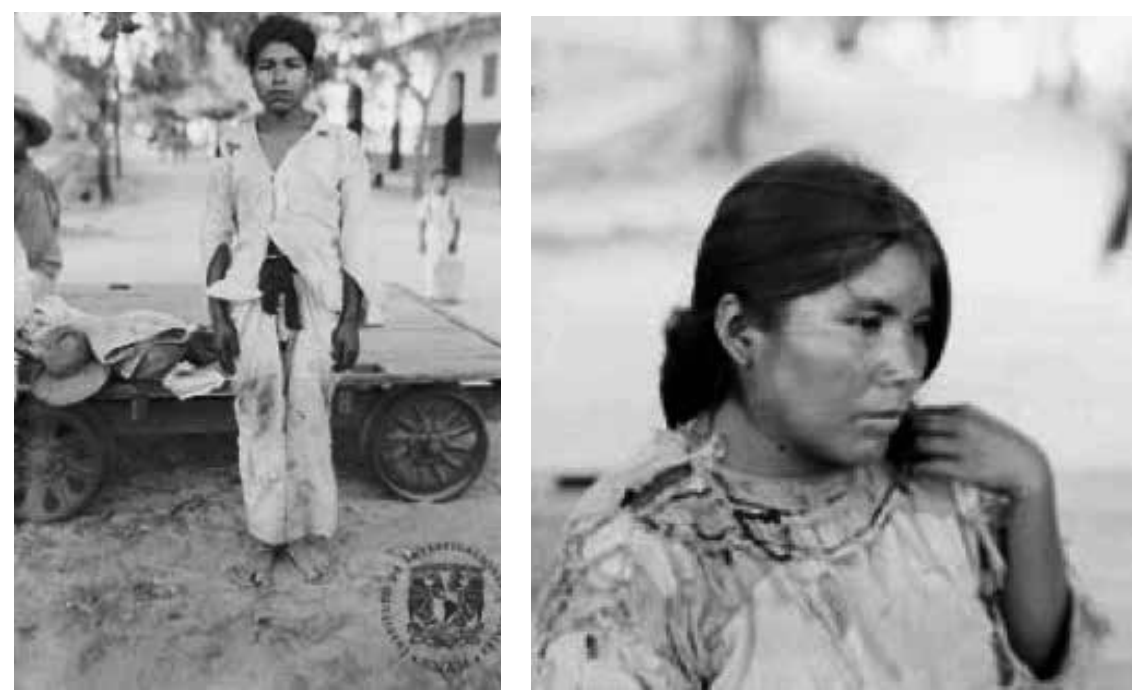

Jóvenes chontales en 1965. (Fotos: IIS-UNAM).

Aunque la población congregada es la máxima unidad de organización política, en la región no queda ninguna huella de la existencia de un poder de centralización o de acción de los principalatos prehispánicos.
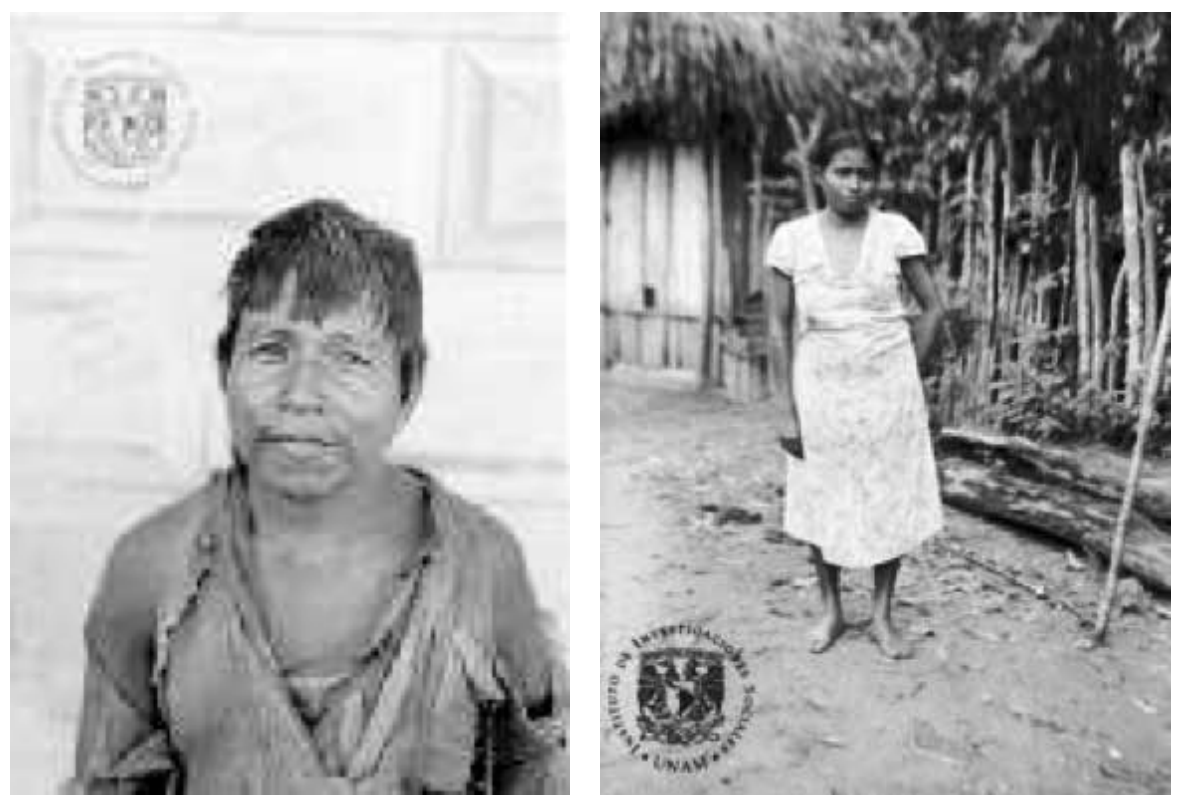

Hombre y mujer chontales. (Fotos: IIS-UNAM).

GOBIERNO. Independientemente del aparato jurídico, constitucional del gobierno mexicano, en la zona chontal subsisten formas de gobierno indígena en las que existen jerarquías y cuyos miembros los van ocupando de acuerdo con la edad y la experiencia. La base del escalafón es el topil, quien es el policía que realiza las labores más simples. En la cima se encuentra el Alcalde, quien se apoya en el Consejo de Principales. 


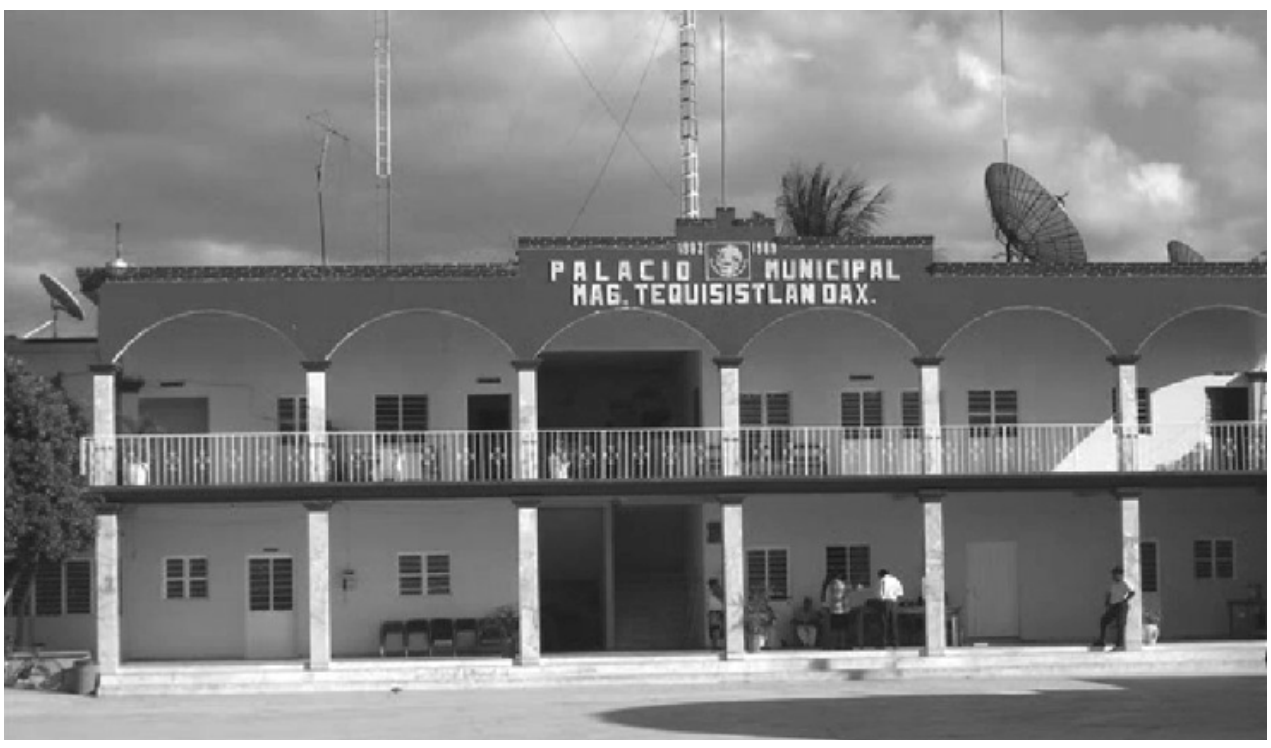

Palacio Municipal de Magdalena Tequisistlán. (Foto: Yotube. Destellos de Plata).

FESTIVIDADES. Como en el resto de las etnias del estado, la substitución del calendario ritual prehispánico y del calendario agrícola por el calendario ritual católico, realizada durante la primera etapa de la administración colonial del país, cambió por completo el orden sucesivo de festividades, por lo cual todas las fechas a conmemorar quedaron establecidas dentro del calendario de la religión católica. Las fechas principales de fiestas en el grupo están relacionadas a los Santos Patrones de las diferentes poblaciones, al carnaval, a la Semana Santa, y a la Navidad y el Fin de Año. Varios autores coinciden en que las fiestas del grupo chontal se presentan en menor número que entre sus vecinos zapotecos, y desde luego la principal de todas es la celebración de un matrimonio dentro del grupo. En Astata y Huamelula reviste importancia una ceremonia presidida por el Comisario de Bienes Comunales, en la que es casada una hembra de cocodrilo, "la lagarta" vestida de novia, con el Presidente Municipal, como rito de fertilidad, como símbolo de unión entre el hombre, la tierra, las montañas y los animales y como la unión de todos en torno a la tierra y el agua (el cocodrilo es un animal de tierra y agua). Este concepto parece derivar de una antigua tradición huave de contactos entre pescadores, trasplantada a la costa chontal, la cual involucra un espíritu femenino. La lagarta (cocodrila) es "La Princesa Novia" o "la Niña Novia" y de acuerdo a lo sabido es "Bonifacia” ¿la de la cara buena y bonita? ¿La bella naturaleza?, el que quizá fue el nombre de algún personaje huave femenino

Una característica muy importante del grupo chontal es la afición por la música, la cual en las fiestas juega un papel muy importante. En la zona se fabrican algunos instrumentos musicales que reciben nombres específicos. Una flauta de madera dura recibe el nombre de Alsikanne; Un tambor es designado como Tamolo, y existe un instrumento de cuerda, fabricado con una calabaza ahuecada, parecido a una mandolina que recibe el nombre de Lalipú, Además, ocasionalmente se utilizan otros instrumentos, principalmente en las pequeñas bandas de la región. La profesión de músico se transmite de padres a hijos, 
aprendiendo éstos de aquellos. Curiosa y tradicionalmente, hasta hace muy poco tiempo, en la región no hubo maestros académicos de música. Además, un guiso frecuente entre los chontales de la costa es el caldo de cuatete (bagre), pez existente en todos los ríos permanentes.

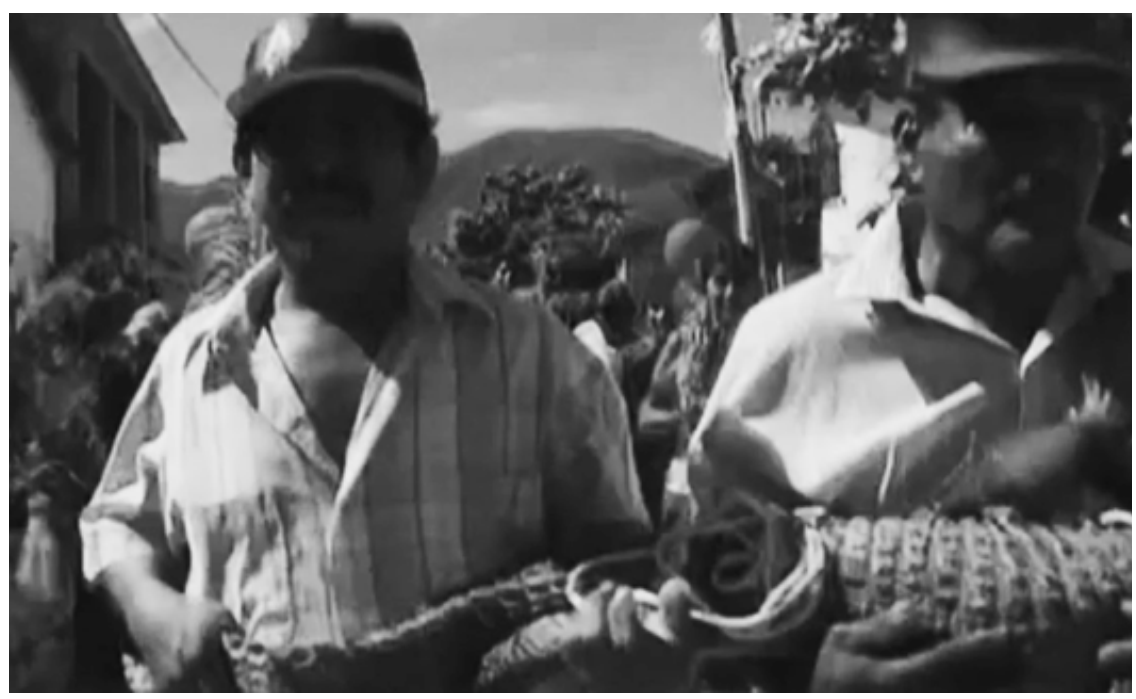

Santiago Astata: Boda con la "lagarta”. (Foto: Youtube. Jaime Zárate).

ORGANIZACIÓN RELIGIOSA. Las iglesias parroquiales de las diferentes poblaciones están a cargo de sacristanes que son designados dentro de cada población. En el grupo se encuentra ampliamente difundida la institución de la mayordomía. El mayordomo es designado por el Consejo de Principales y tiene la responsabilidad de sacar adelante el lucimiento de la fiesta para la que es nombrado. Para el desempeño de sus funciones cuenta con el apoyo de toda la población y debe demostrar su habilidad organizativa. Dentro del grupo chontal existen infinidad de mitos y leyendas. El principal ciclo de mitos se refiere a un héroe cultural del siglo XIV llamado Fane Kansini, Afane Kansini o Lauchini, que nació de un huevo que recogió de una cueva una pareja de chontales, y que vino al mundo dotado de poderes sobrenaturales. Haciendo uso de ellos inventó artificios mas desarrollados para la guerra, con los cuales logró la victoria sobre los zapotecas. Este mito pone al descubierto la enemistad de muchos años entre grupos y los ideales del grupo chontal acerca del comportamiento humano, y en cierto modo, revela también la relación, quizá comercial, que debió existir entre el grupo y los grupos mayenses y olmecas xicalancas de la costa del golfo, que hacia principios del actual milenio se caracterizaban por su belicosidad. Otro mito está relacionado con el sol, y en ese culto queman copal y decapitan un guajolote para que su sangre riegue el suelo; Además, ya hay población adscrita a los Adventistas del Séptimo Día. 

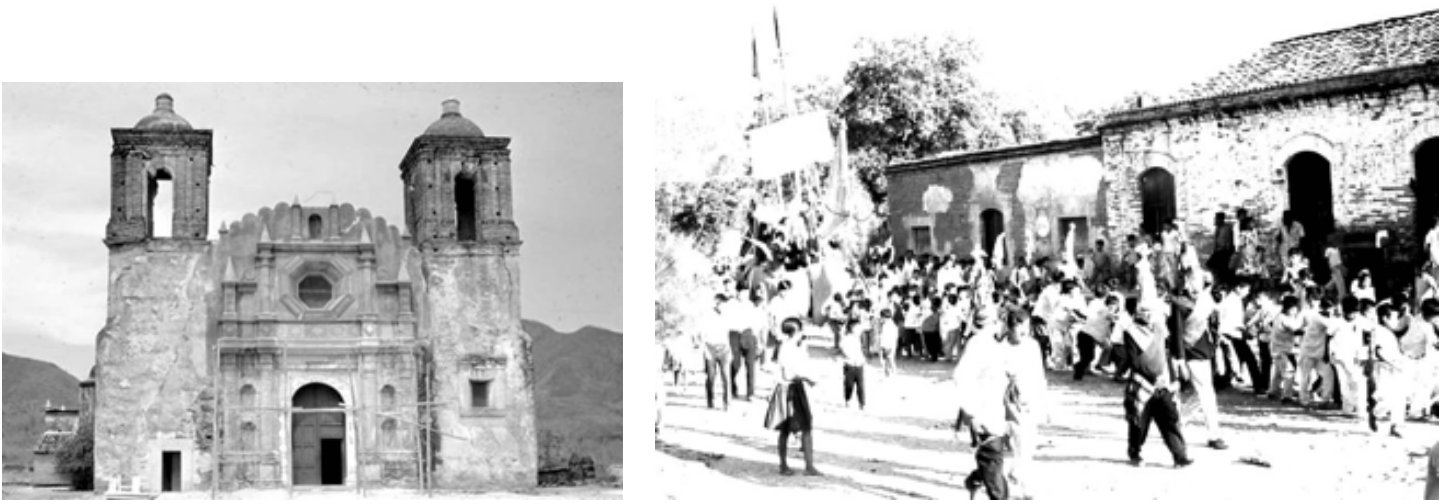

Iglesia de Huamelula (Ubicada sobre una plataforma prehispánica) y Danzantes. (Fotos: Realidades de Oaxaca).

MEDICINA Y MAGIA: En el área ocupada por el grupo existen shamanes, hechiceros y curanderos que desarrollan su actividad en poblaciones, cumbres de los cerros y cuevas, en base a un importante acervo de conocimientos de herbolaria. Para sus actos de magia recurren a huevos, manojos de pelo y ciertas vasijas, así como copal, para garantizar el éxito de la curación y causar una buena impresión al paciente. Además, hacen "limpias". Recientemente se han iniciado las actividades de pasantes de medicina que realizan su servicio social en la región, aunque lamentablemente en dispensarios muy mal dotados de medicina y equipo. En Tequisistlán hay un Centro de Salud, que opera en coordinación con los servicios médicos de la población de Tehuantepec.

EDUCACIÓN. Tanto en la zona Alta como en la Baja existen escuelas primarias en algunas comunidades. El nivel de escolaridad, como en todas las zonas deprimidas del estado no completa el ciclo primario. En Astata, Huamelula y Tequisistlán existen planteles de enseñanza secundaria y de bachillerato, trasladándose a Salina Cruz, Juchitán o Ixtepec, quienes optan por educación profesional.

\section{BIBLIOGRAFÍA}

Acevedo Conde, María Luisa. 2007 "Los Chontales de Oaxaca”. En: Revista A CONTRAGOLPE No 4. Carteles Editores, Oaxaca, Oax. 2007.

Acuña, René. (Editor). 1984 "Relaciones Geográficas de Nejapa, Teguantepec y Huatulco". En: RELACIONES GEOGRAFICAS DE LA DIOCESIS DEL SIGLO XVI. ANTEQUERA. (OAXA-

CA). 2 Tomos. Instituto de Historia. UNAM. México. D F. 1984.

Bartolomé, Miguel. Barabas, Alicia. 1992 HISTORIA CHONTAL. CNCA. INAH, SEP. Serie Historias Étnicas. № 5. Oaxaca, Oax. 1992.

Basauri, Carlos. 1940 "Chontales de Oaxaca”. Reed. 1990 En: LA POBLACION INDIGENA DE MEXICO. Tomo III. INI. Secretaría de Educación Pública. México. D F. 1944. Reed. 1990.

Bradomín, José María. 1978 HISTORIA ANTIGUA DE OAXACA. Editorial Tradición. México. D F. 1978. 
Burgoa, Francisco de. 1674 GEOGRAFICA DESCRIPCION DE LA PARTE SEPTENTRIONAL DEL POLO ARTICO DE LA AMERICA Y NUEVA IGLESIA DE LAS INDIAS OCCIDENTALES Y SITIO ASTRONOMICO DE ESTA PROVINCIA DE PREDICADORES DE ANTEQUERA, VALLE DE OAXACA. Imprenta de Juan Ruíz. México. D F. 1674. Reed. Biblioteca Porrúa. No México. D F. 1996.

Camacho, Juan Pablo. 1991 HISTORIA CHONTAL. Mecanoescrito. Sala de Autores Oaxaqueños. Biblioteca Pública Central. Oaxaca, Oax.

Dalhgren, Bárbara. (Compiladora). 1965 NOCHEZTLI (Grana Cochinilla) ECONOMÍA DE UNA REGION. Nueva Biblioteca Mexicana de Obras Históricas. № 1. Editorial Porrúa. México, D F. 1965.

Gay, José Antonio. 1950 HISTORIA DE OAXACA. Tomos 1 y 2. Ed. Jacobo Dalevuelta. Talleres Venero. México, D F. 1950

Gerhard, Peter. 1986 GEOGRAFIA HISTORICA DE LA NUEVA ESPAÑA. Instituto de Geografía. UNAM. México, D F. 1986.

Iturribarría, Jorge Fernando. 1955 OAXACA EN LA HISTORIA. Editorial Stylo. México, D F. 1955.

Kroefges, Peter. 1998 "El Lienzo de Teccitlán y Tecuatepec. Un Documento Histórico y Cartográfico de la Chontalpa de Oaxaca”. En: THE SHADOW OF MONTE ALBAN. POLITICS AND HISTORIOGRAPHY IN POSTCLASSIC OAXACA. México. Leyden. Edición compilada por Maarten Jansen. 1998. 2001 EXPLORACIONES ARQUEOLOGICAS EN LA COSTA DE LA CHONTALPA EN OAXACA, MEXICO. Department of Anthropology. University of Albany. Albany. N.Y. 2001.

Martínez Gracida, Manuel. 1910 LOS INDIOS OAXAQUEÑOS Y SUS MONUMENTOS ARQUEOLÖGICOS. Sala de Autores Oaxaqueños de la Biblioteca Pública Estatal. Oaxaca, Oax. 1910. 1910 HISTORIA ANTIGUA DE LA CHONTALPA. Manuscrito de la Colección Martínez Gracida. Guadalajara, Jal. México. 1910.

Miranda, José. 1968 "Evolución Cuantitativa y Desplazamiento de la Población Indígena de Oaxaca en la Época Colonial”. En: ESTUDIOS DE HISTORIA NOVOHISPANA. Vol II. Instituto de Historia. UNAM. México. D F. 1968.

Murguía y Galardi, José María. 1861 APUNTAMIENTOS ESTADISTICOS DE LA PROVINCIA DE OAXACA EN ESTA NUEVA ESPAÑA. Imprenta de Ignacio Rincón. Oaxaca, Oax. 1861

Oseguera, Andrés. 2001 "Mito y Danza entre los Huaves y los Chontales de Oaxaca. La Lucha entre El Rayo y La Serpiente”. En: DIMENSIÓN ANTROPOLÓGICA. Año 8. № 21. INAH. Enero-Abril del 2001. México. D F.

Paso y Troncoso, Francisco del. 1905 PAPELES DE NUEVA ESPAÑA. Tomo IV. (Relaciones Geográficas de la Diócesis de Antequera). Imprenta Sucesores de Rivadeneira. Madrid. España. 1905

Pérez García, Rosendo. 1956 LA SIERRA JUÁREZ. 2 Tomos. Edición del Autor. Gráfica Cervantina. México, D F, 1956.

Rodrigo Álvarez, Luis. 2004 GEOGRAFIA GENERAL DEL ESTADO DE OAXACA. Carteles Editores. Oaxaca, Oax. 2004. Rojas, Basilio. 1964. LA REBELION DE TEHUANTEPEC. 
Colección de Materiales para la Historiografía de México. № 2. Sociedad Mexicana de Geografía y Estadística.México, D F. 1964.

Turner, Paul. 1972 LOS CHONTALES DE LOS ALTOS. Col. SEP-SETENTAS. No 199. México, D F. 1972.

Winter, Marcus C. 1990 “La Dinámica Étnica en Oaxaca Prehispánica”. En: ETNICIDAD Y PLURALISMO CULTURAL. LA DINAMICA ETNICA EN OAXACA. Coords: Miguel Bartolomé y Alicia Barabas. Colección Regiones de México. CNCA. INAH. México, D F. 1990

Zárate Morán, Roberto. 1992 LOS CHONTALES DE OAXACA. Reporte Preliminar de Investigación Arqueológica. Mecanuscrito. Centro Regional de Oaxaca. INAH. Oaxaca, Oax. 1995 "Los Chontales y el Patrimonio Cultural”. En: EL PATRIMONIO SITIADO. EL PUNTO DE VISTA DE LOS TRABAJADORES, Delegación D - II - 1 - A - 1. Sección X del SNTE. INAH. México, D F, 1995. 


\section{NAHUAS}

Autodenominación: Nahuas.

Sinónimo en su lengua: Azteca, Nahua. Mexicano.

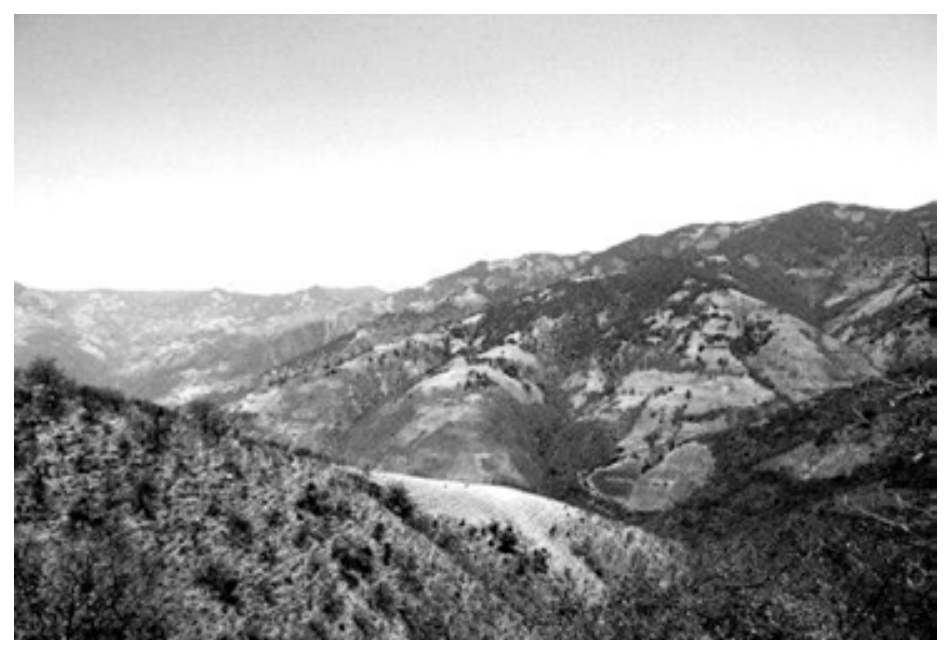

Paisaje. Zona nahua. Teopoxco (Foto Esteban M. Luna).

\section{GRUPO NAHUA}

POSICIÓN GEOGRAFICA. En el estado de Oaxaca los grupos Nahuas ocupan pequeñas áreas en el interior de la Mixteca y en las regiones colindantes con los Estados de Guerrero y Puebla. Dichas áreas se inscriben entre los paralelos $18^{\circ} 15^{\prime}, 18^{\circ} 20^{\prime}$ y $17^{\circ}$ de Latitud Norte, y los meridianos $97^{\circ} 20^{\prime}, 9^{\circ} 21^{\prime}$, y $96^{\circ} 20^{\prime}$, de Longitud Occidental, respectivamente.

Las regiones ocupacionales de los nahuas presentan un relieve de lomeríos altos y montañas de altura media, cuyos escurrimientos vierten a los Ríos Mixteco, Papaloapan y Putla, y cuyo clima es templado semiseco con lluvias en verano y templado subhúmedo con lluvias en verano.

Los suelos de las regiones son migajones que contienen partículas de origen volcánico y que se fueron formando por deposición de materiales y disgregación de rocas de ese tipo, principalmente andesitas y esquistos, así como suelos humíferos de mediana profundidad y otros areno arcillosos sometidos a oxidación. La precipitación pluvial fluctúa entre los 600 y 1200 milimetros anuales, con un mayor índice de nubosidad en los meses de verano. En algunos sectores caen heladas invernales, y la temperatura promedio anual fluctúa 
entre los $15^{\circ}$ y los $25^{\circ} \mathrm{C}$. En la Sierra Mazateca la población nahua se distribuye en las poblaciones de Santa María Teopoxco, Santiago Texcalcingo, Vigastepec, San Bernardino y Capultitlán.

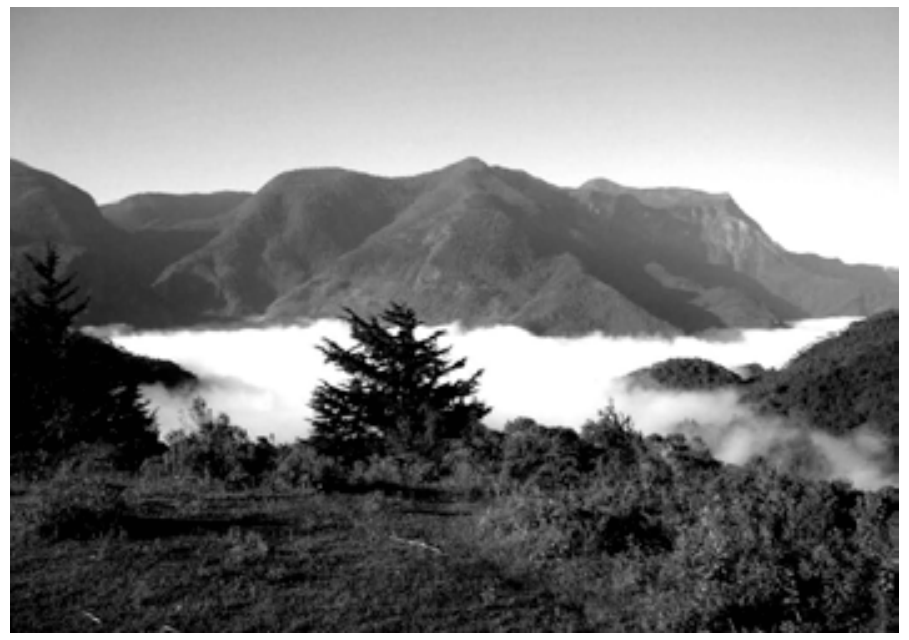

Paisaje en Teopoxco. (Foto: OgUhUg0).

ANTECEDENTES ARQUEOLÓGICOS E HISTÓRICOS. Los territorios actualmente poblados por los grupos nahuas contuvieron inicialmente asentamientos de otras características étnicas. Durante el primer milenio antes de Cristo, fueron áreas de contacto y tránsito entre grupos de tradición olmecoide procedentes de los valles centrales de Oaxaca y algunos grupos que entonces poblaban la región del sur de Puebla y la oriental de Guerrero. Ya hacia la época del principio del clásico mesoamericano, al principio del primer milenio después de Cristo, la región occidental de Oaxaca recibió fuerte influencia teotihuacana y características culturales que ahora reconocemos pertenecientes a grupos de marcada filiación, ya sea ñuiñe, mixteca o popoloca. Hacia el fin del período clásico en la región, aproximadamente hacia el año 750 dC., sobreviene la desintegración teotihuacana y con ella el avance hacia el Sur del país de los primeros grupos de habla náhuatl. A partir de ese momento debió presentarse en esas regiones una marcada influencia de gentes que hablaban ese idioma, habiéndose dado el caso de una superposición cultural en la región que entonces ocupaban los popolocas, parte de los estados de Puebla y Oaxaca. Hacia el 1300 dC, cuando los mexicas se establecieron en la Cuenca de México, comenzó la integración de rutas comerciales y el intercambio de productos con poblaciones de la mixteca. Hacia el año 1470 esas regiones ya estaban pobladas por nahuas que actuaban como puntas de lanza, después de las conquistas de Moctezuma Ilhuicamina de los Principalatos de Tlacotepec y Zinacantepec y la posterior de Tepexi realizada por Izcóatl y, dentro de las rutas a los principalatos mixtecos, a poblaciones situadas más al sur o a la gran población comercial de Tuxtepec. Esos enclaves fueron de gran utilidad para los aztecas en sus avances de conquista tributaria y territorial, y se extendían por las regiones que nos ocupan y toda la sierra madre del sur que bordea la cuenca del Río Balsas en el Estado de Guerrero. 
Al sobrevenir la conquista española, los grupos de esas zonas, que habían sido combatientes y tributarios de Tenochtitlan, quedaron ubicados en las rutas de aproximación de los conquistadores hacia los territorios oaxaqueños. De este modo, rápidamente quedaron sujetos a la autoridad del Capitán General. Hernando Cortés, y muy pronto se vieron sujetos a la institución española de la encomienda para posteriormente quedar en la esfera de la cristianización.

La historia posterior de los nahuas de Oaxaca, los que permanecieron en la sierra sur y sus estribaciones sureñas, los señala como un grupo marginado que sufrió pérdidas territoriales frente a la expansión de algunos poblados mixtecos en el primer siglo de la dominación colonial, así como perdidas demográficas debidas a epidemias y que vio desaparecer la mayor parte de los recursos de su medio ambiente, al producirse la sobreexplotación del pastoreo del ganado menor durante esa época. Este sobrepastoreo determinó la destrucción de grandes zonas de bosques y pastizales y la aceleración de los procesos erosivos que traerían como consecuencia la casi total inutilidad de los suelos de gran parte de los distritos de Huajuapan, Teotitlán, Silacayoapan y Putla. En esta última zona quedaron algunos enclaves de pastores nahuas en la región, a los que despectivamente se denominó Yopes, por ser muchos originarios de Yopitzingo, Gro, y que eran los encargados de arrear a los rebaños de cerdos, borregos, cabras y bovinos para llevarlos al altiplano, enclaves que permanecieron hasta bien entrado el Siglo XX. Durante la época de la Guerra de Independencia, las áreas oaxaqueñas ocupadas por los nahuas fueron escenario de algunos pequeños enfrentamientos entre insurgentes y las fuerzas virreinales, antes y después del sitio de Huajuapan. Los pobladores nahuas del norte-noroeste de Oaxaca aportaron posteriormente una importante cuota a los movimientos armados que han tenido lugar en el país, integrando una pequeña parte del Ejército de Oriente del general Porfırio Díaz Mori bajo las órdenes directas del Gral. Luis Pérez Figueroa durante la Guerra de Intervención Francesa, uno de ellos el Coronel eloxochitleco Teodoro Flores, padre de los hermanos Flores Magón y, además, constituyendo también algunas unidades que participaron en hechos de armas durante el porfiriato y la revolución. Por otra parte, los nahuas del Distrito de Teotitlán mantienen muchos contactos con nahuas del sur del estado de Puebla y los nahuas de los distritos de Huajuapan y Putla han mantenido una relación constante con grupos Nahua-Tlapanecos del Estado de Guerrero.

DEMOGRAFÍA. A principios de 1983 existían aproximadamente 4500 pobladores habitando los pequeños enclaves nahuas en el Estado. De ellos aproximadamente el 70\% hablaba el idioma, aunque en algunas localidades éste se estaba perdiendo, lo que con los años ya es grave en la comunidad de Concepción, cerca de Putla de Guerrero, donde en el 2011 se registraron 12 hablantes. Dicha lengua pertenece al tronco Yuto-Nahua, familia Nahua, muy relacionada con las variantes de Morelos y del sur del Estado de Puebla. Dentro del territorio del estado se conserva en San Bernardino y Santa. María Teopoxco, Distrito de Teotitlán de Flores Magón. En la sierra mazateca, en el 2011 se registraron alrededor de 11 000, con mayoría en los alrededores de Santa María Teopoxco y, en las cercanías de Hua- 
juapan de León, también hay un pequeño enclave que abarca un municipio y sus agencias, pero ya no hablan su idioma.

ACCESOS. Una parte de la región nahua está comunicada y dividida en dos por la Carretera Huajuapan-Juxtlahuaca (zona donde hubo pequeñas guarniciones y puntos de apoyo para el translado de animales). Otra parte tiene acceso por la carretera de terracería que une Teotitlán de Flores Magón con Huautla, de la cual es posible desviarse por un camino que llega a Santa María Teopoxco. A los pobladores nahuas del Distrito de Putla puede llegarse por caminos que parten de la cabecera distrital. En Teotitlán existe una pequeña pista de aterrizaje, e igualmente existe otra en Putla de Guerrero.

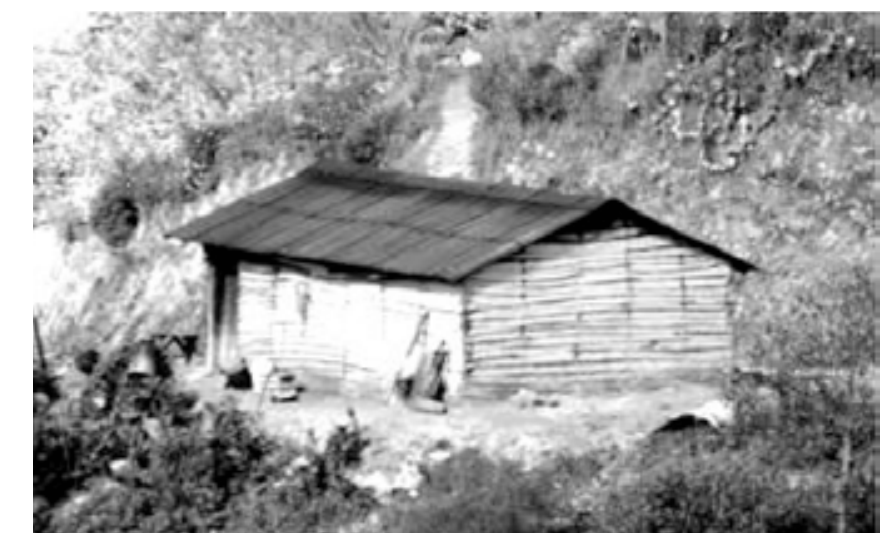

Casa nahua actual. Sta. María Teopoxco. (Foto: Ayuntamiento de Teopoxco).

VIVIENDA. Las casas de los nahuas de Oaxaca eran de planta cuadrangular o rectangular con paredes de adobe y de esquinas de adobes entrecruzados. La puerta fue central y las ventanas solieron ser muy pequeñas, los techos fueron construidos tradicionalmente de zacate y palma entrecruzados y amarrados.

Ahora muchas tienen techos de lámina, ya sea metálica o de cartón. El fogón suele estar en un extremo de la habitación y esta conformado por tres piedras colocadas de tal manera que formen un triángulo equilátero. El solar suele estar cercado por una cortina de cactos $\mathrm{u}$ órganos colocados muy juntos, de tal manera que constituyen una cerca, o bien tener una valla de ramas. Muy próximo a las casas se construye una troje o cuescomate de barro que recubre ramas entrelazadas, de forma ahusada y techada con pasto, en cuya parte superior se coloca una puertecita de forma semi-oval por la que se deposita la mazorca, y que, cuando es necesario extraer la misma, tal cosa se hace por una pequeña puerta trampeada colocada en la parte inferior, en un nivel de más de un metro sobre el nivel del piso de lodo compactado, lo que garantiza el aireamiento. Esta troje garantiza la conservación del maíz en mazorca, frijol, haba, calabazas y, en ocasiones, zacate. Las familias suelen vivir en promiscuidad, durmiendo en las orillas de las habitaciones y repartiéndose la superficie del piso, éste es de tierra compactada. Muy frecuentemente la familia duerme con animales domésticos. 


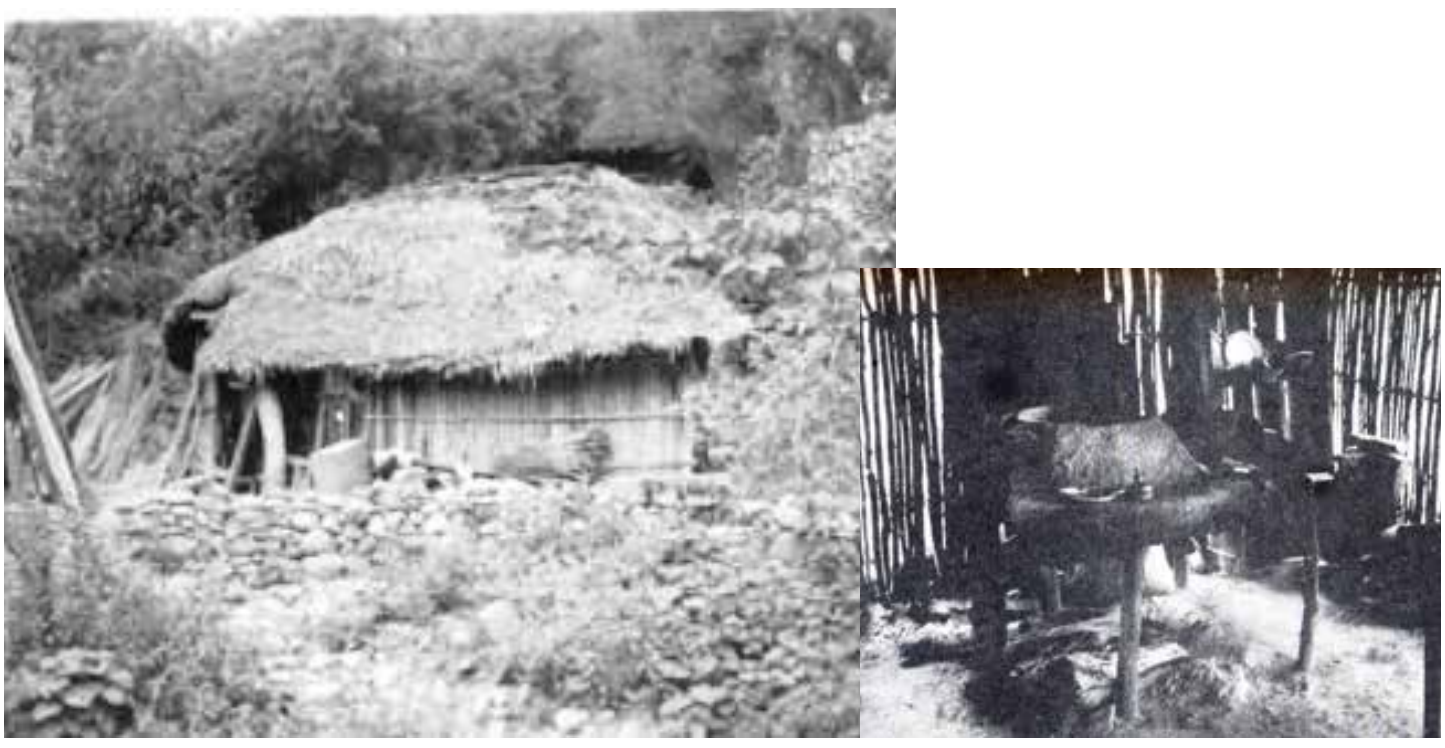

Casa y cocina nahuas. (Fotos IIS-UNAM).

INDUMENTARIA. Los hombres han usado tradicionalmente la camisa y el pantalón de manta, cubriéndose los pies con huaraches de correas de cuero, de los que existen varios tipos según la región, usando además sombrero de palma. Hasta hace poco tiempo las mujeres usaron telares de cintura con los que obtenían huipiles bordados con flores y vestidos de telas de algodón, así como enaguas del mismo material. La indumentaria ha cambiado mucho y ahora también se usa ampliamente el pantalón de dril y los vestidos comerciales. Para protegerse del frío, son comunes los sarapes y los rebozos. En la actualidad muchas mujeres, y aún parte de la población masculina, usan zapatos de plástico.

ECONOMÍA. La economía de los nahuas de Oaxaca es exactamente igual a la de grupos de la misma etnia de otros estados del país. Las limitaciones en los regímenes de precipitación pluvial, la pobreza de los suelos y la destrucción de los ecosistemas zonales, hacen que la economía sea de subsistencia basada en el maíz, un poco de frijol y calabaza, y en ocasiones cantidades muy limitadas de café, estando completamente sujeta al temporal aún en las regiones subhúmedas. Por tanto, tal economía no puede ser analizada conforme a clasificaciones estrictamente económico- políticas, sino que debe ser vista en función de que el indígena productor con frecuencia no puede allegarse todo lo que consume y que para subsistir debe vender parte de su producción o el pequeño excedente de la misma, de tal suerte que, en el proceso de transacción, resultará llevando la peor parte y perdiendo un alto porcentaje de utilidad. Una de las pocas posibilidades que el indígena tiene para intentar nivelar la situación es la emigración. En los grupos que ocupan zonas de mayor depresión económica y éste es el caso de los nahuas, gran parte de la población masculina sale a buscar trabajo a poblaciones mayores de todo el país, de los EE UU o de las áreas agrícolas desarrolladas. Otro elemento importante que participa en el proceso económico del grupo son las actividades de tejido de fibra de palma o de fibra sintética para obtener 
sombreros y diferentes artículos. A esta actividad suele dedicarse toda la familia, logrando con ella una ligera nivelación presupuestal debido a que el producto siempre es vendido a acaparadores que controlan los mercados de las diferentes áreas, a precios siempre inferiores al valor comercial justo. El Fideicomiso de la palma (FIDEPAL), un organismo federal creado por el equipo del Gral. Lázaro Cárdenas del Río como Vocal Ejecutivo de la Comisión del Río Balsas para contrarrestar esta situación, desapareció sin poder cubrir la totalidad de las regiones artesanales de palma en el Estado.

Otro factor importante en la economía del grupo nahua es el problema de la tenencia de la tierra. Esta suele ser comunal, la cual es la forma de tenencia tradicional del grupo, pero las mejores tierras, las situadas en las proximidades de los pocos arroyos, suelen estar bajo los regímenes ejidal y de la pequeña propiedad. Por otra parte, en las regiones ocupadas por los nahuas han abundado los conflictos por la posesión de tierras cultivables. Estos problemas han ocasionado una casi permanente baja productividad.

Los sistemas de cultivo son tradicionales. Las principales innovaciones, que llegaron en el siglo XVI, son el arado de madera, llamado arado de palo, y el arado egipcio con vertedera de acero, de tracción animal. Las yuntas existen de manera limitada. Los sistemas de siembra y cosecha subsisten dentro de un concepto cultural absolutamente prehispánico. Casi no se practica la agricultura de roza debido a que las condiciones fisiográficas de algunas regiones no la permiten, pero los nahuas en el Distrito de Putla la practican regularmente. En general, los suelos son muy calcáreos, y para aumentar su productividad requerirían de recibir, además del agua suficiente, cantidades muy grandes de fertilizantes o de estiércol de ganado vacuno y ovicaprino, de las que en la región no es posible disponer. Sólo algunos suelos de los distritos de Teotitlán y Putla tienen mayor productividad.

CAZA Y PESCA. La pesca en las regiones nahuas es virtualmente inexistente, constreñida sólo a capturas ocasionales. La caza siempre fue una actividad encomendada a mejorar el proteinaje de la dieta familiar, para lo cual se pedía la pieza al "Amo de los Animales". Durante los últimos 50 años algunos individuos en las comunidades han convertido esta actividad en un negocio sistemático, razón por la cual las especies animales de esas áreas, particularmente los venados, han sido considerablemente diezmadas y sólo la liebre de panza blanca, el conejo castellano, el conejo rabo de algodón, la zorra gris, el cacomixtle y la codorniz común han logrado mantener un precario equilibrio que amenaza con una pronta ruptura.

MERCADOS. Los mercados nahuas mantienen una gran tradición. En ellos se presentan, desde la compra de artículos industrializados hasta un intercambio de productos mediante trueque. Las formas de intercambio suelen ser profundamente desiguales con desventajas para los productores indígenas, quienes de este modo ven muy mermados sus beneficios. 


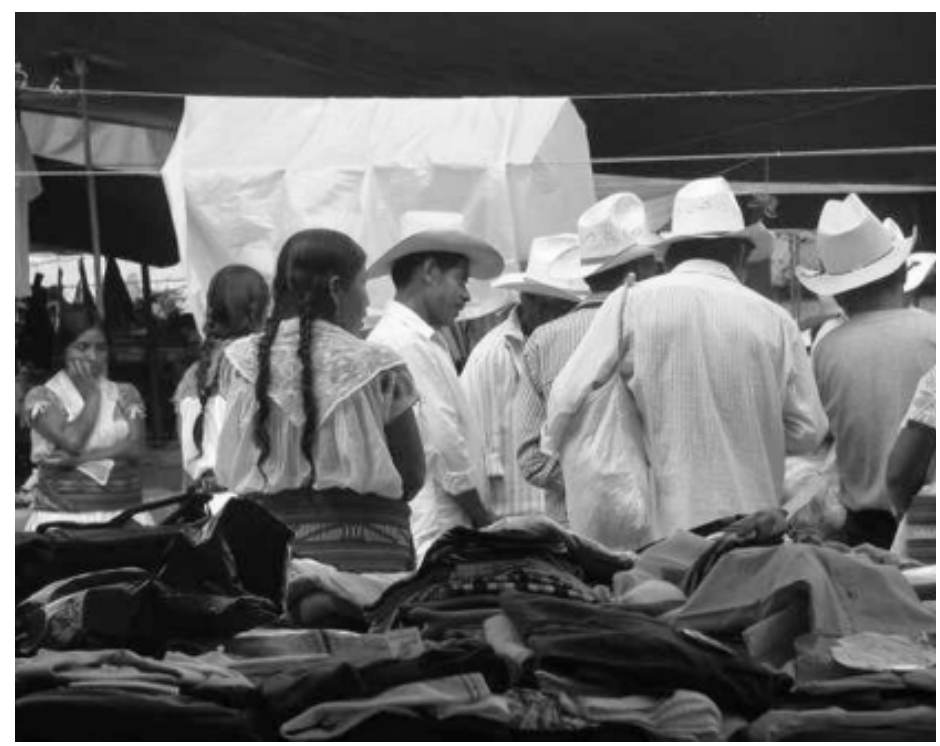

Mercado Nahua. Sta. María Teopoxco. (Foto: Ayto. Sta. María Teopoxco).

ARTESANIAS. Entre los nahuas predomina como principal el tejido de artículos de palma. Entre las mujeres ha sido tradicional el bordado de huipiles y de camisas femeninas. En algunas comunidades han surgido artesanos que elaboran figuras de alta calidad estética con la madera de la raíz de ciertos árboles. En Teopoxco subsiste una tejedora tradicional.
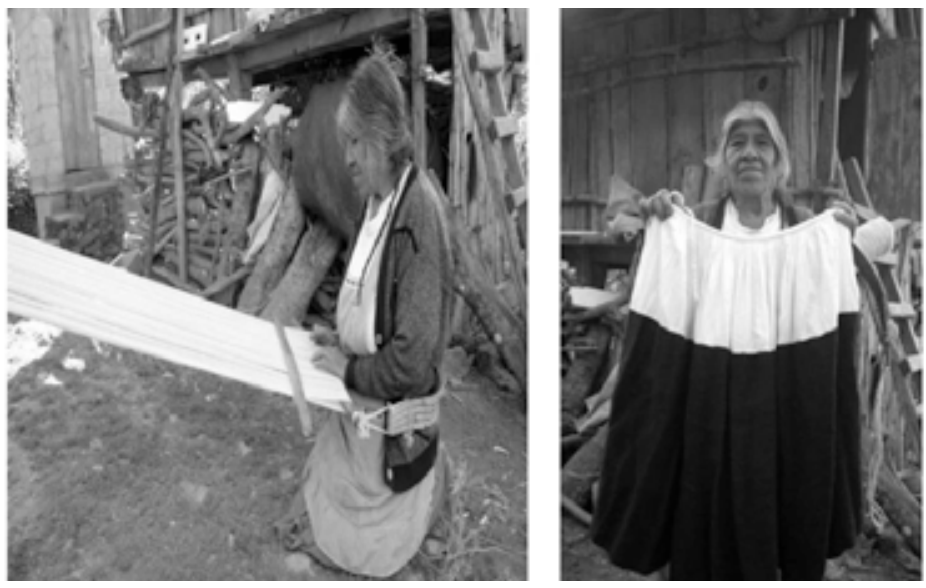

Tejedora y textil nahuas. (Fotos: Ayuntamiento de Teopoxco).

GANADERÍA. La casi totalidad del ganado existente en las regiones con ocupación nahua consiste en hatos de ganado menor compuestos principalmente por cabras, ya que en esas áreas la ganadería bovina no puede tener un gran desarrollo por el relieve y por falta de especies vegetales adecuadas para su consumo. La mayor parte del ganado menor existente en esas regiones pertenece a comerciantes del ramo radicados en las Ciudades de Huajuapan y Tehuacán. Las explotaciones caprinas casi no benefician a las comunidades indígenas. Los nahuas del Distrito de Putla tienen una raquítica ganadería bovina extensiva. 

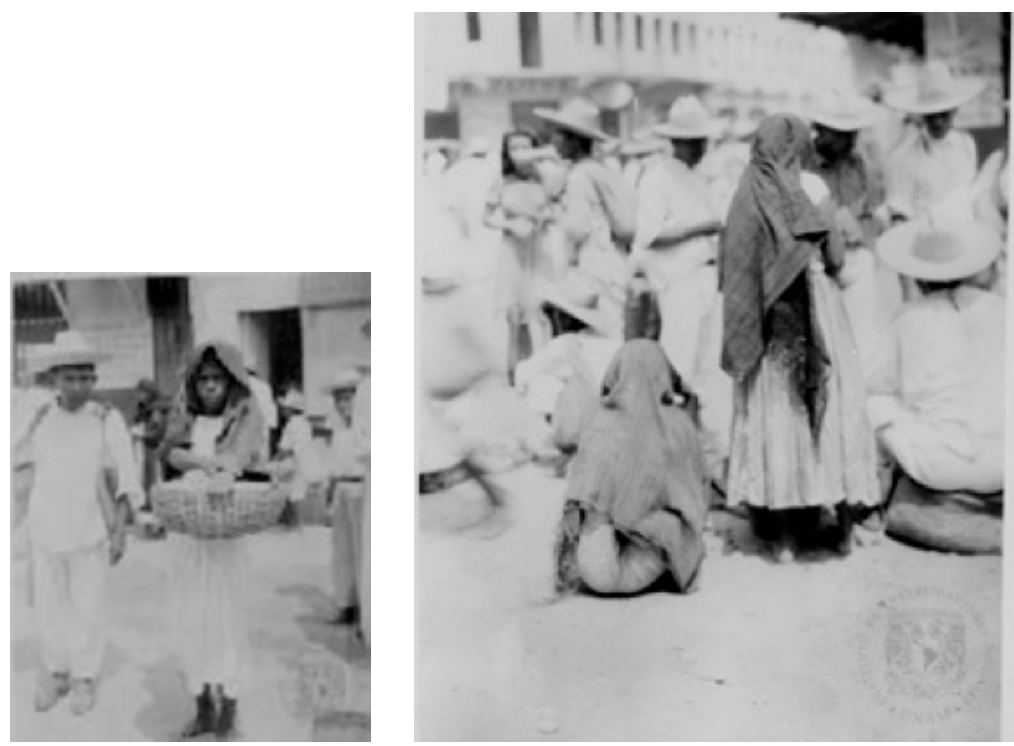

Matrimonio y mercado nahuas. (Fotos: IIS-UNAM)

ORGANIZACIÓN SOCIAL. La sociedad nahua es patrilineal, patrilocal, exogámica y monogámica. Tradicionalmente, el matrimonio recién formado vivió en relativa proximidad con la casa del padre del varón. En ella el varón asumió el principal papel y los matrimonios pudieron celebrarse, ya sea con personas del mismo grupo o con personas de otras comunidades de la etnia o de otras. Los noviazgos podían concertarse por el mutuo conocimiento de los muchachos, o también por las decisiones de los padres. Existe el casamentero, el Huehue o Huehuete, quien suele representar al padre del muchacho al presentarse a pedir la mano de la muchacha, obtenerla y cerrar el compromiso, a lo que seguía la entrega de los presentes. Antiguamente las visitas del casamiento, eran más abundantes que las actuales y, asimismo, en la actualidad muchos matrimonios se concretan por la mutua decisión libre de los contrayentes. Tanto en la celebración de la boda como en la construcción de la nueva casa la participación del grupo es bastante intensa y también se observa una institución de compadrazgo que crea lazos de bastante profundidad.
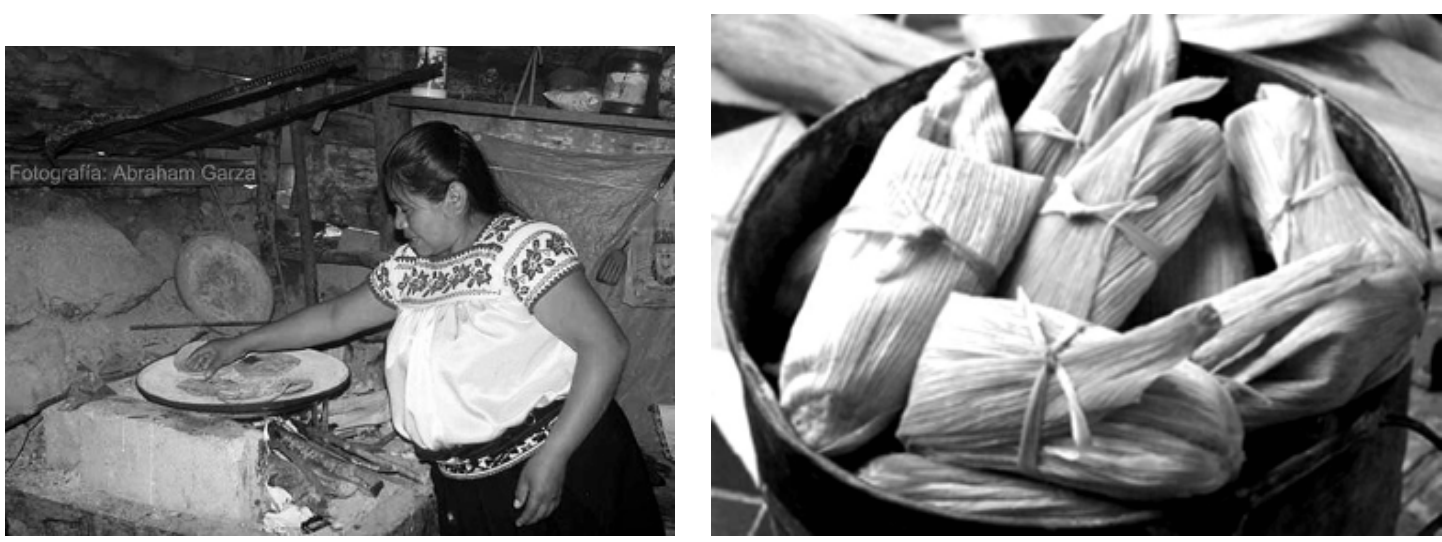

Cocinera y tamales nahuas. (Fotos Abraham Garza y del autor). 
Habitualmente, las comunidades están divididas en barrios y en cada barrio viven varias familias, más la adición de los parientes consanguíneos y por afınidad.

GOBIERNO. Además del aparato jurídico constitucional que señala la política del país, en el grupo han subsistido formas tradicionales de gobierno indígena en el que existen jerarquías y cuyos miembros las van ocupando de acuerdo a un escalafón definido por la edad y la experiencia, las que van estableciendo un orden de méritos. Sin embargo, en el grupo también subsiste una fuerte integración entre las actividades religiosas y las políticas, no obstante que el proceso de aculturación a que se ven sometidos los indígenas de este grupo es muy fuerte. Subsiste el uso del caracol ritual para hacer las llamadas congregatorias, el cual es designado como "concha”. En la localidad subsiste también el tequio.

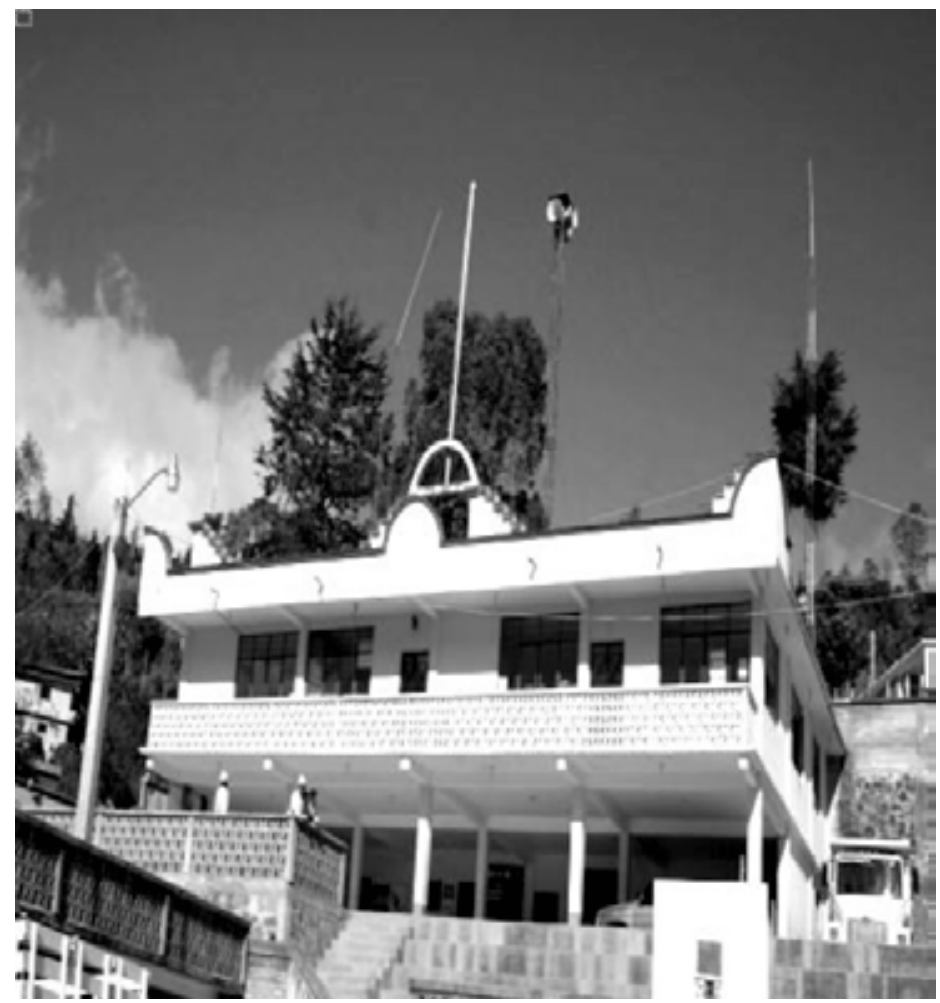

Palacio Municipal. Sta. Ma. Teopoxco (Foto: Ayuntamiento local).

FESTIVIDADES. La substitución del calendario ritual prehispánico y del calendario agrícola por el calendario católico, realizada durante la primera etapa de administración colonial del país, cambió por completo la sucesión de festividades que entonces existía; por lo que las festividades que la colonia dejó impuesta corresponden a las fechas del ritual católico o bien a los días en que se festeja al Santo Patrón de las diferentes poblaciones. Durante las festividades se ejecutaron danzas, principalmente de Moros y Cristianos, y actuaban personajes bufos enmascarados. Hasta hace poco tiempo subsistió en Concepción un baile tradicional con música de violín y guitarra en el que las mujeres usaban blusas floridas y 
enaguas largas de colores. Los hombres, por su parte, lo bailaban con huaraches y ropa de manta blanca. También en las concentraciones debidas a festividades se suele ejecutar la Xochipitzahua, danza tradicional relacionada con el culto a la fertilidad y muy frecuente en el centro y sur de mesoamérica

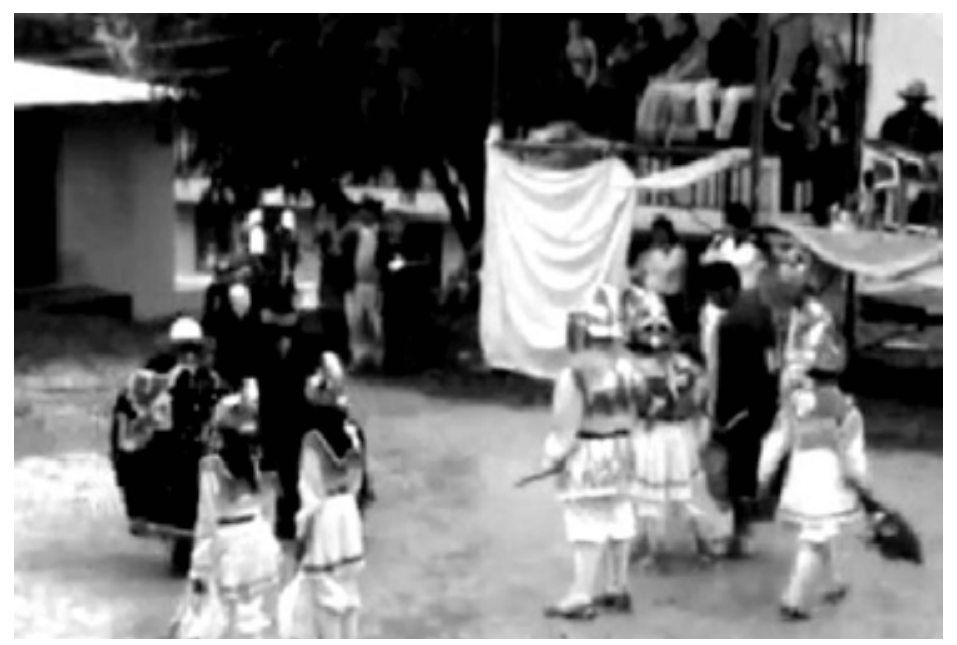

Danzantes de Moros y Cristianos en Teopoxco. (Foto: Ayuntamiento de Teopoxco).

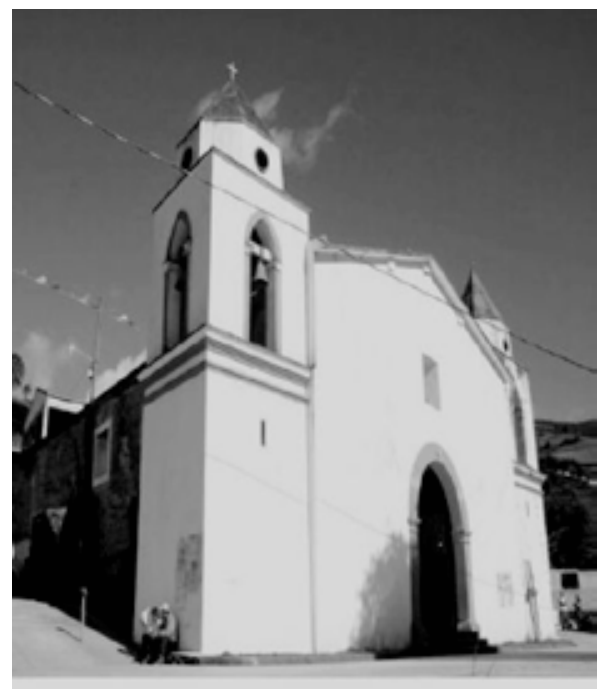

Iglesia en Santa María Teopoxco. (Foto: Ayto. de Teopoxco)

ORGANIZACIÓN RELIGIOSA. De manera habitual las iglesias parroquiales están a cargo de un sacristán. Cuando se aproximan las festividades, la comunidad designa la persona que va a encabezar el grupo organizador; dicha persona tiene a su cargo la organización y se responsabiliza de la buena marcha de las festividades. En condiciones habituales, la comunidad apoya al designado con bastante efectividad. Durante el desarrollo de las fiestas el índice de alcoholismo se eleva en el grupo. Subsiste, como plato principal de la celebración, el caldo de chivo, muy recomendado. 


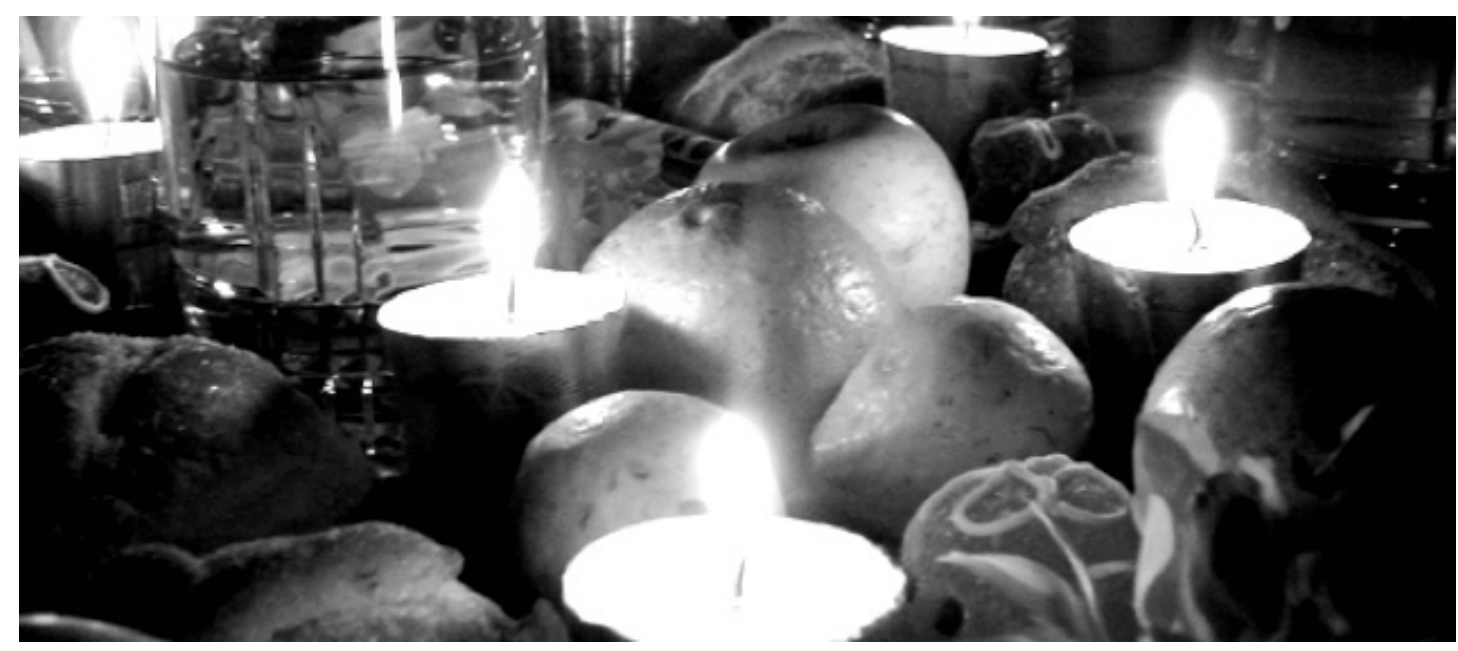

Ofenda de muertos nahua. (Foto: Universidad Panamericana).

MEDICINA Y MAGIA. En gran parte de la comunidad existen personajes relacionados con esta actividad. Algunos de ellos son curanderos o brujos que efectúan sus actos de curación mediante una serie de recursos. En algunas zonas existen personas sumamente conocedoras de herbolaria que curan de ese modo. En cierto modo el conocimiento de las hierbas ocupa un lugar importante en el contexto de las actividades del grupo. Subsiste el concepto de Tona y la hechicería, generalmente aplicada para curar "espantos, "muinas" y "pérdidas del alma".

EDUCACIÓN. En las áreas ocupadas por los náhuas existen varias escuelas primarias y algunas secundarias. La proximidad de unos con la población de Teotitlán de Flores Magón, de otros con la de Putla, y de algunos más con la de Huajuapan, permite que algunos jóvenes de las comunidades tengan acceso también a la educación secundaria y a la que imparten las Escuelas Tecnológicas o los Colegios de Bachilleres de Huajuapan, Putla o Teotitlán. Debido a las carencias económicas, pocos jóvenes indígenas llegan, mediante becas, a la Universidad de la Cañada en Teotitlán de Flores Magón, o a la de la Mixteca en Huajuapan.
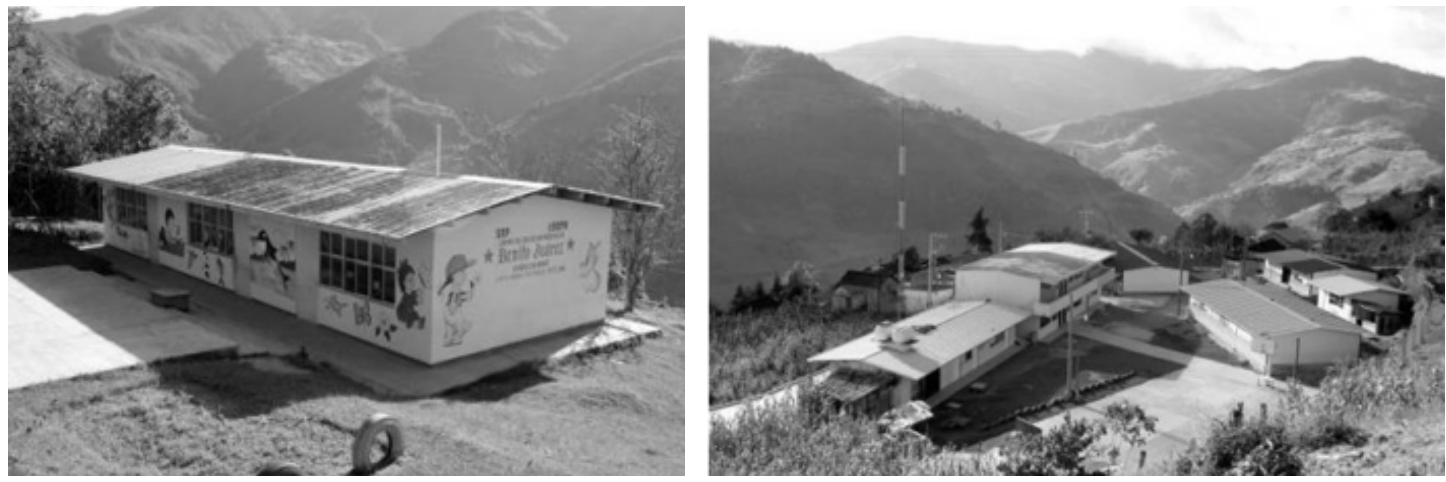

Escuelas en Teopoxco. (Fotos: Ayto. de Teopoxco) 


\section{BIBLIOGRAFÍA}

Acevedo Conde, María Luisa. 2007 "Grupos de habla Nahua”. En: Revista A CONTRAGOLPE No 3 Carteles Editores, Oaxaca, Oax. 2007.

Alva Ixtlixóchitl, Fernando de. 2003 HISTORIA TOLTECA-CHICHIMECA. Edición Facsimilar de la de 1892 . Talleres Gráficos de la Nación. México, D F. 1972.

Basauri, Carlos. 1940 Los Nahuas Reed, 1990 LA POBLACION INDIGENA DE MEXICO. INI. Secretaría de Educación Pública. México, D F. 1990.

Báez Jorge, Félix. 1988 LOS OFICIOS DE LAS DIOSAS. Universidad Veracruzana, Jalapa, Ver. 1988.

Madsen, William. 1969 “The Nahua”. EN: HANDBOOK OF MIDDLE AMERICAN INDIANS. Vol. 8. University of Texas Press. Austin \& London. 1969.

Muñoz Camargo, Diego. 1998 HISTORIA DE TLAXCALA. CIESAS. México, D F. 1998.

Nutini, Hugo. Isaac, Barry. 1989 LOS PUEBLOS DE HABLA NAHUATL DE LA REGION DE TLAXCALA Y PUEBLA. INI. CONACULTA, México, D F. 1989. Starr, Frederick. 1895 Reed. 1995. EN EL MEXICO INDIO. CONACULTA. México D F. 1995. 1904 "Notes upon the Ethnology of Southern Mexico". Davenport Academy of Sciences Proceedings. IX USA. 1904. 


\section{BIBLIOGRAFÍA GENERAL}

Acuña, René. (Editor). Paso y Troncoso, Francisco del. 1984 RELACIONES GEOGRAFICAS DEL SIGLO XVI. OAXACA. Dos Tomos. Instituto de Historia. UNAM. México, D F. 1984. Aguirre Beltrán, Gonzalo. 1973 REGIONES DE REFUGIO. ( El Desarrollo de la Comunidad y el Proceso Dominical en Mestizoamérica). INI. Serie de Antropología Social. № 17. México, D F. 1973.

Álvarez Encarnación, José Rogelio. (Editor). 1988 ENCICLOPEDIA DE MEXICO. (14 Tomos).Editorial Enciclopedia de México. México, D F. 1988.

Basauri, Carlos. 1940 Reed 1990 LA POBLACION INDIGENA DE MEXICO. Instituto Nacional Indigenista. México. D F. 1990.

Benítez, Fernando. 1970 LOS INDIOS DE MEXICO. Mixtecos. Mazatecos. TOMOS I y III. Biblioteca ERA. Editorial Era. México, D F. 1970-

Bonfil Batalla, Guillermo. 1985 EN EL MEXICO PROFUNDO. Editorial Grijalbo. México. D F. 1985

Díaz del Castillo. Bernal. 1970 HISTORIA VERDADERA DE LA CONQUISTA DE LA NUEVA ESPAÑA. 8 ${ }^{a}$ Ed. Ed. Porrúa. México. D F. México, D F . 1970.

Foster, George M. 1962 CULTURA Y CONQUISTA. LA HERENCIA ESPAÑOLA EN AMERICA. Universidad Veracruzana, Jalapa, Ver. 1962.

Galeano, Eduardo. 1971 Reed. 2010 LAS VENAS ABIERTAS DE AMERICA LATINA. Ediciones “El Chanchito”. Imprenta Rosgal. Montevideo. Uruguay. 2010. InstitutoNacional Indigenista. 1978 INI. TREINTA AÑOS DESPUES. REVISION CRÍTICA. Numero especial de Aniversario. MÉXICO. INDIGENA. INI. México. D F. 1978.

Manrique Castañeda, Leonardo. 1994 LA POBLACIÓN INDIGENA MEXICANA. INEGI. INAH. IIS-UNAM. México, D F. 1994.

Musacchio, Humberto. 1989 GRAN DICCIONARIO ENCICLOPEDICO DE MEXICO VISUAL. 4 Tomos.

Andrés León. Editor. México, D F. 1979. Nolasco Armas, Margarita. 1972 OAXACA INDIGENA. PROBLEMAS DE ACULTURACION EN EL ESTADO DE OAXACA Y SUB-AREAS CULTURALES. Instituto de Integración Social del Estado de Oaxaca. Oaxaca, Oax. 1972.

Rodrigo Álvarez, Luis. 2004 GEOGRAFIA GENERAL DL ESTADO DE OAXACA. 4a Edición Aumentada. Carteles Editores, Oaxaca, Oax. 2004. 2008 HISTORIA GENERAL DEL ESTADO DE OAXACA. Siena Editores. Puebla, Pue. 2008. HANDBOOK OF MIDDLE AMERICAN INDIANS. 14 Tomos. 1973 University of Texas Press. Austin \& London. Austin, Texas. U S A. 1969.

Rzedowsky, Jerzy. 1983 VEGETACIÓN DE MÉXICO. Editorial Limusa Willey. México, D F. 1983.

Scheffler, Lilian. 1986 GRUPOS INDIGENAS DE MEXICO. Colección Panorama. Panorama Editorial, S A. México, D F. 1986.

Starker Leopold, R S. 1956 Reed. 1976. FAUNA SLVESTRE DE MEXICO. Consejo de Recursos Naturales Renovables. México. D F. 1976. 
Starr, Frederick. IN INDIAN MEXICO. 1906 INDIANS OF SOUTHERN MEXICO.

Varios Autores: Ismael Colmenares, Arturo Delgado, Miguel Angel Gallo y Francisco González. (Recopiladores). 1986 DE CUAUHTEMOC A JUAREZ Y DE CORTES A MAXIMILIANO. Ediciones Quinto Sol. México, D F. 1986.

Zárate Aquino, Manuel. 1995 PEQUEÑO DICCIONARIO ENCICLOPÉDICO DE OAXACA. Edición de la Universidad Vasconcelos. Compañía Editorial Elecro-Comp. S. A. de C. V. México, D F. 1996. 

